UNIVERSIDADE DE SÃO PAULO

\author{
FACULDADE DE FILOSOFIA, LETRAS E CIÊNCIAS HUMANAS \\ DEPARTAMENTO DE LETRAS CLÁSSICAS \\ PROGRAMA DE PÓS-GRADUAÇÃO EM LITERATURA PORTUGUESA
}

\title{
O riso em movimento
}

\begin{abstract}
Maura Böttcher Curvello
Tese apresentada ao Programa de Pós-Graduação em Literatura Portuguesa do Departamento de Letras Clássicas da Faculdade de Filosofia, Letras e Ciências Humanas da Universidade de São Paulo, para a obtenção do título de Doutor em Letras.
\end{abstract}

Orientador: Profa. Dra. Flavia Maria Corradin

\section{São Paulo}

V.I

2011 
A теи pai, теи alicerce e exemplo,

À minha mãe, meu braço direito,

A meu filho David, que aos 12 anos digitou Amor (também) de perdição e aos 15, continua meu grande amigo,

À minha filha Carolina, melhor surpresa da minha vida,

Ao Deca, meu contrarregra,

À Flávia Maria Corradin, por ser grande orientadora e amiga. 


\section{SUMÁRIO}

\section{INTRODUÇÃO}

Diálogos com o passado

p. 1

De Fernando Gomes

p. 2

Do fado português e universal

p. 5

I. DIALOGAR PARA TECER

p. 8

II. SERES DUAIS

p. 18

II. 1 Da mulher portuguesa

p. 18

II. 2 Da dualidade feminina

p. 30

II. 3 Da dualidade humana

p. 37

III. DAS PAIXÕES HUMANAS

p. 65

III. 1 Amor é perdição

p. 65

III. 2 Perdição é amor

p. 86

IV. FEL E SANGUE

p. 118

IV.1 Fel escorre da pena de Camilo

p. 118

IV.2 O teatro vertendo sangue português

p. 139

V. VIA CRUCIS

p. 154

V.1 Sob a cruz social

p. 154

V.2 Ser ou não ser: Carlota

p. 172

VI. RESTA RIR

p. 189

IV. REFERÊNCIAS

p. 195 


\section{Resumo}

Esta tese visa a apresentar a parte da dramaturgia de Fernando Gomes que dialoga com narrativas de Camilo Castelo Branco a fim de estabelecerem-se relações entre as concepções de mundo dos dois autores no que tange à nacionalidade, à mulher e ao comportamento humano. Nesse sentido, o estudo do cômico tornou-se fundamental já que ambos os escritores se valem do humor para promoverem suas análises da época em que se inserem e do universo interior humano. $\mathrm{O}$ riso movimenta e incentiva a ação, cônscios do valor dessa ferramenta, novelista e dramaturgo apresentam sua cosmovisão sob esse viés. 


\begin{abstract}
This thesis aims to present the part of Fernando Gomes' work that converses with narratives of Camilo Castelo Branco to settle relations between the worldviews of the two authors in relation to nationality, women and human behavior. In this sense, the study of the comic has become crucial once both writers make use humor to promote their analysis of their time, the universe and human interior. Laughter moves and encourages action, conscious of the value of this tool, novelist and playwright presents their worldview from this angle.
\end{abstract}


“[...] a ordem social e humana nem sempre se alcança sem o grotesco, e alguma vez o cruel"

Machado de Assis

\section{INTRODUÇÃO}

\section{Diálogos com o passado}

But humankind, which is ever discovering new meanings, cannot always invent new forms; it must at times be content to invest old forms with new meanings. (Genette, 1997, p. 400)

Esta tese objetiva mostrar em que medida o humor e a ironia camilianos, revisitados e atualizados são ferramentas para que Fernando Gomes revele uma visão peculiar a respeito do ser humano em geral e do português em particular. Os Autor contemporâneo propõe uma reflexão particular acerca do homem nos âmbitos social, temporal e existencial, transformando o riso amargo em humor de cunho popular.

Camilo amalgama sua visão por meio de idealismo, ironia, humor e sentimentalismo, mescla especial que leva o leitor a vislumbrar o aguçado senso crítico do novelista acerca do ser humano. Gomes enfatiza temas que eram apenas aventados e acrescenta cor a algumas cenas empalidecidas para "internalizar" os assuntos, isto é, converte causas externas, políticas ou sociais, em psicológica (Genette, 1997, p. 325). Essa postura condiz com o que Antonio Candido preconiza acerca das tendências da sociologia moderna, a qual mostra que

\footnotetext{
a arte é social nos dois sentidos: depende da ação de fatores do meio, que se exprimem na obra em diversos graus de sublimação; e produz sobre os indivíduos um efeito prático, modificando sua conduta e concepção do mundo, ou reforçando neles o sentimento dos valores sociais. (2000, p. 18)
}

Dessa forma, as peças gomesianas ampliam as narrativas de Camilo, ao mesmo tempo em que reforçam-lhes o caráter universal.

Dono de um estilo bem-humorado, que privilegia a polissemia e o resgate da linguagem popular como forma de conseguir falas ambíguas e irônicas, Gomes compõe com frequência cenas simultâneas, ainda que anacrônicas, sugerindo uma maneira cubista 
de apresentar a realidade. Algumas vezes, um mesmo episódio é narrado ou comentado por diferentes personagens, como se fosse interpretado de diversos pontos de vista. $\mathrm{O}$ riso do dramaturgo põe em xeque valores arraigados e arcaicos, suscitando a visão crítica de seu espectador acerca do teatro, da História, do povo português e do ser humano. Cabe analisar seus textos para inferir em que medida sua dramaturgia é responsável por revivificar Camilo e o homem do nosso século.

\section{De Fernando Gomes}

Fialho de Almeida, consciente da importância dos escritos camilianos, revelou sua indignação diante do desdém de seu povo pela obra e pelo passamento de Camilo Castelo Branco. Depois de dissertar acerca das qualidades da produção camiliana, o crítico finaliza seu texto lamentando não haver discípulos do novelista.

Discípulos não deixa, como já Balzac os não deixara, sendo demasiado grande e
individual para os fazer. A nossa atual literatura é toda filha de pais incógnitos, e
servindo apenas para fazer políticos, não vale que lhe enquadrinhemos da crápula
ordinária. [...] Porventura virá um dia, quando Portugal não for mais que uma
província da nação invasora, e o grupo dos portugueses nostálgicos, retrocedendo
a mágoa às recordações da pátria perdida, procure o símbolo sintético da nossa
antiga vida livre, porventura virá um dia em que o espírito de Camilo se levantará
do passado, como em 1580 viram os portugueses levantar-se o espírito de
Camões. (1941, p. $45-46)$

Almeida parece profetizar a necessidade da retomada da narrativa de Camilo para uma leitura abrangente da psicologia de seu povo, bem como dos tipos que fomentaram o apego nostálgico à grandiosidade de um passado longínquo em detrimento do olhar atento aos problemas do presente com fins de solucioná-los em um futuro promissor. A releitura de narrativas camilianas feitas por Fernando Gomes parece cumprir o vaticínio de Fialho. Nas mãos do dramaturgo, as novelas oitocentistas ganham atualidade enquanto veículo crítico do inconsciente coletivo português.

$\mathrm{O}$ afamado encenador português, cujos trinta anos de carreira foram celebrados pelo Teatro Maria Matos de 24 de Janeiro a 17 de Fevereiro de 2002, deve ser apresentado ao público brasileiro. FERNANDO Alberto de Oliveira GOMES, filho de Alberto José Gomes e de Corina Fernanda da Conceição Oliveira, nasce em 22 de Janeiro de 1944, na cidade do Porto, freguesia do Bonfim. Inicia o Curso Comercial na Escola Oliveira Martins, 
mas não chega a completá-lo, pois começa a trabalhar, aos 16 anos, como empregado de escritório. Inscreve-se, então, na Academia de Bailado Clássico de Pirmin Trecu, mas vê-se obrigado a abandoná-la para cumprir o serviço militar (1966). Em 1967, parte para a Guiné, como Furriel Miliciano (posto militar, entre cabo e sargento oficial que, não fazendo parte do quadro das unidades ativas, está, contudo, obrigado ao serviço, quando convocado) e regressa ao Porto em 1969. É convidado pelo Círculo Portuense de Ópera a participar de Pergolesi: La Serva Padrona, no papel de Vespone, uma personagem muda. Estreia no Teatro S. João do Porto, em 1970. Viaja por Espanha, França, Alemanha e Inglaterra, onde trabalha durante alguns meses. Regressa a Portugal e fixa-se em Lisboa, como escriturário. Pretende inscrever-se no Conservatório de Teatro, mas os horários não lhe permitem continuar a trabalhar. Em 1974 - já com trinta anos - tem conhecimento de que Carlos Avilez, encenador e diretor do Teatro Experimental de Cascais, procura atores sem grande experiência, para dois pequenos papéis na peça de Claude Prin, Cerimonial para um Combate. Gomes passa a integrar o elenco dessa companhia de teatro profissional, uma das mais importantes do país, onde se mantém ao longo de três temporadas.

O Teatro Experimental de Cascais (TEC) foi a escola em que se iniciou na arte de representar e Carlos Avilez seu primeiro professor. Esta aprendizagem continuou com outros grandes encenadores como Filipe Lá Féria, João Brites e João Mota, com quem trabalhou nos anos seguintes.

Nessa época, começa a escrever textos para Café-Teatro, que são representados em bares e pequenas salas; o êxito desta iniciativa encoraja-o para outros voos; escreve, então, algumas versões intertextuais: Alves \& Cia de Eça de Queirós torna-se Viva o casamento! (1986), Drácula Júnior (1987) dialoga com Drácula, de Bram Stoker, e em 1988, cria uma versão teatral de Maria! Não Me Mates que sou tua Mãe!, de Camilo Castelo Branco.

A impossibilidade de ter entrado para o Conservatório privou-lhe de um conhecimento mais abrangente da História do Teatro e dos grandes autores. Todo o seu conhecimento foi adquirido nos palcos, com a prática e seu talento supera a lacuna.

Em 2002, com outros atores, concebe a Klássikus (Associação Cultural), um grupo de atores itinerantes que encena suas diversas peças.

Em 2004, é convidado pela Escola Superior de Teatro e Cinema a trabalhar com os alunos do último ano do curso de Teatro; encena Mestre Ubu. 
Segue um depoimento do autor:

Grande parte do que tenho escrito tem a ver com a realidade dos portugueses e o tema gira sempre à volta dos "sentimentos" desencadeados pela situação em que se encontram.

O amor, as grandes paixões, a saudade e o fado (o de ser português) são temas recorrentes e que me são familiares, tanto pela experiência de vida como pela memória. Além disso, são universais.

Ao escrever, ao encenar e ao representar, o que me motiva é o prazer de estar com os outros, contar-lhes histórias, partilhar com eles os tais sentimentos; e isso só é possível se for sincero. Foi também o caminho que eu encontrei para estar na vida sem me sentir só. ${ }^{1}$

A partir de 1980, Gomes passa a compor textos, interpretá-los e dirigi-los. Suas peças iniciais dirigem-se ao público infantil, faixa etária que nunca abandonou. Em 1981, envereda pelo café-teatro, também cumprindo as três funções. Em 1985, é co-autor de um espetáculo musical, mas é em 1986 que passa a reler os cânones da Literatura Portuguesa e Universal por meio de comédias musicadas. Neste momento, o dramaturgo parece ter estabelecido um estilo próprio que conta sempre com o humor e a música. Assim, abundam narrativas de vários escritores, como Dom João da Câmara (Rosa Enjeitada, 1990), Almeida Garrett (A Tragédia, de 1990, pela qual dialoga com vários textos do autor oitocentista; Romeiro, Romeiro, quem é tu? que relê Frei Luís de Sousa, 2004; Garrett no coração, uma homenagem ao autor, 2005), Alexandre Dumas (Os três mosqueteiros, 1999), Stevenson (A ilha do tesouro, 2000; O médico e o monstro é relido em Jekyll \& Hyde, 2005), Bocage (Bocage e as Ninfas trata da vida e obra do autor, 2005; Du Bocage in Love, nova homenagem, 2006). De Camilo Castelo Branco relê Maria! Não me mates que sou tua mãe! (1988), Amor de perdição (Amor (também) de perdição, 1991), O sangue (2001), Coisas espantosas (A vida trágica de Carlota a filha da engomadeira (2002) e um fato biográfico, Zé do telhado (2006), personagem que conviveu com Camilo na Cadeia do Porto),

O café-teatro e os espetáculos infantis nunca foram abandonados, mas intercalados a cabarés circenses ( KLÁSSIKUS KABARET, 1990), óperas (BA-TA-CLAN, de 1999, tradução e adaptação da ópera de Offenbach, As Madamas do Bolhão, com música de

\footnotetext{
${ }^{1}$ Entrevista concedida por Fernando Gomes ao PROJETO AUTOR POR AUTOR: A LITERATURA PORTUGUESA À LUZ DO TEATRO, organizado e dirigido pelos PROFs. DRs. FRANCISCO MACIEL SILVEIRA E FLAVIA MARIA CORRADIN, DA FACULDADE DE FILOSOFIA, LETRAS, CIÊNCIAS HUMANAS, DA UNIVERSIDADE DE SÃO PAULO.
} 
Offenbach, 2002 e comédia musicada, Elixir do Amor, versão da ópera de Donizetti , 2003, dentre outros.).

Desta lavra, colhemos os textos que dialogam com Camilo Castelo Branco, autor cujo estilo e visão nos interessa estudar.

\section{Do fado português e universal}

A cada final e início de século surge a necessidade de avaliar o passado e questionar em que medida o presente pode reler o que ficou para trás para acrescentar-lhe novos significados. Nesse sentido, parece ser tão recorrente o uso da intertextualidade na literatura da contemporaneidade e no trabalho de críticos atuais. Como estudiosos da Literatura Portuguesa, consideramos relevante, nesse início de século, estudar textos que trabalham com o diálogo intertextual para levantar algumas hipóteses para as seguintes questões: a dramaturgia contemporânea portuguesa interessa-se por examinar a dicotomia das faces social e psicológica do homem de seu tempo, como o fazia a literatura do século XIX? Que exclusões/inclusões/transgressões a literatura atual propõe em relação à mundividência dos escritores dos séculos XIX? Que temas são importantes para o português de nossa época? Como as relações entre memória e herança cultural têm sido exploradas?

Em busca de respostas para essas questões, procuramos um autor crítico em diálogo com seus antepassados. Fernando Gomes chama atenção por retomar procedimentos de Camilo Castelo Branco, que não são muito divulgados nem enfatizados pela crítica. Nesse sentido, cumpre analisar em que medida o riso presente nas releituras de Maria! Não me mates que sou tua mãe!(1848), Amor de perdição (1862), O sangue (1868), Coisas espantosas (1862) extrapola ou perpetua a visão de Camilo acerca do homem, como ser social e sujeito individual.

Camilo, como romântico, refuta o mundo capitalista por ter quantificado, mecanizado e desumanizado a vida, impondo uma regressão do ponto de vista humano. Em oposição a esse mundo dogmático, imperfeito, efêmero e instável, o escritor desse movimento sugere a busca pelo infinito, entendido como a beleza superior, a felicidade

ideal, que deve ser encontrada no interior humano, onde reside o divino. Trata-se, portanto, 
de uma concepção em que predomina a paixão, a busca pelo absoluto, a redescoberta da essência da alma humana por trás das aparências, a valorização do amor sobre a ponderação racional.

\begin{abstract}
O termo romantismo não designa [...] um estilo literário ou artístico, mas um fenômeno muito mais vasto e mais profundo: a corrente de nostalgia das culturas pré-capitalistas e de crítica cultural à sociedade industrial/burguesa, corrente que se manifesta tanto no domínio da arte e da literatura, quanto no pensamento econômico sociológico e político. (Iöwy, 1990, p. 139)
\end{abstract}

Os românticos sentem-se especiais e procuram revelar isso por meio da originalidade. Entretanto essa busca os levou à consciência de sua fraqueza diante dos gigantes do passado. Nesse dilema, o sentimento e a fantasia foram exageradamente valorizados para eclipsar lacunas ou falhas. Camilo, contudo, compreende a importância de retomar os clássicos e renovar-lhes, acrescentando marcas de sua individualidade.

Assim também os escritores a partir do século XX, despojados da obrigação de apresentar originalidade absoluta, puderam explorar mais abertamente o diálogo com seus antecessores. Cumpre investigar em que medida a dramaturgia pós-moderna ${ }^{2}$ acrescenta significados à visão romântica. Nessa esteira, Fernando Gomes relê o novelista colocando o riso em movimento para apresentar sua visão de mundo. A falta de homogeneidade dos temas e gêneros de textos com que dialoga sugere o intuito de abarcar vários aspectos da cultura portuguesa. Maria! Não me mates que sou tua mãe! narra um crime que ocorreu em Lisboa, em Setembro de 1848, e foi divulgado pelos jornais: uma filha mata a mãe para roubá-la. Esta narrativa pertence ao âmbito da literatura de cordel lusitana, é acessível às camadas populares e tem cunho sensacionalista. A realidade popular é observada e transformada em literatura. Amor de perdição, uma espécie de Romeu e Julieta português, narra a história do amor frustrado de Simão Botelho e Teresa de Albuquerque por questões familiares. $O$ sangue é uma novela passional por que perpassa a ironia camiliana. Camilo pensou em tornar Coisas espantosas sua autobiografia romanceada do autor, sob o título de

\footnotetext{
${ }^{2}$ Entende-se por pós-moderno um estilo de cultura que no plano estético tem como indicadores a autoreflexão e a descontração. Com objetivo de eliminar barreiras entre a cultura popular e a cultura erudita, e entre arte e a experiência cotidiana, usa-se muitas vezes a paródia. "Mas chega um momento em que a vanguarda (o moderno) não pode ir mais além porque já produziu uma metalinguagem que fala de seus textos impossíveis (a arte conceptual). A resposta pós-moderna ao moderno consiste em reconhecer que o passado, já que não pode ser destruído porque sua destruição leva ao silêncio, deve ser revisitado: com ironia, de maneira não inocente." ECO, 1985. p. 57.
} 
Os miseráveis de cá, nesse volume, ele não enfoca a burguesia, mas o sofrimento e as conquistas da classe popular.

Nas mãos de Fernando Gomes, o riso amargo e irônico de Camilo diante da condição humana torna-se nonsense e beira o sarcasmo. É o que se pode entrever pelos comentários jornalísticos acerca de alguns desses espetáculos gomesianos.

Fernando Gomes percebeu muito bem a carga paródica do texto camiliano, tornando explícito o que nesse texto vê, muitas vezes, meramente implícito. $\mathrm{O}$ resultado é um texto e um espetáculo que são uma paródia aberta e directa sobre um caso trágico visto de forma paródica por um outro escritor [...] Por isso se pode dizer que, sem esquecer o ponto de partida camiliano, cujo caráter dialógico ajudou o trabalho de adaptação, este texto de Fernando Gomes é uma obra dramática original. (Carlos Porto, 1988)

Com este novo espetáculo [Amor também de perdição], Fernando Gomes voltou a descobrir o ponto de ruptura que lhe permitiu dar a volta ao original camiliano sem destruir a sua fabulação a não ser no desfecho, e, ao mesmo tempo, a criação de um soberbo espetáculo teatral. [...] Fernando Gomes põe em causa, pelo lado da sátira, as personagens e situações criadas por Camilo. (Carlos Porto, 1991)

O Sangue é uma sátira de Fernando Gomes a partir do romance homónimo de Camilo Castelo Branco. É uma crónica, tragicómica, caricatura da sociedade portuense em meados do séc. XIX. O "Dinheiro", a "Felicidade", o "Pecado" e a "Expiação" - elementos essenciais e omnipresentes no universo Camiliano - desta vez, com o rigor de uma atmosfera operática. [...](Isabel Segorbe, Programa de $O$ sangue)

[A vida trágica de Carlota a filha da engomadeira] é um dramalhão de fazer chorar as pedras. Como é que Fernando Gomes transfere estas personagens bacocas para a actualidade cínica e com valores morais mais...digamos, flexíveis? Com humor. O texto é, evidentemente modernizado, aliás com muita competência, pois consegue manter o sabor de antigamente. Mas, ao ridicularizar a tragédia, mostrando a desgraça mais como resultado da parvoíce dos interveninentes do que de um destino cruel, dá uma nova vida a estes fósseis e inverte a moral subjacente ao complot. $O$ humor quando inteligentemente usado é o melhor arremesso contra o conformismo. (José Couto Nogueira, 2002. O grifo é nosso)

Como se vê, o humor é a maneira de Fernando Gomes trazer a narrativa camiliana ao alcance e interesse do público do século XXI. Daí ele ter recebido em 1991 o "Prêmio Especial de Humor", do V Salão Nacional de Caricatura.

Cumpre agora verificar em que medida as relações intertextuais tornam a literatura mais saborosa ao promover a "incessante circulação de textos" e reler criticamente um passado acrescentando-lhe novos significados. 


\section{DIALOGAR PARA TECER}

Tendo apresentado, em linhas gerais, o autor alvo desta tese, cumpre fundamentar teoricamente o método de interpretação escolhido. Importa, para tanto, iniciar pela exposição da diferença entre influência e intertextualidade a fim de que se estabeleçam a relação entre semiótica e intertextualidade, as concepções deste termo e a opção por uma teoria de carnavalização que embasa o diálogo entre os textos selecionados.

Márcia C. F. Gonçalves (A recusa da teoria da mímesis pelas teorias estéticas na virada dos séculos XVIII e XIX e suas consequências" In Rodrigo Duarte e Virgínia Figueiredo, 2001, p.293), ao tratar da recusa de alguns escritores pela mímesis, sugere motivos ideológicos para o aparecimento de um novo modelo de discurso. Para a autora, da busca do romântico pelo infinito teria surgido a necessidade de superar-se a cisão entre o conceito de natureza e o conceito de liberdade. Assim, a tentativa de unir o sensível e o inteligível resultaria na recusa da mímesis, entendida como a reprodução da natureza pela arte, e tornaria a própria arte o modelo de produção estética. "Essa era de fato a intenção última dos primeiros românticos: unir a criatividade subjetiva - que tem como expressão máxima a figura do artista - com a criatividade objetiva e natural de um mundo reinterpretado poeticamente." (Gonçalves, A recusa da teoria da mímesis pelas teorias estéticas na virada dos séculos XVIII e XIX e suas consequências" In Rodrigo Duarte e Virgínia Figueiredo, 2001, p. 294)

Os autores dos séculos XVIII e XIX preocuparam-se, portanto, em recriar a arte com originalidade, intuição e liberdade, o que lhes conferia o status de "gênio". Há que se tomar a arte como base para a recriação estética, sem, no entanto, "copiar" ou "imitar" autores anteriores. Ser influenciado passou a ter caráter pejorativo, como se o artista influente fosse uma autoridade maior e mais digna de prestígio, isso porque a noção de influência traz em seu bojo ideias como preponderância e predomínio. No entanto, a recusa da imitação de discursos anteriores e a busca pelo novo trazem a consciência de que tudo parece já ter sido dito e escrito e muito bem-feito; restando, portanto, a refacção e aprimoramento de grandes trabalhos. 
Já Horácio (65 a.C a 8 a. C.), em sua Epístola aos pisões, propõe a imitação como recurso útil ao escritor que quer ombrear com os grandes.

Harás tuyo lo que antes era de todos, si no te quedas em torno a un círculo mezquino y banal, si no te empeñas, intérprete servil, en traducir palabra por palabra; ni si imitas a outro, te metes em compromiso tal que el decoro y las condiciones de la obra impidan salir de el. (Horácio, 1981, p. 29)

Em outros termos, há que tomar como base um grande trabalho apropriando-se de seu conteúdo e ampliando seu significado original como maneira de compor uma obra-prima.

Para recuperar o que já havia sido escrito sem, por isso, ser acusado de plágio ou inferioridade, o autor moderno passou a retomar textos, não para imitá-los, mas para atribuir-lhes novos significados; assim, rivaliza-se a influência e é possível suplantá-la. Na contemporaneidade, a perspectiva predominante é reler o ortodoxo com consciência crítico-irônica.

Embora a palavra "intertextualidade" tenha sido cunhada como neologismo por Kristeva em $1968^{3}$, o expediente de dialogar com textos ou de apropriar-se de dados de textos alheios para aprimorá-los é, como já se procurou mostrar, antigo na Literatura; no entanto, é na contemporaneidade que esse procedimento tornou-se frequente.

$\mathrm{O}$ conceito de intertextualidade começou a ser elaborado sem que houvesse um termo a conceituá-lo. A noção de “dialogismo", concebida por Bakhtin (2003, p. 201) e seu círculo constituiu o princípio do estudo. Trata-se de um discurso marcado por várias vozes dissonantes, que representam diversas concepções e visões de mundo. Para o crítico russo, isso decorre do fato de um texto inserir-se em determinado contexto cultural e social. Assim, o texto absorve vários aspectos do meio e do momento em que se situa. À fusão de várias vozes que vêm da formação, da erudição, da filosofia de vida, da fundamentação política, do tempo do escritor é dado o nome de dialogismo. Nesse âmbito, reside a intertextualidade, as leituras feitas por um autor transformadas e ampliadas. Pode ocorrer, portanto, um diálogo entre posições sociais e ideológicas diferentes. O texto pode ser resposta a outro texto compreendendo a relação do sujeito / autor e seu interlocutor, ou do texto e seu contexto.

Essa concepção evidencia a importância do outro. "Não há identidade discursiva sem a presença do outro[...]"(Barros, Fiorin (orgs.), 2003, p. 36). Juntas, as relações

\footnotetext{
3 O termo "intertextualidade" é citado pela primeira vez no artigo "O texto fechado", de 1966-7, publicado em Introdução à semanálise, 1969.
} 
produzem a polifonia, uma ideia-chave para Bakhtin, que remete à combinação de vozes ou discursos, e à heteroglossia, a habilidade linguística de um texto conter em si muitas vozes: a do autor e outras. O discurso do outro não constitui apenas tema, mas "pode entrar no discurso e na sua construção sintática." (Bakhtin, 2006, p. 150), integrá-lo enquanto construção, elaboração é estabelecer a recepção ativa do discurso do outro. Trata-se, então, de uma "apreensão apreciativa ativa da enunciação de outrem, [já que] tudo o que pode ser ideologicamente significativo tem sua expressão no discurso interior." (Bakhtin, 2006, p. 153)

O processo do diálogo inicia-se com a recolocação do discurso alheio no contexto de comentário efetivo para que se desenvolva a réplica. Isso sugere a relevância da significação social de alguns discursos em determinadas comunidades.

Para sintetizar, as tendências possíveis das relações entre discurso citado e contexto narrativo, Bakhtin propõe a seguinte sequência:

1. Dogmatismo racionalista, caracterizado pelo estilo linear, impessoal e monumental de transmitir a fala de outrem na Idade Média;

2. Dogmatismo racionalista, com seu estilo linear ainda mais pronunciado nos séculos XVII e XVIII.

3. Individualismo realista e crítico, com seu estilo pictórico e sua tendência para infiltrar o discurso citado com as réplicas e os comentários doautor, fim do século XVIII e começo do XIX e, finalmente,

4. Individualismo relativista, com a diluição do contexto narrativo (época contemporânea). (Bakhtin, 2006, p. 160)

O discurso de Fernando Gomes insere-se não apenas cronologicamente no quadro acima, já que incorpora várias vozes, as dilui e transforma em novo texto.

Kristeva sintetiza esses princípios bakhtinianos e cria o termo "intertextualidade", que se relaciona à ideia de "transposição", isto é, para que ocorra a passagem de um sistema de significado para outro há que se criar nova articulação do enunciado. Essa concepção de intertextualidade relaciona-se com a Semiótica já que a referência ao contexto histórico ou social, ou a outro texto, ou ainda a transposição de um romance ou novela para o drama pode ser considerada um signo, algo que se refere a um elemento que não está presente integralmente, mas apenas como modelo ou sugestão. A intertextualidade constitui um recurso abrangente, que extrapola a relação entre textos e se torna ferramenta primordial 
para o estudo do discurso. Para Kristeva, intertextualidade refere-se à "produtividade" e "permutação de textos". Sua teoria, no entanto, é vaga no que se refere aos seguintes aspectos: a) o modo como o texto social se transforma em texto literário; b) a atenção dada ao gênero literário; c) o fato de não trabalhar com as transformações de gêneros e formas dentro do sistema literário; d) a falta de valorização do papel do leitor.

A intertextualidade kristeviana prescinde de citações ou marcas claras, a relação entre textos pode ser anônima, impessoal, o que torna infinito o número de intertextos e dificulta o limitar as referências relevantes para a definição de um caminho de interpretação.

Barthes em 1981, escreve o ensaio "Teoria do texto" em que parte da etimologia da palavra "texto" ("tecido") para formular sua concepção de intertextualidade. Para ele, o texto seria uma trama de citações extraídas de inumeráveis centros de cultura (Allen, 2006, p. 73), também, como considerava Kristeva, sem marcas ou intenções definidas. Assim, o procedimento de relação entre discursos - enunciados de caráter verbal inseridos em uma situação extra verbal, um contexto histórico e cultural - nem sempre seria consciente ou intencional. A base de um texto não seria a realidade exterior (processo de mimese), mas sempre um conjunto de palavras de um autor, publicado em um livro, um folheto, um documento. Essa concepção tem por base a convicção de que tudo já foi dito e escrito e cabe ao autor contemporâneo aprimorar essas ideias. A apreensão dos múltiplos significados de um texto composto dessa forma deve ser inferida pelo leitor.

Esse crítico apresenta duas concepções de texto. O "legível", que apresenta "doxa", isto é, um discurso estabelecido, estereotipado, constituído por mitos e ideologias dominantes e conta com um leitor passivo e o texto "escritível", dotado de múltiplos significados ("paradoxa") que resistiriam aos dogmas e perturbariam crenças e códigos da cultura sem deixar que um código domine o discurso. Caberia ao leitor inferir os intertextos e relacioná-los ao livro, ainda que o escritor não tivesse em mente ou não conhecesse determinado trabalho, a relação feita pelo leitor seria pertinente porque ele é o responsável por definir as conexões da escritura, dando, assim, unidade à produção. Barthes propõe, com isso, a "morte do autor", isto é, o desvanecimento da figura do autor em sua obra; não é necessário, por isso, que a crítica busque dados da biografia do autor para analisar uma narrativa. 
Riffaterre $^{4}$ em 1978, com Semiótica da Poesia parece resolver o problema da dispersão de intertextos pela concepção da ideia de "matriz", uma palavra, sentença ou trecho cuja expansão dá origem ao discurso. Assim, o princípio da escritura também não é referencial (mimético), mas outro texto, constituído de "hipogramas", isto é, frases e sentenças estereotipadas, associadas umas às outras em relação à palavra central (matriz) à qual as demais estariam subordinadas, o que equivale ao "já-lido" ou "já dito" de Barthes.

Para a interpretação abrangente de um texto, o leitor teria que dominar o "socioleto", discurso normativo de uma sociedade e inferir o que causa estranhamento no livro, esse estranhamento seria causado pela matriz do discurso. A intertextualidade direcionaria a interpretação, seria um guia para uma leitura pertinente, mas, novamente, o leitor é responsável por reconhecer a matriz. Riffaterre define o leitor a que se refere como alguém maduro e experiente, capaz de captar, em uma leitura referencial, que unidades e estruturas semióticas devem ser interpretadas para determinar o significado do texto.

Dentre os críticos americanos que estudam a intertextualidade, destacam-se Harold Bloom e Nancy K. Miller. Aquele propõe, em Angústia da Influência (1973), que os escritores reescrevem textos de seus precursores, aprimorando-os para defender seu papel de escritor. Transforma-se, redireciona-se, reinterpreta-se o que já foi escrito para gerar a ilusão de criar novas imagens e ideias. Sua teoria baseia-se nos mecanismos de defesa de Freud para provar que um texto é um evento relacional e não uma substância independente a ser analisada. A concepção de intertextualidade de Bloom propõe que, em uma época em que tudo parece ter sido escrito de forma exemplar, as motivações para a escrita seriam ditadas pela intenção de superar o precursor. O impulso da intertextualidade decorreria, portanto, do desejo de reconhecimento de um escritor. As imagens de mundo reveladas em textos literários seriam, assim, baseadas não na realidade exterior, mas na leitura que dela fizeram os grandes escritores. Para ele, os contextos sociais e culturais não são intertextos relevantes, mas a presença do autor o é, o que promove o reaparecimento da figura do autor.

Miller ${ }^{5}$, em Arachnologies (1986), também defende a subjetividade do autor, seu livro propõe-se a analisar a literatura de escritoras negras e o cruzamento entre o discurso

\footnotetext{
${ }^{4}$ O pensamento de Rifaterre é sumamente apresentado em Allen, 2006, p. 115 - 132.

${ }^{5}$ O pensamento de Miller é apresentado com maestria por Allen, 2006, p. 154 - 159.
} 
dessas mulheres e o da sociedade machista dominante. Sua concepção de intertextualidade relaciona-se ao plano social e político, ao materialismo cultural e ao criticismo historicista.

Nos críticos citados a noção de intertextualidade é abrangente e não prevê marcas definidas, nem a intencionalidade do autor como guia para a interpretação de um texto.

The notion of intertextuality was formulated and developed by Kristeva (inspired by Bakhtin). [...] In its most general and radical acceptation (Barthes and Kristeva), the term designates the relations between any text (in the broad sense of signifying matter) and the sum of knowledge, the potentially infinite network of codes and signifying practices that allows it to have meaning. (Gerald Prince, 2003, p. 46)

Gerard Genette, entretanto, restringe o uso da palavra, "In its most restricted acceptation (Genette), the term [intertextualidade] designates the relation(s) between one text and other ones which are demonstrably present in it." (Gerald Prince, 2003, p. 46. O grifo é nosso.

Genette, em Palimpsests (1982), considera o trabalho literário como articulações, seleções e combinações particulares de um sistema a ponto de modificar esse sistema. Esse crítico cunha o termo "transtextualidade" para referir-se à transcendência de um texto e transformação em outros. Ele divide a transtextualidade em cinco tipos diferentes:

1. intertextualidade, isto é, a copresença entre vários textos de maneira explícita por citação. Genette considera que se a referência não for explícita trata-se de casos de plágio ou alusão, isto é, somente uma pressuposição da relação com outro texto;

2. paratextualidade, referências ao texto que não façam parte de seu corpus, como títulos, subtítulos, prefácios, posfácios, notas, epígrafes, ilustrações, discussões autorais, editoriais, críticas, comentários, etc;

3. metatextualidade, alusão a um texto para explicá-lo ou comentar seu processo de composição;

4. arquitextualidade, relação inintencional, de natureza taxionômica entre textos de tipos de discurso, modos de enunciação, gêneros literários semelhantes.

5. hipertextualidade, relação intencional e declarada entre dois textos. O hipertexto é um texto literário que deriva inteiramente de outro texto pré-existente, um hipertexto. Não se trata de um comentário, nem de um metatexto, mas de um novo trabalho que se faz como 
releitura de um escrito de outro autor, como é o caso dos textos selecionados de Fernando Gomes.

O conceito de hipertextualidade norteia a tese proposta em Palimpsests. Para desenvolvê-la, Genette propõe dois processos para a hipertextualidade: por imitação, como ocorre na caricatura e no pastiche, e por transposição, um meio mais elaborado de absorver e modificar um texto. Nos primeiros capítulos do referido livro, o crítico explica a diferença entre um texto composto por imitação e por transposição, analisando as peculiaridades das formas caricatura, pastiche, paródia e burlesco.

A hipertextualidade consiste em um meio de reativar livros ou gêneros, expediente típico da Pós-Modernidade, já que se trata de um período de questionamento e ressignificação do passado. Com esse intuito, são feitas alterações no modelo, as transposições formais criam novos sentidos para o hipotexto, e as temáticas tendem a gerar mudanças mais substanciais no paradigma.

A "motivação" é um mecanismo que merece ser citado, pois associa-se à introdução de um motivo que o hipotexto oferecia, mas não desenvolveu. Um meio que possibilita a "motivação" é a inserção de uma personagem feminina que exponha sua mundividência, o que ocorre, por exemplo, na inserção de Rosa na peça Amor (também) de perdição. Já a "desmotivação" constitui-se pela supressão de um motivo que constava do paradigma. Cabe complementar que a "transmotivação", acima relacionada a uma forma de adição + supressão, possibilita a manipulação de temas e a internalização de uma causa externa, isto é, ao substituir um motivo por outro, o escritor elege motivos psicológicos para tomar o lugar de assuntos políticos, sociais, etc.

O mérito da intertextualidade (para Genette, hipertextualidade) é atribuir a trabalhos antigos novos significados críticos; além disso, o hipertexto é mais vantajoso que o metatexto porque tem a liberdade de ampliar o hipotexto, sem ser alterado por ele. É importante frisar que em todo hipertexto existe uma ambiguidade porque ele pode ser lido como um trabalho independente ou relacionado ao hipotexto. No entanto, a leitura sem o cotejo com o paradigma não será capaz de exaurir a função do hipertexto. Dessa forma, é possível afirmar que o hipertexto convida à leitura relacional.

Esse procedimento é preconizado por Borges, em "Pierre Menard, autor do Quixote". O conto sugere que a mera cópia de um texto feita em época diferente da que foi 
originalmente elaborado, isto é, narrar a mesma verdade em contexto histórico diferente, pode ampliar o significado de um paradigma.

O trabalho do crítico, ao utilizar como método de interpretação a intertextualidade ou, em âmbito mais restrito, a hipertextualidade, é estabelecer se o hipertexto consegue superar o hipotexto, ampliando-lhe o significado, isto é, se ocorre uma "estilização" no sentido de "uma transformação do ou no conteúdo do modelo, sem negá-lo ou opor-se a ele [papel da paródia], trazendo-lhe à tona o que está implícito." (Corradin, 1998, p. 36). Caso o hipertexto apenas repita o significado do hipotexto trata-se de paráfrase.

[...] Literature is a perpetual state of transfusion, a transtextual perfusion, constantly present to itself in its totally and as a totally all of whose authors are but one and all its books are one vast, one infinite Book. Hypertextuality is only one name for that ceaseless circulation of texts without which literature would not be worth one hour of exertion. (Genette, 1997, p. 400)

Entre os estudiosos do tema, interessa, para o objeto desta tese, verificar minuciosamente a teoria da "Carnavalização", proposta por Bakhtin em A cultura popular na Idade Média e no Renascimento. Importa, assim, iniciar pela apresentação de elementoschave para a compreensão do pensamento bakhtiniano.

O crítico russo parte do conceito de dialogismo para expor sua concepção de texto. Mikhail Bakhtin propõe que se deva levar em consideração o contexto sócio-histórico em que se insere o texto, já que este é objeto de uma cultura. Assim, as vozes sociais interagem no espaço do texto. Dessa forma, o cruzamento de posições ideológicas é fundamental para refutar-se uma verdade única, absoluta e incontestável.

Assim, todo enunciado é delimitado pela alternância dos sujeitos e não se "encontra pronto e acabado numa determinada obra, num determinado texto; o sentido e as particularidades vão sendo construídos ao longo do conjunto das obras, indissociavelmente implicados em outras noções também paulatinamente construídas.” (Brait, 2007, p. 65)

Com base nesse pressuposto, $\mathrm{o}$

diálogo do homem com o homem" [é] [...] um documento sociológico sumamente interessante. A sensação excepcionalmente aguda do outro indivíduo como outro e do seu $e u$ como um eu nu pressupõe que todas [...] as definições [...] que 
revestem o eu e o outro de corpo concreto-social todas as variedades dessas definições perderam a sua autoridade e a sua força formativa. (Bakhtin, 2003, p. 201)

A palavra só é viva se ouvida e respondida, dialogada. Nesse sentido, o texto é mero fruto de vivência subjetiva, mas do convívio social. Da mesma forma,

"vivências psíquicas" do falante, cuja expressão tendemos a ver [...] [na] enunciação são de fato apenas uma interpretação unilateral, simplificada e cientificamente incorreta de um fenômeno social mais complexo. É uma espécie de "projeção" através da qual investimos (projetamos) na "alma individual" um complexo conjunto de interrelações sociais. (Bakhtin, 2004, p. 79)

Para Bakhtin, não se pode, portanto, considerar o psiquismo humano como refratário à história, o inconsciente é, outrossim, uma "elaboração ideológica do ser” (Bakhtin, 2004, p. 87), o que se opõe ao conceito de Freud, que compara o conteúdo do inconsciente com a

presença de uma população aborígene na mente. Se existem no ser humano formações mentais herdadas - algo análogo ao instinto nos animais -, elas constituem o núcleo do inconsciente. Depois, junta-se a elas o que foi descartado durante o desenvolvimento da infância como sendo inútil; e isso não precisa diferir, em sua natureza, daquilo que é herdado. (Freud, 2006, p. 200. Vol. XIV)

Assim, um texto sugere os processos subjetivos do receptor, os quais não ocorrem na alma individual, mas no grupo social, e a linguagem, o estilo, a seleção de recursos estilísticos e o gênero refletem as finalidades do enunciado e tem uma significação social.

Gomes relê Camilo talvez porque se identifique com um escritor que conhecia o povo e a alma portugueses. O dramaturgo revela conhecer a cultura popular folclórica ao colher e aproveitar provérbios, insultos, juramentos e crenças. Pelo riso, ele incita o senso crítico e põe em xeque tabus, regras e privilégios. Seu humor é festivo e contrário às ideias de superioridade. Para isso, destitui padres e freiras de sua aura sacra, revela a bondade e pureza de algumas prostitutas, evidencia a jovialidade e alegria de bêbados e mendigos. Juramentos adquirem caráter cômico. O rebaixamento da linguagem pontualmente localizados em seu texto remete à sexualidade ("baixo material e corporal") e é um meio de

liberar-se do ponto de vista dominante sobre o mundo, de todas as convenções e elementos banais e habituais, comumente admitidos; permite olhar o universo com novos olhos, compreender até que ponto é relativo tudo o que existe, e portanto permite compreender a possibilidade de uma ordem totalmente diferente do mundo. (Bakhtin, 2010, p. 30)

Já Camilo Castelo Branco apresenta a aguda consciência do romântico de estar isolado, de ser diferente. Por isso, em seu riso sobrepõe-se o sarcasmo e a ironia à diversão 
e à alegria. Trata-se de um humor destrutivo que se volta contra a realidade exterior com intuito de mostrar-se superior e vingar-se do que discorda.

No riso gomesiano, por outro lado, não se tem a pretensão de destruir a realidade, mas de abrir possibilidades de renovação. Parece a expressão do riso popular, não-oficial que põe em xeque o que é temido e instituído como verdade inquestionável. "Esse [riso] liberta não apenas da censura exterior, mas antes de mais nada do grande censor interior, do medo do sagrado, da interdição autoritária, do passado" (Bakhtin, 2010, p. 81) Pelas analogias e trocadilhos, o sério adquire tom cômico e a verdade oficial dá espaço para nova consciência individual e histórica. Inverte-se ou parodia-se o que é considerado convencional e lícito.

O recurso do humor é valioso porque atrai o povo, o calão, o vocabulário popular, os juramentos, os tipos populares promovem uma atmosfera em que todos têm os mesmos direitos, um ambiente familiar, licencioso e franco. $\mathrm{O}$ rebaixamento serve para renovar.

Daí povoarem os textos gomesianos mendigos, prostitutas, taverneiros, bêbados. Também o vinho, símbolo de libertação, é útil para comunicar a verdade sem mascaramento. "O verdadeiro riso, ambivalente e universal, não recusa o sério, ele purificao e completa-o". (Bakhtin, 2010, p. 105). Essa maneira de lidar com a verdade instituída é denominada de "carnavalização", já que "o carnaval torna-se [...] o símbolo e a encarnação da verdadeira festa popular e pública, totalmente independente da Igreja e do Estado (mas tolerada pelos últimos)" (Bakhtin, 2010, p. 191). Nessa festividade, representam-se os símbolos do poder (rei, rainha, a coroação) de forma lúdica, como se o povo fosse coroado. A hierarquia é abolida, as classes sociais e as idades igualam-se, o que promove a relativização do poder e da verdade dominantes.

Romper com a seriedade e rir propicia liberdade para a elaboração de ideias audaciosas, lúcidas, críticas. O objeto do riso, o ridículo, é ultrapassado, revelado em sua estupidez e pretensão risíveis.

Em Gomes, o passado, tão pesado para o português, a melancolia do fado e as crendices vazias de sentido são revisitados como aspectos agonizantes da realidade. Nesse sentido, o resgate da linguagem popular de forma inovadora e crítica corresponde à renovação do que é antigo e dogmático. Também o atrevimento e a impudência, bem como os apelidos relacionados às atitudes ou anomalias das personagens colaboram para o clima carnavalesco, festivo, engraçado, grotesco. 


\section{SERES DUAIS}

\section{1 Da mulher portuguesa}

Contrariando ainda que sutil e ironicamente como o fará em todo o decorrer de sua carreira a ideia dominante de que a literatura de cordel, por não se comprometer com nenhuma ideologia política, é uma literatura menor, Camilo inicia sua carreira literária pelo cordel como a afirmar que não a erudição não é único quesito para se produzir uma obra de arte mais livre e original.

Essa estréia não é apenas uma opção irreverente, mas também um meio de conseguir publicar um livro em um país cujas editoras davam preferência a traduções de textos estrangeiros para as quais tinham público garantido. Além disso, com 24 anos, Camilo mal podia sustentar-se e salvou-se de uma bancarrota com a vendagem do folheto. (Cláudio Giordano, apresentação a Camilo, 1991, p. XII) Se a marginalidade é condição de estímulo do ato criador, o novelista não só a apresenta como também tem consciência desse processo de compor uma obra livre de intenções sociais ou didáticas, o que será comprovado adiante.

A condição essencial para a ocorrência do pensamento produtivo é, sempre, um estado de desequilíbrio do indivíduo, seja desequilíbrio interior, como seria o caso de sentimentos incompatíveis, seja na sua relação com o ambiente. [...] o marginal tende a estar colocado em situação de conflito e a perceber as incoerências de padrões que os indivíduos estáveis aceitam sem discutir. (Leite, 2002, p. $160-161)$

A literatura de cordel, já no século XIX, era menosprezada pela elite cultural como uma literatura menor, quer porque impressa em papel ordinário e sem formatação uniforme, quer pela veiculação: venda itinerante por cegos que viviam de caridade; volanteiros, ou vendedores ambulantes. No entanto, os folhetos de cordel são considerados literatura popular não pela classe que a consumia, mas devido à grande escala em que eram vendidos, afinal a classe baixa além de não ter poder aquisitivo para investir em literatura, era quase completamente analfabeta. Em 1864, a percentagem de analfabetismo era de 88,3\% e antes disso não há dados estatísticos. (Serrão, 1983, p. 27)

A multiplicidade dos temas e a qualidade muito variável do tratamento dos textos de cordel permitem presumir que se tratava de um público leitor heterogêneo, 
com gostos, interesses culturais e poder econômico muito distintos, constituído tanto por gentes ricas e instruídas como por gentes das classes desfavorecidas, da cidade como do campo. (Nogueira, 2004, p. 36)

A primeira narrativa camiliana merece atenção uma vez que, sob a máscara de uma preocupação didático-pedagógica, e de um tema de cunho sensacionalista, Camilo, grande conhecedor da alma portuguesa e do que agrada o público-leitor, compõe um best-seller ${ }^{6}$ que contém germes do que será o grande nome da novela passional portuguesa. Some-se a isso o valor documental desse texto que revela dados importantes acerca do comportamento social e da mentalidade portuguesa de então.

Já na capa da primeira edição, algumas sugestões de que se enuncia mais do que o que se declara são insinuadas. De início, salta aos olhos a aparente incoerência entre o título da narrativa Maria, não me mates que sou tua Mãe! Meditação sobre o espantoso crime Acontecido em Lisboa: uma filha que mata e despedaça sua mãe, mandada imprimir por um mendigo, que foi lançado fora do seu convento, e anda pedindo esmolas pelas portas. Oferecida aos pais de famílias, e àqueles que acreditam em Deus e a ilustração de um monge ajoelhado com a mão no coração. Os folhetins costumavam estabelecer um conjunto coeso entre o conteúdo e a imagem da capa para sintetizar a mensagem a ser veiculada e aguçar a curiosidade do leitor. O folheto de Camilo, no entanto, não trata, em nenhum momento, de figuras religiosas a não ser quando, no título, refere-se ao pretenso editor do texto. Sugere-se, assim, a importância da religiosidade como chamariz para o público da época.

A alusão ao mendigo apresenta, ainda, índole polêmica e provocativa. Essa suposta personagem marginal (o mendigo) ${ }^{7}$ quer divulgar um crime hediondo, ainda que para isso precise usar as esmolas com que vive, depois de ter sido expulso de um convento. Se, de um lado, há a valorização do caráter de um ser posto à margem da sociedade, de outro, há uma crítica mais ou menos indireta aos dirigentes de conventos que relegariam pessoas de

\footnotetext{
6 Luís Sobreira apresentou no IV Congresso Internacional da Associação Portuguesa de Literatura Comparada o trabalho "UMA IMAGEM DO CAMPO LITERÁRIO PORTUGUẾS NO PERÍODO ROMÂNTICO ATRAVÉS DOS BEST-SELLERS PRODUZIDOS ENTRE 1840 E 1860" em que aponta o título de Camilo como o quinto Best-seller da época. www.eventos.uevora.pt/comparada/VolumeI/UMA\%20IMAGEM\%20DO\%20CAMPO\%20LITERARIO\%20 PORTUGUES.pdf

${ }^{7}$ Importa acentuar que também o cordel é considerado literatura marginal.
} 
boa personalidade à mendicância. Cabe salientar que ao criar um mendigo autor ${ }^{8} \mathrm{e}$ editor de um livro, Camilo parece estar retratando irônica e zombeteiramente a condição miserável do escritor ou profissional das letras em Portugal.

Pela frase: "Meditação sobre o espantoso crime acontecido em Lisboa", a narrativa se propõe a levar a pensar, convida a uma análise sobre os valores que regiam aquela sociedade. Considerando-se que meditar significa pensar sobre; ponderar; refletir; estudar; examinar com prudência, sensatez, circunspecção, a frase corrobora a suposta intenção didática da narrativa sugerida pela exortação aos leitores que aprendam a "educar melhor seus filhos" (Branco, 1991, p. 33) e que façam seus filhos decorarem a história. (Branco, 1991, p. 6)

Valendo-se da função apelativa; da adjetivação sugestiva, pela qual caracteriza a moça criminosa e o rapaz sedutor, - como exporemos mais adiante - e da hipérbole, o autor, ao mesmo tempo em que cumpre os ditames da forma escolhida, atendendo às expectativas dos leitores, sugere ironicamente sua visão de mundo.

O título da terceira edição passa a ser Matricídio Sem Exemplo. Uma filha que matou e esquartejou sua própria mãe, Matilde do Rosário da Luz, em Lisboa - na Travessa das Freiras, $n .{ }^{\circ}$ 17. Às almas sensiveis - aos pais de familia - e aos bons Cristãos oferecese em meditação, a descrição do atentado praticado pela perversa matricida Maria José seguido do interrogatório da acusada, e da sentença do tribunal do $1^{\circ}$ distrito, que a condenou a morrer n'uma forca, no campo de Santa Clara em Lisboa. A incongruência entre a ação criminal e o nome da rua onde ocorre o delito sugere um embate entre aparência (nome religioso) e essência (ação criminal) que será preocupação medular na obra camiliana. Já em seu livro de estréia, Camilo sugere que nomes ou títulos não correspondem a valores ou observância de normas. Insinuando-se, portanto, que nem sempre o que se expõe corresponde ao que se é na essência. Essa contradição se refaz de diversas maneiras na narrativa, entre elas, na relação entre o nome das personagens e seu papel, em ambas as edições.

A história, nas duas versões, inicia-se apresentando um pai de família morrendo, "farto de trabalhar para sustentar com o suor de seu rosto a honra de sua família" (Branco, 1991,

\footnotetext{
8 "O que escreveu estas linhas com o seu pouco saber talvez vos terá ido à porta mendigar as migalhas da vossa mesa" (Branco, 1991, p. 6)
} 
p.7). Essa personagem chama-se Agostinho José, que significa, respectivamente, "o maior do império", "consagrado, santo, sublime, venerado" (Guérios, 1994, p. 77), e "Deus dê aumento" ou Deus aumente (com outro filho) (Guérios, 1994, p. 200) ou, na origem egípcia, "Descobridor das coisas ocultas" (<http://pt.wikipedia.org/wiki/Jos\%C3\%A9_(filho_de_Jacob)>)

Além do caráter majestoso e explorador sugeridos pelo prenome, há o cunho religioso, que alude ao padroeiro das famílias. A alcunha parece uma grande ironia, por duas razões:o pater familias sucumbe ao trabalho e morre sem cumprir a função de educar e sustentar sua família, atribuindo à mulher a obrigação de velar pela honra das filhas sob pena de ser responsável pela condenação de sua alma, se a cláusula não fosse cumprida. Além disso alude-se ao fato de que Deus the daria como graça "outro filho".

A sociedade daquela época era patriarcal e machista, e o homem, considerado mais forte e ajuizado e, por isso, seu dever era zelar pela mulher, no caso de Agostinho, três mulheres, entretanto, ele delega à sua mulher o encargo de prover material e moralmente o sustento daquela família.

O nome Agostinho José remete ainda a Santo Agostinho, primeiro filósofo do Cristianismo. Preocupado com problemas práticos e morais, que considera derivarem do fato de Deus conceder a liberdade aos homens, o filósofo propõe que a glória divina está em extrair o bem do mal, em vez de proibir o mal e que, portanto, caberia ao homem optar por salvar-se ou perder-se. A ideia do livre arbítrio é, assim, sugerida. Deus não criou nem propagou o mal, mas deu liberdade ao homem para decidir como dirigir sua vida. Outro conceito importante introduzido por Santo Agostinho, e relevante para a leitura da narrativa, é a ideia da intimidade.

[...] A alma é, em última análise, a grande descoberta de Agostinho, a alma entendida como intimidade. [...] o poder entrar em si mesmo é o que dá a condição de espiritual, não a não-materialidade. (Julián Marías, 1999/2000)

$\mathrm{Na}$ terceira edição desse texto camiliano, o preceito agostiniano parece ser retomado, mas, admiravelmente, invertido, já que, ao adentrar-se, o homem em vez de deparar-se com Deus, descobre "monstros interiores". 
O amor, tema que em Camilo costuma configurar o ponto crítico do enredo, já que tudo gira em torno da proibição dos pais às relações puras e desinteressadas de seus filhos em prol de um casamento conveniente, em Maria, não me mates que sou tua mãe, toma um rumo diferente. Matilde ama incondicional e desinteressadamente sua filha, e, em nome desse amor, permite que a moça eleja um marido, sem preocupar-se com fortuna ou nome, a única condição que impõe é que o rapaz seja "amigo do trabalho" (Branco, 1991, p. 9).

Enfocando a classe popular, Camilo revela que aí duas situações proibidas no meio burguês são possíveis: primeira, a mãe tornar-se tutora das filhas, sem a necessidade da imposição de uma figura masculina que vele pelo patrimônio familiar; segunda, a filha não possuir um dote e, por isso, o casamento conveniente não ser inevitável.

Autorizada a eleger seu namorado, a filha envolve-se com um rapaz sem escrúpulos e, movida pela paixão e luxúria, perde-se na desgraça e condenação. Maria José tem o livre arbítrio e escolhe romper com as regras morais de seu meio. Ironicamente, a proposta de amar a filha acima dos interesses financeiros e incentivá-la a unir-se a um homem por amor leva Matilde à morte. Essa contradição é uma forma de se propagarem os ideais burgueses como coerentes e acertados.

O nome dessa mulher que ousa cumprir o papel masculino de prover e educar a família de maneira diversa à institucionalizada significa "guerreira poderosa" e remete ${ }^{9}$ a duas personagens importantes, uma fictícia e outra histórica.

Na Divina Comédia, Matilde é responsável por imergir o poeta nos rios do Paraíso para que então ele saia purificado e digno de Beatriz. De acordo com os comentadores do trabalho de Dante (http, p.//www.ebooksbrasil.org/eLibris/purgatorio.html), Matilde é inspirada na Condessa de Canossa (1046 -1115).

Interessante notar que essa personagem histórica é órfã de pai, e, com a morte de sua mãe e padrasto, aos 30 anos, torna-se responsável pelo grande patrimônio de sua família, papel de liderança que, guardadas as devidas proporções, também a protagonista camiliana vai cumprir. Junto ao papa Gregório VII, Matilde representou, na época, um desafio aos nobres. O pontífice limita o poder de leigos empossarem clérigos em troca de fidelidade e frutos econômicos das paróquias, ao que o rei Henrique IV reage por

\footnotetext{
${ }^{9}$ Prof. Rosário Farâni Mansur Guérios menciona a relação entre o nome Matilde e a personagem de Dante , Guérios, 1994, p. 230.
} 
considerar um direito da coroa. Gregório VII excomunga o rei e proíbe que lhe obedeçam. Henrique IV pede perdão; no entanto, ao ser absolvido, volta-se novamente contra o poder papal e tem a seu lado o apoio dos nobres. Matilde torna-se a única nobre de renome a apoiar o papa. Atraindo preconceitos por ser uma mulher sozinha, sem marido, a condessa encabeçou e comandou batalhas, mas acabou exonerada de suas funções, e com seus bens confiscados.

Cotejando-se a figura histórica à personagem camiliana, percebe-se que ambas se empenham em propagar os valores cristãos ${ }^{10}$ e têm destinos trágicos. Essa sina poderia indicar a inutilidade da religiosidade em uma sociedade comandada por ideais materialistas. Nesse caso, a intenção didático-pedagógica, apresentada na capa do livro, se desfaria em amargo pessimismo.

O caráter religioso da mãe dedicada, retratada como "virtuosa mulher", "desgraçada viúva", "infeliz mãe", "atribulada viúva cheia de razão", "desgraçada velha", "boa mulher", "boa mãe", "infeliz e atribulada viúva e mãe de todas a mais desgraçada", "infeliz desgraçada velha", "pobre mulher" (Branco, 1991, p. 7, 8, 9, 10, 11, 13, 15, 17, 20, 23, (referemse à $1^{\mathrm{a}}$. edição), 36 - acréscimo da $3^{\mathrm{a}}$. edição), e a perseverança no cumprimento da incumbência que o marido lhe atribui ao morrer parecem fazer de Matilde uma "guerreira poderosa”, uma mártir cristã, que dá a vida por seus valores, já que padece ao ousar contrariar as regras de uma sociedade comandada pela visão masculina.

Maria José seria desonrada se não se unisse a um homem pelo casamento, a liberdade sexual só é concedida ao homem. Assim, ao perceber que a relação de Maria José com o rapaz por ela eleito só trará a desonra de sua filha, já que este não parece pretender casar-se com a moça, Matilde ameaça queixar-se ao administrador do Conselho para que os prendam no Limoeiro como filha desobediente e rapaz sedutor. No entanto, sua ousadia em ameaçar um homem será punida, pois ao saber das intenções de Matilde, o moço impõe à namorada que mate a mãe.

Maria (José), isto é "senhora", "excelsa, sublime", "predileta de Javé" (Guérios, 1994, p.227) antes de conhecer o malfeitor que a levou ao crime, era educada na religião e nos bons costumes, portava-se virtuosamente, trabalhava e obedecia à mãe, "parecia que amava sua mãe com toda a sua alma e coração ", era admirada pela vizinhança "porque já

\footnotetext{
${ }^{10} \mathrm{O}$ caráter religioso da protagonista camiliana também é sugerido por seu sobrenome "Rosário da Luz".
} 
tinha 29 anos, e ainda não havia nota ruim que se lhe pusesse, e ninguém se atrevia a pôr nela a boca. (Branco, 1991, p. 8). Nova proposta irônica se insinua: a inutilidade de uma educação esmerada em uma sociedade corrompida.

A caracterização de Maria José e do namorado diferem um pouco entre a $1^{\text {a }}$ e $3^{\text {a }}$. edições. Em ambas, no entanto, a alteração no caráter da moça ocorre ao passar a conviver com o rapaz.

"A rapariga escutou-lhe as palavras e ficou entendendo que o José Maria não era mau rapaz, e que a não buscava para maus fins." Essa visão denota inocência e ingenuidade diante de um moço que "já tinha sido acusado como vadio e ratoneiro, e era bem conhecido pelos beleguins da administração." (Branco, 1991, p. 14). Maria José configura a antítese do rapaz, apresenta "fraca resistência" diante do "brutal apetite" do namorado (Branco, 1991, p. 10); por conseguinte, sua ingenuidade acaba com o convívio com o rapaz e dá lugar à devassidão e astúcia.

Como se pretende provar, cada edição trata a história por um ângulo, a primeira, à Rousseau, apresenta uma Maria naturalmente boa, corrompida pelo convívio em sociedade; a segunda, à Dr. Jekyll and Mr. Hyde, retrata a maldade interiorizada em Maria José e o rapaz como a outra face da moça.

A primeira edição corrobora uma análise social do problema. Um narrador em $3^{\mathrm{a}}$. pessoa, onisciente, apresenta os fatos, evidenciando seu ponto de vista sobre o assunto. Exagerando nas exclamações, nas adjetivações subjetivas e nas expressões de cunho religioso, esse narrador expõe os acontecimentos acentuando seu horror perante uma sociedade corrompida: "Deus não quis tocar-lhe [à matricida] o coração porque Ele quis ver até que ponto poderiam chegar os crimes no século de desmoralização e pecado em que vivemos." (Branco, 1991, p. 14). Ironicamente, Deus é o culpado pelo crime, já que dá ao homem o livre arbítrio.

Matilde revela, em discurso direto, sua indignação sobre a mudança de comportamento de sua filha:

\footnotetext{
- Ai, minha filha - respondeu a mãe - que linguagem é hoje a tua tão diferente daquela que era antes de este maldito aqui entrar. Ai, minha filha, que estás perdida de todo! Oh meu marido! perdoa-me, perdoa-me: bem vês que eu não fui culpada. (Branco, 1991, p. 12)
} 
A mãe sofre e adverte a filha acerca do perigo que representam os homens em geral e José Maria, em particular:

\begin{abstract}
- Minha filha, eu muitas vezes te disse o que eram os homens, não que eu tivesse queixa do meu, porque teu pai era honrado e virtuoso como aqueles que o são; mas porque os rapazes de hoje em dia não são o que eram os dalgum dia.[...] Não te pude valer. Deus Nosso Senhor me perdoe - se eu não tive forças de te castigar, porque eu tinha-te muito amor, e nunca me capacitei deveras que houvesse um tredo tão grande como o José Maria. Mas já agora que não tem remédio, minha filha, filha do meu coração, em bom pano cai uma nódoa. Minha filha, por alma de teu pai que está na presença de Deus a pedir o teu perdão; pelas cinco chagas te peço que deixes esse homem, que há de acabar de te lançar na perdição, onde não acharás meios de te salvar da justiça de Deus, e das vergonhas do mundo. (Branco, 1991, p. 12)
\end{abstract}

Nessa fala de Matilde, é possível perceber a concepção de uma mulher que se considera fraca por agir pelos sentimentos e por ser incapaz de castigar a filha desobediente. Além disso, revela-se sua ingenuidade por não acreditar que pudesse haver um "tredo", ou um traiçoeiro, como aquele rapaz, permitindo-lhe a entrada em casa. Insinua-se, assim, a inaptidão de uma mulher para prover a educação da família sem a ajuda de um homem. Daí ela acreditar no auxílio do marido, que, no além, estaria suprindo sua culpa ao interceder pela salvação da filha.

José Maria é retratado de maneira caricatural como um lobo ou um lobisomem, e ainda assim as mulheres não desconfiam de seu caráter brutal:

[...] Era um rapaz de mediana estatura, ao que parecia de vinte e quatro anos. Tinha os olhos negros, e quase negras as faces. Os cabelos compridos, com a barba cerrada, pouco lhe deixavam ver das feições. Tinha a testa franzida continuamente como um matador que sente um cancro de remorso a tragar-lhe as entranhas. (Branco, 1991, p. 16 e 17)

Convivendo com José Maria, um "enganador", que tinha "o demônio no coração e a impostura na boca", "brutal apetite", era "pérfido homem", "traidor", "vadio", "ratoneiro"e "infame" (Branco, 1991, p. 10 (cinco primeiras citações), 14 e 15), Maria José passa a ser moça "sem alma, sem medo de Deus, sem temor das penas do inferno, [...] ou com alma de tigre" (Branco, 1991, p. 5 e 6). Considerada "atentada pelo demônio" (Branco, 1991, p. 15), "perversa filha", "dissoluta", "prostituta", "concubina", "malvada", "maldita e condenada" (Branco, 1991, p. 16, 17 ( três citações iniciais), 20 - duas últimas citações). Juntos, eles desdenham as regras sociais ${ }^{11}$, revelam gosto por sexo - "Sabe o que mais? [diz Maria José] Se casar, casou; se não casar é o mesmo: eu gosto e ele gosta..."

11 “Sabe o que mais? Se casar, casou; se não casar é o mesmo eu gosto e ele gosta..." (Branco, 1991, p. 6) 
(Branco, 1991, p. 14) - e desonestidade (Maria José rouba as economias da mãe para dar ao amante).

A ironia está em atribuir o nome dos pais de Jesus, figuras castas e sublimes, a pessoas sórdidas e inescrupulosas. Refaz-se, assim, o embate entre nome e essência, sugerindo-se, por extensão, que há de se investigar as qualidades de uma pessoa em vez de julgar-lhe por aquilo que aparenta.

Sem saber como impedir a corrupção total de sua filha, Matilde ameaça apelar a um poder superior, masculino:

- Pois então sabe que se eu até aqui te tratei como mãe carinhosa, de hoje em diante hei de ser mãe como deve ser. Se de hora em diante aqui tornar a ver José Maria hei de queixar-me à administração do conselho que esse homem vem a minha casa contra a minha vontade, e tu e mais ele haveis de ser atrancados no Limoeiro, tu como filha desobediente, e ele como um sedutor de uma rapariga que se deixou ir de suas palavras. (Branco, 1991, p. 13)

No entanto, sua insignificância diante do poder de um homem evidencia-se pela reação de José Maria à ameaça. O rapaz impõe à Maria José que mate sua mãe, considerando que a presença de Matilde e suas ameaças são desgraças a serem evitadas: “Maria, ou tu hás de dar cabo dessa maldita velha o mais breve, ou então eu deixo-te por uma vez, e não quero saber de desgraças.” (Branco, 1991, p. 17) Maria José titubeia, hesita, declara ter medo de matar, ter dó da mãe e receio de ser ouvida. Por fim, sugere que ele se case com ela para que o problema acabe. José Maria declara que a moça é "uma estúpida" e propõe que ela cometa o crime durante o dia, quando a mestra e as meninas que moram em cima fazem barulho, impedindo que se escute alguma coisa. Maria, "desesperada e aflita com os feios modos e destempero do seu amante" (Branco, 1991, p. 18), a moça descompõe a mãe e, em seguida, sai para encontrar o namorado.

A dor de Matilde diante da situação exaspera-se quando se depara com o roubo do dinheiro reservado para mandar rezar missas por sua alma e a de seu marido. A simonia e as consequências trágicas sobre fiéis simples e ingênuos é, assim, sugerida no livro. Essa mulher, em sua inocência, não acredita que ela e o marido possam ser salvos sem que missas sejam rezadas por suas almas. A religião, que deveria trazer alívio aos fiéis, acentua sua dor. A ironia camiliana torna-se a revelar ainda que em forma embrionária. 
O papel da mulher, subalterno ao masculino, reitera-se pelo sentimento de impotência de Maria diante de situações com as quais não sabe lidar. Os gritos de Matilde fazem a filha recorrer ao regedor e, no seguinte, submeter-se a vontade do namorado.

A dissimulação é a estratégia que resta à mulher. Assim, traiçoeiramente, sob pretexto de procurar parasitas em sua cabeça, a filha esfaqueia a mãe no lado direito do peito e, depois de esta, em discurso direto, lamentar-se por morrer sem ter-se confessado, acerta-a no pescoço, impedindo-a de alcançar uma cruz à cabeceira da cama.

Contra a ação castradora, uma facada no lado direito, símbolo do masculino, da ordem, da retidão, a razão, a tradição (Chevalier e Gheerbrant, 1994, p. 343), e outra no pescoço, "sinal da vida e da alma." (Chevalier e Gheerbrant, 1994, p. 715). Assim, Maria subjuga o que há de racional e espiritual em sua mãe. Depois, a esquarteja, alegando que, dessa forma, seria mais fácil carregar o corpo e livrar-se dele. Interessante notar que a cabeça é mutilada e enterrada na própria casa para, mais tarde, ser eliminada. Maria enterra o tronco da mãe próximo às obras de Santa Engrácia; as pernas e braços na travessa das Mônicas.

As figuras que dão nome aos locais onde os restos são enterrados enunciam a presença de um discurso intertextual que corrobora a visão de mundo do autor sugerida até aqui. O tronco, isto é, a parte central do corpo humano que reúne vísceras e órgãos vitais como os pulmões e o coração é associado a Engrácia. Essa mulher foi uma virgem lusitana, que se recusou a obedecer à vontade do pai e casar-se com um pagão rico. Defensora do cristianismo, foi torturada e mutilada para adorar os deuses pagãos, mas resistindo à dor e aos maus tratos, morre glorificada e anjos vêm entoar cânticos em seu funeral (http, p.//santaengracia-cds.blogspot.com/2005/10/santa-engrcia-histria-da-santa-mrtir.htm.)

Matilde, castigada por impor regras morais, tem a parte central de seu corpo associada à de uma mártir cristã que leva muitos à conversão depois de sua morte.

Braços e pernas, isto é, os membros responsáveis pela atividade e mobilidade motora são relacionados a Mônica, mulher cristã, cujas orações foram responsáveis pela conversão de seu filho Santo Agostinho.

Santa Mônica é o modelo desta tarefa pedagógica vital: a formação da conduta moral e religiosa do filho. Incutir pudor, mansidão, e todas essas condutas cristãs é a virtude deste exemplo de comportamento, que, além de tudo, dá o empenho da conversão, em que pese a 'debilidade estrutural da intervenção feminina no 
interior da família'. (http, p.//www.ricardocosta.com/pub/stamon.htm (VECCHIO, s/d, p. 181.))

Decepar braços e pernas parece ser um ato intuitivo de imobilizar a mãe e impedi-la de agir como Santa Mônica cujas orações e atitudes levam o filho à conversão. Como se vê, Matilde é enterrada em locais que aludem a mulheres santificadas ou pela perseverança em Deus ou, no caso de Santa Mônica, por ser modelo de mãe que vela pela fé de seu filho. A ironia está na inutilidade dos esforços da personagem camiliana que não logrará ver a filha salva; pelo contrário, Maria José será condenada à forca, levantada no campo de Santa Clara. Outro lugar que alude a uma mulher modelo de pureza e oração. Assim como Engrácia, a santa rejeita o casamento para dedicar-se à vida religiosa. Maria José, instintivamente, subjuga as intenções de sua mãe que se relacionam às mulheres santas mencionadas.

O grotesco, o esquartejamento, remete à destruição da ordem e das regras de forma excêntrica, extravagante. A deformidade, em oposição ao sublime, evidencia o caráter problemático do mundo, os desvios de comportamento em relação a um ideal de conduta. Matar e despedaçar a mãe é diabólico. O adjetivo cuja etimologia associa-se a "gritar", "divulgar o renome" sugere as ideias de "rivalidade" e "acusação" que serão aproveitadas e absorvidas pelo humor negro e pelo sarcasmo.

Grotesco vem de grotto que significa gruta ou caverna, espaço subterrâneo, daí sua associação com o que é aberrante. Um fato atroz como o matricídio revela a violação perversa das regras de uma moralidade também distorcida e cruel. Patentear o sórdido ou publicamente inconfessável é um antídoto para a banalidade do mundo oficial. Desfazem-se as imagens artificiais de ética ideal e revela-se a realidade em que há a violência da imposição de máscaras. Tudo se passa como se observar o grotesco fosse um meio de vislumbrar os dados mais profundos e impenetráveis do inconsciente humano. Esses dados ao mesmo tempo em que horrorizam são base para o humor em vários momentos históricos. ${ }^{12}$

\footnotetext{
${ }^{12}$ Minois, 2003, trata do grotesco como fonte de humor sobretudo nas p. 94 a 96 e 138 a 144.
} 
A primeira edição toma, portanto, o caso como motivo de análise social e de meditação de cunho religioso; na introdução à narrativa, já se enuncia o motivo do crime: "Vereis uma filha matar sua mãe, porque esta lhe não deixava fazer o quanto desejava." (Branco, 1991, p. 5). As cenas são retratadas com grande dramaticidade, sobretudo, pelo uso constante do discurso direto. Para finalizar, o narrador exorta o leitor em tom profético:

Estes atentados contra Deus, esta guerra de irmãos contra irmãos, estes acontecimentos de filhos matarem os pais, e esses sinais que nos aparecem no céu, tudo indica que o fim do mundo está chegando. (Branco, 1991, p. 26)

Ressalta-se ainda a questão de gênero masculino e feminino. A mulher é considerada frágil e facilmente manipulável pelo homem. Matilde é incapaz de cumprir a função do homem da casa e manter a filha na linha de conduta condizente com o que se espera naquela sociedade, não só porque valoriza os sentimentos acima da razão, dando à filha o direito de eleger um marido que a agrade, como também por ser fisicamente mais fraca. ${ }^{13}$ Também Maria José sucumbe no universo masculino, é seduzida por José Maria e recorre a um homem - o regedor - em busca de livrar-se da ameaça da mãe, mas vem a ser presa por esse mesmo homem. ${ }^{14}$

A complexidade do ser humano é sugerida pela ambiguidade entre o homem ser apresentado como imprescindível para assegurar o bom andamento da vida familiar e, por outro, levar Maria à perdição ${ }^{15}$.

\footnotetext{
13 “Quis fugir pela porta, mas o José Maria e Maria José não a deixaram[...]”Branco, 1991, p. 17.

${ }^{14}$ Ingenuamente, Maria depois de matar a mãe vai ao regedor dizer que sua mãe já estava boa e não precisava mais ser internada.

${ }^{15}$ Antes desse encontro Maria José era cândida e pura e sua vida só tinha presença feminina, morava com a mãe e era vizinha de uma mestra de meninas.
} 


\section{2 Da dualidade feminina}

A terceira edição, no entanto, dá um novo enfoque aos fatos. Composta pelo método da concisão e extensão, sintetiza o enredo anterior, acrescentando-lhe elementos narrativoestruturais: personagens, episódios, motivos, temas e hipotipos ${ }^{16}$ (como a passagem do discurso direto para o indireto). Consequentemente, a nova versão da história amplia seu significado e cria novas possibilidades de interpretação.

O narrador, também em $3^{a}$. pessoa, onisciente, e igualmente sentimental já não é a única voz da narrativa, pois, ao acrescentar-se o julgamento de Maria José, certa ambiguidade na narrativa é gerada, uma vez que o ponto de vista enfatizado parece ser o de Maria José, já que a história simplesmente repete o depoimento da moça. Corrobora essa suposição, a transposição do que na primeira edição estava em discurso direto para o indireto, o que parece indicar que a narrativa remete a um relato por meio do qual se dá a reconstituição das cenas. Por conseguinte, alguns episódios podem ser meramente produto da imaginação da moça.

A ambiguidade parece permear toda a narrativa. O texto inicia-se apresentando um novo motivo para o crime, não se trata de uma mãe que não quis fazer tudo o que a filha desejava, como na primeira edição, mas o matricídio é consequência de uma "educação pouco desvelada". O termo "desvelada", além de significar "ter cuidado", "vigiar, diligenciar, cuidar", como verbo transitivo direto remete a "tirar o véu a", "descobrir", "esclarecer", "patentear", o que pode insinuar que a razão por que Maria José matou a mãe seria seu parco conhecimento de mundo e de si mesma. Talvez a cosmovisão restrita de Matilde, mulher que vive para a casa e para a religião, impossibilite-a de esclarecer à filha sobre a profundidade do ser humano. Cumpre lembrar que à mulher da época não se estimula a introspecção e sondagem interior, várias atividades lhes são proporcionadas para que não percam tempo meditando.

[...]Abandonada a si mesma, a mulher aplicou aquela curiosidade desassossegada de se encontrar, que o ócio acentuava, no interesse pela moda. Enquanto ao

\footnotetext{
${ }^{16}$ A nomenclatura usada é de Genette, 1997.
} 
companheiro a sociedade permitia a realização integral da individualidade na profissão, nas ciências ou nas artes,a ela negava interesses de outro tipo além dos ligados à casa, aos filhos e a sua pessoa. Era como se não tivesse um cérebro, como se o exercício da inteligência tornasse duros os seus traços e lhe empanasse o brilho da virtude. As preocupações do espírito, estas eram privativas do homem, dono das artes, da literatura e do destino de seus semelhantes. (Souza, 1996, p. 99)

Embora Maria José pertença a uma classe que não lhe possibilita o ócio, suas atividades the proporcionam momentos de solidão e isolamento: "durante o dia, vendia numa pequenina tenda que sua mãe tinha podido arranjar-lhe, e à noite aprendia rezas e orações à Santíssima Virgem, que sua mãe nunca se cansava de ensinar-lhe."17

Maria, conforme declara no julgamento, vende "obras de esparto", isto é, trabalho artesanal em que se confeccionam cestos, esteiras, capachos, cintos, pelo trançado de uma planta gramínea. De um mato flexível, surgem rígidas tranças que se transformam em diversos objetos de decoração. Essa menção parece sugerir que, assim como a trama do esparto, alguns pensamentos maleáveis, dóceis, submissos, podem ter tomado formas mais rigorosas e severas, enformando seu texto no julgamento. A solidão da tenda possibilita também momentos a sós com José Maria. Caso haja esses encontros, eles poderão reconhecer-se e identificar-se. Esse espelhamento em seu duplo favoreceria a autoconsciência da moça e lhe ampliaria características até então encobertas.

O parco esclarecimento de si e da vida poderia, outrossim, tornar Maria José vulnerável às mais variadas influências e tentações. Daí o alerta do narrador: "'Vigiai e orai para que não entreis em tentação' Orai, ó povos, e pedi a Deus e a sua Santíssima Mãe que vos livrem das tentações do demônio, que tentou Maria a cometer o maior de todos os crimes." (Branco, 1991, p. 38) A admoestação enfatiza a importância do "vigiar", isto é, velar, estar alerta, para que não se caia em tentação como se o impulso para o assassinato fizesse parte do inconsciente humano. Sugere-se, dessa maneira, a possibilidade de o matricídio ter sido resultado de uma força psicológica ("a tentação") a induzir ao mal. Essa

\footnotetext{
${ }^{17}$ Branco, 1991, p. 34. Note-se a ênfase dada à atenção da mãe à filha pela repetição de "sua mãe" arranjou ou "sua mãe" ensinou.
} 
visão parece recuperar as teorias dos filósofos românticos alemães acerca do interior humano e reforça a ideia do grotesco como conteúdo do universo interior do homem.

Para Schubert ${ }^{18}$, por exemplo, o sistema ganglionar relaciona-se às atividades inconscientes, onde estão as forças noturnas, isto é, lúgubres, soturnas, da alma humana. Quando o sistema ganglionar é dominado pelo sistema cerebral, essas forças são inibidas e dominadas; mas em estado de sono, loucura, dupla personalidade, sonambulismo, essa energia domina o homem e prevalece sobre seu lado racional.

O sistema ganglionar não é somente responsável pela união do homem ao inconsciente divino e cósmico, mas ele também é capaz de levá-lo a realizar atos criminosos e abomináveis, podendo captar, na mesma intensidade, as influências malignas. (Andrade, 2001, p. 109)

Outro motivo de Maria José ter cometido o crime volta a relacionar-se ao tipo de educação que recebera. A moça parece ser a preferida da mãe, já que com a morte do marido, Matilde manda a outra filha para casa de pessoas para trabalhar e mantém Maria consigo de maneira muito carinhosa "se matava de trabalhar para lhe granjear o necessário sustento corporal e espiritual.” (Branco, 1991, p. 34). Educada como o centro das atenções da mãe, a moça não sabe lidar com restrições e limites e a repreensão quanto ao namoro vem a ser a primeira castração a que é submetida. Enquanto para Freud, a castração é motivo de recalque e denegação, isto é enviar para o inconsciente o que não é agradável; para Jung, é alicerce o sujeito relacionar-se com o mundo, admitindo sua subjetividade. O castrar corresponde ao reconhecimento de limites e a admissão da fraqueza.

A vulnerabilidade da auto-estima torna os indivíduos com Transtorno da Personalidade Narcisista muito sensíveis a "mágoas" por críticas ou derrotas. Embora possam não demonstrar abertamente, as críticas podem assolar esses indivíduos e levá-los a se sentirem humilhados, degradados e vazios. Sua reação pode ser de desdém, raiva ou contra-ataque afrontoso. (http, p.//virtualpsy.locaweb.com.br/dsm janela.php?cod=162)

A agressividade ("tentação") de Maria pode, portanto, ter sido motivada pelo ego ferido. Essa possibilidade pode ser justificada pelo tratamento dado ao corpo da genitora

${ }_{18}$ Andrade, 2001, sintetiza com maestria as vertentes da filosofia alemã. O pensamento de Schubert é retratado nas p. 85 a 90 . 
depois da morte. Não basta matar a mãe, Maria José a decapita e esquarteja. O princípio ativo que simboliza a autoridade de governar, de ordenar, de instruir é eliminado com toda a autoridade e soberania da mãe> Cortando-lhe a cabeça, Maria livra-se do que a incomoda e lhe restringe a liberdade.

Depois, a filha separa o tronco dos membros. Arranca os braços e mãos que representam a força, o poder de dominação. Separa as pernas e pés que dão suporte vertical ao ser humano, isto é, asseguram-lhe postura soberana. Além disso, mutila a face da mãe, extrai-lhe o nariz, as orelhas e os lábios e queima-lhe os cabelos. A desfiguração ressalta o grotesco, a violência e parece ser uma forma de banir as características intelectuais, morais e emocionais da mãe.

Outro acréscimo significativo é local onde alguns membros são enterrados. Agora não se faz menção apenas a figuras religiosas, mas alude-se à rua Marquês de Loulé que remete à personagem histórica célebre por seus títulos de nobreza, que não lhe livraram de ser alvo de suspeita de assassinato dos filhos de D. Pedro, já que enquanto foi presidente do conselho e ministro do reino houve a morte de D. Pedro V e do infante D. Fernando em Novembro de 1861, e a do infante D. João em Dezembro seguinte, correndo também grande perigo a vida do infante D. Augusto, que pôde salvar-se. Sugiram, então, rumores de que o marquês poderia ter envenenado as crianças para que seu primogênito, neto legítimo de D. João VI, fosse o sucessor do trono. Mais tarde sua inocência foi comprovada. (Dicionário Histórico, Corográfico, Heráldico, Biográfico, Bibliográfico, Numismático e Artístico, Volume IV, p. 523 a 525.)

Como se pode perceber, a nova edição apresenta algumas modificações que promovem ampliações de sentido. Essa versão propõe uma análise psicológica e social dos fatos. As vinte páginas que narram a história em Maria, não me mates que sou tua mãe! são reduzidas a seis na terceira edição, isso porque o enredo é sintetizado e ligeiramente modificado. Das mudanças, as mais significativas implicarão a transformação de Maria José. Essa metamorfose decorrerá, sobretudo, da ambiguidade do foco narrativo, criada pela inserção do julgamento, da nova apresentação da personagem José Maria e pela supressão do discurso direto. O narrador dá voz à Maria, o que tem por consequência um 
discurso mais subjetivo, assim os fatos podem ser contestados, perdem um pouco de sua plausibilidade.

Assim, o namorado, cujo nome já sugere um espelhamento, pode ser um duplo, um ser semelhante a ela ou fruto de sua imaginação, já que nenhuma personagem parece conhecer José Maria a não ser a matricida que o cita no julgamento. Mencionado apenas pelo narrador, que repete a versão de Maria José, o rapaz poderia ser apenas um alter ego da matricida, criado por sua mente perturbada.

$\mathrm{Na}$ terceira edição, o narrador introduz a personagem como um ser dissimulado e diabólico: "Mas o demônio que se apresenta debaixo de muitas formas, para conseguir tentá-la, fez com que a rapariga encontrasse um dia um desses rapazes que se fazem de sonsos [...]"(Branco, 1991, p. 34). Novos adjetivos, de cunho psicológico, são empregados em gradação para caracterizar a personagem: "malvado", isto é, "perverso, celerado, malfeitor" e "maldito" ou "amaldiçoado, funesto, abominável, nefando, sacrílego". Sugerese, dessa forma, o caráter diabólico de José Maria que corresponde à tentação que impulsiona a práticas condenáveis, como fora enunciado pelo narrador.

Os testemunhos do julgamento parecem acentuar o caráter misterioso dessa personagem. Segundo depoimentos, José Maria nunca foi visto na casa da acusada; além disso, Maria não sabe identificar o endereço, nem o sobrenome do rapaz, com quem teria convivido catorze meses. Cria-se, assim, uma questão: José Maria poderia ser produto da imaginação de Maria José? Um ser tecido, como obra de esparto? Seria apenas o lado sombrio da personalidade da moça, como um espelho; daí a coincidência e inversão do nome? Ou a moça dissimula e omite informações para proteger seu duplo? Fruto de uma educação pouco desvelada, Maria José é incapaz de reconhecer-se, mas momentos de solidão lhe fornecem um espelho. "Os espelhos simbolizam as possibilidades que tem a Essência de determinar a si mesma; [...] a reciprocidade das consciências" (Chevalier e Gheerbant, 1994, p. 396)

O encontro com o outro possibilita o desenvolvimento de características latentes em Maria José. O que estava submerso emerge pela identificação com seu duplo. O espelho consiste em um desdobramento psicológico, um sujeito torna-se dois. Nesse sentido, José 
Maria consistiria no lado sombrio da moça. O duplo diabólico que desperta no indivíduo os vícios que estão ocultos, mas existem, nas profundezas da alma.

Toda creatura individual, por encima y a um lado de ella, tiene su contrario, que es al mismo tiempo su complemento y que viene a compensar los defectos o las deficiências de la vida separada... Porque estas lagunas son los vasos de elección em que viven a derramarse las fuerzas de la vida superior. Schubert (Apud Béguin, 1993, p. 156)

Valida essa suposição o fato de em Matricídio sem exemplo, as razões apresentadas para o crime diferirem das apresentadas na primeira edição, agora elas parecem ser do interesse da moça. No relato do narrador e no testemunho de Maria, o rapaz teria sugerido o assassinato por dinheiro que repartiria com a namorada, uma vez que se tratava de herança ou de gastar com "criminosos como ele":

Este malvado aconselhou-a que matasse sua mãe! porque lhe tinha pressentido algum dinheiro, e queria botar-lhe a mão, para o gastar com outros criminosos como ele. (Branco, 1991, p. 36)

[...] [José Maria] tinha questões com minha mãe, porque lhe tinha pedido metade da herança, e como ela recusasse, na manhã do dia 12 deu-lhe uma facada com que a matou, e safou-se.

[...]O José Maria foi quem a matou, e eu esquartejei-a; levando ele parte do dinheiro que eu tinha num pé de meia, prometendo depois dar-mo. (Branco, 1991, p. 55)

Nessa versão, a filha não titubeia, nem hesita: mata. Matilde morre abraçada a uma cruz. Morrem a lei e a religiosidade, a ética e a moral. A ação fria e decisiva da moça destoa da insegurança e temor que apresenta na $1^{a}$. edição. Nesse sentido, a mudança de um motivo dá relevo à ambiguidade da personagem. Se José Maria apenas for a face sombria de Maria José, ela é a autora e mentora do matricídio.

Corrobora essa hipótese o fato de depois do matricídio, Maria José ter sonhos aterrorizantes, ver "espectros medonhos, que caminham para ela, e lhe mostram a faca ainda tinta do sangue de sua mãe e a machada com que lhe despedaçara o corpo." (Branco, 1991, p. 37). No sonho, o desdobramento é evidente. Não é ela quem carrega as armas, mas "espectros medonhos". O desdobramento no sonho e nos espectros reforça a ideia do duplo, do reconhecer-se no outro. 
[Assim como no universo do romance do alemão Hoffmann]. En este mundo estamos expuestos a encontrar a cada momento figuras burlescas y temibles, a toparnos de pronto com nuestro doble, a ver cómo los más apacibles consejeros íntimos se agitan como diablos y hacen cabriolas como títeres manejados por manos inhábiles. (Béguin, 1993, p. 366)

Os gestos e atitudes de Maria no julgamento validam a hipótese de a personagem apresentar dualidade de caráter. Maria José comparece ao julgamento, animada, com passo firme e olhos quase sempre imóveis, seu testemunho é contraditório: ora acusa José Maria, ora confessa-se a única responsável pelo crime, além disso, não considera o feito uma barbaridade, isto é, uma crueldade ou desumanidade. Diz não saber por que enterrou as partes do corpo da mãe em diferentes lugares e afirma receber com a visita de José Maria a de uma criança de três anos que vinha de fora da terra. Com a identificação com o outro, surge a criança, isto é, características veladas ou recalcadas podem retornar. Sua identidade encoberta e descuidada por uma rotina e pela religiosidade afloram e renascem.

Insinua-se, assim, tratar-se de uma mente perturbada, de um ser em desordem psicológica, o que corrobora a tese de seu advogado de que a acusada estava fora do "uso de suas faculdades intelectuais".

Um novo motivo enuncia-se pela inserção da personagem do advogado. A crítica ao ardil dessa classe, que manipula fatos pela arte de fazer nascer o equívoco pela linguagem verifica-se no comentário irônico do narrador: "soube honrar a nobre profissão de advogado" (Branco, 1991, p. 55):

É uma representação, eficacíssima, de como através sucessivas interpretações a mensagem é mensagem é desconstruída e levada a exprimir não somente aquilo que o emitente original não queria dizer, mas talvez até aquilo que essa mensagem, como manifestação linear de um texto, equiparado a um código, não deveria dizer, se uma comunidade de intérpretes, inspirada no bom senso e no respeito às regras, chegasse a um acordo, em fatigante interação, para dela extrair uma leitura publicamente aceitável. (Eco, 2006, p. 34)

A história é, portanto, narrada de maneira subjetiva. Por extensão, põe-se em causa, de maneira irônica, dissimulada, a própria tessitura literária que é urdida com fins peculiares de conquistar o interesse do público. O fato de histórias de "faca e alguidar" serem atraentes ao público parece ser o motivo de Camilo transformar uma notícia de jornal em uma narrativa de cordel. A consciência do escritor de que o sensacionalismo atrai muitos espectadores é patente pelas menções feitas a quão repleta estava a sala do julgamento, "cheia de espectadores de todas as classes e hierarquias." (Branco, 1991, p. 39 
e 59). O grotesco é um meio de Camilo Castelo Branco atrair seu público para dissimuladamente começar a problematizar os padrões estabelecidos. No decorrer de sua carreira, o tema servirá para despertar o humor destrutivo e sagaz.

Assim, a narrativa de Camilo ultrapassa os limites de uma arte de cunho social, que seria mero documentário da realidade da época, e amplia seu significado ao tratar do tema o interior humano, abrangente e inesgotável, e da própria literatura como arte de iludir.

O final do texto não apresenta uma solução para o problema da ambiguidade do ser humano, nem deixa o leitor apaziguado, mas repete a violência em busca de evitar que novos crimes como aquele se repitam. A situação de desequilíbrio permanece e proporciona, com isso, que a leitura se abra a várias interpretações.

\section{3 Da dualidade humana}

Nas mãos de Fernando Gomes, o texto parece ganhar um novo tratamento crítico e psicológico, isso porque são acrescentados arquétipos que ampliam a visão camiliana acerca do episódio. Além disso, o humor promove um questionamento acerca de aspectoschave da cultura portuguesa. Para compreender-se a importância dessa visão, há que se retomarem alguns conceitos de Jung, já que para Freud o inconsciente é local onde se armazenam recalques e sublimações individuais, não tem significação social abrangente.

Jung, por seu turno, cria o conceito de inconsciente coletivo, ao referir-se a uma parte da psique que não é formada pela repressão de experiências pessoais ou por conteúdos que já foram conscientes - o que constitui o inconsciente pessoal -, mas por imagens e ideias presentes em todo tempo e em todo lugar: os arquétipos. Essas imagens não são conscientes, mas produtos espontâneos do inconsciente que às vezes manifesta-se em sonhos.

No caso do dramaturgo em questão, os arquétipos parecem ter aflorado, graças à sua imaginação ativa, " uma sequência de fantasias que é gerada pela concentração intencional." (Jung, 2002, p. 59). Assim, surgem na peça as imagens da Lua, do Sol, de São Sebastião, do lobo e lobisomem. Resta analisar os arquétipos a fim de verificarem-se a mundividência do autor e sua colaboração na adaptação da narrativa camiliana. 
Para apreender-se o trajeto transcorrido pelo dramaturgo, é necessário analisar a peça, cotejando-a com seus hipotextos: Maria, não me mates que sou tua mãe! e Matricídio sem exemplo. De início, causa estranhamento que Fernando Gomes tenha elegido preferencialmente a primeira edição do cordel camiliano em detrimento da terceira, que, como já se analisou, ganha em profundidade. Esta parece ter sido resgatada na peça somente em três momentos em que se transcrevem trechos da fala do narrador. A história que o drama narra remete essencialmente à primeira edição. No entanto, os acréscimos ampliam substancialmente o significado do texto camiliano.

A peça de Fernando Gomes é composta por um ato dividido em 30 cenas, em que se destaca a presença da personagem Maria José, já que ela participa de onze cenas, e é mencionada nas demais. Se na narrativa camiliana as qualidades da mãe são retratadas com ênfase, na do dramaturgo, Maria José ganha este relevo, ocorre, assim, a "transvalorização 19 " de personagem.

As rubricas não são precisas quanto ao cenário. Tudo se passa em Lisboa, conforme anuncia o narrador, o leitor compreende tratar-se de cinco espaços diferentes: a casa de Maria José, a tasca, o convento, a rua e o tribunal; no entanto, apenas uma vez se menciona a divisão do palco em três locais diferentes:

(MARIA JOSÉ DESPEDE-SE DA MÃE E COM O SEU CARRINHO CHEIO DE FLORES VAI PARA A RUA. À ESQUERDA ESTÃO AS CARMELITAS E A IRMÃ. À DIREITA A MÃE, QUE REZA. MAIS TARDE SURGIRÁ O JOSÉ MARIA.) (Gomes, p.19)

Quanto ao mobiliário, há referência à "mesa" na casa de Matilde, na tasca e no tribunal. Esse móvel é um meio de aproximar pessoas e de colocá-las umas frente a outras, familiarmente, o que pode possibilitar o confronto e acareação de ideias; remete, outrossim, a alimento, isto é, o que nutre, sustenta, estimula e incentiva o indivíduo. Outro adereço que está presente tanto na casa de Maria quanto no convento é um altar, outra espécie de mesa, agora destinada à veneração. Diante dessa peça, a pessoa é levada a rever sua vida e expô-la ao santo de sua devoção; nesse sentido, o altar propicia um enfrentamento que leva à análise e exame interior.

\footnotetext{
${ }^{19}$ Transvalorizar, para Genette corresponde a acentuar o valor de ações, atitudes e sentimentos que constituem uma personagem.
} 
Desfilam por esses cenários as personagens retiradas da narrativa camiliana: Matilde, Agostinho, Maria José e sua irmã, José Maria, o juiz e os que compõem o tribunal, entre outras figuras criadas por Fernando Gomes: Zé Coxo, um padre, um fadista, um bêbado, três carmelitas: Lua, Sol e Bondade; São Sebastião, e cinco cegos. O acréscimo de personagens será fundamental para a alteração no significado do hipotexto. Padres simpáticos e debochados, mendigos, taverneiras, bêbados e prostitutas povoam as peças gomesianas. Eles representam um grupo inconvencional, livre para expressar-se. Disformes, os mendigos contrapõem-se ao ideal de belo ao mesmo tempo em que são porta-vozes de opiniões não-oficiais. Função semelhante têm os bêbados ou os padres glutões. Dedicados à vida material e corporal, simbolizam a alegria. Também as tavernas e a embriaguez representam a libertação; nesse local, as obscenidades, o riso, a música tomam o lugar das regras do mundo oficial. A prostituta afronta o convencional e indica que o prazer existe e pode ser vivenciado. Essas personagens insinuam-se sob outras figuras, sugerindo o desprezo pelas normas estabelecidas.

Do mesmo círculo de marginalizados, Diogo Alves, assassino que viveu em meados do século XIX, é citado e permite situar a história temporalmente. Não há alusão ao vestuário. Como Fernando Gomes é o encenador de suas peças, ele não se preocupa em detalhar informações geralmente destinadas a orientar outros diretores.

A peça se abre lançando mão do recurso da transvocalização ${ }^{20}$, isto é, o que no cordel é comentado pelo narrador como prólogo à história, no palco várias personagens dividem essa tarefa. Somente na cena dois entram Agostinho e sua família interpretando o que um narrador conta: a felicidade beata em meio à pobreza. Nessa cena, uma característica de Agostinho é acrescentada, ele é retratado como alguém que trata a esposa com boas maneiras. A família parece representar o povo português em sua cultura e linguagem, visão ressaltada pela inserção de ditados populares. Como o nome indica, o ditado popular é a expressão da cultura do povo, por meio do qual se veiculam exemplos morais, filosóficos e religiosos. Seguem provérbios e expressões coloquiais presentes na peça:

\footnotetext{
Eram pobres... talvez; mas muito honrados (inserção de "talvez")

$\mathrm{E}$ a honradez era a riqueza e o orgulho daquela gente

Tanta felicidade nem parecia deste mundo
}

\footnotetext{
${ }^{20}$ Genette chama de transvocalização a alteração do foco narrativo.
} 
Quem nada tem com pouco se contenta (p. 3 )

"Cada um tem sua pedra" (paródia de "Cada um tem sua cruz")

O cascalho que o diabo amassou" (p8) (paródia a "O pão que o diabo amassou")

E quando Deus quer, não há santo que se atreva a contrariá-lo (p. 15)

vão ter que comer sopa de pedra (p. 17)

Quem não vê não peca

O pecado mora ao lado (p. 19)

Deus é testemunha (p. 25)

Damos o dito por não dito (p. 26)

Ninguém quer levar a tristeza para casa...

Não me atira mais poeira pros olhos (p. 29)

Quem pela erinha passou,

E um raminho não tirou,

Do seu amor não se lembrou (p. 30)

Ente marido e mulher ninguém meta a colher (p. 42 refere-se ironicamente à relação entre Matilde e sua filha)

Os temas veiculados pelos ditados e provérbios referem-se a alguns valores do povo português, como honradez, religiosidade, temor a Deus, aceitação pacífica das contrariedades, trabalho braçal, malícia para evitar ilusões e decepções e o distanciamento de problemas conjugais alheios. A versão da narrativa também apresentará uma concepção do povo português.

Retrato da alma do povo, os ditados veiculam os valores e as crenças portuguesas. Reformá-los sugere uma das funções do humor gomesiano: alterar ideologias aceitas e veiculadas sem questionamento, nem inferências. Os provérbios são conceitos-chave acolhidos como premissa. Infiltram-se no imaginário coletivo como dogmas e enformam a mentalidade popular. A alteração dos dizeres gera o riso e promove a análise crítica de seus valores, o estranhamento ao que é instituído.

A paródia ou alteração de alguns ditos sugere uma revisão crítica da cultura popular. A resignação associada a uma religiosidade beata e acrítica proposta pela maioria dos ditados parece ser a base da ideologia do povo a ser questionada e problematizada por Gomes.

Com esse intuito, a religiosidade que beira à superstição é retratada na cena três, um acréscimo de episódio. Enfoca-se, então, um jantar da família de Agostinho. Com o atraso do marido, Matilde desespera-se e apela aos santos, em ladainha com as filhas. A chegada do pai apazigua a família, mas é pretexto para as mulheres exporem o que cada uma faria se algo acontecesse ao patriarca. Esse acréscimo é relevante, já que a personalidade de cada uma das mulheres é, então, sugerida. 
O destino de cada uma das mulheres diferencia-se substancialmente daquele apresentado por Camilo. Maria do Céu, cujo nome constitui um acréscimo e parece sugerir seu caráter contemplativo, é passiva e limita-se a planejar sua ida para um convento. Matilde, ainda mais inerte, declara que se vestiria de negro, não mais comeria, nem beberia, nem cortaria os cabelos, como evidência de seu sofrimento. A apatia de Matilde em decorrência da ausência do marido sugere um estado de alienação doentio que resultaria numa alteração significativa em sua aparência, o que, do seu ponto de vista, poderia ser associado ao aspecto de um "belizomem" ou lobisomem. "E que me importaria, se tu tinhas partido para sempre?! O povo, ao passar, até podia dizer horrorizado: Está ali um belizomem! Está ali um belizomem!” (Gomes, p. 5). Essa imagem é reiterada pela escolha da cor da roupa. $\mathrm{O}$ negro remete à selvageria, impulsividade assassina.

Sem o saber, Matilde aponta para o distúrbio psiquiátrico da licantropia, isto é, um transtorno de identidade que pode decorrer de um distúrbio afetivo e leva o paciente a sentir-se como um animal. O problema pode ser de ordem psiquiátrica e indicar emoções suprimidas, especialmente de ordem agressiva ou sexual, através da figura do animal; ou algo factício para obter algum tipo de gratificação ou atenção (http, p.//brasiliavirtual.info/tudo-sobre/licantropia e http, p.//www.einstein.br/REVISTA/arquivos/PDF/216-Vol4_N1_P59.pdf.) Em qualquer um dos casos, a mudança de personalidade de Matilde sugere um caráter selvagem e devorador. O lobisomem simboliza um obstáculo no caminho para a libertação ou individuação. (Chevalier e Gheerbrant, 1994, p. 557). Essa imagem pode ser associada à dualidade do arquétipo da Grande Mãe, que, de tanto abrigar e acolher, sufoca, aprisiona e oprime. Assumindo o lugar do lobo-alfa, ela consumiria outros seres, como um animal faminto.

Como sombra leal e devota da mãe, sugada pela sua apatia, Maria José parece querer suprir a inação da mãe ao se dispor a ir à rua pedir esmolas a fim de mandar rezar missas para a alma do pai. A atividade e iniciativa de Maria José parecem fruto de um esforço por agradar a mãe, já que se destinam a colocar em prática um dos preceitos da matriarca: a religiosidade. Não há uma característica pessoal de Maria José enunciada por sua intenção, apenas uma identificação com os valores da mãe e uma projeção de sua personalidade. Seu mundo instintivo parece obliterado pela figura materna, e ela configurase como mero prolongamento da mãe. 
Satisfeito por sentir-se necessário em sua casa, Agostinho relaxa após ter-se sobrecarregado no trabalho para ajudar Zé Coxo, um funcionário da pedreira que sofre de pedras nos rins e, por isso, não consegue quebrar as pedras. O colega de trabalho é personagem que não consta da narrativa camiliana e parece constituir uma ironia, suas pedras, aparentemente um entrave para o trabalho, possibilitam-lhe momentos de descanso. Além disso, uma voz comenta: "A continuar assim, qualquer dia nem precisa de trabalhar! Monta uma pedreira por conta própria!” Já Agostinho, que não tem pedras nos rins, trabalha demais e sucumbe, caindo como morto sobre o prato.

A cena quatro acrescenta um fadista, que também será considerado janota, um padre e um bêbado. $\mathrm{O}$ fadista narra uma história sensacionalista acerca de um embate entre um colega apelidado Cinco Chagas e um touro cornibaixo. Enquanto o padre presta atenção e parece entusiasmado com a narrativa - exatamente como o público que se anima com as histórias sensacionalistas -, o bêbado tece comentários que podem ser considerados uma crítica aos que se deleitam com escândalos, atitudes chocantes ou hábitos exóticos. "O touro é uma besta só por si... besta é o Cinco Chagas para se pôr na frente dos cornos de um cornibaixo e mais besta ainda é todo aquele que vai ver estas bestialidades!” (Gomes, p. 8). A bebedeira é uma forma de romper com as regras de uma sociedade que impõe a seriedade e o desapego aos prazeres como condição para a manutenção da ordem. Por meio dessa personagem, críticas contundentes serão feitas.

A reprovação aos que cultivam o sensacionalismo, seja como espectador, seja como divulgador, será retomada no decorrer da peça.

Na continuação da cena, Maria José irrompe, obstando o início de uma discussão entre o fadista e o bêbado. A moça vem atordoada solicitar socorro ao pai, desastrada, derruba tudo o que está sobre a mesa da tasca.

O caráter imperativo (ou devorador) de Matilde é recuperado na cena cinco em que impõe a Maria do Céu o que fazer e como agir, outro acréscimo de episódio e situação. Sem iniciativa, a filha limita-se a obedecer à mãe de maneira submissa. Enquanto põe a filha para rezar, Matilde tenta reanimar o marido. Agostinho volta a si e tenta falar, mas a esposa o impede, preenchendo suas reticências de maneira afoita. Quando consegue expressar-se, o marido atribui à esposa o papel de sustentar as filhas, deixando-lhe como herança uma mala cheia de cascalho, que não parece referir-se ao cunho da palavra na gíria 
de Portugal: dinheiro, mas a mais sofrimento, "dureza". A cena encerra-se contextualizando a narração como um depoimento de Zé Coxo em juízo. Durante a cena aflitiva, Maria José olha obliquamente para o janota.

O episódio seguinte constitui uma substituição, em vez de, como no cordel, a outra filha ser enviada a uma casa de família para servir, ela decide ir para o convento das Carmelitas Descalças. Ao adentrar uma ordem contemplativa, que propõe a vida em clausura e o respeito à amizade, à oração e ao trabalho, a moça parece apresentar a falta de interesse pela vida em família, o que é reforçado por sua declaração de que, em vez de chorar como a mãe e irmã, observa ou faz alguma coisa para "desanuviar".

A cena inicia-se com o acréscimo de episódio, personagens e motivo. No convento, as irmãs Lua, Sol e Bondade conversam. Lua é castradora, diz ter-se tornado cega para não pecar pelo olhar; repreende Sol por esta admirar a beleza de São Sebastião, recomenda-lhe flagelar-se e, se necessário, arrancar os próprios olhos . Ela vive tropeçando e quebrando seus óculos escuros; para a freira, esses choques são um aviso divino de que caminhava por lugares errados; no entanto, o caráter cômico da cena sugere sua incompetência em lidar com a realidade circundante. Além disso, quebrar os óculos com tanta frequência pode insinuar o desejo latente de desobstruir a visão e enxergar realmente. Corrobora essa acepção da Lua como entidade repressora seu significado na Astrologia e nas cartas. No Tarô, o $18^{\circ}$. Arcano remete à tristeza, à neurose, ao fanatismo, às chantagens e aos extravios. (Chevalier e Gheerbrant, 1994, p. 565)

Na mitologia, folclore, contos populares e poesia, este símbolo [Lua] diz respeito à divindade da mulher e à força fecundadora da vida, encarnadas nas divindades da fecundidade vegetal e animal, fundidas no culto da Grande Mãe (Mater magna). Essa corrente eterna e universal se prolonga no simbolismo astrológico, que associa ao astro das noites a presença da influência materna no indivíduo, enquanto mãe-alimento, mãe-calor, mãe-carinho, mãe-universo afetivo. (Chevalier e Gheerbrant, 1994, p. 564)

Irmã Sol, por seu turno, é mais "humana", não só por contemplar o homem-santo, como por fingir que se flagela. A simbologia do Sol também valida sua concepção na peça. O Sol é o princípio ativo, já que ilumina enquanto a Lua apenas reflete a luz solar. Por isso

representa o rosto que a personalidade apresenta nas suas mais elevadas sínteses psíquicas, no nível das suas maiores exigências, das suas mais elevadas aspirações, da sua mais forte individualização, ou no malogro feito de orgulho ou de delírio de poder. (Chevalier e Gheerbrant, 1994, pp. 839 e 840) 
Assim, o Sol representa o ser em harmonia com a natureza, a clareza de julgamento e expressão, a verdade do ser e do mundo, enquanto luz do conhecimento e fonte de energia.

Bondade parece alheia a tudo, limita-se a observar os animais e a tratá-los com amor. É contemplativa, não parece pertencer ao plano terreno.

Verifica-se, na caracterização das três freiras, um desdobramento de Matilde, Maria José e Maria do Céu. Como a Lua, Matilde é imperativa e repressora; como Sol, Maria também se interessa por saber o que há além dos limites de sua casa, como, por exemplo, quando observa obliquamente o janota; como Bondade, Céu aliena-se. Além desse espelhamento, Lua e Sol são arquétipos. Aquela, da mulher em suas múltiplas faces, seu psiquismo sombrio, sua instabilidade; este, da luz que aguça o conhecimento. Dessa forma, o convento reflete a vida em família ${ }^{21}$ ao mesmo tempo em que aponta para um novo significado: a psicologia feminina instável e a busca por conhecimento.

$\mathrm{O}$ desdobramento, o reflexo ou o duplo podem corresponder à imagem no espelho, que propicia o encontro consigo mesmo. Assim também o encontro entre Maria José e José Maria possibilitará àquela dar um passo em direção a seu interior, à sua verdadeira face, a qual mantém encoberta com intuito de adequar-se às normas morais.

Em seguida, há um corte na narração, a cena se passa em um tribunal onde Maria do Céu depõe. Uma voz, supostamente a do juiz, quer dados sobre Maria José e tenta aplacar a ira do tribunal que grita: "Culpada! Assassina!" Apresenta-se, assim, um salto no tempo, um fato posterior ao matricídio que ainda não foi mencionado.

Uma rápida cena enfoca a tristeza de Maria José e sua mãe que se consolam pela ausência de Maria do Céu.

A próxima cena apresenta acréscimo de episódio e motivo ${ }^{22}$, flagra-se Maria do Céu na igreja do convento, conversando com São Sebastião. A moça crava o santo com perguntas acerca da morte do pai. O santo responde-lhe que foi feita a vontade de Deus e chama a atenção da moça para o fato de também ele ter morrido novo. Verifica-se, assim,

\footnotetext{
${ }^{21}$ Talvez por isso Maria do Céu desista de ser freira e "não se habitue ao hábito".

${ }^{22}$ Entende-se por motivo a unidade mínima da intriga de um texto narrativo ou dramático. Genette chama de "motivação" o acréscimo de um escopo ou objeto que promova mudanças significativas no conjunto de acontecimentos que formam o fio condutor de uma peça, filme ou narrativa, enredo, história, ação, conforme já se apontou anteriormente.
} 
um espelhamento entre o santo e a figura paterna. Além disso, trata-se de São Sebastião da Pedreira, que como Agostinho relaciona-se à pedra.

A moça chama atenção para as flechas que trespassam o peito de São Sebastião. A flecha simboliza o penetrar um invólucro, o pensamento fecundante, pelo qual se ultrapassam as condições normais para a libertação do ser. (Chevalier e Gheerbrant, 1994, p. 435). Além disso, a imagem de um ser flechado remete à figura da divindade mitológica hindu, Shiva. Essa divindade teve o coração perpassado por flechas do deus amor para tornar-se capaz de cumprir sua missão de unir-se à sua esposa (Shakti) e se tornasse um deus completo. Masculino e feminino, Shiva é o deus hábil a livrar o homem do sofrimento, representa o arquétipo do si-mesmo, isto é, uma imagem divina que simboliza os conteúdos do inconsciente coletivo. (Jung, 2000, Cap. IV). A hipótese é corroborada pela resposta do anjo à fala de Maria do Céu acerca de sentir que alguém lhe responde, embora fale sozinha: "Sim!... mas não! Tu própria perguntas e respondes. É muito do povo! Perguntar e responder imitando a voz da pessoa a quem dirigiram a pergunta.”. O diálogo parece constituir um monólogo interior já que possibilita o confronto da moça consigo mesma. Também a conversa de Maria do Céu com as freiras tem essa função, uma vez que Céu reflete-se na irmã Bondade. O diálogo com o santo, contudo, parece ser uma forma de perscrutar o próprio interior, em busca do animus, uma figura masculina que alude à figura paterna; um sinal masculino no inconsciente da mulher (Jung, 2000, p. 12), que também remete ao si-mesmo. A crença popular nos santos é satirizada pelo que informa a rubrica subsequente.

ASSIM QUE MARIA DO CÉU PÕE AS MOEDAS NA CAIXA DE ESMOLAS,
O SANTO MOVIMENTA-SE AO SOM DUMA MÚSICA. CHEGA MESMO A
SAIR DO ALTAR E ENTOA UMA CANÇÃO DE CARIZ RELIGIOSO.FAZ
UMA DANÇA À VOLTA DE MARIA DO CÉU. ELA VÊ ESTE
ACONTECIMENTO COMO UM "MILAGRE". NO FINAL DO TEMA O
SANTO REGRESSA AO ALTAR E MARIA DO CẼU CAI DESMAIADA.
É ASSIM QUE A ENCONTRAM AS IRMÃS, QUE A DESPERTAM. (Gomes,
p. 16 )

A atuação do santo mediante a esmola lembra o procedimento das estátuas humanas que ficam imóveis nas ruas até que alguém lhe faça um donativo; então, movem-se e entregam algo àquele que lhe doou o dinheiro. A associação sugere uma crítica à igreja que também se valeria dos santos como artifício para conquistar ofertas. 
A referência ao mártir adquire nova conotação quando se nota que seu nome remete a D. Sebastião, uma personagem importante da história portuguesa que representa um pai para o povo, já que com sua morte, o português fica desamparado e cai sob domínio espanhol. Dessa forma, São Sebastião pode representar o si-mesmo do povo português, o que complementa o interesse do dramaturgo pelo seu povo, já aventado pela caracterização da família e pela citação de ditados populares.

Verifica-se, assim, a inserção de dois motivos: a análise do interior humano em busca de autoconhecimento, e a caracterização da alma portuguesa. Diferente do que ocorre no texto de Camilo, o objetivo da peça não é retratar um episódio hediondo para educar o leitor, mas desvendar da alma humana e portuguesa, problematizar a identidade nacional. Ocorre, portanto, o que Genette chama de motivação ${ }^{23}$.

$\mathrm{Na}$ cena seguinte, Maria do Céu conversa com as freiras e lhes apresenta características de sua mãe e irmã, que configuram acréscimos à narrativa camiliana. Ao contrário da mulher forte e determinada do cordel, Matilde não trabalha, enjoa de andar de burro e, por isso, não pode ir até o único emprego que conseguira. Além disso, não pode costurar porque suas mãos tremem; por isso, limita-se a ficar em casa e chorar.

O trabalho de Maria José, apresentado pela narração de Maria do Céu, é uma substituição do que em Camilo era o emprego de vendedora de obras de esparto. Maria José faz meias à noite e vende flores durante o dia. Sem coragem de apregoar, as flores murcham e não são vendidas. Esses dois fatos - não apregoar e as flores murcharem merecem atenção. Sua mudez sugere a incapacidade de expressar-se, tamanha a submissão às regras sociais e, por extensão, medo de ser desmoralizada. Afinal, o pai, em sua presença, afirmara que perderia sua alma se alguma de suas filhas se desencaminhasse. As flores, por seu turno, representam o princípio passivo e a efemeridade da beleza e dos prazeres. Assim como elas, Maria José começa a murchar para a vida, que não the apresenta prazeres, mas eterno sofrimento ao lado da mãe debilitada e deprimida, o que se verifica pela cena seguinte, na qual Matilde afirma: "apetece-me chorar". (Gomes, 15)

A cena onze inicia-se pela voz do narrador que retoma a história de Matilde e Maria José, repetindo os dizeres de Camilo, enfoca-se novamente a felicidade beata mesmo com a escassez de recursos. O verbo "ensinar", no pretérito imperfeito, indica o

\footnotetext{
${ }^{23}$ A nota 30 esclarece o termo.
} 
hábito de Matilde doutrinar a filha a "passar a vida com honra e sem vergonhas do mundo!" (Gomes, p. 19). Depois de rezar com a mãe, Maria José sai para vender flores. O palco divide-se, então, em três cenários, à esquerda - lado das emoções - ficam as carmelitas; à direita - lado da razão - a mãe rezando e, ao centro, Maria José. O narrador retoma os dizeres camilianos, salientando a boa fama da moça pela vizinhança.

O palco esvazia-se e permanecem apenas Maria José e José Maria, as personagens que se associavam ao inconsciente ou aos padrões morais são eliminadas. O moço aproxima-se de Maria José, com certa familiaridade que ela rejeita. A rapariga deixa claro ser séria, ter a mãe à sua espera e só aceitar conversar com clientes interessados em suas flores. Sem deixar-se contrariar, José Maria afirma querer comprar uma flor "que se possuísse, poderia conservar para toda a vida." (Gomes, p.20). Maria José, no entanto, não entende a alusão. Essa ingenuidade parece atrair ou incentivar o rapaz a prosseguir em sua sedução. Para cativá-la, ele se declara igualmente tímido e senhor de grande respeito, mas assevera-lhe que o sentimento de amor é tão grande que não pode calar e precisa confessar o que sente pela "flor". Salienta-se, por conseguinte, a associação, antes apenas sugerida, entre a moça e a flor.

Maria José surpreende-se no momento em que o rapaz revela o nome da pretendida flor e faz menção de sair para ver a "mãezinha que deve estar impaciente" (Gomes, p. 21), mas afrouxa diante da revelação do nome do rapaz. O nome a atrai e ela se lembra de uma capicua, ideia acrescentada por Fernando Gomes, que revela sua atenção ao espelhamento sugerido pelos nomes das personagens.

José Maria aproveita o ensejo e pede a moça em casamento. Desnorteada, ela deixa claro que a mãe é quem a governa e quem decidirá por ela. O jovem sugere que a suposta namorada mencione a capicua à mãe e propõe-se a acompanhá-la e conversar com a senhora. Maria deixa a cena exclamando "L'amour".

A submissão da moça revela que projeta a moralidade rigorosa de sua mãe, bloqueia a própria iniciativa e passa a desconsiderar seu eros. Sua ingenuidade exacerbada é um atrativo ao gênero masculino, pois o homem tem a oportunidade de agir como um galanteador. Também a ela a relação parece interessante porque relacionar-se com um homem poderia levá-la a libertar-se do poder da mãe. As atitudes de Maria José parecem 
configurar umas das versões do complexo materno, descrito por Jung como a "Identificação com a mãe".

\begin{abstract}
Dá-se [...] uma projeção da personalidade da filha sobre a mãe, em virtude da inconsciência de seu mundo instintivo materno e de seu Eros. [...] Tamanha indefinição feminina é a contraface almejada de uma definição masculina inequívoca, a qual só pode ser estabelecida de uma forma algo satisfatória quando há condições de empurrar tudo o que é duvidoso, ambíguo, indefinido, obscuro para a projeção de uma encantadora inocência feminina. [...]cabe ao homem o papel privilegiado de poder suportar essas conhecidas fraquezas femininas, com a magnanimidade e superioridade cavalheiresca. (Jung, 2002, p. 99)
\end{abstract}

A relação amorosa seria uma forma de Maria libertar-se do domínio da mãe, mas ela só parece intuir essa possibilidade quando é revelada a coincidência do nome do rapaz. A moça parece pressentir que, projetando-se em um espelho, poderá descobrir-se e conscientizar-se de que não é mera extensão da mãe. Essa descoberta poderá levar-lhe a individuar-se, a identificação com o duplo leva a autoconsciência.

Normalmente há [...] a possibilidade de que, mediante uma projeção intensa da anima, se encha o recipiente vazio [daquela que se identifica com a mãe]. Disto depende esta mulher: sem o homem, ela não consegue nem de longe chegar a si mesma; deverá ser literalmente raptada da mãe. (Jung, 2002, p. 105)

A próxima cena interrompe a linearidade da narrativa e torna a remeter a um momento posterior ao matricídio. Maria do Céu depõe em juramento e, pelos comentários da acusação, depreende-se que seu testemunho coincide com o ponto de vista do narrador das cenas anteriores, como se as cenas anteriores tivessem sido narradas de acordo com a visão de Maria do Céu, já que expõe os fatos de maneira exageradamente sentimental e supersticiosa. O raciocínio e explanação dos fatos são criticados pela acusação como fantasistas, já que se referem ao diálogo com São Sebastião e ao fato de Céu ter encontrado um trevo de quatro folhas que, assim como a capicua, traria sorte. Além disso, Maria do Céu culpa o demônio pelo crime cometido. Essa menção às crenças populares complementa o retrato do povo português que vem sendo urdido pela peça, além de aludir a uma característica da psicologia humana: atribuir a forças místicas aquilo que o homem não quer assumir como sua culpa.

A narração continua com o encontro do casal com a mãe da moça. A cena repete com algumas pequenas alterações o episódio em que Matilde se certifica de que José Maria gosta de trabalhar e se dedica a isso como condição para namorar-lhe a filha. Dois 
acréscimos de situação merecem ser mencionados: Matilde leva o casal a rezar pela salvação da alma do marido, essa atividade é interrompida pelo barulho da vizinha dando aula. José Maria aproveita o ensejo para revelar-se religioso, enunciando o desejo de que Deus tenha piedade da mestra, e despedindo-se com recomendações que fiquem com Deus. Ressalta-se, assim, a figura da mãe como alguém que quer doutrinar os que se acercam dela e a flexibilidade do caráter do rapaz que parece saber como conquistar Matilde.

O próximo episódio ocorre em um tribunal, onde um cego é testemunha. A cena inicia-se com a dificuldade do juiz em fazer essa testemunha jurar dizer a verdade, pois o cego responde com o ditado: “Deus é testemunha!” Assim, relativiza-se a onipotência divina e se enuncia um contra-senso, pois ainda que Deus seja testemunha não pode depor em juízo, mas um cego sim, desde que jure por Deus. Regras estratificadas são, dessa forma, ridicularizadas.

Além de apresentar uma crítica sutil a normas cristalizadas, a cena retoma um motivo que foi apresentado no episódio em que Agostinho balbucia palavras que não se entendem: a diferença substancial entre falar e dizer. $\mathrm{O}$ diálogo vazio de sentido entre o juiz e o cego é retratado como perda de tempo, já que "não disseram nada de jeito" (Gomes, p. 26)

A inserção de uma testemunha cega parece ter vários motivos, ou há uma alusão à sua sabedoria, já que, sem perder-se observando a realidade exterior, desenvolve a introvisão; ou consiste em uma crítica ao sistema judiciário português que permitiria testemunhas que não viram o caso, mas apenas ouviram boatos, já que o cego afirma: “A mim, contaram-me de fonte limpa.” Ao que o juiz responde: “É o que todos dizem!”

O testemunho do cego é subjetivo e parcial, em sua boca são colocadas palavras do narrador de Matricídio sem exemplo; no entanto, no contexto da peça, a frase: "meditai um pouco nas causas que concorreram para endurecer o coração duma filha" (Gomes, p. 26) toma também outro sentido, já que a figura da mãe sofre grandes deformações nas mãos do dramaturgo.

As próximas cenas constituem uma retrospectiva narrada pelo cego. Sua história remonta a certo dia em que um grupo de "cegos estropiados" lamenta já não haver desgraças que comovam o público para que possam ganhar dinheiro com isso. Eles sentem saudades do tempo em que o ladrão e assassino Diogo Alves jogava pessoas do aqueduto 
(Gomes, p. 28): “Aquilo é que era uma história! Púnhamos as pessoas todas a chorar!” (Gomes, p. 28) "E só pela tristeza ninguém dá esmola, ninguém compra os versos..." (Gomes, p. 29) A cena pode remeter ironicamente à venda itinerante de folhetos de cordel, forma do hipotexto. Dessa forma, Fernando Gomes além de referir-se ao procedimento de Camilo para lançar-se como autor e tornar seu cordel um best seller, refaz a crítica ao grande público, ávido por histórias de "faca e alguidar" e insensível à desgraça alheia.

Entre os cegos, Matilde passa a comentar o motivo de sua tristeza: ter uma filha desonrada. Dessa forma, dois pontos de vista são sugeridos: o da mãe e o dos cegos, que comentam os dizeres de Matilde e fazem versos sobre o enredo. Paralelamente, outra cena se abre com a interpretação do que é narrado, sugere-se, assim, um novo foco da história, agora pelo viés do espectador. O rapaz é descrito como um jovem muito carinhoso, no entanto não era essa a qualidade que a mãe buscava, ela queria alguém que preservasse sua visão de mundo. A cena dá mais cor ao que já havia como sugestão no cordel camiliano. Uma fala de Matilde merece atenção, pois acrescenta uma imagem significativa: "O Lobo começou então a tirar a pele de cordeiro." (Gomes, p. 31) A imagem do lobo é reiterada pela associação que José Maria faz entre si e o lobo mau, do conto de fada "Chapeuzinho vermelho". O namorado representa o lado instintivo, animalesco de Maria José, até então desconhecido da moça. Reconhecer esse seu lado é importante para libertar-se do jugo da mãe e individuar-se. Para verificar como esse processo ocorre, importa reler alguns trechos:

I.

MARIA

A minha mãe está preocupada.

JOSÉ

Por quê?!

MARIA

É por causa dos banhos!

JOSÉ

Eu já lhe disse que os banhos estão a correr!

MARIA

Também eu mas... que queres?! Ela é muito minha amiga e tem medo que... só pensa nos banhos, pronto!

JOSÉ

E tu, Maria José, também sé pensas nos banhos?

MARIA

Eu só penso em ti.

A mãezinha... a mãezinha está quase a chegar!

II.

MARIA

Fecha os olhos.

JOSÉ 
Por quê?

MARIA

É uma surpresa! Para o casamento... gostas?

JOSÉ

Vais ficar linda. Tam-tam-taram!

MARIA

Espera! Toma!

OS DOIS

Tam-tam-taram!!! (Gomes, p. 32)

\section{III.}

MATILDE

Ele não vai casar com ela! Ele não vai casar com ela!

CEGO

É capaz de ter razão, D. Matilde!

MATILDE

Eu já a aconselhei; eu já a repreendi com boas maneiras, pois mesmo assim toda ela se arrufa! E não casa! Estou mesmo a ver que não casa!

CORCUNDA

Também eu!

LUVAS

Olhe esta aqui que também fica bonita:

Cantam:

As águas que vêm do monte

Correm direitas pró mar

Se sua filha não casa

Não o sei onde ir parar!

CEGO

E daí... talvez case...

Tam-tam-taram!!!

MARIA

A mãezinha... está quase a chegar!

JOSÉ

Sim?!

MARIA

Sim! Sim, sim.

JOSÉ

O que é que disseste?!

MARIA

Sim, sim.

JOSÉ

O quê?

MARIA

Nada. ( Gomes, pp. 32 a 34)

O desdém pela possível intervenção materna e a entrega ao prazer denota a alteração gradativa da submissão da moça. O processo de individuação de Maria José vai acontecendo à medida que ela deixa de se interessar pela mundividência da mãe e passa a ter ideias próprias. No trecho I, Maria começa a pensar diferentemente da mãe, enquanto a mãe só pensa no casamento, a moça interessa-se pelo namoro. No trecho II, a sugestão de 
"fechar os olhos", feita por José Maria parece consistir em uma metáfora para o desconsiderar a realidade exterior e entregar-se cegamente às emoções.

No trecho III, a voz do cego apresenta um contraste à de Matilde. Ele que ouviu toda a narração da senhora acerca do caso de sua filha não está tão certo de que não haverá casamento. Outro cego, de luvas, faz versos sobre o caso e, neles, traça um paralelo entre "águas descerem de um monte e correrem ao mar" e Maria não casar. No poema, a água, símbolo de vida espiritual, de purificação e de regenerescência, vem de um monte, isto é lugar elevado que aponta ao céu, e, por isso, remete a Deus, e desembocam no mar, que representa o coração humano, lugar de paixões, cujo dinamismo oferece possibilidades e ambivalências à vida humana. Além disso, a profundeza do mar é a imagem do subconsciente. Observa-se, assim, a alusão ao trajeto percorrido por Maria José: ela deixa o espaço seguro das normas religiosas, benévolas, mas repressoras, para voltar-se para seu coração ou subconsciente em busca de construir uma vida própria e deixar de ser mera sombra da mãe.

Matilde parece pressentir que a relação de Maria com um homem representa a completa separação entre si e a filha. Ela repete, como para convencer a si mesma que o rapaz não irá casar-se com sua filha: "Ele não vai casar com ela! Ele não vai casar com ela!”. A insistência parece sugerir sua necessidade de que o casamento não ocorra, como argumento para convencer a filha a deixar o rapaz.

Em outra parte do palco, a ruptura paulatina entre mãe e filha evidencia-se. Maria José que, a princípio preocupa-se com a chegada da mãe e o juízo que esta fará ao encontrála em intimidade com o namorado, entrega-se à paixão e deixa que o instinto prevaleça sobre a razão ou as normas.

A cena subsequente parece oferecer à Matilde um motivo para uma epifania. Ela admira-se de os cegos irem à uma tasca e eles respondem: "Mas até um cego tem direito a descansar de vez em quando.” Matilde, cega pelas convenções e por uma religiosidade feita de regras castradoras, parece nunca ter considerado que também ela poderia ter direito a prazeres. A rubrica parece indicar que alguma alteração ocorreu: "MATILDE ENCAMINHA-SE PARA CASA. VEM UM BOCADO TOCADA E A CANTAR O TAM-TAM-TARAM." (Gomes, p. 34) Matilde vem "tocada", isto é, ébria. Ela entrega-se a um momento de prazer. No entanto, sua moralidade nem assim é entorpecida, já que ao 
chegar em casa e flagrar a filha em intimidade com José Maria, ela grita e fala mal dos rapazes da época. Maria José, por seu turno, evidencia o contra-senso de uma senhora que vive enclausurada, ou sai apenas para cumprir deveres religiosos, ser capaz de analisar "o que são os rapazes" da época. Matilde coloca-se como vítima sem culpa e cospe no chão.

Em um divertido artigo intitulado "Cuspir no chão", Jota Vilela defende o ato de cuspir como costume tipicamente português, desde tempos imemoráveis:

um homem digno desse nome não deixava de marcar no passeio da rua com uma meia dúzia diária de impressões indeléveis, que o ajudavam a manter o seu equilíbrio psicológico, descarregando dessa forma simples e terna toda a raiva acumulada ( http, p.//www.anjoscaidos.jor.br/temas/temas/idiotice.html

Já para Ernout e Meillet (Dictionnaire étymologique de la langue latine (Paris, p. Klincksieck, 1967 s.v. spuo), o cuspe, na crença popular, tinha o poder de afugentar os males. O ato também remete à serpente cuspideira que lança seu veneno a metros de distância visando a acertar os olhos da vítima. De acordo com a primeira alternativa, o dramaturgo recupera atitudes tipicamente portuguesas para continuar traçando o perfil de sua nação. Em conformidade com a segunda hipótese, a atitude de Matilde sugere caráter rude e a intenção de afastar o que lhe causa repugnância. A filha declara que não limparia a sujeira da mãe, o que denota mudança de mentalidade, ela já não quer apenas fazer o que agrada a mãe e nem estar submissa às suas regras.

Interessante notar que Matilde não usa a cena da intimidade da filha com o namorado para a imposição do casamento, mas volta a pedir o rompimento da relação, agora apelando em nome de Agostinho e do sofrimento de Jesus. A exclamação "O valerme era a tempo!" parece um desabafo de alívio de Maria, e sugere que ela está agora no comando e ditará novas regras: ou a mãe respeita sua individualidade, ou deverá sair de casa.

"Casa" representa o ser interior, é também um símbolo do feminino, já que consiste em um espaço fechado que fornece proteção como um útero, ou o colo materno, um refúgio desejado. Dessa forma, Maria insinua o rompimento completo com a mãe e a completa posse de seu ser interior. Matilde toma a declaração como um desafio de forças: "Veremos, Maria, veremos qual de nós é que vence!" (Gomes, p.36)

A cena que segue mostra o desdobramento das atitudes de Maria José e José Maria. Ele, na tasca; ela, em casa, dedicam-se a cartas. Ele joga, ela "deita cartas". Considerando- 
se a formação religiosa de Maria, seu ato parece, na visão católica, herético; no entanto, o tarô não precisa estar relacionado à cartomancia. Jung vê nas imagens do tarô arquétipos; assim, "Uma viagem às cartas do Tarô, primeiro que tudo, é uma viagem às nossas próprias profundezas." (Nichols, 2007, p. 18) Entrar em contato com arquétipos significa tomar consciência de alguns dados do inconsciente coletivo, o que leva à individuação, isto é, possibilita que a pessoa se torne inteira e distinta de outras pessoas ou da psicologia coletiva.

Há um salto na linearidade da história para voltar à cena do cego no tribunal, que se revela narrador das cenas subsequentes, que são simultâneas e revelam o desdobramento das atitudes do casal. Enquanto José Maria, na tasca, joga cartas, Maria José, em casa, deita cartas.

Somente depois de consultar as cartas, Maria vai ao encontro do namorado na tasca, local onde o rapaz não quer que ela frequente. Essa cena aglutina as duas anteriores. A atitude da moça denota certa autonomia da moça também no que se refere ao namorado, já que não se submete inteiramente a José.

Repreendida pelo moço, ela revela que tem consciência de estar em um local que ele não quer, mas declara tratar-se de assunto urgente: a proibição do namoro pela mãe e a ameaça de prisão. Aqui, há transvocalização ${ }^{24}$, um dado que é apresentado por Camilo pela fala do narrador, agora é introduzido por Maria. A mãe teria ouvido que José foi acusado de vadio e ratoneiro, o que acentua a aversão de Matilde pelo rapaz. A opinião de José Maria sobre Matilde é expressa em uma palavra: "Bruxa" ${ }^{25 "}$ (Gomes, p. 36) Dessa forma, o rapaz parece intuir o poder de fascinação que Matilde, manipuladora, exerce sobre Maria a ponto de colocar em risco o desenvolvimento do eu da moça.

Frente ao desespero de Maria José - que revela uma recaída diante do poder materno - o namorado, sem abandonar as cartas, responde friamente que, nessas condições, o namoro deve ser rompido para que Maria não tenha mais problemas.

A atitude de José Maria sugere segurança e autonomia. Ele não desiste de ser quem é, não se dispõe a implorar misericórdia nem mesmo abandonar os prazeres - já que não larga o baralho. Seu desdém mostra a consciência que tem de que o problema reside na

\footnotetext{
${ }^{24}$ A nota 31 indica o significado do termo.

${ }^{25}$ Interessante notar que a vestimenta negra também alude à figura da bruxa.
} 
relação entre mãe e filha e não em sua reputação, mero pretexto para Matilde separar os amantes.

Importa ressaltar a inserção da ideia do baralho. O jogo é símbolo de luta,

é um universo, no qual, através de oportunidades e riscos, cada qual precisa achar seu lugar."[...] Mas debaixo do respeito às regras, o jogo deixa transparecer a espontaneidade mais profunda, as reações mais pessoais às pressões externas. (Chevalier e Gheerbrant, 1994, p. 518)

José Maria estimula sua emotividade e imaginação pelo jogo, pelo prazer; assim, mantém sua individualidade em meio a uma sociedade repressora. Essa índole do rapaz é o contraponto da subordinação passiva de Maria José, é a outra face no espelho, e representa tudo de que ela carece para libertar-se do jugo da mãe.

Perante a postura altiva do namorado, Maria sucumbe e implora pela relação, argumentando que o rapaz deve isso a ela já que ela "se desgraçou" por ele. José questiona essa fala e ela reconhece que não foi coagida, mas agiu espontaneamente ao entregar-se a ele. Aqui surge a proposta: "Se não posso entrar lá em casa por causa da velha... fá-la desaparecer." (Gomes, p. 37) José Maria não fala em matar, mas sugere o "fazer desaparecer", que pode ser uma metáfora para libertar-se do jugo da mãe; assim também o "matar a mãe" pode associar-se a extinguir o domínio materno.

Na próxima cena, Matilde, em casa, implora a Deus pela filha e o cego/narrador, no tribunal, comenta que "Deus não quis tocar-lhe o coração." (Gomes, p. 37) Verifica-se novamente a técnica da simultaneidade ${ }^{26}$.

A ação é subitamente interrompida por um fado, a música retrata o matricídio como obra do destino, como fruto da vontade de Deus, o que condiz com o conceito de "fado" como "destino". Nega-se, dessa forma, o livre arbítrio:

Conceber a autoridade interna como 'vontade de Deus' (o que implica admitir que as 'forças naturais' são 'forças divinas') tem a vantagem de a decisão se apresentar, em tal caso, como um ato de obediência e o resultado deste último como algo planejado por Deus. Contra esta concepção objeta-se, aparentemente com razão, que ela não só é muito cômoda, como também lança o manto da virtude sobre o que não passa de um afrouxamento moral. (Jung, 2000, p. 24)

\footnotetext{
${ }^{26}$ Processo de narração que consiste em apresentar, sem transição, acontecimentos que se desenrolam ao mesmo tempo em lugares ou em momentos diferentes.
} 
A relação entre a letra da música e fado, como destino, parece elucidar o motivo de a peça apresentar a canção magoada. O sentimento fatalista revela pessimismo, espírito de resignação e inércia diante de um destino inalterável. Fernando Gomes retoma alguns dizeres exageradamente sentimentais do narrador camiliano e os transforma em um hino que evidencie o sentimentalismo, não como uma característica do romancista, mas do povo português.

O cego retoma a narrativa enunciando que Maria encontra sua mãe atordoada, sem comer nem beber. Novo corte na linearidade dos fatos ocorre e proporciona a sobreposição de dois planos temporais. Os "cegos estropiados", que remetem a um momento da história, posterior aos acontecimentos, comentarão sentimentalmente a cena do encontro entre Maria José e a mãe. Essa cena torna-se fragmentada, já que é cortada pelos comentários dos cegos.

A mesma inação que Matilde planejara ao perder o marido agora se dá pela iminência de perder metaforicamente a filha. Retomando os dizeres da narrativa camiliana (transvocalização), os cegos contam a história e repetem que "atentada pelo demônio", a filha é cruel com a mãe. Cabe ressaltar que o termo "demônio" pode não ter sido usado no sentido religioso, mas sim em sua acepção etimológica: "Demônio conforme a etimologia grega, daimónion: [é o] gênio inspirador, não necessariamente mau, mas sempre disruptor em relação à tábua de valores vigente ${ }^{27}$ Trata-se, portanto, de um impulso que leva à transgressão de regras, atitude que Maria só poderia ter, como já se afirmou anteriormente, pela influência de um homem - ou do outro eu - que a libertasse do domínio materno.

Matilde, em atitude de humilhação e súplica, procura suscitar a culpa na filha por ser ingrata a uma mãe sempre carinhosa e presente. Refaz-se aqui o caráter lupino da mãe, ela procura devorar o "eu" da filha pela opressão "através de um prolongamento excessivo da função alimentadora e guia: a genitora devorando o futuro genitor, a generosidade transformando-se em captadora e castradora." (Chevalier e Gheerbrant, 1994, p.580). Maria, no entanto, não sucumbe, e ameaça a mãe. José Maria chega e a moça abraça-o e beija-o na frente de Matilde, que arranca "do peito um grito de dor" (Gomes, p. 38). Ela parece sentir fisicamente a dor de ter uma filha que já não compartilha de sua visão de

\footnotetext{
${ }^{27}$ Per Johns, "Realismo fantástico e floração ecológica" http,p.//www.revista.agulha.nom.br/ag51johns.htm.
} 
mundo. Deslocando para este momento o episódio de não encontrar o dinheiro, que, em Camilo, ocorre quando a moça está ausente, Fernando Gomes torna a cena mais dramática.

Sem encontrar o dinheiro, Matilde desmaia, José Maria propõe que a filha dê cabo da mãe e depois usa a palavra "matar". Cumpre reiterar que a proposta não precisaria ser tomada denotativamente, mas é assim que a moça consegue captá-la. Como na primeira edição da narrativa camiliana, Maria hesita, declara ter pena da mãe, temer que alguém a escute e propõe que todo o problema se dissolva pelo casamento. O rapaz sugere que a namorada o faça durante as aulas da Mestra. José Maria não é retratado como o vilão do livro camiliano, mas sua rejeição ao casamento parece representar a recusa da visão de mundo de Matilde; assim, José Maria sai sem dar atenção às palavras de Maria.

Indignada com a situação, Maria descompõe a mãe, chamando-a de "estupor" e "estafermo". Essas palavras, além de possuírem sentido pejorativo, referem-se a estados de entorpecimento ou suspensão de atividade. "Estupor" é um substantivo masculino (do latim stupóre, «entorpecimento») que denota o estado de suspensão da atividade física e psicológica em que o doente, embora consciente, se mantém imóvel e não responde a estímulos externos; "estafermo" também um substantivo masculino (do italiano stà fermo, «está firme») é depreciativo e refere-se à pessoa parada. ${ }^{28}$ Em Camilo, não seria pertinente tomar as palavras nesse sentido; em Fernando Gomes, no entanto, talvez a inação seja a característica de Matilde que mais incomode a filha, já que cabe a ela preencher a lacuna deixada pela falta de atitude da mãe.

Maria José parece tornar-se consciente da incapacidade da mãe de adaptar-se a novas situações, e o estatismo e apego a regras estratificadas decorrente dessa inabilidade perturbam a moça. Irritada, ela manda a mãe sair de casa. Esta concorda, desde que tenha seu dinheiro de volta.

Sob pretexto de buscar o dinheiro, Maria sai, calculando a que horas mataria a mãe. Fernando Gomes altera o horário da narrativa de Camilo, em vez de o matricídio ocorrer às dez horas; na peça, acontece às onze e meia. Dez é o número da totalidade, do universo; onze pode ser considerado um "desdobramento hipertrófico e desequilibrador de um dos elementos constitutivos do universo (10): o que determina a desordem, a doença, o erro." Para Santo Agostinho, onze é o brasão do pecado. Além disso, o número remete à iniciativa

\footnotetext{
${ }^{28}$ http, p.//www.infopedia.pt/pesquisa?qsFiltro=14
} 
individual, sem levar-se em conta a harmonia cósmica. (Chevalier e Gheerbrant, 1994, p. 660 e 661). A atitude de Maria é, assim, determinada como um erro de julgamento, a proposta de José Maria poderia ter sido realizada metaforicamente, isto é, a filha deveria eliminar a influência da mãe, não tornar-se assassina. O rapaz não fala em matar a mãe e ainda elogia a atitude da filha em preocupar-se com devolver-lhe o dinheiro.

Na próxima cena, Maria volta à taverna para contar da descoberta da mãe acerca do dinheiro. Cumpre transcrever a cena:

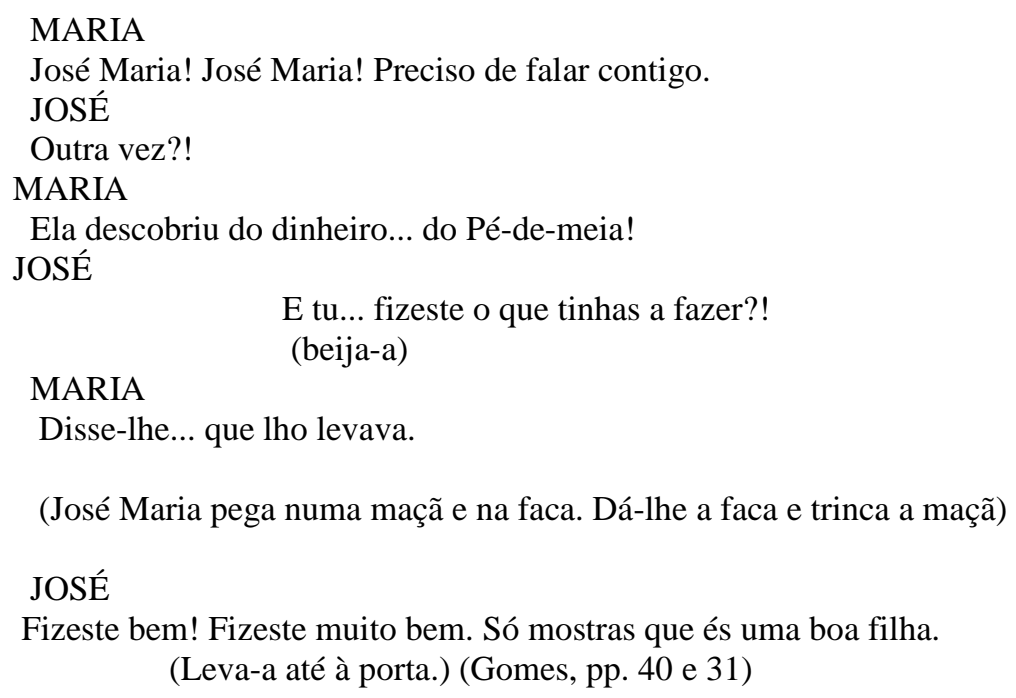

A rubrica apresenta um acréscimo de episódio e dá informações valiosas sobre a mundividência de José Maria. A maçã é símbolo de conhecimento e de liberdade, o moço come da maçã e dá a faca à Maria, instrumento que tem o poder de afastar as influências maléficas, o princípio ativo modificando a matéria passiva. ${ }^{29}$ Refaz-se, assim, o sentido metafórico de eliminar a mãe; no entanto, a moça vai tomar a faca como um instrumento de sacrifício.

A cena posterior, enfoca José Maria, na tasca, em conversa com os cegos, matando Matilde metaforicamente, uma vez que a desmoraliza, apresentando-a como louca. Ele mente, dizendo que Matilde está enlouquecendo, que se recusa a comer e grita que quer ir com o marido. Os cegos comentam que ela nunca teve muita saúde e repetem o fato, narrado em cena anterior, de ela enjoar de andar de burro. Este animal ou o asno representa a vida no plano terreno e sensual, a libido, o elemento instintivo ${ }^{30}$; nesse sentido, a recusa

${ }^{29}$ (Chevalier e Gheerbrant, 1994, p. 414)

${ }^{30}$ Chevalier e Gheerbrant, 1994, p. 93) 
de Matilde a andar no animal pode relacionar-se à sua opção, depois da morte do marido, por tornar-se alheia a tudo a que se refere à matéria, o que a torna ainda mais repressora, porque o é também consigo mesma.

A cena seguinte ao mesmo tempo em que a anterior se fecha, promove-se, inicialmente a simultaneidade dos fatos. Em diálogo com a mãe, Maria José diz estar muito nervosa, ao que a mãe atribui a uma característica de família, já que também ela e Maria do Céu sofrem dos nervos. A moça dissimula ser carinhosa e pede à mãe que a cate.

Em Camilo, a filha oferece-se a catar a mãe, aqui as circunstâncias invertem-se. Aparentemente submissa, a moça desarma a prevenção da mãe e investe contra ela, esfaqueando-a no peito e no pescoço, como no texto de Camilo.

A peça finaliza com a opinião do narrador que apenas repete os dizeres sentimentais camilianos e situa o matricídio em Lisboa de 1848. Não há menção ao esquartejamento, este só é sugerido na cena inicial em que narradores repetem a introdução do cordel camiliano. Em Camilo, o enfoque social e psicológico vale-se da cena atroz para renovar as convenções e sugerir a artificialidade e hipocrisia da moral vigente. Em Gomes, a paródia do comportamento pacato e resignado do português sobrepõe-se ao grotesco. A individuação de Maria José, conquistada pelo matricídio, importa como sugestão de que é necessário romper com as normas estratificadas para haver renovação.

Corrobora essa tese a inserção do fado. Esse tipo de música é símbolo da nação portuguesa; por isso sua introdução abre a possibilidade de haver dois significados para o ato de matar a mãe. Por um lado, pode referir-se à situação específica de Maria que, para individuar-se, precisaria extinguir a ideologia materna. Por outro, remete ao português que deve abandonar a visão fatalista e desfazer-se do apego a uma pátria gloriosa no passado para poder se afirmar como nação. Nesse sentido, o nome das personagens não faz, como em Camilo, uma menção irônica a figuras religiosas, mas é um meio de tornar os protagonistas um retrato genérico do português; são nomes comuns que podem aludir a qualquer portuguesa ou português.

Assim, a peça amplia o texto camiliano. Camilo quer comover e apenas insinua uma crítica a alguns elementos-chave da concepção de nacionalidade portuguesa. Fernando Gomes emprega o humor, sobretudo o nonsense, para revelar a falta de sentido da resignação diante das dificuldades. A frase do pai de família diante das propostas de esposa 
e filhas de se sacrificarem após sua morte - "Que falta eu faço nesta casa!" - em contraposição à ação dessas mulheres depois do falecimento sugere como é vã a crença na imprescindibilidade do patriarca. Inserida no contexto da peça, a frase denota um orgulho exacerbado e ridículo que gera o riso. Declarar-se um homem insubstituível mostra um sentimento de superioridade diante da família que pode ser comparado à conduta prepotente de alguns no poder.

Entretanto, este patriarca altivo e arrogante contracena com um bêbado momentos antes de morrer e sua fala tem que ser traduzida pelo rapaz ébrio que bebe o vinho da família e domina a situação enquanto todos os demais ficam sem ação.

Ainda mais rebaixado é Agostinho, pai de Maria, por morrer sobre um prato de comida, deixando à família o cascalho que o patrão lhe legara por anos de trabalho em uma pedreira. As mulheres, submissas ao destino, agradecem a Deus e declaram: "Quem nada tem, com pouco se contenta." (Gomes, p. 13)

O humor amplia-se pela inserção de seres diferentes do padrão: um fadista, um padre que frequenta tavernas, um bêbado, um coxo, freiras pecadoras, um cego, um cego surdo-mudo, um cego mouco, um cego corcunda e um cego enluvado, imagens disformes, incompletas, distantes do sublime, cumprem a função de promover a libertação do ponto de vista dominante e sugerem a possibilidade de haver uma nova ordem. Alegres, essas personagens deixam entrever que seguir padrões não significa lograr ou alcançar a felicidade. As fronteiras entre o real e o ideal são colocadas em xeque.

O riso e a visão carnavalesca do mundo, que estão na base do grotesco, destroem a seriedade unilateral e as pretensões de significação incondicional e intemporal e liberam a consciência, o pensamento e a imaginação humana, que ficam assim disponíveis para o desenvolvimento de novas possibilidades. (Bakhtin, 2010, p. 43)

Além disso, há a censura a religiosidade beata pela menção à simonia; sugere-se algum desinteresse pela ideia de família já que sustentar esposa e filhos pode ser tão pesado que pode levar à morte; e insinua-se um julgamento desfavorável à pátria, ao declarar que "o maior crime que já viu o mundo" foi praticado em Lisboa.

Justifica-se, por esse viés, a escolha do dramaturgo pela primeira edição em detrimento da terceira. O foco de Fernando Gomes não está em analisar a dualidade do ser humano, como a terceira edição, mas em ampliar a análise de Camilo e, passando pela 
realidade de seu país, torná-la universal. A peça funciona como um alerta de que se há de desfazer o procedimento de atribuir a forças divinas o que é responsabilidade humana para que, assumindo-se erros e defeitos, se possa estabelecer uma identidade própria e original. Trata-se de "matar a mãe" metaforicamente para libertar-se do jugo opressor de um passado pretensamente honrado e digno a fim de construir-se um futuro próspero e peculiar, tanto no âmbito individual - e, por extensão, humano, universal, - quanto no coletivo ou pátrio.

A lascívia gera o crime, mas, ao contrário do que ocorre no texto camiliano, trata-se também de um meio de individuar-se. Maria José não sabe como libertar-se de um espectro de proporções tão desmedidas. No texto camiliano, a lascívia, o desregramento da vontade, levam ao pecado, Matilde é mártir, já que mãe dedicada e altruísta, sofre em nome das regras. Em Fernando Gomes, por outro lado, a mãe é mesquinha, nociva, egoísta, devoradora. Derrotá-la corresponde a eliminar o lobisomem, combater uma disciplina estratificada e sem sentido. O mecanismo da desvalorização ${ }^{31}$ e da contra-valorização ${ }^{32}$ são, portanto, fundamental para a alteração e alargamento do significado da narrativa camiliana.

Desvaloriza-se Matilde e contra-valoriza-se o discurso português cristalizado pelo uso de ditados, de expressões populares e pela inserção do fado. Assim, Maria José e José Maria são transvalorizados ${ }^{33}$, não são apenas filha ingrata e moço desonesto, como no hipotexto, mas indivíduos com visão própria, pessoas que procuram impor-se, combatendo o domínio e a opressão.

Outros mecanismos utilizados por Fernando Gomes que colaboram para a alteração do sentido do hipotexto são a transposição de caráter semântico, que se verifica nas modificações verbais para efeito cômico $^{34}$ e nos ditados $\operatorname{modificados}^{35}$; a

31 Genette considera "desvalorização" o alterar o papel de uma personagem superior, rebaixando-a, conferindo-lhe uma condição meramente humana.

32 Em Genette, a "contra-valorização" tem por objeto um discurso desencantado que repete verdades cristalizadas e ressalta a solidão da natureza humana comum.

33 “Transvalorizar" significa, em Genette, dar valor a uma personagem que era desvalorizada (ou vice-versa).

${ }^{34}$ Gomes aproveita o fato de o nome do pai da família estar no diminutivo para gracejar.

\section{MATILDE}

Agostinho!

CÉU

Paizinho!

\section{AGOSTINHO}

Minhas queridas filhinhas! 
"transmodalização" ou a alteração na forma, de narrativa para drama (dramatização) ; a "motivação" ao, por exemplo, introduzir o diálogo de Maria do Céu com o santo, ou, ao tecer uma crítica à simonia, motivos que o hipotexto oferecia, mas não desenvolveu. Também a ampliação pela inserção de episódios de cunho humorístico, como o julgamento com cegos por testemunhas e as cenas na tasca ampliam o significado do texto camiliano. A extensão pelo acréscimo de personagem, de episódio, de motivo, de tema, e de recursos linguísticos, colabora para a estilização do livro.

Cumpre, ainda apresentar um recurso que não havia sido elencado por Genette: a transtonalização, isto é, a alteração no tom com que a narrativa é veiculada. Se em Camilo o tom é sentimental e comovido, em Gomes, há um caráter jocoso que perpassa todas as cenas. O humor é o meio de o dramaturgo veicular sua visão de mundo. Na peça, as personagens são retratadas como ridículas (Matilde, Agostinho, Lua) ou inconsistentes (Maria José, Maria do Céu, Sol), o que não gera a identificação do leitor/ espectador, condição essencial para o riso. Em um meio constituído por pessoas supersticiosas e ignorantes, prevalece o senso crítico de um Bêbado, a perspicácia de um malandro (José Maria) ou a jovialidade de alguns cegos que sabem se divertir e meio às desgraças. Talvez quem melhor enxergue a realidade sejam estes últimos que sabem tirar proveito de calamidades. Como se intuísse que o cômico é provocado pela rigidez dos que se recusam a abandonar antigos valores para progredir, Fernando Gomes castiga os costumes pelo humor.

Toda a rigidez de carácter, de espírito, e até de corpo, será por isso suspeita à sociedade, porque ela é o sintoma possível de uma atividade que se isola, que tende a fugir do centro comum em volta do qual a sociedade gravita, duma excentricidade, enfim.

[...] uma certa rigidez de corpo, de espírito e de carácter que a sociedade gostaria ainda de eliminar para obter de seus membros o máximo de maleabilidade e a mais alta sociabilidade possível . Essa rigidez é o cômico e o riso é seu castigo. (Bergson, 1993, pp. 27 e 28)

Os meios pelos quais Gomes suscita o riso são vários, mas os motivos giram em torno do automatismo individual e social: são os dogmas religiosos, a inércia na desgraça (ser feliz na pobreza, no contexto, significa não agir para mudar a situação) e o

\section{Gomes, p. 4.}

Em "comer sopa de pedra" torna denotativo o uso da palavra "pedra" p. 16.

35 " Cada um tem sua pedra." Gomes, p. 6. (pedra está no lugar de cruz)

"O cascalho que o diabo amassou" Gomes, p. 9. (cascalho no lugar de pão) 
oportunismo (cegos, que ganham dinheiro vendendo histórias de desgraças, lamentam-se por não haver muitos crimes que levem à compaixão). Assim, o dramaturgo revela-se, também como Camilo, conhecedor da alma portuguesa e atento à sua época. Pela transtonalização, Gomes gera a paródia; pelos acréscimos, a estilização. Cabe criar uma expressão que dê conta de sintetizar esses procedimentos. Propomos estabelecer que Gomes cria uma paródia estilizadora. Paródia, enquanto sugestão de uma intenção diferente da do paradigma; estilizadora, por ampliar conceitos e significados já presentes em Camilo.

Corrobora essa hipótese, o tom adotado por Gomes. Não se trata mais de uma narrativa melancólica, mas de um humor alegre e festivo que convida o leitor / espectador a tornar-se cúmplice da perspectiva adotada. $\mathrm{O}$ riso exige um espectador que se distancie do que é ridículo para que possa divertir-se com ele. Também o modo como o dramaturgo fragmenta o texto camiliano e o recompõe validam a tese. Episódios que se passam em lugares e tempos diferentes se justapõem, sugerindo simultaneidade, desconcerto, alinearidade. Assim, a desintegração do texto espelha o esfacelamento de Maria José, já que, inicialmente, ela não tem personalidade própria por ser mera sombra da mãe e depois, não sabe organizar seus lampejos de consciência. Como ela, o texto parece fragmentado e somente com seu decurso surge uma síntese. Outro mecanismo ainda não previsto por Genette deve ser nomeado: a transorganização, ou alteração da ordem estabelecida pelo hipotexto dos fatos e dos dizeres do narrador.

Esquartejando o texto camiliano, Gomes revela o intuito, semelhante ao do cubista, de renunciar à perspectiva tradicional. Pela linearidade, um julgamento seria conduzido, uma causa seria apresentada. A fragmentação e a multiplicidade de focos narrativos, por outro lado, pulveriza uma sentença única e irrevogável, coloca a verdade instituída em xeque. Duas técnicas cubistas foram, então utilizadas. Como um pintor cubista da fase imitativa e visual, Gomes lança mão do espelhamento (Maria José / José Maria; Maria José / povo português; Matilde / pátria; fragmentação do texto / dilaceração da personalidade de Maria) para sugerir a simultaneidade. Além disso, da mesma forma que os cubistas da fase analítica e experimental, o dramaturgo se vale do rebatimento e superposição ou fragmentação poliédrica de planos para sugerir a necessidade de se observar a realidade sob ângulos diferentes.

A aplicação do simultaneísmo caracteriza a segunda fase do Cubismo, qualificada por Juan Gris de "analítica", devido à decomposição crescente da forma. 
Reúnem-se em uma tela única diversos aspectos do mesmo objeto, de maneira tal que se apresenta quebrado, desenvolvido por todas as faces, aberto no interior [...] não tal como se vê mas como se pensa, como existe em si e no espírito. ${ }^{36}$

O rompimento com a linearidade sugere o quebrar de um invólucro para que se possa sondar o que há em seu interior. Daí, como as máscaras de Picasso, as personagens revelam, em cada cenário, uma face. Semelha-se à identidade do homem da pósmodernidade, composto por várias faces.

O texto camiliano, nas mãos do dramaturgo, terá intuito semelhante ao da colagem da areia, vidro, jornal nos quadros cubistas, remeterá à realidade do cotidiano. Dessa forma, o texto, como a arte cubista, dirige-se à inteligência, ao espírito.

A proposta de romper com uma ideologia passadista, ou com um ponto de vista único acerca da realidade, reitera-se, portanto, pela "transorganização" do texto. O desconcerto é sugerido pelo rompimento com uma perspectiva única do fato narrado, a estrutura da peça sugere o descompasso do homem moderno em meio a uma mentalidade retrógrada.

\footnotetext{
${ }^{36}$ Ashbery et alii, 1981, p. 76.
} 


\section{DAS PAIXÕES HUMANAS}

\section{1 Amor é perdição}

Camilo tornou-se célebre com a novela passional Amor de perdição. O escritor suspeita, no entanto, do êxito do livro e desaprova a qualificação da novela como o ponto alto de sua produção literária e, portanto, superior ao Romance de um Homem Rico e às Estrelas propícias (Branco, 1984, p. 378). Em notas à segunda e quinta edições, ele evidenciou seu ponto de vista crítico, julgando que o público-leitor e a crítica valorizam o livro por trazer peripécias abundantes, diálogos concisos, linguagem acessível e ausência de digressões filosóficas. Em outros termos, o novelista sugere que a superficialidade do livro é motivo da conquista do público. Nesse sentido, o autor lança ironicamente sua primeira crítica aos leitores e apresenta dissimuladamente a consciência de que sabe que seus livros menos aceitos revelam muito mais sagacidade e espirituosidade que o Amor de perdição. Entretanto o caráter polêmico do novelista nunca foi sua face mais agradável à sociedade da época.

Em 1863, antes de o Realismo instaurar-se em Portugal, Camilo já sugere uma preocupação realista no que tange à análise psicológica do ser humano: "estou quase convencido de que o romance, tendendo a apelar da iníqua sentença, que o condena a fulgir e a apagar-se, tem de firmar sua duração em alguma espécie de utilidade, tal como o estudo da alma, ou a pureza do dizer." (Branco, 1984, p. 378). O novelista exime-se, no entanto, de dedicar-se a essas tarefas, alegando que o estudo da alma humana já foi feito sobejamente pelos clássicos e que o estudo da língua não lhe pode ocupar o tempo quando outras preocupações lhe dominam. Contudo, a atenção à língua portuguesa verifica-se, sobretudo, pela transcrição de ditados populares ${ }^{37}$. Dessa forma, Camilo corrobora para a veiculação de um retrato realista ${ }^{38}$ do povo português em sua cultura e mentalidade; as personagens burguesas expressam-se de maneira semelhante à do narrador, mas o povo parece dotado de um estilo próprio e vigoroso.

\footnotetext{
${ }^{37}$ Os ditados populares são veiculados em Branco, 1984, p. 419, 421, 431, 432, 453, 461, 462, 511.

${ }^{38}$ Realista aqui se refere não apenas à fidelidade ao mundo concreto, como também à preocupação com a alma humana.
} 
Os paratextos são essenciais para a compreensão do livro. No "Prefácio da Quinta edição", redigido em 1879, quando o Realismo domina o gosto do público-leitor, Camilo não deixa de revelar sua concepção acerca dessa literatura quando cotejada com a narrativa que lhe tornou famoso.

O Amor de Perdição, visto à luz elétrica do criticismo moderno, é um romance romântico, declamatório, com bastantes aleijões líricos, e umas ideias celeradas que chegam a tocar no desaforo do sentimentalismo. Eu não cessarei de dizer mal dessa novela, que tem a boçal inocência de não devassar as alcovas, a fim de que as senhoras a possam ler nas salas, em presença de suas filhas ou de suas mães, e não precisam de esconder-se com o livro no seu quarto de banho. Dizem, porém, que o Amor de Perdição fez chorar. Mau foi isso. Mas agora, como indenização, faz rir: tornou-se cômico pela seriedade antiga, pelo raposinho que lhe deixou o ranço das velhas histórias do Trancoso e do padre Teodoro de Almeida ${ }^{39}$.

[...] Faz-me tristeza pensar eu que floresci nesta futilidade da novela quando as dores da alma podiam ser descritas sem grande desaire da gramática e da decência. Usava-se então a retórica de preferência ao calão. O escritor antepunha a frequência de Quintiliano ‘a do 'Colete Encarnado'.[...] Naquele tempo, enflorava-se a pústula; agora, a carne com vareja pendura-se na escápula e vendese bem, porque muita gente não desgosta de se narcisar num espelho fiel. ${ }^{40}$

A ironia camiliana amarga e aguda é evidente no excerto transcrito, em que julga, com certo rancor, o Realismo/Naturalismo. Caracterizada por enunciados enganadores sob variedade complexa e extensa de tons, intenção e efeitos" (Hutcheon, 2009, p. 73), trata-se de uma ferramenta útil para subverter, criar cúmplices, desestabilizar, e ao mesmo tempo, autoproteger-se. O que desgosta o novelista naquela literatura não é a análise que beira o cientificismo, não é o desvendar da psicologia e comportamento humanos, não é o tom de deboche para com a hipocrisia coetânea, mas a predileção por seres de exceção, patológicos, que não condizem com a realidade em geral. Daí lançar ao leitor assíduo dessas narrativas uma crítica a seu comportamento: "vende-se bem, porque muita gente não desgosta de se narcisar num espelho fiel.” (Branco, 1984, p. 381-2)

Em seu texto, Camilo não se restringe a mazelas, mas elege elementos universais: "as dores da alma". Nesse sentido, as personagens camilianas revelam o modo de ser do ser humano em geral. A dor que angustia esses seres é fruto de um sentimentalismo característico do português. É o descontrole perante as emoções, o lirismo que domina o inconsciente coletivo português.

\footnotetext{
${ }^{39}$ Gonçalo Fernandes TRANCOSO (n. Trancoso?, 1510?- m. Lisboa, 1580?) Padre Teodoro de Almeida (1722-1804) Ambos os escritores apresentam reflexões claramente moralizantes.

${ }^{40}$ (Branco, 1984, p. 381-2)
} 
Outro dado fundamental para o estudo da mundividência camiliana é a alusão intertextual a dois escritores portugueses: Trancoso e Pe. Teodoro de Almeida. A leitura dos livros revela o intuito de Camilo ao compor seu Amor de Perdição.

As Histórias de Trancoso evidenciam a importância de valores como coerência entre ações e fala, a perseverança na fé, o cultivar a verdade, a manutenção da serenidade nos infortúnios, o controle sobre os impulsos de soberba, a dedicação à caridade e à amizade. As virtudes são o cerne dessa narrativa que enfatiza a caridade como a síntese das qualidades necessárias ao homem.

A referência ao livro de Gonçalo Fernandes Trancoso parece sugerir a busca de Camilo por caminhos que levem à serenidade necessária a um espírito atribulado como o seu, essencialmente romântico e português. O amor desinteressado, gratuito, surge como meio de dirigir as emoções de um ser que sofre por ser dominado por paixões imoderadas. Pela caridade, alcançar-se-ia equilíbrio e bem-estar, refrear-se-iam os impulsos insensatos, ditados por uma natureza excessivamente apaixonada.

As ideias apresentadas no texto de Trancoso são reiteradas pelo livro do filósofo português Pe. Teodoro de Almeida. Em O Feliz Independente, o autor propõe a contenção de emoções como chave para o homem ser feliz. Assim como as personagens camilianas, as de Almeida referem-se às desgraças como uma fatalidade, obra de um Fado impiedoso. No entanto, no decorrer da narrativa, uma princesa chamada Sofia (Sabedoria) revela que o Fado é "uma coisa fabulosa e que nunca existiu, senão na cabeça do vulgo!" (Almeida, 2001, p. 103) ao que o protagonista responde:

A Mão suprema (diz Misseno) que, com altos e justos desígnios, vai governando este mundo, nem sempre nos deixa ver quais são os seus fins soberanos. Nós ignorantes e cegos, toda a vez que vemos certos acontecimentos, sem poder descobrir o motivo deles, julgamos que não houve desígnio algum premeditado; e, deste modo, antes queremos supor o defeito em Deus [...]. Eis aqui o que o povo chama de Fado ou Acaso é um acontecimento do qual se ignora o motivo: ora se o sucesso, cuja causa ignora, foi favorável, lhe chamam Fortuna, se injucundo, Desgraça. (Almeida, 2001, p. 103)

Assim, Misseno, o protagonista, não desfaz a noção de Destino, mas o atribui a um Deus misericordioso que não pode tramar o mal do homem, apenas o seu bem. O próprio homem, no entanto, quando se deixa levar pelas paixões, desencaminha-se e se entrega à Tristeza. Quem leva o homem ao fracasso é, portanto, o descontrole emocional. Pronuncia- 
se, assim, que há o meio de o ser humano alcançar a felicidade e é o autocontrole, o que só pode advir da ponderação racional.

O Amor excessivo é fonte e origem de todo sofrimento, entregar-se às paixões é mera ilusão de felicidade. As personagens camilianas são movidas pelo Amor, pela Vaidade, pelo desejo de Glória e pelo Interesse, as Paixões consideradas por Pe. Teodoro como as mais nocivas e vigorosas. Sofia sintetiza-as como efeito do Amor-Próprio excessivo e explica que mesmo Amor se subordina ao Amor-Próprio pelo fato de o amante querer no convívio com a amada a auto-satisfação. Em Camilo, o herói desiste de servir sua amada quando, para isso, tem que abrir mão de sua liberdade. Simão evidencia que nem o amor de Teresa é o suficiente para que aceite permanecer no cárcere em Portugal por dez anos.

A narrativa camiliana retrata uma sociedade egoísta preocupada com as aparências, com a boa reputação na opinião pública. Granjeia-se a glória, cultivando-se a vaidade e o interesse.

O tema do desequilíbrio oriundo da entrega às paixões interessa particularmente Camilo. Entregue ao estudo dos sentimentos humanos, da alma humana, o novelista dedicase, nos quinze dias em que esteve preso por adultério, a recompor uma história de paixão de familiares próximos. Espelhando sua experiência nos relatos que encontra sobre um caso de amor também de perdição. O intuito do escritor parece ser alcançar o autocontrole pelo estudo da alma humana: “[...] cada vez conheço mais os homens, cada dia me posso governar melhor nas minhas acções, porque este é o principal fruto que cada qual há-de tirar do conhecimento dos outros." (Almeida, 2001, p. 390)

Como na tragédia, a narrativa camiliana suscita o horror e a piedade para levar o homem à reflexão sobre sua conduta. O sucesso do livro como o Romeu e Julieta português não agrada o escritor. $O$ final de sua narrativa sugeriria a intenção de reorganizar a índole dos que não sabem controlar suas emoções e sofrem por isso.

No "Prefácio" à primeira edição, Camilo apresenta Teresa e Simão como pessoas "perdidas" pelo amor. O narrador afirma que o moço perdera a "honra, reabilitação, pátria, liberdade, irmãs, mãe, vida, tudo"; no entanto as ações e dizeres do protagonista, bem como os comentários das demais personagens acerca de Simão apresentam-no como homem cuja dignidade está acima de suspeitas. 
Simão tem índole arrogante, considera desonra deixar uma ameaça impune (Branco, 1984, p. 412), e a submissão uma ignomínia quando o poder paternal é uma afronta (Branco, 1984, p. 447 ). Ao assassinar Baltazar, não foge, mas declara-se culpado e considera a forca um triunfo quando se encontra ao cabo do caminho da honra (Branco, 1984, p. 483). É associado a Louis Antoine Léon de Saint-Just, Mirabeau, Danton, Robbespierre, Desmoulins, personagens que lideraram a Revolução Francesa. Não é de estranhar que pronuncie frases como " meu coração é indiferente ao destino de minha cabeça “ (Branco, 1984, p. 474) ou

\footnotetext{
Abomino a pátria, abomino a minha família; todo este solo está aos meus olhos coberto de forcas, e quantos homens falam a minha língua, creio que os ouço vociferar as imprecações do carrasco. Em Portugal, nem a liberdade com a opulência; nem já agora a realização das esperanças que me dava o teu amor, Teresa! (Branco, 1984, p. 525)
}

Teresa, por seu turno, resiste à vontade do pai, declara morrer contente, mas não casar com o primo (Branco, 1984, p. 435), considera-se mais livre no convento, já que mantém a liberdade do coração, ainda que esteja em meio corrupto (Branco, 1984, p. 436). Para ela, a morte é a misericórdia divina (Branco, 1984, p. 534). "É mulher varonil, tem força de caráter, orgulho fortalecido pelo amor, desapego das vulgares apreensões, se são apreensões a renúncia que uma filha fez do seu alvedrio às imprevidentes e caprichosas vontades de seu pai." (Branco, 1984, p. 409). Tanto Teresa quanto Simão desdenham sua vida cômoda em meio à família em prol da luta frustrada por um amor impossível. Essa é a face genuinamente romântica do casal: entregar-se cegamente às emoções. A sociedade é afigurada como um ente tirano que lhes impõe determinados comportamentos e emoções dos quais o homem não consegue escapar.

Mariana ama sem ser correspondida, sem ter ao menos a ilusão de que um dia possa casar-se com o homem amado. Ela dedica sua vida, juventude, reputação e bens em nome de um sentimento puro e desinteressado. Mais de uma vez, João da Cruz e a filha deixam claro saberem que não é possível haver uma relação de amor entre a filha de um ferreiro e o filho do juiz Domingos Botelho. A filha do ferreiro é dotada de nobreza interior, não de linhagem, por isso não interessa à sociedade burguesa. Cumpre resignadamente o papel de criada do rapaz que ama. Antes de conhecê-lo, nunca se interessara por outro, era o amparo 
e proteção do pai que the satisfazia a vontade, refreando os impulsos nocivos. A devoção ao pai também era-lhe excessiva já que estava disposta a suicidar-se, ou ir com ele ao degredo, se este fosse condenado.

O sentimento filial parece intensificar-se no amor por Simão. Assim que o vê como filho do homem que livrou seu pai da forca, Mariana encanta-se. Sua resignação e humildade é tal que se torna a confidente de Simão e Teresa e dispõe-se a ajudarem-nos a comunicar-se.

O caráter romântico da personagem insinua-se de várias maneiras: pela abdicação de si em prol do amor; por sua intuição aguçada revelada em sonhos e presságios; pela sensibilidade intensa que a leva à loucura ao saber que o amado fora condenado à forca. Sua vida gira em torno da de Simão; por isso declara que "saberá morrer" (Branco, 1984, p. 517) se o rapaz for condenado. É presença constante e fiel ao lado do moço quando este já não tem com que contar. Diante desse amor tão dedicado, o narrador comenta:

O que tu sofrias, nobre coração de mulher pura! Se o que fazes por esse moço é gratidão ao homem que salvou a vida de teu pai, que rara virtude a tua! Se o amas, se por lhe dar alívio às dores tu mesma lhe desempeces o caminho por onde te ele há de fugir para sempre, que nome darei ao teu heroísmo! Que anjo te fadou o coração para a santidade desse obscuro martírio?! (Branco, 1984, p. 456-7)

Esse questionamento sugere que o título de amor de perdição cabe, também, a Mariana e a todos os que sofrem por amor. O texto sugere, então, o dilema do homem da época, a angústia de um ser cindido entre suas emoções e as convenções que o limitam, impondo-lhe a dissimulação como meio de conquistar o reconhecimento e aceitação públicos.

Nesse contexto, o autoconhecimento é uma das chaves para o reencontro da completude, da tranquilidade perdida pela exacerbação dos sentimentos.

Porque el Amor es um anticipo de esos sufrimientos y de ese deleite que experimentará el alma cuando vuelva a Dios, cuando se rompan los sofocantes lazos del cuerpo y de la ilusión... Al elevarse en el alma la poderosa voz del Amor, no es uma fuerza solamente, sino todas las fuerzas del alma y del cuerpo las que se despiertan y agitan. Y ese movimiento ejerce una acción disolvente sobre el individuo estrechamente limitado; es como una atracción que arrebata al alma fuera de sus fronteras terrestres, hacia una nueva existencia. (Béguin, 1993, p. 157) 
O Amor desinteressado, gratuito, conduziria o homem ao retorno a si mesmo, ao eu sem máscaras sociais. Cultivar o sentimento de caridade torna o ser humano equilibrado e apto a sondar as regiões profundas em que todas as almas relacionam-se com a Unidade comum. Esse sentimento elevado seria capaz de extinguir o isolamento do indivíduo, de exterminar os limites físicos e temporais. $\mathrm{O}$ mundo efêmero e castrador perderia a importância pela magia de um sentimento virtuoso o bastante para derrubar as imposições da realidade material.

A caridade é também uma forma de o homem buscar Deus em si mesmo, reconciliar-se com os vestígios da divindade que ainda lhe restam a fim de restituir a unidade primitiva. O romântico elege locais ermos e sombrios, propícios à auto-sondagem em busca da integridade perdida.

O universo interior humano só é integral quando não se reconhece como indivíduo e ser social. O autor romântico, incentiva o contato com o universo interior, alertando para a necessidade de abandonar as exigências de uma sociedade que incita a agravação do individualismo egoísta. Camilo considera a história de Simão e Teresa um meio de apresentar sentenças "contra a falsa virtude de homens, feitos bárbaros, em nome da sua honra." (Branco, 1984, p. 384).

O novelista apresenta no caso de Simão e Teresa o amor espiritualizado que prescinde do contato físico. Tanto Teresa quanto Simão sabem da impossibilidade da realização de seus sentimentos, mas nem por isso desistem de sua união que se dará após a morte, na eternidade. Trata-se do ideal de amor neoplatônico pelo qual o homem poderia sublimar-se e elevar-se espiritual e filosoficamente.

As demais personagens, por outro lado, são ridicularizadas em suas paixões mesquinhas, sobretudo, Domingos Botelho, que representa a vacuidade intelectual do magistrado português, eleito não por merecimento e qualidades, mas por apadrinhamentos.

Domingos alcança a simpatia da rainha D. Maria I de Portugal, por fazer rir a soberana considerada louca devido à doença mental manifestada com veemência nos últimos 24 anos de vida. Essa afinidade lhe granjeia uma pensão, o cargo de juiz de fora de Cascais, e Rita, uma dama do paço, a quem tentou conquistar por dez anos, mas cuja benevolência só alcança com a intercessão da rainha. O marido de Rita Preciosa é descrito 
como fidalgo de linhagem, extremamente feio, sem bens de fortuna, nem dotes de espírito ou de inteligência, o que torna o matrimônio desagradável à esposa. Camilo compara o casal à Vênus e Vulcano, sugerindo, assim, o casamento arranjado a contragosto da esposa e a possibilidade de adultério.

A personalidade do magistrado parece frágil, ele não parece ter opiniões consistentes, mas deixa-se levar pelos juízos de Rita. É assim que passa a desprezar o filho Simão, que, a princípio, admira por sua audácia, coragem em distinção nas notas, mesmo sem dedicar-se a isso. "O corregedor via as coisas pelos olhos de sua mulher, e tomou parte no desgosto dela e na aversão ao filho." (Branco, 1984, p. 395). Domingos Botelho representa a paixão pelo reconhecimento público, para o que se lança a castigar impiedosamente a injúria de acordo com seu ponto de vista subjetivo. Dessa forma, absolve João da Cruz por vingar-se de um rapaz que lhe insultou e condena Simão por matar em legítima defesa. A noção de justiça do magistrado acaba causando males superiores ao que devem ser punidos. Ele é incapaz de julgar serenamente, é severo em seus juízos e age como um tirano. Só se empenha em soltar o filho para provar a superioridade de seu poder ao de Tadeu de Albuquerque.

D. Rita é motivo de interferências do narrador. Descrevendo-a, o escritor estuda o comportamento social e humano. Preocupada com as aparências e acostumada com o luxo e pompa do paço real, essa mulher age de maneira arrogante e soberba, procura ridicularizar o marido e sua nobreza decadente em todas as oportunidades. A rivalidade que nutre pelo esposo é motivo de contestá-lo para indicar sua superioridade sobre ele; no entanto, na condição de mulher não pode prevalecer sempre. Essa oposição é valiosa para o escritor tratar da vaidade humana.

Ausente o meirinho, disse D. Rita Preciosa ao marido:

- Que significa esse modo de falar de seu filho?

- Significa que sou corregedor desta comarca, e que não protejo assassinos por ciúmes, e ciúmes da filha dum homem, que eu detesto. Eu antes queria ver mil vezes morto Simão que ligado a essa família. Escrevi-lhe muitas vezes dizendolhe que o expulsava de minha casa, se alguém me desse a certeza de que ele tinha correspondência com tal mulher. Não há de querer a senhora que eu vá sacrificar a minha integridade a um filho rebelde, e de mais a mais homicida.

D. Rita, algum tanto por afeto maternal e bastante por espírito de contradição, contendeu largo espaço; mas desistiu, obrigada pela insólita pertinácia e cólera do marido. Tão iracundo e áspero em palavras nunca o ela vira. Quando the ele disse: - "Senhora, em coisas de pouca monta o seu domínio era tolerável; em questões de honra, o seu domínio acabou: deixe-me!" - D. Rita, quando tal ouviu, e reparou na fisionomia de Domingos Botelho, sentiu-se mulher, e retirou-se. (Branco, 1984, p. 472) 
No excerto transcrito, a atitude de Rita é pretexto para sugerir uma característica do comportamento humano. O episódio não traz apenas uma questão social - o papel de conformidade da mulher na sociedade da época com as regras ditadas pelo homem - mas aponta características do universo interior humano, o que eleva o discurso de Camilo a outro patamar e torna a narrativa mais atual e abrangente. No trecho - "D. Rita, algum tanto por afeto maternal e bastante por espírito de contradição[...]" - aparece um traço fundamental da índole humana que será tema de vários romances de cunho psicológico: o sestro de contestar, de fazer objeções como forma de distinguir-se e elevar-se perante o outro. Essa característica torna ainda mais pesada a inevitabilidade da resignação e sujeição à ordem imposta.

A ambiguidade entre a altivez de caráter e a necessidade de submissão dá relevo a personagens femininas; os homens são menos complexos, caracterizados pela teimosia e obceção por imporem-se uns aos outros. Assim, Simão opõe-se ao pai, Domingos ataca e é atacado por Tadeu; Baltazar entra em combate com Simão.

Os homens da família Albuquerque destacam-se pela conivência. Tadeu, cujo nome significa "o amável, o amoroso" 41 , é descrito como pai astuto que espera em silêncio por dois anos que a paixão da filha se abrande para armar uma emboscada e casá-la subitamente com o primo. Declama um discurso sentimental e piegas a fim de convencê-la ao matrimônio; no entanto, assim que nota a irreversibilidade da decisão da filha, mostra-se iracundo e colérico, prometendo-lhe encerrá-la para sempre em um convento.

Baltasar, ferido em seu amor próprio, é quem trama ciladas para Simão e Teresa. Essa personagem afigura-se como um ser repelente e nocivo. A escolha de seu nome parece indicar a ironia de Camilo ao caracterizá-lo. Baltasar significa "o deus Baal projeta (shar) o rei (usur)". Baal é um deus cananeu, cuja história remete a traição e violência. Baal aproveita o momento em que seu pai, o deus soberano, está velho para invadir o Panteão e arrancar suas entranhas fecundas e torná-lo um deus impotente e debilitado. Depois disso, rouba as duas mulheres do pai e declara-se o novo deus soberano. Como se pode notar, a narrativa camiliana ganha em profundidade quando considerada com cuidado em todos os seus elementos.

\footnotetext{
${ }^{41}$ Todos os significados de nomes foram retirados de Guérios, 1994.
} 
Embora a história enfoque em primeiro plano os conflitos de um casal de namorados, o alvo do escritor parece apresentar sua visão desiludida em torno da infelicidade do ser humano. Isso se pode vislumbrar, por exemplo, pela digressão em que trata da morte por paixão.

[...] tinha morrido de paixão e vergonha talvez! - exclama uma leitora sensível.

- Não, minha senhora; o estudante continuava nesse ano a frequentar a Universidade; e, como tinha já vasta instrução em patologia, poupou-se à morte da vergonha, que é uma morte inventada pelo visconde de A. Garrett no Fr. Luiz de Sousa, e à morte da paixão, que é outra morte inventada pelos namorados nas cartas despeitosas, e que não pega nos maridos a quem o século dotou de uns longes de filosofia, filosofia grega e romana, porque bem sabem que os filósofos da antiguidade davam por mimo as mulheres aos seus amigos, quando os seus amigos por favor lhas não tiravam, E esta filosofia hoje então... (Branco, 1984, p. 508)

Interessante notar que o Camilo polemista não se exime do novelista passional, apenas torna-se dissimulado ou dotado de uma ironia mais fina. Esse é o Camilo das divagações filosóficas; o Camilo agudo e espirituoso que analisa a hipocrisia social sem piedade. No Amor de perdição, o lirismo das cartas de Simão e de Teresa ganha tal ênfase que o leitor conclui tratar-se de narrativa ultra-romântica em que predominam o derramamento sentimental e o culto pela morte como escape para uma vida angustiante.

[...] a grandeza trágica da história, a maneira comovida de contar, a identificação sentimental de Camilo com o herói, a convergência de todos os efeitos para os lances culminantes da ação, o valor cênico dalguns passos, a força realista doutros, o casticismo dos sentimentos, o lirismo das cartas amorosas (Coelho, 1982, p. 429)

arrebatam o leitor e o tornam incapaz de desviar seu olhar para a mensagem subjacente que quer ser divulgada. O lirismo que domina o inconsciente coletivo português fala nas cartas dos amantes e extasia o público-leitor que se torna cego para a mensagem mais profunda do livro.

Nota-se, pelos comentários do narrador, a intenção de compreender a alma humana, sugerida no prólogo é um dos focos do livro.

Se, de acordo com o trecho camiliano, o estudante de Patologia saberá que não há morte de vergonha, mera invenção de Garrett no Frei Luís de Sousa; e se a morte por paixão é invenção de namorados despeitados, vírus que não passa aos maridos afeitos aos casos de suas esposas, de que morrem Teresa e Simão? Qual a doença que os acomete? 
Camilo parece insinuar que o casal abandona o intuito inicial de um amor caridoso, desinteressado, ao deparar-se com a punição cruel de Tadeu Albuquerque. A violência do pai em privar Teresa de seu próprio lar, encerrando-a em um convento, desenvolve no casal uma paixão incontrolável e obcecada. A cegueira oriunda da paixão tem consequências catastróficas: a morte de Baltasar, o sofrimento de Mariana, a separação de João da Cruz e sua filha.

No início da narrativa, o plano do casal era virtuoso, Simão dispunha-se a formar-se com êxito para sustentar Teresa. Entretanto, diante da crueldade do pai da moça, o rapaz desenvolve o desejo de vingança, a obstinação por sequestrar a namorada e ódio a Baltazar.

E necessário arrancar-te daí - dizia a carta de Simão. — Esse convento há de ter uma evasiva. Procura-a, e dize-me a noite e a hora em que devo esperar-te. Se não puderes fugir, essas portas hão de abrir-se diante da minha cólera. Se daí te mandarem para outro convento mais longe, avisa-me, que eu irei, sozinho ou acompanhado, roubar-te ao caminho. É indispensável que te refaças de ânimo para te não assustarem os arrojos da minha paixão. És minha! Não sei de que me serve a vida, se a não sacrificar a salvar-te. Creio em ti, Teresa, creio. Ser-meás fiel na vida e na morte. Não sofras com paciência; luta com heroísmo. A submissão é uma ignomínia quando o poder paternal é uma afronta.

(Branco, 1984, p. 447 O grifo é nosso)

A índole impetuosa do rapaz, amenizada pelo amor meigo e singelo, torna a brotar, agora dilatada pela paixão. Dessa expansão resultará a morte de Baltazar e a prisão do herói. No entanto, a luta contra inimigos desiguais gera o sentimento de derrota e, com ele, a sensação de pessimismo e desdém pela vida.

Assim te sentias tu, infeliz, quando dezoito meses de cárcere, com o patíbulo ou o degredo na linha do teu porvir, te haviam matado o melhor da alma.

A ti mesmo perguntavas pelo teu passado, e o coração, se ousava responder, retraía-se, recriminado pelos ditames da razão.

De além, daquele convento onde outra existência agonizava, gementes queixas te vinham espremer fel na chaga; e tu, que não sabias nem podias consolar, pedias palavras ao anjo da compaixão para ela, e as do demônio do desespero para ti. (Branco, 1984, p. 524)

Consciente de que a batalha é inútil porque sua paixão o levou a tornar-se criminoso, Simão é tomado pelo abatimento e professa desgosto pela vida, pela família e pela pátria. A prostração decorrente dos meses de cárcere fazem-no abrir mão do amor e querer abraçar a morte. 
Esquece-te de mim, e adormece no seio do nada. Eu quero morrer, mas não aqui. Apague-se a luz dos meus olhos; mas a luz do céu, quero-a! Quero ver o céu no meu último olhar!

$[\ldots]$

Salva-te, se podes, Teresa. Renuncia ao prestígio dum grande desgraçado. Se teu pai te chama, vai. Se tem de renascer para ti uma aurora de paz, vive para a felicidade desse dia. E, se não, morre, Teresa, que a felicidade é a morte, é o desfazerem-se em pó as fibras laceradas pela dor, é o esquecimento que salva das injúrias a memória dos padecentes".

[...]

Seguiram-se a esta carta muitos dias de terrível taciturnidade. Simão Botelho não respondia às perguntas de Mariana, Di-lo-íeis arroubado nas voluptuosas angústias do seu próprio aniquilamento. (Branco, 1984, p. 525)

À languidez do espírito, seguem sentimentos de mágoa, repugnância, a falta de fervor para servir a amada e a consequente morte do casal. Entregar-se às paixões causaria, então, o desenvolvimento de distúrbios e de sintomas físicos para os quais não se encontra nenhuma lesão orgânica objetiva, mas que ainda assim são o suficiente para causar a morte.

Diferente do que ocorre em Shakespeare, onde os amantes mantêm o amor na adversidade, em Camilo, o amor vira paixão, desgosto e culpa. O leitor que não atentar para as sugestões intertextuais fornecidas no prefácio do livro encontrará na novela uma história de amor que sublima pelo sofrimento e eleva espiritualmente. Entretanto, a menção aos outros textos de Trancoso e de Pe. Almeida parecem sugerir a proposta de contenção de sentimentos e a consequente obtenção da serenidade. Nesse sentido, o texto torna-se um espelho do coração humano, que Camilo conhecia como ninguém, embora não conseguisse dominá-lo.

O mal das paixões imoderadas assola também o novelista daí a necessidade de espelhar-se em um caso de amor mal-sucedido para compreender o que lhe vai na alma.

[...] preciso é afastarmo-nos um pouco do que queremos ver, para conhecer esse objecto. Ora, meu amigo, tudo o que nos pertence a nós, está demasiadamente perto dos olhos do entendimento; é necessário afastarmo-nos de nós mesmos, e considerar as nossas acções como se fossem de outros; e deste modo veremos as coisas como elas são em si mesmas. [...] Lástima é que os homens não tenham espelhos para ver as próprias acções, pois então olhariam para elas como se fossem alheias, e conheceriam a sua deformidade. (Almeida, 2001, p. 394)

O espelhamento é sugerido também na narrativa. O contraste entre os valores de Simão e Teresa e os dos homens de sua época é exemplo da inversão propiciada pelo 
reflexo especular. Essa oposição é pretexto para o novelista analisar criticamente sua sociedade. A constância do amor de Teresa, uma mulher ${ }^{42}$ de quinze anos, idade em que o amor "carece de consistência para sobreviver a uma ausência de seis meses." (Branco, 1984, p. 403), explica-se pelo fato de a moça não frequentar a sociedade:

[...] Teresa não vai à sociedade, não tem altar em cada noite na sala, não provou o incenso de outros galãs, nem teve ainda uma hora de comparar a imagem amada, desluzida pela ausência, com a imagem amante, amor nos olhos que a fitam, e amor nas palavras que a convencem de que há um coração para cada homem, e uma só mocidade para cada mulher. Quem me diz a mim que Teresa teria em si as quatro mulheres da máxima, se o vapor de quatro incensórios lhe estonteasse o espírito? Não é fácil, nem preciso decidir. (Branco, 1984, p. 404)

Enquanto Baltasar é caracterizado como alguém que alia a covardia à "absoluta carência de brios" (Branco, 1984, p, 441), Simão revela coragem e ousadia, não apresenta o comportamento padrão de sua sociedade quando se declara culpado de um crime e nega contar com as prerrogativas de ter um pai juiz. A índole sanguinária do rapaz só é refreada quando ele se depara com sua antítese, Mariana, que sofre tudo silenciosa e resignadamente. Também a vida distante da alta sociedade é motivo para Simão encontrar paz uma única vez, já que na casa simples do ferreiro o rapaz "[...] estava-se gozando na simpleza daquele quadro rústico, mas sublime de naturalidade." (Branco, 1984, p. 444). No entanto, no momento em que Simão desconsidera o direito do outro para fazer de sua vontade e obstinação sua única lei assemelha-se aos outros homens e, como eles, torna-se infeliz.

Na narrativa, todas as personagens sofrem por deixarem-se levar pelas paixões. João da Cruz parece constituir a epítome do homem rústico português na visão camiliana. Ele revela a ambiguidade do caráter de seu povo pela índole bárbara, pela valentia que beira a crueldade, em contraposição à ternura e lealdade de um coração dedicado e constante aos que lhe são caros. Três dos ditados veiculados por João da Cruz parecem sintetizar-lhe o modo de pensar:

"Quem o seu inimigo poupa, nas mãos lhe morre." (Branco, 1984, p.431)

"Quem semeia colhe" (Branco, 1984, p.453)

"Vão-se os anéis e fiquem os dedos." (Branco, 1984, p.511)

\footnotetext{
42 Para Camilo, a índole feminina é marcada pela volubilidade: "Em cada mulher, quatro mulheres incompreensíveis, pensando alternadamente como hão-de desmentir umas às outras.' " 1984, p. 404.
} 
Assolada por paixões, todas as personagens da narrativa são seres frágeis, títeres de suas emoções. Incapazes de controlarem-se, sofrem tiranizados por suas escolhas.

A índole sanguinária de João da Cruz que faz justiça com as próprias mãos, primeiro por ser zeloso pela equidade; depois por desacreditar na justiça daquele país é pretexto para Camilo sugerir um retrato da justiça em Portugal.

[...]Vossa Senhoria , como é filho de ministro não terá perigo; mas eu, que sou ferrador, posso contar que desta vez tenho o baraço no pescoço. [...] Vossa Senhoria é doutor, saberá muito, mas de justiça não sabe nada, e há-de perdoar meu atrevimento. Basta uma só testemunha para guiar a justiça na devassa. (Branco, 1984, p. 431)

A opinião sobre a irregularidade da justiça no país é compartilhada por pessoas do povo, como se vê pelo comentário de um espectador do julgamento de Simão: "Matasse ele um pobre, e tu verias como ele estava em casa!" (Branco, 1984, p. 481). As atitudes de João da Cruz, embora à primeira vista pareçam brutais, na verdade, são um meio de lidar com a falta de igualdade vigente no país. O narrador semelha concordar com essa visão já que apresenta fatos como o seguinte episódio:

-Ides ter um belo espetáculo, Senhores! [exclama Simão] A forca é a única festa do povo! [...]

- Tu hás de levar os teus pequenos para ver o padecente?

-Pudera não! Estes exemplos não se devem perder.

- Eu cá de mim já vi enforcar três, que me lembre, todos por matadores.

- Por isso tu, há dois anos, não atiraste com a vida do Amaro Lampreia a casa do Diabo!...

- Assim foi; mas se eu o não matasse, matava-me ele.

- Então de que voga o exemplo?!

- Eu sei cá de que voga? O frei Anselmo dos Franciscanos é que prega aos pais que levem os filhos a verem os enforcados.

- Isso há-de ser para não o esfolarem a ele, quando ele nos esfola com os peditórios.

Tão desassombrado ia o espírito de Simão, que algumas vezes lhe esvoaçou nos lábios um sorriso, desafiado pela filosofia do povo, acerca da forca. (Branco, 1984, p. 481-482)

A crítica estende-se, aqui, à Igreja incoerente com os mandamentos que prega: propor assistência a um enforcamento como exemplo para não matar é um paradoxo que cumpre ser ridicularizado.

Inserido nesse contexto, o povo não deixará de apresentar sentimentos nobres e desinteressados. Daí a outra face de João revelar o desdém pelo material em prol do amor. Com saudades da filha que está no Porto em companhia de Simão, o ferrador planeja deixar 
o trabalho e gastar suas economias para encontrar-se com Mariana. Seu intuito é malogrado, no entanto, por ser assassinado pelo filho do homem que o ferreiro havia matado.

Todas as personagens são perseguidas pelas más escolhas que fizeram no passado, escolhas ditadas pelo amor-próprio, pelas paixões. Domingos Botelho sofre a incerteza da correspondência no amor e as consequências de sua tirania como juiz, já que perde o filho pela implicância que Tadeu de Albuquerque tem a ele por causa de uma demanda. Rita sofre por ver os filhos mancharem o nome de sua família que, para ela, é o que deve ser preservado à custa de sacrifícios e renúncias. Tadeu padece a perda da única filha por não saber perdoar e por colocar o lucro acima do amor filial. Baltasar é morto pelo atrevimento de impor-se sobre a vontade da prima e do namorado. João da Cruz é privado da paz e do convívio da filha por ter que pagar o benefício de ter sido solto depois de matar um homem num ímpeto de raiva.

Verifica-se, pelos exemplos acima, que o comentário do novelista sobre não tecer uma análise da alma humana, nem dedicar-se à pesquisa linguística é uma ironia. $\mathrm{O}$ fingimento camiliano é o meio de o autor ludibriar o leitor ingênuo e estimular o atento.

Pelo jogo de revelar / esconder, Camilo sugere dissimuladamente sua mundividência. Somente levando em consideração as digressões do narrador, o leitor poderá adentrar a visão camiliana.

Por meio de comentários do narrador, são tecidas críticas contundentes, inclusive ao fazer literário. Promove-se, dessa maneira, o distanciamento do ledor, enquanto se incentiva a atitude crítica diante da ficção. A ironia romântica é fundamental nesse processe, o escritor insere-se na narrativa como autor e personagem. Em outros termos, o autor assume-se como demiurgo e trata do próprio processo de criação, incluindo o leitor nesse sistema. "A ironia é, pois, o meio que o eu usa para se auto-representar artisticamente, movimento dialético entre realidade e ficção." (Ferraz, 1987, p. 43). Além disso, remete à dissimulação.

Neste capítulo, já foram transcritos excertos em que se verifica essa atitude do narrador. Ao desdenhar de poetas que louvavam o amor aos quinze anos e ao apresentar o amor de Teresa em idade tão jovem como exceção, o narrador aproveita para escarnecer dos exageros de textos românticos. Também quando retrata a astúcia da fidalga ao ludibriar 
o pai, mentindo que só viveria para ele, o narrador comenta que a mulher do romance é extraordinária. Esses comentários desmitificam o fazer literário e incentivam o senso crítico do leitor.

Outro exemplo de ironia romântica ocorre no trecho em que o narrador comenta a inverossimilhança flagrante nos romances que jamais retratam problemas financeiros do herói. A situação financeira do protagonista, filho de família burguesa, mas abandonado por ousar contrariar suas regras é motivo de digressão do narrador.

E ficou pensando na sua espinhosa situação. Deviam de ocorrer-lhe ideias aflitivas que os romancistas raras vezes atribuem aos seus heróis. Nos romances todas as crises se explicam, menos a crise ignóbil da falta de dinheiro. Entendem os novelistas que a matéria é baixa e plebeia. O estilo vai de má vontade para coisas rasas. Balzac fala muito em dinheiro; mas dinheiro a milhões. Não conheço, nos cinquenta livros que tenho dele, um galã num entre ato da sua tragédia a cismar no modo de arranjar uma quantia com que um usurário lhe lança, desde a casa do juiz de paz a todas as esquinas, donde o assaltam o capital e o juro de oitenta por cento. Disto é que os mestres em romances se escapam sempre. Bem sabem eles que o interesse do leitor se gela a passo igual que o herói se encolhe nas proporções destes heróizinhos de botequim, de quem o leitor dinheiroso foge por instinto, e o outro foge também, porque não tem que fazer com ele. A coisa é vilmente prosaica, de todo o meu coração o confesso. Não é bonito deixar a gente vulgarizar-se o seu herói a ponto de pensar na falta de dinheiro, um momento depois que escreveu à mulher estremecida uma carta como aquela de Simão Botelho. Quem a lesse, diria que o rapaz tinha postadas, em diferentes estações das estradas do país, carroças e folgadas parelhas de mulas para transportarem a Paris, a Veneza, ou ao Japão a bela fugitiva! A estradas, naquele tempo, deviam ser boas para isso, mas não tenho a certeza de que houvesse estradas para o Japão. Agora creio que há, porque me dizem que há tudo. (Branco, 1984, p. 448)

O realismo da cena que flagra o herói em dificuldade financeiras, e o tom de deboche para com novelistas e público ávidos pela idealização de personagens enquanto desdenham dos menos afortunados revela a ousadia camiliana diante das convenções.

O comentário metalinguistico põe em ridículo a idealização romanesca e evidencia o disparate da condição do herói desprezado por seus pais. A pseudoverdade literária é posta em xeque. O narrador maneja a relação realidade / ficção evidenciando o descompasso entre as duas.

O leitor / narratário é, deste modo, o outro cuja existência se torna necessária para que o eu se reconheça como tal - como sujeito - numa mescla de mistificação e autenticidade cuja coexistência paradoxal só a ironia pode expressar; a ironia da própria literatura, que vive precisamente daquilo que não é - a vida. (Ferraz, 1987, p.152) 
O espelhamento criado é necessário para que o sujeito enunciador se manifeste e insinue sua visão de mundo. No fragmento transcrito, o narrador expõe que Simão não pode desconsiderar a importância do dinheiro uma vez que necessita de mostrar sua gratidão ao ferreiro e sustentar Teresa, no caso de fugir com ela. Mariana, assim como o hóspede, preocupa-se com as circunstâncias em que ele se encontra e, muito prática, resolve dispor de seus bens para auxiliá-lo. A realidade concreta e prosaica chama a atenção, não deixa a ilusão tomar conta do leitor, as finanças são descritas como um meio de tornar possível a realização do amor.

Como se pode perceber, além de suscitar uma visão crítica acerca do fazer literário e da realidade cotidiana, o comentário sobre a falta de dinheiro do protagonista é um meio sutil de Camilo expor sua visão acerca da astúcia e sagacidade da mulher do povo em contraste com a ingenuidade da burguesa. Mariana é pragmática, não se ilude como Teresa que espera encontrar no trabalho de Simão e na morte do pai os recursos para manter-se. A filha do ferreiro considera-se mais forte que a fidalga ${ }^{43}$ Opõem-se, assim, a submissão e ingenuidade da mulher burguesa à astúcia e sagacidade da mulher do povo. O novelista valoriza a mulher do povo como uma pessoa mais hábil para lidar com os reveses da vida, enquanto insinua a deficiência da educação da mulher burguesa, moldada para o conforto do lar e para a submissão.

Outro excerto que merece ser destacado refere-se à verdade na literatura.

A verdade é algumas vezes o escolho de um romance.

$\mathrm{Na}$ vida real, recebemo-la como ela sai dos encontrados casos, ou da lógica implacável das coisas; mas, na novela, custa-nos a sofrer que o autor, se inventa, não invente melhor; e, se copia, não minta por amor da arte.

Um romance que estriba na verdade o seu merecimento é frio, é impertinente, é uma coisa que não sacode os nervos, nem a gente, sequer uma temporada, enquanto ele nos lembra, deste jogo de nora, cujos alcatruzes somos, uns a subir, outros a descer, movidos pela manivela do egoísmo.

A verdade! Se ela é feia, para que oferecê-la em painéis ao público!?

A verdade do coração humano! Se o coração humano tem filamentos de ferro que o prendem ao barro doente saiu, ou pesam nele e o submergem no charco da culpa primitiva, para que é emergi-lo, retratá-lo e pô-lo à venda!?

\footnotetext{
${ }^{43}$ E mais a fidalga é fraquinha, e eu sou mulher do campo, vezada a todos os trabalhos; e, se fosse preciso meter uma lanceta no braço e deixar correr o sangue até morrer, fazia-o como quem o diz. Branco, 1984, p. 517.
} 
Os reparos são de quem tem o juízo no seu lugar; mas, pois que eu perdi o meu a estudar a verdade, já agora a desforra que tenho é pintá-la como ela é feia e repugnante.

A desgraça afervora ou quebranta o amor?

Isto é que eu submeto à decisão do leitor inteligente. Fatos e não teses é o que eu trago para aqui. $\mathrm{O}$ pintor retrata uns olhos, e não explica as funções ópticas do aparelho visual.

Ao cabo de dezenove meses de cárcere, Simão Botelho almejava um raio de Sol, uma lufada do ar não coada pelos ferros, o pavimento do céu, que o da abóbada do seu cubículo pesava-lhe o peito. (Branco, 1984, p. 522 - 523)

A problemática relação entre literatura e verdade é tratada em tom zombeteiro. o narrador rompe com a posição heterodiegética e apresenta-se como autor da história.

A vida é dialógica por natureza. Viver significa participar do diálogo: interrogar, ouvir, responder, concordar, etc. Nesse diálogo, o homem participa inteiro com toda a vida [...] (Bakhtin, 2003, p. 348)

Assim, ele censura o leitor que busca na ficção fantasias e disposições de caráter que não se possam encontrar na vida cotidiana. Alegando ter perdido o juízo ao estudar a verdade, o narrador / autor declara que terá de ser coerente e, por isso, apresentará o abatimento de Simão diante do amor. O jogo irônico possibilita que se apresente um retrato mais fiel do universo interior humano, que, muitas vezes, é idealizado nos romances românticos. O estuda da alma humana torna-se, por conseguinte, mais aprofundado.

Seguindo esta verdade, Mariana não será apenas o anjo, mas mulher. Embora dotada de inúmeras qualidades, ela inveja a beleza e a condição de Teresa e planeja a vida no exílio onde ficará sozinha com Simão.

um secreto júbilo endoidecia o coração de Mariana. Não inventemos maravilhas de abnegação. Era de mulher o coração de Mariana. Amava como a fantasia se compraz de idear o amor duns anjos que batem as asas de baile em baile, e apenas quedam o tempo preciso para se fazerem ver e adorar a um reflexo de poesia apaixonada. Amava, e tinha ciúmes de Teresa, não ciúmes que se refrigeram na expansão ou no despeito, mas infernos surdos, que não rompiam em labareda aos lábios, porque os olhos se abriam prontos em lágrimas para apagá-la. Sonhava com as delícias do desterro, porque voz humana alguma não iria lá gemer à cabeceira do desgraçado. Se a forçassem a resignar a sua inglória missão de irmã daquele homem, resigná-la-ia, dizendo: - "Ninguém lhe adoçará as penas tão desinteresseiramente como o eu fiz".(Branco, 1984, p.519) 
Mariana lida com um conflito que a revela como uma personagem sem idealização. O amor completamente despojado e altruísta não é humano, mas divino. A moça, entretanto, não é completamente resignada, necessita do contato com Simão e vislumbra no exílio a possibilidade de tê-lo somente para si. Também o rapaz, diante da fidelidade da moça, titubeia:

Perguntou por Mariana, e o carcereiro lhe disse que a mandava chamar. Veio João da Cruz, e a chorar se lastimou de perder a filha, porque a via delirante a falar em forca e a pedir que a matassem primeiro. Agudíssima foi então a dor do acadêmico ao compreender, como se instantaneamente lhe fulgurasse a verdade, que Mariana o amava até o extremo de morrer. Por momentos se lhe esvaiu do coração a imagem de Teresa, se é possível assim pensá-lo. Vê-la-ia porventura como um anjo redimido em serena contemplação do seu criador; e veria Mariana como o símbolo da tortura, morrer a pedaços, sem instantes de amor remunerado que lhe dessem a glória do martírio. Uma, morrendo amada; outra, agonizando, sem ter ouvido a palavra "amor" dos lábios que escassamente balbuciavam frias palavras de gratidão.

A personagem é mais complexa que as demais. $\mathrm{O}$ amor completamente resignado não é humano, mas divino. Mariana, entretanto, não é completamente resignada, necessita do contato com Simão e vislumbra no exílio a possibilidade de tê-lo somente para si. Também o rapaz, diante da fidelidade da moça, titubeia.

Perguntou por Mariana, e o carcereiro lhe disse que a mandava chamar. Veio João da Cruz, e a chorar se lastimou de perder a filha, porque a via delirante a falar em forca e a pedir que a matassem primeiro. Agudíssíma foi então a dor do acadêmico ao compreender, como se instantaneamente lhe fulgurasse a verdade, que Mariana o amava até o extremo de morrer. Por momentos se lhe esvaiu do coração a imagem de Teresa, se é possível assim pensá-lo. Vê-la-ia porventura como um anjo redimido em serena contemplação do seu criador; e veria Mariana como o símbolo da tortura, morrer a pedaços, sem instantes de amor remunerado que lhe dessem a glória do martírio. Uma, morrendo amada; outra, agonizando, sem ter ouvido a palavra "amor" dos lábios que escassamente balbuciavam frias palavras de gratidão. (Branco, 1984, p. 482. O grifo é nosso)

Simão é homem e, como tal, sente-se em conflito diante da paixão de Mariana. Quer corresponder a seu amor, mas sente-se em débito com Teresa a quem jurou fidelidade. As paixões tornam-se acirradas diante de impedimentos culturais e sociais. Camilo vai observando atentamente essas reações para conhecer-se melhor e chegar à plenitude.

O romântico vê o indivíduo como um reflexo incompleto do Todo, e, em cada ser, um germe da unidade perdida a qual deve ser restabelecida para se efetivar a reintegração do homem. Considera, por isso, a Alma Universal a fonte de onde emanam os seres, e o homem, um microcosmo que reflete o macrocosmo. 
Em outros termos, o Uno funda a polaridade que rege o universo. Estabelece-se, então, um jogo de espelhos: a alma humana é espelho/reflexo da alma universal; portanto, para conhecer o Todo, o homem deve sondar a si mesmo, em suas regiões mais profundas e inconscientes.

Dividido por duas forças contrárias, o homem é impulsionado, por um lado, à individualização, ao prazer efêmero e momentâneo que a matéria proporciona, e, por outro, à união perdida para o quê deve desdenhar de qualquer ímpeto egocêntrico.

Com efeito, o humano individual acha-se na dependência de factores exteriores, de leis, de instituições políticas, de um preexistente estatuto civil perante os quais é obrigado a curvar-se sem que se possa interrogar sobre eles se eles estão ou não de acordo com sua interioridade. (Hegel, 1993, p. 90)

O romântico não é, portanto, um ser alheio ao mundo real e contemporâneo, mas alguém consciente da ambiguidade do ser humano. Por conseguinte, esse homem distanciase da existência trivial pela sede do infinito.

A melancolia decorrente desse fado é sugerida pela epígrafe do livro: "Quem viu jamais vida amorosa, que não a visse afogada nas lágrimas do desastre ou do rependimento?", retirada da Epanáfora Amorosa, de D. Francisco Manuel. (http://cfp.cmlisboa.pt/pls/htmldb/f?p=334:17:2767918072361543::::P17_AUT_ID:79). A alusão à narrativa é uma sugestão irônica da intenção de Camilo ao compor seu texto.

D. Francisco Manuel compõe seu livro em condições semelhantes às do novelista oitocentista; ele escreve depois de ter sido preso, e afirma sentir-se solitário, querer extravasar sua dor. Tudo se passa como se seu intuito fosse transformar a "dor sentida" em "dor fingida" para entreter o "comboio de corda" chamado coração. ${ }^{44}$

Outro ponto de proximidade entre os autores é o fato de a narrativa barroca basearse em uma história real que se tornará lenda. Ambas as histórias giram em torno de amores proibidos. Na Epanáfora amorosa, no entanto, a família da moça, quando descobre o namoro, obriga-a a casar-se. Por isso, Ana, a protagonista ${ }^{45}$ foge com o amado. Previdente e apegada à matéria, a moça leva consigo suas jóias mais preciosas para que possa manterse. No entanto, ela morre ao ver-se em uma ilha desconhecida ${ }^{46}$, distante do esplendor da

\footnotetext{
${ }^{44}$ As informações sobre a vida e obra de D. Francisco Manuel de Melo foram extraídas das notas informativas de José Manuel de Castro, a Melo, s/d.

${ }^{45}$ Não bastasse tratar de um caso de adultério, a protagonista ainda tem o mesmo nome da amante de Camilo.

${ }^{46}$ Roberto e Ana, auxiliados por marinheiros amigos do herói, partem para França, mas ventos os desviam do caminho e os fazem aportar em uma terra desconhecida, dá-se, assim, a fundação da Ilha da Madeira.
} 
vida civilizada. Roberto, o amante, morre cinco dias depois, sentindo-se culpado pela morte da amada.

Em digressão, o escritor barroco apresenta o Amor como filho de Vênus e Marte, sugerindo, assim, o desconcerto causado por esse sentimento. Mesmo a palavra "perdição" é apresentada na Epanáfora: "Por horas, conheciam os miseráveis navegantes, caminhavam à perdição" (Melo, s/d, p. 44). O lirismo português, magoado e saudoso, povoa as páginas de D. Francisco Manuel e de Camilo. Todos choram diante do sofrimento de Roberto, bem como perante o de Simão. A ideia de fatalidade, de martírio e de morte como consequência de emoções angustiantes são ingredientes enunciados no texto de Melo e aproveitados por Camilo.

A epígrafe usada por Camilo é retirada da fala de um dos amigos de Roberto que quer encorajá-lo a partir em busca de aventuras, deixando Ana sepultada na ilha desconhecida. Essa fala revela visão de mundo pessimista, o herói não é incentivado a iludir-se a encontrar um mundo melhor, mas a certificar-se de que "[...] $]$ entre as tragédias de um mundo sempre trágico, nenhuma estimada novidade traz a maior desaventura." (Melo, s/d, p. 51). O fado os levou àquela ilha, o fado determinou a morte dos amantes, o fado persegue os infelizes que se deixam dominar pelo também impiedoso deus Amor.

A oposição irônica entre a busca de satisfação interior e um destino impiedoso não pode deixar de ser veiculada. O paradoxo torna-se uma maneira de reflexão, de revelar a presença de "espírito", aliviando a angústia de levar-se a vida demasiadamente a sério. A realidade aparente é mera máscara e encobre outro plano rico em significações. Há que se libertar do apego à boa reputação, da Medusa / Sociedade que ousa transformar em pedra o que para ela olhar.

Em Amor de perdição, Camilo redigirá mais que uma versão de Romeu e Julieta. Às famílias inimigas e repressoras, ao primo assassinado, que motiva a condenação do amante infeliz, ao casal amante vítima de emoções descontroladas não sucede a reconciliação entre as famílias, mas a perdição por amor. A dedicação ao amor é associada à questão do autoconhecimento e da busca pela completude perdida.

Dessa forma, o Autor, revela-se mais realista que os seus conterrâneos assim denominados. Há que se rechaçarem as aparências enganosas, o zelo pelo amor-próprio para chegar à unidade primitiva. É necessário abandonar a autocontemplação para 
conquistar a liberdade. Somente pelo despojamento de suas particularidades, o homem poderá desfazer-se da dualidade matéria espírito e reestruturar a unidade primitiva. A dualidade do ser é refletida no movimento de introversão para a conquista da união com o cosmo.

Nasce, assim, a ironia romântica, o escritor faz-se espectador de si mesmo e espectador desse espectador, isto é, coloca-se fora e acima da realidade para julgá-la e governá-la, sem comprometer-se. A existência torna-se palco para a representação da vida como advertência de que o mundo zomba do homem. Além disso, promove-se a libertação da ameaça do Fado.

\section{2 Perdição é amor}

Fernando Gomes retoma a célebre narrativa camiliana para expor seu amor "também" de perdição. A peça é composta por dois atos. O primeiro deles contém 21 cenas e o segundo, 18. O texto camiliano é sintetizado em seus elementos essenciais e acrescentado por vários episódios e motivos relevantes para a compreensão da mundividência do dramaturgo. São episódios os incidentes acessórios, intimamente relacionados com a ação principal; as cenas secundárias de um quadro, ou aventuras. Por motivos, deve-se entender ideias que geram ou determinam novos conflitos ou novos temas. O dramaturgo evidencia dados subjacentes no paradigma, dando-lhes enfoque psicológico.

Pela paráfrase resumitiva, os criados da casa dos Botelho narram a vida pregressa da família, agora estabelecida em Viseu, distante do luxo e da alta sociedade com que conviviam em Cascais.

A visão crítica e penetrante de Gomes começa a insinuar-se por um acréscimo significante, a música com que a peça se inicia. $\mathrm{O}$ amor é associado à paixão, enfoca-se, por conseguinte, um sentimento avassalador, violento, dominador que leva a sofrimento intenso e prolongado e não um afeito dócil e delicado. Paixão deriva da palavra latina

passio - onis e remete a emoções em tão alto grau de intensidade que se sobrepõem à 
lucidez e à razão. A ênfase é dada a essa emoção, já que se substitui o motivo "amor / paixão" pelo "paixão / desejo".

Para condensar a novela ao tempo adequado a uma peça, o dramaturgo elimina vários episódios a fim de compactar os acontecimentos. Nesse intuito, a peça não apresenta muitas informações acerca da vida pregressa de Domingos Botelho. Os conflitos dessa personagem acerca da sua aparência disforme diante da beleza da esposa são rapidamente veiculados pelo diálogo entre o casal. Por outro lado, Gomes amplia a narrativa camiliana ao acrescentar o tema do casamento por conveniência, pois Rita, na peça, teria casado com Botelho por causa do dinheiro desse homem. Esse acréscimo é relevante por enfatizar a falta de amor do casal.

Também os fatos da vida de Simão que antecedem seu encontro com Teresa são sintetizados. Gomes utiliza a redução por excisão, isto é, subtrai algumas partes do texto, reduzindo-as a algumas falas. Pelos comentários maldosos de criados, personagens acrescidas na peça, o leitor / espectador intera-se da rebeldia do rapaz, pela qual é associado, como no modelo, aos revolucionários da Revolução Francesa. Interessante notar que ao mesmo tempo em que o dramaturgo resume o texto camiliano, ele o estende, acrescentando elementos à narrativa: personagens, episódios, motivos, temas, sentimentos, e hipotipos (recursos linguísticos como tom coloquial, dialogismo, detalhamento ou minúcia, preciosismo, questionamentos).

Nas cenas iniciais, Domingos Botelho, indignado com as atitudes do filho, questiona a esposa acerca de quem o rapaz teria herdado aquela rebeldia, já que os irmãos e os pais eram pacatos e tranquilos? Esse questionamento é um acréscimo de motivo que sugere a desconfiança do juiz acerca da possibilidade de sua esposa tê-lo traído. Novamente assevera-se o retrato de um relação corrompida e artificial. A resposta da mulher reforça essa imagem, pois declara que Simão é filho legítimo do casal, porém esta não é matéria relevante, importa, outrossim, preocupar-se em manter a boa reputação da família, escondendo da sociedade os desatinos do moço. A desconfiança do marido não lhe importa, sua imagem pública é mais relevante.

Diferente do que ocorre em Camilo, Domingos antipatiza com o filho desde o início da peça e não por influência da esposa. Essa atitude parece reiterar a desconfiança em torno da procedência hereditária da índole do rapaz, tema recuperado em uma canção: "não sei a 
quem sai, não é à mãe nem é ao pai.” Em Fernando Gomes, as canções revelam as situações apresentadas de forma crítica.

A desconfiança do juiz, no entanto, parece advir primeiro de sua baixa auto-estima, depois da falta de consciência de seus próprios defeitos. O coro, outro elemento da expansão feita por Gomes, apontando a semelhança do rapaz com os pais: ele tem o orgulho do pai e a teimosia da mãe. Insinuam-se, assim, dois acréscimos fundamentais da peça: a) Domingos e Rita não percebem seus defeitos e b) Simão apresenta algumas características de seus pais.

O coro é um recurso clássico recuperado por Gomes por compor-se de elementos que lhe interessam particularmente. Formado por pessoas do povo que geralmente não têm a ocasião de expor suas ideias, o coro possibilita essa expressão. Promove-se, então, o diálogo com uma camada social diferente da retratada nos romances. Símbolo da multidão subjugada pelas convenções, o coro profere sentenças e anuncia verdades, estimulando "a disposição dionisíaca do auditório até o ponto em que aparecendo o herói trágico sobre as cenas, não haja o homem enfarpelado ridiculamente [...]" (Niezsche Apud Borie et alii, 2004, p. 350). Toma-se, assim, coletivamente a palavra para comentar a ação, advertir, aconselhar, enquanto se provoca o distanciamento da cena.

Domingos Botelho compartilha da preocupação da esposa com a opinião pública e repreende Manuel por não ter encaminhado melhor o irmão mais novo. A relação conflituosa entre Rita e Domingos reflete-se no relacionamento dos filhos. Ambos se acusam mutuamente. Os filhos, comparados a Caim e Abel, devem ser separados para que não haja mais problemas. A menção intertextual sugere um conflito causado por ciúmes o qual poderia acabar em morte se não houvesse intervenção paterna. Assim, acrescenta-se um motivo à narrativa camiliana, a rivalidade entre irmãos causada pelo desejo de conquistar a preferência dos pais. A fraqueza, à primeira vista, parece relacionar-se a Manuel, pois Simão prima por contrariar os ideais da família. Contudo, suas atitudes podem configurar um meio de atrair a atenção dos progenitores, já que estes são tão egocêntricos que não se dedicam a ninguém a não ser a si mesmos. Dessa forma, as personagens ganham em complexidade. O caçula revelaria uma carência e uma índole semelhante à de Caim, o qual comete fratricídio em busca de eliminar a concorrência diante de Deus. 
Sem saber explicar o comportamento de Simão, o pai atribui a culpa ao diabo. Esse acréscimo de motivo merece ser examinado com cuidado, pois traz luzes acerca da visão de mundo gomesiana.

A menção ao diabo, ao mesmo tempo em que é uma sugestão da ideia de fado - já que se refere a uma força mística ambiciosa por açambarcar o destino das pessoas - remete à divisão. Refletir-se em Teresa e reconhecer nela a sua própria sede de isolamento e de abstenção da subordinação às regras sem sentido, fá-lo perceber que não é um indivíduo único. Essa fragmentação pode ser associada à palavra "diabo". Etimologicamente, a palavra grega diábolos significa o que desune, calunia, acusa. Fatalidade e crise de identidade são duas ideias sugeridas pelo acréscimo de motivo que permearão toda a peça.

O casal exalta-se e acaba discutindo. A controvérsia culmina com a revelação do sentimento de inferioridade de Domingos diante da formosura da esposa. Gomes usa o tema como pretexto para inserir outra alusão intertextual relevante. Rita declara que o marido tem uma "triste figura". A alcunha remete a Dom Quixote, "o cavaleiro da triste figura". Botelho apresenta atitudes semelhantes às da personagem cervantina. Iludido com seu próprio poder, quer "desfazer todo o gênero de agravos, e pondo-se em ocasiões e perigos, donde, levando-as a cabo, cobrasse perpétuo nome e fama" (Saavedra, 1960, p. 19), o juiz acredita-se um grande justiceiro.

A figura de Domingos é tão disparatada quanto a do protagonista de Cervantes. Como Quixote cria monstros para combater, Botelho imagina os malfeitores, de acordo com seu ideal de justiça peculiar e subjetivo. Essa concepção da personagem já é sugerida em Camilo quando Domingos absolve João da Cruz por ter matado um homem em um ímpeto, mas condena seu filho por assassinar alguém em legítima defesa. O desejo de Domingos por ver-se renomado por suas façanhas parece fazer dele as seguintes palavras de Quixote: "Ditosa idade e século ditoso aquele em que hão de sair à luz as minhas famigeradas façanhas." (Saavedra, 1960, p. 24). Importa ressaltar que a frase adequa-se à personagem camiliana, sobretudo, pela polissemia do vocábulo "famigerada": célebre, ou, em sentido pejorativo, que tem má fama. Para desfazer-se de sua imagem original que lhe é repulsiva, Domingos recria-se em juiz zeloso e inflexível. A extinção da personagem João da Cruz reforça essa imagem. No paradigma, ele é contraponto do pai de Simão. Protege o rapaz como a um filho e revela o lado justo de Domingos, que lhe deu ganho de causa 
contra um homem influente. Sem João, cabe ao marido de Rita o papel de um juiz impiedoso e cruel.

$\mathrm{O}$ acréscimo sugerido pela fala de Rita revela que o homem recria-se como juiz temido para favorecer sua auto-imagem. Recusando a realidade por não aceitá-la como tal, criam-se ilusões para transformar o real em algo muito diferente. Novamente a peça expande a narrativa de Camilo pelo processo de "motivação", isto é, pela introdução de um motivo que o hipotexto oferecia, mas não desenvolveu.

A cena três reforça alguns traços do caráter de Simão. Em diálogo com os pais, o moço patenteia desdém pelos valores familiares quando é rechaçado pelos progenitores. Assim, ele conta aos pais que travara amizade com uma rata de esgoto no cárcere acadêmico. Esse acréscimo de motivo revela o esforço do rapaz por chamar atenção para si, ainda que negativamente, enquanto tenta criar uma identidade própria, uma vez que sua família o rejeita. Estabelece-se, então, um novo motivo na peça.

O desprezo altivo do moço a tudo o que for do agrado dos pais denota o desejo de proteger seu eu diante de um meio que se recusa a acolhê-lo, o que o torna duplo de Teresa. É-lhe necessário recriar-se como indivíduo autônomo, diferente dos que o criaram, mas não o amparam. Corrobora a ideia sua postura revolucionária, seu desejo de modificar estruturas que o faz ser considerado pelo pai como um Robbespierre de capa e batina.

A menção ao revolucionário francês é relevante. Alcunhado "o Incorruptível", Robbespierre defendia a luta pela dignidade humana e pela liberdade de pensamento. Além disso, o francês acreditava em que a solidão era preferível ao convívio social, pois possibilitaria a manutenção da tranquilidade da consciência. O caráter de Simão pode ser associado ao do rebelde francês, também alter ego do romântico, e porta-voz de todo revolucionário.

Simão parece promover ideais de liberdade e misantropia, pois declara preferir o convívio de uma rata na cadeia ao de sua família, afinal somente na clausura não era repreendido por ser diferente. Em Camilo, o filho é enjeitado pelos pais e apenas reage a esse abandono com a indiferença. Em Gomes, o rapaz afronta os pais e escarnece de seus valores, configurando-se como o duplo de sua família.

Para progenitores mesquinhos e egoístas, o filho só interessaria se correspondesse a seus ideais. Simão é visto com alguma simpatia quando se transfigura e torna-se manso e 
introvertido. A mudança comportamental, na peça, é motivo de os pais revelarem sua vaidade. Domingos e Rita consideram-se, individualmente, responsáveis pela transfiguração do filho, já que lhe teriam dado boa educação e exemplo. O dramaturgo aproveita o ensejo para evidenciar que naquela família tudo motiva as expansões do egocentrismo. Como se percebe, Gomes evidencia a vaidade do ser humano como mola propulsora de suas ações e da cegueira para a verdade e para o autoconhecimento.

Para acentuar a inverdade da hipótese de a conduta dos pais ser a causa da mudança do rapaz, narradores comentam a ineficiência de punições e exemplos para a alteração do caráter ou do comportamento de uma pessoa. $\mathrm{O}$ dramaturgo sugere, com essa inserção, que o único modo de alguém modificar-se é por vontade própria. Nega qualquer Determinismo e apresenta a razão como único meio de autocontrole. Por conseguinte, a frase: "Nesse caso [da alteração do rapaz] tem de haver uma razão" (p. 15) torna-se ambígua, porque "razão" pode significar motivo, ou a faculdade de raciocinar; a lógica do raciocínio própria do ser humano.

A extensão do retrato de Simão sugere o recurso da "transvalorização" operação de natureza axiológica que consiste, como já foi apontado, na valorização de ações e sentimentos de uma personagem. Esse acréscimo de características torna o caso de amor entre o rapaz e Teresa mais complexo, o filho dos Botelho ama a filha de Tadeu de Albuquerque ou esta é a forma mais atroz de afrontar pais que desdenham de sua existência? A peça acentua essa ambiguidade ao apresentar o amor de Simão por Teresa ao mesmo tempo em que revela o ódio de Domingos por Tadeu. A inversão sugere o espelhamento das atitudes dos pares apresentados.

Também o ódio nasce do amor-próprio ferido: uma sentença dada por Domingos contra Tadeu suscita a desavença. Domingos justifica suas sentenças de maneira peculiar, afirma que só "sua consciência é julgadora de seus atos" (p. 16). Considera-se como um deus poderoso, cujo julgamento é suficiente para condenar ou absolver alguém. O juiz não menciona provas, nem testemunhos, conta apenas com sua própria apreciação dos fatos. Essa egolatria ofusca o amor-próprio de Tadeu, diminuído pela autoridade do magistrado, o que o faz considerá-lo um rival pernicioso.

Até aqui faz-se uma paráfrase da narrativa camiliana, um acréscimo relevante, entretanto, é apresentado, pelo diálogo entre os oponentes. Tadeu alcunha Domingos de 
"espantalho" e o juiz apelida o pai de Teresa de "palhaço". Esses apelidos são significativos, já que "espantalho", em Portugal, na variedade familiar, remete à pessoa que tira a vista ou a luz de outra defronte da qual se colocou. Palhaço, na gíria, significa a moeda de um escudo. Os epítetos sugerem o motivo da adversidade entre as personagens. Tadeu ressente-se por ser colocado à sombra da elevação do cargo de Domingos e o juiz ofende-se pelo fato de Tadeu ter mais dinheiro que ele. Novamente o recurso da extensão (de motivo) sugere que tudo gira em torno do amor-próprio ferido.

Ao colocar Simão e Teresa como antítese de seus pais, Gomes acresce um motivo ao paradigma, o par amoroso pode ter-se apaixonado como forma de afrontar os progenitores e, assim, assegurar sua individualidade. O herói e a heroína seriam, então, rebeldes que para firmarem sua personalidade inverteriam as atitudes dos pais. Na mesma proporção que Tadeu e Domingos se odeiam, Teresa e Simão se amam. A eleição do cônjuge no descendente do inimigo paterno é, portanto, significativa.

A discussão entre os pais de família ofendidos é interrompida por um aforismo do narrador: "Na vida cada um tem o papel que tem". Há aqui outra luz importante para a interpretação da peça. "Papel" pode significar representação, imagem, ou, em outra acepção, remeter a documento de identidade. Ambos os significados sugerem que a identidade é um ato público, só perceptível quando se torna exterior. Dessa forma, ressaltase a importância do outro para a formação do autoconceito.

O aforismo remete também à relação entre vida e teatro. Nesse caso, o "papel" seria a função, a parte que cabe a cada ator numa peça ou num filme e o texto corresponderia ao destino.

A ficção como duplo da vida, sugerida pelo aforismo, passa a ser reiterada por comentários metateatrais de narradores e personagens. Em vários momentos, a intenção do encenador / diretor é retratada pelos atores. Assim, as músicas enunciam estratégias do dramaturgo; o "amor perfeito" é considerado, por Simão, produto dos livros, cinema e teatro; atores apresentam-se como tal, destituídos de seu papel; a referência ao público, suas expectativas e gostos.

A ideia do duplo, antes enunciada pelo retrato das personagens, é reforçada pelo paralelo entre realidade e ficção, disfarces e personalidade, nome e identidade. A oposição 
antes sugerida pela rivalidade entre Rita e Domingos, Manuel e Simão, Simão e os pais, Teresa e Tadeu, agora refere-se à contraposição entre verdade e ficção.

Para acentuar essa dualidade, o dramaturgo cria uma cena em um jardim onde as flores espelham o comportamento das personagens e alegorizam ideias-chave a serem ressaltadas. O local é também o duplo da realidade coetânea. Mágico, feérico, o jardim representa um paraíso, distante das preocupações e normas do cotidiano.

A cena é uma alegoria, isto é, história com personagens e acontecimentos simbólicos, os quais visam a tornar concretas ideias abstratas. As flores personificam as paixões humanas, tornando-as perceptíveis; cada flor fixa uma emoção. A violeta assume o caráter dogmático e repressor dos pais; a papoula remete a entorpecimento das paixões; o girassol revela desejos carnais e o amor-perfeito representa um ideal inatingível. Nova extensão à narrativa de Camilo que corrobora a intenção de tratar de um amor de perdição sob enfoque psicológico.

Na sequência, o paralelo realidade e ficção é reiterado, já que Domingos Botelho e Tadeu de Albuquerque passam de personagens a narradores e atores. Os atores analisam o papel dos pais tiranos e confessam que, como pessoas, e não atores, têm dó dos amantes. Amplia-se, assim, a ideia do paradigma. Lá, os pais são apenas egocêntricos; aqui, há o conflito entre ter que cumprir o papel de autoridade repressora e, ao mesmo tempo, ser dotado de emoções semelhantes às do casal. Como personagens, Botelho e Albuquerque são dominados pela vaidade e amor-próprio, mas, como pessoas, os atores sensibilizam-se com a situação do par amoroso. Acrescenta-se, assim, um motivo relevante, a complexidade do ser humano, que é colocado diante de vários papéis sociais e, em cada um deles, deve agir conforme predeterminam as regras.

Outro aspecto relevante trazido pela cena é problematizar a expectativa do público diante da peça. A ironia romântica, recorrente em Camilo, não é abandonada, mas transformada em ironia dramática. Por ironia romântica entende-se a presentificação do autor que conversa com o leitor como se este fizesse parte do processo de construção do texto. Já a ironia dramática refere-se ao conhecimento do espectador acerca dos dados da peça que, muitas vezes, é mais amplo que o de algumas personagens. 
Pela metateatralidade, o público, além de dominar o enredo, adquire consciência do fazer dramático. A ilusão, engano dos sentidos ou da inteligência, as fantasias, o efeito artístico que reproduz a impressão da realidade passa a ser tema da peça.

O ator é a figura mais importante nesse teatro. Além de interpretar seu papel, ele narra os acontecimentos de modo a apresentar sua personagem sem anular sua identidade como pessoa. Trata-se de uma postura brechtiana que destitui a quarta parede e promove o distanciamento da ficção. Isso ocorre, em Amor (também) de perdição, nos vários momentos em que os atores comentam a peça e a comparam com o paradigma; mas é na cena em que Domingos e Tadeu se mostram como atores, destituídos de seus papéis, que a ironia dramática e o distanciamento se torna mais evidente. Dessa forma, o público não se identifica com o que vê porque passa a ter consciência de que se trata de uma representação.

Assim, a realidade representada é revelada sob a perspectiva "desilusionante", bem ao gosto de Brecht. O artifício da construção da personagem e da peça são evidenciados, o que desperta o senso crítico do espectador.

A peça é compreendida como o duplo do modelo e este se torna o Destino a ser cumprido. Subitamente, o original revela-se o outro e a peça uma representação por meio da qual se intenta decifrar a realidade imediata. A perdição adquire, com estes acréscimos, nova conotação e refere-se à perda da identidade ou à perda da ilusão.

Desprovidos das máscaras, os atores deixam transparecer a face humana da personagem que, no modelo, não existe. Domingos e Tadeu adquirem complexidade que não têm no paradigma. Em Camilo, esses homens não parecem humanos, tal a indiferença que nutrem por tudo o que não for agradável a eles. Os atores, ao abandonarem a máscara da tirania, revelam compaixão, ternura e interesse pelo par amoroso, sentimentos que condizem com emoções chamadas paternais.

A letra da canção entoada após essa cena enuncia a entrega sem reserva de Simão e Teresa ao amor / paixão. O casal cria um universo em que tudo se resume a seu amor. "Tudo o mais é fugaz - nada nos apraz - apenas o amor. / Só quero amar! Só quero amar!" (Gomes, p.20) Eles iludem-se, protegem-se do real pela criação de um mundo paralelo, duplo da realidade hostil em que vivem. A motivação é, portanto, essencial para a ampliação dos significados do livro de Camilo. 
O espelhamento que perpassa toda a peça é reiterado, na cena seguinte, pela associação entre Teresa e algumas flores. A moça confessa a Simão o desejo de ser uma flor, isso gera a euforia das flores do jardim que disputam ser o reflexo da fidalga. Cada uma delas quer ter suas qualidades citadas para distinguir-se das demais e tornar-se alter ego da filha de Tadeu. Simão, no entanto, rejeita a analogia com as flores por aludirem a sensações incômodas: entorpecimento (papoula), morbidez (da cor da violeta), desespero (o amarelo do girassol). Por fim, o amor-perfeito é desprezado por configurar um ideal inatingível.

A recusa da identificação entre o caso de Simão e Teresa e um "amor perfeito" contraria as características da narrativa camiliana e dessacraliza o amor puro. Enquanto no paradigma o amor do casal é a epítome de um sentimento sublime e idealizado, no intertexto, o amor é carnal e nasce do amor-próprio ferido. O Simão camiliano é sonhador e acredita em que realizará seu amor na vida após a morte, prescinde da relação física com a amada. O Simão gomesiano, ao contrário, é mais objetivo e prático, quer Teresa enquanto mulher. Enquanto na novela oitocentista, o protagonista declara "Nunca os meus pensamentos foram denegridos por um desejo que eu não possa confessar alto diante de todo o mundo. Diz tu, Teresa, se os meus lábios profanaram a pureza de teus ouvidos. Pergunta a Deus quando quis eu fazer do meu amor o teu opróbrio.” (Branco, 1984, p. 498). A personagem de Fernando Gomes professa o amor carnal, ela não gira na esfera do idealismo, não crê em amor perfeito, mas afirma: "Gosto de ti em carne e osso." (Gomes, p. 25).

Em Camilo, o céu traça o Destino e o céu é o alvo dos amantes. A realização do amor puro e desinteressado ocorreria na vida após a morte.

E o apostólico capelão do mosteiro não sabia dizer se os bens do céu tinham comum com os do mundo as delícias que falsamente na terra se chamam assim. Aquelas sutilezas espirituais que vêm com algumas espécies de física, assim à maneira dos últimos lampejos da vital flama, tinha-as a enferma, quando acontecia falarem-lhe as religiosas na bem-aventurança. Às vezes, se o capelão, convidado pela lucidez de Teresa, entrava os domínios da filosofia, tratando como tema a imortalidade da alma, a inculta senhora argumentava em breves termos, com razões tão claras a favor da união eterna das almas, já deste mundo esposas, que o padre ficava em dúvidas se seria herético contestar uma cláusula não inscrita em algum dos quatro evangelhos. (Branco, 1984, p. 488)

Em Gomes, o amor deve ser realizado no plano físico, concreto, mas a mesquinhez e a vaidade impedem essa realização. A expansão de características de personagens 
promove a inversão do caráter e das intenções de Simão, o que sugere uma intenção paródica. O resultado disso é o surgimento de um caso de amor mais concreto e passível de realizar-se. Eles não precisam casar-se para ficarem juntos, esta ideia é recorrentemente sugerida por diálogos entre Tadeu e Baltazar os quais insinuam que Simão teria "dado" a Teresa ou feito "algo" à moça que o primo, engessado, não poderia oferecer.

A cena de idílio é interrompida pela chegada dos pais que repetem, com algumas alterações, o discurso das personagens do modelo quando descobrem o namoro. Domingos ofende Teresa aconselhando-a a buscar um marido "trolha", digno dela e do "labrego" de seu pai. A visão de Botelho sobre a moça e sua família constitui acréscimo de Gomes. Hábil em utilizar a linguagem popular portuguesa como forma de caracterizar seu povo, o dramaturgo mostra o despeito do juiz diante da proeminência da figura do vizinho pelos termos "trolha", que se refere a um pedreiro ordinário ou servente de pedreiro e "labrego", homem rústico, camponês, aldeão, grosseiro. Dessa forma, a psicologia humana é sugerida pela linguagem. Tadeu replica que não quer a filha próxima a "espantalhos", o que ressalta, por um lado, o aspecto desagradável de Domingos e, por outro, o motivo da rivalidade de Tadeu: a relevância do cargo do vizinho.

Um narrador intervém dispensando as personagens e agradecendo-lhes a colaboração. Com a queda da quarta parede, a peça é novamente retratada como duplo do modelo. O jogo entre dois planos insinua uma concepção da vida como sonho, ilusão, reflexo de outro universo mais perfeito, que daria sentido à realidade.

Como prenunciava Brecht:

[...] A quarta parede não mais faz desaparecer o espectador. Graças a grandes painéis que permitiam recolocar na memória outros processos que se desenrolavam simultaneamente noutros locais, contradizer ou confirmar as falas de algumas personagens $[\ldots]$

Não mais era permitido ao espectador que, de boa fé, se identificasse com as personagens e se abandonasse acrítica e apaticamente às emoções (das quais não retirava nenhuma consequência de ordem prática). A representação submetia os sujeitos e os procedimentos a um processo de distanciamento. $\mathrm{O}$ distanciamento era indispensável para que a peça fosse compreendida. (Brecht Apud Borie et alii, 2004, p. $468-469)$

Como se percebe, o teatro de Fernando Gomes adota perspectiva épica, a mimese é muitas vezes abandonada em prol da diégese. A ação é narrada ou comentada em vez de dramatizada. Importa ressaltar, no entanto, que a intenção não é apresentar um ponto de vista sobre a fabulação, mas múltiplas intervenções de diversas fontes, diferentes vozes 
opinam sobre a história que é retratada de vários ângulos simultaneamente, como em um quadro cubista.

Na cena onze, Tadeu, como no paradigma, finge acreditar na filha, embora a ameace com o convento. O desdobramento artificial da personagem de pai tirano a pai carinhoso, já presente em Camilo, é reiterado na peça.

A ameaça de Tadeu a Teresa é repetida, em contexto diferente, por assaltantes que põem a vida de um homem em risco se ele não lhes entregar tudo o que possui. O rapaz, no entanto, é um ator e, como tal, não tem nada além da roupa do corpo, e do texto. O texto não interessa aos malfeitores por ser já conhecido, sugere-se, assim, que o teatro português costuma divulgar sempre as mesmas peças, ideia também será enunciada por Camilo em outras narrativas. O público passadista e ignorante só seria atraído por títulos que remetessem a fatos históricos relevantes ou por peças estrangeiras. O assalto é, então, malogrado, porque o corpo seria difícil de esconder e a roupa não serve a nenhum deles. Diante disso, um dos ladrões desiste do intento, atitude condenada por um companheiro que considera um erro ameaçar e não cumprir. A vítima do assalto concorda com o segundo assaltante e acrescenta que "ameaçar, seja por que motivo for, é que não é bonito!" e cita o exemplo de Tadeu como prova de sua assertiva. A partir daí todos vão discutir o enredo de Amor de perdição.

O episódio é, portanto, pretexto para o dramaturgo apresentar a novela de Camilo sob o ponto de vista das personagens que não estão envolvidas na história. Um dos criminosos passa a ler o texto de Camilo e os demais comentam o vocabulário. Assim, o termo "prosápia", que se refere a Baltazar, é ressaltado na leitura do livro. As personagens julgam que a palavra se refere a endinheirado. O vocábulo, no entanto, associa-se à linhagem e, em linguagem figurada, à vaidade, bazófia. A ênfase dada ao termo revela o ponto de vista atento de Fernando Gomes acerca do modelo. Baltazar é descrito pelo novelista como "senhor de casa, e igualmente nobre da mesma prosápia." (Branco, 1984, p. 403). À primeira vista o escritor oitocentista parece referir-se à linhagem dos Albuquerque, mas no contexto da história, percebe-se que se trata da ironia de Camilo ao asseverar que os primos assemelham-se em sua vaidade e presunção, característica que parece peculiar ao ser humano, já que se revela com ênfase em todas as personagens. Assaltado e assaltantes comentam o texto. A história é, dessa forma, analisada sob vários ângulos. Outro acréscimo 
relevante de Gomes é a extensão, feita pela multifacetação da realidade visando a que esta seja vista sob diferentes enfoques.

O desdobramento da novela na peça parece indicar que esta busca sua identidade naquela, pela identificação. Espelhando-se no paradigma, o texto reconhece seus fundamentos para, sobre este alicerce poder criar-se. Além disso, o discurso sobre o discurso coloca em pauta o tema da palavra e da literatura como forma de recriar um mundo. Ansioso por criar fantasias que lhe auxiliem a lidar com o real, o espectador / leitor pode identificar-se com as personagens que leem com avidez a narrativa de Camilo em busca de entretenimento. A imaginação e o engano são, pois, parte dos pressupostos da vida.

A Literatura e o Teatro possibilitam que se veja o mundo pelos olhos de outrem; no caso do texto de Gomes, por múltiplas perspectivas. Outro elemento épico bretchiano, o distanciamento proporcionado por esse caleidoscópio possibilita a formação de um senso crítico acerca do texto e do retrato do ser humano.

A cena é interrompida por um acréscimo de episódio ${ }^{47}$ em que se enfoca um encontro de Tadeu e Baltazar. Esse excerto da peça evidencia a covardia do sobrinho de Tadeu. Para fugir de um pastor alemão, o moço precipita-se sobre uma árvore e se machuca a ponto de ter seu tronco e quadris engessados. A postura que o gesso lhe confere é considerada por Tadeu como "empertigada". A palavra parece ter cunho polissêmico: tanto pode associar-se à postura reta, tesa, quanto a encher-se de vaidade. Assim, a fatuidade de Coutinho é reiterada aqui como em outros momentos em que se revelam atitudes do rapaz tão afetadas e presunçosas que beiram a insensatez.

Como se pode notar, a expansão conta, na peça, com o trabalho com a linguagem para que se trate, ironicamente, de alguns assuntos e se explore uma concepção específica acerca do homem.

A pesquisa linguística é relevante na peça, o dramaturgo lança mão dos ditados e expressões populares para desvendar a alma portuguesa. Mesmo Tadeu e Domingos usam termos próprios do povo. O pai de Teresa refere-se à paixão da filha como "estar

\footnotetext{
${ }^{47}$ Gomes acrescenta elementos como personagem, episódio, motivo, tema, sentimentos do narrador, ou de hipotipos (recursos linguísticos como tom coloquial, enumeração, dialogismo, detalhamento ou minúcia, preciosismo, questionamentos) para ampliar o significado do paradigma. Também a contaminação com outro trabalho, ou com personagens e temas de outro livro colabora para essa ampliação.
} 
embeiçada" e a obstar o namoro como por um "travão" nos acontecimentos. Dessa forma, verifica-se que as personagens representam, antes de mais nada, o próprio povo português.

A cena continua patenteando a intenção de Albuquerque com o casamento da filha: unir duas casas igualmente endinheiradas e evitar o consórcio com alguém da família do juiz que lhe maculou a auto-estima.

Diferente da Teresa camiliana que, embora decidida, prefere não revelar o nome do amado a Baltazar e a princípio não quer ferir-lhe os sentimentos com respostas ríspidas, a personagem gomesiana cresce em desenvoltura e altivez. No caso de Teresa, trata-se de uma valorização positiva uma vez que ela tem papel mais relevante que tinha no hipotexto, pois seu comportamento é mais nobre. Assim, a personagem de Fernando Gomes é capaz de declarar abertamente desdenhar a união com o primo, amar Simão e estar "borrifando" para a união com um moço cujo ar convencido lhe é detestável. Diante do desprezo da prima, o fidalgo de Castro-Daire ameaça-lhe, afirmando que ela se arrependerá de sua decisão e que ele assistirá a esse arrependimento.

O diálogo entre as personagens é veiculado por uma canção, na qual o coro, constituído por pobres mendigos, repete ameaças do rapaz e sintetiza o final da discussão, assegurando tratar-se de um amor de perdição. $\mathrm{O}$ eco produzido por essa voz parece soar como um fado impiedoso a perseguir Teresa. O tema da fatalidade, já enunciado, é reiterado como uma realidade inelutável. O paradigma parece, portanto, configurar-se como um Fado do qual é inútil tentar fugir. Trata-se, portanto, da mescla do coro trágico que anuncia o destino das personagens e reafirma dados da moral vigente, e do coro épico que promove o distanciamento do que se vê pela explicação do conceito de "amor de perdição".

Aconselhado pelo sobrinho, Tadeu trata a filha com ternura a fim de convencê-la a unir-se ao primo. A postura de Baltazar diante da recusa de Teresa não denota submissão ou paixão, mas amor-próprio excessivo ao insistir no cumprimento de uma resolução que tomara e por isso deve ser efetivada. A irreversibilidade da decisão da filha faz Tadeu repetir a ameaça de interná-la em um convento.

Da mesma forma que em Camilo, Teresa promete morrer para todos os homens, menos para o pai, desde que ele permita que ela permaneça em sua casa. Um dos narradores comenta que a proposta denota a astúcia da moça, assim como o narrador camiliano havia sugerido que, naquela realidade, era impossível manter a franqueza e a sinceridade. Nesse 
trecho da novela, Camilo vale-se da metalinguagem para comentar que a atitude da moça é rara em mulher naquela idade, mas que a mulher no romance quase nunca é trivial e esta era distintíssima, sobretudo, pela celebridade que ganhou com a desgraça. Sugere-se, dessa forma, que a ficção, ao refletir a realidade, a incrementa e a transforma em outra. A ficção passa, por isso, a ser o mundo ideal e faz da realidade empírica um mundo deficiente. Verifica-se, portanto, que Fernando Gomes colheu no novelista o expediente de comentar criticamente seu texto, desvendando o paralelo ficção e realidade.

A astúcia feminina, capaz de criar um ardil para preservar sua liberdade e perseguir seus próprios ideais, deve ser observada na peça com cuidado. A importância da índole feminina, caracterizada pela sensibilidade e pela devoção, é relevante já que faz parte do universo interior de todo ser humano (trata-se da anima, descrita por Jung como o Eros materno); no entanto poucos se preocupam em cultivar essas qualidades para preservar sua personalidade individual e única. A sensibilidade humana é rechaçada em uma sociedade patriarcal. Nesse contexto, vale o individualismo, a vaidade, o poder, atitudes que relegam as emoções, o encontro consigo mesmo, a autoconsciência ao desprezo.

Teresa tem que valer-se da astúcia para manter sua feminilidade em um mundo regido pela lei do homem. Ela não tem outra opção que dissimular seus sentimentos para mantê-los. A vida social leva à fragmentação do eu pela imposição de máscaras que agradem a opinião pública. Teresa divide-se em filha obediente, fingida, subjugada em suas emoções a fim de manter o domínio masculino patriarcal, e amante fervorosa, feminina.

As demais mulheres da peça parecem sucumbir a esse universo. Rita é caracterizada pelo amor às aparências, não é mãe carinhosa, não se preocupa com o bem-estar dos filhos, nem os acolhe em momento de adversidade, apenas prima por manter a boa reputação frente à opinião pública, como um típico homem de negócios. Ela inverte a imagem de mulher, esvazia sua feminilidade em benefício da manutenção do statu quo.

Também Mariana, na versão de Fernando Gomes, incumbida de reger a própria vida, torna-se prática e extremamente ponderada em suas decisões. A personagem se molda de acordo com o padrão de comportamento ditado pelo homem. Seu instinto feminino quer aflorar pela sensualidade, mas é constantemente reprimido. Ela sente essa repressão e a compara ao aperto de um ônibus lotado que caminha sem nunca chegar aonde 
se quer ir. Seu pragmatismo atinge o ponto de levá-la a alertar Simão a ser menos exagerado em suas manifestações.

Quanto mais civilizado, mais consciente e complicado for o homem, tanto menos ele será capaz de obedecer aos instintos. As complicadas situações de sua vida e as influências do meio ambiente se fazem sentir de maneira tão forte, que abafam a débil voz da natureza. Esta é substituída então por opiniões e crenças, teorias e tendências coletivas que reforçam os desvios da consciência. (Jung, 2000, p. 18)

Rebelde, Simão quer afrontar o sistema e firmar-se como indivíduo consciente de si. Para isso, por um lado, cultiva os sentimentos de amor e caridade, por outro, revolta-se contra os pais e a estagnação de seu país. O caráter revolucionário do rapaz parece ser motivado pela convicção de que deve abandonar a resignação dócil aos preceitos sociais e cultivar sua anima a fim de individuar-se.

A dualidade que permeia toda a peça parece remeter aqui à oposição básica da natureza: os gêneros feminino e masculino. A extinção de um em prol do crescimento do outro faz com que o homem perca sua identidade. Para recuperá-la, é necessária a reflexão em vários espelhos, há que se desvalorizarem as aparências enganosas para chegar-se à unidade primitiva; rechaçar a contemplação de si mesmo para conquistar a individualidade. A autocontemplação leva ao engano, o homem se ilude com sua imagem e esquece-se de sua essência. Somente pelo despojamento de suas particularidades, o homem poderá reestruturar a unidade primitiva. A alusão ao espelhamento parece, portanto, ser um meio de o dramaturgo apresentar um recurso que leve o homem a voltar-se para si mesmo em busca de reencontrar-se.

Eu tomo consciência de mim e me torno eu mesmo unicamente me revelando para o outro, através do outro e com auxílio do outro. Os atos mais importantes, que constituem a autoconsciência, são determinados pela relação com outra consciência (com o tu). A separação, o desligamento, o ensimesmamento como causa central da perda de si mesmo. (Bakhtin, 2003, p. 341)

A Literatura e o Teatro também são espelhos. Por meio deles, o leitor / espectador pode avaliar o comportamento humano, identificar-se e resgatar seu próprio eu. Para continuar a mostrar a peça como duplo da novela, Gomes acrescenta um episódio em que um mendigo toma nota dos acontecimentos relacionados à Teresa porque "isto é material que bem contado ainda vai render muito!” (Gomes, p. 31) Assim, o divulgar de histórias como forma de garantir rendimento, expediente com o qual Camilo sustentava a si e a família, torna-se um motivo do texto gomesiano. 
A sagacidade desse mendigo se refaz pela aprovação à rebeldia da Teresa às normas estabelecidas pelo pai: "Não faz senão bem! Se estivéssemos todos de acordo a vida seria monótona!" (Gomes, p. 29) Dessa forma, ressalta-se a irreverência como um meio de dar sabor à vida.

A subordinação à realidade significa fazer parte de um rebanho inconsciente, viver uma mentira - já que a vida em sociedade exige o fingimento e a hipocrisia. A contestação revela-se, na peça, como um recurso valioso para a transformação social. É inerente ao ser humano o desejo de escapar do previsível e do corriqueiro. Ao lado da irreverência, o amor é uma forma de oposição ao utilitarismo do mundo burguês. Simão e Teresa identificam-se entre si, reconhecem-se como seres providos de sentimentos rechaçados pelas concepções e unem-se contra os representantes da visão de que discordam.

O conteúdo da carta de Teresa é veiculado por uma canção dos mendigos em que se reitera a associação entre amor e paixão e se sugere a consciência da fidalga de "aldrabar" o pai, isto, em linguagem figurada, significa revelar impostura, embuste, astúcia para ludibriar o entendimento. Ressalta-se, assim, a dissimulação de Teresa como meio de preservar o relacionamento com o namorado.

A cena seguinte apresenta um acréscimo de episódio: o narrador veste-se de padre para não ser assaltado. "Deve ser a batina que afugenta o Diabo!" (Gomes, p. 30) A importância do traje como representação de poder é aventada pelo trecho e ridicularizada pelo humor dessacralizante. As aparências ludibriam e dominam a opinião pública. Também Simão tentará mascarar-se para aproximar-se de Teresa. A inserção dos tipos populares, as alusões a relações sexuais, os quiprocós e o nonsense geram o humor alegre, renovador, porta-voz de opiniões não-oficiais.

Há um corte de cena e Tadeu é enfocado impondo o casamento à filha, tal qual o faz na novela camiliana. A diferença é que, no palco, os mendigos comentam a atitude do pai da moça. O foco narrativo se multiplica, a história é, dessa forma, considerada sob vários ângulos. Pode-se chamar de multivocalização, a diluição de um narrador em várias vozes.

Tadeu é chamado pelos mendigos de "foleiro", termo que na variedade linguística popular remete à pessoa que merece desprezo, e, coloquialmente, à pessoa que não presta. Além disso, reputam-no um "gajo", velhaco, espertalhão fingido, que pensa em "bojarde", provincianismo, corruptela de "bojarda", que significa peta, asneira. 
A cena continua sem alterações em relação ao paradigma, Tadeu irrita-se com a irreverência da filha e declara que a colocará em um convento. Depois, lamenta a Baltazar não poder dar-lhe a filha.

Novo corte de cena ocorre. Focaliza-se agora o narrador, ainda como padre, comentando que não desgosta de pobres, mas incomoda-se com os roubos. Um coro responde às observações do narrador, ora louvando-as, ora vaiando-as. O padre declara que os "pobres são as formigas de nosso piquenique" porque proporcionam o céu aos ilustres, inspiram os artistas, amedrontam as crianças que não querem comer, motivam os discursos políticos. Conclui seu pensamento afirmando que Deus sabe a razão por lhes ter feito sem recursos, ou porque thes "deu dentes, mas ao mesmo tempo se esqueceu de lhes dar nozes." (Gomes, p. 32)

Como se vê, Fernando Gomes acrescenta um episódio e um motivo à narrativa camiliana. Sua peça estende-se, assim, a uma dimensão sócio-religiosa, afinal trata-se de um padre evidenciando a hipocrisia de sua classe e dos que simpatizam com suas ideias (coro) diante da desigualdade social. A motivação ocorre porque no paradigma havia uma mendiga explorada por Teresa. A pobreza daquela era conveniente a esta, já que com alguns trocados conseguia que suas cartas fossem levadas a Simão onde quer que este estivesse. O dramaturgo apresenta o pobre como duplo do rico; sujeitos a esmolas, eles possibilitam a comodidade dos endinheirados. Como se verifica, o coro cumpre, muitas vezes, o papel de enunciador e comentador, raramente com intenção moralizante. O propósito frequentemente é apresentar novas formas de interpretar um assunto, como uma atualização crítica da parábase. Assim, ele desilude, reforça o distanciamento, sugere leituras de um espectador atento e crítico. Reforça-se, dessa forma, o caráter épico da peça.

Nesse ponto do texto surge uma rubrica. Como Fernando Gomes é encenador (diretor) de suas peças, ele não sente necessidade de elucidar dados sobre cenário; vestimentas, movimentação e gestos dos atores. Então, o leitor só agora se inteira que no início da peça os atores entraram com exemplares de Amor de perdição, procedimento que será repetido nesse ponto da peça. Os atores entram em cena cantando uma canção que antecipa as próximas cenas, ao sugerir a continuação do drama e o impasse acerca do ânimo do espectador diante dos novos acontecimentos: haverá riso ou choro? Também essa reação 
ambígua do público reflete a dualidade que permeia toda a peça. Outra sugestão de que a peça pode dar novo curso à narrativa camiliana, e que o fado poderia ser ludibriado.

Finalizada a canção, alguns atores comentam os seguintes fatos: Simão, em Coimbra, recebe carta de Teresa avisando-lhe da ameaça do convento; desesperado, parte impetuosamente para Viseu, onde se encontra com a namorada às escondidas em um jardim. Tadeu intercepta a correspondência dos amantes e trama com o sobrinho a morte de Simão. Há alusões ao amor carnal. Pela narração, é possível a concisão do paradigma.

Nova canção ao mesmo tempo em que anuncia o intervalo propõe a dúvida se haverá realmente um amor de perdição, questionando se peça suscitará riso ou choro do público. Restabelece-se, dessa forma, a expectativa de que a novela camiliana poderá ser alterada.

A segunda parte do espetáculo se abre com uma música entoada por bêbados. Novo elogio à irreverência é feito ao mesmo tempo em que se propõe o romper com as desilusões. A canção sugere que o homem ludibrie seu destino pela embriaguez. A bebida é apresentada como um meio de se modificar as "voltas do Destino". O termo "voltas" remete a duas ideias: retorno e criação. Sinônimo de giro, o vocábulo pode ser associado ao Mito do Eterno Retorno, de Nietzsche, pelo qual a alma está destinada a cumprir uma missão e por isso retornaria eternamente. Essa teoria relaciona-se à ideia de fatalidade, um guia que arrasta o ser a cumprir sua sina ainda que este tente escapar. Por outro lado, "volta", em poesia, refere-se à criação de réplicas a um mote, o que traz em seu bojo o tema da criação, da ficção ou da ilusão como forma de alterar a realidade. Essa reelaboração da realidade, como já se procurou enfatizar, é um meio de tornar o homem espectador de si mesmo.

A cena seguinte é um acréscimo de episódio e de motivo. Uma rubrica apresenta uma taberna como um ambiente festivo, onde se bebe e canta. $\mathrm{O}$ entusiasmo dos que lá se encontram parece a antítese da gravidade e severidade das personagens da primeira parte da peça. A rebeldia é reapresentada como um meio de tornar a vida mais emocionante.

Mariana irrompe à cena com excessivo recato e declara não saber como entrou na história, culpa o destino por tê-la colocado ali. Sua fala volta a colocar em pauta o plano da ficção. Depois, ela revela sentir-se inadequada àquele lugar, "há sempre uns sítios que só são bons para os outros.”( Gomes, p.36) Limitada pela opinião pública, Mariana revelará 
ser moça ingênua, dotada de sensações e intuições que desconhece e com as quais não sabe lidar. A moral parece restringir-lhe os movimentos. Para amenizar a seriedade da cena, o dramaturgo vale-se da comparação entre a vida da moça e o aperto de um ônibus: "pisamnos e a gente só tem vontade de sair e continuar a pé... Mas a pé... não se vai longe...” (Gomes, p.36) Pelo humor, o sistema é problematizado de forma sutil, mas não menos penetrante. Trata-se de uma ampliação, uma vez que consiste no desenvolvimento temático e na expansão em nível diegético.

Outro acréscimo de característica de personagem Mariana ocorre por meio de sua afirmação acerca da vida: "As pessoas dão importância a pequenas coisas quando não têm com que se preocupar." A fala revela o lado masculino, racional, ponderado ( do animus) da moça. Fernando Gomes elimina a personagem João da Cruz e dá à Mariana a autonomia de proporcionar estada a Simão. Ocorre, assim, a transmotivação, já que se suprime um motivo para a inserção de outro. Ela é ao mesmo tempo emotiva e racional, ingênua e perspicaz, voluptuosa e recatada. Trata-se da transvalorização de personagem, já que a moça ganha relevo na peça. $O$ primeiro encontro entre a moça ingênua e o fidalgo é repleto de quiproquós, já que a rapariga tem dificuldade de lidar com suas emoções na presença do rapaz e desmaia com frequência. Importante verificar que o caráter pragmático dessa personagem feminina faz com que ela sugira a Toino - homem simples do povo, personagem criada por Gomes - várias soluções ao problema de Simão antes de aceitar oferecer-lhe refúgio.

Na peça, Mariana não tem nenhuma obrigação moral de acolher o rapaz. Na novela, há um pacto de honra, João da Cruz é fiel a Domingos Botelho por ter-lhe salvado a vida e, por isso, sua filha deve ser grata a Simão. Na peça, a moça acolheria o rapaz para ganhar algum dinheiro. Nesse intuito, ela deve ceder-lhe a única cama que tem em casa e dormir no chão.

O fato de Mariana sustentar-se sozinha dá a ela certa independência que a torna menos sentimental; os desmaios diante do rapaz decorrem do desejo que sente por ele, já que desde o momento em que o conhece passa a ter sonhos com braços e pernas que se entrelaçam e se confundem, e intui que deve haver algo mais que braços e pernas em um relacionamento entre homem e mulher. Nesse caso, não se trata do amor resignado e servil, mas de uma paixão carnal. Transformar o amor idealizado do modelo em paixão sensual 
sugere uma visão de vida prazerosa, com bons momentos, ainda que estes possam levar ao sofrimento.

"Sete olhinhos", o nome da taberna onde a cena se passa alude à bisbilhotice, o que se confirma pelo fato de a história de Simão ser ali conhecida e comentada por todos. Também os desmaios de Mariana se tornam mote de comentários. O taberneiro afirma "E o grande problema das mulheres honestas é que vivem inconsoláveis" (Gomes, p.41) e sua fala é complementada pela de sua esposa: "[inconsoláveis] por causa dos pecados que não cometeram" (Gomes, p.41). O desejo carnal não é, portanto, visto como um problema, mas como a solução para alguns males. Esse ponto de vista não é moralista, nem repete servilmente a norma vigente; pelo contrário, sugere o romper com a noção cristalizada de "honestidade" como meio de se alcançar consolo e satisfação. Como se vê, vários motivos são inseridos por meio da criação de novas personagens, o que consiste no recurso da extensão.

Mariana termina a cena narrando reconhecer que Simão é motivo de seus calores e desmaios. Logo após, divulga-se a notícia de que o rapaz fora ferido pelos criados de Baltazar em uma emboscada. Cabe à Mariana tirar a bala que, desta vez, the fere nas nádegas, isso gera novo desmaio. A narração é fragmentada por uma cena em flash back, que remonta ao momento em que a moça conhece Simão. O jogo cubista entre planos diferentes, já enunciado na peça Maria, não me mates que sou tua mãe!, ocorre desde o início de Amor (também) de perdição e se evidencia pelo simultaneísmo de dois episódios anacrônicos encenados nesse ponto da peça. $\mathrm{O}$ novo tratamento das cenas revela também o procedimento da ampliação.

A música dos bêbados volta a ser entoada, reforçando o apelo à entrega aos prazeres.

A notícia de Teresa ter sido enviada a um convento faz Simão recorrer à Mariana a fim de levar uma carta à fidalga. Diante da declaração do rapaz de que sem Teresa renunciaria a vida, Mariana o adverte: "Não precisa ser tão dramático! A situação já é dramática por si... e nestas alturas convém distanciarmo-nos um bocadinho." (Gomes, p. 44). A ponderação da moça contrasta com a histeria do rapaz. Neste momento, nela, predomina o lado masculino (o animus) e nele, o feminino (a anima). 
A partir dessa cena, Mariana fará alusões a seu desejo por Simão que passarão despercebidas pelo rapaz. O final da cena apresenta o espelhamento entre as atitudes de Simão e Teresa: ele se questiona se Mariana estará apaixonada por ele, enquanto Teresa se indaga acerca de o namorado permanecer apaixonado por ela. Também a expressão do desejo de Mariana por Simão apaixonar-se por ela reflete-se no anseio de Baltazar por Teresa aceitá-lo em casamento. Verifica-se, dessa forma, que sentimentos semelhantes podem ter índoles ou intenções diferentes. Embora as personagens não tenham consciência do espelhamento das atitudes expressas, o leitor / espectador tem e pode inferir que a paixão, a dúvida, a insegurança são marcas do ser humano que só se compreendem pela observação do outro.

Há um corte de cena e enfoca-se o convento onde Mariana dialoga com a fidalga. A cena segue o modelo com um único acréscimo de motivo: as freiras chamam Teresa de "bruxa" ao perceberem que ela consegue comunicar-se com o namorado, mesmo sem tinteiro e papel. Bruxa parece remeter à mulher cuja energia criadora não foi domesticada e, por isso, quer ser ouvida como agente do desenvolvimento da consciência humana. Essa mulher não consente ser reprimida, quer ser livre. O retrato condiz com as artimanhas da moça para ludibriar o pai e manter o namoro. A índole feminina dissimulada e astuta é revelada no fragmento.

Em seguida três cenas ocorrem simultaneamente: o diálogo entre Simão e Mariana, por meio do qual se patenteia o desejo do rapaz de visitar Teresa no convento; a conversa de Rosa e seu marido taberneiro sobre os sucessos de Simão ter ido ao convento e o colóquio entre Teresa e Baltazar à saída do convento. A simultaneidade confere agilidade à peça ao mesmo tempo em que revela um mesmo episódio de vários pontos de vista. $\mathrm{O}$ caráter cubista da peça torna-se mais evidente pela justaposição de cenas anacrônicas.

O diálogo entre Simão e Mariana ocorre antes de ele defrontar-se com Baltazar. A conversa entre os primos dá-se antes dos fatos narrados por Rosa ao marido. O simultaneísmo tem também o intuito de revelar o espelhamento entre palavras de Baltazar à Teresa e as de Mariana a Simão. Ambos alertam o interlocutor a não persistirem em suas decisões para que não venham a arrepender-se. As palavras de Baltazar, no entanto, configuram uma ameaça e as de Mariana, uma advertência amiga. Essas coincidências e divergências parecem apontar para a necessidade de, em um julgamento, investigarem-se 
motivos que transcendam evidências superficiais, pois ditos e atitudes semelhantes podem ter intenções diversas.

Além do simultaneísmo, outro acréscimo de motivo feito por Fernando Gomes é a sugestão astuta de Mariana a Simão que se fantasie para encontrar Teresa a fim de não ser reconhecido. Novamente a importância do traje é colocada em pauta. Simão, entusiasmado com o plano, beija Mariana como se beijasse Teresa. Reforça-se, assim, o espelhamento, reiterado pelas seguintes falas:

MARIANA: Ele beijou-me!

BATAZAR: Ela rejeitou-me!

MARIANA: Foi sem querer!

BALTAZAR: Foi de propósito! (Gomes, p.48)

A inversão especular é ressaltada e parece alertar o leitor / espectador de que o caráter dual da realidade cotidiana deve ser observado com atenção. Espelho carrega, dessa forma, toda a ambiguidade semântica de sua etimologia, já que "deriva da palavra latina speculum - na origem, especular significa 'observar os movimentos das estrelas no céu, através de um espelho"' (Cherubini), com o tempo o termo passou a ser usado no sentido de meditar ou pensar a respeito. A etimologia sugere um conhecimento indireto, por meio da observação, o que se parece apontar na peça. Além disso, quando se leva em conta o mito de Narciso, considera-se o perigo de admirar-se excessivamente a própria imagem, uma vez que esta atitude cega para a realidade e faz o indivíduo perecer. Para o autoconhecimento, é necessário, portanto, usar o outro como espelho, já que o juízo que o outro faz do eu mostra quem é o "eu" para o próximo.

Autoconhece-se quem se faz outro, fragmentando-se no próximo. Representar tornase, por isso, uma forma de adquirir autoconhecimento e essa concepção vem sendo sugerida desde o início da peça com os rompimentos com a quarta parede.

A história prossegue com a inserção de uma canção enunciando os sucessos decorrentes da ida de Simão ao encontro de Teresa, que evidenciam as perdas ocorridas: Simão perdeu a liberdade, Baltazar perdeu a vida e Teresa, a chance de casar-se com o amado.

Somente depois de ter sido várias vezes narrado, o encontro de Simão e Baltazar vem à cena. Na versão de Gomes, o senhor de Castro-Daire está armado e chama o rival de 
"espantalho". Diante da ameaça e do insulto, Simão atira no adversário, dizendo mandarlhe, assim, ao inferno. As palavras do primo de Teresa indicam novo desdobramento, assim como Tadeu se sente à sombra de Domingos Botelho, Baltazar se sente encoberto por Simão, por isso the chama "espantalho". Embora Gomes não faça menção à fisionomia do herói, em Camilo, o filho mais moço dos Botelho teria puxado a beleza da mãe, portanto a denominação dada ao moço não pode referir-se à sua aparência.

O jogo de espelhos, iniciado pela associação entre Baltazar / Tadeu, Simão / Domingos, amplia-se com outro acréscimo, as freiras tiram seus hábitos, revelam-se agentes de polícia disfarçados e levam o rapaz preso. Gomes elimina a possibilidade de Simão entregar-se e assumir a responsabilidade por seus atos, ele é capturado em uma emboscada. Ocorre, portanto uma supressão ou redução. Em Camilo, a postura idônea do rapaz em assumir a culpa de seu ato quando tem a chance de fugir ou de valer-se de seu nome para escapar impune de seu crime fazem de Simão um herói e o diferencia de seus familiares. Em Gomes, o rapaz não tem oportunidade de revelar esse heroísmo e de firmar sua identidade, diferente da de seus pais. Seu ato apenas reflete a herança paterna de considerar-se poderoso o suficiente para julgar, condenar e punir o primo de Teresa.

Simão é condenado à forca e, em outro local do palco, Mariana desmaia, o que evidencia o simultaneísmo.

Para impedir a condenação do rapaz, Rosa, taberneira criada por Fernando Gomes, prontifica-se a salvar o rapaz. A atenção que Camilo confere às personagens femininas é recuperada e ampliada pelo dramaturgo. Se, no paradigma, Mariana apresenta a ousadia de desafiar a sociedade e colocar em risco a própria reputação para permanecer ao lado de Simão na cadeia, no exílio e na morte, na peça, várias mulheres revelam semelhante intrepidez e desembaraço. É o que se verifica na taberneira que se encaminha ao juiz, decidida a fazê-lo alterar a sentença dada a Simão. Novamente a inserção de personagens populares colaboram com o humor e, por extensão, com a revisão crítica de regras estratificadas.

No paradigma, o poder do magistrado Domingos Botelho adultera o julgamento pronunciado; na peça, a sagacidade e sedução de uma mulher do povo são responsáveis por isso. Essa alteração põe em causa o poder feminino, desprezado na sociedade do século 
XIX, enquanto ressalta a capacidade feminina de criar planos para manobrar a situação adversa, a ponto de o juiz ter dificuldade em acompanhar as propostas da dona da taberna.

A fragilidade do sistema judiciário, já sugerida no paradigma, é reiterada por novo acréscimo de motivo. $O$ juiz alega à Rosa que não poderia modificar a sentença para não chatear o carcereiro, nem o algoz que há muito não matam ninguém; no entanto, seguindo a lei do benefício próprio, o magistrado altera seu julgamento, seduzido por Rosa. Como se percebe, o poder judiciário revela-se fútil e facilmente manipulável e corruptível.

O contrassenso da justificativa do juiz gera o humor pela quebra de expectativa pela evidenciação do que geralmente se encobre. Pretextos mesquinhos são motivo para determinadas sentenças. Prevalece a vontade de quem relaciona-se com o poder instituído.

A cena é interrompida por um diálogo acerca do destino de Mariana que teria enlouquecido ao saber da sentença de morte dada a Simão. A ideia de que a moça seria amante do rapaz, apenas aventada na novela, é evidenciada no intertexto.

Em uma canção, a moça revela também possuir um amor de perdição. Diferente do amor espiritualizado do texto oitocentista, a personagem gomesiana revela-se lasciva e sensual. Em Camilo, a felicidade e o amor só ocorrem na vida após a morte, nega-se todo amor e felicidade terrenos, exalta-se o amor infeliz, perpetuamente insatisfeito. Gomes apresenta meios de se obter a felicidade terrena: a irreverência e o amor carnal.

A voluptuosidade feminina é também tematizada no episódio da aproximação de Rosa ao juiz. Nas juras de amor entre o juiz seduzido e a taberneira, há menção metateatral: "Se isto fosse ficção científica a D. Rosa era um micro-ondas." (Gomes, p.55). Permanece, portanto, um alerta constante acerca da dualidade ficção versus realidade.

Seduzido, o juiz altera a sentença e o diz em linguagem popular: "A justiça esteve a refletir... e acabou de verificar que se baralhou um bocadito." (Gomes, p. 55) A alteração no tom cerimonioso do paradigma gera o humor. Novamente dessacraliza-se o que é oficial. Além disso, Baltazar intervém, clamando por uma revisão do processo, mas é silenciado, por já ter morrido.

A audiência sanguinária sugere que Simão seja enviado à câmara de gás, ou morto a pedrada, afogado como os gatos, ou guilhotinado. O juiz declara não estar na Idade Média e ser necessário um final feliz para agradar ao público; por isso comuta a sentença em degredo para a Ilha da Madeira. 
O padre interpõe-se, aludindo ao paradigma: "Ele é deportado para a Índia, mas morre antes de lá chegar." (Gomes, p.56). Rosa censura a crueldade do padre que desja a morte do rapaz. O juiz alega que cabe a ele decidir o destino do rapaz. Animado com o poder do magistrado, Baltazar pergunta acerca de seu próprio destino e o juiz responde que não é Deus, pode deixá-lo falar algumas vezes, mas não ressuscitá-lo por completo.

Essa concepção do poder judiciário parece associar a magistratura à autoridade do ficcionista, já que , como um literato, o juiz pode dar a palavra para personagens que, fora do âmbito da imaginação, não poderiam falar. Como o reflexo implica semelhança entre duas partes, pode-se depreender uma concepção da Literatura como jurisdição. Nesse sentido, o literato deveria, como um juiz, investigar os costumes, opiniões e comportamento de um indivíduo ou de um grupo de indivíduos, bem como avaliar a ética, as regras de comportamento consideradas válidas. O espelhamento sugeriria, assim, o caráter filosófico da arte. Novamente, está em foco o recurso da extensão.

De volta ao plano da ação, Rosa relaciona a Ilha da Madeira, local para onde Simão seria enviado, a um jardim. Simão entusiasma-se com esse destino e não menciona nenhuma preocupação com Teresa nesse momento. Como a Ilha da Madeira é território português, o herói não seria exilado; pelo contrário, seria mandado a um local paradisíaco. Paraíso remete ao primórdio da criação; no contexto da peça, pode ser uma alusão a um recomeço ou renascimento. Longe das regras da família, Simão teria autonomia para dispor de si e fazer qualquer coisa por seu livre arbítrio; assim, ele gozaria dos direitos do homem livre, seria independente. Essa liberdade é, todavia, intimidante. Adiciona-se um motivo (viagem a local paradisíaco, prêmio) enquanto se suprime outro (exílio, punição) a fim de alterar significativamente a sentença de Simão.

Na Epanáfora amorosa, obra aludida na epígrafe do paradigma, os amantes fogem da Inglaterra e vão parar na Ilha da Madeira, local então desconhecido. As personagens da narrativa agem de forma significativa. Ana sucumbe diante dessa nova condição e Roberto morre pela culpa de levar a amada à morte. A liberdade gera perdas. Ana, acostumada à opulência da corte, leva consigo suas jóias para manter seu padrão de vida; no entanto, ao deparar-se com uma floresta desabitada, percebe que de nada valerão seus bens e que uma mudança radical lhe será necessária. Frente a essa nova realidade, a moça deixa-se abater e morre. Negar a liberdade equivale a abdicar da própria consciência; no entanto, para alguns, 
isso é menos custoso que aventurar-se pelo desconhecido. Aceitar a identidade conferida pela identificação com o outro e subjugar-se a ela é muitas vezes mais cômodo e confortável. O novo destino de Simão sugerido pela peça colocaria o rapaz em confronto com seus valores e ideais; propiciaria distanciamento da opinião pública, o que possibilitaria chegar-se ao autoconhecimento. O padre, representante da tradição, discorda desse novo destino e impõe o paradigma como sina do herói. O humor coloca-se de novo a serviço da libertação da submissão à ordem estabelecida. Torna-se ridículo o padre que remete ao poder instituído querer manter as regras ainda que elas não façam sentido.

O apego à tradição é característico do povo português, para ressaltar sua consciência disso, Fernando Gomes coloca o som de um realejo sob muitas cenas. Tudo ocorre como se o passado e seus valores permeassem a história. Por outro lado, a música de Offenbach rompe ironicamente com o tradicional e sugere uma postura iconoclasta. Essa ambiguidade revela a leitura do dramaturgo acerca de seu povo e do ser humano em geral. A contraposição entre velho e novo é evidenciada em Amor (também) de perdição na próxima cena.

Apresentam-se as alegorias da Lisboa Antiga e da Lisboa Moderna discutindo o destino do herói. Enquanto esta anseia por um final feliz, aquela espera um drama em que todos morram. Importa ressaltar que a diferença entre as duas é superficial, reside na tendência do gosto de cada época. No século XIX, era costume que se frequentasse o teatro munido de lenços para chorar. Esse derramamento sentimental supriria a necessidade de expandir as emoções, o que era vedado em uma sociedade pautada pelo lucro. Nos séculos XX e XXI, o riso substitui o choro, a necessidade de entretenimento de distração que afaste a mente da meditação e da reflexão dos problemas diários torna-se uma necessidade.

O diálogo entre as duas Lisboas sugere, por isso, a busca do ser humano por expandir emoções e fantasiar. A cena desemboca em um fado, cuja letra define a vida como mentira, o amor como castigo divino e apresenta a morte de Simão, Teresa e Mariana como final da peça. Aparentemente, o intertexto repetiria, assim, o texto de Camilo; no entanto, há uma alteração significativa entre os desfechos.

Em Camilo, Simão vai para o exílio por vontade própria, ao optar por não permanecer no cárcere por dez anos. Contrariando a vontade da amada, o rapaz decide viver livremente e confessa que nem o amor que sente por ela o fará mudar de opinião. 
Embarca com dignidade e altivez, decidido a viver com Mariana uma nova vida em local inóspito, porém destituído da hipocrisia de sua pátria.

Contudo, ao ler a última carta de Teresa, o herói percebe ter sido um mau servidor de sua senhora e, por isso, ter causado a morte da moça. Essa consciência o torna infeliz até a morte.

[...] - A infeliz espera-te noutro mundo, e pede ao Senhor que te resgate. - Se te pudesses iludir, meu amigo, quererias antes pensar que eu ficava com a vida e com esperança de ver-te na volta do degredo? Assim pode ser, mas, ainda agora, neste solene momento, me domina a vontade de fazer-te sentir que eu não podia viver. Parece que a mesma infelicidade tem às vezes vaidade de mostrar que o é, até não podê-lo ser mais! Quero que digas: — Está morta, e morreu quando eu lhe tirei a última esperança. -

— Isto não é queixar-me, Simão: não é. Talvez, que eu pudesse resistir alguns dias à morte, se tu ficasses; mas, de um modo ou de outro, era inevitável fechar os olhos quando se rompesse o último fio, este último que se está partindo, e eu mesma o ouço partir.

$[\ldots]$

Tu nunca hás de amar, não, meu esposo? Terias pejo de ti mesmo, se uma vez visses passar rapidamente a minha sombra por diante dos teus olhos enxutos? Sofre, sofre ao coração da tua amiga estas derradeiras perguntas, a que tu responderás, no alto mar, quando esta carta leres. (Branco, 1984, p. 532 - 535)

A carta de Teresa desperta a consciência de Simão e a culpa que lhe causa a morte. O amor, concebido como único e eterno, impede o rapaz de amar novamente e é sob o jugo desse sentimento tirano que ele sucumbe.

Em Fernando Gomes, suprimem-se a última carta de Teresa e a tuberculose que acomete a moça no convento. A culpa não será motivo da morte de Simão, mas a novela. O fado impiedoso, e não o amor, leva à morte. O Fado, retratado como o paradigma, remete ao apego à tradição, essa característica tipicamente portuguesa impede a renovação da história.

$\mathrm{Na}$ disputa entre os filhos rebeldes e os pais reacionários, vencem os pais. Simão não terá oportunidade de afastar-se daquele meio e individuar-se. O dramaturgo propõe-se a alterar o paradigma, mas a tradição - na peça, representada pela figura de um padre e da Lisboa Antiga - não permite. Isso gera um final desiludido, mas significativamente diferente do modelo, já que a causa da morte dos protagonistas é causada por novo motivo. O Fado impede a realização dos desejos, não a culpa. A inserção de novos motivos leva à internalização, isto é, substitui-se um motivo social por motivos psicológicos. 
A ideia de Fado apresentada no final do século XX parece um contra-senso; no entanto, o conceito de fatalidade existe no inconsciente coletivo português como uma âncora que não deixa novos barcos lançarem-se ao mar da irreverência. Em outros termos, o Fado consiste em uma representação mental que não permite à juventude a liberdade de expressão, a contestação às regras ou às situações estabelecidas.

O diálogo com uma obra canônica da Literatura Portuguesa é chamariz para a peça, mas é a paródia altera o paradigma e revela a mundividência do dramaturgo. Assim sugerese que o fatalismo português que coloca o povo à espera de um Destino Grandioso, do Quinto Império, do Encoberto, de um futuro que repita o passado de glória impede a contestação necessária à renovação. Há que se assumirem responsabilidades e defeitos, reconstruírem valores para a prosperidade.

Fernando Gomes, pela paródia dos moldes camilianos, sugere essa postura. Se simplesmente tivesse repetido o texto de Camilo, revelaria falta de identidade. Dessacralizando o modelo, o dramaturgo rompe com a tradição, denota maturidade literária e a assunção de identidade própria. $\mathrm{O}$ amor não é apresentado como meio de elevação e sublimação, mas como uma forma de afrontamento. O sofrimento não leva à salvação da alma, mas à perda da identidade.

Toda a ilusão criada pelas frequentes menções à possibilidade de alteração do final trágico gera a desilusão. A tristeza diante desse desfecho faria com que o povo caminhasse em procissão com velas para a "grande catedral do fado", "expoente da perdição nacional". (Gomes, p. 61) Há um anticlímax, tudo parecia indicar que o texto romperia com o modelo e, no entanto, os heróis morrem no final.

Os acréscimos de personagens e motivos e a eliminação das cartas ampliam o significado do texto camiliano. As epístolas, no paradigma, conferem tom sentimental e pessimista à narrativa. Sem essa correspondência, a novela apresenta apenas o amor obstado pela vaidade de pais tiranos. Extinguir as cartas e acrescentar personagens irreverentes é uma forma de o dramaturgo parodiar Camilo. Enquanto este enfoca o sentimento e os males oriundos das paixões, aquele sugere a subversão como meio de extinguir os males. O riso substitui o choro; o deboche, o sentimentalismo.

Na primeira parte da peça, predominam personagens que constituem o statu quo. São seres mesquinhos, egoístas, vaidosos, inconscientes de suas fraquezas e limitações, 
preocupados com aparências e reputação. Na segunda parte, abundam seres marginalizados: bêbados, mendigos, prostitutas, pessoas do povo. Esses vivem plenamente, entregam-se aos prazeres sem preocuparem-se com a opinião pública.

Mariana destoa desse grupo por sua extrema ingenuidade e é considerada por isso “inconsolável”. A história parece encaminhar-se para um rompimento com a novela oitocentista, muitas personagens do modelo quase que desaparecem no segundo ato; no entanto, o fado entoa a morte dos protagonistas.

Fernando Gomes aventa, pela canção, que a Lisboa Moderna difere apenas aparentemente da Lisboa Antiga. O desejo por um final feliz corresponde ao gosto do público antigo pelo trágico, a busca por sentimentos intensos que desviem a atenção da realidade concreta. Ambos os públicos querem a ilusão. A insatisfação gera o desejo de fuga, de criar ilusões. O anti-clímax é uma forma de romper com a ilusão e revelar a oposição entre verdade e mentira, realidade e ficção. A peça apresenta-se como espelho em que o eu possa refletir acerca de si mesmo.

O teatro como representação possibilita ver o mundo através dos olhos de outrem, simular para tentar compreender o plano sensível, real. Ao gosto do teatro épico, Gomes usa elementos que estimulam a problematização e a conscientização do espectador acerca do fazer teatral, da vida cotidiana, dos dados do inconsciente coletivo português. A peça sugere que o mundo é um palco e a vida é um sonho, interferir na reação do público interrompendo-a ou restringindo-a, corrobora essa concepção.

Gomes, como dramaturgo contemporâneo, incumbe-se de transcender os limites da cena tradicional, restrita pela preocupação com a verossimilhança e pela necessidade de criar a ilusão. Pela queda da quarta parede, seu teatro revela-se ficção. Assim, a cronologia não importa, derruba-se a quarta parede, estabelece-se a comunicação direta entre ator e espectador, fundem-se ficção e realidade. Abole-se a perspectiva, multiplicam-se os focos narrativos. A ação desvincula-se do enredo, em alguns momentos, para problematizar o fazer teatral. Sobem ao palco temas como a psicologia individual e coletiva, por isso é impertinente a linearidade. Por outro lado, fazem-se necessárias a superposição espacial e a simultaneidade temporal. Assim como o outro é projeção da consciência do eu, a peça espelha - e, algumas vezes, distorce - a vida social. Decorre daí a necessidade de empregar formas do teatro épico, de expandir o espaço cênico pela narração, por comentários, coros, 
canções. O diálogo hipertextual caminha para a paródia, para a desconstrução do paradigma.

Na peça, o intertexto funciona como a tradição a ser respeitada. Criam-se ilusões, mas a cópia repete a fatalidade funesta do modelo, o Fado inelutável se perpetua. O problema está em que a sociedade não está preparada para abandonar seus hábitos e individuar-se. Espera-se a salvação no alhures, mas quando se percebe que o aqui e o alhures são o mesmo gera-se a desilusão. No final, o espectador reconhece que tudo o que foi mostrado acabou repetindo o modelo e o passado, o que, na verdade, sugere a premonição de um futuro iminente.

Simão e Teresa são a antítese de seus pais, eles se amam, os pais se odeiam. Teresa declara seu amor ao mesmo tempo em que confessa "aldrabar" o pai.

Durante toda a peça, o som do realejo permeia cenas indicando a presença da tradição. Essa sonoridade amplia a sensação de fantasia e causa bem-estar, comodidade. $\mathrm{O}$ tradicional é território conhecido, não amedronta; por outro lado, Offenbach causa estranhamento. Também a sonoplastia sugere a duplicidade de emoções e sensações. De um lado, o realejo oferece a sensação de saudosismo; de outro, a menção a Offenbach sugere a paródia.

A solução para o dilema humano de autoconhecer-se no outro é afastar-se de estigmas e estereótipos, desembaraçar-se de uma imagem preconcebida. Assim, o português para individuar-se deve abandonar a imagem que tem de um ser que não existe mais. $\mathrm{O}$ amor de perdição é, portanto, o amor-próprio que impõe o culto à auto-imagem.

Corrobora a hipótese de dissociação do eu em busca de encontrar sua identidade, o uso de músicas de filme mudo como sonoplastia. A música no início da história do cinema mudo não era relacionada à ação transcorrida na tela, não fornecia o clima, nem enfatizava a imagem porque não se conseguia sincronizar o movimento e o som por algumas décadas. Tratava-se, portanto, de acompanhamento musical, função meramente ilustrativa, e não de cinema sonoro.

Colocar música de cinema mudo na peça não tem intuito de enfatizar a ação, já que a música não foi criada para aquele texto, revela, outrossim, a inadequação entre ação e som, gerando uma sensação de deslocamento. 
Não é esse afinal o dilema do ser humano? Lutar contra um rival implacável que lhe restringe os movimentos e lhe impede de individuar-se? As máscaras usadas como escudo em uma sociedade hipócrita apegam-se de tal modo à pele que se encobrem e modificam a identidade original. O juízo que o outro faz do eu torna-se tão importante que o eu acaba se tornando outro. Ansioso por escapar aos moldes, o eu quer escapar pelo riso, pela paródia, mas acaba no trágico, do qual não consegue desvencilhar-se. 


\section{FEL E SANGUE}

\section{1 Fel escorre da pena de Camilo}

O humor está presente na Literatura desde seus primórdios. A cada momento histórico, a manifestação do cômico adquire novas nuances, por isso não é de estranhar que tantos filósofos tenham se debruçado sobre o assunto. Também Camilo valeu-se do cômico para promover um retrato bastante amplo de sua época, de seu povo e dos sentimentos humanos.

O recurso já era apontado por Quintiliano como "um meio excepcionalmente poderoso de solaparmos nossos adversários" (Skinner, 1999, p.268), Crasso, personagem de Cícero, contribui com a questão sugerindo motivos que levam ao riso: "é possível encontrar material para o ridículo nos vícios observáveis no comportamento das pessoas" (Apud Skinner, 1999, p. 268). Como se percebe, a oratória antiga reconhecia o humor como um procedimento útil para conquistar o público e, ao mesmo tempo, expressar derrisão.

Considerando-se as citações feitas por Camilo em $O$ sangue de textos que se valem do humor, nota-se que o escritor estudou e apreciou o recurso. Um dos livros mais antigos, de feição irônica, aludidos na novela em questão, é $A$ arte de furtar, texto anônimo, escrito no século XVII. A narrativa apresenta o intuito de "ensinar a conhecê-los [os ladrões], para os evitar" (2006, p. 30) Permeada por ironia ferina e estilo jocoso, o livro dedica-se a satirizar os costumes da época, revelando que os verdadeiros ladrões e piratas não são punidos; pelo contrário, ocupam tronos e recebem homenagens. Nesse texto, são feitas críticas severas aos poderosos, ao sistema judiciário e à nobreza. Entretanto, o foco da censura feita pelo livro não é a sociedade, mas o ser humano; por isso, a vaidade, a ambição, a soberba, o zelo pela opulência e o excesso de amor próprio são julgados com veemência.

Outros autores que se dedicam ao humor, citados pelo novelista são Molière e Gavarni. O dramaturgo do século XVII tratou, em suas peças, de vários temas que aludem ao comportamento do homem da época. Suas críticas dirigem-se aos modos afetados da nobreza, à falsidade das relações matrimoniais, à hipocrisia da classe dominante - sobretudo a do clero -; ao ridículo procedimento dos novos-ricos de imitar a nobreza; à soberba e à 
arrogância. Seu humor é corrosivo e erudito, não se trata do burlesco, do grosseiro, do agressivo, mas revela o poder do dito espirituoso, parece corresponder ao que Freud preconizava como um riso que revela um sentimento de superioridade e de superação e confere liberdade quanto à fraqueza do outro. Esse tratamento do cômico vai abrir espaço para a caricatura, amplamente cultivada no século XIX.

Nesse âmbito, Gavarni revelou-se genial, apresentando por seus desenhos os costumes de sua época em traços burlescos e picantes. Ele iniciou seu trabalho ridicularizando tipos sociais, mas, em fase mais madura, passou a retratar o lado grotesco da vida familiar e da natureza humana. Suas gravuras sugeriam pessimismo e indignação diante do ridículo dos vícios. A caricatura exagera traços psíquicos, dessacraliza, servindo até mesmo aos iletrados, daí Baudelaire afirmar:

[A caricatura] realiza desproporções e deformações que devem ter existido na natureza em estado de veleidades mas que não podem desabrochar, recalcadas por uma força maior. Sua arte, que tem qualquer coisa de diabólico, ressalta o demônio que derrotou o anjo. (fonte)

O filósofo considerava esse riso de perfil demoníaco como profundamente humano uma vez que sugere a debilidade do homem em seu orgulho, sua intenção de humilhar, de vingar-se, de agredir.

O cômico em Camilo, no entanto, parece transcender essa intenção e vincular-se à dialética do riso e da tristeza preconizada por Victor Hugo. Para o autor, o cômico advém da tomada de consciência de que a realidade é grotesca e muito distante do ideal. Essa concepção vai ao encontro da busca romântica pela unidade perdida.

El espíritu del hombre, creatura separada, es el espejo más puro del universo y del Alma universal. Más aún, esta Alma no puede llegar a la consciência y conocerse a si misma sino en su imagen, que es la alma humana; pero no [...] en el alma tal cual es, inculta y abandonada, sino únicamente en el hombre que há sabido llegar a ser lo que ya es. Lo que debemos hacer es habituar nuestro oído para percibir el diálogo interior del Todo consigo mismo, alcanzar em nosotros mismos las regiones inconscientes, que son de la semejanza divina. (Béguin, 1993, p. $103-$ 104)

O riso camiliano reúne as várias gradações do humor clássico e romântico, incidindo, fundamentalmente, sobre a psicologia humana de forma dissimulada, irônica. Antídoto contra a atitude sisuda e nada criativa de uma sociedade pautada em regras que se articulam de acordo com os interesses da classe dominante, o humor de Camilo parece ter o 
intuito de gerar prazer psicológico a si e ao leitor sagaz que escarnece de procedimentos indicativos de certa economia mental.

Em $O$ sangue, o cômico relaciona-se ao próprio processo narrativo, já que Camilo elabora seu texto revelando a literatura como fingimento e como representação, para o quê se vale da ironia romântica. Exemplo desse procedimento são as sínteses com que se iniciam os capítulos, cabe citar um trecho modelar:

Desengano aos fariscadores de escândalos. Como pode o engenho fazer o milagre de conservar personagens honestos até o $4^{\circ}$. capítulo inclusive. De como no Porto de há vinte anos houve homens endiabrados com senhoras, e outras coisas tristes. Por que dizem que a esperança é verde. [...] Dizem outras coisas que tocam o coração. (Camilo, 1907, p. 53)

A consciência crítica do autor refreia-lhe o sentimentalismo e faz irromper um escritor irônico, capaz de dessacralizar seu tempo, sua gente e seu próprio texto. Também a compreensão de que a vida social é composta por disfarces e dissimulações é sugerida por comentários críticos de teor metalinguístico os quais perpassam as cenas de pura farsa. Esse saber torna a melancolia, a desilusão, a amargura diante da estupidez humana o cerne do humor de Camilo. Em suma, é necessário brincar com a dor para obter consolo e autopreservação.

A índole do riso camiliano é sugerida nessa narrativa, sobretudo, pelas alusões intertextuais. O livro é permeado de um riso ácido que desorganiza as convenções, liberta das circunstâncias exteriores, esfacela a moral social hipócrita, para tornar o leitor apto a ver o mundo com olhos mais críticos e atentos. "No grotesco romântico [...] a loucura adquire os tons sombrios e trágicos do isolamento do indivíduo." (Bakhtin, 2010, p. 35)

O narrador inicia o romance, em tom de deboche, a pedir a um amigo um lance extraordinário para um escritor que de uma ideia sem originalidade nenhuma compõe dez livros singulares. A alusão metalinguística e a intertextualidade são elementos fundamentais para a compreensão do processo narrativo camiliano.

Com base nesse pressuposto, importa iniciar o estudo do romance pela apreciação crítica dos textos aludidos pelo escritor. Como já se enunciou, um índice onomástico das citações de Camilo caminharia dos clássicos aos românticos pela vertente do blague, do 
chiste. Percebe-se, por isso, o valor que o novelista atribui ao humor como forma de desentorpecer os sentidos para produzir mudanças.

Alerta de que a vida é efêmera e, por isso, há que se valorizar o eterno e o risco, o novelista promove a caricatura da sociedade burguesa de forma a evidenciar quão frágil e insignificante é sua moralidade, enquanto defende a integridade do interior humano. Para afrontar a falta de entendimento e a hipocrisia, Camilo emprega um riso amargo, misto de prazer e dor, que denota censura e compaixão. "\{...\} Num mundo fechado, acabado, estável, no qual se traçam fronteiras nítidas e imutáveis entre todos os fenômenos e valores, o infinito interior não poderia ser revelado.[...] (Bakhtin, 2010, p. 39) Para isso contribui o uso triste da sátira.

A análise crítica inicia-se desde a primeira página da narrativa, que se abre com uma conversa entre o narrador-autor e Antônio Joaquim. Esse diálogo é pretexto para Camilo zombar dos ricos que louvam a pobreza e não conseguem conviver com a ideia de velhice pelo apego excessivo à vida. As reflexões do amigo abastado lembram ao narrador a Arte de furtar.

Antônio Joaquim, por seu turno, considera a moralidade do personagem-autor semelhante à de Droz e de Franklin e a conduta ética dos desvalidos similar à de Sócrates, Philo, Jesus Cristo e Jean Jacques Rousseau.

Sem perder o tom de deboche, o narrador-autor rebate que pouco sabe desses filósofos e só se incomoda em tentar desvendar o significado das palavras de Cristo, "Benditos os que choram". Para Camilo, cultivar e expressar emoções definem o cerne do homem; no entanto, ele olha com desconfiança o versículo citado já que o consolo prometido aos que sofrem é substituído, em sua sociedade, por zombaria e menosprezo. Choram os pobres e oprimidos que são rejeitados e escarnecidos.

Como se pode notar, em poucas páginas há um grande número de citações. Cabe lançar alguma luz sobre as ideias sugeridas por essas alusões intertextuais a fim de adentrar-se o universo camiliano.

Sobre os filósofos citados, basta recordar algumas ideias-chave que corroboram a visão camiliana. Droz propunha que o homem deve ser educado para privilegiar os deveres em detrimento dos direitos a fim de construir uma sociedade exemplar. Em Franklin, são coletados ideais de liberdade para a conquista da independência individual privada, livre da 
opressão de soberanos. Em Rousseau, o desdém pela sociedade urbana, corruptora que deve ser problematizado.

Quanto à filosofia de Sócrates, o que parece interessar a Camilo é o ideal de aprimoramento pessoal e o menosprezo pelo enriquecimento material. Já em Philo, o novelista parece recuperar o conceito, distorcido pelo individualismo burguês, de que as paixões desviam o homem do caminho da perfeição e da virtude; por isso há que se reprimirem os desejos para que a bondade, a prudência, a coragem, o autocontrole sejam cultivados. A Burguesia, em prol do lucro, materializa as relações, subjuga os sentimentos para travar casamentos convenientes.

Depois dessas sugestões filosóficas, Antônio Joaquim oferece-se a contar ao suposto autor um lance original que lhe dê ideia para um romance. As personagens de sua história foram apresentadas ao narrador-autor em certa ocasião em que ceiam um cordeiro ao assistir pela oitava vez à peça Degolação dos Inocentes. Enquanto assistem à dramatização do episódio em que Herodes manda perseguir e executar os primogênitos, a família come um cordeiro do qual deixa cair uma perna do camarote para a plateia. O grupo em que se insere o narrador vai até o local para devolver o quitute em tom de zombaria.

O grotesco é motivo de riso, é

[...] uma espécie de carnaval que o indivíduo representa na solidão, com a consciência aguda do seu isolamento. A sensação carnavalesca do mundo transpõe-se de alguma forma à linguagem do pensamento filosófico idealista e subjetivo, e deixa de ser a sensação vivida [...] da unidade e do caráter inesgotável da existência que ela constituía no grotesco da Idade Média e do Renascimento.

O princípio do riso sofre uma transformação muito importante. Certamente, o riso subsiste; não desaparece nem é excluído como nas obras "sérias", mas no grotesco romântico o riso se atenua, e toma a forma do humor, ironia ou sarcasmo. Deixa de ser jocoso e alegre. $\mathrm{O}$ aspecto regenerador e positivo do riso reduz-se ao mesmo. (Bakhtin, 2010, p. 33)

O paralelo entre a peça e um grupo de cristãos-novos que destroça e devora um cordeiro é um índice de como o novelista enxerga a hipocrisia daquele grupo. Tal como Herodes manda sacrificar os primogênitos para assegurar seu poder, os burgueses da rua das Cangostas imolam sua religião e seus filhos em prol de seus interesses. O sacrifício do cordeiro, antes oferecido a Deus, é agora meio de saciar a gula.

Verifica-se, assim, que a acidez e profundidade da visão camiliana permeia as primeiras páginas de seu livro por meio de alusões críticas que somente serão captadas e compreendidas apenas por um grupo seleto apto a rir com o novelista. 
O tema da sujeição ao lucro entrelaça-se a assuntos relacionados à psique humana, como o amor-próprio. O enredo de $O$ Sangue tem como nó o casamento de Tomásia e Inocêncio, tramado por Gervásio em busca de direcionar a vida do filho e ao mesmo tempo agraciar a órfã, que criou com amor de pai, tornando-a sua filha. Cabe aqui uma paráfrase resumitiva da novela para enfatizarem-se alguns dados relevantes para análise.

Assim que nasce a menina, sua mãe falece nos braços da vizinha, a rica cristã nova Tomásia de Barros. Imediatamente a família Barros encarrega-se de criar e educar o bebê que recebe o nome de sua madrinha. Quando atinge idade suficiente, o padrinho planeja casá-la com seu próprio filho para manter o dinheiro em família. Os moços titubeiam, mas acabam consentindo. $\mathrm{O}$ casamento fracassa já na lua-de-mel, quando o rapaz se revela doentiamente ciumento. Na primeira oportunidade, Inocêncio viaja e amanceba-se com uma francesa. Tomásia permanece solitária até reencontrar um moço que a assediara com longos olhares em sua lua-de-mel. Eles trocam cartas, ela identifica-se com a solidão do rapaz, engravida e tem que fugir com ele depois de o bebê nascer, para livrar-se da vingança do marido. Na fuga, tem que abandonar o bebê, mas planeja vir buscá-lo logo que possível. Entretanto, Inocêncio morre antes de voltar para casa e a família Barros sai de Portugal anonimamente para criar o "neto" na Inglaterra. Já adulto, Pedro toma conhecimento de que a mãe é viva e casada com o homem que teria arruinado a reputação de seu pai. Impetuosamente, o rapaz decide desafrontar a honra do pai, travando um duelo com Nicolau, sem revelar sua identidade; no entanto, é ferido de morte. O marido de Tomásia vem a saber que baleou o filho e enlouquece. Pedro visita Nicolau percebe que aquele é seu verdadeiro pai, mas decide afastar-se e assumir-se herdeiro universal dos Barros. Diante do desfecho, um amigo do narrador comenta: "Um filho só pode ser filho de quem é seu pai, quando não herda oitenta contos de outro que foi casado com sua mãe." (Branco, 1907 , p. 254)

A trama constitui-se a partir dos interesses mesquinhos de cada personagem. No ancião, há o desejo de preservar seus bens, sem ter que dividi-los com outra família. No rapaz, o interesse por Tomásia é despertado pela inveja de um adversário mais elegante, moço que "cavalgava guapamente, era bem parecido, galeava pelos figurinos, tinha uns ares soberbos de quem despreza invejosos, entrava na roda dos provincianos fidalgos, e, de mais a mais, [era] rico.” (Branco, 1907, p. 73) A órfã aceita a proposta movida pelo 
despeito, pois fora ridicularizada por Costa Guimarães. Além disso, a ama lhe assegura que não acharia marido melhor.

A psicologia é tema caro ao novelista. Cada personagem configura-se um meio de Camilo apresentar traços de comportamentos individuais e sociais. A astúcia feminina introduz-se pela personagem Custódia. Interessada em desvincular Tomásia de Inocêncio por antipatizar com o rapaz que sempre a maltratou, ela manipula a menina a corresponderse com outro. Clama a São Gonçalo de Amarante por um marido para a moça e acredita têlo encontrado no dandy Costa Guimarães. Entretanto, quando toma conhecimento de que este desdenha de sua senhora, aconselha Tomásia a corresponder ao filho do Sr. Barros. A sagacidade de Custódia contrasta com sua ingenuidade. Se, por um lado, revela-se engenhosa ao tentar dissuadir Tomásia, mostra-se tola e ridícula quando é crédula, ou retoma as quadrinhas de um antigo pretendente como índice de sabedoria.

Como a ama, as personagens apresentam qualidades e defeitos, os heróis são dessacralizados. No livro, Camilo põe em xeque os exageros românticos e encaminha-se a estabelecer seu realismo romântico, que apresenta consciência dos limites da representação literária, questiona o fazer narrativo, revelando suas incongruências, sem, no entanto, deixar de criticar a arte que se quer retrato imparcial, sem imaginação e criatividade. "O que faz parecer a novela Camiliana realista é, pois, a sua intensidade romântica, ou seja, a verossimilhança conseguida depende mais da relação enunciador-linguagem-mundo do que de uma adequação da linguagem e do enunciador ao mundo real." (Ferraz, 1991, p. 81)

No intuito de revelar o ser humano por meio de personagens, Inocêncio, sem saber com que moça se casa, é ridicularizado e comparado ao burro de Buridan. Esse jumento, indeciso, morre de fome diante de dois fardos de palha exatamente iguais. Assim, veiculase a falta de iniciativa de um rapaz educado sob o controle da vontade paterna. Esse traço torna o nome da personagem ainda mais irônico, pois não se trata de ingenuidade, mas de parvoíce.

O caráter ridículo do rapaz é ainda acentuado quando este se põe a citar versos do Ciúme do Bardo, "em voz soturna", ao lado de barqueiros ignorantes e de senhoras que the tomam medo.

O texto de Castilho citada apresenta um poeta em desespero por acreditar-se traído por sua amada. $\mathrm{O}$ eu lírico oscila entre ímpetos de vingança e de morte, e a iminência de 
enlouquecer. O ciúme é, no poema, uma paixão sensual e voluptuosa que aguça os sentidos e a imaginação. $\mathrm{O}$ adultério faz com que o sujeito poético deseje o mal de sua amada para que sua desgraça sirva de exemplo à humanidade.

A história de amor do bardo apresenta algum ponto de semelhança com a de Inocêncio e Tomásia. Ambos os casais conhecem-se desde a infância; no entanto, em Castilho, há amor do que decorre o desejo do sujeito lírico de perdoar a amada. O amor que rompe barreiras não ocorre em Camilo; pelo contrário, o casamento é mero contrato. A insegurança do rapaz gera o ciúme e a desconfiança, esses sentimentos são exacerbados a tal ponto que a esposa aviltada pelas constantes acusações passa a desdenhar do marido e pede ao padrinho que a ponha em um convento.

Camilo concebe Inocêncio como homem pervertido pela sociedade. Acostumado a frequentar bares, jogar, beber, o rapaz entedia-se no isolamento da lua-de-mel. Ao lado da "Fonte dos Sátiros", propõe à esposa que retornem a Lisboa.

A alusão aos sátiros é irônica, pois refere-se aos companheiros de Dionísio que passavam seu tempo perseguindo as ninfas, bebendo vinho, dançando e tocando harmônica de canos, flauta ou gaita. A associação convida ao riso os que são capazes de compreender a alusão.

Hábil conhecedor da psicologia feminina, o autor zomba da situação dos protagonistas, sugerindo que Tomásia, se fosse mulher experiente, teria usado o ciúme para suscitar o desejo do marido. Dessa forma, o narrador evidencia a inocência e inexperiência da moça, o que será valioso para configurar a visão geral do narrador acerca da personagem.

Para asseverar a verossimilhança dos tipos que cria, o narrador compara Costa Guimarães, motivo do ciúme de Inocêncio, a Saint-Preux, “ terror da moral desde a Porta dos Nobres até o Poço das Patas" A menção refere-se a uma personagem de Júlia ou a Nova Heloísa, de Rousseau. Diferente da moça que dá nome ao livro e seu marido Wolmar, com quem casa para satisfazer a vontade paterna, o ex-namorado de Júlia, Saint-Preux, não é resignado e virtuoso, mas apaixonado e disposto a viver um amor adúltero. Júlia e o esposo representam o controle racional, como uma virtude que motiva a verdadeira felicidade, a paz da alma. As personagens da narrativa de Rousseau são seres superiores, muito além do homem comum. A moça subordina sua vontade particular à paterna, visando 
a preservar a imagem da família. Wolmar configura-se um Inocêncio às avessas, é forte, controlado, domina situação e quer conhecer o antigo namorado da esposa. Saint-Preux não atinge o autocontrole, com ele o leitor pode identificar-se. Entretanto, Rousseau parece negar o que afirma, já que sugere a ataraxia, ao mesmo tempo em que mostra a impossibilidade de o homem comum segui-la.

A Nova Heloísa aponta a contenção racional como possibilidade de resolver os conflitos gerados pelo amor-próprio e por outras tendências humanas, as quais fazem do homem um ser incompleto e insatisfeito; por outro lado, nega essa possibilidade pela confissão do sofrimento de Júlia antes de morrer.

Já em Camilo, os embates humanos são intensificados pelo caráter passional das personagens, o controle dos sentimentos não é um ideal. Incapaz de vigiar a si mesmo e de vencer seu maior desafio, que é o próprio eu, o homem não alcança a virtude e tem destino trágico. Em Rousseau, as belas almas atraem os homens comuns para aperfeiçoá-los; em Camilo, as belas almas são as que se entregam ao amor, rechaçando as convenções, contudo essa façanha é cruelmente castigada.

Rousseau propõe a conduta estóica, mas parece negar sua efetividade pelo sofrimento de Júlia. Camilo propõe o amor sem barreiras, porém sua realização é comprometida pelo embate com as regras sociais, daí o destino trágico dos que se arriscam.

Na mesma linha satírica, a relação entre Tomásia e Inocêncio é retratada. Eles se casam na igreja de São Nicolau. Além de o nome do santo coincidir com o do futuro amante da moça, associa-se a um homem célebre por prodigalizar discreta e desinteressadamente seus bens em prol de menos afortunados. $\mathrm{O}$ altruísmo não se verifica em nenhuma personagem da narrativa, sobretudo em Inocêncio cuja mesquinhez é tal que se vale da herança de um tio para viajar com uma amante em vez de compartilhar com a esposa e família.

A alusão remete também a Nicolau, cuja fortuna é aplicada a granjear meios de namorar Tomásia ou de evidenciar seu poder diante da sociedade do Porto. Não há menção à filantropia do rapaz. Ele não é um herói tipicamente romântico, é descrito, outrossim, como quem um galanteador ridículo, cujo perigo estava em querer morrer ou matar por amor. Antônio Joaquim também colabora para a dessacralização do herói ao questionar o amor do amigo por uma mulher casada: 
- Que julgas tu que sou capaz de fazer por aquela mulher? [Nicolau referindo-se à Tomásia]

- Asneiras superiores ao meu cálculo - respondeu meu discreto amigo.

- Arrebatá-la, e estrangulá-la, se me perseguirem e eu me vir em risco de a perder.

- Vês? - tornou Antônio - aí está uma parvoiçada a que não chegava o arrojo da

minha imaginação! Arrebatá-la e estrangulá-la!... Não és rapaz de meias medidas. Faltou-te, no programa, enterrá-la. É preciso enterrá-la; e depois uma sangueira de vampiro. Vais por noite morta ao cemitério e sugas-lhes as artérias.

- Não podes entender-me: és bom rapaz, mas não conheço coração mais estúpido que o teu! - atalhou o acadêmico, com um sorriso em que ressumava o despeito delicado.

- Não é estúpido, quanto cuidas - contradisse gravemente o meu atilado amigo. Tem um vício que vocês alcunham estupidez: o vício da virtude. Condeno com quanta sinceridade posso essa cruel brincadeira que tu chamas fatalidade. Já me disseste que é casada a mulher.

- Que me faz isso a mim? - obviou Nicolau sem tergiversar na protervia da refutação. - Eu sei lá o que é ser casada a mulher onde está uma alma que me pertence?

- Então a alma da mulher de um tal Inocêncio pertence-te?!

- Não zombes!

- Pois tu crês que possa sustentar-se contigo diálogo sério? Que distinções estás aí talhando entre corpo e alma!... Não me atarantes com sutilezas. Agacha-te ao raso do meu entendimento. A mulher é casada ou não?

- É.

- Então, deixa-a; porque não sabes quantas desgraças evitas à mulher que amas.

Deixa-a em virtude do amor que lhe tens. (Camilo, 1907, p. 156 - 157)

O desejo de Nicolau por viver um grande amor com uma mulher casada não escapa ao humor amargo camiliano. Já no início do livro há um índice narrativo a sugerir a tragicidade do destino dos que ousam afrontar as regras sociais. Antônio Joaquim defende o respeito de homem por uma mulher casada como uma virtude, ainda que esta seja alvo de seus sentimentos. Virtude não é um dom, uma qualidade inata, mas fruto de intenso trabalho de autocontrole e perseverança. O comentário de Joaquim poderia ter sido feito pelo próprio autor, que também vivenciou a questão e sabe as implicações legais e emocionais de um adultério. Enfrentar a sociedade em nome do amor não é tarefa fácil, nem passível de ser empreendida por um sujeito sem muito dinheiro e poder.

Outro excerto que sugere a dessacralização de Nicolau transcreve-se a seguir:

Tinham entrado na estalagem quando o secundarista retrocedeu a botar inculcas sobre a procedência e destino da mulher que, a seu juízo, lhe era enviada como um acepipe dos festins de Lucrécia Bórgia, um cálice de água tufana, uma coisa que lhe caíra do céu como a tartaruga que matou Ésquilo. Os rapazes têm coisas! (Branco, 1907, p. 115 e 116) 
Lucrécia Bórgia assemelha-se à Tomásia em vários aspectos, não só no que se refere à beleza da moça que seduzia a todos os que a conheciam - menos o marido, em ambos os casos - como também a uma gravidez de paternidade desconhecida. A personagem não apresenta a castidade, resignação e nobreza da heroína romântica, é uma mulher sedutora, consciente de sua sexualidade e pronta a dissimulá-la, se necessário .

Além de a referência trazer em seu bojo uma conotação sexual rara em romances românticos, é associada ao episódio trágico - ao mesmo tempo cômico - da morte de Ésquilo, alvo de uma tartaruga arremessada por uma águia que tentava quebrar-lhe o casco para comê-la. Assim, introduz-se, de maneira dessacralizante, o caso de Nicolau e Tomásia: há uma alusão à sexualidade e a um final trágico que viria de forma repentina e inesperada (tragicômica). A conduta típica do herói romântico que se lança em aventuras e riscos por amor a uma mulher fatal é ridicularizada no trecho. A cena parece consistir em uma advertência aos que se deixam levar pelas emoções de que se deve ponderar refletidamente antes de arriscar-se porque os infortúnios são inevitáveis.

Por sua obra, Camilo problematiza a vida, apropria-se racionalmente de seus dados para analisá-los e interpretá-los. Em suas narrativas, ele preserva episódios da vida do cotidiano e estuda a psique humana. As personagens não procuram sujeitar-se às adversidades em busca de salvação na vida após a morte, o universo interior nobre, desinteressado, que se apresentava em Simão e Teresa do Amor de perdição esvanece-se em $O$ sangue . A visão do livro é mais realista e cética, mostra uma humanidade que suscita o escárnio.

Lançando mão do cômico, o novelista se põe acima dos que analisa, e zomba da mesquinhez desses tipos. O humor camiliano decorre, portanto, de quatro fatores: da consciência crítica da realidade, da observância de uma crise de valores; de uma crise individual - motivada por ver-se menosprezado por pessoas que lhe condenam por crimes semelhantes aos que cometem, mas encobrem - e da desilusão diante de um mundo corrompido.

O ciúme, fruto do amor-próprio ferido, parece ser o tema que recebe mais luz no livro, prova disso é o paralelo que se traça entre a história de Tomásia e Inocêncio e a peça Fayel, de François Thomas Marie de Baculard d'Arnaud. A menção é feita em diferentes momentos. Durante o momento em que as personagens assistem ao primeiro ato da peça, o 
marido de Tomásia observa Rosinha; no intervalo, é advertido pelo irmão da ex-namorada que Tomásia escrevia cartas a outro. Essas ocorrências aguçam-lhe os ciúmes e o tornam implacável com a esposa.

Importa estabelecer o paralelo entre a peça de Arnaud e $O$ sangue para configurar a visão de mundo de Camilo. O primeiro ato da peça apresenta Fayel, um marido cruel que quer vingar-se da esposa por suspeita de infidelidade. A causa da desconfiança é uma carta anônima encontrada junto ao quarto de Gabriela - o mesmo motivo do rancor de Inocêncio. $\mathrm{Na}$ peça, o pai da moça rasga a carta, considera injusto o receio do genro e atribui ao excessivo ciúme do moço a causa da tristeza constante da filha. O sogro, no entanto, reconhece na carta a letra de um antigo namorado da filha; ele finge para preservar o casamento que tramou por conveniência própria. Fayel assume ter caráter violento, intratável, e concorda em remover a esposa da torre onde a encarcerara.

Inocêncio, transtornado pela intriga de Roque, não assiste ao segundo ato, em que se enfoca Gabriela, no cativeiro, consolando-se com a ama. A moça revela sua inocência, embora declare amar Cuci, que ela acredita estar em batalha. Isaura aconselha a esposa de Fayel a escrever a Cuci, reafirmando-lhe seu amor. Vergi vem encontrar a filha para culpála de ingratidão, declarar-se um desgraçado e dizer-lhe que Cuci morreu heróicamente em guerra.

Fayel junta-se ao grupo e apresenta momentos de ciúme intercalados a crises de choro e de arrependimento. Vergi, à parte, aconselha a filha a dissimular seu sofrimento pela morte do ex-namorado.

Inocêncio retorna ao camarote no fim do segundo ato, o pai retira-se com ele para saber o motivo da ausência do rapaz. Assim como Vergi, Gervásio - note-se a transposição de algumas letras dos nomes das personagens - defende a moça para proteger a reputação de seu nome e de sua família e "diz coisas escorreitas das mulheres com o tino e o siso de um Balzac" . A menção ao romancista francês decorre do fato de ele ter sido atento observador e franco retratista de seu povo, o que fazia sem escrúpulos, revelando a hipocrisia e a corrupção de sua gente. Assim, Gervásio é retratado como um homem experiente no convívio social; daí aconselhar o filho a manter a aparência de tranquilidade para não instigar comentários malévolos. 
Diante da advertência paterna, Inocêncio "entrou a rir-se no camarote com a mais infeliz cara que imaginaram Gavarni e Molière.” (Branco, 1907, p. 134) A menção ao caricaturista e ao dramaturgo que se tornaram célebres por retratarem, de forma zombeteira, os tipos humanos e a vida das famílias burguesas, sugere o intuito de aprofundamento no estudo da natureza humana e suas relações sociais. Os aspectos da vulgaridade e do vício, da miséria e da degradação moral são reprovados pelo riso.

No terceiro ato, Cuci retorna da guerra e por obra do acaso encontra Gabriela em um bosque. Ao saber que ela está casada tenciona matar-se ou assassinar-lhe o marido, a moça insiste em que mantenham a dignidade e a honra. Ainda que inocentes, eles são aprisionados por pajens de Fayel.

No ato seguinte, Fayel confessa amar Gabriela e culpa o pajem por acender-lhe os ciúmes. Essas cenas não são mencionadas na novela, afinal o tratamento dado ao tema do amor difere-se nos dois textos: Inocêncio não ama a esposa, casa-se por deixar-se levar pelo amor-próprio ferido. No entanto, Tomásia pede que Inocêncio deixe-lhe prestar atenção à última cena do quinto ato. Embora essa fala não seja transcrita por Camilo, importa recuperá-la para que se compreenda a menção feita pela personagem. Gabriela exclama, depois de Fayel ter matado Cuci:

Se te queres, cruel, fartar de sangue,

Quem te suspende? Mil punhais me crava.

Há muito tempo espero, e te suplico,

Que termines meus dias; despedaça

Um peito, de teus golpes desejoso;

Rasga o coração angustiado,

Que, à sua fé rebelde, já não pode

Sentir mais do que horror a teu respeito...

Os vínculos sagrados, que até hoje

Nos ligaram, cruel, tu os quebraste;

O crime para sempre nos separa...

Acaba de vingar-te; escuta os brados

Da raiva, que te inflama; ajunta, ajunta

Também aquela vítima a Consorte...

$\mathrm{O}$ teu fatal poder já não conheço,

Nem razão, nem dever; a glória, a fama,

Nada, nada m'importa; desesp'rada,

Embebida na dor, que me espedaça;

Cheia de uma lembrança, que em minh'alma

Há de sempre existir, ver-me-hás entregue

A pesares eternos, até que morra:

Continuamente me hás de ouvir, tirano,

Repetir-te que amei Cuci sempre;

Que o tempo, as tuas iras atiçarão

Meu amor inda mais: apesar da morte, 
Esta imagem querida há de gravar-se

Cada vez mais, e mais em meus sentidos.

Agora mesmo o adoro mais que nunca!

Sim, meus votos recebe, sombra amada,

Por teus manes ensanguentado juro,

Um amor te prometo, que escarneça

De teus furores...( a Fayel em tom desprezador)

Não, já te não temo;

A minha mesma dor me arranca a vida. (Arnaud, 1803, p. 96 e 97)

O desespero e insubordinação de Gabriela a um marido cruel serão refletidos no desdém de Tomásia pelo marido. A mesma aversão indignada será apresentada por Tomásia em dois momentos: diante da ama morta em decorrência das intrigas de Inocêncio, e perante a indiferença de Pedro pelo sofrimento de Nicolau. A morte de Custódia determina o rompimento dos votos do matrimônio, pela completa indiferença e o mais amargo rancor de uma esposa aviltada pelo ciúme de um marido cruel e injusto. Ao invés dos brados excessivamente sentimentais de Gabriela, Tomásia adota a indiferença e pede para ser colocada em um convento, proposta sumamente rejeitada por Gervásio. Este prima por manter as aparências e conservar a união do filho com uma mulher que não colocasse sua fortuna em risco.

Nesse ínterim, Luís Pinhel, tio de Inocêncio, falece. O rapaz vai ao Pará receber a herança que the foi deixada. Ironicamente, o navio em que o rapaz viaja para o Pará se chama Romeu. A história de amor de Shakespeare, consagrada por séculos, altera-se nas mãos de Camilo, Romeu passa a figurar-se como um homem mesquinho, egoísta, que se despede secamente da esposa para angariar o que lhe cabe de uma herança que divide com os filhos ilegítimos do tio. Esse é o Romeu do final do século XIX.

Além desse diálogo intertextual, outro é sugerido pela conduta de Inocêncio. A personagem parodia o filho pródigo. Assim como a figura bíblica, ele despreza o convívio familiar e lança-se a uma vida de prazeres que financia com o dinheiro de uma herança. $\mathrm{O}$ desfecho, contudo, inverte o paradigma. $\mathrm{O}$ rapaz não se arrepende, nem intenciona pedir perdão por sua imoralidade. Desprezado pela amante que até então lhe retinha a correspondência, receberá a notícia de que sua esposa está grávida. Enfurecido, quer retornar à pátria para vingar-se, mas acometido por uma febre, morre antes de realizar seu intento. O padecer não purifica nem regenera, apenas sugere a degradação do ser humano vitimizado por seus desejos. A família, como a bíblica, tem a oportunidade de acolher um 
filho perdido na figura de Tomásia, que abandona a casa e foge com o amante. Entretanto, o Barros abstém-se do contato com a moça, difamam-na e fogem com o suposto neto para que ela não tenha contato com o menino, nem possa requerer parte da fortuna da família. Novamente os valores são invertidos em nome do lucro.

A atitude vil de Inocêncio quando cotejada com o procedimento de Tomásia, torna a traição da moça menos torpe. Dessa forma, Camilo sugere que nem sempre as relações extraconjugais são motivo de difamação. A conduta hipócrita do homem perante a vida pode ser muito mais ofensiva.

Para reafirmar quem é a vítima e quem o algoz, Camilo retoma o paralelo com a peça Degolação dos Inocentes ou a "carnificina dos meninos que ameaçavam a dinastia do rei de Jerusalém", e descreve Tomásia entre a família de cristãos novos como uma "menina que se escondia entre as mulheres gordas como uma andorinha entre três peruas" . A delicadeza de Tomásia contrasta com a corpulência e modos desajeitados das burguesas da rua das Cangotas. A imagem que parece remeter a uma presa junto ao predador - ainda mais se levar-se em conta o tema da narrativa - é fortificada pela menção à peça Inês de Castro, moça que é assassinada por poderosos amedrontados diante de seu domínio sobre o príncipe, seu amante.

A associação insinua certa simpatia do autor pela personagem. Assim como Inês, Tomásia seria vítima da ambição de pessoas que, para conservar suas propriedades, precisam sacrificá-la. Como a amante de D. Pedro, Tomásia seria condenada por amar. O que se leva em conta, na visão de Camilo, não são as relações sociais, mas os motivos interiores. Assim, Inocêncio é culpado de adultério por abandonar a esposa e unir-se a uma mulher a quem apenas deseja. Tomásia, por outro lado, é inocentada por amar um homem que the compreende e respeita. Seus atos são ditados por amor, não por desejo. Ela seria tão culpada quanto os primogênitos mortos por Herodes, ou Inês degolada pelos ministros de D. Afonso VI. Tomásia e seu caso com Nicolau contrariam a ordem estabelecida, por isso não pode ser poupada.

Além de servir para insinuar sua visão de mundo, as menções intertextuais prestamse à proposição de uma reforma cultural. O narrador comenta que, no Palácio de Cristal, revezavam-se as peças Pedro Sem e Inês de Castro, "enquanto o progresso não abranger Manuel Mendes Enxúndia, sugerindo, assim, que o português é passadista, nostálgico e, 
nesse andar, desvia os olhos do presente e do futuro. A alusão à peça de António Xavier Ferreira de Azevedo, célebre poeta dramático do século XIX, corrobora a visão do novelista sobre o casamento. Sobre o dramaturgo, o Dicionário Bibliográfico Português:

\begin{abstract}
Destituído de estudos, por isso que além dos rudimentos da instrução primária, apenas possuía o conhecimento medíocre das línguas francesa e espanhola, uma vocação ingênita o levou a compor para o teatro, tornando-se escritor fecundíssimo, e bem aceito ao publico, que aplaudia com entusiasmo as suas produções. Estas passando dos teatros públicos para os particulares, constituíam ainda não ha muitos anos o repertorio dramático das associações de curiosos. Não é que nos seus dramas houvesse originalidade e verossimilhança na contextura das fabulas, disposição e escolha nos caracteres, colorido local, e observância dos costumes nacionais; porém supria todas essas faltas, e as mais que os críticos the notavam com a facilidade de inventar lances e situações de grande efeito teatral, com a vivacidade e rapidez do dialogo; com a eloquência patética dos afetos, e com o interesse vivo e progressivo que sabia derramar por suas composições, ou antes imitações livres das peças francesas e castelhanas, que tomava por modelos, e que ajeitava a seu modo, para lisonjear o gosto e aprovação d'aqueles para quem escrevia. (Silva, 2001, CD ROM)
\end{abstract}

A farsa citada em $O$ sangue é composta por apenas quinze cenas em um ato e tematiza a proposta de casamento de Manuel Mendes Enxúndia a Isabel, sua sobrinha. Viúva, ela agora possui o cabedal que o marido lhe deixou, o que a torna interessante aos olhos do parente. Inconformada, ela pede a seu escudeiro que a auxilie a dissuadir o ancião. Além de não se interessar pelo tio, Isabel já namora outro homem. As falas são repletas de trocadilhos e de insinuações que geram o humor. Veiculam-se provérbios populares e tratase do próprio fazer teatral, já que o marido de Isabel compunha peças. Rebolo, encarregado de armar uma farsa para mudar a intenção de Manuel, parece ser alter ego do escritor, já que revela astúcia e sagacidade de quem conhece as regras sociais. Sua fala final sugere a visão crítica e zombeteira do dramaturgo acerca das relações sociais:

Rebelo: E aqui está Rebelo, por alcunha homem de bem, que prostrado suplica perdão, e profere uma Sentença extraída do Livro das Experiências, folha três, Capítulo das cautelas. "Todo o homem, que chega aos quarenta sem casar, deve passar outros tantos sem o fazer; e depois dos oitenta faça o que quiser. É certo que nem todas as mulheres matam; mas o que é certo, é que todas moem; e aqui está o Senhor Manuel Mendes que o diga: e à vista do exposto. (Azevedo, 1815, p. 32)

Como se pode perceber, o tom de deboche e o tratamento irreverente dado ao casamento suscitavam o riso do público e a simpatia de Camilo, tanto assim que o novelista chegou a adotar o pseudônimo de José Mendes Enxúndia, alegando ser neto de Manuel 
Mendes. Cabe, no entanto, ressaltar que a peça é citada como modelo de literatura atualizada por não repetir as mesmas histórias enraizadas na cultura popular.

Em $O$ sangue, o tema da renovação da cultura portuguesa resvala no tema da educação das mulheres portuguesas. A questão é, no entanto, apresentada de maneira sutil, por meio dos retratos de personagens ou comentários do narrador. Tomásia, por exemplo, é descrita como uma mulher bela e, por conseguinte, um tipo que despreza os estudos "Era a soberana ordem das cousas, raramente desconcertada. Chovia-lhe a natureza dons de infantil formosura, e dava-lhe ao mesmo tempo sequidões esterilizadoras de inteligência". (Branco, 1907, p. 37)

A antítese - chuva e sequidão - sugere que, em uma mulher, beleza e inteligência são opostas e excludentes. Esse retrato da mulher consiste, no entanto, em ironia veemente, já que reflete a concepção preconceituosa das pessoas da época, o que se verifica, sobretudo, em comentários dos pais de Inocêncio. A mãe concebe a leitura como um passatempo: “[...] para as fidalgas que não sabem no que hão de gastar as horas.” (Branco, 1907, p. 37), e o pai " [...] entendia que as quatro operações não the desconvinham e a leitura de uma carta lhe podia ser útil. Daqui em diante, nem ele sabia nem lhe constava que mulheres pudessem aprender coisa proveitosa." (Branco, 1907, p. 38)

Esse conceito parece consistir em uma atitude cautelosa em relação à astúcia feminina na esteira de tantos outros preconceitos contra a mulher. Camilo sugere que a precaução é pertinente afinal a aprendizagem de Tomásia possibilitou-lhe corresponder-se com Costa Guimarães - o que deu pretexto ao marido a abandoná-la - e a cartear-se com Nicolau, apaixonando-se por ele. A instrução afigura-se, assim, uma ameaça ao sistema e, como tal, deve granjear a simpatia do novelista.

A educação intelectual da mulher é exibida como uma arma perigosa, capaz de incitar à rebelião. Educar mulheres, restringindo-lhes às habilidade musicais e manuais é conveniente, pois elas se tornam mais facilmente manipuláveis.

Cabe salientar que o tema associa-se a outro, que constitui uma contenda antiga do novelista. $\mathrm{O}$ fato de em Portugal não se valorizar a instrução, o homem de espírito, mas celebrizarem-se os mesquinhos e ignorantes com dinheiro e poder sempre incomodou Camilo. Sua pena frequentemente era usada em prol de censurar e ridicularizar os 
responsáveis pela situação. A crítica abarca, portanto, até mesmo o governo que não incentiva o ensino e menospreza os homens de letras que não servirem a seus propósitos. ${ }^{48}$

Com base nesse pressuposto, Camilo, subjacente a um primeiro plano no qual veicula a visão dominante na época, defende a valorização das letras a fim de capacitar o povo a ter meios para refletir sobre seu papel e, com isso, tornar-se hábil a desvincular-se das ideias cristalizadas. Somente pelo abandono do saudosismo, o povo poderia reconstruir o país.

“ Eu não quero que ela seja bruta!” (Branco, 1907, p. 38) A exclamação de Inocêncio gera, por um lado, a indignação de sua mãe e tias e, por outro, o súbito interesse de Tomásia pelos estudos: "Ora vejam agora como a serpente da vaidade mordeu de assalto o amor próprio da menina." (Branco, 1907, p. 38)

Retoma-se, assim, o tema recorrente em $O$ sangue, a psicologia feminina. Em toda a novela, há frequentes comentários sobre o comportamento da mulher. Muitas vezes em tom chocarreiro, o narrador parece menosprezar o modo de ser feminino; no entanto, trata-se de fina ironia por meio da qual se sugere a complexidade desse ser que atordoa o homem.

Com esse intuito, o novelista traça o perfil da mulher, cuja característica mais marcante lhe parece ser a vaidade que deriva do exacerbado amor-próprio. Vários situações remetem a esse traço da personalidade feminina: para ostentar sua beleza que Tomásia deseja apresentar-se em teatros, bailes e jardins como mulher casada. Rosinha recusa-se a chorar, quando desprezada por Inocêncio, para não rebaixar-se. Jacqueline livra-se das cartas de Gervásio e Tomásia para não despertar sentimentos em Inocêncio que desvaneçam sua imagem diante dele.

O desejo de ser cortejada e adorada é o que atrai Tomásia em Nicolau, reencontrar o rapaz dá-lhe novo alento:

Levantou-se. Sentiu-se leve, nova, reflorescida ao calor da juventude, desejosa de se mirar no espelho, a cuidar que via flores, a imaginar-se solteira, desligada de juramentos que a maniatavam, a conhecer que a alma batia as asas para voar longe, a gozar-se do prazer de estar sozinha, de cismar sozinha, de não ter ninguém que soubesse traduzir-lhe nos olhos o doce alvoroço do coração. (Branco, 1907, p. 159)

\footnotetext{
${ }^{48}$ Sobre esta contenda escrevi um artigo "Portugal sob a pena de Camilo" a ser publicado pela revista Vínculo.
} 
Também o amor-próprio incita Tomásia a pensar em aborto para não dar a prova de sua desonra. Nicolau não a podia compreender, afinal:

\begin{abstract}
não pudera ainda confrontar duas mulheres amadas, quatro, vinte mulheres sublimes, infames, castas no vício, almas dissolutas em invólucro imaculado, esmagando a força da consciência própria e acovardadas diante da maledicência de uma vizinha; arrojando-se afrontadoras contra a sociedade e sucumbindo imbeles e pueris à condenação de si mesmas; temendo a justiça do inferno nas venialidades e desprezando o juízo da providência nos crimes enormes; rindo no cairel do abismo e chorando se lhe empecem dissabores passageiros.[...] Então quem era ela afinal? Mulher. (Branco, 1907, p. 180 e 181)
\end{abstract}

$\mathrm{O}$ excerto evidencia o amor-próprio ou a vaidade como fulcro da alma feminina, Camilo não considera contraditório o desejo de Tomásia de livrar-se do filho para assegurar sua honra, julga apenas característico do ser feminino, em particular, e do ser humano, em geral, como se verifica pela descrição que faz de Nicolau.

"Urgia que os acadêmicos se anafassem e lustrassem a grenha como cozinheira em domingo, para que as ideias de Goettingue, entrajadas de lantejoulas, se enamorassem de rapazes tão de sua feição e peso." (Branco, 1907, p. 155 e 156) Misto de ostentação e desejo de afetar dignidade, o modo como os rapazes da época se arrumavam para os namoros é apresentado de maneira a evidenciar-lhes o ridículo, e acentuar-lhes a vaidade.

O almanaque Goettingue, publicado de 1776 a 1812, definia a moda de então, trazia, como muitos da época, gravuras com modelos de vestidos, genealogia de casas reais, além de imagens de pontos turísticos, histórias para entretenimento e tabela de pesos e medidas. A menção à peça é metonímia para a ideologia da época que gira em torno da importância das aparências.

Como se verifica, o novelista parte da análise do gênero feminino para conquistar a simpatia do público e poder, então, despender críticas ao comportamento do homem da época. Assim, a beleza de Tomásia é comparada a de entidades mitológicas com fins críticos: "A estátua decerto tinha vida bastante para valer em tresdobro da Galateia e das notórias Vênus de inocente mármore." (Branco, 1907, p. 39) A menção à Galateia é significativa, pois refere-se a uma mulher vítima do amor de um ciclope que lhe assassina o amante, sem o qual ela não pode ser feliz. Em $O$ sangue, também a protagonista será vítima de uma ideologia que impossibilitará a realização de seus sonhos de mãe. O paralelo entre a figura mitológica e a personagem reitera o retrato da família das Cangostas como torpe e 
indigna, e de Tomásia, como um ser vitimizado pela vilania daquelas pessoas. Essa caracterização reitera a aversão de Camilo por pessoas que afetam comportamentos incoerentes com a moral que intimamente professam. A hipocrisia denota a cisão do ser, subordinado às convenções sociais. O romântico é consciente de que o homem fragmentouse, perdeu a unidade primitiva e essa cisão o atormenta. Como todo romântico, Camilo "tuvo sed de infinito y aspiro a uma posesión total, em que nada estuviera negado, em que El mismo fuera capaz de no negarse a nada. (Béguin, 1993, p. 207) ${ }^{49}$

Como vítima de constantes barreiras à liberdade de expressão, o ser feminino tem que criar fantasias para preservar-se em uma sociedade patriarcal. Assim, seu caráter sonhador e lírico é estimulado como meio de evasão dos problemas. Da mesma forma que o romântico busca escapar de uma realidade opressora pela fantasia, a mulher lida com seus problemas, criando sonhos que a aliviem do peso da vida diária, sem prazer, nem realizações pessoais. Custódia, Florência, Sebastiana e Tomásia, esposa de Gervásio, entregam-se à religião e ao misticismo, Tomásia, às promessas de amor de Nicolau.

Outro aspecto da psicologia feminina incitado pelos obstáculos oferecidos pelo meio é a dissimulação. Tomásia, diante de problemas, pensa em fingir desmaios ou inventar mentiras para sair de situações embaraçosas. Para livrar-se de suspeitas e continuar encontrando-se furtivamente com Nicolau, a moça aparentemente cede às exigências do padrinho, mas exerce, dissimuladamente, sua liberdade. Sua carta a Inocêncio é tão resignada que leva Gervásio a exclamar: “- Ó menina, isto não é da tua cachimônia! Parece copiado do Feliz Independente que tua mãe me leu no Douro há mais de vinte anos! Tu já leste a história do Feliz Independente?!" (Branco, 1907, p.171)

O texto de Padre Almeida é considerado aqui simulacro de emoções. O humor amargo destrói possibilidades de escape para o grande problema do ser humano: o descontrole emocional, o homem é descrito como um ser condenado a sofrer por não conseguir controlar suas emoções.

A dissimulação não é suficiente, entretanto, para livrar uma pessoa sensível da desforra da sociedade a quem ousa afrontar-lhe. Somente quem abandona seus sentimentos em prol do lucro obtém o aval da sociedade.

\footnotetext{
${ }^{49} \mathrm{O}$ fragmento refere-se a Hölderlin, mas consideramos apropriado associá-lo à visão de Camilo.
} 
Com essa ideia, Camilo encerra sua narrativa. O tom é pessimista e desiludido. Antes de morrer, Gervásio aconselha o suposto neto a ter cuidado para não empobrecer, como Pedro Sem. Mencionada pela segunda vez em $O$ sangue, a narrativa é parte do imaginário coletivo português e funciona como um alerta a que se evite a soberba, já que Pedro Sem era rico comerciante e onzeneiro que empobrece em decorrência de um castigo divino quando ousa afrontar Deus, dizendo que nem o criador seria capaz de torná-lo pobre. Camilo inverte o significado da história de boa ensinança. Diferente do destino trágico, que incentiva, por compaixão e identificação, a evitar-se a soberba e o desrespeito a Deus, a novela apresenta a impunidade aos poderosos decorrente das prerrogativas do dinheiro. Pedro Barros, diferente da personagem homônima, pode afrontar a moral, abandonar seus pais à solidão e à loucura para preservar a herança dos Barros. Ele não é Pedro "Sem", tem um sobrenome que lhe assegure posição e privilégios.

Diante desse desfecho, o narrador-autor e Antônio Joaquim ponderam:

[...] a mim o que mais me convinha era saber dar à tua história um título.

- Eu chamava-lhe o SANGUE.

$[\ldots]$

- o sangue, que tem ares de título filosófico e assim com presunções de tese.

$[\ldots]$

- Mas, sem embargo do título, qual achas tu que seja a moralidade do romance?

- A moralidade é clara.

- A expiação de Tomásia, não é verdade?

- Homem, eu nisto de expiações não tenho ainda formado perfeito juízo. Conheço muitas famílias que me autorizam a supor que a expiação é um castigo da tolice e não do vício.

- Homem, essa! Vão lá escrever o absurdo num livro que tem de melhorar os costumes e usos...

$[\ldots]$

- Mas, - tornei eu farejando a moralidade do romance - não posso eu dizer que o pai de Pedro de Barros era...?

- Era o que as núpcias demonstravam, como diz a lei romana. Era Inocêncio. O sangue de Pedro vinha a ser o dinheiro de Inocêncio. Lá está o axioma que diz: $O$ dinheiro é sangue. Um filho só pode ser filho de quem é seu pai, quando não herda oitenta contos de outro que foi casado com sua mãe. (Branco, 1907, p. 253254)

Trata-se de uma história que enquanto suscita o riso, destila o fel. O riso não impõe nenhuma interdição, nenhuma restrição. Jamais o poder, a violência, a autoridade empregam a linguagem do riso.” (Bakhtin, 2010, p.79). O humor desestabelece o temível e abre a possibilidade de outras leituras de mundo. Muitos são os modos de ver a realidade, uma órfã entrega-se a fantasias amorosas; mulheres simplórias são guiadas por superstições e crendices; um empreendedor preserva seus bens às custas do sofrimento alheio. A ênfase 
é dada à história de um "morto-vivo", um romântico sonhador que ao dedicar-se a cortejar sua mulher fatal e é condenado por isso, pois na sociedade burguesa, não há lugar para o despojamento.

\section{IV.2 O teatro vertendo sangue português}

Pela peça $O$ sangue, Fernando Gomes recupera a novela homônima de Camilo Castelo Branco, atualizando-a e enfatizando temas que apenas haviam sido sugeridos no paradigma.

O diálogo da peça com o modelo apresenta vários pontos de interesse. Ressalta-se aqui o valor documental do texto para a análise tanto da mentalidade do português dos séculos XIX e XXI, quanto do ser humano universal diante das opções oferecidas pela vida. $\mathrm{O}$ intrigante trabalho de Fernando Gomes convida à reflexão por meio do riso; a atmosfera operática encanta, mas não encobre sério questionamento sobre as atitudes humanas.

De acordo com Fialho de Almeida, na obra de Camilo

[...] a natureza é imortal, e a sociedade um montão de paixões lascivas e grosseiras. Toda a atividade tem por móvel único o apetite. O ser é improgressivo, e a humanidade pior, de século para século. É ver como os bons tem nos seus romances, constantemente um lugar de sacrifício. Os seus tipos honestos quase todos claudicam, e o mesmo amor que ele diviniza, a quando puro, contrariam-no, e só toma curso paixão sublime, nos exasperos do estado irregular, ou seja a mancebia, ou seja o adultério. [...] Jamais em livros portugueses, se viu alma assim feroz e vingativa, interpretando o espetáculo do mundo e o frenesi das gentes, em sensações mais violentas, e em crises de escárnio mais esmagadoras. (Almeida, 1941, p. 39-40)

Essa concepção parece ser o foco do interesse de Fernando Gomes em retomar a narrativa do escritor oitocentista. Seu riso, ampliando o de Camilo, é perturbador, desinquietante, capaz de afastar a resignação e o conformismo.

Esse [o riso] liberta não apenas da censura exterior, mas antes de mais nada do grande censor interior, do medo do sagrado, da interdição autoritária, do passado, do poder, medo ancorado no espírito humano há milhares de anos [...] Abrir os olhos para o novo e o futuro [...] O riso revelou de maneira nova o mundo no seu aspecto mais alegre e lúcido. (Bakhtin, 2010, p. 81)

Assim como o novelista português, o dramaturgo enfoca o homem português, procurando nele o que há de universal. No entanto, seu texto não fecha os olhos para o que, 
em nome do progresso, ocorre no país e no mundo. Nesse sentido, a caricatura lhe é arma poderosa e necessária para compor uma comédia portuguesa.

Em $O$ sangue, Fernando Gomes colhe o melhor da narrativa de Camilo, atualiza-a e amplia-lhe o significado. A peça inicia-se estabelecendo um diálogo com $O$ fantasma da ópera, a qual substitui a menção que Camilo faz à peça Degolação dos Inocentes. Em Camilo, o paradigma aborda como tema o episódio em que Herodes, visando a livrar-se da ameaça de ser sucedido por um homem que, no momento, é apenas um recém-nascido da casa de Davi, manda degolar todos os primogênitos de tenra idade. $\mathrm{O}$ assunto agrada o público a julgar pelas vezes que o novelista cita a peça em vários de seus livros e pelo fato de que na época era comum encenarem-se autos que narravam o nascimento de Cristo para celebrar o Natal, incluindo o episódio da degolação dos primogênitos. O público estaria, portanto, acostumado a assistir à peça, bem como apreciá-la com respeito religioso. Não é de estranhar, portanto, que as personagens camilianas, uma família de cristãos novos, estejam diante da peça pela oitava vez. A ironia está em colocar judeus, que tiveram que abandonar seus princípios religiosos para assumirem-se cristãos, assistindo à tentativa de Herodes de exterminar aquele que deu origem ao Cristianismo. Talvez seja essa uma forma de Camilo retomar o tema do preconceito contra os judeus. Em um texto publicado em jornal, o escritor, destemidamente, afrontou a prevenção contra semitas da seguinte maneira:

O povo não os odiava [aos judeus] porque se abstinham de toucinho e escarneciam as imagens. As imagens e o toucinho eram pretextos para refolgar uma vingança retraída através de séculos e à proporção que se sentia humilhado pela sua riqueza e inteligência. $\mathrm{O}$ castigo era urgente e indeclinável.

[...] Pela audácia gananciosa, quer comercial, quer política de alguns chamados "judeus" que aí subsistem no reino, calculem como, ao cabo de cem anos, os seus avoengos teriam - a nós, calaceiros e vadios - absorvido a autonomia intelectual e a propriedade, se D. Manuel e o filho não lhes tolhessem o cérebro criador e o braço laborioso! A esta hora, o nosso, tão nosso, tão querido Portugal, jardim da Europa, e vasta cripta sagrada de tanta ossada de santos autênticos, seria o reino de Israel que o imperador Juliano, o Apóstata, não pudera reorganizar. (Branco, 1993 , p. 600 a 602)

Contudo, no texto em questão, a censura não se evidencia, é apenas sugerida pelo episódio citado e pela frequente alusão à família como "cristãos novos". Essas personagens parecem incomodar Camilo, sobretudo, por terem-se dissipado de suas crenças e valores primitivos em prol do lucro. 
Fernando Gomes, embora não mencione a Degolação dos Inocentes, explora a visão do português sobre os judeus, divulgando vários preconceitos pela boca de diferentes personagens. A primeira referência ao tema é ambígua:

[Tomásia dá seu parecer sobre casar-se com Inocêncio a pedido do padrinho] TOMASINHA: A madrinha bem sabe minha vontade... mas eu sou órfã... e venho doutra classe social... não me corre nas veias sangue judeu... e sou pobre... GERVÁSIO: Qual quê?! Fica sabendo que mesmo que ele não te queira, metade do que eu tenho há-de ser teu; essa fortuna, já nem a justiça nem o Bersabu ta tiram! Quanto ao nosso sangue, ainda não te corre nas veias... mas há-de correr! [...](Gomes, p. 17)

O sangue judeu seria, na visão da personagem, transmissível, como se o intenso convívio entre pessoas da raça fosse capaz de alterar a índole da pessoa, adequando-a aos moldes morais e mesmo fisiológicos da raça.

A segunda menção ao "sangue judeu" vem impregnada de ironia, já que Gervásio se dirige a Deus, agradecido por ter seu dinheiro salvo:

GERVÁSIO: Eu vos agradeço meu Deus! Sou um homem feliz!... Não posso ser mais feliz!... O meu filho vai dar o sagrado nó com a minha afilhada... que já era minha filha adoptiva... e que muito em breve também vai passar a ser ... a minha nora... a futura mãe dos meus futuros netos... herdeiros absolutos da fortuna que os Barros acumularam ao longo dos anos! Eu sei que sou judeu, e vós sabeis que eu sou e que me orgulho do meu sangue de judeu... mas não tenho vergonha de me ajoelhar perante vós... porque agora... eu já posso morrer com a consciência tranquila... já posso morrer e descansar em paz... porque o dinheiro dos Barros... vai continuar na família dos Barros!!! (Gomes, p. 25)

Gervásio louva a Deus pelo casamento do filho com a afilhada, já que esta união possibilitará que seu dinheiro permaneça intacto, inacessível a pessoas de outras famílias. Nesse momento, dá ênfase a ter sangue judeu e declara poder morrer em paz, com a "consciência tranquila" por ter preservado sua fortuna. A imagem do judeu ganancioso que valoriza o lucro acima de tudo é, assim, caricaturizada e vilipendiada pelo riso.

A ridicularização associa-se ao destronamento e à renovação. O motivo de profusão dos bens materiais sempre foi tema de folguedos populares e, por extensão, do carnaval. Gomes promove, pelo humor, a carnavalização de um símbolo de poder.

Algumas cenas à frente, o tema volta a ser retratado; desta vez, é motivo de insatisfação de Tomásia diante do caráter extremamente econômico do marido. A ama aconselha-a a relegar o assunto, já que quando a família morrer, a moça terá todo o dinheiro economizado para gastar como bem entender. Essa é uma forma de contrapor o apreço a carpe diem às restrições impostas pela ambição exacerbada. 
Por fim, a alusão à raça é recuperada, com deboche, por Nicolau que ridiculariza a família por não saber contar há quantos meses Tomásia está grávida: "São mesmo judeus! Só sabem fazer contas ao dinheiro!" (Gomes, p. 53)

O verdadeiro riso, ambivalente e universal, não recusa o sério, ele purifica-o completa-o. Purifica-o do dogmatismo, do caráter unilateral, da esclerose, do fanatismo e do espírito categórico, dos elementos de medo ou intimidação, do didatismo, da ingenuidade e das ilusões, de uma nefasta fixação sobre um plano único, do esgotamento estúpido. O riso impede que o sério se fixe e se isole da integridade inacabada da existência cotidiana. (Bakhtin, 2010, p. 105)

Embora o tom seja de desprezo, a personagem parece apresentar o despeito a que Camilo se refere no texto transcrito, já que cita a habilidade contábil dos semitas.

Como se pode verificar, Gomes não retoma a peça de tema judaico; no entanto, não abandona o assunto, revelando sua concepção acerca da matéria. O paradigma eleito pelo dramaturgo é $O$ fantasma da Ópera, a peça mais vista de todos os tempos, que narra a história de Erik, um homem cuja identidade deve ser mascarada em decorrência de um defeito físico. Em uma tentativa desesperada de relacionar-se com o mundo e de revelar seu talento musical, o protagonista elege como protegida Christine, visando a torná-la uma diva da ópera. Ele inicia seu intento, assassinando Carlotta, a protagonista do espetáculo. A partir de então, Erik dá lições à Christine, sem que ela o veja, por isso é considerado por ela o anjo da música. Apresentando-se, ela conquista o público e a atenção especial do patrocinador do teatro, o visconde Raoul de Chagny. Erik, procurando afastar a moça de Raoul, a rapta e a leva ao subterrâneo do teatro, onde ele vive. O lugar é frio e sombrio, ali Christine retira a máscara de seu anjo e reconhece tratar-se de um homem deformado, o fantasma que assola o teatro. O tutor não está preparado para afastar-se de sua protegida. Para retê-la, ele força Christine a prometer voltar ao subterrâneo voluntariamente e não amar outro homem a não ser ele. A moça entra em conflito pelo embate entre seu amor por Raoul e a atração por Erik que representa o apoio à sua carreira. Contudo a face deformada de seu tutor faz com que ela queira prescindir de sua carreira e casar-se com Raoul. Erik descobre os planos da moça e a leva para seu mundo, Raoul os persegue e, consciente de que seus planos não podem realizar-se, Erik apreende o rapaz e volta para Christine, beija-a na testa e chora por não ter sido repudiado por ela. Diante das lágrimas da moça e de sua compaixão por ele, o fantasma enternece-se, e ofereça a ela um anel e a liberdade para casar-se com o namorado. Erik liberta o visconde e pede a Christine que lhe devolva o anel 
quando souber que ele morreu. Anos depois, um corpo é encontrado no subterrâneo da Ópera de Paris com um anel de ouro no dedo. Na adaptação para o palco o desfecho modifica-se: Erik enlouquece e morre diante da impossibilidade de realizar seu amor.

A ênfase dada ao embate entre o grotesco e o sublime, o subterrâneo e o terreno, a possibilidade de ascensão individual ou a entrega a uma vida pacata e abastada é fulcral no romance de Leroux. Essa dualidade parece ter sido o foco de interesse de Fernando Gomes pela peça. As escolhas que derivam em renúncias e geram resignações fazem parte do cotidiano do homem; observador atento do comportamento humano, o dramaturgo vale-se desse tema tão relevante. As personagens da peça $O$ sangue também tem que fazer escolhas e são essas opções que lhes determinam o caráter.

Já na primeira cena do trabalho de Gomes, Nicolau é associado a Erik. A acepção de um fantasma é perfeita para a caracterização do namorado de Tomásia. Embora não se trate de um espectro, ele é um vulto que assombra. Em Camilo, Nicolau suscita a curiosidade do novelista por "viver morto", isto porque depois de pensar ter matado o próprio filho, a personagem alienar-se da vida real e viver em constante alucinação.

Como o monstro de Leroux, a personagem gomesiana não se insere no meio. $\mathrm{O}$ motivo de ser repelente ao grupo não se relaciona à aparência física, mas ao fato de ser filho natural e ter uma visão de mundo que lhe impele ao isolamento. Nicolau é filho de um padre e de uma senhora simples. Para que não soubesse de sua origem ilegítima e degenerada, foi criado como órfão; somente após a morte dos que o educaram vem a saber que se tratavam de seus verdadeiros pais. Assim, torna-se um homem dramático, romântico, adepto a conceber a vida como uma sucessão de fatalidades. Por isso, é um misantropo, ridicularizado em seus excessos por seu único amigo.

Diferente do dandy camiliano, fidalgo de Caminha, a personagem de Fernando Gomes não tem o estilo pomposo de galanteador romântico. Não escreve cartas a Tomásia, conversa com ela em termos simples, mas conquista por ser semelhante a ela. Seu estilo não é afetado, nem artificial; pelo contrário, ele retoma quadrinhas, bem ao gosto popular, para revelar seus sentimentos. A linguagem popular desempenha um papel estilístico importante. Exterior ao domínio do instituído como norma, ela apresenta caráter próprio que contribui para criar a atmosfera de liberdade em que superior e inferior nivelam-se pelo tom familiar. 
Nesse sentido, a união do casal é mais verossímil que o da narrativa camiliana. Seria difícil conceber que o fidalgo descrito pelo novelista permanecesse idealizando Tomásia depois de deparar-se com as cartas insossas da moça que apenas parafraseavam com muita dificuldade as suas. $\mathrm{O}$ mais coerente seria repetir-se o que ocorreu com o primeiro rapaz com que ela se correspondeu, o qual zombou das cartas dela entre seus amigos.

O Nicolau gomesiano não é um intelectual; além disso, ele não tem que se preocupar com nome ou posição social, seu dinheiro provém de um padre que tinha uma amante. Ele tem, como Erik, uma mácula a esconder da sociedade. A carência do amor paterno torná-lo-ia mais suscetível a entregar-se às paixões idealizadas. A escolha de Nicolau por Tomásia parece óbvia, trata-se de um rapaz que se encanta pela beleza sem par de uma jovem moça de olhos tristes. Quanto ao súbito interesse da moça pelo rapaz, explica-se pela carência dela em relação a um namorado que the aprecie como é, sem ridicularizá-la, nem persegui-la com ciúmes exagerados. O empecilho de ser ela casada é facilmente contornável, afinal, o marido a abandona. Com base nessas alterações, algumas cenas da novela são suprimidas na peça. Não faria sentido, por exemplo, recuperar o baile que Nicolau oferece à sociedade portuense para desafrontar Tomásia das injúrias que lhes atribuíram quando esta abandonou o marido. Assim, nem a sociedade incrimina Tomásia, nem o novo marido lhe oferece um baile como pretexto para enfatizar a hipocrisia social.

O interesse de Gomes não parece estar em castigar a hipocrisia social, mas estudar o comportamento humano em sociedade. Daí a seleção de $O$ fantasma da ópera para um diálogo intertextual. Por outro lado, é possível, vislumbrar ainda outro objetivo menos relevante, mas pertinente, para a seleção do livro de Leroux, trata-se de apontar uma crítica sutil à admiração do português pelo elemento estrangeiro. Lotam-se as grandes casas de teatro nas quais se apresentam peças importadas, enquanto o texto nacional limita-se a espaços menores e público restrito. Assim que Nicolau assiste aO fantasma da ópera umas quatro ou cinco vezes, "privilégio de quem tem dinheiro para correr mundo". (Gomes, p. 1) Também Camilo ocupou-se do tema pela menção a Manuel Mendes Enxúndia". Corrobora nossa hipótese o comentário apresentado no site do Teatro Esfera:

Este Espectáculo foi feito sem apoio do Ministério da Cultura e contando com o trabalho gratuito de todos os criadores e colegas.

Temos esperança que esta seja a excepção que confirma a regra, para que o futuro do Teatro em Portugal sofra um processo de dignificação, que passa pela criação (com meios) de infra-estruturas, pelo aparecimento de novos projectos (estáveis e com continuidade) e também pela elaboração de um estatuto profissional para 
todos os que trabalham nesta nobre arte de representar. (http://www.teatroesfera.com/sangue/sangue.htm)

Trata-se, portanto, de uma problematização do teatro, como forma de enfatizar o que é nacional. O jogo entre temas e tempos é frequente na obra gomesiana. A estrutura de $O$ sangue exemplifica seus procedimentos. No início do primeiro ato, o amor de Nicolau por Tomásia é apresentado, mas somente no segundo ato a cena terá continuidade e os dois irão encontrar-se. As demais cenas do primeiro ato sintetizam, em flash back, a vida de Tomásia desde a troca de cartas com Guimarães até a viagem de seu marido Inocêncio ao Pará em busca de distanciar-se da esposa.

A peça enfoca, na primeira parte, várias personagens femininas como seres imbuídos de uma sagacidade e astúcia capazes de captar as incongruências de seu meio, bem como simular comportamentos que agradem o homem, já que este é quem comanda a sociedade. A Tomásia gomesiana amplia a índole dissimulada da personagem de Camilo quando declara que Guimarães sugere casamento em uma carta apenas galanteadora, enganando a própria ama, uma beata parva que repete orações e crendices servilmente.

Também o padrinho é iludido pelos ardis de Tomásia. Ao ser flagrada escrevendo uma carta a Guimarães, ela afirma compor o texto para Inocêncio. Não só o fingimento da personagem é ampliado, como também se acrescentam características a ela. Sua lua-de-mel frustra-lhe não apenas pelo ciúme exagerado do esposo, mas, antes de tudo, por não ter saído de Portugal. Tomásia idealizara uma viagem a outros países da Europa e questiona-se de que vale ter dinheiro se não pode usufruir das vantagens que este pode proporcionar. Declara ainda sentir-se envergonhada de dizer que passou a lua-de-mel em Caminha. Bem diferente da moça, a personagem camiliana é submissa, não tem sonhos, nem decepções quanto à vida pacata oferecida pelo marido.

A impetuosidade de Tomásia amplia-se ao afrontar o marido, patenteando que "uma mulher gosta de ser admirada" (Gomes, p. 30) e que o marido é ridículo em querer impedir que os homens olhem para ela, sugere-lhe, em tom de zombaria, que os cegue ou estabeleça uma lei que os proíba de admira-lhe. O marido submete-se a ela, jurando-lhe amor, ela, entretanto, confidencia à ama que se arrepende de ter-se casado.

Outras personagens femininas intrincadas são Sebastiana e Sarita Star. Aquela, no paradigma, não passa de uma beata, repleta de terrores e tolices. Na peça, entretanto, é 
mulher atenta aos comportamentos dos que a rodeiam e alerta às suas impropriedades e incongruências. Por isso, desconfia da súbita felicidade de Tomásia no momento em que esta se corresponde com Guimarães; tem falas ambivalentes e cômicas como quando declara que S. Gonçalo de Amarante é mais prestativo às velhas que lhe pedem algo, agarrando-lhe o bastão; ou ao declarar que ficou de "Freitas" por seu defunto já que "freitar" significa "aproveitar a terra para dar frutos". Alerta, nota que Inocêncio se comporta diferente na época em que este tem namoros com meninas da vizinhança e aprova a decisão do cunhado de afastar o moço da redondeza quando se trata de fazê-lo ponderar acerca do casamento com Tomásia.

É dona de comentários sarcásticos como ao responder à irmã, aflita pelo filho fora de casa, que mal fora se não acontecesse nada a Inocêncio e Tomásia em sua lua-de-mel; ou ao zombar de Florência, dizendo-lhe que apanhar o buquê da noiva é fácil, difícil é agarrar um homem. Por isso é considerada pela irmã mais parecida com um homem do que com uma mulher. Esse comentário não a prostra, mas incentiva-a a deixar claro que a irmã não tem mais que a saia para mostrar sua feminilidade e que sabe ser difamada pelas irmãs quando ausente.

Ridicularizando os repetidos chiliques de sua irmã Tomásia, dessacraliza a mulher frágil. Por fim, a gravidez de Tomásia não lhe passa despercebida.

Além de astuta, Sebastiana é alérgica aos mortos e espirra quando se aproxima de um cadáver. Esse dom tem efeito cômico, e sugere que a vivacidade de uma mulher alerta é incompatível com a inação e indiferença de um morto. O humor decorre da exaltação da deformidade, do grotesco e dá leveza às imagens mais aterrorizantes, tornando-as compreensíveis e familiares.

Seu papel dilata-se e parece tornar-se alter ego do dramaturgo, quando se consideram falas polissêmicas e seus comentários metateatrais que evidenciam a autoironia do autor. Assim, ela sugere que as personagens em determinada cena, apenas "debitam texto"; em outras, que há personagens repetitivas. Há momento em que alerta para o fato de uma personagem não ter percebido que uma cena já passou há muito tempo e quem a retoma está desatualizado com o andar da peça. Essa auto-análise bem-humorada é recorrente nos textos gomesianos e parece sugerir o caráter atento do dramaturgo ao papel do teatro. 
Outra personagem feminina destacada é Sarita Star, mulher que manipula dois homens ao mesmo tempo. Inocêncio de cujos recursos se vale para sustentar-se e atrair um amante a quem jura amor e sujeita a seus caprichos.

$\mathrm{O}$ segundo ato retoma $O$ fantasma da ópera. Uma paráfrase resumitiva faz-se necessária para a contextualização dos dados a serem interpretados. No momento em que o Fantasma derruba o candelabro sobre o público. É diante do grito de susto da esposa, que Gervásio derruba a coxa de carneiro que ia comer. Aproveitando a oportunidade, Nicolau aproxima-se da família para restituir ao patriarca o petisco. Sebastiana reprova a cena que poderia ter sido mais impressionante se tivesse matado mais que dois figurantes. O grotesco é motivo de humor. A família sai para ir ao banheiro e restam apenas Nicolau e Tomásia no camarote. A primeira impressão que revelam ter um do outro é a semelhança dos olhos tristes. Em seguida, o rapaz declara seu amor à moça. Tomásia rejeita-o, pedindo-lhe silêncio e declarando já ter sofrido muito. Nicolau aproveita para falar dos próprios sofrimentos como filho natural.

A confidência de Nicolau parece equivaler ao momento em que Erik se desmascara diante de Christine e, em lágrimas, beija-lhe a testa. Do mesmo modo com que a personagem de Leroux simpatiza com o sofrimento do moço e passa a ver nele um homem sensível e não um monstro assustador, Tomásia, à frente do despojamento de Nicolau, comove-se e percebe ter encontrado um par. Ele não é como Inocêncio, um homem de classe superior, nem tem sangue diferente do dela. Ela não precisa adequar-se a ele; seu sangue não precisa passar por uma metamorfose para moldar-se ao dele. São somente homem e mulher, livres de toda carga que a sociedade impõe aos que precisam preservar determinada reputação na opinião pública.

A família retorna e Tomásia, com lágrimas nos olhos, afirma desejar ver o final do espetáculo "Quem aguentou até aqui... aguenta até o fim... seja ele qual for." (Gomes, p. 43). A rubrica anuncia a paixão do casal e a ansiedade do público por verem-nos intimamente juntos.

Importa ressaltar que embora as rubricas, nos textos de Gomes, costumam ser muito reduzidas, já que ele é encenador de suas peças, em $O$ sangue, há comentários mais frequentes, em tom que recupera técnicas utilizadas por Camilo. Segue exemplo do procedimento: 
E pronto! Tomasinha e Nicolau já estão completamente perdidos um pelo outro! E o público já só anseia vê-los...

na cena de sexo!

Vamos agora mudar de cena e surpreender o público com... CABARET!!!

Inocêncio está no quarto de hotel. Olha para o relógio. Está nervoso porque aguarda a chegada duma artista de cabaret. O público não sabe... Ouve-se a campainha da porta. Ele levanta-se para se mirar rapidamente num espelho. Poderá por um spray na boca, não vá estar com mau hálito! Vai finalmente para abrir a porta, mas ela entra, plena de salero! Vê-se a légua que é espanhola. Traz uma mala, de onde irá tirar os "adereços" necessários ao "número" que vai fazer em privado. Na mala poderá ou não ler-se "Sarita Star" - "Spanish Private Dancer". Fala em espanhol, Inocêncio fala em português, tentando fazer-se entender pela beldade do país vizinho. (Gomes, p. 43)

A introdução de personagens em tom de conversa, por meio de comentários como "não vá estar com mau hálito" parece recuperar o expediente camiliano de introduzir o leitor em suas narrativas e conversar sobre o próprio processo narrativo em tom bemhumorado. A problematização do próprio fazer narrativo / dramático sugere o intuito de romper com papéis pré-estabelecidos. Trata-se de um convite a olhar o texto, como reflexo da realidade. Estabelece-se pelo humor e pelo diálogo um incentivo à recriação do que era instituído e engessado. Gomes revela, assim, estar atento às grandes qualidades do texto de Camilo e não querer ficar aquém dele.

A cena enunciada pela rubrica acima apresenta Inocêncio jurando amor e fidelidade e uma dançarina profissional. Isso ocorre, como se vai saber por Tomásia, na cena posterior, dois meses depois da partida do rapaz. Em Gomes, Inocêncio não vai à França e Inglaterra, encontra Sarita no Brasil e fica no país enamorado dela, apenas anuncia ao pai a pretensão de visitar o México.

Quando Tomásia deixa os padrinhos, prometendo-lhes escrever uma carta ao marido na tentativa de sensibilizar-lhe, uma rubrica enuncia a próxima cena com humor e problematizando o fazer teatral:

Tomasinha entra no seu quarto. O público só percebe que lá está também Nicolau, no momento em que ele responde (Se fosse uma comédia de boulevard, ele surgiria do roupeiro, da varanda ou de baixo da cama; todo nu, é claro e segurando na mão a roupa com que taparia ou não as "partes baixas", Neste "melodrama"... ainda não sei de onde ele aparecerá! A ideia do "todo nu" mantém-se...) Tomasinha entra apreensiva. Estava muito bem, mas aquela chamada do Padrinho por causa da carta caiu-lhe muito mal e veio fazer-lhe lembrar que é uma grandessíssima pecadora! Com este espírito de remorso primeira do diálogo, após o que se entregam às mais lindas fantasias de amor! (Gomes, p. 46) 
Como se verifica, o tom de ironia e deboche apresenta-se também em comentários digressivos ao longo das rubricas, Gomes incorpora procedimentos camilianos com maestria. Neste tom, paralelamente ao romance de Tomásia e Nicolau, é retratado o caso entre Inocêncio e Sarita Star. No paradigma, o filho dos Barros trava relacionamento com uma francesa Jacqueline Beaulieu de Rastingnac; para ele, vítima de um sedutor que a raptara no chateau de seus pais, fidalgos picardos de primeira raça, mas, na verdade, antiga costureira e comensal de estudantes no Quartier Latin. Gomes transforma a personagem em uma portuguesa que vive no Brasil e se faz passar por espanhola. Em rubrica, comenta: “[...] Sarita Star (que afinal é falsa espanhola! Ou seja, é uma portuguesa que vive de expedientes no Brasil... e um dos expedientes é fazer-se passar por espanhola! Camilo havia de gostar desta ideia!). (Gomes, p. 48) O diálogo com o leitor é evidente, além disso, reiteram-se as digressões em torno da construção do texto. Gomes cria uma literatura autocrítica nos moldes camilianos.

Sarita Star, cujo nome parece anagrama de seu sobrenome, é o estereótipo da garota de programa. Ela tem um amante mais novo e entrega-se a outros homens para sustentá-lo; no entanto, é uma mulher experiente e declara: "os homens acreditam sempre naquilo que eu quero que eles acreditem!" (Gomes, p. 49) Uma rubrica sugere o descaso de José, o amante, por Sarita, evidenciando que seu interesse por ela é somente pecuniário. No entanto, ele conhece o poder desta mulher. Quando ela diz dominar o espanhol, ele completa que ela domina os homens e é "uma mulher...fatal!" (Gomes, p. 49)

Fatalidade remete ao universo ultrarromântico das novelas camilianas. Nelas, o Destino é uma força intransponível que rege a vida humana de forma impiedosa. Aqui, Gomes apenas sugere a ideia, mas no relacionamento entre Nicolau e Tomásia, ela torna-se fundamental, sobretudo, para que se analise a psicologia das personagens.

Tomásia entrega-se ao rapaz para saborear o gosto de uma aventura, correr riscos, sentir desejos, criar fantasias que nunca concebera. Nicolau, por outro lado, concebe Tomásia como sua doce fatalidade.

TOMASINHA: Agora... eu só quero pensar que está tudo bem... porque tu estás aqui... e eu amo-te muito... És o meu Fantasma...

NICOLAU: E tu a minha Diva... vou ter de raptar-te...

TOMASINHA: Sim... leva-me para teu refúgio...

NICOLAU: Podes ter a certeza que te levo...

TOMASINHA: Não penso noutra coisa...

NICOLAU: Nãos tens medo de estar comigo?!... 
TOMASINHA: Sim... mas é este medo que me faz desejar-te ainda mais!... NICOLAU: És a minha doce fatalidade!

TOMASINHA: E tu, a minha doce fantasia... (GOMES, p. 48)

O relacionamento entre Tomásia e Nicolau parece recuperar a concepção lírica trovadoresca, o amante trata a mulher como um bem superior ("diva"), sua "doce fatalidade". Essa visão revela como Fernando Gomes conhece o inconsciente coletivo português e se vale desse saber para articular temas de interesse comum, captar a atenção do público e a partir daí expor sua visão crítica acerca do homem e suas relações.

Tomásia revela-se mais astuta e pragmática que o namorado. Enquanto ele sonha com a fuga e com uma vida a dois, sensata e tranquila, ela aproveita os prazeres do momento presente. Quando a família Barros descobre sua gravidez, ela faz com que todos pensem que a criança é de Inocêncio, mas teme por sua reputação com a iminência do retorno do marido. No entanto, recusa-se a fugir, conta com a possibilidade de o marido abandoná-la para que possa permanecer à sombra de uma família que lhe oferece conforto e tranquilidade. Assim, convence o amante a esperar o nascimento do bebê para que depois fujam.

É Nicolau quem apressa a fuga por não querer que Inocêncio torne a ver a mulher. Seu amor possessivo não é capaz de conceber que sua diva seja sequer vista pelo primeiro marido. Esse receio e sua impaciência fazem com que partam antes de o bebê retornar da ama de leite, o que determina o destino do casal.

Em Camilo, Tomásia sai de casa enlouquecida porque a criança está fora com a ama e vai pedir a Nicolau que pegue o filho para que fujam. O rapaz, no ímpeto de salvá-la de um marido vingativo, leva-a para Caminha, prometendo-lhe recuperar o bebê assim que possível.

O caráter prático e provedor do Nicolau camiliano é substituído pela índole possessiva e passional em Gomes. A essa personagem importa apenas ficar aos pés de sua musa, para o quê não pondera, nem reflete. No paradigma, o caso de amor ocorre em um quarto alugado na casa de um marceneiro subornado pelo fidalgo de Caminha; na peça, eles permanecem sob o teto de Gervásio. A eleição do local revela quem tem domínio sobre a relação. 
Tomásia trata o amante com familiaridade e certa altivez desde o primeiro encontro quando ri do embaraço do rapaz e faz-lhe perguntas para as quais não tem resposta. Ela é sedutora e só se deixa conduzir à fuga para proteger a própria reputação.

Nicolau, por outro lado, abandona-se a ela, deixa uma vida farta e sossegada para viver sua fatalidade. Essa atitude resignada remete à visão de mundo do português, que canta o fado melancólico e magoado, tão saudoso dos tempos de glória que não tem olhos para o presente. O caráter sonhador impede o senso crítico e distancia da realidade, lançando a utopias. A personagem representa, assim, o homem tradicional, regido por crenças arraigadas que lhe impede de reagir na adversidade e assumir seu próprio destino.

A ambiguidade sugerida pelo diálogo com $O$ fantasma da ópera entre o subterrâneo ou o terreno; a reputação ou o amor é recuperada no final da peça. No subterrâneo, permanecem os fantasmas, as dores, as frustrações; no plano terreno, estratégias para lidar com malogros. Quem opta pelo subterrâneo, sucumbe no mundo terreno. Nicolau, que se entrega a um fado impiedoso, é incapaz de ter senso prático e crítico diante da realidade. Ele sucumbe ao perceber seu fracasso no intento de satisfazer sua musa a encontrar o filho.

A história do casal é retomada dezoito anos depois da fuga. Nicolau agora é um homem alienado da realidade, sempre a procurar pelo filho, uma criança que teria saído a passeio e demora a retornar. As saudades e a monotonia de sua voz sempre a repetir que o filho "saiu de casa e não voltou" (Gomes, p. 68 e 70) lembra os cantares de amigo, em que a jovem saudosa se lamenta da ausência e demora do namorado. Novamente dados do inconsciente coletivo são retomados de maneira sutil e ardilosa. O lamento entorpece e embota a percepção, torna o homem inepto e indolente, recupera a melancolia saudosa dos fados portugueses.

Nicolau pretende atrair Pedro pela voz do sangue a que "um filho nunca pode ficar indiferente". (Gomes, p. 68). Concomitante a essa cena, enfoca-se Gervásio de volta da Inglaterra com o neto, narrando-lhe sua história. Nos dizeres do avô, Tomásia trocara o filho por um homem na noite em que o marido faleceu. Antes de morrer, o patriarca da família Barros declara que Pedro é herdeiro universal de sua fortuna e cabe a ele vingar o pai: "se algum dia encontrares com esse homem... - chama-se Nicolau de Almeida... podes fazer o que te ditar a voz do sangue... toda a minha fortuna é tua... e a vingança também!”. (Gomes, p. 69) 
Sabendo do retorno do filho, Tomásia vai até a casa dos padrinhos, na esperança de trazer a lucidez ao espírito do marido. Lá encontra Pedro e explica-lhe que Nicolau de Almeida é seu pai. O rapaz fala inglês e compreende o português com dificuldade. O acréscimo é relevante, Tomásia e Pedro falam línguas diferentes, o que pode ser uma metáfora para ideologias desiguais. Antes que a mãe termine de dizer que Nicolau de Almeida é o verdadeiro pai do rapaz, Pedro saca de uma arma e mata-o. A peça encerra-se pela frase de Nicolau: "Não tens que me pedir perdão!... Desde aquele dia em que te vi... em Caminha... eu sabia que tu havias de ser a minha doce fatalidade!” (Gomes, p.71)

A ideia de um destino inexorável que predispõe os acontecimentos poderia ser complementada pela expressão "voz do sangue”, força também implacável que levaria um filho a reconhecer seu pai em qualquer que fosse a circunstância. No entanto, Pedro rompe com essa teoria e faz seu destino como lhe convém, age de acordo com sua própria vontade, seja levado pelo desejo de vingança, seja orientado pela ambição e ganância.

Em Camilo, o desfecho tem caráter sentimental. Lopo, segundo filho do casal, lamenta-se da insensibilidade do irmão e o convida a abandonar aquela família que poderia ser sua. Pedro é retratado como um ser somente ambicioso, não há nenhuma ambiguidade em sua atitude de abandonar o pai à loucura em prol do dinheiro dos Barros. Em Gomes, não é possível estabelecer com exatidão o motivo de Pedro matar Nicolau. Contudo, essa abertura parece indicar que o objetivo da cena não é social. O parricídio representa a ousadia do filho em seguir sua própria vontade, eliminando a autoridade paterna. Trata-se do novo eliminando o velho, de um homem prático, educado na Inglaterra, sob novos conceitos e valores, eliminando o homem tradicional, filho de um padre, orientado a seguir crenças e regras ultrapassadas, submetendo-se mansamente a um Fado impiedoso.

O destino de Nicolau é trágico e intransponível porque ele se entrega à fatalidade sem rebelar-se. Ele crê em um Fado, resigna-se, sucumbe e perece. Essa ideologia milenar condiz com a mentalidade dos que o criaram, mas é contrariada pela mundividência de um jovem educado na Inglaterra no fim do século XIX. Pedro, matando o pai, pode individualizar-se e receber a herança que escolher. Ele não precisa submeter-se ao fatalismo nem às ideias preconcebidas, pode criar novos ideais. O legado dos Barros parece adquirir novos significados e associar-se tanto ao estudo no exterior e quanto à convivência com um novo modo de conceber a vida. 
Fernando Gomes acrescenta, assim, à narrativa de Camilo novos significados, atribuindo-lhe conotação psicológica. A ganância, no paradigma, é motivo de censura; no intertexto, pode relacionar-se à reforma, à revolução nos ideais mesquinhos que devem ser alterados em prol do bem comum. Pedro pode não ser apenas um homem ambicioso, mas símbolo de uma afronta a ideias preconcebidas.

Nas mãos do dramaturgo, o texto camiliano ganha foros de tratado sobre o comportamento humano, universalizando-se, e o sangue verte sobre o palco português 


\section{VIA CRUCIS}

\section{V.1 Sob a cruz social}

Muito antes de Drummond proclamar: "Meu Deus, por que me abandonaste / se sabias que eu não era Deus / se sabias que eu era fraco", Camilo já revelava a vida como uma via crucis protagonizada por homens débeis. Conhecedor da alma humana, o novelista sabe que, insignificante diante de seus desejos, assolado por injustiças e desconcertos, o homem encontra-se desamparado. O novelista compreende o amor sensual, a paixão, o amor filial, a fraternidade, o desejo de vingança como forças que tornam o homem mero títere de seus impulsos incontroláveis. Percebe, sobretudo, a dificuldade da entrega à compaixão, quando a culpa e a autocondenação dominam o ser.

Em Coisas Espantosas, o enfoque é dado ao sofrimento e à autocondenação. Uma paráfrase explicativa faz-se necessária à interpretação do texto. A narrativa inicia-se com a morte de Inácio Botelho "solitário, abandonado, sem amor, sem família, sem lágrimas, sem mão amiga que the enxugasse da fronte o derradeiro suor." (Branco, 1984, p. 568). Esse final trágico parece consistir numa (auto?) punição às escolhas feitas em vida pela personagem. Quando jovem, Inácio arrebatara de sua família Balbina, a qual, por amor, se resigna a tornar-se sua amante e, com o passar do tempo, apenas amiga. A visão amarga a respeito da união de um casal, que, nas narrativas camilianas sempre desembocam no tédio e aborrecimento, reitera-se e é acrescido, como de outras vezes, do tema do filho natural.

Balbina, no final da vida, implora que o amante perfilhe seu filho. Depois de ela morrer, Botelho não só esquece o perfilhamento como também seduz outra vítima de seus desejos. Encantado com a beleza da filha de sua engomadeira, contrata a moça para mestre de Augusto, a fim de seduzi-la e não contrair com ela nenhum compromisso pessoal. Para amenizar o peso de sua culpa, submete os criados às ordens de Carlota e paga-lhe bem.

A jovem cuida de Augusto, mas sacrifica não só a criança como a si mesma para atender aos desejos do "primeiro homem que a encarou significativamente" (Branco, 1984, p. 554). Vítima de uma grande carência afetiva, a moça deixa-se seduzir e dominar por Manuel de Castro, moço sem profissão, vadio, viciado em jogo, infame, fraco e quase um homicida. 
Somente no leito de morte, Inácio escreve um documento reconhecendo Augusto como filho, mas como não tem tempo de registrar sua intenção, entrega ao menino o papel, pedindo-lhe que o dê a determinados amigos. A criança dorme e Carlota rouba o papel com o testamento para dar o dinheiro a seu amante.

Contratando com a indignidade dessas personagens, Gregório, fiel criado da casa, tenta impedir que Augusto seja lesado em seu patrimônio e é ferido de morte por Manuel.

Como se pode verificar, as quinze primeiras páginas da novela trazem o tom exacerbadamente sentimental e trágico do melodrama. As desgraças oriundas da entrega às paixões dão azo a discursos melancólicos e a atitudes impetuosas, extraordinárias e inverossímeis. As confissões e revelações surpreendentes impedidas por golpes ou problemas na garganta. No entanto, o encaminhamento dado ao tema amoroso destoa do modo como o melodrama o conduz. Não se trata do embate entre heróis e vilões, ou da virtude e do vício, mas os opostos conjugam-se, fundem-se a ponto de perderem seu caráter original. Isso porque o intuito do novelista é estudar o comportamento humano e não ocultar conflitos sociais para alienar o espectador e levá-lo a crer na força redentora da virtude.

O leitor camiliano atento não terá deixado de notar que o sobrenome Botelho é também o do escritor. A biografia de Camilo torna-se recorrentemente motivo de sua ficção, assim ele preserva acontecimentos efêmeros, medita sobre eles, vingando-se do que não poderia tirar desforra na vida real. O duplo se refaz, o espelho realidade / ficção volta a ser um meio de compreender a si e ao ser humano. Botelho é, então, retratado como um homem vil e desprezível. Na mesma linha autobiográfica, páginas adiante, uma senhora piedosa e maternal receberá o nome de Rosa, como (homenagem a?) a mãe do escritor. Cabe enfatizar, no entanto, que a menção biográfica é mais um viés da ampla visão de Camilo acerca do ser humano. Ele revela-se, assim, crítico sagaz não apenas do outro, mas de si mesmo.

Também como Camilo, o órfão Augusto é entregue aos cuidados de uma tia, esta, entretanto, acolhe a herança de seu irmão, mas rejeita o menino por ser filho de uma mulher sem nome de prestígio. O escritor, tendo vivido com uma tia, após a morte do pai, teve como tutor o amante dessa mulher, mas deixa-lhes para ir morar com sua própria irmã quando esta se casa. A vida adquire novas nuances: a dor sentida, a dor fingida e a dor lida 
giram "a entreter a razão,/ Esse comboio de corda/ Que se chama coração." ${ }^{50} \mathrm{O}$ escritor reinventa seu sofrimento pela literatura, estudando sua dor e refletindo sobre os interesses que movem o ser humano.

O destino de Carlota é cruel. Enlouquecida pela culpa, ela é internada em uma instituição de onde sai para mendigar com sua mãe e, em seguida, sozinha, pois Carolina morre pouco tempo depois. Não se constrói, então, uma personagem livre de defeitos. A moça inicia sua trajetória como pobre jovem, destituída de privilégios e seduzida por um homem rico. Torna-se maliciosa, consegue um amante e engana patrão e empregados para sustentar os vícios deste homem. Vítima de sua própria carência, é conivente com este homem que a leva a roubar e a assistir ao suposto assassinato de Gregório. Arrependida, torna-se dócil e religiosa: digna de piedade.

Antípoda de Castro, o galego de baixa extração Gregório de Redondela é descrito como fiel empregado de Inácio, cujo ímpeto de dedicação é abrandado pela paixão que nutre à cozinheira da casa. Em busca de angariar os recursos prometidos por Carlota para casar-se com Joana, o pobre homem resigna-se a levar e trazer cartas da mestra de Augusto a Manuel. Mais ainda, concede não contar a Botelho ter flagrado o casal à noite no pátio da casa. Sua dignidade é ainda mais aviltada quando aceita dinheiro de Carlota para calar-se, já que o vínculo com a cozinheira se rompe no momento em que ela se casa com outro homem e o abandona. O rebaixamento da personagem é censurado e justificado pelo narrador:

Esta terceira queda de Gregório é menos desculpável que as outras: atendendo, porém, a que o coração humano, despojado das galas do amor, se veste de preto, repele o doce alimento das sensações generosas, e ama nutrir-se de vícios e indignidades, tem desculpa o coração de Gregório como o de tantos Manfredos, que o leitor festeja e imita, porque não nasceram em Santiago de Compostela.

Sempre injustos e inconsequentes, olhamos com certa seriedade e acatamento para o homem bem nascido e educado, que sofreu reveses na luta do coração com a sociedade, ou tragou o fel da perfídia, e protestou vingar-se da espécie humana $[\ldots]$

Isto compreendemos e admiramos.

Que Gregório, porém, desiludido e cético, misantropo, arado de fogo infernal na alma, estanque de lágrimas, estéril de aspirações ao ideal em que devaneava, outrora, sentado no barril; que Gregório, enfim, descrido de quimeras, golpeado o coração de afrontosas dores, se aturda no tráfego delicioso duma taverna, seu segundo, e já agora único sonho de ouro realizável; disso, que tão triste é, rimos nós, Balzacs pífios, que não sabemos trabalhar com o escalpelo observador no coração do nosso irmão da Galiza, mais nosso irmão por sangue, que nenhum

\footnotetext{
${ }^{50}$ Trecho de "Autopsicografia" de Fernando Pessoa
} 
outro desses que andamos sempre a pintar nos nossos romances, remendados por capa de pedinte. (Branco, 1984, p. 560)

A comparação com "Manfredos" remete ao rei da Sicília que promulgou o combate já travado por seu pai contra o papa. Ele foi, por isso, colocado sob interdição papal. Afinal os "Manfredos" não nasceram em "Santiago de Compostela", isto é, não são galegos. A ironia torna-se fina e aguda. Os galegos eram desdenhados pelos portugueses que, no entanto, consideravam a cidade de Santiago santa por abrigar o manto de Sant'Iago, apóstolo de Jesus. A hipocrisia é flagrada e censurada. No Romantismo, o "humor destrutivo não se dirige contra fenômenos negativos isolados da realidade, mas contra toda a realidade, contra o mundo perfeito e acabado. O perfeito é aniquilado como tal pelo humor" (Bakhtin, 2010, p. 37)

A crítica direciona-se para o ponto fundamental do comportamento social rechaçado por Camilo: a valorização da reputação em detrimento da essência do homem. Nesse sentido, considera seus leitores "Balzacs pífios", já que na obra do autor francês as roupas, a aparência, as atitudes, um tipo de vida, uma profissão, o nome revelam o caráter, definem as personagens, condicionadas pelo meio.

O novelista português sugere o desprezo pela valorização dos endinheirados em detrimento dos pobres. Segue Gregório, sublimando sua dor pelo trabalho, mas, como sua taverna dá prejuízos, o galego vai confessar-se em busca de salvação para sua alma e seus negócios. O confessor impõe-lhe que relate tudo ao patrão, pois na visão do frade, Carlota era um meio que o Demônio usara para perder a alma de Inácio Botelho. Somente expulsando a amante, o fidalgo se salvaria. Gregório propõe-se a obedecer ao "santo conselho", mas encontra seu amo no leito, acometido pelo cólera. Daí sua atitude heróica em colocar a vida em risco para salvar a fortuna de Augusto.

Manuel de Castro golpeia o galego para salvar o dinheiro e atinge a garganta de Gregório. Ferido na garganta, bem ao gosto melodramático, ele é impedido de apontar o nome do ladrão aos policiais. Sai do hospital com a reputação de galego honrado, o que the granjeia doações para estabelecer um armazém e uma pousada. Seus estabelecimentos prosperam e ele, além disso, ganha na loteria. Investe em uma grande casa, armazéns e uma padaria. Desiludido com o casamento da mulher amada, enamora-se de uma pobre viúva com quem se casa. São muito felizes, mas não podem ter filhos. Ricos, vão viajar pelo país. Assim encontram e salvam Augusto, empobrecido e abandonado. O galego 
emprega bem seu dinheiro e torna-se opulento capitalista, credor do governo de Portugal. A ironia crítica, ácida, de Camilo Castelo Branco verifica-se aqui em relação à personagem galego. Vítima de preconceitos quando pobre, torna-se prestigiado pela alta roda e requisitado pelo Estado, ao tornar-se rico. Subjacente à melancolia predominante, insinuase o humor amargo, cínico que castiga a hipocrisia social. Como se vê, a personagem transita pelo ilícito, mas rapidamente encaminha-se para a ordem e destaca-se como homem de bem.

A benevolência de Gregório prospera em Augusto. Depois de formado na faculdade, o filho bastardo de Botelho procura Carlota e, com o auxílio de seus novos pais, resgata a moça que pede para ser enclausurada em um convento. Gregório levanta-se de suas quedas com maestria e dignidade. Como se vê, Camilo não desdenha a realidade da época, mas apresenta-a de forma sarcástica ao afrontar os preconceitos criando um galego credor do Estado português e o filho de um oficial general e neto de outro como um homem viciado, ladrão e com ímpetos homicidas.

No entanto, também Manuel de Castro não é retratado de maneira maniqueísta. Aquele que "negou três vezes" ter qualquer relação com Carlota e com Gregório Redondela tem final feliz e reconhecimento social. Quando descobre que o galego não morrera, ingressa no exército, muda de partido e foge do país. Multiplica o dinheiro roubado por meio do jogo, e é enfocado novamente, cortejado em Paris como Dom Álvaro Barrada, nobre espanhol. Neste momento da narrativa, ele se encanta por uma moça da aristocracia decadente, tenta seduzi-la a fugir com ele e é rechaçado pelo pai aviltado. Esta recusa leva a uma revisão de atitudes. O rapaz retrata-se e o pai da donzela acaba consentindo o casamento. $\mathrm{O}$ destino do rapaz sugere uma recusa à narrativa moralizante e uma releitura crítica das ideias cristalizadas. O filho de um bom cidadão nem sempre é correto. Ao passo que um simples galego pode ser virtuoso.

Não há um embate entre o vício e a virtude, há a regeneração pelo amor e compaixão. O casal parte para Suíça e constitui uma família serena e virtuosa. Novamente, o mal se dilui e desvanece. A ênfase é dada ao dinheiro como motivo de aceitação social em oposição ao amor compassivo de Matilde que dá origem à virtude. O narrador crítico comenta o episódio comparando-o ao caso de Fausto e Margarida. 
O diálogo intertextual estabelece-se em vários sentidos. Um deles, mais imediato, refere-se à semelhança entre a riqueza e prodigalidade de Manuel e do protagonista da peça que não é a mola propulsora do interesse de Matilde. Recusam-se novamente as ideias instituídas e preconceituosas.

Outra associação possível tange a relação entre Manuel e Carlota. O par parece configurar uma paródia ao caso de Fausto e Margarida. Em Goethe, Fausto é um jovem irreverente, ávido por conhecimento e reconhecimento. Desiludido por não progredir, faz um pacto com Mefistófeles, o demônio, dando-lhe sua alma em troca de opulência. A ambição do protagonista goethiano lembra a da personagem camiliana. Contudo, Fausto realmente se apaixona por uma moça simples e ingênua. Para conquistá-la, segue conselhos de Mefistófeles e passa a presenteá-la com joias. A moça deixa-se seduzir pelos presentes e entrega-se, no entanto, dessas atitudes decorrem severos castigos. O moço sofre impotente diante da dor da amante. Margarida aflige-se diante da morte de mãe e do irmão e de uma gravidez indesejada que lhe ampliam o sentimento de culpa e a levam à prostração e à loucura. Aterrada, ela se entrega à justiça divina e é perdoada. Ele, por outro lado, não tem direito à salvação e é levado por Mefistófeles. O moralismo é patente, a virtude é recompensada e o pecado, castigado.

Diferente do texto alemão, na novela camiliana, Manuel seduz e abandona Carlota, mas não se sente culpado por isso, nem quer salvá-la. Somente quando quer refazer sua vida com Matilde é levado a um exame de consciência. Reflete, então, acerca dos métodos empregados para conseguir ascensão social e financeira, mas não se ocupa de Carlota. Reergue-se moralmente pela influência do amor. Diante da súbita aceitação social deste homem o narrador clama: "Santo Deus! por que é que ninguém odiava Manuel de Castro? Donde procedia o compadecerem-se todos dele, e andarem como a esconder de si mesmos o afeto que the tinham?" (Branco, 1984, p. 642) A opinião do narrador diante da impostura da personagem sugere uma visão diferente da socialmente aceita; no entnato, o destino opulento de Manuel revela a recusa ao moralismo. Parece-lhe impróprio acolher um homem para quem remorsos eram "inquietação de ânimos fracos" (Branco, 1984, p. 572). A compaixão do narrador evidencia-se, contudo, quando trata de personagens arrependidas e injustiçadas. 
A inquietação do narrador torna-se mais patente no momento em que revela a inverossimilhança da atitude de Francisco Valdez perdoar o futuro genro por este ter restituído à tia de Augusto o dinheiro roubado, como prova de sua benevolência e regeneração. O narrador deixa claro que a quantia restituída é irrisória quando comparada À fortuna que Castro lucrou nos jogos, e sugere a leitura do capítulo "Dos ladrões, que furtando muito, nada ficam a dever na sua opinião", da Arte de Furtar. O excerto destina-se a evidenciar como não se sentem culpados os que lucram pela especulação.

E a desgraça de tantas desgraças é que os autores destas empresas [especulação], depois de roubarem com elas a el-rei, aos soldados e a todo o reino, porque a todo abrangem tantas perdas, ficam-se saboreando da destreza com que fizeram seu ofício. E, se a consciência os pica [...], limpam o bico à mesma consciência: que a ninguém puseram o punhal nos peitos, nem venderam nada às escondidas; e o que se faz na bochecha do sol, com aceitação das partes, vai livre de coimas e de escrúpulos. Parece que ainda não leram, nem ouviram, que há vontades coatas e forçadas sem punhais nos peitos. (Arte de furtar, 2006, p. 90)

Consideram-se apropriadas atividades ilícitas, desde que elas sejam feitas com aval e conhecimento do grupo. O lucro obtido pelo jogo é aceito pela sociedade, embora condene os perdedores à miséria. A crítica opõe-se ao perdão e reconhecimento social de Manuel, o que revela o desejo de tratar do caso de forma mais realista. A divergência sugere não haver um juízo moral definitivo.

A reputação angariada à base do dinheiro desvanece o crime e a culpa. Castro usa o dinheiro roubado para jogar e ter mulheres, permanece, pois, no vício. Mas a sociedade o acolhe sem reservas. Mesmo o nobre Valdez pede empréstimo a Barrada, sem conhecer por que meios este era rico, somente quando sua filha é requestada para amante deste senhor, ele devolve-lhe a quantia emprestada com fumos de nobreza aviltada.

Manuel escarnece desta sociedade, sob a figura do nobre Álvaro Barrada, zomba de um grupo que lhe acolhe por seu dinheiro. Sua conduta depravada somente se altera pelo amor e pelo olhar compassivo de Matilde. Destoando dos demais que condenam Castro ao ouvirem sua história, sem saber que se trata do pretenso nobre que têm à frente, a moça escuta-lhe a história e se apieda dele, não o reprova, apenas mostra "compaixão" (Branco, 1984, p. 629). Modificado pelo amor e pela caridade, Manuel escreve à filha de Valdez revelando-lhe o desejo por regenerar-se e confessando orar constantemente para conseguir de Deus forças para alcançar seu intento. 
Nesta carta, a associação entre Castro e Fausto torna-se mais nítida, já que ele declara ter a seu lado um demônio que lhe provê a boa sorte no jogo ao mesmo tempo em que concede a consciência de que o sucesso advém da ruína de muitas famílias. "O mundo aplaudia-me os triunfos, e as almas aviltadas à protérvia feliz - tantas, meu Deus rodeavam-me devoradas de inveja umas, e outras devoradas de amor. Mulheres e homens todos de rastos na trilha do ouro que eu deixava após de mim!” (Branco, 1984, p. 636). O desprezo pelo sucesso financeiro e o reconhecimento social associados à influência demoníaca sugere uma revisão crítica do próprio Manuel acerca de sua conduta. A consciência de ter errado, pelo menos enquanto jogador, é o primeiro passo para a regeneração.

Para alterar o curso de sua vida, Manuel vende seus pertences e compra um chalé na Suíça, onde vai morar com sua família, "na obscuridade e esquecimento do mundo" (Branco, 1984, p. 643). A ironia cresce quando se leva em consideração o destino escolhido por Castro para seu refúgio, Manuel parte com sua nova família para Genebra e vive em paz, na pátria de Rousseau.

Ácida é a crítica à visão rousseauniana de que em meio à natureza o homem se regenera, quando se leva em consideração que nas novelas camilianas o refúgio de um casal no campo gera tédio e aborrecimento. Camilo parece flagrar o contrassenso de que o homem primitivo seria amigo incondicional de seus semelhantes (Rousseau, 2009, p. 100) e somente a sociedade gera o desejo de tirar vantagens do prejuízo de seus semelhantes. (Rousseau, 2009, p. 99). A concepção de Rousseau desconsidera que o progresso material e a vida em sociedade surgem em decorrência das necessidades do homem, que quer sempre ser o líder, o mais forte.

O leitor camiliano sabe que o destino do casamento nas novelas do escritor português é triste. No caso de Castro, no entanto, o narrador limita-se a declarar: "Como temo de ouvir argumentar que a felicidade absoluta neste mundo é uma paradoxal visão dos poetas, por isso me reprimo de dizer que Matilde e Manuel de Castro tinham sido absolutamente felizes nos oito anos que haviam vivido à margem do lago de Genebra." (Branco, 1984, p. 643)

A felicidade do casal não decorre, portanto, do contato com a natureza. É recorrente nas narrativas camilianas a concepção de que o dinheiro traz a felicidade. Doze casamentos 
felizes e Onde está a felicidade? corroboram a assertiva. Assim, ingênua é a visão de que "o homem selvagem só deseja as coisas que conhece e como só conhece aquelas cuja posse está a seu alcance $[. .$.$] nada deve ser tão tranquilo como sua alma e nada tão limitado como$ o seu espírito." (Rousseau, 2009, p. 113)

O filósofo suíço idealiza o selvagem e o homem distante da sociedade como um ser refratário ao ódio ou à vingança, Camilo, por outro lado, retrata esses sentimentos como inerentes ao ser humano. Rousseau não parece levar em consideração que a sociedade se estabeleceu como um meio de o homem solucionar problemas de segurança e de alimentação que se apresentavam, pois o amor-próprio e o desejo de autoconservação imperam na natureza humana. O novelista mostra que o amor próprio é qualidade fulcral do homem que, por isso, só experimenta a paz na opulência. O chalé de Castro é uma grande propriedade rural com lagos e vistas deslumbrantes. O tema da regeneração social já havia sido tratado em A queda dum anjo, em que Calisto Elói deixa de ser um nobre rural ultrapassado e ridículo quando vai para Lisboa e se envolve com a alta sociedade. O tema é, nas duas narrativas, motivo de riso.

Castro e Matilde são felizes na obscuridade da natureza com muitos recursos financeiros. Embrenhar-se no mato sem ter como sustentar a si, à família e aos pequenos prazeres levaria ao vício e não à regeneração. Manuel mantém sua nova vida regenerada graças ao dinheiro roubado e aumentado pelo jogo, pois é a fortuna que the permite requestar a moça que lhe agrada na alta sociedade e, com ela, viver um belo caso de amor. Carlota, por outro lado, não se permite refazer-se. Tudo indica que o tabu em relação à mulher decaída seja intransponível, o que não ocorre no universo masculino.

Associado à desigualdade de gênero, outro tema recorrente em Camilo é o desconcerto dos destinos humanos, uns nascem com uma "fatal estrela", outros, com "estrela propícia”. As expressões, utilizadas pelo narrador para justificar, respectivamente, a vida de Augusto e de Manuel, reiteram a visão fatalista de Camilo. Nessa vereda, a sina do filho de Inácio e da filha de Carolina é padecer até a morte. Carlota nunca é perdoada por si mesma de seus atos.

Preconceitos insinuam-se toda a história, é lícito, portanto, atentar que em Totem e Tabu e outros trabalhos(Freud, 2006, vol. XIII), Freud discorre sobre como o horror a determinadas condutas permeiam as nas regras sociais estabelecidas por várias sociedades, 
mesmo as mais primitivas como a de aborígenes australianos, canibais pobres e desnudos, a dos bantos orientais e a dos melanésios das Ilhas Banks, entre outros. Assim, a aversão ao incesto verifica-se no totemismo, um sistema classificatório de parentesco que impõe rigorosas proibições às relações incestuosas. Dessa constatação, o pai da psicanálise deduz que este é um dos impulsos mais atávicos do ser humano. Instintivamente o homem encontra seu primeiro amor pelo incesto - mãe e irmã.

Tabus são as normas éticas não escritas mais antigas do homem, não têm teor religioso, mas suscitam o temor sagrado, misterioso, que faz evitar o que é considerado impuro, proibido, ou perigoso. Os tabus visam a diversos fins, entre eles, à proteção à vida em seus momentos de nascimento, maturação e casamento. Os que violam tabus devem expiar sua culpa e purificar-se. "Essas proibições dirigem-se principalmente contra a liberdade de prazer e contra a liberdade de movimento e comunicação." (Freud, 2006, vol. XIII, p. 40). E é a convicção moral interna que conduz ao medo e ao sofrimento. "Em seu inconsciente não existe nada que mais gostariam de fazer do que violá-los, mas temem fazê-lo; temem precisamente porque gostariam, e o medo é mais forte que o desejo." (Freud, 2006, vol. XIII, p.48 e 49). Quem viola um tabu, torna-se um tabu porque configura um exemplo que incentiva a transgressão; por isso, deve ser evitado. O transgressor apresenta determinado poder, pois lembra desejos proibidos; daí a importância da expiação.

Carlota viola dois grandes tabus da sociedade burguesa. Desrespeita a regra da desigualdade social, ao tornar-se amante de um homem rico e, com isso, obter vantagens pecuniárias e a norma de não ter um caso de amor, sem pretensões ao casamento. $O$ problema aumenta porque ela sustenta os vícios do amante. Por essas infrações, ela terá de expiar a culpa e ser punida. Não mais terá direito ao amor, nem ao casamento. Consciente disso, ela promove a fuga de um dos pretendentes à sua mão de rica herdeira, narrando-lhe sua vida pregressa. Como se vê, nem o dinheiro do pai que volta rico do Brasil é capaz de regenerar-lhe a seus olhos e, por extensão, à visão do grupo.

Condenada, sobretudo, por si mesma, Carlota percorre sua via crucis. Jesus também foi condenado pela sociedade por ter violado tabus, pois como andava com pessoas consideradas impuras e praticou milagres aos sábados. 
O trajeto percorrido por Carlota e Augusto é associado pelo narrador, em sutis menções intertextuais, aos passos da Cruz. Para iniciar a narrativa, são feitos comentários ácidos acerca da época em que se passam os acontecimentos. Tudo ocorre num momento em que o cólera e a guerra assolam Portugal. Assim, as pessoas sofrem os "flagelos gerados pelo homem na peçonha do pecado" (Branco, 1984, p. 551), "como dizem bons teólogos e doutos moralistas" (Branco, 1984, p. 551) e o barulho de artilharia somado ao dobre dos finados "eram o antagonismo da crença e da religião". (Branco, 1984, p. 551). O tom mordaz dirige-se, mormente, ao moralismo vazio de sentido. "Bons teólogos e doutos moralistas" proclamam as consequências nefastas do pecado. "Crença"(ideologias) revelam hipocrisia quando se tornam combates, a "religião" leva a rituais vãos e ineficazes ("dobre dos finados"). Como algumas solenidades repetidas ano após ano que gradativamente tornam-se folclore, tradição automática e festiva, a via crucis parece consistir em uma punição absurda aos olhos do novelista que, por isso, se vale do dogma para acentuar o sofrimento de Carlota e Augusto.

Muitos fatos da narrativa coincidirão com as estações da Via Crucis. Coisas espantosas inicia-se em uma casa na Rua das Oliveiras. Também a paixão tem início no Monte das Oliveiras, onde Cristo se reunia com seus discípulos para orar. Para asseverar tratar-se de um diálogo com o texto bíblico, as páginas seguintes citam "a terceira queda" e um episódio em que uma personagem "nega três vezes" conhecer a outra. Esta esteira é, portanto, uma sugestão para interpretar-se a narrativa.

A primeira estação do caminho da cruz ocorre quando Jesus é condenado à morte. Depois de interrogar Cristo e de ser alertado por sua esposa acerca de uma revelação em sonho de que se tratava de um homem especial, Pilatos mandou vir água e lavou as mãos diante da multidão, recusando-se ser responsabilizado pela morte de Jesus. No entanto, ele manda açoitá-lo e o entrega para ser crucificado. Na segunda Estação, Jesus carrega a cruz, um instrumento de suplício. O terceiro momento é marcado pela primeira queda de Cristo, abatido sob o peso da cruz. Com chicotes, os soldados que o escoltavam o forçam a levantar-se.

Na narrativa camiliana, Carlota, é condenada à sedução de Inácio por ser filha de uma pobre engomadeira. Sua dor amplia-se por submeter-se aos desmandos de um amante 
ao qual se entrega por carência. Paripassu, Augusto, como filho natural, é privado por lei da herança do pai e entregue à irmã de seu pai. Ela o repudia como filho de uma mulher sem nome ilustre, e o envia a ser aprendiz de caixeiro numa tenda de especieiro e, depois, enviado ao Porto para a loja de um chapeleiro. Adoece, e no hospital conhece um mesário que toma o rapaz para seu ajudante. Passa, então, a trabalhar gratuitamente como tipógrafo da Vedeta da Liberdade. O órgão da ala esquerda do Liberalismo é flagrado em contrassenso, defende a liberdade, mas escraviza, emprega crianças, sem pagar-lhes salário. Atitude aparentemente correta, mas basicamente infrutífera é a do mesário consente que o menino aprenda latinidade com um mestre nos momentos de folga. Quando seu protetor morre e ele volta à miséria aos doze anos de idade. É, portanto, condenado pela vida à desgraça, à cruz.

Na quarta Estação, Jesus encontra alívio à dor pela presença de Maria, sua mãe. Na narrativa camiliana, depois de abandonada em um hospício por Manuel, Carlota vai pedir esmola com a mãe, uma apoia e conforta a outra. Após a morte da senhora, passa a costurar para remediar a fome. Augusto é adotado por Gregório e Rosa. O casal não podia ter filhos e encontra o menino magro, mal vestido e triste. A alegria da decisão de levarem o filho do Sr. Botelho agrada a todos. À criança, a compaixão gera gratidão e amor, ao galego e sua esposa, o encontro preenche a vida, agora muito farta materialmente, mas até aquele momento, carente de filhos.

A caminho do Calvário, Jesus recebe ajuda de Simão para carregar a cruz. Este o faz por obediência aos soldados que, vendo Cristo muito fraco, ordenam a um dos transeuntes que o auxiliem a fim de preservá-lo vivo para a crucifixão. Gregório, por outro lado, é compassivo por vontade própria e auxilia o menino em sua formação, dando-lhe recursos abundantes para educar-se intelectualmente.

O sexto passo em direção à cruz é marcado pelo encontro com Verônica, moça que enxuga a face de Jesus tingida de sangue. No tecido, fica estampada a imagem do rosto. Também Augusto deixará marcas em seu caminho. Preocupado com a mulher que até os nove anos educou-lhe e mimou-lhe como mãe, o rapaz, com dezenove anos, quer reencontrá-la. Depara-se, então, com Carlota na miséria e pede licença aos pais adotivos para trazê-la para casa, retira-a da miséria e dá-lhe condições de recuperar a vivacidade e beleza. 
A marca que a ação caridosa terá na vida do casal será indissolúvel como a imagem do pano de Verônica.

O caminho para a crucificação é árduo e Jesus cai pela segunda vez. Abatido pelos açoites e pelo peso da madeira, ele caminha com dificuldade, tropeça e vai ao chão. A queda representa a dificuldade de ultrapassar obstáculos, o que se verifica em toda trajetória humana. Na novela de Camilo, parodicamente, a queda de Manuel leva-o à ascensão social e, posteriormente à redenção. Entretanto em relação a Augusto e Carlota, a queda associase ao amor intransponível. Embora não configure um caso de incesto, namorar e casar com a mulher que teve o papel de mãe na primeira infância constitui um tabu. O leitor saberá muito depois que este é o motivo da insatisfação de Augusto e de sua súbita decisão de deixar Portugal, trata-se de uma fuga. Apaixonado pela moça e sem condições psicológicas de assumir uma relação com ela, o rapaz vai para a Suíça onde encontra e trava amizade com Castro e sua família, sem reconhecê-lo ex-amante de Carlota. Também ela evade e sublima seu amor, encerrando-se em um convento.

A oitava Estação apresenta o encontro de Jesus com algumas mulheres que, chorando, lamentavam o seu sofrimento. Cristo consola, mesmo em momento de extrema dor e aflição. Assim, Carlota deixa a paz do convento para fazer companhia à Rosa alquebrada pelo reumatismo.

Na nona estação, Cristo cai pela terceira vez. O número três é simbólico e remete à trindade, Pai, Filho e Espírito Santo. Por conseguinte, reitera o mistério de um deus fazer-se homem e fraco para evidenciar a compaixão por suas criaturas. Queda adquire, neste momento da narrativa camiliana, a conotação de desvio, incorreção. Na vida pregressa de Carlota, o abandono e a calúnia sofridas por Carolina sugerem a fraqueza que a levam a deixar a filha trabalhar para Botelho. Eduardo, pai da protagonista, é demitido por influência do homem com quem o pai de Carolina queria casá-la. Sem conseguir emprego e com a obrigação de sustentar Carolina, uma filha, e duas irmãs, o moço pretende suicidarse, mas é convencido pelo capitão de um navio a embarcar para o Brasil em busca de dinheiro. As cunhadas arranjam amantes que as sustentam. Carolina sai de casa com a filha de um ano e meio e torna-se engomadeira. Eduardo enriquece, envia dinheiro para as irmãs, mas elas não repartem com Carolina e difamam a moça ao irmão. Cronologicamente, esta seria a primeira queda que daria origem a tantas outras. 
A décima estação enfatiza a humilhação de Jesus. Neste momento, Ele é despojado de suas vestes. Em Coisas espantosas, Eduardo, agora rico, re-encontra Carlota e depara-se com a possibilidade de a filha estar apaixonada por Augusto que não se propõe a casar-se com ela. Sem conhecer profundamente a história da filha, o homem sente-se aviltado, propondo a arranjar-lhe um rico casamento. Carlota, humilhada pela imposição paterna, conta ao pretendente de sua mão, as atrocidades de sua juventude. Ele não volta mais. Verifica-se, pelo episódio que a autocondenação pelo despojamento de sua prima é o cerne do conflito principal, ela não se permite uma nova chance.

Nas estações onze a quinze, Jesus é pregado e morre na cruz. Sepultado, abandona o túmulo e ressuscita. Símbolo ascensional, a cruz parte da terra e aponta ao céu. Seus braços remetem aos pontos cardeais e o número quatro aos elementos terra, ar, fogo e água; assim, a cruz representa o conjunto da humanidade atraída para a eternidade pela integração e unificação com Deus. É pelo sofrimento e morte na cruz que se resgata o pecador. Também o padecer de Carlota configura um meio de purificação. Ter rompido um tabu, torna-a um mal exemplo, ela deve padecer para não estimular a outros. Ela espera obter perdão de suas faltas para merecer a companhia do rapaz no céu. $\mathrm{O}$ moço decide-se casar com ela depois de dois anos de ausência. No entanto, a culpa dela impediria o consórcio e a morte veda a possibilidade de ele expor sua intenção. Carlota morre no dia em que Augusto decide ultrapassar os seus próprios preconceitos e casar-se com ela. A esperança na vida após a morte é o único alento do casal.

Eu só podia ser sua esposa no Céu, onde a alma está pura das nódoas do corpo. Lá o espero, filho da minha alma. Enquanto viver, creio que verá a minha imagem sem o estigma fatal. A terra do sepulcro é um crisol de purificação.

Agora lhe digo que o amei até morrer, e morri porque Deus não quis que dos meus olhos se afastasse o negro quadro do meu passado. As maiores desgraçadas são aquelas que a si próprias não podem perdoar. (Branco, 1984, p. 712)

"Estigma fatal" remete ao universo das ideias camilianas e amplia sua extensão ao adentrar o universo interior do homem. Já não se trata de um fado impiedoso que castiga os amantes, mas de autopunição pelo peso da culpa.

Em Augusto, o amor por Carlota vincula-se a um dos desejos mais primitivos do homem: a atração pela figura materna. Freud, em Interpretação dos sonhos (Freud, 2006, vol. IV e V) mostra que o menino deseja possuir a mãe e por isso quer matar o próprio pai. Esse impulso foi associado à história de Édipo e nomeado, por Jung, Complexo de Édipo. 
A associação entre o complexo e a narrativa camiliana é pertinente uma vez que Carlota foi a única mãe que o rapaz conheceu em sua infância.

Talvez dessa relação melindrosa com Carlota advenha o perdão fácil de Augusto a Manuel de Castro. É mais coerente e menos inverossímil perdoar um homem que realizou seu próprio intento: eliminar o pai - suscitando a desconsideração de Carlota por Inácio - e ficar com a mãe.

O tabu é tão forte que Augusto não consente casar-se com ela, mesmo com a permissão do pai da agora Viscondessa dos Reis. O pai de Carlota propõe a Augusto que se case com sua filha, pois desconhece ter sido ela amante de Inácio Botelho. Em nome do amor-próprio, ele aceita sem contestar, nem procurar mais informações, a história narrada pelo capitão do navio que lhe livra da morte no momento de miséria e o leva ao Brasil onde granjeia fortuna. O marinheiro, com aspecto terrível, confessa ter-se arrependido de impedir que Eduardo tivesse se suicidado ao saber do destino de Carolina e Carlota. Sobre elas apenas declara: "Sua mulher, depois de uma vida honrada, morreu a pedir esmola; sua filha, depois de ter-se dado a quem lhe matasse a fome, esteve douda no hospital, e de lá saiu para dar a mão à mãe que tinha perdido os olhos.” (Branco, 1984, p. 663). A revelação de teor melodramático faz Eduardo retornar a Portugal, vinga-se das irmãs mentirosas, anuncia, anonimamente, no jornal a busca da filha que vai encontrar no mosteiro de Évora. Para o brasileiro, sua filha fora vítima de sedução e abandono e o remorso a causa de ter enlouquecido, por isso consente que ela se case com Augusto.

Já Gregório não concebe a união do casal. Rosa e Gregório choram com a miséria de Augusto e com a loucura de Carlota, oferecem-lhes a casa e o coração. Mas Gregório surpreende-se com a revelação do amor dos dois, fica pasmado diante de "crime tamanho" (Branco, 1984, p. 700), pois conhecia Carlota como amante de Inácio, substituta da mãe do rapaz (Branco, 1984, p. 702).

O narrador considera o amor de Augusto uma FATALIDADE - e a caixa alta é empregada duas vezes para enfatizar o destino trágico e irremediável. Entretanto, não the parece criminoso esse sentimento. Para expor sua visão sobre assunto tão delicado, o narrador se vale da técnica do leitor incluso e dispõe-se a confrontar opiniões. 
- Parece-me um escândalo inaudito! Eu tenho lido todos os romances de mais nomeada pela extravagância, e nunca vi uma coisa assim! Tenho desculpado todos os amores extravagantes; mas à minha bondade repugna escusar que estas duas pessoas se amem, embora a razão aceite a possibilidade de se amarem.

- Ah! Vossa Excelência confessa que a razão aceita? Pois se a razão se conforma, que fará o coração? Não vê que aquela mulher é bela, daquela expressiva, imperiosa, e fascinante beleza dos trinta e três?

- Pois sim; mas não esteja você a puxar pelo fiado, que eu, se me apoquenta, lembro-lhe que Carlota...

- Foi a amante do pai de Augusto? é o que quer dizer-me?

- Está claro.

- Então Vossa Excelência ainda não sabe nada do coração humano, nem da história. Repare que não há aqui sequer um amor incestuoso. Não há Neros, nem Hipólitos, nem Ciniras, nem as fillhas do duque d'Orleans, que Vossa Excelência conhece d'O Século de Luís $X V$, e dos romances que esmoeu sem amargos de boca. Trata-se de uma mulher formosa, e de um moço de vinte e um anos que ama pela primeira vez, e que já amava - saiba-o agora, já que eu tive pejo de lho dizer em tempo mais oportuno -, já amava, quando foi viajar, e esconder o seu coração no chalet da Suíça.

- Seja como quiser; mas não é de bom gosto o episódio do seu romance.

- A natureza, meu bom amigo, não se amolda ao bom ou mau gosto dos romancistas. A natureza faz destes amores - monstruosos, se Vossa Excelência quer -, atira-os à circulação, e diz: "os noveleiros que vos definam, se podem.” E não está bem definida a coisa? Que tem o coração de Augusto com o passado?

- A dignidade.

- Com o que Vossa Excelência me vem;... A dignidade!... A dignidade, quando a paixão lhe sai de rosto, agacha-se, e deixa-se sovar aos pés, se é que a paixão pode ter pés, não tendo cabeça.

E dou a polêmica por concluída.

O amor do casal é configurado como característico do "coração humano". Quem não o compreende é porque "não sabe nada do coração humano, nem da história", não conhece, enfim, a natureza que amolda amores "monstruosos". Camilo perdoa o casal porque é um profundo conhecedor da alma humana e um destemido oponente aos preconceitos. Novamente rejeita-se um conceito moral definitivo.

As paixões dominam a razão, mas a busca pela manutenção da dignidade sobrepõese a todos os demais fatores. O conflito recorrente em Camilo, o choque entre duas forças antagônicas, entre dois titãs poderosos e adversários - a paixão e a razão - torna-se agora mais profundo, pois o inimigo está dentro do próprio se humano. $\mathrm{O}$ embate interno entre forças desiguais, característico da lírica portuguesa, ganha novas cores trágicas. As forças internas sobrelevam-se à razão, mas os tabus e preconceitos ganham mais ênfase.

Assim, a narrativa parece renovar um grito de socorro, um pedido de comiseração, um clamor por compaixão, já que o homem é novamente vítima não somente de seus desejos e emoções, como também da moralidade instituída. 
Mais que afrontar a sociedade burguesa, o amor entre Carlota e Augusto é um meio de expor como a natureza humana deve ser recalcada para respeitar os tabus e preconceitos. Só a autocompaixão salvaria o casal.

"Compaixão" deriva dos radicais latinos "cum" e "patire" e significa "sofrer ou padecer com". Ser compassivo refere-se, portanto, à capacidade de identificar-se com a dor alheia e partilhar dela. Somente quem sente a dor quer aliviar-se, assim, a compaixão acarreta atitudes, não se trata de empatia ou de dó. Trata-se de colaborar para diminuir a dor do outro como se fosse seu próprio padecer. Há necessidade de um desdobramento do "eu", de colocar-se no lugar do outro para sentir sua dor e querer remediá-la. Manuel foi salvo pela compaixão de Matilde, Augusto foi recuperado pela compaixão de Gregório e Rosa. No entanto, não há compaixão pelo casal Carlota e Augusto. Assim, a filha de Carolina torna-se mártir como Eurico, personagem do romance que adora ouvir ler.

Enclausurada em um convento, ela revê Augusto e escuta-lhe a leitura do romance histórico de Herculano que se abre com uma crítica ao celibato; para o autor, a castidade imposta como dogma é rival ao interesse das nações, danosa moral e politicamente, irremediável solidão da alma a que a Igreja condenou seus ministros, amputação espiritual em que para o sacerdote morre a esperança de completar a sua existência na terra. (Herculano,1972, p. 22)

Carlota assemelha-se ao protagonista de Herculano. Senhor de um coração de poeta, Eurico vela pelo que ama, prefere a solidão e a tristeza do convento onde não poderia ter contentamentos já que seu fado é a solidão. O presbítero morre como mártir nas mãos do inimigo da raça e da crença para remir o crime de amar Hermengarda, sendo um padre. $\mathrm{O}$ conflito de Eurico é interno, ele jamais teve atitude indigna. Também a personagem camiliana encerra-se em um convento na tentativa de sublimar o amor que sente pelo filho de seu amante. Amar Augusto e ser amada por ele configura-lhe um crime que não pode ser perdoado. Daí Carlota aconselhar Augusto:

[...] Não me queira mais. Lembre-se da minha indignidade. Não há ferida de coração que resista a esse bálsamo. [...] Sabe os quadros de minha vida horrenda, um por um. Lembre-se de todos. Em pouco tempo terá pejo de si próprio, pejo do seu amor, e admiração dolorosa de uma fraqueza. Tenha tudo; mas conserve de mim uma piedosa lembrança. A compaixão é o único sentimento que eu devia inspirar-lhe, se o coração humano fosse menos absurdo. Eu sou uma desgraçada sem igual. Até de lhe abrir a minha alma devo ter vergonha. Sou 
mulher condenada a jamais poder dizer-lhe o que sinto. Vê-se que não expiei os meus crimes ainda: agora é que eu reconheço o castigo. Vá, fujas de mim, meu querido filho. Veja-me no passado; olhe que infâmias lá ficam sem reabilitação possível... Deixe-me morrer, por misericórdia lho peço; porque já não espero uma hora da vida em paz. A vergonha é mil vezes mais pungente que o remorso!... (Branco, 1984, p. 703)

Como se vê, é o conflito e a condenação internos que punem o casal. A sensação de culpa suscita o pavor da consciência, reprime os desejos. Prepondera o medo sobre o instinto. O único sentimento que Carlota pode almejar é a compaixão. Não há ameaças externas de punição, mas ainda assim impera a certeza interna de que o crime conduzirá à desgraça.

Vítima de emoções com as quais não sabe lidar, a vida do rapaz torna-se tão insossa que sua lápide revela quão pouco viveu. Os dizeres VELUT UMBRA ou SEMELHANTE A SOMBRA sugerem que ele foi mero reflexo de alguém e, por isso, nunca conseguiu estabelecer sua própria identidade. Reflexo de seu pai, cujas paixões deixaram-lhe como herança o desprezo e a impossibilidade de conhecer o amor.

A análise junguiana qualifica de sombra tudo o que o sujeito recusa reconhecer ou admitir e que, entretanto, sempre se impõe a ele [...]. Ao filho de Balbina, foi negado o amor de mãe, o reconhecimento como filho legítimo e a possibilidade de amar. Invertem-se os papéis da narrativa herculiana. Augusto, como Hermengarda, não tem chance de tomar as próprias decisões e esvanece-se. Carlota, vítima de sua condição social, torna-se ela mesma um tabu e martiriza-se para purificar-se. 


\section{2 Ser ou não ser: Carlota}

Fernando Gomes assenhora-se da narrativa camiliana, tornando-a novo texto pósmoderno. Seja por sua irreverência, semelhante à de Camilo, seja por sua índole de contador de histórias, nas mãos do dramaturgo, a novela adquire novas cores e feições sempre atuais. A interiorização dos conteúdos e a problematização do que estava apenas sugerido nos textos do escritor do século XIX colaboram para a criação de textos originais. Imprescindíveis para alcançar seu sucesso são a criação de novas personagens e motivos.

Em A Vida Trágica de Carlota, a filha da engomadeira, já a alteração no título enuncia a valorização da tragicidade da vida da protagonista. Não se trata mais de "Coisas espantosas", mas de vida, em seus aspectos mais intrínsecos e comuns a todos os homens. Afinal, não se enfocará a vida de uma pessoa renomada, mas a da "filha da engomadeira".

Desde o início da narrativa, a miséria econômica de Carlota é enfatizada. Aliada a essa condição, agrava-se o quadro pelo fato de a moça precisar protagonizar sua vida muito cedo, sem o auxílio dos pais:

Meu Deus!... não sei como é que a gente aguenta tanta desgraça! Elas são umas atrás das outras!...

É a fome que aperta, o dinheiro que escasseia, o paizinho que está mais que visto que já não volta, as dívidas que aumentam, a mãezinha que está quase cega [...](Gomes, p. 14)

O desabafo sugere uma visão crítica e madura acerca dos fatos. Embora se trate de um lamento, não predomina o sentimentalismo, uma vez que ela "aguenta as desgraças", mas prevalece a consciência de uma situação social que deveria ser alterada. Esse ponto de vista revela um acréscimo de motivo ao texto, já que remete ao discurso masculino, ponderado e racional e sugere um diálogo com Os miseráveis, de Victor Hugo.

A intertextualidade com o romance francês já vem sugerida no "Prólogo" à peça. Apesar de Carlota apresentar características de Fantine, pois é obrigada a ceder à sedução em decorrência da falta de recursos, ela ousa tomar proveito da situação e inverter papéis.

De início, sua irreverência é apenas sugerida sutilmente ao propor à mãe que busque melhores condições salariais. Mais tarde, torna-se mais ousada ao escolher e sustentar um amante, traindo, assim, seu provedor. O discurso humanitário e igualitário da narrativa hugoana adquire novas tonalidades ainda mais fortes. Diferente do que ocorre em Hugo, 
não se trata de um narrador consciente e engajado a retratar a miséria de seres ingênuos e submissos a uma realidade injusta, mas de uma mulher que afronta, ainda que de maneira muito sutil, a repressão e a miséria do mundo patriarcal.

Várias alterações são promovidas no paradigma camiliano a fim de ampliar-lhe o significado. Em Camilo, a burguesia é a classe enfocada. Servos são valorizados quando ascendem socialmente e modificam hábitos para viver de forma pródiga. Na peça, prevalecem pessoas simples e ingênuas, crédulas e sensíveis, Gregório não enriquece como na novela, adquire meios de sustentar-se com fartura, mas é rodeado de pessoas humildes no "Rei do Garfo", restaurante cujo nome já sugere, de forma bem-humorada, a falta de requinte e a transformação do grotesco em cômico. Para enfatizar que se trata de pessoas simples, inserem-se mendigos como narradores, tabernas e prostíbulos como cenários e seus frequentadores como personagens. $\mathrm{O}$ atraso do país é tema frequente em Gomes e, aqui, colabora para que o diálogo com Hugo se estabeleça.

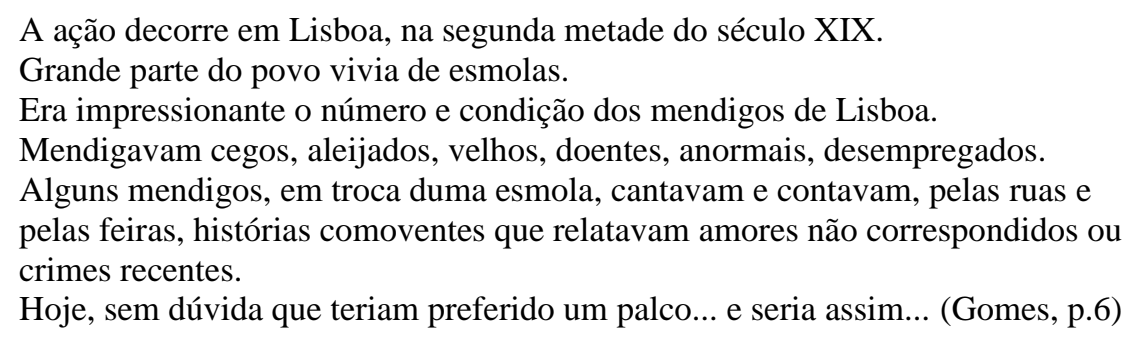

A associação entre mendigos e atores de teatro, frequente na obra de Gomes, é reiterada na peça. A relação parece reforçar o caráter irreverente, marginalizado dos atores. Espirituosos, eles conseguem manter a individualidade de opiniões e protestos sem deixarem-se contaminar pelas concepções dominantes. A arte em um mundo onde o tempo é convertido em moeda acaba cultivada pelos poucos sensíveis que conseguem desviar o curso de suas rotinas para ouvir o outro. Atores são como mendigos porque estão à margem da sociedade, não querem fazer parte de um grupo social que apresenta convicções inquestionáveis, vivem livremente e, veem, por isso, a realidade com olhar descongestionado, capaz de identificar o que é digno de riso.

Em A Vida Trágica de Carlota: a Filha da Engomadeira, a narração não se faz apenas pelos mendigos, ocorre novamente a diluição do foco narrativo, já que pela paráfrase resumitiva, várias personagens sintetizam acontecimentos de que participaram direta ou indiretamente. Dessa "multivocalização" - termo cunhado agora para sintetizar a 
multiplicidade de narradores - decorre a alteração de como são apresentadas algumas personagens. Em Camilo, um narrador amargurado e um tanto vingativo, desforra-se de alguns tipos que o incomodam. Assim, Inácio Botelho, nobre que engravida uma moça e não se casa com ela, nem lhe reconhece o filho, morre solitário e roubado pelos que humilhou. Eduardo é envilecido por suas mentalidade usurária.

Na peça, por outro lado, Inácio é visto por seus empregados como "um homem como deve ser!" (Gomes, p. 11), pois a simplicidade e falta de consciência social da maioria das personagens impedem-nas de vê-lo como um tirano, opressor. Manuel, por seu turno, adquire foros de herói.

O acréscimo de personagens oriundas da classe popular é relevante para a estilização do paradigma. A taberna e seus frequentadores tornam a ser cenários em que bêbados e homens do povo libertam-se e conversam tranquilamente. A personagem Taberneira volta à cena com acentuada carga de feminismo e senso crítico. Ela não deixa de censurar Gregório quando ingenuamente sugere que Carlota teria seduzido seu pobre amo, instruída pela mãe: "Pois!... de certeza!... A mãe devia ter cá uma instrução!..." (Gomes, p.21). A alteração de "instruída", isto é, motivada pela instrução ou "educação" revela uma crítica irônica ao abandono social. E o humor flui, em cima de trocadilhos, castigando a ignorância e tolice de alguns homens ávidos por manter o poder estabelecido, enquanto esclarece que a pobreza leva à miséria moral. Também a mãe de Augusto é moça simples. Em Gomes, Balbina é a cozinheira, seduzida e grávida pelo patrão. Como ocorre com Carlota, o único reconhecimento oferecido à amante é ser chamada de "dona" pelos criados. Acréscimo significativo são as prostitutas esbanjam inveja e rancor entre si em busca de garantir o sustento. São mulheres comuns, rebaixadas pela fome, oprimidas por um homem e iludidas com a re-inserção social. A miséria moral é, portanto, outra acepção do termo na peça. Em uma sociedade com ideologia cristalizada e repressora, muitos são marginalizados, mas esses não se rebelam, pois são dominados pela mentalidade dominante e querem fazer parte do grupo.

O grotesco como motivo de riso e de revisão da mentalidade dominante vem à cena pela a personagem "anão", um contraponto para a figura do médico. Responsável por assobiar para acalmar os pacientes, o anão sente-se privilegiado por ter um papel social. Médico e monstro têm aqui novo significado, são, como no romance inglês, seres 
complementares, mas não pela disparidade de índoles opostas. Completam-se porque a um cabe o papel de culto e racional e ao outro, o de sensível e acolhedor. Transforma-se, pelo humor, o feio em belo. Somente com a ajuda de seu duplo, o médico cumpre papel mais amplo, pois traz alívio à dor física e psicológica, sem destituir-se de sua postura de ser privilegiado pela Ciência. Tendo a seu lado um ser "menor", que se digna a olhar para as necessidades emocionais dos pacientes, ele pode dedicar-se a ser apenas um cientista. $\mathrm{O}$ anão é capaz de fazer papel de filho, de amante e até de padre para acalmar e acolher. Monstruoso, porque diferente, é coadjuvante, menor e sem relevância, mas imprescindível. Sugere-se, por esse quadro, que a dualidade complementar das duas personagens sugere a incompletude de figuras socialmente valorizadas.

A peça enfatiza, portanto, uma massa sofrida e inferiorizada que necessita de um porta-voz íntegro e idôneo. Cabe ao novo Manuel de Castro este papel. No amante, Carlota encontra um confidente que respeita sua condição e propõe a lutar por alterá-la. Ela não é tratada como um ser frágil e incapaz, mas como uma pessoa que deve desenvolver o senso crítico e não se deixar subjugar. Manuel oferece a possibilidade de aceitação do diferente.

A transvalorização da personagem Castro é significativa e justifica a ênfase dada no Prólogo da peça à associação entre a narrativa e Os miseráveis, de Victor Hugo. Com o mesmo tom revolucionário e crítico, Manuel contesta uma sociedade em que há

[...] proscrição social, forçando a existência, em plena civilização, de verdadeiros infernos, e desvirtuando, por humana fatalidade, um destino por natureza divino; [...] [uma sociedade onde prevalecem] os três problemas do século, - a degradação do homem pelo proletariado, a prostituição da mulher pela fome, e a atrofia da criança pela ignorância [...](Hugo, 1956, p. 9)

A personagem gomesiana, diferente do repulsivo viciado de Coisas espantosas, faz discursos libertários e alerta para os males da desigualdade social. A relação intertextual com a narrativa hugoana é um meio de criticar o atraso da sociedade portuguesa.

Estes ricaços são todos iguais: passam a vida a encher o bandulho e a lixar o próximo; olham p'ra gente todos empertigados, como se tivessem o rei na barriga; põem-se nas criadas, e elas... bico calado ou lá se vai o emprego; são mais miseráveis que aqueles desgraçados que têm de roubar p'ra comer, ou daquelas que para aguentar a vida têm de aguentar com eles!...

$[\ldots]$

E gajos deste calibre são tão gananciosos que nunca se contentam com a riqueza que tiveram em vida [...] (Gomes, p. 25) 
Assim, roubar parte do dinheiro de Inácio deixa de figurar um crime para representar partilha e distribuição de riqueza. Diferente das demais personagens, Manuel não acredita em Fado, nem é crédulo, recusa-se a entregar-se nas mãos de Deus, quer refazer sua vida com igualdade e justiça.

Sempre fomos uns miseráveis, Carlota... e sabes por quê?! Porque há outros, ainda mais miseráveis que nós, que fazem sempre as contas à maneira deles, e à maneira deles gente como nós nunca tem direito a nada!... Mas "cá se fazem, cá se pagam!" ... e agora... podemos refazer a nossa vida... (Gomes, p. 29)

O termo "miseráveis" passa a ter nova conotação. Patrões miseráveis são os egocentrados, os ególatras, que dispõem da vida dos menos privilegiados em prol de prazeres pessoais e mesquinhos. São os que não se importam com o destino dos mais pobres que lhes configuram apenas como um meio de manter prerrogativas. Miseráveis porque mesquinhos e egoístas, isentos de compaixão e ética.

Carlota apresenta-se como ingênua e mostra não conseguir compreender a visão de Manuel, ao insistir em considerar Inácio um bom homem, afinal este "até mandou que toda a gente me chamasse dona... dona Carlota..."(Gomes, p. 25). Afigura-se moça inocente e crédula fazendo com que Castro evidencie seu caráter revolucionário e propague que um título em troca da dignidade não é índice de que o patrão esteja preocupado com ela. A atitude de Carlota deve ser considerada com certa prevenção, afinal há um contrassenso no comportamento da moça em elogiar o patrão e traí-lo. Esse antagonismo sugere que pode haver fingimento ou dissimulação na personagem, hipótese que é reforçada pela apresentação da moça no início da peça como alguém que fingia para a mãe: "Carlota fingia dormir, para não atormentar ainda mais a pobre mãe ... e continuou a fingir ... a fingir ..."(Gomes, p. 9)

Com base nesse pressuposto, a astúcia de Manuel diminui muito em relação à amante. Ele tenta manipulá-la considerando-lhe as crendices, assim preconiza que foi o destino que lhes deu a oportunidade de ter o dinheiro para serem felizes. Entretanto, caso se considere que também as crenças e receios da moça são mero fingimento, o rapaz revela-se tolo diante de um indivíduo mais arguto. Essa inversão dissimulada de papéis já se enuncia pelo fato de ela sustentar-lhe, tomando, por isso, prerrogativas no relacionamento. 
A fim de garantir a idoneidade do caráter de Manuel, na peça a quantia de que ele se apropria não consta do testamento oficial, mas de um bilhete deixado ao filho. $\mathrm{O}$ rapaz não rouba o dinheiro oficialmente legado à família, nem falsifica a carta, já que Inácio mantém a paternidade como um ato ilícito e desvia dinheiro para o sustento do filho. Na novela, o testamento é dado ao filho, no intertexto, mero bilhete lhe é entregue, não há intenção de perfilhação. Percebe-se, portanto, que também Inácio usa de dissimulação e fingimento. A vida em sociedade, repleta de convicções e normas estratificadas, suscita a mentira para assegurar a viabilidade do eu e evitar complicações com o grupo.

Manuel, entretanto, mostra-se fiel a seus princípios e não os abandona. Apropria-se do valor não para usá-lo de maneira individualista e medíocre, como no paradigma, mas, ao contrário, propõe-se a estabelecer alguma condição de igualdade e justiça.

Nesse sentido, também o ataque a Gregório compõe-se de modo diferente. Surpreendido pelo empregado, Manuel defende-se com um garfo e fere de morte o oponente. Elimina-se a cena do texto camiliano em que o servo chantageia Carlota e ela insinua ao namorado o desejo de matar o funcionário da casa. Tudo se passa em minutos, não há premeditação, nem intenção homicida. A agressão a Gregório torna-se episódio tragicômico. Em vez de facadas, Manuel defende-se com um garfo. Para tornar ainda mais ridícula a cena, o rapaz não se apressa em fugir porque considera que podem pensar que houve um suicídio. Diante da possibilidade de que o amante seja condenado, Carlota propõe que ele se esconda. Manuel hesita, pretexta ter ouvido uma caravana passando. Essa fala é motivo para a inserção de um ditado popular:

"Mendigos: Se fosse uma caravana, o malandro fiava-se no ditado que diz: Manuel e Mendigos: Os cães ladram e a caravana passa." (Gomes, p. 31)

$\mathrm{O}$ nonsense do dito no contexto em que se insere sugere que nem sempre a associação entre episódios do cotidiano e provérbios populares é eficaz. Insinua-se, dessa forma, que o povo submisso às ideias preconcebidas torna-se cego para a verdade e tem pouco senso crítico.

Carlota mostra ver a situação por ângulo diametralmente oposto ao de Castro. Enquanto ele encara o dinheiro como possibilidade de ter um papel social, ela diz considerar o ato como um crime contra a sociedade e contra Deus. Manuel compadece-se do sofrimento de uma mulher que lhe parece ignorante e miserável. Seu discurso, embora repita quase que ipsis litteris o do paradigma, insere-se em outro contexto. Em Camilo, 
Manuel ilude Carlota e sua fala é mera chantagem para que ela conceba o furto. Na peça, ele é sincero, propõe-se a abandonar o dinheiro e confessar o homicídio para livrá-la do remorso. A inserção de um mesmo discurso em contexto diferente relativiza a palavra, sugerindo que nada é definitivo, nem deve ser interpretado de uma só maneira, o que colabora para tornar alerta o leitor / espectador diante da verdade estabelecida e cristalizada.

Entretanto a visão da moça pode ter outro motivo. Deve-se considerar que, com o dinheiro, a situação dos amantes se alteraria radicalmente, pois ele deixaria de necessitar dela para sobreviver. Assim, ela perderia o papel de provedor e deixaria de ter algum domínio sobre ele. Considerando o fingimento de Carlota como um traço de seu caráter, há que se desconfiar dos motivos apresentados para sua aversão ao roubo.

A cena é interrompida pela entrada do médico e do anão, agora vestido de padre. Deparam-se com Inácio morto e leem o testamento. Ao perceber que havia herdado dez mil cruzados, Carlota enlouquece e é recolhida a um hospício. Novamente, o espectador - leitor deve olhar com desconfiança para a atitude da moça. Ela pode ter fingido enlouquecer para não chamar atenção para seus atos e desvencilhar-se de uma situação-problema. Outra hipótese seria a de que a perda da sensatez decorra do fato de perceber que poderia manter a situação com Manuel como estava, com ela no comando, sem necessidade do roubo, daí o desespero e a dor.

A inclusão da cena do médico, e a supressão do episódio em que o próprio Manuel revela à amante que teria herdado dinheiro do patrão, colaboram para a transvalorização da personagem. Castro não chantageia a namorada, alegando que somente quando ela se reconhece como herdeira, arrepende-se do furto. Ele já não está mais em cena, o público só saberá de seu destino cenas adiante, quando em Paris o moço revela preocupar-se com saber o que teria acontecido com Carlota. Revigora-se, então, Manuel, como legítimo portavoz de uma classe, rapaz íntegro e preocupado com o bem-estar dos seus pares.

A classe a que Castro defende apresenta crendices e superstições, trata-se de personagens socialmente marginalizados, ávidos por encontrarem um espaço na sociedade. Rosa, na peça, é ex-prostituta, Gregório casa-se com ela, conhecendo seu passado porque se sente predestinado a "salvá-la", reconciliando-a com a sociedade. Augusto não se torna o dandy do paradigma, passa a vida em meio a pessoas que lhe desprezam e oprimem, é 
vítima de todo tipo de carência. Os narradores são mendigos crédulos que insistem na ideia de fado. A relação dessas personagens com o misticismo é evidente. A peça parece rumar à dessacralização de símbolos do imaginário coletivo português. A asserção se comprova quando se leva em conta a frequência com que a crença nos ditados é colocada em xeque e ridicularizada.

Exemplos dessa postura diante da cultura popular são a crença no Milagre do Rato (Gomes, p. 58) pelo fato de Gregório ter-se livrado de ser enterrado vivo porque um roedor, no caixão, faz barulho. Carlota, ao verificar que Gregório ainda estava vivo, recusa-se a acreditar em que não houve o crime e considera que sua aparição é um castigo enviado por Deus. Neste caso, deve-se considerar a ambiguidade do caráter da moça e levar-se em conta o crime como condição para separação do casal, trata-se de uma grande ironia e um imenso castigo para Carlota o fato de ter que conviver com Gregório.

Foi Deus... que o mandou... para me castigar... daqui a nada vai desaparecer... é um aviso de Deus para me lembrar que eu ainda não estou preparada para ser feliz... Deus, com toda sua misericórdia mostra-me a felicidade que ele podia ter alcançado... se eu tivesse forças para impedir o ato cruel com que meu amante lhe tirou a vida... (Gomes, p.59)

A fala sugere dramaticidade e sentimentalismo bastante afetados, cumpre desconfiar de Carlota em seus discursos inflamados e piegas, eles podem ser apenas um meio para ela ocultar seus verdadeiros interesses e intenções. Ela pode, entretanto, apenas desejar que Gregório seja um fantasma. Cabe ressaltar a ironia entre considerar "Deus, com toda [...] misericórdia" e a intenção divina de puni-la. Tudo parece indicar que ela quer ser feliz e está pronta para isso, mas finge sentir-se culpada e indigna para não evidenciar seu desejo de permanecer no erro, já que, para ela, a felicidade está em sustentar com o amante criminoso . Assim, pela máscara, ela preserva sua interioridade e o desejo de transgressão, sem ser julgada e condenada por isso. Interessante considerar que a máscara elegida por ela consiste no repetir ideias-chave da concepção de mundo retrógrada portuguesa. Assim, ela mantém-se anônima numa multidão semelhante entre si.

O ditado "Deus escreve direito por linhas tortas" é repetido à exaustão para mostrar uma mentalidade resignada a um suposto destino traçado por Deus. Nessa esteira, Gregório considera lembrar-se do rosto de Rosa, meretriz com quem já tinha ficado, em momento de completa amnésia após o coma, um sinal de Deus para resgatá-la da prostituição. De acordo 
com essa concepção, ele foi "instrumento nas mãos do Senhor para a D. Rosa ser feliz!" (Gomes, p. 62). Nota-se, aqui, como a inserção social é importante para esse grupo.

Deus e a religião estão a serviço do homem e de sua vontade. Os elementos que motivariam a felicidade são a mão de Deus em ação. Com a mesma mundividência, Leonor, senhora de classe abastada, irmã de Inácio Botelho, considera alguém que fale Português em Paris "um enviado de Deus" (Gomes, p. 67) e pretende enriquecer e vencer "Só porque Deus assim o quer" (Gomes, p. 39).

Augusto chega a acreditar em que seja uma afronta a Deus vomitar o que não suportava comer (Gomes, p. 56). Irmã Gama entrega a carta de Carlota a Augusto "Porque Deus, através da Carlota, confiou [...] [lhe] a missão de entregar esta carta" (Gomes, p. 89).

Carlota, para preservar-se e não sucumbir a um meio que propõe a reconciliação com a sociedade pelo casamento, pretexta não poder livrar-se da mão repressora de Deus a constantemente puni-la por seus erros passados. Considera-se "pobre a mal agradecida" (Gomes, p. 76) por não poder conceber, como sua protetora, a possibilidade de ser feliz. Augusto, também ignorante e crédulo - na peça não chega a ir à universidade - considera que se Carlota pecou, Deus já a perdoou (Gomes, p. 52). Os narradores são mendigos crentes em que "[Carlota] Com a graça de Deus tem Augusto a seu lado!/ Seu mal fadado fado acabou[...]"(Gomes, p. 57). Contudo, ao invés de, como Rosa, conceber a possibilidade de ser uma nova pessoa, acreditar em que "o futuro está nas tuas mãos" (Gomes, p. 75), a filha da engomadeira resigna-se a sofrer por acreditar em que essa seja a vontade de Deus.

Aquele que não atravessou convicções diversas, mas fica comprometido na crença que por primeiro o prendeu em sua rede é, [...] em decorrência de sua própria imutabilidade, um representante de culturas atrasadas; é, por essa falta de educação [...] duro, ininteligente, rebelde a todo ensino, sem delicadeza, ser eternamente suspeitoso, sem escrúpulos, que toma meios de fazer prevalecer sua opinião, porque não pode mesmo compreender que deve haver opiniões de outros[...](Nietszche, 2006, p. 298)

Cabe ressaltar que a perífrase é também uma sugestão de que Carlota pensa diferente por ter sido educada apenas por uma mulher. Na peça, o pai nunca retorna, ela não tem que se submeter ao patriarca. Ela domina a mãe e exerce certa influência sobre a humilde mulher. Quando percebe que a genitora não tem mais condições de sustentá-la, propõe-se a "fazer algo que se veja". Toma para si a tarefa de sustentar a família. 
Já que a minha mãe está cega, chegou a altura de eu fazer alguma coisa que se veja!!! [...] Vou malhar no ferro enquanto ele ainda está quente

A minha querida mãe não está cega, mas pouco falta! ... e eu juro-lhe, por alma do meu querido paizinho ... o pão não há-de faltar nesta casa!

Vou ser a mãe do menino Augusto ... e vou passar a engomar as camisas do pai!!!

Juro-lhe que o pão não há-de faltar nesta casa, não seja eu Carlota, a filha da engomadeira. (Gomes, p. 14 e 15)

Sua altivez diante da dificuldade nunca se esvai. Com a morte de Inácio, pede esmola, mas nunca se submete à prostituição, cria máscaras para evitar sucumbir ao meio.

Para preservar-se, ela recusa a vida em sociedade, permanece à margem como "a filha da engomadeira". Diferente do que ocorre no paradigma, Augusto, em Fernando Gomes, pede Carlota em casamento. A moça, no entanto, diz-se fadada à infelicidade pela culpa. Não concebe casar-se com um homem dez anos mais jovem e que foi, em sua infância, mimado por ela como um filho. Rosa usa do saber popular para incentivá-la a esquecer o passado e construir o futuro: "[O que Carlota fez] Não tem remédio! Mas o que não tem remédio remediado está! E toda a gente te perdoou [...]"(Gomes, p. 76). A resignação diante de um obstáculo é reforçada pelo ditado popular. Entretanto, Carlota foge e ingressa em um convento. Ela não não quer ceder a pressão para o retorno à sociedade e à submissão ao casamento, não quer submeter-se, por isso busca um refúgio fora do grupo.

$\mathrm{O}$ convento funciona como um disfarce e reforça o fingimento de Carlota. Fingir gera o isolamento, a desagregação social, já que sua cosmovisão é contrária à do grupo. A recusa de participar da sociedade revela a insistência na valorização do "eu" e de uma visão particular de mundo. Opção semelhante parece ser a das freiras da peça, todas infratoras, isoladas no convento, e a de algumas prostitutas que não pretendem casar-se e inserir-se na sociedade.

A caracterização das freiras é sugerida pelos apelidos das personagens que indicam suas peculiaridades. As religiosas acolhem Carlota e deixam claro que todas têm "telhados de vidro" (Gomes, p. 84) e não estariam, portanto, propensas a julgar, nem a condenar a moça. Irmã Gama desde criança roubava esmolas nas igrejas; Lufadinha passou a vida "numa lufa-lufa à procura dum marido... nessa lufa-lufa conheci [eu] muitos, mas nenhum me [a] quis" (Gomes, p. 84). Borbulha tem tantas bolhas que se torna muito nervosa. (Gomes, p. 85) O hábito é, portanto, um mascaramento, um meio de preservação, e, como 
tal, gera o anonimato, a alteridade. Assim, um risco coloca-se: a perda da identidade pela identificação com a máscara.

$\mathrm{O}$ acolhimento e a confidência das freiras remetem à primeira cena da "Segunda Parte" da peça em que prostitutas conversam com a filha de Carolina. Também meretrizes fingem e ocultam sua verdadeira identidade, estão à margem da sociedade e não preservam as normas. Com aparência chamativa, seduzem, mas escondem sua identidade. Atraem como animais vistosos suas presas e, mestres do engodo, iludem, fazem uso do poder subversor do simulacro. Entretanto, ainda assim submetem-se a um homem e dividem com ele seus ganhos. Apesar de haver tanto entre as prostitutas quanto entre as freiras, certo mal-estar como se disputassem a primazia do bem-querer de Carlota, as mulheres são acolhedoras, parecem reconhecer na moça um semelhante. Todavia, Carlota não pode pertencer a esses grupos, nenhum deles é livre como ela, nenhum deseja a infração. A relação entre os dois grupos considerados antagônicos é um meio de propor uma revisão de ideias estigmatizadas. Sugere-se que se deve ver além das aparências e títulos, ultrapassando preconceitos.

Prostitutas e freiras assemelham-se pela irreverência e aparente resignação. O episódio no "Beco das Atafonas", reitera a visão revolucionária diante da pobreza e desigualdade: "Este mundo é uma miséria... [diz Betinha, uma das meretrizes] ninguém quer saber de ninguém... e p'rá gente não morrer de fome... somos condenadas a morrer de vergonha..." (Gomes, p. 47) O paralelo freiras / prostitutas equiparando os tipos e insinua que estes se aproximam enquanto alegoria dos desejos humanos, na essência são seres semelhantes.. Tanto o convento quanto a prostituição afiguram modos de evasão de problemas. Esta acolhe mulheres famintas; aquele, mulheres sedentas de paz. Trata-se, portanto, de duas formas de marginalização. A reverência cega a um grupo é colocada em xeque. Gama deixa claro que a culpa leva à vida religiosa: "ainda nem sabemos qual foi o pecado que a trouxe até nós!"” (Gomes, p. 83). Carlota recusa a prostituição, porque esta impõe a submissão ao homem; elege o convento como lugar de isolamento e proteção.

O desejo de autopunição é aventado na cena em que as irmãs vão encontrá-la na "Sala de torturas" à busca de castigos. Entretanto, todas as evidências em Carlota devem ser vistas como estratégias de camuflagem. No convento, ela pode desvencilhar-se da presença angustiante de Gregório, prova de que poderia ter seguido com Manuel sem medo de 
repreensões e com recursos próprios para manter sua posição altiva, de "dona" da situação. Além disso, distancia-se de Rosa e sua insistência no casamento e de Augusto com sua proposta de inserção social. Não parece, portanto, buscar castigo ou penitência, mas abrigo para suas convicções.

Em Um estudo autobiográfico, inibições, sintomas e ansiedade leiga e outros trabalhos, Freud estuda os motivos que geram o desejo de isolamento. O caso de Carlota parece elucidar as hipóteses levantadas pelo Pai da Psicanálise acerca da ansiedade e inibição. Para o estudioso austríaco, inibições cumprem diferentes funções, entre as quais estão a autopunição ou a autodefesa. Uma tremenda supressão de afeto faz com que o ego se desequilibre. Como não existe proteção contra estímulos internos, o indivíduo desagrega-se do grupo em busca de proteger-se contra novos traumas ou situações de perigo.

A vida de Carlota é trágica, perde o pai ainda bebê, o amante provedor morre, o namorado foge e sua mãe falece mais tarde. Resta-lhe fortalecer seu eu e autodefender-se. Desviando-se do toque e do contato físico, ela remove a possibilidade de expor-se à perda da própria identidade. Para evitar a repressão e ludibriar a opinião pública, ela cria um meio de manter seu próprio ego, mostrando uma máscara de mulher especialmente conscienciosa e crente, o que agrada à opinião pública.

Nesse sentido, autoprotege-se, cria resistência a qualquer situação que remeta às perdas iniciais. Além disso, guarda um segredo, seu desejo por Manuel e toda a infração que ele representa. Manter um segredo fortalece, torna a pessoa menos manipulável e conserva-se às custas da dissimulação. Há astúcia nas atitudes de Carlota, a mentira exige invenção e memória. A moça transfigura-se, não é mais a personagem frágil e crédula de Camilo, é responsável por autodeterminar-se.

O amor da protagonista por Manuel configura-se um meio de autopreservação: "Deus é testemunha de que te amo mais que a tudo na vida ... se não fosses tu ... eu não sei se teria aguentado tanto tempo ..."(Gomes, p. 26) O convívio com o moço confere-lhe a autonomia de que necessita, daí a importância do rapaz. Ele consiste em um meio de preservar sua identidade e de não sucumbir às convenções. Nessa hipótese, ela não teria arrependimento, nem remorso, mas pretextaria tê-los para preservar-se. Além disso, ao suscitar a compaixão, exerce domínio sobre o outro, atitude que lhe é peculiar. 
Em uma sociedade atrasada e crédula, "mau é ser 'não-moral' (imoral), praticar uma imoralidade, resistir à tradição, por mais radical ou absurda que possa ser." (Nietzsche, 2006, p. 83). Carlota deve preservar, portanto, a aparência de moralidade e tornar-se agradável à opinião pública. Essa atitude decorre da compreensão de que as relações humanas dão segurança ao indivíduo e a simpatia do outro gera a sensação de conforto. Entretanto, viver uma mentira é um fardo muito pesado, e não poder desvencilhar-se dele é um grande problema.

Manuel contraria a visão crédula dominante e deixa claro não ter sido enviado por Deus a Leonor, mas apenas estar por coincidência no mesmo local que ele. Ele é diferente dos outros, tem ideais revolucionários, contesta as convenções. Este espírito é o único, naquele meio, capaz de compreender a irreverência de Carlota. Sem ele, ela não tem um par e pode sucumbir. O duplo fortalece pela identificação e pela comunhão de ideias. Aqui, ver-se no outro não despersonaliza pela percepção de que não se é único, mas fortifica pela consciência de não estar só.Ela teria de lutar contra uma força estável e muito maior que a dela.

De origem humilde, inserida em um meio repleto de crendices e superstições, filha de uma engomadeira, ela ousa pensar diferente do ponto de vista dominante: a religiosidade supersticiosa e o apreço ao casamento. Onde os demais buscam uma crença, ela, como Manuel, questiona ou desilude-se.

\footnotetext{
O pai natal não existe $\ldots$ o paizinho não vai voltar ... as dívidas aumentam ... e Deus dorme ... [...]

Não podemos ficar mais tempo à espera, a ver o que é que acontece amanhã, ou no outro dia, ou no outro ...

O sr. Inácio Botelho ... a mãezinha está sempre a dizer que ele é muito boa pessoa ...

$[\ldots]$

Podia pedir-lhe um aumento de ordenado ...(Gomes, p. 10 e 11)
}

Ela, como seu duplo, parece perceber ou intuir que as normas fundamentam-se na crença de pessoas dependentes e submissas. Daí, a sociedade valorizar a submissão. “Chama-se 'bom caráter' numa criança a manifestação de sua subordinação progressiva." (Nietzsche, 2006, p. 167) Por oposição, a conduta insubordinada é considerada amoral ou imoral, passível de condenação e punição.

A educação aliada à fé trabalha para tornar o homem submisso e dependente, Carlota, no entanto, não recebeu educação convencional, é criada e sustentada por uma 
mulher sozinha, fácil de ser compreendida em suas intenções e estratégias de manipulação. Também a mãe finge e ilude. Entretanto, é crédula. Astuta, a filha percebe que a crença na providência divina enfraquece a autodeterminação. Interessante notar que o nome da mãe e da filha é o mesmo, com sufixos diferentes. Carlota ou Carolina são o feminino de Carlos e significam "viril, varonil" (Guérios, 1994, p. 108). Essa escolha já aponta para o duplo, já que a filha reflete a posição social da mãe - engomadeira - e ocupa seu lugar.

Embora a protagonista não tenha acesso à erudição, ela não recebe restrições do universo masculino em sua educação. Permanece, por isso, com sua vontade de conhecer e de ultrapassar barreiras. O fundamento da subordinação coloca-se pela fé na autoridade absoluta, algo de sobre-humano, geralmente associado ao patriarca. Carlota não pode acreditar nesse ser, pois o que de mais próximo poderia provar essa existência seria a figura paterna, mas ela não a conheceu, foi abandonada.

Sua crença é abalada pelo abandono. A religião poderia trazer-lhe paz e confiança, mas ela perdeu suas ilusões ("Deus dorme" p. 10). A fé amalgama opiniões e ratifica convicções, tornando-as poderosas, mas Carlota desvencilha-se dessa corrente pela desilusão.

Ser filha da engomadeira significa não ser filha de Eduardo, desprezar a paternidade, e, com ela, toda a cosmovisão de uma sociedade patriarcal. "Das paixões nascem as opiniões:a preguiça de espírito as faz cristalizar em convicções." Carlota concebe diferentes motivos de paixão: o abandono do pai, a corrupção moral em prol de sustentar a família, a rejeição do amante. Desse sofrimento, decorre a derrubada de crenças e a geração de nova mundividência, contrária à convencional.

Para Carlota permanecer na busca pela verdade, na recusa às convicções cristalizadas, ela precisa de um par, um duplo, alguém com que se identifique, como Manuel, o revolucionário. Essa hipótese se confirma pela maneira com que ela o recebe no convento:

CARLOTA

Foi o destino ... mas também estava escrito que tu havias de voltar, Manuel ...

MANUEL

Para te ouvir dizer ... "perdoo-te"; ... só assim poderei encontrar a felicidade.

CARLOTA

Se tu dizes que só assim poderemos ser felizes, então eu ... eu perdoo-te. 


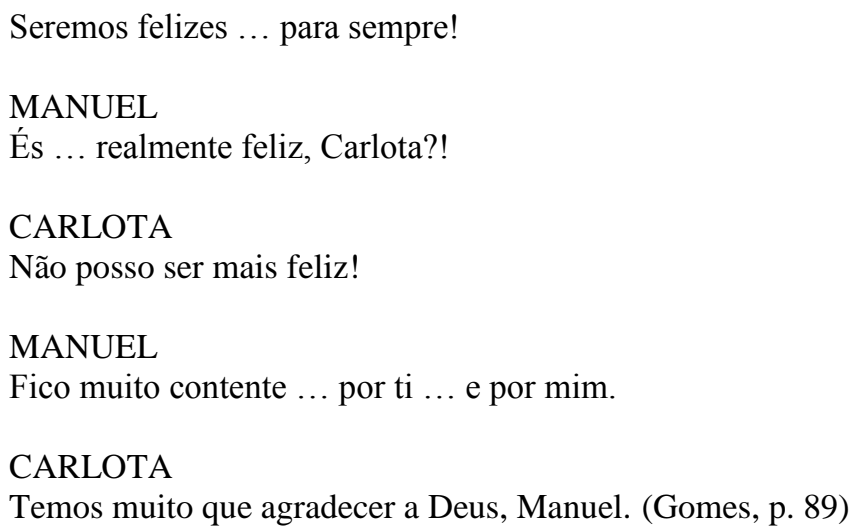

A euforia de Carlota diante do amante revela como ela permanece apaixonada por ele. Assim, sua fuga da casa de Gregório não pode associar-se ao receio de ficar com Augusto, mas à evasão da companhia daquele grupo. Entretanto, ao deparar-se com o amante prestes a sucumbir à sociedade pelo casamento, sente-se sozinha e abandonada. Percebe que não pode viver a verdade, nem permanecer com as máscaras. Nesse impasse, suicida-se. A morte é um meio de alertar para o fim trágico dos que se recusam a obedecer às normas.

Contudo, mesmo após a morte, ela mantém a máscara, pois não deixa sugestões de que seu ato se relaciona ao abandono de Manuel. A inserção da carta redigida pela personagem camiliana a Augusto como confissão de um sentimento que, no intertexto, não existe é a prova cabal da dissimulação e fingimento de Carlota. Aqui o texto transfigura o paradigma, sem alterá-lo, novamente pela descontextualização transforma-lhe os significados.

Nessa esteira, inverte-se o conceito de tragédia. Enquanto esta busca representar o mundo moral e estimular o espectador a fortalecer-se diante dos impulsos do instinto, a peça gomesiana associa o trágico à resignação e ao prevalecer da ignorância. Em um universo repleto de convicções cristalizadas, Carlota não tem espaço e resta extinguir-se para não sucumbir. Assim, ela é dona de seu destino quando opta pela morte. Por outro lado, sua irreverência perde-se com a morte. Ao revelar a tragicidade da vida de Carlota, Gomes propõe a defesa da irreverência. A dor decorre da inadequação aos padrões estabelecidos, da audácia de uma mulher querer afrontar as convenções e relacionar-se com um homem a quem pode dominar. Desfaz-se, assim, o moralismo da tragédia. Propõe-se a transgressão como possibilidade de criarem-se espíritos livres. Não há intenção de castigar. 
A benevolência com os infelizes adquire um novo significado, trata-se de julgar o transgressor como uma vítima e não como um infrator. O suicídio não é, por isso, um delito, mas um ato desesperado por liberdade.

Corrobora esta tese a acepção de "mulher perdida" veiculada em alguns trechos:

Eu já sei que de hoje em diante sou entre as mulheres perdidas a mais desgraçada de todas. (Gomes, p. 31, 42)

D. ROSA

Pobre mulher! ...É uma mulher ... perdida!

\section{MENDIGOS}

Quem vir uma mulher perdida

Que nunca a trate com desdém.

Eu vos lembro que Deus castiga!

Sem dizer quando nem a quem!

Todos devemos ter compaixão

Da mulher desprezada, chorosa!

Antes de cair na perdição,

ela também foi virtuosa!

(Gomes, p. 60)

Fui uma mulher perdida, mas Deus, deu-me o mais que podem ter mulheres como eu ... o amor do menino que eu ajudei a criar ... (Gomes, p. 91)

Carlota considera-se e é julgada como uma "mulher perdida", entretanto, o coro sugere o respeito e a compaixão por esse tipo de pessoa. Esse alerta parece uma sugestão sutil e, portanto, irônica, de que a "perdição" nem sempre é motivo de descaso e deve, por isso, ser levada em consideração. Os conceitos cristalizados são novamente revisitados e desmontados.

O coro final interrompe o pasmo do leitor / espectador e ativa-lhe o senso crítico: "Ninguém sabe quando nasce / P'ro que nasce uma pessoa." (Gomes, p. 92), sugerindo que o destino pode ser traçado pelo próprio indivíduo.

Sem o desvencilhar-se de ideias preconcebidas como o "fado", não se tem consciência da própria força, não se ultrapassam barreiras, concepções antiquadas e seus representantes. Não se evolui. Ousadia gera progresso, instrução, perseverança no raciocínio.

Como uma sombra, o que não se liberta de tabus e crenças, vive sem individualidade, sem expressão, é plano, vazio. 
Pelo suicídio, Carlota tece o próprio destino. A ideia de fado, tão evidente e enfatizada, parece esvaziar-se e o aforismo "O futuro está em suas mãos" (Gomes, p. 77) passa a prevalecer. Não há um destino imposto por uma força mística, mas o livre-arbítrio. Gomes constrói um drama e não uma tragédia.

Ainda mais relevante é notar que a valorização do fingimento, da mentira como meio de autodeterminação é, em última instância, a valorização da própria ficção que subverte a verdade e a recria. Para isso, concorrem as citações do paradigma, o uso do metateatro, com a quebra da quarta parede. (Gomes, p. 6, 7, 8, 58, 66) Trata-se de uma literatura autoconsciente, em que as personagens mostram a ilusão pari passu à realidade. Todas têm consciência de sua própria teatralidade. Essa postura pode ser uma sugestão de que também o leitor / espectador deva repensar os acontecimentos, como se tivessem sido planejados e não apenas acidentalmente ocorridos. Ser ou não ser torna-se chave para o desvendar de intencionalidades e convicções a fim de não deixá-las cristalizar. 


\section{RESTA RIR}

Os conflitos do romântico refletem-se no homem contemporâneo, já que se inserem em um mundo que não conseguem compreender. Aquele discorda de seu meio, este vive em um lugar em constante transição, tanto um como outro colocam sua identidade em xeque e procuram espelhos em busca de identificar-se e individuar-se. A ironia está em que o outro, quando reflete as características do eu, não só lhe dá uma identidade, como também sugere que esta não é única e individual, o que gera a despersonalização.

Camilo e seus heróis vivem no mesmo universo dramático, de cores intensas, ao mesmo tempo sublime e sórdido. $\mathrm{O}$ ideal dum programa imaginário e a realidade duma experiência vivida encontram-se unidos e indissociáveis [...] [Assim] pôde edificar a expressão dum drama que era bem um drama nacional. (França, 1993, p.285)

Além das condições históricas, o romântico vive um dilema ideológico. Partindo da concepção de que o processo da evolução cósmica parte da "união mística", o homem da época concebe a existência separada como um mal, já que é mero reflexo do Todo. Cada indivíduo traz em si um gérmen da unidade perdida, o que o torna ambiguamente um princípio de individuação e de separação. Do mesmo modo, toda criatura é apenas reflexo da realidade sublime de completude. Nesse sentido, somente a morte ou o Amor podem reunir os indivíduos. Inicia-se, pois, a busca pela segunda criatura que possa acabar com o isolamento do eu.

Contudo só é possível encontrar-se no outro quando as aparências, efêmeras e enganosas, são rechaçadas. Despojado de aspectos materiais, o indivíduo deixa entrever seu eu verdadeiro, sua identidade original. Daí o desprezo do romântico pela materialização do mundo burguês.

Considerada neste aspecto, a existência imediata apresenta-se como um sistema de relações necessárias entre indivíduos e forças na aparência independentes no qual cada elemento ou é utilizado como meio ao serviço de fins que lhe são estranhos ou carece ele próprio do que lhe é exterior para o utilizar como meio. (Hegel, 1993, p. 90) 
O exterior é finito e particular, levado em consideração, suscita paixões estéreis que desfiguram o ser tal como era originalmente, os traços mais profundos do espírito, livres e infinitos. O dilema consiste em transpor a finitude da existência para a conquista da liberdade genuína.

A contemporaneidade traz negações às antigas certezas. Não é possível resgatar a vitalidade e a simbologia do passado. A identidade do presente compromete-se pelo prefixo "pós", o qual não só sugere o esgotamento potencial de um tempo, como o esvaziamento do potencial criativo e racional já que não constrói, apenas restaura, recompõe com cinismo e desencantamento. Insinua a sensação de fadiga, crise de sentido ético e existencial.

Não se trata de mera nostalgia ou conservadorismo, mas de revelar em que medida as transformações estruturais deslocaram valores, propuseram uma inovação contínua que gera mal-estar e grave crise cultural.

As concepções de sujeito, relacionadas ao racionalismo e ao empirismo, tornam-se insuficientes, não abarcam a subjetividade do indivíduo, a qual cresce e deve ser problematizada. A posição do Homem no universo não é mais central, organizada e hierarquizada desde a revolução científica do século XVIII que trouxe a noção da infinitude do Cosmo.

Os fundamentos para a teoria e para a práxis, antes concretos e organizados, agora se esfacelam. O indivíduo torna-se mero reflexo da exterioridade e, como tal, deve ser construído, assim como o conhecimento científico.

Para acentuar a sensação de dilaceração do "eu", as Guerras Mundiais evidenciaram a quebra da relação entre razão científica e emancipação da humanidade, demolindo a ideologia do progresso global como alicerce da modernidade. As atrocidades decorrentes das guerras apresentaram como a razão pode voltar-se contra a humanidade, revelando o prejuízo da aparente prosperidade científica.

Dessa desilusão, nascem o cinismo, o tédio e uma nova sensibilidade para o questionamento das verdades instituídas e para a reavaliação do passado. Entretanto, em meio ao ceticismo, é necessário criar novas técnicas para essa análise e para o incentivo ao abandono da inércia, da resignação diante da tirania dos fatos. A indiferença, o individualismo destrutivo devem ser desafiados e colocados em xeque.

O pessimismo, a banalidade, a subjetividade narcísica devem ser derrocados. A 
alteridade, a diferença, a investigação ontológica devem ser estimuladas. a estratégia utilizada por Fernando Gomes para desentorpecer, minar o ceticismo e estimular a criação é o humor. Pela astúcia, manifesta não mero cinismo cético, mas a alegria que a vida pode ter quando valorizada em seus aspectos mais simples e divertidos.

Nesse sentido, o cômico é, em Gomes, um convite para um novo olhar para a interação. Para isso, alguns recursos linguísticos são fundamentais. Os alogismos sugerem o desmascaramento do que é estúpido e está encoberto. Evidencia-se, dessa forma, a ignorância como fonte do cômico. A oposição entre argúcia de um e a estupidez do outro gera o riso saudável, sem arrogância, nem prepotência, mas simpático. A ignorância muitas vezes revela bondade, benevolência.

Os recursos linguísticos de que se vale Gomes associam-se ao caráter popular de suas personagens. Os trocadilhos revelam a agudeza do dramaturgo, sua capacidade de explorar a polissemia e a paronomásia.

Pela ironia, o autor torna seu público cúmplice de suas ideias. Riem com ele os que o compreendem. A ironia tem destinatário e um alvo, por isso cria comunidades capazes de perceber seus significados. É uma modalidade reflexiva, suscita uma atitude intelectual, já que pressupõe a consciência entre o dito e o não dito e a capacidade de representar a realidade de maneira figurada e literal. Além disso, a comunidade de fala deve compartilhar pressupostos, crenças, valores. Há, portanto, necessidade de um contexto discursivo compartilhado.

Gomes, por compreender a ideologia de seu espectador, dialoga com textos que enformam sua cultura a fim de despertar-lhe o interesse e a reflexão. Pela ironia, os interpretadores tornam-se agentes, não recebem passivamente o enunciado.

Também a chamada ironia romântica e a metalinguagem são recursos úteis às peças gomesianas.

[...] a ironia romântica [...] abarca dois planos da manifestação literária [...]. Um envolve a reformulação do fazer literário e o questionar desse fazer. [...] Outro pressupõe a reformulação do conceito de 'inspiração' [...] De sopro divino, de móbil de certo modo exterior ao poeta, a inspiração internando-se, torna-se sopro vital por obra do tão apregoado centrar do eu. [...] a arte passa a ser uma 'forma pública de auto-análise'. [...]

A ironia como autocrítica tende a estabelecer o equilíbrio no excesso de convicção, é tensão primordial no dizer que afirma negando. (Ferraz, 1987, p. 39)

Esse é um recurso especialmente eficaz para promover o desentorpecimento porque desilude, apresenta a diferença entre realidade e ficção. 
Considerando que ironia vem de dissimulação, a intertextualidade é, em última instância, um recurso irônico já que sugere ideias indiretamente (Hutcheon, 2000, p. 207). Somente pela leitura e interpretação do paradigma alguns significados tornam-se concretos. Com base nesse pressuposto, o contexto textual camiliano antecipa características do comportamento humano e social de maneira que serão retomadas e revisitadas por Gomes.

Também a escolha do tipo e do nome das personagens é um recurso irônico ou humorístico. As personagens criadas por Gomes recebem apelidos que enfatizam defeitos físicos ou sua condição social. Gimbrinhas, por exemplo, é usado em dialeto local para referir-se ao indivíduo fraco, insignificante.

Povoam o universo gomesiano personagens grotescas, diversas do que é considerado e aceito como "normal". Cegos, fanhosos, anões, corcundas, ou até mesmo um cego surdo-mudo ou um cego corcunda abundam nas peças, trazendo o riso e a irreverência. Fazem parte desse universo seres considerados sublimes, pois são retratados comicamente. As freiras de A vida trágica de Carlota, a filha da engomadeira, por exemplo, equiparam-se a prostitutas e são alcunhadas com base em seus pecados.

O reaproveitamento de ditados populares e a distorção de alguns deles dá novo colorido à ideologia de pessoas simples, além de sugerir a revisão de ideias cristalizadas. Interessante notar que o recurso foi utilizado por Saramago, em Ensaio sobre a cegueira como sugestão de que a alteração da concepção de mundo das pessoas cegas reflete-se na sabedoria popular, modificando os provérbios.

Em um mundo em que a violência oprime e as modificações tecnológicas despersonalizam, é necessário encontrar um meio de exorcizar e desmitificar os grandes fantasmas. Em um universo onde prevalece uma visão passadista e acomodada, é necessário estimular o movimento.

O riso torna-se ferramenta para a reorganização das concepções ultrapassadas, dos medos, dos entraves para o progresso intelectual. Tem, portanto, conotação psicológica e social.

O humor revela-se, em Fernando Gomes, como aptidão, inclinação para reelaboração dos dados mais prosaicos da realidade, evidenciando o que há de lúdico e deve ser valorizado. Dessa forma, desentorpece-se o olhar, regeneram-se as forças reprimidas, promove-se a renovação. 
O nonsense toma o lugar do cinismo, renova o humor espirituoso do Romantismo, sem afetação, irreverentemente. Olhar a realidade de forma bem-humorada, jovial, encanta, é um convite para a re-interpretação da vida. A sagacidade coloca-se a serviço da dessacralização e desmitificação de certa maneira receosa de ver a realidade. O cômico suscita cumplicidade e elimina terrores.

Não se trata de hedonismo, nem de otimismo infundado, mas de um tônico regenerador das forças reprimidas. Promove-se uma reorganização mental, uma revisão de como se deve olhar o mundo para eliminar a depressão que causa a inércia. Não apenas se elege o grotesco como motivo de riso, como também nasce a necessidade de reformar as concepções vigentes que estimulam o atraso pessoal e social.

O humor negro presta-se, então, a problematizar os motivos de medo. A linguagem obscena popular promove o diálogo, a identificação do povo e sua participação, possibilita maior interação. Possibilita que a "arraia miúda" construa a história. Daí a importância dos narradores e das personagens populares, as cenas são construídas e comentadas com base em princípios diferentes dos socialmente instituídos.

Gomes parece mostrar como se pode reaprender a rir de forma alegre e descontraída. O dramaturgo parece criar lentes que dão coloridos às cenas cotidianas e fazem rejeitar o previsível. A credulidade é ridicularizada e o senso crítico valorizado. Contribuem para isso o paralelo estabelecido entre grupos tradicionalmente considerados antitéticos, como freiras e prostitutas.

A redundância, a estabilização, o conhecido entorpecem, geram a inércia que deve ser suspensa e obstada. O obstáculo, entretanto, impede o movimento, ainda que temporariamente e é necessário promover a ação. Nesse sentido, o humor é valioso, pois desperta, estimula o movimento em outra velocidade ou direção.

O previsível dá origem à inação, ao acomodamento e, por extensão, a uma postura acrítica, sem criatividade, apática. Diante da impassibilidade da massa, os que a representam ganham poder de manipulação, além de autonomia para direcionar o povo sem entraves.

No âmbito individual, da resignação decorre o retrocesso, a falta de progressão. $\mathrm{O}$ resignado não evolui, nem mesmo em autoconhecimento. Iludido, não tem sonhos, não cria, submete-se à rotina e ao cotidiano, sem conquistas, nem autoconfiança. 
O humor mobiliza, ventila e ilumina consciências empoeiradas, ideias armazenadas no sótão a fim de que elas sejam renovadas. Nessa esteira, o chiste romântico é ferramenta para o projeto de recuperação da totalidade perdida. Conciliar a consciência racional à criativa pelo dito espirituoso é um meio de reunir o lado humano ao espiritual, sublime, o Todo. A capacidade de elaborar o chiste revela qualidades de um sujeito hábil, criativo e crítico que se dirige a seus pares, estimulando-os e provocando-os.

Em Gomes, o cômico oscila entre o nonsense e o humor negro. $\mathrm{O}$ trocadilho recupera o chiste e corrobora o propósito de despertar entorpecidos. Promover a crítica é estimular o indivíduo a reordenar sua visão de mundo e a si mesmo, tornar consciente o que jazia no inconsciente. $\mathrm{O}$ dito espirituoso promove a reflexão e põe em movimento tudo o que há no eu, sua razão e fantasia, reunindo o eu inteligível ao eu empírico.

A força encantatória da literatura amplia-se pelo humor já que este incentiva a participação, a cumplicidade. Pela força da palavra plurissignificativa, o espírito toma forma, concretiza-se.

“O trabalho da 'crítica genuína' é despertar o gênio próprio de cada um, mas isso implica, paradoxalmente, entender sobretudo o gênio dos outros." (Suzuki, 1998. p. 216). Assim, o literato que movimenta pela crítica bem-humorada é o que, antes de tudo, conhece a alma humana e pretende despertá-la.

O cômico, então, acaba gerando a reflexão filosófica, ontológica, incentiva o exame do sujeito, do ser. Nesse sentido, o diálogo intertextual colabora como duplo. Eleger Camilo, reconhecido intérprete da alma humana e do povo português e reavivar seu texto promove um questionamento em torno de "Quem sou eu?", já que o encontro com o duplo gera autoconsciência.

Reconhecer a diferença entre o paradigma e o intertexto promove a capacidade de perceber os vários pontos de vista sobre um tema.A simultaneidade de cenas, ou as cenas que são narradas por várias personagens diferentes - a multivocalização - são uma sugestão de que o mesmo episódio pode ser visto de vários ângulos.

Revisitar o texto camiliano e acrescentar cores ao que parecia desbotado pode ser um meio de reavaliação do ser humano enquanto fragmento de uma realidade. Refletido no texto, o homem se revê, reconhece-se e amplia-se. O comum e conhecido adquire aspecto 
misterioso, intenso, mítico. Dessa forma, o sujeito se encontra. A arte eleva o homem por representar seus anseios e potencializá-los.

A consciência que cada um tem de si e dos objetos que o cercam realiza-se e concretiza-se no texto. Enquanto diálogo, a intertextualidade possibilita a organização do ser, a exploração da densidade da vida que se recria e se renova. Idealismo e realismo unificam-se, o caráter ideal, ideológico, original, transcendental e eterno do pensamento humano presentifica-se, realiza-se no objeto - texto - tornando-se real.

O texto proporciona o encontro entre o que há de transcendental e de concreto no homem, por ele, o homem observa-se e compreende-se. "A individualidade construída pelo romancista [ e pelo literato, em geral] não é uma pálida imagem do criador, mas a coesão orgânica interna de um caráter plural." (Suzuki, 1998, p. 114). O texto torna-se a efetivação de um saber transcendental e, por siso, a cada escritura novos conhecimentos são revelados.

A importância da decodificação de conceitos gera o dialogismo e a participação efetiva do leitor / espectador. Frente ao desconhecido, devem-se procurar alternativas de autogerenciamento. O duplo - mesmo outro texto - é um meio de conquistar o autoconhecimento. Diante da acomodação, é necessário movimento, resta, portanto, rir e fazer rir. 


\section{REFERÊNCIAS}

\section{Teatro}

ABEL, Lionel. Metateatro: uma visão nova da forma dramática. Rio de Janeiro: Jorge Zahar Editor, 1968.

ARTAUD, Antonin. O teatro e o seu duplo. Tradução Fiama Hasse Pais Brandão Lisboa: Fenda Edições, 1996.

BORIE, Monique, ROUGEMONT, Martine de, SHERER, Jacques (org.) Estética teatral: textos de Platão a Brecht. 2.ed. Lisboa: Ed. da Fundação Calouste Gulbekian, 2004.

BORNHEIM, Gerd. O sentido e a máscara. São Paulo: Perspectiva, 2004.

CRUZ, Duarte Ivo. Introdução à história do teatro português. Lisboa: Guimarães \& Cia Editores, 1983.

DESGRANGES, Flávio. A pedagogia do espectador. São Paulo, Editora Hucitec, 2003.

GUINSBURG, Jacó. Da Cena em Cena: ensaios de teatro. São Paulo: Perspectiva, s/d. et allii. Semiologia do teatro. São Paulo: Perspectiva, 1978. HEGEL, Friedrich Estética. Lisboa, Guimarães, 1980.

MAGALDI, Sábato - Iniciação ao teatro. 2 ed., São Paulo, Ática, 1985. MOUNIN, George

- "La comunicación teatral", in Introducción a la semiologia. Barcelona, Anagrama, 1972, p. 99-102.

PAVIS, Patrice. Dicionário de teatro.2.ed., tradução para a língua portuguesa sob a direção de J. Guinsburg e Maria Lúcia Pereira. São Paulo: Perspectiva, 2005.

REBELLO, Luiz Francisco. 100 anos de teatro português. Porto: Brasília Editora, 1984.

ROUBINE, Jean-Jacques. Introdução às grandes teorias do teatro. Tradução André Telles. Rio de Janeiro: Jorge Zahar, 2003.

RYNGAERT, Jean-Pierre. Introdução à análise do teatro.tradução Paulo Neves São Paulo: Martins Fontes, 1996.

ROSENFELD, Anatol. Prismas do teatro. São Paulo, Editora Perspectiva, 1993.

SCHILLER, Friedrich. Teoria da tragédia introdução e notas de Anatol Rosenfeld São Paulo: EPU, 1991. 
SZONDI, Peter. Teoria do drama burguês. Tradução Luiz Sérgio Repa São Paulo: Cosac Naify, 2004.

\section{Humor e Ironia}

ALBERTI, Verena. $O$ riso e o risível na história do pensamento. 2 ed. Rio de Janeiro: Jorge Zahar Editor, 1999.

BAKHTIN, Mikhail. A cultura popular na Idade Média e no Renascimento: o contexto de Françoi Rabelais. 7 ed.Tradução de Yara Frateschi Vieira. São Paulo: Hucitec, 2010.

BEAUCHAMP, J. C.. The eternal instant - undestanding irony: an inquiry into meaning, paradoxes and apparent contradictions. Estados Unidos: Universal Publishers, 200.

BERGSON, Henri. O riso: ensaio sobre a significação do cômico. tradução Guilherme de Castilho 2. ed. Lisboa: Guimarães Editores, 1993.

BLOK, Aleksandr. Da ironia. tradução Dimíter Ánguelov. Lisboa: Editoria Pergaminho, 1995.

BRAIT, Beth. Ironia em perspectiva polifônica. Campinas: Editora UNICAMP, 1996.

BOOTH, Wayne C. A rhetoric of irony. Chicago e Londres: The University of Chicago Press, 1975.

BREMER, Jan. ROODENBURG, Herman (orgs.). Uma história cultural do humor. tradução de Cyntia Azevedo e Paulo Soares. Rio de Janeiro: Record, 2000.

COLEBRROK, Claire. Irony: the critical idiom. Londres e Nova York: Routledge, 2004. DUARTE, Leila Parreira. Ironia e humor na literatura. São Paulo: Alameda Casa Editorial, 2006.

DUCROT, Oswald. El decir y lo dicho. tradução Sara Vassallo. 3 ed. Buenos Aires: Edicial, 2001.

ECO, Umberto. Entre a mentira e a ironia. tradução Eliana Aguiar Rio de Janeiro: Editora Record, 2006.

FERRAZ, Maria de Lourdes. A ironia romântica. Lisboa: Imprensa Nacional - Casa da Moeda, 1987.

GARBER, Frederick. Self, Text, and Romantic Irony: the example of Byron. Princeton, New Jersey: Princeton University Press, 1988. 
HUTCHEON, Linda. Teoria e política da ironia. tradução Julio Jeha. Belo Horizonte: Editora da UFMG, 2000.

KIERKEGAARD, S.A.. O conceito de ironia: constantemente referido a Sócrates. Petrópolis, 1991.

LANG, Candance D.. Irony / Humor: critical paradigms. Baltimore e Londres: The Jonh Hopkins University Press, 1988.

MAURON, Charles. Psicocrítica del gênero cômico. tradução Maria del Carmen Bobes Madrid: Arco Libros, 1998.

MINOIS, Georges. História do Riso e do Escárnio. tradução Maria Elena o. Ortiz Assumpção São Paulo: Editora UNESP, 2003.

MOTTA, Leda Tenório da. Proust: a violência sutil do riso. São Paulo: Perspectiva: Fapesp, 2007.

MUECKE, D.C.. A Ironia e o irônico. tradução Geraldo Gerson de Souza. São Paulo: Editora Perspectiva, 1982. Irony: The critical idiom. 4 ed. London: Methuen \& Co Ltd, 1978.

PROPP, Vladimir. Comicidade e riso. tradução Aurora Fornoni Bernardini e Homero Freitas de Andrade. São Paulo, Editora Ática, 1992.

SEDGEWICK, G.G.. Of Irony: Especially in Drama. 3. ed. Vancouver, Rondsdale Press, 2003.

THOMPSON, Alan Reynolds. The dry mock: a study of irony in drama. Berkeley e Los Angeles: University of California Press, 1948.

\section{Intertextualidade}

ALLEN, Graham. Intertextuality. 7 ed. Londres e Nova Iorque: Routledge, 2006.

BAKHTIN, Mikhail. Estética da Criação Verbal; introdução e tradução do russo Paulo Bezerra; prefácio À edição francesa Tzvetan Todorov. 4 ed. São Paulo: Editora Martins Fontes, 2003.

. O Freudismo; introdução de Paulo Bezerra, tradução de Paulo Bezerra et allii São Paulo: Editora Perspectiva, 2004.

- Marxismo e Filosofia da Linguagem: problemas fundamentais do método sociológico da linguagem; prefácio de Roman Jakobson; apresnetação de marina Yaguello; 
tradução de Michel Lahud e Yara Frateschi Vieira, com a colaboração de Lúcia Teixeira Wisnik e Carlos Henrique D. Chagas Cruz. 12 ed. São Paulo, Editora Hucitec, 2006.

BARBOSA, Márcia Helena et ORMEZZANO, Graciela (orgs.). Questões de intertextualidade. Passo Fundo: Editora da Universidade de Passo Fundo, 2005.

BARROS, Diana Luz Pessoa de et FIORIN, José Luiz (orgs.) 2 ed. 1 reimpr. Dialogismo, Polifonia, Intertextualidade. São Paulo: Edusp, 1994.

BARTHES, Roland. Elements of Semilogy. tradução de Annette Lavers e Colin Smith. New York: Hill and Wang, 1977.

. The Pleasure of the Text. tradução de Richard Miller,15 ed.New York: The Noonday Press, 1990.

.S/Z: An Essay. tradução de Richard Miller, 20 ed. New York: Hill and Wang, 1993.

BRAIT, Beth (org.). Bakhtin: conceitos-chave. 4 ed.São Paulo: Contexto, 2007.

BUBER. Martin. Do Diálogo e do Dialógico. tradução de Marta Ekstein de Souza Queiroz e Regina Weinberg. São Paulo: Editora Perspectiva, 1982.

CLAYTON, Jay et ROTHSTEIN, Eric (Orgs.). Influence and Intertextuality in Literary History. Wisconsin: The University of Wisconsin Press, 1991.

CORRADIN, Flavia Maria. Antônio José da Silva, o judeu: textos versus (con)textos. Cotia: Editora Íbis, 1998.

COWART, David. Literary symbiosis: the reconfigured text in twentieth-century writing. Georgia, University of Georgia Press, 1993.

Criticism, History, and Intertextuality. London e Toronto: Associated University Presses, 1988.

ECO, Umberto. Pós-escrito ao Nome da Rosa, Trad. Aurora Fornoni Bernardini e Homero Freitas de Andrade. São Paulo: Editora Fronteira, 1985.

. The role of the reader: Explorations in the Semiotics of Texts. Bloomington: Indiana University Press, 1984.

. Semiotics and the Philosophy of Language. Bloomington \& Indianapolis: Indiana University Press, 1986.

GENETTE, Gerard. Palimpsests: Literature in the second degree. tradução de Channa Newman e Claude Doubinsky Lincoln e Londres: University of Nebraska Press, 1997.

Intertextuality: new perspectives criticism. New York: New York Literary Forum, 1978. 
KADOTA, A escritura inquieta: linguagem, criação, intertextualidade. São Paulo,: Estação Liberdade, 1999.

KOCH, Ingedore G. Villaça, BENTES, Anna Cristina, CAVALCANTE, Mônica Magalhães. Intertextualidade: Diálogos possíveis. São Paulo: Cortez Editora, 2007.

KRISTEVA, Julia. Introdução à semanálise. tradução de Lúcia Helena França Ferraz 2 ed. São Paulo: Perspectiva, 2005.

ORR, Mary. Intertextuality: Debates and Contexts. Cambridge e Malden: Polity, 2005.

PERRONE-MOISÉS, Leila. Texto, crítica, escritura. 3. ed. São Paulo: Martins Fontes, 2005.

PRINCE, Gerald. Dictionary of Narratology. revised edition Lincoln \& London: University of Nebraska Press, 2003.

RODRÍGUEZ, Mariano. La mente en sus máscaras: Ensayos de filosofia de La psicologia. Madrid: Editorial Biblioteca Nueva, 2005.

SANT'ANNA, Affonso Romano de. Paródia, paráfrase e Cia. 5 ed. São Paulo: Editora Ática, 1995.

\section{Geral}

ALIGHIERI, Dante. A divina comédia: purgatório. Disponível em <http://www.ebooksbrasil.org/eLibris/purgatorio.html>. Acesso em: 25 set. 2008.

ALMEIDA, Fialho d'. Camilo, Eça e Malheiro Dias. Lisboa: Livraria Clássica Editora, 1941.

ALMEIDA, P. Teodoro de. O Feliz Independente. Porto: Campo das Letras, 2001.

ALVES, José Edil de Lima. A paródia em novelas-folhetins camilianas. Lisboa: Biblioteca Breve, 1990.

ANDRADE, Ricardo Sobral de. A face noturna do pensamento freudiano: Freud e o Romantismo Alemão. Niterói: EdUFF, 2001.

ARNAUD, François Thomas Marie de Baculard d'. Fayel. Porto: Oficina de Antônio Álvares Ribeiro, 1803.

ASHBERY, John et alii. Dicionário da Pintura Moderna. São Paulo: Hemus Livraria Editora Limitada, 1981. 
AZEVEDO, António Xavier Ferreira de. Farça Manoel Mendes. Lisboa: Impressão de J.F. Monteiro de Campos, 1815.

BAPTISTA, Abel Barros. Camilo e a revolução camiliana.Lisboa: Quetzal Editores, 1988.

BÉGUIN, Albert. El alma romantica y el sueño. tradução de Mario Monteforte Toledo 2. ed Madrid: Fondo de Cultura Económica, 1993.

BRANCO, Camilo Castelo. "Narcóticos: Traços de D. João 3"." In Obra Completa de Camilo Castelo Branco. Porto: Lello \& Irmãos Editores, 1993, Vol. XV.

BRANCO, Camilo Castelo. Amor de Perdição In: Obras completas. Porto: Lello \& Irmão Editores, 1984. v. III.

BRANCO, Camilo Castelo. Maria não me mates que sou tua mãe! Apresentação Cláudio Giordano São Paulo: Loyola, 1991.

BRANCO, Camilo Castelo. O sangue. Lisboa: Parceria António Maria Pereira, 1907.

BRAGA, Teófilo, História do Romantismo em Portugal fac-símile da edição de 1880. Lisboa: Ulmeiro, 1984.

BOËCHAT, Neide Coelho. As máscaras do cogito: A interpretação da realidade humana pela ontologia fenomenológica de Jean-Paul Sarte. Rio de Janeiro: Nau, 2004.

BROWN, Peter. The body and society: men, women, and sexual renuciation in early Christianity. New York: Columbia University Press, 1988.

CÂNDIDO, Antonio. Tese e antítese. 5 ed. Rio de Janeiro: Ouro sobre o azul, 2006. . Literatura e sociedade. 8.ed. São Paulo: Publifolha, 2000. . O Romantismo no Brasil. São Paulo: Humanitas, 2002.

CHERUBINI, Laura. Uma arqueologia do presente. Disponível em: http://www.toseeinthedark.it/Pt/Laura\%20Cherubini.htm. Acesso em: 04 set. 2009. CHEVALIER e GHEERBRANT. Dicionário de Símbolos. Rio de Janeiro: José Olímpio Editora, 1994.

CINTRA, Sônia Maria de Araújo. A fish with a smile: uma animação que remete ao duplo. Caderno de Pós-Graduação em Letras, São Paulo, Volume 10, no. 2, 2010.

COELHO, Jacinto do Prado. Introdução ao Estudo da Novela Camiliana. 2. ed. refund. e aum. Lisboa: Imprensa Nacional - Casa da Moeda, 1982. v. 1.

COELHO, Neide Böechat. As máscaras do cogito. Rio de Janeiro: Editora Nau, 2004. 
CORRADIN, Flavia Maria. Camilo Castelo Branco: uma dramaturgia entre a lágrima e o riso. Aveiro: Suplemento 2 da revista Forma Breve, 2008.

. Camilo Castelo Branco: - Dramaturgia e Romantismo. 205 folhas. São Paulo, 1997. Tese (Doutorado em Literatura Portuguesa) FFLCH, Universidade de São Paulo.

COSTA, João Bénard. Histórias do Cinema. Col. Sínteses da Cultura Portuguesa. Lisboa:

Ed. Imprensa Nacional-Casa da Moeda, 1991. Disponível em < http://www.amordeperdicao.pt/basedados_filmes.asp?filmeid=499>. Acesso em 25 set. 2008.

COSTA, Ricardo da. Santa Mônica: a criação do ideal da mãe cristã. Disponível em <http://www.ricardocosta.com/pub/stamon.htm>. Acesso em 25 set. 2008.

Dicionário Cronológico de Autores Portugueses In: http://cfp.cmlisboa.pt/pls/htmldb/f?p=334:17:2239811450680509::::P17_AUT_ID:79

Dictionnaire étymologique de la langue latine (Paris, p. Klincksieck, 1967 s.v. spuo)

CURVELlO, Maura Böttcher. Cenas contemporâneas: as máscaras em Camilo. São Paulo, 1997. 154 folhas. Dissertação (Mestrado em Literatura Portuguesa) FFLCH, Universidade São Paulo.

DUARTE, Rodrigo et FIGUEIREDO, Virginia (orgs.). Mímesis e Expressão. Belo Horizonte: Editora UFMG, 2001.

FERRAZ, Maria Cristina Franco. Platão: As artimanhas do Fingimento. Rio de Janeiro: Relume Dumará, 1999.

FERRAZ, Maria de Lourdes. "O Realismo Romântico de Camilo", Arquivos do Centro Cultural Português, XXIX, Lisboa - Paris: Fundação Calouste Gulbekian, 31/12/1991, p. $71-84$

FERREIRA, Alberto. Perspectiva do Romantismo português. Lisboa: Textos de Cultura Portuguesa, 1971.

FRANÇA, José-Augusto, O romantismo em Portugal. $2^{\text {a }}$. ed. Lisboa: Livros Horizonte, 1993.

GARLIPP, Godecke-Koch T, DIETRICH, Haltenhof H. Licantropia: aspectos psicológicos $e$ psicodinâmicos. Acta Psychiatr Scand. 2004. Disponível em <http://www.einstein.br/REVISTA/arquivos/PDF/216-Vol4_N1_P59.pdf>. Acesso em 25 set. 2008. 
GOMES, Álvaro Cardoso e VECHI, Carlos Alberto. A estética romântica: textos doutrinários comentados. São Paulo: Editora Atlas, 1992.

GOMES, Fernando. Amor (também) de perdição.

. A vida trágica de Carlota, a filha da engomadeira.

. Maria, não me mates que sou tua mãe!

. O sangue.

GUÉRIOS, Rosário Farâni Mansur. Dicionário etimológico: Nomes e sobrenomes. Tudo o que você gostaria de saber e não lhe contaram. 4. ed. Curitiba: Edições Ave Maria, 1994. HERCULANO, Alexandre. Eurico, o presbítero. Rio de Janeiro: Editora Três, 1972.

HORACIO. Epístola a los pisones. texto, tradução, ordenação e versão Helena Valentí. Barcelona: Casa Editorial Bosch, 1981.

INFOPÉDIA. Enciclopédia e Dicionários Porto Editora. Disponível em <http://www.infopedia.pt/pesquisa?qsFiltro=14>. Acesso em 25 set. 2008.

IÖWY, Michel, Romantismo e Messianismo. São Paulo: Perspectiva / Edusp, 1990.

José, filho de Jacob WIKIPÉDIA. Disponível em: <http://pt.wikipedia.org/wiki/Jos\%C3\%A9_(filho_de_Jacob)>. Acesso em: 25 set.2008.

JOHNS, Per. Realismo fantástico e floração ecológica. Disponível em < http://www.jornaldepoesia.jor.br/ag51johns.htm>. Acesso em 25 set. 2008.

JOHNSON, Robert A. Feminilidade perdida e reconquistada. tradução Júlia Bárány Bartolomei São Paulo: Mercuryo, 1991.

JUNG, Carl G. AION: Estudos sobre o Simbolismo do Si-Mesmo. 6 ed. Petrópolis: Editora Vozes, 2000.

Ab-reação, análise dos sonhos, transferência. Petrópolis: Editora Vozes, s/d. Os arquétipos e o inconsciente coletivo. 5 ed. Petrópolis: Editora Vozes, 2002.

KISHIDA, Clara Akiko, LANNES, Edson Soares, BRITO, Eliud Lucia de Medeiros Guerreiro, ALBUQUERQUE, José Durval Cavalcante de, SAMPAIO, Naira (Orgs.) Cultura da ilusão. Rio de Janeiro: Contra Capa Livraria, 1998.

LEITE, Dante Moreira. Psicologia e Literatura. 5 ed. rev. São Paulo: Editora Unesp, 2002. Lenda das obras de Santa Engrácia. Disponível em: <http://santaengraciacds.blogspot.com/2005/10/lenda-das-obras-de-santa-engrcia.html> . Acesso em 25 setembro 2008 . 
LERNER, Harriet Goldhor. O jogo da dissimulação: uma provocante análise do fingimento da falsidade e do engano no universo feminino. tradução de Beatriz Raposo de Medeiros São Paulo: Editora Best Seller Círculo do Livro, 1993.

MARÍAS, Juliá. Agostinho. Conferência do curso "Los estilos de la Filosofía", Madrid, 1999/2000. Tradução, p. Ho Yeh Chia, Edição, p. Renato José de Moraes. I Disponível em <http://www.hottopos.com/harvard3/jmagost.htm>. Acesso em 25 set. 2008.

MARTINS, Oliveira. História de Portugal. 17. ed. Lisboa, Guimarães Editores, 1977.

MELO, D. Francisco Manuel de. Epanáfora Amorosa. Lisboa: Livraria Ler,n s/d.

MENDES, João. Literatura Portuguesa IV. Lisboa: Editorial Verbo, 1979.

NETO, Nefatalin Gonçalves. O homem duplicado: tragédia pós-moderna em José Saramago Caderno de Pós-Graduação em Letras, São Paulo, Volume 10, no. 2, 2010.

NICHOLS, Sallie. Jung e o tarô: Uma jornada arquetípica. tradução Octavio Mendes Cajado São Paulo: Cultrix, 2007.

NIETZSCHE, Friedrich. Sobre a verdade e a mentira. Tradução e organização Fernando Moraes de Barros São Paulo: Editora Hedra, 2008.

. Humano, demasiado humano. Tradução Antonio Carlos Braga São Paulo: Editora

Escala, 2006.

NOGUEIRA, Carlos. O essencial sobre a Literatura de Cordel Portuguesa. Lisboa: Imprensa Nacional Casa da Moeda, 2004.

NOGUEIRA, José Couto. In O independente Lisboa 23 agosto 2002

PORTO, Carlos. In Diário de Lisboa, 23 agosto 1988

. In Jornal de Letras, 15 outubro 1991.

PEYRE, Henri. Introdução ao Romantismo. tradução José Sampaio Marinho. 3.ed. Sintra:

Publicações Europa-América, 1995

PORTUGAl, Dicionário Histórico, Corográfico, Heráldico, Biográfico, Bibliográfico,

Numismático e Artístico, Volume IV. Disponível em: 〈http://www.arqnet.pt/dicionario>. Acesso em: 26 abr 2011

RICHTER, Jean Paul. Introducción a la estética. edição de Pedro Aullón de Haro. Madrid:Editorial Verbum, 1991.

ROSSET, Clément. O real e seu duplo: Ensaio sobre a ilusão. Tradução José Thomaz Brum 2. Ed. Rio de Janeiro: José Olympio, 2008. 
ROUSSEAU, Jean-Jacques. Discurso sobre a origem e os fundamentos da desigualdade entre os homens. Tradução Alex Marins São Paulo: Editora Martins Claret, 2004.

RORTY, Richard. Contingência, ironia e solidariedade. tradução Nuno Fonseca. Lisboa: editorial Presença, 1992.

ROUGEMONT, Denis de. O amor e o Ocidente. tradução de Anna Hatherly 2. ed. Lisboa: Veja Editora, 1999.

SAAVEDRA, Cervantes. Dom Quixote. São Paulo, Edigraf, 1960.

SALIBA, Elias Thomé. As utopias românticas. São Paulo: Editora Brasiliense, 1991.

SANTOS, João Camilo. Os malefícios da literatura, do amor e da civilização: ensaios sobre Camilo Castelo Branco. Lisboa: Fim de século Edições, 1992.

SCHEIBE, Karl E.. Espelhos, máscaras, mentiras e segredos: Os limites da previsibilidade humana. tradução de Francisco Gilberto Labate e Sônia Maria Caiuby Labate Rio de Janeiro: Interamericana, 1981.

SCHLAFMAN. Léo. A verdade e a mentira: novos caminhos para a literatura. Rio de Janeiro: Civilização Brasileira, 1998.

SEGORBE, Isabel, Programa da peça In Gomes, $O$ sangue.

SERRÃO, Joel. Temas de cultura portuguesa. Lisboa: Livros Horizonte, 1983.

SILVA, Inocêncio Francisco da. Dicionário Bibliográfico Português. Lisboa: CNCDP, 2001. CD ROM.

SODRÉ, Muniz e PAIVA, Raquel. O império do grotesco. Rio de Janeiro: Mauad Editora, 2002.

SKINNER, Quentin. Hobbes e a teoria clássica do riso. São Leopoldo: Editora Unisinos, 2002.

. Razão e retórica na filosofia de Hobbes. tradução Alessandro Zir São Paulo: Editora UNESP, 1999.

SOBREIRA, Luís. Uma imagem do Campo Literário Português no Período Romântico através dos Best-selleres produzidos entre 1840 e 1860. Disponível em <www.eventos.uevora.pt/comparada/VolumeI/UMA\%20IMAGEM\%20DO\%20CAMPO\% 20LITERARIO\%20PORTUGUES.pdf.>. Acesso em: 25 set. 2008.

SOUZA, Gilda de Mello e. O Espírito das Roupas: A Moda no Século XIX. 3. impr.São Paulo: Companhia das Letras, 1996. 
SOUZA, Eli Fernandes de. O medo do encontro e a crise identitária: Auto dos Anfitriões e O homem duplicado Caderno de Pós-Graduação em Letras, São Paulo, Volume 10, no. 2, 2010.

SUZUKI, Márcio. O gênio romântico: crítica e história da Filosofia em Friedrich Schlegel. São Paulo: Editora Iluminuras, 1998.

Teatro Esfera. Disponível em: http://www.teatroesfera.com/sangue/sangue.htm. Acesso em: 13 jun 2011.

TOMPKINS, Jonhs. Reader-Response Criticism: From Formalism to Post-Structuralism. Baltimore and London: The Jonhs Hopkins University Press, 1986.

TRANCOSO, Gonçalo Fernandes. Histórias de Trancoso. Rio de Janeiro: Calibán Editora, 2008.

Transtorno de Personalidade Narcisista - DSM.I V Disponível em $<$ http://virtualpsy.locaweb.com.br/dsm_janela.php?cod=162>. Acesso em 25 setembro 2008.

TRILLING, Lionel. O eu romântico. Tradução Maria Beatriz Nizza da Silva Rio de Janeiro: Lidador, 1965.

VERDASCA, Fernanda Martins. Fígados de tigre: em busca da origem e genealogia do melodrama.São Paulo, 2002. 262 folhas. Tese (Doutorado em Literatura Portuguesa) . FFLCH, Universidade de São Paulo.

VILELA, Jota. Cuspir no chão. Disponível em <http://www.anjoscaidos.jor.br/temas/temas/idiotice.html>. Acesso em 25 set. 2008.

VIZINCZEY, Stephen. Verdade e mentira na literatura. Lisboa: Editorial Presença, 1992.

YOUNG- EISENDRATH, Polly. Bruxas e heróis: Uma abordagem feminist na terapia junguiana de casais.tradução de Carlos Eugênio Marcondes de Moura. São Paulo: Summus, 1995.

\section{Intertextualidade}

ALLEN, Graham. Intertextuality. 7 ed. Londres e Nova Iorque: Routledge, 2006.

BAKHTIN, Mikhail. Estética da Criação Verbal; introdução e tradução do russo Paulo Bezerra; prefácio À edição francesa Tzvetan Todorov. 4 ed. São Paulo: Editora Martins Fontes, 2003. 
. O Freudismo; introdução de Paulo Bezerra, tradução de Paulo Bezerra et allii São Paulo: Editora Perspectiva, 2004.

- Marxismo e Filosofia da Linguagem: problemas fundamentais do método sociológico da linguagem; prefácio de Roman Jakobson; apresnetação de marina Yaguello; tradução de Michel Lahud e Yara Frateschi Vieira, com a colaboração de Lúcia Teixeira Wisnik e Carlos Henrique D. Chagas Cruz. 12 ed. São Paulo, Editora Hucitec, 2006.

BARBOSA, Márcia Helena et ORMEZZANO, Graciela (orgs.). Questões de intertextualidade. Passo Fundo: Editora da Universidade de Passo Fundo, 2005.

BARROS, Diana Luz Pessoa de et FIORIN, José Luiz (orgs.) 2 ed. 1 reimpr. Dialogismo, Polifonia, Intertextualidade. São Paulo: Edusp, 1994.

BARTHES, Roland. Elements of Semilogy. tradução de Annette Lavers e Colin Smith. New York: Hill and Wang, 1977.

. The Pleasure of the Text. tradução de Richard Miller,15 ed.New York: The Noonday Press, 1990.

.S/Z: An Essay. tradução de Richard Miller, 20 ed. New York: Hill and Wang, 1993.

BRAIT, Beth (org.). Bakhtin: conceitos-chave. 4 ed.São Paulo: Contexto, 2007.

BUBER. Martin. Do Diálogo e do Dialógico. tradução de Marta Ekstein de Souza Queiroz e Regina Weinberg. São Paulo: Editora Perspectiva, 1982.

CLAYTON, Jay et ROTHSTEIN, Eric (Orgs.). Influence and Intertextuality in Literary History. Wisconsin: The University of Wisconsin Press, 1991.

CORRADIN, Flavia Maria. Antônio José da Silva, o judeu: textos versus (con)textos. Cotia: Editora Íbis, 1998.

COWART, David. Literary symbiosis: the reconfigured text in twentieth-century writing. Georgia, University of Georgia Press, 1993.

Criticism, History, and Intertextuality. London e Toronto: Associated University Presses, 1988.

ECO, Umberto. Pós-escrito ao Nome da Rosa, Trad. Aurora Fornoni Bernardini e Homero Freitas de Andrade. São Paulo: Editora Fronteira, 1985.

. The role of the reader: Explorations in the Semiotics of Texts. Bloomington: Indiana University Press, 1984. 
Semiotics and the Philosophy of Language. Bloomington \& Indianapolis: Indiana University Press, 1986.

GENETTE, Gerard. Palimpsests: Literature in the second degree. tradução de Channa Newman e Claude Doubinsky Lincoln e Londres: University of Nebraska Press, 1997.

Intertextuality: new perspectives criticism. New York: New York Literary Forum, 1978.

KADOTA, A escritura inquieta: linguagem, criação, intertextualidade. São Paulo,: Estação Liberdade, 1999.

KOCH, Ingedore G. Villaça, BENTES, Anna Cristina, CAVALCANTE, Mônica Magalhães. Intertextualidade: Diálogos possíveis. São Paulo: Cortez Editora, 2007.

KRISTEVA, Julia. Introdução à semanálise. tradução de Lúcia Helena França Ferraz 2 ed. São Paulo: Perspectiva, 2005.

ORR, Mary. Intertextuality: Debates and Contexts. Cambridge e Malden: Polity, 2005.

PERRONE-MOISÉS, Leila. Texto, crítica, escritura. 3. ed. São Paulo: Martins Fontes, 2005.

PRINCE, Gerald. Dictionary of Narratology. revised edition Lincoln \& London: University of Nebraska Press, 2003.

SANT'ANNA, Affonso Romano de. Paródia, paráfrase e Cia. 5 ed. São Paulo: Editora Ática, 1995.

\section{Geral}

ALIGHIERI, Dante. A divina comédia: purgatório. Disponível em <http://www.ebooksbrasil.org/eLibris/purgatorio.html>. Acesso em: 25 set. 2008.

ALMEIDA, Fialho d'. Camilo, Eça e Malheiro Dias. Lisboa: Livraria Clássica Editora, 1941.

ALMEIDA, P. Teodoro de. O Feliz Independente. Porto: Campo das Letras, 2001.

ANDRADE, Ricardo Sobral de. A face noturna do pensamento freudiano: Freud e o Romantismo Alemão. Niterói: EdUFF, 2001.

ARNAUD, François Thomas Marie de Baculard d'. Fayel. Porto: Oficina de Antônio Álvares Ribeiro, 1803.

ASHBERY, John et alii. Dicionário da Pintura Moderna. São Paulo: Hemus Livraria Editora Limitada, 1981. 
AZEVEDO, António Xavier Ferreira de. Farça Manoel Mendes. Lisboa: Impressão de J.F. Monteiro de Campos, 1815.

BÉGUIN, Albert. El alma romantica y el sueño. tradução de Mario Monteforte Toledo 2. ed Madrid: Fondo de Cultura Económica, 1993.

BRANCO, Camilo Castelo. "Narcóticos: Traços de D. João 3․" In Obra Completa de Camilo Castelo Branco. Porto: Lello \& Irmãos Editores, Vol. XV, 1993.

BRANCO, Camilo Castelo. Amor de Perdição In: Obras completas. Porto: Lello \& Irmão Editores, 1984. v. III.

BRANCO, Camilo Castelo. Maria não me mates que sou tua mãe! São Paulo: Loyola, 1991.

BRANCO, Camilo Castelo. O sangue. Lisboa: Parceria António Maria Pereira, 1907.

BOËCHAT, Neide Coelho. As máscaras do cogito: A interpretação da realidade humana pela ontologia fenomenológica de Jean-Paul Sarte. Rio de Janeiro: Nau, 2004.

CÂNDIDO, Antonio. Tese e antítese. 5 ed. Rio de Janeiro: Ouro sobre o azul, 2006.

CHERUBINI, Laura. Uma arqueologia do presente. Disponível em: http://www.toseeinthedark.it/Pt/Laura\%20Cherubini.htm. Acesso em: 04 set. 2009.

CHEVALIER e GHEERBRANT. Dicionário de Símbolos. Rio de Janeiro: José Olímpio Editora, 1994.

COELHO, Jacinto do Prado. Introdução ao Estudo da Novela Camiliana. 2. ed. refund. e aum. Lisboa: Imprensa Nacional - Casa da Moeda, 1982. v. 1.

COELHO, Neide Böechat. As máscaras do cogito. Rio de Janeiro: Editora Nau, 2004.

COSTA, João Bénard. Histórias do Cinema. Col. Sínteses da Cultura Portuguesa. Lisboa:

Ed. Imprensa Nacional-Casa da Moeda, 1991. Disponível em < http://www.amordeperdicao.pt/basedados_filmes.asp?filmeid=499>. Acesso em 25 set. 2008.

COSTA, Ricardo da. Santa Mônica: a criação do ideal da mãe cristã. Disponível em <http://www.ricardocosta.com/pub/stamon.htm>. Acesso em 25 set. 2008.

Dicionário Cronológico de Autores Portugueses In: http://cfp.cmlisboa.pt/pls/htmldb/f?p=334:17:2239811450680509::::P17_AUT_ID:79

Dictionnaire étymologique de la langue latine (Paris, p. Klincksieck, 1967 s.v. spuo) 
DUARTE, Rodrigo et FIGUEIREDO, Virginia (orgs.). Mímesis e Expressão. Belo Horizonte: Editora UFMG, 2001.

FERRAZ, Maria Cristina Franco. Platão: As artimanhas do Fingimento. Rio de Janeiro: Relume Dumará, 1999.

FERRAZ, Maria de Lourdes. "O Realismo Romântico de Camilo", Arquivos do Centro Cultural Português, XXIX, Lisboa - Paris: Fundação Calouste Gulbekian, 31/12/1991, p. $71-84$

FRANÇA, José-Augusto, $O$ romantismo em Portugal. 2a . ed. Lisboa: Livros Horizonte, 1993.

GARLIPP, Godecke-Koch T, DIETRICH, Haltenhof H. Licantropia: aspectos psicológicos $e$ psicodinâmicos. Acta Psychiatr Scand. 2004. Disponível em <http://www.einstein.br/REVISTA/arquivos/PDF/216-Vol4_N1_P59.pdf〉. Acesso em 25 set. 2008.

GIORDANO Cláudio, apresentação a BRANCO, Camilo Castelo. Maria não me mates que sou tua mãe! São Paulo: Loyola, 1991.

GOMES, Fernando. Amor (também) de perdição.

GUÉRIOS, Rosário Farâni Mansur. Dicionário etimológico: Nomes e sobrenomes. Tudo o que você gostaria de saber e não lhe contaram. Curitiba: Edições Ave Maria, 1994.

HORACIO. Epístola a los pisones. Barcelona: Casa Editorial Bosch, 1981.

INFOPÉDIA. Enciclopédia e Dicionários Porto Editora. Disponível em <http://www.infopedia.pt/pesquisa?qsFiltro=14>. Acesso em 25 set. 2008.

IÖWY, Michel, Romantismo e Messianismo. São Paulo: Perspectiva / Edusp, 1990.

José, filho de Jacob WIKIPÉDIA. Disponível em: <http://pt.wikipedia.org/wiki/Jos\%C3\%A9_(filho_de_Jacob)> . Acesso em: 25 set.2008.

JOHNS, Per. Realismo fantástico e floração ecológica. Disponível em < http://www.jornaldepoesia.jor.br/ag51johns.htm>. Acesso em 25 set. 2008.

JOHNSON, Robert A. Feminilidade perdida e reconquistada. tradução Júlia Bárány Bartolomei São Paulo: Mercuryo, 1991.

JUNG, Carl G. AION: Estudos sobre o Simbolismo do Si-Mesmo. 6 ed. Petrópolis: Editora Vozes, 2000. Ab-reação, análise dos sonhos, transferência. Petrópolis: Editora Vozes, s/d. 
Os arquétipos e o inconsciente coletivo. 5 ed. Petrópolis: Editora Vozes, 2002.

LEITE, Dante Moreira. Psicologia e Literatura. 5 ed. rev. São Paulo: Editora Unesp, 2002. Lenda das obras de Santa Engrácia. Disponível em: <http://santaengraciacds.blogspot.com/2005/10/lenda-das-obras-de-santa-engrcia.html> . Acesso em 25 setembro 2008.

LERNER, Harriet Goldhor. $O$ jogo da dissimulação: uma provocante análise do fingimento da falsidade e do engano no universo feminino. tradução de Beatriz Raposo de Medeiros São Paulo: Editora Best Seller Círculo do Livro, 1993.

MARÍAS, Juliá. Agostinho. Conferência do curso "Los estilos de la Filosofía", Madrid, 1999/2000. Tradução, p. Ho Yeh Chia, Edição, p. Renato José de Moraes. I Disponível em <http://www.hottopos.com/harvard3/jmagost.htm〉. Acesso em 25 set. 2008.

MARTINS, Oliveira. História de Portugal. Lisboa, Guimarães Editores, 1987.

MELO, D. Francisco Manuel de. Epanáfora Amorosa. Lisboa: Livraria Ler,n s/d.

NICHOLS, Sallie. Jung e o tarô: Uma jornada arquetípica. tradução Octavio Mendes Cajado São Paulo: Cultrix, 2007.

NIETZSCHE, Friedrich. Sobre a verdade e a mentira. São Paulo: Editora Hedra, 2008.

NOGUEIRA, Carlos. O essencial sobre a Literatura de Cordel Portuguesa. Lisboa: Imprensa Nacional Casa da Moeda, 2004.

PEYRE, Henri. Introdução ao Romantismo. Sintra: Publicações Europa-América, 1995

PORTUGAl, Dicionário Histórico, Corográfico, Heráldico, Biográfico, Bibliográfico, Numismático e Artístico, Volume IV. Disponível em: 〈http://www.arqnet.pt/dicionario〉. Acesso em: 26 abr 2011

RICHTER, Jean Paul. Introducción a la estética. Madrid:Editorial Verbum, 1991.

ROSSET, Clément. O real e seu duplo: Ensaio sobre a ilusão. Rio de Janeiro: José Olympio, 2008.

ROUGEMONT, Denis de. O amor e o Ocidente. tradução de Anna Hatherly 2. ed. Lisboa: Veja Editora, 1999.

SAAVEDRA, Cervantes. Dom Quixote. São Paulo, Edigraf, 1960.

SCHEIBE, Karl E.. Espelhos, máscaras, mentiras e segredos: Os limites da previsibilidade humana. tradução de Francisco Gilberto Labate e Sônia Maria Caiuby Labate Rio de Janeiro: Interamericana, 1981. 
SCHLAFMAN. Léo. A verdade e a mentira: novos caminhos para a literatura. Rio de Janeiro: Civilização Brasileira, 1998.

SERRÃO, Joel. Temas de cultura portuguesa. Lisboa: Livros Horizonte, 1983.

SILVA, Inocêncio Francisco da. Dicionário Bibliográfico Português. Lisboa: CNCDP, 2001. CD ROM.

SKINNER, Quentin. Hobbes e a teoria clássica do riso. São Leopoldo: Editora Unisinos, 2002.

. Razão e retórica na filosofia de Hobbes. tradução Alessandro Zir São Paulo: Editora UNESP, 1999.

SOBREIRA, Luís. Uma imagem do Campo Literário Português no Período Romântico através dos Best-selleres produzidos entre 1840 e 1860. Disponível em <www.eventos.uevora.pt/comparada/VolumeI/UMA\%20IMAGEM\%20DO\%20CAMPO\% 20LITERARIO\%20PORTUGUES.pdf.>. Acesso em: 25 set. 2008.

SOUZA, Gilda de Mello e. O Espírito das Roupas: A Moda no Século XIX. São Paulo: Companhia das Letras, 1996.

TOMPKINS, Jonhs. Reader-Response Criticism: From Formalism to Post-Structuralism. Baltimore and London: The Jonhs Hopkins University Press, 1986.

TRANCOSO, Gonçalo Fernandes. Histórias de Trancoso. Rio de Janeiro: Calibán Editora, 2008 .

Transtorno de Personalidade Narcisista - DSM.I V Disponível em $<$ http://virtualpsy.locaweb.com.br/dsm_janela.php?cod=162>. Acesso em 25 setembro 2008.

VILELA, Jota. Cuspir no chão. Disponível em <http://www.anjoscaidos.jor.br/temas/temas/idiotice.html>. Acesso em 25 set. 2008.

VIZINCZEY, Stephen. Verdade e mentira na literatura. Lisboa: Editorial Presença, 1992. 


\author{
UNIVERSIDADE DE SÃO PAULO \\ FACULDADE DE FILOSOFIA, LETRAS E CIÊNCIAS HUMANAS \\ DEPARTAMENTO DE LETRAS CLÁSSICAS \\ PROGRAMA DE PÓS-GRADUAÇÃO EM LITERATURA PORTUGUESA
}

$O$ riso em movimento

Maura Böttcher Curvello

Tese apresentada ao Programa de Pós-Graduação em Literatura Portuguesa do Departamento de Letras Clássicas da Faculdade de Filosofia, Letras e Ciências Humanas da Universidade de São Paulo, para a obtenção do título de Doutor em Letras.

Orientador: Profa. Dra. Flavia Maria Corradin

São Paulo

Vol. II 


\section{SUMÁRIO}

Maria, não me mates que sou tua mãe!

Amor (também) de perdição

O sangue

A vida trágica de Carlota, a filha da engomadeira 


\section{Observação}

Este volume apresenta, com a autorização do autor, os textos de Fernando Gomes. A formatação e a enumeração correspondem aos arquivos originais, enviados pelo dramaturgo. 


\section{MARIA!}

NÃO ME MATES

QUE SOU TUA MÃE!

Meditação sobre o espantoso crime acontecido em Lisboa:

Uma filha que mata e despedaça a sua mãe!

Mandada imprimir por um mendigo, que foi lançado fora do seu convento, e anda pedindo esmola pelas portas

Oferecida aos pais de família e àqueles que acreditam em Deus

1848

De Camilo Castelo Branco

Versão de FERNANDO GOMES 
$\Rightarrow$ Pais de Famílias!

$\Rightarrow$ Atendei!

$\Rightarrow$ E vereis o maior de quantos crimes se tem visto no mundo!

$\Rightarrow$ Vereis uma filha matar a sua mãe, porque esta lhe não deixava fazer o quanto desejava.

$\Rightarrow$ Matricídio!

$\Rightarrow$ Vereis como essa filha corta a cabeça de sua mãe, e os braços, e as pernas,

$\Rightarrow$ E vai pôr cada pedaço de corpo de sua mãe em diferentes lugares.

$\Rightarrow$ Misericórdia!

$\Rightarrow$ Para que ninguém conhecesse o cadáver da morta, nem a mão que a matara e despedaçara.

$\Rightarrow$ Atendei!

$\Rightarrow$ E vereis como a matadora de sua mãe, de sua mãe ó pais de famílias, de sua mãe, que a trouxera nas entranhas, que Ihe dera o alimento dos seus peitos, que a criara ao seu lado com beijos e afagos, que tirara o pão da sua boca para o dar a sua filha, que fora talvez pedir uma esmola para que a sua filha não tivesse fome, e no desse seu corpo em troca de um bocado de pão!

$\Rightarrow$ Vereis como esta filha sem alma

$\Rightarrow$ Sem medo de Deus

$\Rightarrow$ Sem temor das penas do inferno

$\Rightarrow$ Descoberta como matadora de sua mãe, por um milagre, pela providência de Deus!

$\Rightarrow$ Deus seja louvado!

$\Rightarrow$ Vereis aquela mulher com alma de tigre comer com toda a vontade e contentamento, ao pé da cabeça ensanguentada de sua mãe, e responder quando lhe perguntam se aquela a cabeça de sua mãe.

$\Rightarrow$ Sim. Essa é a cabeça de minha mãe.

$\Rightarrow$ Misericórdia!

$\Rightarrow$ Pais de famílias!

$\Rightarrow$ Vamos contar-vos o mais triste e espantoso acontecimento que viu o mundo, e que talvez não torne a ver. Deus Nosso Senhor Jesus Cristo permita que possamos levar a compaixão aos vossos corações. 


\section{A FAMÍLIA}

\section{NARRADOR}

Na travessa das Freiras, no 17 vivia um homem chamado Agostinho José, casado com Matilde do Rosário da Luz; tinham duas filhas.

Agostinho José era quem sustentava a família, com o suor do seu rosto, enquanto sua esposa Matilde tratava da lide doméstica, no que era ajudada pelas suas filhas: Maria do Céu e Maria José.

Agostinho era um bom homem, que tratava a mulher com boas maneiras e tinha uma extrema adoração pelas filhas.

As filhas, retribuíam o amor dos pais. Aquela família dava constantemente graças a Deus por tamanha felicidade.

Eram pobres... talvez; mas muito honrados. E a honradez era a riqueza e o orgulho daquela gente.

Tanta felicidade nem parecia deste mundo; comovia até às lágrimas. Das bocas daquela família, só se ouviam palavras boas, palavras de amor e era até normal, que pelo menos duas vezes por dia, perante a pobreza que as rodeava, elas se confortassem comentando:

\section{ELAS}

Quem nada tem, com pouco se contenta.

\section{NARRADOR}

E nunca se cansavam de agradecer a Deus tanta riqueza!

\section{AGOSTINHO CHEGA A CASA PARA JANTAR \\ Matilde e as filhas estão à mesa.}

\section{MATILDE}

Já deram as 8 badaladas.

\section{MARIA}

O paizinho hoje demora a chegar!

CÉU

Estou tão preocupada!

\section{MATILDE}

Não é costume ele chegar tão tarde! Rezemos! Rezemos minhas filhas.

\section{Iniciam uma ladainha.}

\section{MATILDE}

Nossa Senhora da Saúde: dai-Ihe forças.

\section{Recomeçam a ladainha.}


MATILDE

Senhor dos Passos: indicai-Ihe o caminho.

Retomam a ladainha.

\section{MATILDE}

Virgem Maria!

(ouve-se bater)

Abre a porta.

\section{Entra o pai, vergado pelo cansaço.}

\section{MARIA}

Paizinho!

\section{AGOSTINHO}

Deus seja louvado!

\section{MATILDE}

Agostinho!

CÉU

Paizinho!

\section{AGOSTINHO}

Minhas queridas filhinhas!

\section{MATILDE}

Estava tão preocupada com a tua demora!

\section{CÉU}

Que aconteceu?

\section{MARIA}

Conte-nos o que aconteceu, paizinho!

\section{AGOSTINHO}

Não quero que se preocupem comigo!

\section{MARIA}

A casa limpa, o jantar feito, a mesa posta... e o paizinho que não havia meio de chegar.

CÉU

Foi então que começamos a rezar à Senhora da Saúde.

\section{MARIA}

E ao Senhor dos Passos.

\section{MATILDE}

E já íamos começar a rezar à Virgem Maria quando tu chegaste.

\section{AGOSTINHO}

\section{Deus seja louvado!}

\section{MARIA}

A mana já tinha dito que se acontecesse alguma coisa ao paizinho, ia para freira! 


\section{AGOSTINHO}

Minha querida Maria do Céu!

MATILDE

Rica filha! E tu, Maria, que fazias se o teu paizinho fosse ter com Deus?

\section{MARIA}

Eu?... Eu ia pedir esmola... corria as ruas de Lisboa a pedir esmola por amor de meu pai.... até que os pés me sangrassem, a dor fosse insuportável, mas enquanto Deus me desse voz para pedir, eu pedia, e havia de juntar, migalha a migalha, o bastante para lhe mandarmos rezar muitas missas, muitas missas, paizinho!

\section{MATILDE}

Deus seja louvado!

\section{AGOSTINHO}

E tu, Matilde, que iria ser de ti se eu te deixasse?

\section{MATILDE}

Havia de vestir-me de negro e fechar-me nestas quatro paredes, sem comer, sem beber, até a morte me vir buscar para junto de ti. E deixava crescer os cabelos!

\section{AGOSTINHO}

Os teus lindos cabelos!

\section{MATILDE}

Não os penteava! Deixava-os crescer como Deus quisesse, e uma vez por outra ia até à janela, para que a vizinhança fosse testemunho da minha dor!

\section{AGOSTINHO}

Havias de causar muita pena e muito dó a quem te visse!

\section{MATILDE}

E que me importava, se tu tinhas partido para sempre?! O povo, ao passar, até podia dizer horrorizado: Está ali um belizomem! Está ali um belizomem!

\section{AGOSTINHO}

Lobisomem!

\section{MATILDE}

Sim... um belizomem!

\section{AGOSTINHO}

A falta que eu faço nesta casa!

\section{CÉU}

Agora que o paizinho chegou...

\section{MARIA}

Podemos começar a comer.

\section{MATILDE}

Já deve estar tudo frio!

\section{AGOSTINHO}

E a culpa minha! Mas hoje, lá na pedreira...

\section{MARIA}

Havia muito cascalho para partir? 


\section{AGOSTINHO}

Bem... cada um tem a sua pedra. Para partir e transformar em cascalho. Ainda faltavam 15 minutos para a hora da saída e já a minha pedra estava toda desfeita.

\section{CÉU}

A fazer cascalho o paizinho o melhor, não é?

\section{AGOSTINHO}

Sem vaidades! Deus deu-me jeito para aquilo! Mas então é que reparei que a pedra do Zé Coxo era muito maior que a minha. Sabes que ele aqui há tempos teve de fazer uma operação aos rins - tinha pedra!

\section{FILHAS}

\section{Coitado!}

\section{MATILDE}

Mas também não admira, com a profissão que tem!

\section{AGOSTINHO}

Mas a operação não valeu de nada. E então eu olho para ele e vejo-o a fazer um esforço danado a querer fazer cascalho e a não dar vazão... cheio de dores mas a disfarçar... a querer cumprir... ele sempre foi um bom operário... o cascalho para ele não tem segredos... mas estava hoje duma maneira que até me vieram as lágrimas aos olhos. E então fui ajudá-lo e por isso é que cheguei mais tarde.

\section{MATILDE}

Não devias trabalhar tanto, Agostinho!

\section{AGOSTINHO}

Não digas isso, Matilde! O Zé Coxo não podia chegar a casa sem o salário! O que é que tu fazias se visses um amigo a torcer-se com dores de rins?

\section{MATILDE}

Tens razão! O que tu fizeste está certo. Eu só disse isto - não foi por mim! Deus testemunha, mas é pelas nossas filhas, que ainda precisam de ti. Tenho receio... é cascalho a mais.

\section{AGOSTINHO}

O trabalho nunca me cansou, Matilde!

\section{MATILDE}

Mas é cascalho a mais!

\section{AGOSTINHO}

O trabalho não me mete medo!

\section{MATILDE}

Eu sei, mas...

\section{AGOSTINHO}

Graças a Deus, tenho uma saúde de ferro!

\section{(E cai em cima do prato)}




\section{MARIA}

A mãezinha bem dizia que era cascalho a mais!

\section{À PORTA DA TASCA \\ Um afadistado conversa com o padre. \\ Um bêbado segue a conversa.}

\section{FADISTA}

Era um cornibaixo digo-Ihe eu!

\section{PADRE}

Mas, o que é um cornibaixo?!

\section{FADISTA}

Atão! Um touro, com os cornos inclinados para baixo!

\section{BÊBADO}

Vá ofender pró seu bairro, ó janota!

\section{PADRE}

Não bebas mais, Gimbrinhas!

\section{FADISTA}

Atão o Cinco Chagas salta para a arena, o cornibaixo mesmo ali! Olha para o povo e diz laia de osga: "Tomem viso! Aqui vai um homem testo, um gajo com ralé. Se cliso à palma algum cornibaixo, afogueado ou almarado, endrago-Ihe as batas ou noco-lhe a noz que o estafo. É como canta!"

Pois só Ihe digo que o cornibaixo avança pró Cinco Chagas cá com uma destas velocidades! Que besta!

\section{PADRE}

E o Cinco Chagas?!

\section{BÊBADO}

Deve ter ficado que nem um Cristo!

\section{FADISTA}

O Cinco Chagas também não desarmou! Agarra-se aos cornos do cornibaixo e mordeIhe a nuca! Que besta! Que espectáculo!

Aquilo eram duas bestas a ver quem ganhava!

\section{BÊBADO}

Três, pelo menos!

\section{PADRE}

Pára de beber, ó Gimbrinhas!

\section{BÊBADO}

Três bestas!

\section{FADISTA}

Cala-te ó bêbado, que não estavas lá!

\section{BÊBADO}

Mas estavas tu! Logo, eram três bestas! 


\section{FADISTA}

Ai a merda!

\section{PADRE}

Isso nem parece linguagem deste século! Não vê que ele está bêbado! Nem sabe o que diz!

\section{BÊBADO}

Isso é que sei! O touro é uma besta só por si... besta é o Cinco Chagas para se pôr à frente dos cornos dum cornibaixo e mais besta ainda é todo aquele que vai ver estas bestialidades! Logo, e não contando com as outras bestazinhas todas, estavam lá, pelo menos três bestas!

\section{(Cai na mesa)}

\section{FADISTA}

É mesmo besta!

\section{MARIA}

Acudam! Acudam! Ajudem-me, por amor de Deus! O meu pai... a minha mãe... a minha irmã... eu... chamem um médico... chamem um médico... um padre... ajudemme!

\section{PADRE}

Que aconteceu, minha filha?

\section{FADISTA}

Explique-se melhor!

\section{MARIA}

Estávamos todas a rezar e... de repente ele entrou e... pumba! Em cima do prato! Ajudem-no! Ajudem-no!

\section{Eles tentam erguer o Gimbrinhas.}

\section{MARIA}

Esse já não pode fazer nada! Venham vocês ajudar-me, por amor de Deus.

\section{Eles largam o Gimbrinhas, que cai.}

\section{MARIA}

Um médico... um padre... água...

\section{FADISTA}

Foi do vinho!

\section{MARIA}

O meu paizinho não bebe! Aquilo foi do cascalho! Uh! Maldito cascalho! O cascalho que o diabo amassou! 
(agarra-se à toalha e tudo cai)

\section{PADRE}

Não blasfemes, Maria!

\section{FADISTA}

Que teria acontecido para a pôr neste estado?!

\section{PADRE}

Que havemos de fazer, meu Deus?!

\section{BÊBADO}

Não me pergunte coisas a que eu não sei responder!

\section{FADISTA}

É mesmo besta!

\section{BÊBADO}

Olhem só o que me fizeram ao estaminé!

\section{FADISTA}

Não entende uma!

\section{BÊBADO}

Ah não?! Pois tomem viso! Aqui vai um homem testo, um gajo com ralé. Se cliso à palma algum pedaço de asno, endrago-lhe as batas ou noco-lhe a noz que o estafo. É como canta!

\section{AS ÚLTIMAS PALAVRAS DE AGOSTINHO JOSÉ}

\section{MATILDE}

Agostinho! Responde! Fala! Diz qualquer coisa! Ó Meu Deus! Ajuda-me a sentá-lo aqui. Faz qualquer coisa, Maria do Céu, que eu já não sei que fazer mais! CÉU

Paizinho! Paizinho! Sou eu, a Maria do Céu! Que hei-de fazer, mãezinha?!

MATILDE - Reza! Reza o terço! Bem alto, para Deus te poder ouvir!

\section{Maria do Céu começa a rezar.}

\section{MATILDE}

Acorda meu amor, acorda! Meu querido! Meu querido! Ó Meu Deus!

(Grita. A filha pára de rezar)

Continua a rezar! Não te quero ver assim tão quieto e calado! Mexe-te! Acorda! Diz qualquer coisa!

(Agostinho mexe-se e tenta falar)

Sim... sim!

(para a filha)

Cala-te!

\section{(Agostinho pára de mexer)}


Não é contigo! Era com ela! Estava quase... continua a rezar! Mais baixo, senão não consigo ouvi-lo! Reza para dentro! Reza para ti! Fala! Diz-me que estás vivo, Agostinho!

\section{AGOSTINHO}

Ma... til... de.

\section{MATILDE}

Matilde... sou eu; estou aqui.

\section{AGOSTINHO}

Matilde!

\section{MATILDE}

Já ouvi... continua.

\section{AGOSTINHO}

Não dei... não dei...

\section{MATILDE}

Não! Não deste! Está descansado.

\section{AGOSTINHO}

Dei... dei...

\section{MATILDE}

Deste?! Fizeste bem; pronto, está dado, não penses agora nisso.

\section{AGOSTINHO}

Não... não... deixes cair...

\section{MATILDE}

Descansa que não cais, estás sentadinho, eu estou aqui, estás bem!

\section{Entram MARIA JOSÉ, O PADRE, O JANOTA E O BÊBADO.}

\section{MATILDE}

Já fala! Já fala!

MARIA

Já fala?!

\section{MATILDE}

Sim, não se percebe bem o que ele diz mas já fala, graças a Deus! Já fala!

\section{BÊBADO}

Ah! Sim?! E então o que é que ele diz?!

\section{CÉU}

Ainda não se consegue perceber muito bem!

\section{BÊBADO}

Se não se percebe... isso é o mesmo que não tenha dito nada!

\section{JANOTA}

Você é mesmo besta!

\section{AGOSTINHO}

Matilde! 
(Céu e o Padre rezam; Maria olha muito de esguelha para o Janota e ele para ela. O Bêbado pega numa garrafa que estava na mesa.)

MATILDE

Agostinho!

AGOSTINHO

Matilde! Está atenta!

MATILDE

Estou, estou! Fala! Bebo-te as palavras!

BÊBADO

E eu bebo-te o vinho!

MATILDE

(ajoelhando-se no chão e erguendo as mãos postas para o céu)

Oh! Oh! Ele vai falar!

(Ficam todos a olhar para cima espera.)

AGOSTINHO

... ilha...

MATILDE

Qual ilha?

AGOSTINHO

Ilha ... ilhas ..... filhas!

MATILDE

Filhas!

BÊBADO

Filhas, o paizinho está a chamar!

\section{FILHAS}

(correndo e abraçando o pai)

Paizinho!

\section{AGOSTINHO}

Matilde... quando não puderes trabalhar, vai pedir uma esmola... para dares às tuas filhas um bocado de pão... mas não as deixes cair na desgraça de mundanas!

Porque eu não me poderei salvar se minhas filhas desonrarem minhas cinzas. Ali... ali... não... ali... ali... não... ali... ali... aqui. Aqui está um pé-de-meia... para me mandares rezar trinta missas e ali... ali... não ali... ali... aqui. Aqui está uma mala... está cheia... cheia

(murmúrios de "cheia")

Sou um homem honrado... isto foi ganho com o suor do meu rosto... são bónus... bónus que o senhor Carvalhal, o meu patrão, me dava quando eu fazia... horas... horas... extraordinárias 
(murmúrios de "extraordinário" - "um bom patrão" - "um patrão como já não há")

Está cheia... cheia... é tudo para ti... Matilde.

E agora sim, posso morrer descansado!

(senta-se à mesa e volta a cair sobre o prato.)

\section{NARRADOR}

E Agostinho José, cansado pela idade e não menos pelo trabalho, entregou a alma ao criador, deixando neste mundo uma viúva e duas filhas. Comovia até às lágrimas. Porque das bocas daquelas almas continuavam a ouvir-se palavras boas, palavras de amor e davam "Graças a Deus" constantemente.

\section{ELAS}

\section{(Abrindo a mala)} Graças a Deus! (desmaiam.)

\section{NARRADOR}

E nunca se cansavam de agradecer a Deus tanta riqueza!

\section{FILHAS}

Cascalho! A mala está cheia de cascalho!

\section{MATILDE}

Quem nada tem, com pouco se contenta.

\section{NO TRIBUNAL}

\section{VOZ}

O que acabou de nos contar foi a história do Agostinho, que não vem aqui pró caso! Mais uma perca de tempo! Tem mais alguma coisa a acrescentar?!

\section{ZÉ COXO}

Sim, quero dizer...

VOZ

Despache-se homem! Despache-se!

\section{ZÉ COXo}

Era uma família honrada!

Não tinham nada que se lhes apontasse! Não havia nódoa que se lhes pusesse... mesmo a filha...

\section{VOZES}

Culpada! Culpada!

voz

Silêncio! Continue, despache-se!

\section{ZÉ COXO}

Depois da morte do pai, ainda as vi umas duas ou três vezes... depois fui para o hospital, para ser operado.

\section{VOZ}

Já não tinha sido operado?!

\section{ZÉ COXO}


Sim, Sr. Dr. Juiz. Esta foi a $6^{a}$ operação. Sou muito achacado dos rins. Tenho pedra.

VOZ

Outra vez?!

ZÉ coxo

Sim... tenho pedra nos rins!

VOZ

A continuar assim, qualquer dia nem precisa de trabalhar! Monta uma pedreira por conta própria!

(BARULHO DE CASCALHO A CAIR)

\section{AS CARMELITAS DESCALÇAS \\ SÃO SEBASTIÃO canta um cântico celestial.}

\section{LUA}

Irmãs... que voz!

SOL

Tanta voz!

BONDADE

Um autêntico anjinho!

\section{LUA}

Santa inocência!

SOL

É tão bonito!

\section{LUA}

Irmã Sol, uma Carmelita não pode ver essas coisas!

\section{BONDADE}

Tem razão! Uma Carmelita não pode ver essas coisas.

\section{LUA}

Flagele-se e peça perdão ao Senhor!

SOL

(Fingindo que se flagela)

Ai... ai... ai!

\section{LUA}

Se não consegue resistir tentação de olhar, faça como eu: compre uns óculos escuros! Ou arranque os olhos!

\section{BONDADE}

Irmã Lua! Esse pecado nem parece seu! 


\section{LUA}

Tem razão! A cegueira descontrola-me a língua! Tenho de ser punida pelas minhas palavras. Logo noite, vou crivar a língua de pregos... ou então entalo-a na gaveta da mesinha de cabeceira.

\section{BONDADE}

Mas, irmã Lua, não temos mesinhas de cabeceira!

SOL

Pode entalá-la a porta.

\section{LUA}

Obrigado pelo seu conselho, irmã Sol. Perdoe-me e deixe-me oferecer-lhe estes óculos. Tome, aceite.

SOL

Que Deus Ihe perdoe.

\section{LUA}

Trago sempre comigo óculos, para o que der e vier. Estou constantemente a parti-los. Ainda ontem ao ir beijar os pés daquela imagem do Senhor que está nos claustros, bati com o cabeça nos joelhinhos e como são de pedra, parti logo um par de óculos! Precipitei-me! E já hoje pela manhã fui de encontro... àquela coluna que segura o púlpito!

\section{SOL}

Partiu então outro par de óculos?

\section{LUA}

Graças a Deus, não! Caiu foi a coluna...

SOL

E o púlpito!

\section{LUA}

E a irmã Piedade que lá tinha subido para limpar o pó e mudar as flores. Felizmente já tinha mudado as flores!

SOL

E a irmã Piedade magoou-se muito?

\section{LUA}

Não sei... eu já não vejo nada! E ninguém me tira da ideia que isto de eu ir contra as coisas é um aviso de Deus! Não devia ir por aqueles caminhos!

\section{(irmã Bondade tem andado de joelhos a seguir uma formiga)}

\section{BONDADE}

Formiguinha, formiguinha, que andas aqui a fazer?! Pelo meio do salão, eu já te disse que não! Alguém te pisa e podes morrer!

\section{LUA}

Tão amiga de animais!

SOL

Tão bondosa! 


\section{BONDADE}

Por isso me chamam a irmã Bondade!

\section{NO TRIBUNAL}

VOZ

... É então a irmã? Diga o que tem a dizer sem mais delongas.

\section{CÉU}

Quando o meu paizinho morreu!

VOZ

O seu pai já não pertence aos vivos e não para aqui chamado! O que nos interessa é a sua irmã!

VOZES

Culpada! Assassina!

VOZ

Silêncio!

CÉU

Estive com ela uma vez e ela contou-me como o conheceu. Foi depois de ter ido para... freira.

voz

Não consta no processo que ela tenha ido para freira!

CÉU

Eu que fui freira.

VOZ

E já não é freira?!

CÉU

Não me habituei... ao hábito. Ouvia cânticos... ouvia vozes... mas não sentia o chamamento do Senhor!

\section{EM CASA, MATILDE CHORA.}

\section{MARIA}

Não chore mais mãezinha, não chore mais! A mana queria ser freira e está melhor no convento do que aqui.

\section{MATILDE}

Eu sei, Maria, eu sei! A nossa Maria do Céu vai ficar muito bonita, vestida de freira, eu sei, mas mesmo assim apetece-me chorar, que queres!

\section{MARIA}

Uma freira é como uma noiva: uma freira é sempre bonita, tão bonita! 


\section{O CONVENTO}

Uma freira limpa o chão, de costas para o público. Abre a cortina que deixa ver o altar e volta-se na última frase de Maria. Sai. Entra Maria do Céu, vê que não está ninguém. Observa o altar.

\section{CÉU}

São Sebastião! São Sebastião! Estou aqui... porque o meu paizinho morreu. Lembraste do meu paizinho? Fazia cascalho. Deves lembrar-te... eras o patrono do meu paizinho... São Sebastião da Pedreira.

Porque morreu o meu paizinho? Era ainda tão novo!

\section{SANTO}

Porque Deus assim o quis. E quando Deus quer, não há santo que se atreva a contrariá-lo!

CÉU

... era ainda tão novo!

\section{SANTO}

Também eu! Olha bem para mim...

CÉU

Trespassaram-Ihe o peito alvo com três setas!

\section{SANTO}

Quatro! Ontem caiu uma quando me vieram limpar o pó.

\section{CÉU}

Que estranho! Falo sozinha... faço perguntas e tenho a sensação de ouvir as respostas.

\section{SANTO}

Sim!... mas não! Tu própria perguntas e respondes. É muito do povo! Perguntar e responder imitando a voz da pessoa a quem dirigiram a pergunta.

CÉU

Isto é muito verdade! O meu paizinho, quantas vezes! Chegava a casa e contava-nos o que o patrão Ihe dizia e o que ele respondia e... imitava a voz do patrão; devia ser para a gente entender melhor.

\section{SANTO}

O patrão, quando chegava a casa, fazia o mesmo com as filhas e a mulher!

CÉU

Imitava a voz do paizinho?

\section{SANTO}

Sim! E quando imitava um outro operário, o Zé Coxo, até coxeava!

\section{CÉU}

Nunca pensei!

\section{SANTO}

Nem eles! Nem eles!

CÉU

São Sebastião da Pedreira... deves saber... porque é que morreu o meu paizinho?! Não respondes?! Claro, és de gesso... de madeira... ou de pedra! Só um milagre, de que eu 
não sou digna, poderia fazer com que falasses! Que silêncio! As freiras não devem tardar! Não paro de falar sozinha! É dos nervos. Pareces mesmo verdadeiro São Sebastião! Estou mortinha por ser freira; depois venho aqui rezar-te todos os dias.

Vou dar-te uma esmolinha! As caixas de esmolas estão aqui para isso!

Uma... duas... três!

ACENDEM-SE LUZES NO ALTAR E O SANTO CANTA.

MARIA DO CÉU CAI DESMAIADA.

BONDADE

Deve ser ela.

CÉU

Sou a Maria do Céu.

AS TRÊS

É ela!

CÉU

O meu paizinho... morreu!

\section{AS TRÊS}

Oh!

\section{LUA}

És então... órfã!

CÉU

Eu e a minha irmã Maria José.

\section{BONDADE}

São as duas órfãs!

SOL

De que morreu o teu paizinho?

CÉU

Bateu com a cabeça no prato da comida.

LUA

Era então... ceguinho?

CÉu

Não!... Era pedreiro... sou uma órfã...

\section{LUA}

Órfã de pai e mãe?

CÉU

Não, só de pai!

BONDADE

Graças a Deus! 


\section{CÉU}

Mas a minha mãe é muito pobrezinha, o meu paizinho só lhe deixou um pé-de-meia e uma mala cheia de cascalho, vão ter de comer sopa de pedra todos os dias, metade do pé-de-meia foi para o funeral e a outra metade para the rezar missas, a minha mãe não arranja emprego, o único que Ihe apareceu foi para "lavadeira de Caneças" e até Ihe davam transporte, mas a minha mãezinha a andar de burro enjoa!

\section{BONDADE}

Deus seja louvado!

CÉU

E então a minha mãezinha fica em casa, a chorar e a rezar e com o paizinho atravessado na garganta...

\section{LUA}

Que sufoco! Que tragédia!

CÉU

A minha irmã, a Maria José, à noite apanha malhas em meias, que a minha mãe já tentou mas nem isso pode fazer!

\section{LUA}

Está a ficar ceguinha?

CÉU

Não, mas tremem-lhe as mãos e espeta os dedinhos todos em vez de espetar nas meias... tem os dedos que parecem um crivo...

\section{LUA}

É como eu vou ficar com a língua!

CÉU

E durante o dia a minha irmã vende flores na rua, mas vende muito pouco, não tem jeito, nunca tinha vendido nada, tem vergonha de apregoar, as flores murcham, anda dum lado para o outro com as flores tão murchinhas que aquilo até parece uma carroça de funeral retardado! Chega a casa; a minha mãe ao ver as flores faz-lhe lembrar o paizinho e desatam as duas numa choradeira!

\section{BONDADE}

E tu, minha filhinha, não choras também?

\section{CÉU}

Choro, mas não choro tanto! Sou mais do estilo de ficar a ver, ou então vou fazer qualquer coisa para desanuviar. Batatas, gosto de descascar batatas! Mas as últimas mas que tínhamos foram roídas pelo escaravelho!

\section{BONDADE}

O escaravelho! O escaravelho da batata! Se ele gosta de a roer é porque Deus assim o quer! Não se come, não se mata! Nem o escaravelho, nem a batata!

\section{LUA}

Tão amiga de animais!

\section{SOL}

Tão bondosa!

\section{BONDADE}


Por isso me chamam a irmã Bondade!

CÉU

Quero ser Franciscana! Quero ser Franciscana!

\section{LUA}

Mas, filha! Nós somos as Carmelitas, descalças.

CÉU

Então... quero ser Carmelita!

\section{BONDADE}

Mais uma!

SOL

Mais uma!

AS TRÊS

Graças a Deus!

BONDADE

Vais ter de cortar o cabelo, andar descalça...

\section{LUA}

Ofereço-te uns óculos, minha filha... quem não vê não peca... e o pecado mora ao lado!

\section{BONDADE}

E vais ter de ser muito amiga dos animais. Lição número um: se acaso, vires alguma barata aqui no salão, só tens de lhe dizer, com muito amor: Baratinha, baratinha, o teu lugar na cozinha! A barata é divertida e também tem direito à vida!

\section{FLORES... MURCHAS}

\section{NARRADOR}

Metia compaixão ver aquela mãe, tão contente com a sua filha, depois de terem ambas repartido entre si os poucos lucros do seu trabalho, aplicados para um bocado de pão e uma sardinha, ver como ela ensinava à filha as orações que já sua mãe lhe havia ensinado, o modo de pedir a Deus um meio de passar a vida com honra e sem vergonhas do mundo! Maria José amava sua mãe com toda a sua alma e coração.

(MARIA JOSÉ DESPEDE-SE DA MÃE E COM O SEU CARRINHO CHEIO DE FLORES VAI PARA A RUA. À ESQUERDA ESTÃO AS CARMELITAS E A IRMÃ. À DIREITA A MÃE, QUE REZA. MAIS TARDE SURGIRÁ O JOSÉ MARIA.)

\section{Canção da pobre florista, em que todos intervêm.}

\section{NARRADOR}

Toda a vizinhança olhava para esta rapariga com admiração. Não havia nota ruim que se lhe pusesse, e ninguém se atrevia a pôr nela a boca.

Todos saem de cena ficando apenas MARIA JOSÉ E JOSÉ MARIA. 


\section{O ENCONTRO}

\section{JOSÉ MARIA aproxima-se de MARIA JOSÉ.}

\section{JOSÉ}

Menina... Maria José!

\section{MARIA}

Como que sabe o meu nome?!

JosÉ

Disse-mo... um passarinho que passou.

\section{MARIA}

... Os passarinhos não falam!

\section{JosÉ}

Aquela, falava! E disse-me mais coisas... disse-me que a menina Maria José...

\section{MARIA}

Não quero saber! Não o conheço... não vi nenhum pássaro e mesmo que visse... mesmo que fosse verdade, eu não sou dessas; não me interessam as conversas dos outros... sou uma menina séria... a minha mãezinha está à minha espera... se não quer flores, faça o favor de se ir embora.

\section{JOSÉ}

Mas... eu quero.

\section{MARIA}

Então... escolha.

\section{JosÉ}

Já escolhi: só uma flor é do meu agrado. Adivinha qual?

\section{MARIA}

Estão todas tão murchinhas que metem dó... Ah! Deve querer esta: é uma rosa e ainda está viçosa... mas em breve as pétalas cairão...

\section{José}

Não. A flor que eu quero não se chama Rosa. E é uma flor, que se eu possuísse, poderia conservar para toda a vida.

\section{MARIA}

Não conheço tal flor; estas são todas naturais... e naturalmente... as flores naturais murcham e morrem. Triste fim, o de uma rosa!

\section{JosÉ}

Como é bondosa!

\section{MARIA}

Há quem guarde as pétalas, depois de caírem, dentro dum livro.

JosÉ

Mas ficam... espalmadas... e secas!

\section{MARIA}

Pobrezinhas! 


\section{JOSÉ}

A flor que eu quero é uma flor rara... desde que a vi, amo-a, em silêncio e sempre temi dirigir-lhe a menor frase de amor. Acanhamento meu... fruto duma grande timidez, mas também dum enorme respeito...

\section{MARIA}

Pela... flor?!

JOSÉ

Sim. Agora, não posso mais calar este afecto que me domina e que é a razão de ser da minha própria vida. Prende-me porém esta timidez ao ponto de não saber o que hei-de dizer. E não é porque não tivesse muito para lhe contar, mas porque essa maldita tibieza me inibe de o fazer. O receio do ridículo, da pouca importância que possa ligar às minhas palavras, tudo isto me põe de tal modo inquieto e nervoso, que...

\section{MARIA}

Meu Deus! Não conheço flor capaz de provocar tanta dor... tanto sofrimento... está a suar... sente-se bem?

JosÉ

... tanta paixão!

\section{MARIA}

Mas, diga-me, como se chama essa flor inquietante?

\section{JosÉ}

Maria José.

\section{(MARIA JOSÉ DEITA AS FLORES AO CHÃO, COM OS NERVOS)}

Vi-a pela primeira vez no dia em que faleceu o seu paizinho. Não se lembra de mim?!

\section{MARIA}

Nesse dia, tinha os olhos turvos de lágrimas.

\section{JosÉ}

Caiam-Ihe em gotas... cobriam-Ihe o rosto... parecia orvalho...

\section{MARIA}

Tenho de me ir embora... a minha mãezinha deve estar impaciente...

\section{JosÉ}

A sua graça é Maria José e a minha, José Maria.

\section{MARIA}

Que graça! Maria José, José Maria! É assim... como uma capicua! 2.442, ou 99.399, ou 324.101.423...

\section{JosÉ}

Sim... e uma capicua, diz-se, costuma dar sorte. Quer casar comigo?!

\section{(Voltam a cair as flores.)}

\section{MARIA}

Tenho de falar primeiro com a minha mãezinha ela quem governa em mim... se ela disser que sim... eu digo que sim... mas tenho de lhe perguntar primeiro... 


\section{JosÉ}

Mostra que tem sentimentos, que uma boa filha.

\section{MARIA}

E depois, vai o senhor José Maria falar com ela... ela há-de querer conhecê-lo... e talvez lhe diga que sim... a mãezinha não me quer para freira.

JOSÉ

Fale-lhe... na capicua...

\section{MARIA}

Vou contar-Ihe tudo... e amanhã, se ainda me tiver na ideia... pode ir falar com ela.

\section{JosÉ}

E porque não... hoje... agora... já.

\section{MARIA}

Então... vamos.

JOSÉ

Maria José!

\section{MARIA}

José Maria!

OS DOIS

99.399!

\section{MARIA}

(enquanto saem)

L'amour... l'amour... etc.

\section{NO TRIBUNAL}

\section{CÉU}

Uma capicua costuma dar sorte... e um trevo de quatro folhas também... eu, estava um dia nos jardins do convento... ia distraída e, de repente...

\section{ACUSAÇÃO}

... de repente... calcou bosta de boi!

\section{CÉU}

Não! Porquê?!

\section{ACUSAÇÃO}

Também dizem que costuma dar sorte!

CÉU

Não! Encontrei... um trevo de quatro folhas... e logo a seguir...

ACUSAÇÃO

O Jardineiro do convento!

CÉU

Como é que adivinhou? 


\section{ACUSAÇÃo}

Há sempre um jardineiro nos jardins dum convento! Não vê que a sua história com o jardineiro não nos interessa! Está a ser interrogada pela acusação! Não é óbvio que o que me interessa é enterrar a sua irmã e não desenterrar trevos de quatro folhas?! Estamos a julgar um matricídio! Matricídio! Deixe-se de fantasias, menina Maria do Céu!!! O São Sebastião! As freiras! Os cânticos! Trevos! Capicuas! FANTASIAS! Deixese de rodriguinhos! Só o que a sua irmã lhe contou é que nos interessa!

\section{CÉU}

Foi o demónio que a tentou! Foi o demónio!

\section{ACUSAÇÃO}

Claro! A culpa é toda do demónio!

CÉU

A princípio o José Maria...

\section{ACUSAÇÃO}

Conversou com ela com muito bom modo... um sonso... e deu-lhe a entender que a não buscava para mau fim! Ela levou-o a casa... e depois?!

CÉU

A mãezinha consentiu que eles fossem conversados... ele afirmou que ia mandar ler os banhos... para o casamento...

\section{EM CASA DE MATILDE}

\section{MATILDE}

O senhor... José Maria... é amigo do trabalho?... É amigo do trabalho?

\section{José}

Sim, sim... claro, sou muito amigo do trabalho. O trabalho não me mete medo.

\section{MATILDE}

Agora até me fez lembrar o meu Agostinho! Tão amigo do trabalho, o patrão antes dele morrer, até Ihe deu uma mala cheiinha de cascalho! Já está meia! Ele fazia pela vida! Ele fazia pela vida! O senhor faz pela vida?

\section{JOSÉ}

Faço... faço!

\section{MATILDE}

Tem de se fazer pela vida!

\section{MARIA}

Ele faz mãezinha!

\section{MATILDE}

Tem de se fazer pela vida e ser amigo do trabalho.

\section{MARIA}

Ele é, mãezinha, ele é!

José

E Graças a Deus, tenho uma saúde de ferro! 


\section{MATILDE}

Sim, foi isso que ele disse... e caiu em cima da alheira! Era alheira e arroz de tomate! Ele gostava tanto!

JosÉ

Que Deus o tenha em eterno descanso!

MATILDE

Rezemos! Rezemos pela salvação da sua alma! Todos de joelhos!

(Começa a ouvir-se as vozes dos alunos da Mestra)

MARIA

Em casa da nossa vizinha, a D. Guiomar. É Mestra...

JosÉ

Ah...

\section{MARIA}

Ensina a ler...

\section{MATILDE}

É! Quando ela começa as lições...

JosÉ

O quê?!

MARIA

Quando ela começa as lições...

JosÉ

Ah!

\section{MATILDE}

Acaba o sossego nesta casa!

JosÉ

Que Deus tenha piedade dela!

\section{MATILDE}

O quê?!

JOSÉ

Que Deus tenha piedade dela!

\section{MATILDE}

Ah!

JOSÉ

Não devia dar aulas a esta hora!

\section{MATILDE}

O quê?

\section{MARIA}

Diz ele, que ela não devia dar aulas a esta hora.

JOSÉ

A gente assim, não consegue nem rezar nem falar... sobre... 


\section{MARIA}

Sobre aquele assunto, que eu já Ihe tinha falado.

\section{MATILDE}

E como é dos banhos?

\section{JOSÉ}

Não percebi.

\section{MARIA}

Os banhos! Ela pergunta como é dos banhos.

\section{JOSÉ}

Vou já mandar ler os banhos.

\section{MATILDE}

O quê?

\section{MARIA}

Diz que vai já mandar ler os banhos!

\section{MATILDE}

Ah! Que vá com Deus!

\section{MARIA}

Diz que vás com Deus!

\section{JOSÉ}

Fique com Deus!

\section{MATILDE}

Vá com Deus!

\section{NO TRIBUNAL}

\section{JUIZ}

Jura dizer a verdade, só a verdade e nada mais do que a verdade?

\section{CEGO}

Deus é testemunha.

\section{JUIZ}

Não estou a falar com Deus! Estou a falar consigo!

\section{CEGO}

Eu sei Sr. Doutor Juiz?

\section{JUIZ}

Então responda!

\section{CEGO}

Pode perguntar, Sr. Doutor Juiz!

\section{JUIZ}

Jura dizer a verdade, só a verdade e na mais do que a verdade?

CEGO

Deus é testemunha!

JUIZ

Já sei! Isso eu já sei! 


\section{CEGO}

Como o Sr. Doutor Juiz perguntou eu respondi!

\section{JUIZ}

Só tem que responder: "juro". Quando eu lhe fizer a pergunta só tem de responder "juro"!

CEGO

Agora já percebi.

JUIZ

Não vai testemunhar?

CEGO

Juro!

JUIZ

Não é agora! Só quando eu Ihe perguntar!

CEGO

Afinal não percebi! Pensei que estava a falar comigo.

JUIZ

E estou a falar consigo!

CEGO

Então não me enganei!

\section{JUIZ}

Vamos combinar uma coisa: vamos fazer de conta que não dissemos nada um ao outro!

CEGO

Mas dissemos!!

\section{JUIZ}

Mas fazemos de conta que não dissemos!

CEGO

Porquê?!

\section{JUIZ}

Porque até agora não dissemos nada de jeito!

CEGO

Concordo! Concordo!

JUIZ

Esquecemos tudo!

CEGO

Percebo! Damos o dito por no dito!

JUIZ

E recomeçamos tudo de novo!

CEGO

Mas, se não dissemos nada de jeito!

JUIZ

Por isso mesmo! 


\section{CEGO}

Não estaremos a perder tempo?!

\section{JUIZ}

Exactamente!

\section{CEGO}

Podíamos então ir direitos ao assunto!

\section{JUIZ}

Primeiro tem de jurar!

\section{CEGO}

Está bom de ver!

\section{JUIZ}

Jura dizer a verdade, só a verdade e nada mais do que a verdade?

\section{CEGO}

Juro!

\section{JUIZ}

Graças a Deus!!!! Agora... diga o que tem a dizer.

\section{CEGO}

Conheci a ré desde pequenina, Sr. Dr. Juiz. E depois foi crescendo e crescendo... Toda a vizinhança se admirava do bom porte da rapariga e do amor que parecia ter a sua mãe! "Até admira!" - diziam às vezes os vizinhos - "como esta rapariga tem podido conservar-se sem dar que falar ao mundo". E depois... Horrorizai-vos! Pais de Famílias! Horrorizai-vos com a narração que vou fazer, mas reconhecei ao mesmo tempo o dedo de Deus, que guiou a justiça para descobrir a criminosa que derramara o sangue de sua mãe, e meditai por um pouco nas causas que concorreriam para endurecer o coração d'uma filha a ponto de que, vendo o cadáver de sua mãe feito em pedaços, nem o menor sinal deu de compaixão! E por último lembrai-vos que há no céu um juiz mais recto que todos os juízes da terra, e ensinai vossos filhos a amá-lo e a temê-lo, porque Ele a todos nos há-de julgar.

\section{JUIZ}

O que acabou de nos dizer não ajuda a esclarecer o crime!

\section{CEGO}

Foi um preâmbulo, Sr. Doutor Juiz.

\section{JUIZ}

Limite-se aos factos. Diga o que sabe!

\section{CEGO}

Sr. Doutor Juiz, eu não vi, mas sei tudo!

\section{JUIZ}

Toda a gente parece saber tudo!

\section{CEGO}

A mim, contaram-me de fonte limpa.

\section{JUIZ}

É o que todos dizem! 
CEGO

Mas eu ouvi da boca da própria vítima! Da boca da própria Matilde, antes de ter sido brutalmente assassinada pela filha... um crime espantoso! Um crime como nunca se viu! O maior de todos os crimes! Um matricídio!!!

JUIZ

Silêncio! Lembro esta audiência que a ré ainda está a ser julgada!

CEGO

Já foi! Aos olhos de Deus!

JUIZ

Por enquanto é apenas suspeita!

CEGO

Assassina!

JUIZ

Será feita justiça!

CEGO

Vai demorar o seu tempo!

JUIZ

Demora o tempo que tiver que demorar! O que é que ouviu da boca da vítima?

CEGO

Vou ter de recuar no tempo...

OS CEGOS - ESTROPIADOS

\section{Cantam:}

Tudo o que é triste no mundo

Quisera que fora meu

Só pra ver se tudo junto

Era mais triste do que eu

CEGO SURDO-MUDO

CEGO MOUCO

CEGO CORCUNDA

CEGO ENLUVADO

\section{CORCUNDA}

Isto hoje não cai nada!

\section{MOUCO}

O quê?!

\section{LUVAS}

Não cai nada! Quando andávamos a cantar os crimes do Diogo Alves sempre se juntava mais gente a ouvir. 


\section{CEGO}

Até dava gosto!

\section{MOUCO}

Bons tempos!

\section{CORCUNDA}

Aquilo é que era uma história! Púnhamos as pessoas todas a chorar!

\section{LUVAS}

Tudo cheio de compaixão! Cheios de pena! Era uma história que Ihes tocava o coração! CEGO

Até dava gosto! Lembras-te?!

\section{MOUCO}

De quê?!

\section{Cantam:}

Diogo Alves foi preso

E executado no patíbulo

Aí pagou o tributo

Pois tanta gente roubou

E outra tanta matou

E fechou-se o Aqueduto!

\section{MATILDE}

Era lindo, sim senhor! Fazia chorar!

\section{CORCUNDA}

O Diogo Alves a atirar aquela gente toda do Aqueduto abaixo, depois de as ter roubado!

\section{LUVAS}

Havia quem dissesse que aquilo já nem era o Aqueduto das Águas Livres! Era o Aqueduto das quedas livres!

\section{MATILDE}

Sim, deu uns versos muito bonitos; ainda os tenho guardados: duas folhas dum lado e doutro!

\section{LUVAS}

Metia muita gente assassinada!

\section{CORCUNDA}

Bons tempos!

CEGO

Que tragédia!

\section{MOUCO}

Que saudades!

\section{CORCUNDA}

Agora não acontece nada em que a gente se possa inspirar! 


\section{LUVAS}

E inventar não a mesma coisa! Não causa tanta pena!

\section{MATILDE}

Mas aqueles versos da tristeza que estavam a cantar também são muito bonitos.

\section{CEGO}

Mas não mete crime! E só pela tristeza ninguém dá esmola, ninguém compra os versos...

\section{LUVAS}

Ninguém quer levar a tristeza para casa...

\section{MATILDE}

Nem me falem em tristeza que tenho a casa cheia dela, olhem! Até dava para fazer uns versos... Há já seis meses que o meu marido morreu... e agora a minha filha... a minha Maria José...

\section{CEGO}

A Zezinha está a morrer?!

\section{MATILDE}

Não, mas... que Deus me perdoe, antes estivesse, antes queria vê-la morta do que assim... caiu na desgraça de se enamorar dum malandro, dum patife, enganou-me a mim e enganou a minha Maria José... já vai para três meses que se encontram... disse que ia mandar ler os banhos... todas as semanas dizia que já tinha botado os banhos para o casamento...

\section{CORCUNDA}

Os banhos às vezes uma coisa que demora o seu tempo.

\section{MATILDE}

Mas tanto tempo?! Não! Não! Ele agora não me atira mais poeira prós olhos! Já não me engana!

\section{LUVAS}

Já enganou!

MATILDE

A princípio, todo ele era mesuras e cheio de salamaleques...

\section{(BATEM à PORTA)}

\section{MARIA}

Quem é?!

\section{(entra um braço pelo postigo.)}

Oh! Pregou-me um susto! É o José Maria, Mãezinha! Posso mandá-lo entrar um bocadinho?!

\section{MATILDE}

E eu dizia: Podes sim, minha filha, podes sim.

\section{JosÉ}

Boa noite, menina Maria José! Boa noite, D. Matilde! Maria José! 


\section{MARIA}

José Maria!

JosÉ

Quem pela erinha passou e um ranquinho não tirou, do seu amor não se lembrou!

\section{MARIA}

Tem então... pensado muito em mim?!

JosÉ

Não penso noutra coisa. Ao ver a era arranquei um pedaço e... sabe porquê.

\section{MARIA}

Sim. Porque... quem pela erinha passou e um ranquinho não tirou do seu amor não se lembrou.

\section{JOSÉ}

A... quer dizer, amor. B...

\section{MARIA}

... banhos!

JosÉ

Já mandei ler os banhos!

C , D, E, F, G, H, I... J.

\section{MARIA}

J... de José.

JosÉ

E M... de Maria.

\section{MARIA}

José e Maria.

\section{JOSÉ}

Amo-a... amo-a tanto, Zézinha!

\section{MARIA}

Eu... eu também o amo.

\section{MATILDE}

Ela afez-se a ter paixão por ele, porque o via a todas as horas... dizia-me que o amava e quem ama, não considera.

\section{LUVAS}

Dava um começo bonito para uns versos.

\section{Cantam:}

Quem ama não considera

O que lhe pode acontecer

Cuida que tudo são rosas

Que ao jardim se vão colher. 


\section{CORCUNDA}

Dava uns versos lindos, sim senhor, mas depois para se vender tinha de acontecer qualquer coisa mais trágica!

\section{MATILDE}

E aconteceu!

\section{CEGO}

Deixem ouvir! Deixem ouvir!

\section{MATILDE}

Aconteceu e depressa! O lobo começou então a tirar a pele de cordeiro!

\section{(BATEM À PORTA)}

\section{MARIA}

(Abre a porta)

Meu amor!

JosÉ

Boa noite, D. Matilde!

MARIA

Não está. Foi à novena.

\section{JOSÉ}

Parece impossível! Deixar a filha, sozinha, entregue ao lobo mau!

\section{MARIA}

O José Maria é o meu querido lobo mau?!

\section{JOSÉ}

Sim... meu Capuchinho Vermelho.

\section{MARIA}

A minha mãe está preocupada.

JosÉ

Porquê?!

\section{MARIA}

É por causa dos banhos!

JosÉ

Eu já Ihe disse que os banhos estão a correr!

\section{MARIA}

Também eu mas... que queres?! Ela é muito minha amiga e tem medo que... só pensa nos banhos, pronto!

\section{JosÉ}

E tu, Maria José, também sé pensas nos banhos?

\section{MARIA}

Eu só penso em ti.

A mãezinha... a mãezinha está quase a chegar! 


\section{MATILDE}

Eu pressenti! Eu pressenti a desonra e pela confiança com que ele começava a tratála, uma confiança como se fosse o marido dela!

\section{CORCUNDA}

E o enganador José Maria, com o demónio no coração, a impostura na boca, foi pouco a pouco amolecendo a fraca resistência que Maria José fazia ao seu brutal apetite.

\section{MATILDE}

Sim... dito assim até parece bonito...

\section{LUVAS}

Comove, sim senhor... comove.

\section{MATILDE}

O amor é cego! O amor é cego!

\section{Cantam:}

Quem pintou o amor cego

Não o soube bem pintar

O amor nasce da vista

Quem não vê não pode amar.

\section{MARIA}

Fecha os olhos.

JosÉ

Porquê?

\section{MARIA}

É uma surpresa! Para o casamento... gostas?

JosÉ

Vais ficar linda. Tam-tam-taram!

\section{MARIA}

Espera! Toma!

\section{OS DOIS}

Tam-tam-taram!!!

\section{MATILDE}

Ele não vai casar com ela! Ele não vai casar com ela!

\section{CEGO}

É capaz de ter razão, D. Matilde!

\section{MATILDE}

Eu já a aconselhei; eu já a repreendi com boas maneiras, pois mesmo assim toda ela se arrufa! E não casa! Estou mesmo a ver que não casa!

\section{CORCUNDA}

Também eu!

\section{LUVAS}

Olhe esta aqui que também fica bonita: 


\section{Cantam:}

As águas que vêm do monte

Correm direitas pró mar

Se sua filha não casa

Não o sei onde ir parar!

\section{CEGO}

E daí... talvez case...

Tam-tam-taram!!!

\section{MARIA}

A mãezinha... está quase a chegar!

JosÉ

Sim?!

\section{MARIA}

Sim! Sim, sim.

José

O que é que disseste?!

\section{MARIA}

Sim, sim.

JOSÉ

O quê?

MARIA

Nada.

\section{OS CEgos VÃo PARA A TASCA.}

\section{MATILDE}

Mas... então... não são ceguinhos?!

\section{CEGO}

Somos, somos. Mas um cego tem direito a descansar de vez em quando.

\section{MARIA}

A minha mãe... está quase... a chegar...

JosÉ

Sim... sim... está quase...

\section{MARIA}

A minha mãe!

JOSÉ

Oh! A tua mãe... a tua mãe... a tua mãe!

\section{MARIA}

Está quase!

JosÉ

Está quase! 


\section{MARIA}

Sim...

JosÉ

Sim... está quase!

\section{MATILDE ENCAMINHA-SE PARA CASA. VEM UM BOCADO TOCADA E A CANTAR O TAM-TAM-TARAM.}

\section{MATILDE}

Maria! Minha filha! O que é que tu estavas a fazer, minha filha! Maria! Maria!

MARIA

Isso! Grite mais! Grite mais alto que é prá vizinhança toda acordar!

\section{MATILDE}

Eu muitas vezes te disse o que eram os homens...

\section{MARIA}

Até amanhã meu amor, até amanhã.

\section{MATILDE}

Não que eu tivesse queixa do meu, porque teu pai era honrado e virtuoso como aqueles que o são. Os rapazes de hoje não são o que eram os dalgum dia!

\section{MARIA}

Deve conhecê-los a todos! Para falar assim!

\section{MATILDE}

Não te pude valer. Deus Nosso Senhor me perdoe, se eu não tive forças para te castigar, porque eu tinha-te muito amor, e nunca me capacitei deveras que houvesse um tredo tão grande como o José Maria.

(cospe)

\section{MARIA}

Pois! Suje! Suje a ver se eu depois limpo!

\section{MATILDE}

Filha do meu coração, em bom pano cai uma nódoa.

\section{(Maria cantarola)}

\section{MATILDE}

Por alma do teu pai, que está na presença de Deus a pedir o teu perdão, pelas cinco chagas te peço que deixes esse homem, que há-de acabar de te lançar na perdição, onde não acharás meios de te salvar da justiça de Deus e das vergonhas do mundo.

\section{MARIA}

Largue-me! Deixe-me! Não vê que não estou para aturá-la?! Os seus sermões hão-de valer de muito!

\section{MATILDE}

Minha filha! 


\section{MARIA}

O valer-me era a tempo! Agora, que sou dele como se fosse sua mulher, hei-de ser com ele desgraçada até à morte.

\section{MATILDE}

Não vês que ele te mentiu quando falou dos banhos!

\section{MARIA}

Quero lá saber dos banhos! Sabe que mais? Se casar, casou; se não casar é o mesmo; eu gosto e ele gosta...

\section{MATILDE}

Que linguagem é hoje a tua, tão diferente daquela que era antes deste maldito aqui entrar.

\section{MARIA}

Se não gosta tape os ouvidos!

\section{MATILDE}

Ai minha filha, que estás de todo! Ó meu marido! Perdoa-me, perdoa-me, bem vês que eu não fui culpada.

\section{MARIA}

\section{(canta)}

Ó minha mãe, minha mãe, minha mãe, minha amada... Olhe, sabe que mais?!

\section{MATILDE}

Diz, filha...

\section{MARIA}

Não estou para aturá-la! Se quer estar comigo há-de ver, ouvir e calar, que é a regra de bem viver! Se não quiser, a rua é larga! O mundo é grande.

\section{MATILDE}

Queres dizer com isso que me pões fora de casa?... Não isso que queres dizer?!

\section{MARIA}

É isso! Pois! É isso! Até que enfim que percebeu!

\section{MATILDE}

Pois então fica sabendo: se até aqui te tratei como mãe carinhosa, de hoje em diante hei-de ser mãe como deve ser. Se esse José Maria volta a pôr aqui os pés, queixo-me à administração do concelho que esse homem vem a minha casa contra a minha vontade, e tu e mais ele haveis de ser atrancados no limoeiro.

\section{MARIA}

Cá estou para ver!

\section{MATILDE}

Pois então verás! Tu como filha desobediente e ele como um sedutor de uma rapariga que se deixou ir nas suas palavras.

\section{MARIA}

Bem me importa a mim isso que está para aí a dizer! Pela constituição não se prende ninguém por seduzir raparigas. 


\section{MATILDE}

Ah! Não?

\section{MARIA}

Pois não. E de mais a mais, foi muito de meu gosto! Meta bem isto na cabeça! Foi muito de meu gosto!

\section{MATILDE}

Veremos, Maria, veremos qual de nós é que vence!

\section{CEGO}

\section{(no tribunal)}

A filha ria-se de escárnio e ao mesmo tempo estava com ódio a sua mãe.

\section{Na tasca, Zé Maria joga às cartas com os pobres cegos. \\ Em casa, Matilde deita as cartas \\ ZÉ MARIA e os CEGOS fazem um jogo. \\ Entra MARIA JOSÉ}

\section{MARIA}

Zé Maria! Zé Maria! Preciso de falar contigo!

\section{JosÉ}

Já te disse que não te quero ver por aqui!

\section{MARIA}

Bem sei, desculpa meu amor, mas... eu preciso de falar contigo; é por causa da minha mãe. Ela não quer que voltes lá a casa!

\section{JosÉ}

Ah! Não quer?

\section{MARIA}

Diz que se lá voltares se vai queixar à administração do concelho!

JosÉ

Ah! Vai então queixar-se.

\section{MARIA}

Sim, tenho medo, Zé Maria. Parece louca.

JosÉ

E vai queixar-se de quê?

\section{MARIA}

Andou a perguntar coisas, aqui e ali, alguém Ihe disse...

JosÉ

O quê?

\section{MARIA}

Ela sabe que já foste acusado de vadio e ratoneiro. (PAUSA) Diz qualquer coisa. JosÉ

Bruxa. 


\section{MARIA}

Que havemos de fazer, Zé Maria?! Ameaçou de nos meter no limoeiro! Nunca a vi assim! Parece outra! Vi nos olhos dela que o que estava a dizer era verdade. Se voltares lá a casa ela mete-nos no limoeiro. (PAUSA)

\section{José}

Está bem. Nunca mais nos encontramos e pronto. Deixas de ter esse problema. Adeus. (volta para as cartas.)

\section{MARIA}

Zé Maria!!! Não! Isso não, Zé Maria! Eu amo-te! Não quero perder-te. Quero continuar a ser tua, meu amor.

\section{JosÉ}

Se gostasses de mim como dizes, não me vinhas aqui chatear com essa história.

\section{MARIA}

Vim aqui porque te quero, porque te amo! Não te provei já tantas vezes o meu amor. Porque é que não acreditas em mim? Eu desgracei-me por ti, Zé Maria. Eu desgraceime por ti. E agora ainda queres fazer de mim mais desgraçada.

\section{JosÉ}

Foi isso que disseste à tua mãe?! Que fui eu que te desgracei?

\section{MARIA}

O que eu the disse foi que te amava e que havia de ser sempre tua!

\section{JosÉ}

Mas fui eu que te desgracei.

\section{MARIA}

Não, não!!! Foi porque eu quis, meu amor, foi porque eu quis! Pede-me tudo o que quiseres e tudo farei, Zé Maria, farei tudo para te dar mais uma prova do meu amor, por ti sou capaz de tudo, mas não me deixes, não me deixes... porque tu és o meu homem, o único amor da minha vida!

\section{José}

Se não posso entrar lá em casa por causa da velha, fá-la desaparecer.

\section{MARIA}

Beija-me, meu amor.

\section{(MARIA SAI)}

\section{MATILDE}

Ó Meu Deus, mudai as intenções de minha filha...

\section{CEGO}

... mas Deus não quis tocar-lhe o coração!

\section{FADO "Deus não quis tocar-me o coração"}

Adeus mãezinha 
porque Deus

Não quis tocar-me o coração

Sou uma filha perdida

Porque nesta triste vida

Fui possuída p'la paixão

Que alguém teceu

Que me envolveu

Que me perdeu... Ai!

Quem diria

Que um dia aquela menina

Que eu nos braços embalava

Que eu beijava

Que eu amava

Teria esta triste sina... Ai

Deus assim quis

Ele é quem traça o destino

Do seu alto pedestal

Ergueu-se e disse que não

Porque não quis

Não quis tocar-me o coração.

\section{CEGO}

Maria José, quando tornou para casa, ainda sua mãe não tinha comido nem bebido e estava deitada sobre a cama.

\section{(pausa - corte)}

\section{CORCUNDA}

Vestida, com os olhos inchados de chorar. Parece que tinha envelhecido vinte anos.

\section{MARIA}

Então, que faz aí, sua tola?

\section{CORCUNDA}

Disse a filha já atentada pelo demónio à desgraçada velha. A mãe, depois de dar magoadíssimos suspiros, atirou-se da cama abaixo e lançou-se aos pés da filha.

\section{MATILDE}

Minha desgraçada filha! Atende às lágrimas de tua mãe. Bem vês que é aquela que te deu ao mundo, que sofreu as dores de mãe, que se lança de joelhos a teus pés, pedindo que não the cubras a cara com o negro véu da vergonha nos últimos dias de sua vida.

\section{MARIA}

Cale-se, minha mãe, cale-se! Que se assim continuar não há-de viver muito. Das duas, uma: ou o José Maria há-de ter aqui entrada a toda a hora do dia e da noite, ou então... 
(José Maria aparece à porta. Maria abraça-o e beija-o)

\section{CORCUNDA}

Matilde, assim escarnecida por essa filha prostituta, arrancou do peito um grito de dor.

(Matilde tenta fugir mas eles não deixam)

JOSÉ

Onde é que pensa que vai?

MARIA

Não sai! Você daqui não sai, está a ouvir?!

(Mãe vai até ao altar e vê que falta dinheiro do pé de meia.)

\section{MOUCA}

Matilde, ao ver que Ihe faltava dinheiro no pé-de-meia...

\section{CEGO}

Quis dar um grito do fundo do coração, mas não teve forças...

\section{LUVAS}

Perdeu os sentidos e caiu redonda no chão.

\section{CORCUNDA}

Esse dinheiro, já a filha Iho tinha roubado, para dar ao seu amante.

\section{José}

Isto assim não pode continuar! Ou tu dás cabo dela, ou então eu deixo-te e duma vez para sempre.

\section{MARIA}

Que hei-de fazer... que hei-de fazer?!

\section{JOSÉ}

Já te disse... mata-a e acabou-se!

\section{CORCUNDA}

Ó céus! Onde estão os vossos raios que não caem sobre a cabeça deste infame, que pede a uma amante que mate sua mãe, para mais a salvamento gozar os seus escandalosos e torpes desejos! Meu Deus! Eu sou um fraco bichinho na terra, e atrevome a interrogar a vossa alta sabedoria! Perdoai-me, meu Deus!

\section{MARIA}

Tenho medo de a matar, ela grita e cá por cima mora a mestra de meninas, que a ouve, e depois se se sabe, que há-de ser de mim?

\section{José}

O matá-la é de dia porque as meninas fazem barulho a ler, e não se devem ouvir os gritos de tua mãe. 


\section{MARIA}

Mas... eu tenho tanto medo de matá-la! Tenho alguma pena dela... Se tu casasses comigo já ela te não proibia que cá viesses, e se me tens amor, a ponto de quereres que eu mate minha mãe, então, porque não casas comigo?

\section{José}

Está bom, está bom... temos lamurias?!

Se queres, queres, se não queres, nentes que se escama o gajo.

(SAI)

\section{CEGO}

Isto são ditos que os vadios e brejeiros têm sempre prontos.

Se queres, queres, se não queres, nentes que se escama o gajo.

\section{MOUCA}

A rapariga, desesperada e aflita com os feios modos e destemperos do seu amante, foi-se ter com a mãe, e descompô-la com estas e outras palavras:

\section{MARIA}

Você, seu estupor velho, é a causadora da minha perdição. O meu regalo era pegar nesta machada e abrir-Ihe a cabeça com ela. Saia daqui. Saia daqui seu estafermo!

\section{MATILDE}

Está bem, eu saio! Mas primeiro hás-de me dar o dinheiro que me roubaste. Ladra! Depois de tudo o que fizeste ainda me roubas, não é?! Onde está o dinheiro?! DesteIho, não foi?! Quero o meu dinheirinho, que é para a salvação da minha alma e do meu falecido Agostinho.

\section{(Maria vai para sair)}

Onde é que vais?!

\section{MARIA}

Não quer o seu dinheiro? Pois... vou buscá-lo.

\section{CEGO}

A infeliz desgraçada velha, com isto sossegou alguma coisa, mas... ó desgraça! Ó dor!

\section{CORCUNDA}

Ó crime sem igual! A maldita e condenada filha já a estas horas... fazia de conta que às mesmas horas do dia seguinte teria matado sua mãe.

\section{CEGO}

Que horas são?

\section{MOUCA}

Onze e meia.

\section{CEGO}

Eram onze e meia quando ela entrou pela última vez na taverna.

\section{MARIA}

José Maria! José Maria! Preciso de falar contigo.

\section{JosÉ}

Outra vez?! 


\section{MARIA}

Ela descobriu do dinheiro... do Pé-de-meia!

JosÉ

E tu... fizeste o que tinhas a fazer?!

(beija-a)

MARIA

Disse-Ihe... que lho levava.

(José Maria pega numa maçã e na faca. Dá-lhe a faca e trinca a maçã)

JOSÉ

Fizeste bem! Fizeste muito bem. Só mostras que és uma boa filha.

(Leva-a até à porta.)

CORCUNDA

Problemas, ó Zé Maria?

JosÉ

Ná! Parece que a pobre da mãe está a enlouquecer, por causa da morte do homem. Não quer comer... deixa arrefecer a sopa... a filha preocupa-se, claro... grita muito que quer ir ter com o homem...

\section{MOUCA}

A D. Matilde?

JosÉ

Sim. Grita... grita... está aqui está a ficar sem voz.

\section{CEGO}

Ela nunca teve muita saúde.

\section{LUVAS}

Ouvi dizer que até enjoava a andar de burro!

\section{MOUCA}

O quê?

\section{LUVAS}

A Matilde! Que enjoava a andar de burro.

\section{MOUCA}

É verdade, sim senhor! Perdeu um rico emprego por causa dos enjoos!

\section{José}

E agora está a ficar louca.

\section{CORCUNDA}

Isto é de família! O homem morreu em cima duma alheira com arroz de tomate e agora a mulher deixa arrefecer a sopa!

\section{CEGO}

Uma gente pobre e a desperdiçar assim a comida!

\section{MOUCA}

Ele há gente capaz de cada uma! 
JosÉ

$\operatorname{Sim} . .$.

\section{CORCUNDA}

Ele há gente capaz de tudo!

José

A quem o diz!

\section{LUVAS}

Coitadinha da Maria José! Que há-de ela fazer?!

José

Não sei... não sei... mas...

CEGO

Ele há gente capaz de fazer coisas, que nem nos passa pela cabeça!

JosÉ

Pois! E com o feitio dela, eu nem sei, mas é até capaz de...

\section{LUVAS}

... de obrigar a pobre da mãe a comer a sopa, mesmo fria!

JOSÉ

Sim, mas eu não me meto nessas coisas! É lá com elas!

\section{(surge o tasqueiro com uma rodada)}

\section{CEGO}

Tem razão: entre marido e mulher ninguém meta a colher.

\section{MOUCA}

O quê?!

CEGO

Esquece.

\section{MOUCA}

Ah! Percebo.

JosÉ

Eu pago esta rodada!

\section{CORCUNDA}

Ora até que enfim que alguém diz alguma coisa de jeito!

\section{TODOS}

Ió! IÓ! Ió! IÓ! Ió! Ió!

\section{MARIA}

Mãezinha!

TODOS

Ió!

\section{MATILDE}

Filha! Filhinha! Minha Maria José! Trouxeste o dinheiro? 


\section{MARIA}

Sim, mãezinha, está aqui. Mãezinha! Posso pedir-Ihe uma coisa?

\section{MATILDE}

O quê, minha filha?

\section{MARIA}

Tenho andado... tão nervosa... tão nervosa...

\section{MATILDE}

Eu sei, filha, eu sei. O teu pai era um homem calmo, mas eu sempre fui muito nervosa! A mínima coisa faz tremer o meu coração e enervo-me! o teu paizinho até dizia "Matilde, tens um coração de passarinho". É dos nervos, dizia-lhe eu. Tu andas nervosa... é de família! Olha a tua irmã Maria do Céu. Sempre a bater com os pés no chão... era uma barulheira... e era tudo dos nervos. Que me querias pedir?

\section{MARIA}

Gostava tanto que a mãezinha me catasse!

\section{MATILDE}

Que trazes do bolso, Maria?

\section{MARIA}

É uma faca.

\section{MATILDE}

Para que andas de faca?

\section{MARIA}

É do José Maria. Pediu-me para eu a mandar amolar ao barbeiro.

Virgem Maria, suspendei o braço dessa filha que vai matar sua mãe!

\section{MATILDE}

Maria, porque me matas? Maria minha filha, tiveste coração de enterrar uma faca no peito de tua mãe! Tiveste coração de rasgar aquelas entranhas que te geraram! Maria, porque me matas? Que mal te fiz eu, minha filha, para me dares esta facada por onde me foge a vida? E se tinhas tenções de me matar, porque me não mandaste confessar, ou pelo menos fazer o acto de contrição? Ah Maria, Maria, que tens de dar contas a Deus pela minha e pela tua alma!

\section{(Maria José deu-lhe outra facada no pescoço. )}

\section{MATILDE}

Meu Pai do Céu... perdoai-me.

COBRE-TE DE LUTO Ó NATUREZA!

CHORA NO CÉU VIRGEM MARIA, QUE TAMBÉM FOSTE MÃE CARINHOSA!

CHORAI AVES DO AR

QUE CRIAIS OS VOSSOS FILHOS DEBAIXO DAS VOSSAS ASAS! 
CHORAI QUE AÍ CAIU UMA BOA MÃE

MORTA COM DUAS FACADAS AOS PÉS DE UMA FILHA JÁ CONDENADA!

... etc.

AQUI TENDES, Ó POVOS!

O MAIOR CRIME QUE VIU O MUNDO, PRATICADO EM LISBOA, NO ANO DE 1848 !

ESTES ATENTADOS CONTRA DEUS, ESTA GUERRA DE IRMÃOS COM IRMÃOS, ESTES ACONTECIMENTOS DE FILHOS MATAREM PAIS, E ESSES SINAIS QUE NOS APARECEM NO CÉU, TUDO INDICA QUE O FIM DO MUNDO ESTÁ CHEGADO.

FIM de "MARIA! NÃO ME MATES, QUE SOU TUA MÃE!" 
Amor

(também)

de perdição

Fernando Gomes 
-Amor (também) de perdição-

Caixa Música (realejo)

Segue

Música abertura

10 tema-REALEJO

MÚSICA DE ABERTURA

Foi um drama

Romance passional

E que acaba mal

Mas que trama

tão triste a história de Simão

por isso foi amor de perdição

Foi um amor

de de de de de de

Perdição

Repete

Nunca se viu tamanha dor

Nunca se viu tanta paixão

cruel destino o de

Teresa e Simão

Mas que perdição

É uma história

que dá para pensar

A quem ama

ia quem nunca abriu o coração 
com o que vai ver pode aprender

o que é paixão!

Aos paizinhos

que dá para pensar!

a desgraça de Teresa e de Simão

Mas que trama, tão grande amor e tal paixão

por isso foi amor de perdição

Foi um amor

paixão! paixão!

Foi um amor paixão ! paixão!

Foi um amor paixão ! paixão !

A-MOR

A-MOR

e de

Perdição Foi paixão

Perdição $\quad$ Foi paixão

Perdição $\quad$ Foi paixão

Perdição $\quad$ Foi paixão

Perdição Foi paixão

Perdição Foi paixão

Perdição Foi paixão

Perdição $\quad$ Foi paixão

NARRADOR - A primeira cena passa-se em casa de Domingos Botelho de Mesquita e Meneses, corregedor Viseu. 
MÚSICA 3‥ TEMA “PIANO” (FILME MUDO)

(VOLTAS À CADEIRA COMEÇA A BAIXAR A MÚSICA ATÉ PARAR)

Criada 1 - Aposto que vai haver tempestade.

Criada 2 - Nem duvides! Tem andado todo o dia a remoer para dentro.

Criado 1 - Está aqui, está a remoer p'ra fora!

Criado 2 - Vocês já viram, que ele hoje está com umas trombas!

Criada 2 - Quando o menino Simão chegar, vai haver bronca, de certeza!

Criado 1 - A D. Rita também não está nos melhores dias!

Criada 2- Ora! Desde que vieram viver para o Viseu, que para ela os dias são todos péssimos!

Criada 1 - Odeia Viseu e já em Vila Real era a mesma coisa!

Criado 1 - Quando o marido era juiz de fora em Cascais andava um bocadinho mais airosa!

Criado 2 - Pudera!!! Tinha uma corte de amigos e de primos!

Criada 2 - Mas ficou pior que estragada quando o marido foi transferido aqui para Viseu.

Criado 2 - Já lá vão dois anos!

Criada 1 - Os amigos...

Criado 2 - Os primos!

Criado 1 - A praia!

Criada 2 - E o sol de Cascais...

Todos - Foi sol de pouca dura!

Criado 2 - Agora ele está agarrado à testa ...

Criado 1 - E a senhora?

Criado 2 - Está a olhar para ele com ar de reprovação.

Criada 2 - Isto é tudo por causa do menino Simão.

Criada 1 - Estava a estudar em Coimbra, mas em vez de estudar.

Criada 2 - Metia-se nos corpos.

Criado 2 - E com as tricanas!

Criado 1 - Também se meteu com um doutor qualquer !

Criada 1 - Com um doutor?

Criado 1 - Sim!

Criada 2 - Então não ouviste o menino Manuel a contar à mãe? 
Criado 1 - Deu dois murros num doutor, para lhe mostrar que não estava de acordo com qualquer coisa.

Criado 2 - E o menino Simão também se metia na política; por isso é que foi preso!

Criada 1 - Que excitante!

Criada 2 - Também ouvi falar qualquer coisa sobre a Revolução Francesa.

Criada 1 - Seria ele que a provocou?

Criado 1 - Parece-me que não.

Criado 2 - Mas provocou uma revolução familiar, e essa já ninguém lha tira do curriculum!

MÚSICA 4ㅇ. TEMA “PIANO” (FILME MUDO)

Criado 1 - Atenção! Vêm aí!!!

Domingos - Se bem me lembro, D. Rita, temos três filhas: a Rosinha, a Rutezinha e a ... e a ... como é que se chama a outra? A mais nova?

Manuel - Ritinha!

Rita - A Ritinha.

Domingos- A Ritinha; e temos dois filhos:

Rita - O Manuel

Manuel - e o mano Simão.

Domingos - Agora diga-me, D. Rita Preciosa, porque é que Simão havia de sair diferente dos irmãos e dos pais?

Rita - Tenha calma!

Domingos - Como é que pode pedir uma coisa dessas, depois de ter acontecido o que aconteceu?!

Rita - Mas não podemos esquecer que, apesar de tudo, Simão também é nosso filho!

Domingos - Oxalara que não fosse!

Rita - Menezes! Não blasfeme!

Domingos - Isto não é blasfémia! Foi um desabafo!

Rita - Pois agradeço-Ihe que não desabafe na minha presença!

Domingos - Prefere então que vá desabafar com estranhos?

Rita - Não leve tanto à letra o que eu digo!

Domingos - Pode ter a certeza que não levo! 


\section{MÚSICA IDEM DA ANTERIOR \\ 5․ TEMA “PIANO" (FILME MUDO)}

Rita - Trata-se do nosso filho.

Domingos - Devia tê-lo deixado ficar na prisão!

Rita - Menezes! Lembre-se que não somos uma família qualquer! Não nos podemos dar ao luxo de ter um filho na cadeia! É publicidade negativa. E para ser Marlon Brando ainda Ihe falta muito!!!

Domingos - Mas talvez não falte assim tanto para a obrigar a engolir essas palavras!

Rita - Ciumento!

Manuel - Fora da cadeia, o mano Simão vai continuar a criar problemas.

Criados - Olá, se vai!

Rita - O senhor é pai, tem o dever de impedi-lo de cometer mais loucuras.

Domingos - D. Rita Preciosa, não insinue que a culpa do que aconteceu é minha!

Rita - Minha também não é!

Domingos - Pois se não é sua nem minha, a culpa é do diabo!

Rita - Menezes! Não ... não desabafe!

Domingos - Desta vez não foi um desabafo, foi uma blasfémia!

Rita - Que santa Rita Ihe perdoe, porque eu não consigo!

Domingos - A senhora não vê que esteja onde estiver, Simão há-de continuar a manchar a honra dos Menezes!

Rita - Menezes, nisso, por acaso, tem razão, o nosso filho é um empecilho: só faz e diz aquilo que não deve, é um susto sair com ele para qualquer lado; não sabe comportar-se!

Manuel - Um susto e uma vergonha.

Domingos - Impede-nos de caminhar de cabeça erguida!

Criados - É um empecilho!

MÚSICA (ENQUANTO OCORRE A DISCUSSÃO EM CASA DO MENEZES)

6․ TEMA “ESTE NOSSO FILHO É UM EMPECILHO” 
Rita - Este nosso filho

É um empecilho

Lutas, brigas, rixas, discussões e confusões.

Os dois- Simão é mesmo um empecilho.

Coro - Este vosso filho! Este vosso filho!

Domingos - Este nosso filho

é um empecilho

não sei a quem sai, não é à mãe, nem é ao pai.

Os dois: Simão é mesmo um empecilho.

Coro - Este vosso filho! Este vosso filho!

Os dois - Este nosso filho

é um empecilho

Temos cinco filhos só Simão nos dá cadilhos

Coro - Ele é mesmo um empecilho!

Os dois - Este nosso filho!

Coro - Orgulhoso como o pai

E teimoso como a mãe

É rebelde até não mais

Os dois - Mas nisso não sai aos pais!

Coro - Este vosso filho

É um empecilho

Manuel - A culpa é das más companhias!

Domingos - O senhor, que é irmão e mais velho, bem podia ter feito qualquer coisa! Mandei-os para Coimbra para quê!? Para estudarem.

Manuel - Simão gastava todo o dinheiro dos livros ... em pistolas.

Rita - Um filho meu armado e pistoleiro!

Manuel - E convivia com os mais famosos perturbadores da academia.

Rita - Que vergonha!

Domingos - Vergonha é roubar, D. Rita!

Manuel - Corria de noite pelas ruas, insultando os habitantes e provocando-os à luta. 
Domingos - E entretanto que é que o senhor fazia?

Manuel - Eu?!... roubava ...

Domingos e Rita - Roubava?

Manuel - Roubava horas aos estudos ... porque viver com o mano Simão é difícil ... e eu não conseguia concentrar-me.

Domingos - Enquanto um andava aos tiros o outro não conseguia concentrar-se.

Se não conseguia concentrar-se, fizesse ao menos qualquer coisa para salvar a reputação dos Menezes!

Rita - Nisso, por acaso, o senhor tem, outra vez, razão!

Domingos e Rita - Nós aqui em Viseu é que não podíamos fazer nada!

MÚSICA “PAM! PAM! PAM! PAM!” 70. TEMA RUFOS

Manuel - Eu tentei indicá-lo o bom caminho.

Rita - Então e ele?!

Manuel - Dizia que eu era ... um Choninhas.

Rita - O quê?

Manuel - Mandava-me calar e chamava-me de Choninhas.

Rita - Choninhas!

Manuel - E à frente dos outros.

Rita - O teu pai tem de saber isto.

Manuel - Não lhe conte, senão ele ri-se.

Rita - O teu pai rir-se ?!!! Vê-se bem como não o conheces. Menezes!

Domingos - Sim, D. Rita.

Rita - Simão chamava constantemente ao irmão Choninhas.

(Domingos ri-se e todos os outros menos Rita e Manuel)

Domingos - E o que a gente pensou para lhe chamar Manuel!

Rita - O irmão chama-Ihe Choninhas!

Domingos - Chama-lhe então Choninhas! Nunca ouvi. 
Assenta-Ihe que nem uma luva.

Rita - Nunca ouviu porque o senhor só ouve o que lhe convém!

Domingos - E por que é que havia de ouvir?

MÚSICA SEGUE ATÉ O FIM (A FALA CONTINUA ACIMA DA MÚSICA)

8 TEMA FILME MUDO COM TEXTO DRAMA

Rita - Porque o senhor é pai e devia pôr cobro a estas impertinências de Simão!

Domingos - Sou pai, mas também sou corregedor e tenho mais o que fazer!

Rita - Menezes!!!

Domingos- E para pôr cobro a esse tipo de impertinências, nada melhor que a mãe! Mas a mãe, D.

Rita Teresa Margarida Preciosa da Veiga Caldeirão Castelo Branco de Mesquita Menezes, onde é que estava a mãe?

Rita - Aqui em Viseu!!!

Domingos - Em frente ao tocador, recordando os tempos em que era dama do paço, cortejada por tudo quanto era homem, incluindo os primos; e esquecendo por completo que é uma senhora casada com cinco filhos! A sua cabeça está vazia, D. Rita!

Rita - Pois a sua está bem cheia!

Todos - Cheia?

Rita - Cheia de pensamentos ignóbeis e mesquinhos!

Sempre Ihe fui fiel, senhor Domingos José Correia Botelho de Mesquita e Menezes!

Domingos - Muito obrigado!

Criados - Era obrigada! Pelo fidalgo!

Rita - Mas o senhor, de fidalgo só tem nome!

O teu pai foi terrivelmente ciumento.

Manuel - Por quê?

Rita - Porque quando olha para o espelho vê o rosto que eu tenho que ver todas as manhãs, todas as noites, e o que vê não Ihe inspira confiança nenhuma!

Domingos - Basta D. Rita! Basta!

É verdade que a sua mãe enlouqueceu muitos homens, 
Todos: Incluindo os primos

Domingos: Mas nenhum ficou louco ao ponto de a pedir em casamento; beleza sem dote pode proporcionar um bom futuro ... mas perde-se a liberdade por completo, não é D. Rita?

Rita - O senhor não tem nem motivo, nem idade, nem figura para me falar nesse tom e dessa maneira!

Domingos - Sou seu marido e falo-lhe no tom que me apetecer!

Quanto às alusões que fez a minha figura...

Rita - Triste figura!

Domingos - Devo lembrar- Ihe que quando me casei consigo a minha figura era mesma, mas isso não a impediu de aceitar o meu idiota pedido de casamento, nem tão pouco que nos reproduzíssemos em três filhas e dois filhos!

Mas eu sei que casou comigo por causa de meu dinheiro!

Rita - Casei porque simpatizava consigo! Achava-lhe uma certa graça, descobri-lhe um encanto que afinal era mentira! O senhor está diferente!

Domingos - Pois a senhora está a mesma, continua a parece que tem 20 anos e isso põe-me doido!

Rita - Não aguento mais!

Domingos - Nem eu!

Os outros - Nem nós!

Manuel - Por favor, não discutam por minha causa!

Rita - Tréguas! Menezes, Tréguas!

Domingos - Tréguas.

Criados - Tréguas.

MÚSICA 9․ TEMA: TANGO

(FINAL DA DISSENÇÃO DOS MENEZES)

(ENTRA SIMÃO)

Simão - Juro que não estava à espera desta recepção! 
Domingos - E eu esperava que esses seis meses no cárcere académico lhe tivesse feito perder a arrogância ... mas verifico que me enganei.

Simão - Enganou-se redondamente, senhor meu pai.

Domingos - E ainda se atreve a confessá-lo?

Simão - De que me vale negar?!

Domingos - Insolente!

Rita - O seu pai mando-o para Coimbra para estudar, não foi para se meter em politiquices.

Simão: Tem razão, minha mãe.

Manuel - Nem se meter com tricanas.

Rita - Nem para se meter com ... o que é uma tricana?

Simão - Uma espécie de barco rebelo minha mãe!

Rita - Vejo que agora também se interessa pela marinha!

Não admira que nos estudos tenha metido tanta água!

Domingos - O senhor transformou-se no terror de Coimbra!

Uma espécie de Robbespièrre de capa e batina!

Rita - E foi preso, isso é muito lindo, não é? A cadeia!

Simão - Fiz amizade com uma ratazana que adorava o nosso apartamento! Uma ratazana de esgoto! Assim!

Rita - Não me fale em ratazanas que me provoca peles de galinha!

Menezes! Mande o seu filho calar-se!

Domingos - Cale-se!

Rita - Para o tirarmos da prisão tivemos de recorrer aos amigos e aos parentes; uma vergonha, um enxame!

MÚSICA 10․ TEMA FILME MUDO (SEGUE PARA A OUTRA CANÇÃO)

MÚSICA DA CONFUSÃO (VAI BAIXANDO PARA A FALA)

Simão - A Margarida não tinha parentes, nem outros amigos, além de mim!

Rita - Margarida? Quem é essa Margarida? 
Simão - Não posso dizer-lhe minha mãe.

Rita - Quero saber quem é!

Simão - Não vai gostar.

Rita - Mesmo assim quero saber!

Domingos (FALA POR CIMA) - Responda a sua mãe!

Simão - Margarida ... eu chamava-Ihe Guida ... foi o nome que dei à ratazana!

Rita - Menezes! Isto é demais! O nosso filho quer dar cabo de mim! Chamar um nome tão lindo a uma coisa tão feia!

Manuel-E a mim chamava-me Choninhas!

Criado 1- Margarida à ratazana ....

Manuel - E a mim, Choninhas!

Criada 2 - Parece impossível !

Manuel - Simão defendia que Portugal devia regenerar-se num baptismo de sangue!

Criada 1 - Impressionante!

Manuel-E foi preso!

Simão - Fui denunciado!

Domingos - Eu próprio o denunciaria se lá estivesse!

Criados - Foi então preso por denúncia.

Simão - Traíram-me, é verdade! E fui preso.

Criado 1 - Pronto! Já passou!

Criada 1 - Já passou, já passou!

Domingos - Fique sabendo que não consisto que volte a dirigir-me a palavra. Saia!

A partir de agora, ou se porta ou deve ser ou...

Rita - Menezes, não lhe diga mais nada, que não vale a pena!

Domingos - Tem razão, é gastar o meu latim para nada!

Simão - Tem razão, meu pai, é gastar o seu latim para nada! 
Simão - Queridos pais, meus queridos pais, mais uma vez estamos de acordo. Quase já sinto saudades da prisão.

(SEGUE PARA O ROCK)

MÚSICA 13․ TEMA ROCK “PRA PRISÃO”

Simão - Indesejado sempre fui e sou um empecilho; não sei para onde vou!

Peço perdão; estou arrependido

oh! quem me dera dizer-lhes ao ouvido.

Todos - Já já já já já já já...

P'ra prisão!

Deviam ver p'racreditar

Aquele hotel é de tarar

o da prisão!

Dão-nos comida estragada

bons conselhos e porrada

na prisão!

Na prisão!

Com um grãozinho na asa

É bem melhor que estar em casa

Na prisão!

TODOS - TODOS P'RA PRISÃO!

TODOS P'RA PRISÃO!

TODOS P'RA PRISÃO!

VÃO JÁ TODOS P'RA PRISÃO!

SIMÃO - PASSEI UNS DIAS DIVERTIDOS

BELOS DIAS BEM CURTIDOS 


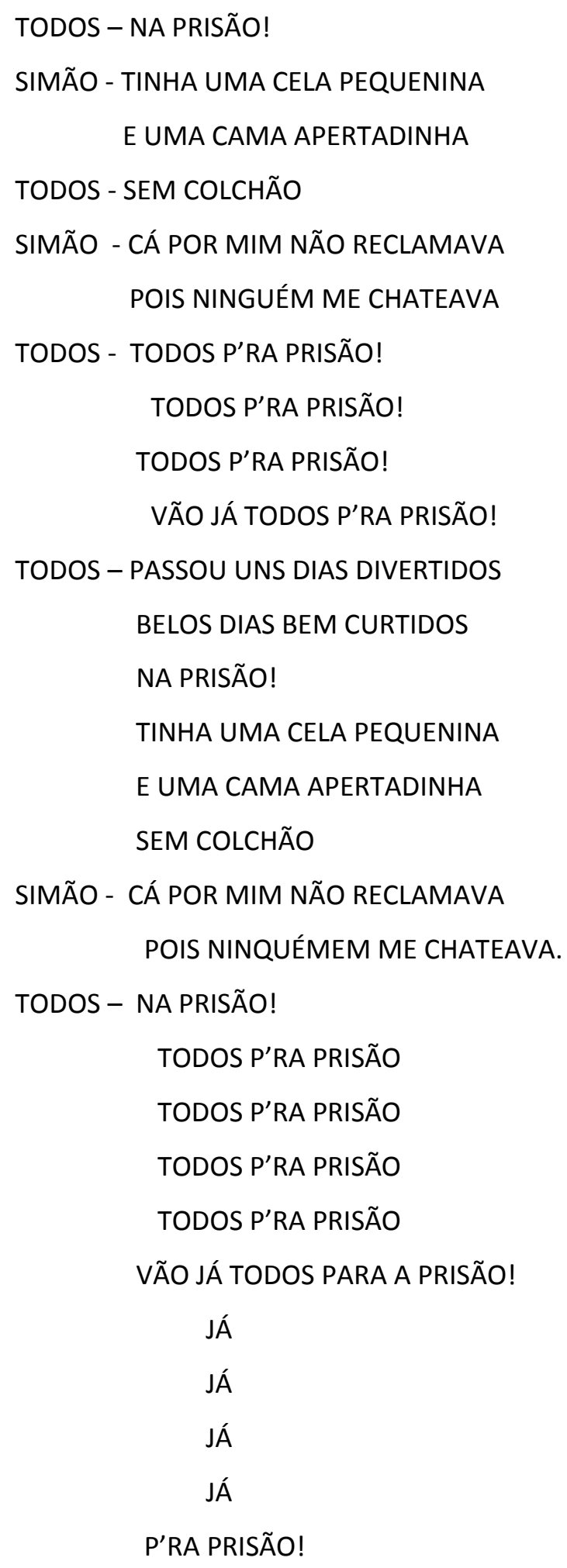


RITA - Não nos podemos esquecer de Caim e Abel! E estavam no paraíso! DOMINGOS - E nós no inferno! Simão fica em Viseu.

RITA - Mas no fim do período de férias regressa a universidade de Coimbra!

MANUEL - Com aquele feitio, aposto que não se vai aguentar lá por muito tempo!

DOMINGOS - Alguém lhe perguntou alguma coisa? Alguém Ihe pediu sua opinião?

NARRAÇÃO - MÚSICA - CAIXA DE MÚSICA (REALEJO)

15은. (CONTINUAÇÃO)

HOMEM - E assim passou um mês ... dois meses .. e depois três.

Estou a faltar a cena!

CRIADA 2 - No espaço de três meses

fez-se maravilhosa mudança nos costumes de Simão.

CRIADO 2 - Simão estava diferente

Parecia outro Simão.

CRIADA 2 - E todos se admiravam com esta transformação.

CRIADO 2 - Mas de todos, quem mais se admirava era o pai quantas vezes pensava:

DOMINGOS - Alguma coisa se passa!

Desconheço este meu filho!

CRIADA 2 - Porque Simão deixou de ser um rebelde, um empecilho!

RITA - Já sei! Foram os conselhos que eu lhe dei!

DOMINGOS - Ou então ficou mansinho porque eu lhe castiguei!

CRIADO 2 - Mas é sabido que não são as punições; os castigos

CRIADA 2 - Grandes exemplos ou conselhos

OS DOIS CRIADOS - Quer eles venham dos novos quer eles venham dos mais velhos.

CRIADA 2 - Que modificam alguém

CRIADO 2 - E neste caso: Simão.

CRIADA 2 - Mas tem de haver uma razão.

CRIADO 2 - Simão estava diferente... 
OS DOIS CRIADOS - Porquê?

MÚSICA (CAIXA DE MÚSICA) (BAIXO COM A FALA EM CIMA)

16․ TEMA: REALEJO

HOMEM - Porque Simão amava sua vizinha, menina de quinze anos, rica herdeira e bem nascida: Teresa.

Filha de Tadeu Albuquerque, que odiava profundamente Domingos Botelho.

TADEU - É verdade, sim senhor, e digo-o com orgulho: ódio! O ódio que eu sinto por esse corregedor de meia tigela vem cá de dentro, das entranhas!

Esse espantalho já proferiu uma sentença contra mim, mas asseguro-lhe que não perde pela demora.

DOMINGOS - Diga a esse patife, que só minha consciência é julgadora dos meus actos.

TADEU - Espantalho! Onde você estava bem era a espantar pardais.

DOMINGOS - Se continua com as suas torpezas, far-lhe-ei saber que os Correia Botelho de Mesquita e Menezes saberão responder as injúrias pela boca de um bacamarte!

TADEU - O senhor é um espantalho vestido de juiz!

DOMINGOS - Pois o senhor para palhaço rico nem precisa de lantejoulas! O seu lugar é no circo. HOMEM - Nesta vida, cada um tem o papel que tem!

MÚSICA 17ㅇ. TEMA REALEJO (ATÉ O FIM)

NARRADOR - Teresa e Simão, conhecedores deste ódio, encontraram ao fim forma de iludir as duas famílias.

E durante três meses, às escondidas dos pais, trocaram mais lindas palavras de amor. A cena passa-se num jardim.

E entendeu o encenador realçar toda a magia deste inocente amor 
num quadro de fantasia

MÚSICA 18․ TEMA "SOU UMA FLOR DELICADA"

VIOLETA - Sou uma flor delicada

Fico bem numa opereta

Sou muito solicitada

o meu nome é Violeta

AMOR PERFEITO - Sou único! Sou diferente!

Observam-me com respeito

Faço feliz quem me tem

Eu sou Amor Perfeito

PAPOILA - Eu sou fogo, labareda

Não há outra, quente assim!

Entonteço quem me cheira

Sou Papoila de Jardim

GIRASSOL - $\quad$ Eu, sou amarelado

Tostadinho pelo sol

Não sou um ovo estrelado

Sou um simples girassol

AMOR PERFEITO - Papoila! ó Papoila!

PAPOILA - Quem me chama?

AMOR PERFEITO. - Sou eu, o amor perfeito. Que horas são?

VIOLETA - São horas de te calares porque eles devem estar a chegar!

GIRASSOL - D.Violeta! Tenho tanto medo de ser desflorado!

AMOR PERFEITO - Convencido!

PAPOILA - Peneirento!

VIOLETA - Não és nenhum malmequer! 
PAPOILA - Eles gostavam de arrancar pétalas aos malmequeres!

GIRASSOL - Mas é de noite, podem-me confundir, não podem?!

Tenho tanto medo de ser desflorado! Era a 1ㅇv vez!

AMOR PERFEITO - Estão a ouvir o mesmo que eu? O amarelo convencido que passa por branco!

GIRASSOL - De noite todos os gatos são pardos!

PAPOILA - E todos os girassóis parvos!

GIRASSOL - Drogada!

VIOLETA - Que flor tão saloia!

PAPOILA - Campesino!

AMOR PERFEITO. - Calem-se! Aí vêm eles!

19․ tema BEM-ME-QUER MAL-ME-QUER

... A cena passa-se num jardim.

E entendeu o encenador

realçar toda a magia

deste inocente amor

num quadro de fantasia

PAPOILA - Estás muito contente ó Girassol!

GIRASSOL - Deve ser por estar perto de ti!

AMOR PERFEITO - Diz lá o que tens!

GIRASOL - Nada! Só estou contente!

VIOLETA - Se estás a espera que eu te pergunte por que, estás muito enganado!

GIRASOL - Então eu digo: Vocês repararam que já não há um único malmequer no jardim?

OS OUTROS - E então?

GIRASOL - Eu sou o mais parecido com um malmequer!

PAPOILA - Coitadinho! Ainda não perdeu a ideia de ser desflorado!

VIOLETA - Pode pôr as pétalas de molho que eles não vão repetir a cena!

GIRASSOL - Têm a certeza?

OS OUTRA - Claro! 
GIRASSOL - Acabar de me dar um grande desgosto: uma cena tão linda! VIOLETA - Um bocadinho lenta!

AMOR PERFEITO - Uma cena de amor nunca pode ser feita á pressa!

PAPOILA - Falou o entendido!

GIRASSOL - Vocês por acaso não sabem se haverá alguma cena com abelhas?

VIOLETA - Por quê?

GIRASSOL - Não é para vos fazer inveja, mas estou carregadinho de pólen!

HOMEM - E assim passou mais um mês ... dois meses e depois três.

DOMINGOS - Seis meses!

TADEU - Seis!!

DOMINGOS - Durante seis meses Simão e Teresa encontram-se no jardim e sem nós sabermos!

TADEU - Nessas coisas somos os últimos a saber!

DOMINGOS - Problema maior é quando somos os últimos a saber noutras coisas!

TADEU - Sou viúvo: tenho esse problema enterrado!

DOMINGOS - Os meus sentidos são pensamentos.

TADEU - Muito obrigado.

DOMINGOS - Não se deixe iludir por esta aparência de amizade

TADEU - A verdade é que estávamos lá dentro

DOMINGOS - Nos bastidores

TADEU - e resolvemos abandonar por alguns instantes o papel de "pais tiranos"

DOMINGOS - Para podermos partilhar com os nossos filhos ... e convosco o próximo número.

TADEU - O número sobre o amor!

DOMINGOS - Aí vêm eles!

TADEU - Lindos!

DOMINDOS - Apaixonados!

TADEU - Chego a ter pena por ser obrigado a impedir o casamento!

DOMINGOS - Eu também; o público normal, não lhe parece?

TADEU - Sim , sim.

DOMINGOS - Portanto, apenas em espírito, porque as personagens ficaram no camarim.

TADEU - Mas não se esqueça que somos os maus da história.

DOMINGOS - Num parente sobre o amor!

TERESA - Há já seis meses que nos conhecemos 
SIMÃO - Que nos encontramos

OS DOIS - Em segredo!

PAIS - Shuuu!

TERESA - Se os nossos pais soubessem!

SIMÃO - Mais não sabem!

TERESA - Nem sonham ...

PAIS - Shuuu!

DOMINGOS - Formam um bom par.

TADEU - Seu filho é ...

TERESA - Simão ...

TADEU - Um rapaz perfeito

DOMINGOS - E a sua filha, sim!

SIMÃO - Teresa.

DOMINGOS - É a mulher ideal!

TADEU - Pst ! Irão ... fazer amor?

21‥ TEMA "JÁ TENHO PAR"

Para fazer amor você primeiro vai ter de encontrar

A mulher ideal para amar

Só depois de serem dois

Olhos nos olhos

Bate Bate o coração

SALTA MAIS E MAIS E MAIS - QUASE A ARREBENTAR

MÃO NA MÃO E SEM FALAR - MAS QUE PAR

JÁ TENHO PAR! JÁ TENHO PAR!

AGORA TAMBÉM POSSO AMAR!

SINTO TONTURAS COM AMOR

BATE O MEU CORAÇÃO COM ESTA PAIXÃO CADA VEZ MAIOR

TUDO O MAIS É FULGAZ - NADA NOS APRAZ - APENAS O AMOR

SÓ QUERO AMAR! SÓ QUERO AMAR! 
CONTIGO VOU PODER VIBRAR

COM AS DELÍCIAS DO AMOR

TALVEZ DEPOIS! TALVEZ DEPOIS!

OU DOCE BEIJO OU ATÉ DOIS

ASSIM SE DESCOBRE O AMOR

DEPOIS TALVEZ! DEPOIS TALVEZ!

EM VEZ DE DOIS SEREMOS TRÊS

E ASSIM AUMENTA O AMOR!

BATE O MEU CORAÇÃO CADA VEZ MAIOR

TUDO O MAIS BATE É FUGAZ - NADA NOS APRAZ - APENAS O AMOR

JÁ TENHO PAR! JÁ TENHO PAR! AGORA TAMBÉM POSSO AMAR

SINTO TONTURAS COM O AMOR!

MÚSICA REALEJO (BAIXO PARA TEXTO)

TERESA - Quem me dera ser uma flor!

SIMÃO - Qual flor?

TERESA - Podia ser ... uma Papoila

SIMÃO - las entontecer-me ...

GIRASSOL - Pudera ! é só droga!

PAPOILA - Démodé!

TERESA - .... Ou uma violeta

SIMÃO - A violeta é ...

VIOLETA - Uma lady!

SIMÃO - .... Demasiado fúnebre

PAPOILA - Se não mudas de cor, não te safas!

TERESA - Ou então ... um girassol

GIRASSOL - Sim ... sim.

VIOLETA - Não te excites que entortas o pólen todo!

SIMÃO - O amarelo é desespero.

TERESA - Quero saber então ...

AMOR PERFEITO - Mas é evidente que sou a flor preferida pelos apaixonados! 
SIMÃO - Querias ser um amor perfeito?

TERESA - Sim ... para ti, eu quero ser um amor perfeito.

AMOR PERFEITO - Tem tão bom gosto de rapariga.

SIMÃO - O amor perfeito ... não existe!

GIRASSOL - Toma e vai-te curar!

PAPOILA - Nem deu pela sua presença!

TERESA - Não existe ?

SIMÃO - Só nos livros, no cinema e no teatro!

TEREA - Mas então ...

SIMÃO - Gosto de ti assim em carne e osso

TERESA - Oh! Meu galã de ponta!

SIMÃO - Oh! Minha ingénua dramática!

TERESA - Vem aí o seu pai!

SIMÃO - Oh! Vem aí o meu pai!

DOMINGOS - Vá imediatamente para casa!

Desde quando é que uma flor canta?!

TERESA - Eu... não sou uma flor...

IA A PASSAR...

DOMINGOS - Pois passe muito bem... mas passe ao largo... de forma a não se encontrar comigo e muito menos com o meu filho!!!

TADEU - Teresa!

DOMINGOS - Se quer casar, case com um trolha, que é um digno genro para o labrego do seu pai! TADEU - Teresa! Já te disse que não quero que fales com espantalhos!

DOMINGOS - Se o senhor não Ihe sabe dar educação, tenha ao menos vergonha nessa cara! Seu pai-palhaço!

FERNANDO GOMES: Clown!

MÚSICA 23․ TEMA REALEJO

HOMEM - Podem sair. Muito obrigado pela vossa colaboração.

TADEU - Não chores, minha filha. Conta-me tudo, Teresa. O que é que aquele espantalho quis dizer ao proferir tais palavras? 
HOMEM - Tadeu de Albuquerque fingiu acreditar na filha quando ela se justificou dizendo que tinha ido ao jardim dar de beber às flores, quando por ali passou Simão, que ela nem sabia ser filho do corregedor.

Que apenas tinham dito um ao outro "olá" e depois apareceu o pai...

TERESA - ... e eu nem percebi porque é que ele ficou assim, tão zangado!

HOMEM - E o pai fingiu acreditar esperançado de que tudo aquilo não passasse duma criancice de Teresa.

TERESA - Obrigada por ter acreditado em mim, senhor meu pai.

TADEU - Mas só por esta vez. E se o que aquele espantalho disse é verdade... vais para um convento!

E agora, não te quero ver triste.

Quem é a mais linda flor do nosso jardim?

MÚSICA 24 TEMA “AS FLORES QUE NASCEM NO JARDIM”

TADEU - As flores que nascem no jardim

CORO - Lá lá!

TADEU - São plenas de cor e beleza.

Nenhuma é tão bela, tão linda assim

CORO - Nenhuma é tão bela tão linda assim

TADEU - Ao lado da mais bela: Teresa

CORO - Da sua filhinha Teresa.

TADEU - Menina bonita do meu coração

Canta p'ro Papá uma linda canção

TERESA - Trá - lá - lá - lá - lá - á

Trá - lá - lá - lá - lá - á

TADEU - Filhinha do meu coração

CORO - Trá - lá - lá - lá - lá

Trá - lá - lá - lá - lá

Trá - lá - lá - lá - lá 
Trá - lá - lá - lá - lá

TADEU - Quem quer ao seu pai agradar

CORO - Lá-lá!

TERESA - Tem de ser sempre obediente

TADEU - E então o Papá não tem de ralhar

TERESA E CORO - Não tem de bater nem castigar

\section{E diz babado e contente}

TADEU - A minha filha é obediente.

CORO E PAI - Mas se algum dia desobedecer

Vai para um convento e até morrer.

CORO - Trá - lá - lá - lá - lá

$$
\begin{aligned}
& \text { Trá - lá - lá - lá - lá } \\
& \text { Trá - lá - lá - lá - lá } \\
& \text { Trá - lá - lá - lá - lá }
\end{aligned}
$$

Fica lá até morrer.

\section{MENDIGOS}

MENDIGA 1 - Por que é que eles haviam de disparar primeiro?

MENDIGO 1 - Porque são polícias!

MENDIGO 2 - Pode baixar os braços que ninguém aqui p'ró roubar!

MENDIGA 1 - Nem p'ra roubar nem p'ra pedir que a gente agora mudou de tática!

MENDIGO 3 - É, a gente agora só ameaça!

MENDIGO 1 - Ou dás o que tens ou atiramos-te deste precipício!

HOMEM - Eu só tenho a roupa que trago no corpo!

MENDIGO 2 - Pensando bem, a roupa não serve a nenhum de nós e mesmo que ele dê o corpo, onde é que a gente esconde?

MENDIGA 1 - Lá estás tu com pena do homem!

MENDIGO 2 - A gente ameaçou não é para sair daqui com as mãos a abanar!

HOMEM - Isso não é nada bonito!

MENDIGA 1 - Estás a ver? Que até ele concorda 
HOMEM - Ameaçar, seja porque motivo for, é que não é bonito! Tadeu ameaçou a filha mas não serviu-lhe nada!

MENDIGO 3 - Quem é esse Tadeu?

HOMEM - É aquele!

MENDIGA 1 - Tem ar de quem tem!

HOMEM - A filha gosta de um tal Simão que foi estudar para Coimbra. O pai mandou vir o sobrinho de Castro Daire...

MENDIGO 2 - (lendo) Baltazar Coutinho, senhor de casa igualmente nobre da mesma prosápia

MENDIGA 1 - Deve ser podre de rico!

MENDIGO 1 -É aquele!

TADEU E O SOBRINHO

TADEU - Mandei-o chamar a Viseu porque...

BALTAZAR - Fez-me estranheza tanta urgência ....

TADEU - É que tem acontecido umas coisas ...

BALTAZAR - Só vim pelo muito respeito que tenho ao meu tio ...

TADEU - E eu penso que não devemos atrasar

BALTAZAR - Porque para Ihe falar com franqueza , nessa altura ...

TADEU - Atrasar por mais tempo a nossa combinação ..

BALTAZAR -Nesta altura não me dá feição!

TADEU - Não lhe dá feição?

BALTAZAR - Não me dá jeito ... por motivos de doença, claro!

TADEU - O meu sobrinho está doente ?

BALTAZAR - Pensei até que já se tinha apercebido ... por causa da minha postura!

TADEU - Por causa da sua postura?

BALTAZAR - Meu tio! Prezo-me de normalmente ter outra postura que não é esta!

TADEU - Sim, realmente está um bocadinho ... como direi .... empertigado!

BALTAZAR - Desde pequenino que sou alérgico a cães.

TADEU - Cães!

BALTAZAR - O tio não tem cães em casa?

TADEU - Não, não! Teresa tem um canário. 
BALTAZAR - Aguento canários e até gatos, mas cães não!

TADEU - Fica ... empertigado!

BALTAZAR - Pois ontem, sem querer, claro! Fui confrontado com um lobo da alsácia! Ainda subi para uma árvore, mas fiquei com as marcas.

TADEU - O lobo da alsácia mordeu-lhe?

BALTAZAR - Não, mas com a precipitação da subida, raspou-se-me esta parte toda no tronco da árvore. Era um carvalho.

TADEU - C'os diabos! Isso podia ter sido fatal!

BALTAZAR - Se eu tivesse pensado um bocado, tinha saltado em vez de trepar ... mas não ocorreu! TADEU - Então trepou de frente?

BALTAZAR - De costas é mais difícil.

TADEU - Claro, claro.

BALTAZAR - E nem convinha porque ficar com essa parte para frente do lobo de alsácia.

TADEU - Trepou entanto de frente, fez muito bem!

BALTAZAR - Muito bem não teria sido, porque raspou-se-me esta parte todo no tronco do carvalho. Mas isto que estou a contar é confidencial!

TADEU - Mas sem gravidade, espero!

BALTAZAR - Eu também! Vamos lá a ver como é que isto fica quando me tirarem o gesso!

TADEU - Está então engessado?

BALTAZAR - Daqui até aqui! Custa-me andar, custa-me a comer, custa-me ....

TADEU - Agradeço-lhe mesmo ter vindo.

BALTAZAR - Disse que era urgente espero que seja.

TADEU - É ! É porque receio que Teresa esteja embeiçada pelo filho daquele ... espantalho!

BALTAZAR - A prima Teresa embeiçada pelo filho dum espantalho?

TADEU - Domingos Botelho É esse o meu receio! Simão agora está em Coimbra

BALTAZAR - Sendo assim, não receie: longe da vista, longe do coração! E agora estou cá eu!

TADEU - Pois! Mas se agente não põe um travão nos acontecimentos, também pode acontecer que do longe se faça perto! Tem de se declarar, de lhe abrir que o seu coração!

BALTAZAR - Mas o senhor meu tio! Como é que lhe posso abrir o meu coração com uma couraça de gesso? 
TADEU - Amanhã pode ser tarde! O vosso casamento seria a suprema felicidade da minha velhice ... e um grande alívio em relação ao espantalho!

BALTAZAR - Bem , já que cá estou ...

TADEU - Viseu ... Castro Daire!

BALTAZAR - Posso dar-Ihe a nossa união como certa. Daqui para o futuro, deixará de ser meu tio, para passar a ser: Meu pai!

TADEU - Teresa ! Deixo-os a sós para ficar mais a vontade!

BALTAZAR - Eu bem queria, mas a couraça tolhe-me os movimentos.

\section{MÚSICA 26 TEMA- “CANÇÃO PRIMO BALTAZAR"}

BALTAZAR -Prima Teresa é a altura de lhe abrir o coração está pronta p'ra me ouvir?

TERESA - Comece, pois então!

BALTAZAR - Como saberá o seu pai tem um sonho - Deus do céu! É juntar as nossas casas, Castro Daire e Viseu. Estamos de perfeito acordo eu e ele e então só falta a prima Teresa dar a sua opinião eu já tenho a certeza daquilo que vai dizer esse seu silêncio é "sim" está claro de entender diz o velho ditado que quem se cala consente diga lá o que é que sente diga lá o que é que sente

POBRES - Diz o velho ditado que quem se cala consente

Diga lá o que é que sente

Diga lá o que é que sente

TERESA - Se quem se cala consente vou começar a falar

Eu detesto o seu visual! essa forma de estar!

O seu, ar convencido de que vou dizer sim

Falhou completamente, porque eu penso assim :

Há muito tempo que sou toda do meu querido Simão

E estou-me borrifando para a nossa união

Por isso se pergunta "Qual a minha opinião"

Está na ponta da língua: evidentemente é NÃO

BALTAZAR - Dessas suas palavras ainda se há-de arrepender

eu cá estarei p'ra ver

eu cá estarei p'ra ver 
POBRES - Dessas suas palavras ainda se há-de arrepender eu cá estarei p'ra ver eu cá estarei p'ra ver

POBRES - Continuaram a conversa que acabou em discussão ele dizendo sim! Ela gritando não!

BALTAZAR - Assim é que eu posso

Chamar-lhe de "paizinho"

Diz que ama Simão, o filho daquele espantalho.

TADEU - Há de se casar consigo!

Tem medo quando eu ralho!

Vou dar-lhe uma tareia muda já de opinião!

Vai ficar num frangalho, depressa esquece de Simão!

BALTAZAR - Talvez seja melhor, por bem, chamá-la à razão!

Falar-Ihe ao coração!

Falar-Ihe ao coração!

TODOS - Talvez seja melhor, por bem, chamá-la a razão!

Falar-lhe ao coração!

Falar-lhe ao coração!

TADEU - Teresinha, minha filha! tu sabes como eu gostava de te ver casada com seu primo!

TERESA - Eu sei, meu pai, mas essa união é impossível!

POBRES - Castro Daire - Viseu!

TERESA - É impossível!

TADEU - Essa tua decisão, esse teu gesto, faz-me revelar para a sepultura, e tu ... resvalas para um convento, não tarda a nada! Morreste para mim!

TERESA - Senhor meu pai! Não me mande para um convento, peço-lhe! Não me prive sua companhia. Prometo-lhe que morrerei para todos os homens, menos para si.

MENDIGO 3 - Astúcia tem ela!

MENDIGO 2 - Aquilo é hipocrisia!

MENDIGA 1 - Seria mais correto chamar-Ihe...

MENDIGO 1 - Perspicácia!

TADEU - Faço-Ihe mais um ou dois choradinhos deste estilo e casa com o primo! Viseu-Castro Daire!

MENDIGO 2 - Ainda não sei bem como, mais isto é capaz de render qualquer coisita! 
TERESA - Pst! ó PST!

MENDIGO 2 - Como está a menina Teresa?

TERESA - Preciso que me faça um favor ....

MENDIGO 2 - A menina manda!

TERESA - Não, não! Quem manda é o meu pai, mas estou pronta a desobedecer-lhe!

MENDIGO 2 - Não faz se não bem! Se estivéssemos todos de acordo a vida era monótona!

TERESA - Sabes onde fica Coimbra?

MENDIGO 2 - Sabem onde fica Coimbra?

TODOS - É p'rali!

TERESA - É p'raquele lado!

TERESA - Precisava que me levasses esta carta a Simão .....

MENDIGO 2 - .... e então lá vou eu a Coimbra!

MENDIGO 1 - Esta visto que o pai não lhe dá dinheiro p'ros selos!

MENDIGO 3 - E vais de bolas?

MENDIGO 2 - Deu-me um anelzinho ... mas já prometeu um par de luvas e brincos!

MENDIGO 3 - Então a gente vai contigo! Viseu-Coimbra

MENDIGA 1 - E Coimbra - Viseu!

MENDIGO 2 - Porquê ?

MENDIGA 1 - Então havias de ir sozinha? E podemos pedir pelo caminho!

MENDIGO 1 - E a gente até gosta de viajar, lá por sermos pobres

MENDIGO 2 - Cá vai uma cartinha p'ra contar tudo ao Simão

TODO - E DIZ-LHE QUE JÁ MANDOU BUGIAR

O PRIMO BALTAZAR QUE

JÁ SE FOI

JÁ PARTIU

JÁ NÃO VOLTA A VISEU

O AMOR É TEU!

O AMOR É TEU!

E EU

CONTINUO A ALDRABAR AO MEU PAI SEM PARAR

ESTARÃO A PENSAR ESTARÃO A PENSAR

QUE MENTIR ASSIM AO PAI NÃO É BONITO 
TALVEZ NÃO SEJA, MAS HÁ-DE FAZER!

O NOSSO AMOR É BEM MAIOR QUE UMA PAIXÃO

EU SEI QUE ELE SERÁ AMANHÃ DE PERDIÇÃO

MAS TEM DE SER CONTINUAR E PERDER OU GANHAR

SE O AMOR ACONTECE NUNCA MAIS ARREFECE

E EU JURO NO PAPEL AO AMOR SER FIEL

SEJA AMOR OU PAIXÃO HÁ-DE SER PERDIÇÃO

29 TEMA - SINOS.

HOMEM - Ainda bem que já se foram todos embora! Vesti-me desta maneira porque pus-me a pensar e não me lembro de saber de único padre que tenha sido assaltado! Assaltam ricos, pobres, homens, mulheres, novos, velhos mas padres? Nunca ouvi dizer! Deve ser a batina que afugenta o diabo!

TADEU - Vais hoje dar a mão ao teu primo Baltazar. É preciso que te deixes guiar cegamente pela mão do teu pai.

Logo que deres esse passo difícil, conhecerás que a tua felicidade é daquelas que precisam de ser impostas pela violência.

Mas repara minha filha, que a violência dum pai é sempre amor.

POBRES - Eh!

MENDIGA 1 - O velho é mesmo foleiro!

TADEU - Dás-me o que peço ? Enches de contentamento os poucos dias que me restam?

MENDIGO 4 - Olha-me só o gajo, a fazer de conta que está com os pés p’ra cova!

TERESA - E será o pai feliz com o meu sacrifício?

MENDIGO 3 - Olha-me só o pai a pensar na bojarde que há-de dizer a seguir!

TADEU - Não digas sacrifício Teresa... Amanhã a estas horas verás que transfiguração se fez na tua alma. Teu primo é um composto de todas as virtudes.... será um marido excelente.

MENDIGO 1 - Estás muito calada!

MENDIGO 2 - Estou a tomar nota de tudo... isto é material que bem contado ainda vai render muito!

TERESA - E ele quer-me,depois de eu me ter negado? 
TADEU - Se ele está apaixonado, filha! E tem bastante confiança em si para crer que hás-de amálo muito!

TERESA - Pois pode ter a certeza que hei-de odiá-lo para sempre!

MENDIGO 5 - Agora é que vão ser elas!

TADEU - Hás-de casar!

TERESA - É escusada a violência porque eu não caso!

TADEU - Hás-de casar, ou então morrerás num convento! Nenhum infame há-de pôr um pé nas alcatifas de meus avós! E com o filho daquele espantalho, nunca! Maldita sejas! Já para o seu quarto! E espere que daí a arranquem para outro, onde não verá um raio de sol!

(Para Baltazar) Não te posso dar a minha filha, porque já não tenho filha!A miserável a quem eu dei este nome, perdeu-se para nós e para ela!

32 - TEMA - SINOS

PADRE - Eu não tenho nada contra os pobrezinhos, mas quando começam a roubar, chateiam-me! TODOS - ÚÚÚ!

PADRE - Claro que eles têm o seu valor.

TODOS - Ah!

PADRE - Aos beneméritos eles proporcionam as portas do céu!

33ㅇTEMA - ORGÃO

TODOS - Aleluia!

PADRE - São motivo de inspiração para os artistas!

TODOS - Aleluia!

PADRE - O papão que leva as criancinhas a comer sopa! A nobre causa que faz elevar a voz dos políticos! 
TODOS - Aleluia! Aleluia! Aleluia!

PADRE - Sim! Eles têm o seu valor e fazem falta!

TODOS - Fazem falta!

PADRE - E se Deus lhe deu dentes, mas ao mesmo tempo se esqueceu de lhes dar nozes, Ele lá sabe por quê! Os pobrezinhos são as formigas do nosso piquenique. Não deixem morrer as formigas.

34 TEMA - "DEUS DO CÉU”

O padre e a Freira saem Durante o "sermão" os actores estiveram a embelezar-se para o final. Tal como no princípio trazem os livros do Amor de Perdição.

\section{Cantam:}

DEUS DO CÉU - MAS QUE MAIS ESTARÁ P'RA ACONTECER JÁ NEM SEI SE VAI DAR P'RA SOFRER ESTE DRAMA CONTINUARÁ E A CONCLUSÃO VAI SER: UM AMOR DE PERDIÇÃO!

MENDIGO 4 - Simão está em Coimbra, transtornado, desesperado, porque acabou de receber uma carta de Teresa em que lhe diz que o pai a vai mandar para um convento!

MENDIGO 2 - A carta é um pedido de socorro que não lhe sai do pensamento.

TERESA - Socorro!

MENDIGO 4 - E Simão não se conforma!

SIMÃO - Isto não pode acabar assim!

MENDIGO 4 - E regressa a Viseu, decidido a enfrentar o pai, o primo, e se necessário for a raptar Teresa!

MENDIGO 2 - E como isto não pode acabar assim, marca-lhe um último encontro no jardim. 
MÚSICA 35ㅇTEMA - "NO JARDIM"

JARDIM - E DE NOITE PARA NINGUÉM VER

MAS ALGUÉM JÁ SABE O QUE ESTÁ P'RA ACONTECER

O PAI DELA DESCOBRE TUDO E ENTÃO

VAI SER: UM AMOR DE PERDIÇÃO!

MENDIGO 4 - Por ironia do destino, o pai descobre o bilhete que Simão enviara à Teresa:

TADEU - Temos de fazer qualquer coisa!

BALTAZAR - Primeiro, deixamo-lo encontrar-se com Teresa. Quero saber o que é que ele diz que eu não Ihe tenha dito; o que é que ele Ihe fez que eu não tenha feito!

TADEU - O que é que o meu sobrinho lhe fez? Nada!!

BALTAZAR - Aquilo que não fiz, só não fiz por causa da couraça: tolhe-me os movimento!

TADEU - O filho do espantalho não tem couraça!

BALTAZAR - Mas nós vamos oferecer-Ihe um sobretudo de madeira!

TADEU - Um caixão ?

BALTAZAR - Mas primeiro quero vê-los no jardim!

TADEU - E se eles forem longe demais?

BALTAZAR - Impossível: o jardim é pequeno.

TADEU - Sendo assim .... 
BALTAZAR - Esperamos que eles se despeçam e depois PUM PUM

TADEU - E era uma vez o filho do espantalho!

VÃO - VÃO TER DE ESPERAR - POIS!

É CHEGANDO O MOMENTO DE INTERVALAR.

O MELODRAMA CONTINUARÁ POIS É ALTURA IDEAL PARA DESCANSAR DEPOIS DESTE FINAL

DEUS DO CÉU - MAS QUE MAIS ESTARÁ P'RA ACONTECER

ESTE DRAMA CONTINUARÁ E A CONCLUSÃO

VAI SER - UM AMOR DE PERDIÃO

OU NÃO?

Canção dos bêbados

NO BORDEL A VIDA TEM MAIS EMOÇÃO

O AMOR COM VINHO Á MISTURA É BOM!

NO COVIL SÓ ENTRAM MARGINAIS E ATÉ

FAZ LEMBRAR UM VELHO CABARET

RECORDAÇ ÕES / P'RA RECORDAR

DESILUSÃO / PARA APAGAR

PORQUE A MEMÓRIA / NESTA HISTÓRIA

SEM MEMÓRIA / FOI-SE NO AR

NÃO É FIEL / DIZ O LEITOR 
NEM AO PAPEL / NEM AO AUTOR

MAS SE O DESTINO / É UM DESATINO

TROCA-LHE AS VOLTAS P'RA MELHOR!

NO BORDEL A VIDA TEM MAIS EMOÇÃO

O AMOR COM VINHO À MISTURA É BOM!

NO COVIL SÓ ENTRAM MARGINAIS E ATÉ

FAZ LEMBRAR UM VELHO CABARET

NÃO É FIEL / DIZ O LEITOR

NEM AO PAPEL / NEM O AUTOR

MAS SE O DESTINO / É UM DESATINO

TROCA-LHE AS VOLTAS P'RA MELHOR!

E BEBE UM COPO / E BEBE DOIS

VAIS AGUENTAR / AGUENTAS POIS

ATÉ TALVEZ / AGUENTA TRÊS

E SEIS E SETE E CHEGA AO DEZ!

NO BORDEL A VIDA TEM MAIS EMOÇÃO

A VIDA É BOA / P'RA BEBER

ANDAR À TOA / E ESQUECER

QUE O AMANHÃ / NÃO VAI TARDAR

UM NOVO DIA ESTÁ A CHEGAR

QUARTA PARTE - Na taberna do Sete Olhinhos 
Na TABERNA, bebe-se e canta-se uma canção. $O$ ambiente é de grande alegria. A meio da canção surge MARIANA.

MARIANA - Não sei bem como é que entrei nesta história. Eu não fazia idéia ...... foi o destino.

\section{CANÇÃO DA TABERNA}

Também nunca tinha entrado na taberna do Sete Olhinhos .... Diziam-me que aquilo não era lugar para mim... há sempre uns sítios que só são bons para os outros.

MÚSICA - 2ำTEMA - OFFENBACH

\section{APARECE SIMÃO}

.... e pessoas.

A gente nunca chega aonde quer; só chega até onde vai

.... e se às vezes não vai mais longe ... é porque

o nosso autocarro não há meio de passar .... ou se passa é porque já vai cheio ... e se mesmo assim a gente insiste em entrar .... sentimos lá dentro e cá dentro .... um aperto .... e pisam-nos .... e a gente só tem é vontade de sair e continuar a pé. Mas a pé ... não se vai longe. 


\section{3․ TEMA "CANÇÃO DOS BÊBADOS"}

SIMÃO SAI. FIM DA CANÇÃO DA TABERNA!

MARIANA - O meu nome é Mariana. Tinha uma vida simples; as coisas com que me preocupava eram aquelas coisas do dia a dia, que a gente às vezes até lhes dá muita importância porque não tem nada com que verdadeiramente se preocupe. Não acontecia nada.

\section{PEQUENO DIÁLOGO NA TABERNA}

MARIANA - Sou solteira .... e virgem. Mas isso não me preocupava; tinha me habituado à idéia de continuar assim e comecei a amar o trabalho, as flores, os pássaros ... eu sei que não é bem a mesma coisa, mas rezava muito, e como não sabia como é que era a outra coisa, pelo menos não sentia saudades.

Não sabia, nem sei; só que agora tenho sonhos ...sonhos estranhos, porque como ainda não sei como é, os meus sonhos são uma confusão de braços e de pernas ... e quando acordo, acordo extenuada ... e preocupada ... porque aquilo do sonho não deve ser bem assim ... tem de haver mais qualquer coisa para além dos braços e das pernas.

PEQUENO DIÁLOGO NA TABERNA

SIMÃO - Boa noite a todos!

TODOS - 'noite! 
TABERNEIRO - Isto é dos diabos! Olhe que inda mesmo a bocado estava a falar em si! Mas onde é que anda metido o senhor Simão, que há já um ror de tempo que não aparece por aqui, num foi, ó Rosa? que ela até me veio cá com uma história que eu nem percebi patavina!

ROSA - Vê lá mas é se te calas!

TABERNEIRO - Que nem parecia seu ter ido para Coimbra!

SIMÃO - Tem razão,eu não devia ter deixado Viseu!

TOINO - Então sempre a verdade aquilo da...

SIMÃO - Aquilo da quê?

EMBARCADIÇO - Tenha calma, ó Sr. Simão!

TABERNEIRO - Não se enxofre!

TOINO - Só perguntei se era verdade, gaita!

ROSA - Largue lá o homem!

TABERNEIRO - A gente ouve aqui, ouve ali ....

SIMÃO - O que é que ouviram?

TABERNEIRO - O que .... o que é que ouviste?

ROSA - Eu já nem te oiço!

TABERNEIRO - É tu .... ouviste alguma coisa? !

EMBARCADIÇO - Sou cego, surdo e mudo?

TOINO - Eu já nem sei o que é que ouvi!

TABERNEIRO - Está a ver ? Isto é tudo pessoal fixe! A gente o que entre por um ouvido sai pelo outro!

ROSA - Beba um corpo e acalme-se!

TABERNEIRO - É oferta da casa!

SI MÃO - Preciso de falar contigo, Toino!

TOINO - Se é por causa daquilo de há bocado ...

SIMÃO - Isso já passou à história! Preciso que me faças um favor. 
MARIANA - E calores. Também comecei a sentir calores e não era, nem sol, nem por ser verão. Foi desde aquele dia, em que entrei nesta história e conheci o senhor Simão. Eu ia passar á porta da taberna do Sete olhinhos e ouvi chamar...

TOINO - Mariana! Mariana!

MARIANA - O Toino chamou outra vez e eu também pensei que era uma falta de educação não responder ... e eu tenho esta mania de ser muito educada!

TOINO - Estás a falar com quem?

MARIANA - Falava comigo e com Deus.

TOINO - E então?

MARIANA - Então o quê ?

TOINO - Como é que correu?

MARIANA - Como é que correu o quê?

TOINO - A conversa!

MARIANA - Não zombes! que me queres?

TOINO - Não é isso ! Ele está em Viseu mas não quer que os sabiam; precisa de um sítio para esconder-se

MARIANA - Não sou nenhum buraco!

TOINO - Precisa de um sítio para dormir ... ele paga!

MARIANA - Se tem dinheiro que compre um saco cama!

TOINO - É o senhor Simão Botelho! Só tens de o deixar ficar lá em casa enquanto ele resolve o problema.

MARIANA - Que problema?

TOINO - É um problema lá dele!

MARIANA - E vai resolvê-lo p'ra minha casa?

TOINO - Não! O problema está noutra casa. 
MARIANA - Então porque é que não dorme na casa onde já está o problema?!

TOINO - Por quê?!

MARIANA - Só tenho uma cama!

TOINO - Uma cama serve muito bem.

MARIANA - É de corpo e meio.

TOINO - Se serve para ti, também serve para ele!

MARIANA - E onde é que eu durmo?!

TOINO - Podes ir para o palheiro .... ganhar uns dinheiritos e é só enquanto ele resolve o tal problema!

MARIANA - E vai demorar muito tempo a resolver?

TOINO - Ele está ali à espera da resposta .... entras e já falas com Toino; aquilo não é sítio para mim!

TOINO - Podes entrar à vontade que as pegas já se foram embora!

MARIANA - Lá dentro é que começaram os problemas, porque eu assim que o vi ... (desmaia)

SIMÃO - Toino, a pequena estará doente?!

TOINO - Há pouco estava fresca que nem um alface!

SIMÃO - A pequena está com baixa tensão.

TABERNEIRO - Foi-se abaixo só de olhar para si!

TOINO - Inda agora estava com muita atenção.

ROSA - Tanta ingenuidade eu juro nunca vi!

EMBARCADIÇO - Nunca namorou, não sabe o que isso é!

TODOS - Tanta ingenuidade eu juro nunca vi!

ROSA - Julga que a cegonha é que traz o bebê.

SIMÃO - Ah! Sim?!

TABERNEIRO- Ela pensa....

TODOS - Só serve pra fazer xixi. 
SIMÃO - Já acordou! está a abrir os olhos.

MARIANA - Onde é que eu estou?!

SIMÃO - Mariana,o Toino disse-me que a Mariana me podia ajudar ....

MARIANA - Ajudar? ...

SIMÃO - Ceder-me o seu quarto enquanto eu resolvo o problema....

MARIANA - Toino!

SIMÃO - São só duas ou três noites. Que me diz?

MARIANA - Toino!

TOINO - Ah?

MARIANA - Está um homem atrás de mim!

TOINO - É o Sr. Simão Botelho!

MARIANA - O Sr. Simão quê?

SIMÃO - O meu nome é Botelho! Simão Botelho!

(MARIANA DESMAIA NOVAMENTE)

SIMÃO - Ela desmaiou outra vez Toino!

TOINO - Deve ser por não estar habituada ao ambiente de taberna!

TABERNEIRO - É a primeira vez que põe os pés aqui dentro!

EMBARCADIÇO - É uma rapariga muito honesta ... percebe?

ROSA - Aqui dentro cheira-Ihe o pecado e não agüenta com a tentação!

SIMÃO - Tem realmente um ar de ...

TODOS - Honesta!

TABERNEIRO - E o grande problema das mulheres honestas é que vivem inconsoláveis.

SIMÃO - Inconsoláveis, por quê ?

ROSA - Por causa dos pecados que não cometeram.

TABERNEIRO - Do que ela precisava era duma ... 
ROSA - Tu cala-te, libidinoso, que eu já nem te oiço!

SIMÃO - Tenho de ir com Teresa, está na hora. Achas que posso contar com o quarto?

TOINO - Mais que certo, que ela é boa rapariga! Quando ela acordar eu acerto os pormenores.

SIMÃO - Obrigado, Toino.

TOINO - Esperamos aqui por si.

SIMÃO - O mais tardar, dentro de uma hora já cá estou.

MARIANA - Foi então que descobri que não poda olhar para o senhor Simão, porque começavam a subir-me uns calores pelo corpo acima ... e eu caía redonda. Depois comecei a evitar olhar para ele porque também parecia mal estar-lhe sempre a cair aos pés.

Nessa noite, fiquei à espera dele e depois .... ainda desmaiei mais uma vez.

EMBARCADIÇO - Ajudem aqui ! o senhor Simão foi Ferido!

VOZES - Como é que foi? O Sr. Simão foi ferido! Foi uma emboscada! Fizeram-lhe uma emboscada!

TOINO - Foram os criados do Sr. Baltazar Coutinho!

VOZES - Meu Deus! Irá morrer? Que grande desgraça!

MARIANA - Que drama!

4ำ tema - drama

TODOS - Ó DRAMA MAS QUE GRANDE DRAMA

FIZERAM-LHE UMA GRANDE EMBOSCADA

SIMÃO FERIU-SE NUMA PERNA

MAS NÃO LHE ACONTECEU NADA

TOINO - Temos de tirar-lhe a bala! 
TODOS - Tiremos-Ihe a bala !

SIMÃO - Esperem! Precisava escrever uma carta!

TODOS - RAIOS PARTAM COM TANTA ESCRITA PRIMEIRO VAIS BAIXAR AS CALÇAS P'RA LHE TRATARMOS DA PERNA

TOINO - Temos de tirar-Ihe a bala!

MARIANA - Onde é que ela está? Onde é que ela está?

\section{TODOS - AI A PEQUENA DESMAIOU FOI COUSA DE BELZEBU FICOU BASTANTE IMPRESSIONADA NÃO É RAPAZ DE VER O CU.}

ROSA - Uma mulher que nunca viu nada, com qualquer coisa se vê abaixo duas coisas se vê abaixo duas canetas!

MÚSICA (tem o Registro muito baixo)

MARIANA - E levaram o Sr. Simão para minha casa, deitaram-no na minha cama;

e desde essa noite passei a dormir, não no palheiro, mas aos pés da cama;

e sentia cada vez mais calores

e comecei a ter aqueles sonhos com braços e com pernas

.... e mais nada!

(sobe música) Música segue caixa música (Realejo) 
TABERNEIRO - O pai da menina Teresa mandou-a para um convento.

$7^{\circ}$ TEMA - NUM BORDEL A VIDA TEM MAIS EMOÇÃO

NO BORDEL A VIDA TEM MAIS EMOÇÃO

O AMOR COM VINHO A MISTURA É BOM

NO COVIL SÓ ENTRAM MARGINAIS E ATÉ

FAZ LEMBRAR UM VELHO CABARET

E BEBE UM COPO / E BEBE DOIS

VAIS AGUENTAR / AGUENTAS POIS

ATÉ TALVEZ / AGUENTE TRÊS

E SEIS E SETE E CHEGA AO DEZ!

A NOITE É BOA / P'RA BEBER

ANDAR À TOA / E ESQUECER

QUE O AMANHÃ / NÃO VAI TARDAR

UM NOVO DIA ESTÁ A CHEGAR!

Mariana vai à frente baixa música para deixa.

MARIANA - (quando fala sai) Não vai contra o destino! Não vale de nada,

Sr. Simão

SIMÃO - Por que diz isso?

MARIANA - É o meu coração que fala por mim! Tenho o coração na boca! 
SIMÃO - Peço-lhe Mariana, pelo que mais ama neste mundo ... leve este bilhete a Teresa e diga-lhe ... diga-Ihe que a vida só faz sentido ao lado dela ... e se eu não a voltar a ver...

MARIANA - Se não voltar a ver? ...

SIMÃO - Prefiro renunciar à vida!

MARIANA - Não precisa de ser tão dramático ! a situação já é dramática só por si ... e nestas alturas convém distanciarmo-nos um bocadinho.

Guarde essa arma; ainda pode precisar dela!

Eu levo o bilhete.

Posso não levar mais nada ... mas o bilhete eu levo.

SIMÃO - Não sei como pagar-lhe mais este favor.

MARIANA - Pois eu sei o que gostava que me desses ....

SIMÃO - Diga o que quer ! Por amor de Teresa eu dou-lhe, seja o que for!

MARIANA - Promessas ....

SIMÃO - Mariana, por que é que não me olha nos olhos?!

MARIANA - Já caí vezes demais ! Devemos parar a tempo.

$9^{\circ}$ tema - realejo

SIMÃO - Estará apaixonada por mim?

TERESA - Simão continuará apaixonado por mim?

MARIANA - Se eu conseguisse que ele se apaixonasse por mim!

BALATAZAR - A priminha ainda se há-de apaixonar por mim!

FREIRAS - SR BALTAZAR COUTINHO (3 badaladas e segue)

11 TEMA -ÓRGÃO

NO CONVENTO

TERESA - Não a conheço. 
MARIANA - Pois conheço-a eu que nestas últimas horas tenha ouvido falar senão na menina.

TERESA - A quem?

MARIANA - O senhor Simão.

$12^{\circ}$ TEMA - (sinos 3 badaladas)

TERESA - Onde é que está? Ficou ferido?! Morreu?!

MARIANA - Não, menina. Só o atingiram no ânus.

TERESA - Onde?!

MARIANA - No cu! Eu própria lhe tirei a bala!

TERESA - Graças a Deus! Podia ter sido pior!

MARIANA - Sim! Se fosse mais ao lado, ficava inutilizado!

TERESA - Inutilizado?!

MARIANA - Foi o médico que disse porque eu desses assuntos não percebo!

13ํTEMA - SINOS - 3 BADALADAS

Teresa - Diga-me: ele pensa em mim?!

MARIANA - Não pensa noutra coisa.

TERESA - Se ao menos eu pudesse vê-lo! ... se tivesse vindo ele ...

MARINA - Em vez de mim?

TERESA - Sim ... eu .... havia de lhe cair aos pés.

MARIANA - Eu sei o que isso é.

TERESA - É amor.

MARIANA - Ele diz que não quer viver sem a menina .... manda-lhe este bilhete.

TERESA - Eu não posso escrever; as freiras tiraram-me o tinteiro. Diga-lhe ....

MARIANA - Diga, diga!

TERESA - Que amanhã me vão mandar para outro convento, no Porto; ordens do meu pai. Para ficar bem longe dele, do Simão .....

FREIRAS - Terminou a visita.

TERESA - E então ....

MARIANA - Então, boa viagem menina Teresa. 
FREIRAS - Não ouviu menina?! Terminou a visita!

TERESA - Diga-lhe que o meu primo Baltazar vai comigo. Tem medo que eu fuja!

FEIRAS - Bruxa!

(Elsa - Mulas - Música - órgão)

Pausa

14ํTEMA - ORGÃO

FREIRAS - Sr. Baltazar Coutinho!

BALTAZAR - A Priminha está preparada para seguir para o Porto? Elsa levantase. (começam - Sinos - segue Música - segue sinos)

15 TEMA - SINOS

16ํTEMA - JÁ TENHO PAR....

MARIANA - ... e vai para um convento.

SIMÃO - Tenho de vê-la antes de partir!

MARIANA - Não faça uma coisa dessas!

SIMÃO - Tenho de vê-la, Mariana. Nem que seja pela última vez.

17으는 - SINOS

TABERNEIRO- Ninguém estava à espera que aquilo acontecesse!

ROSA - E à porta do convento ! Que desgraça!

(música 3 - piano)

18ํTEMA - DRAMA PIANO 
BALTAZAR - A carruagem está à espera, prima Teresa.

TERESA - Eu sei, primo Baltazar.

SIMÃO - Agradeço-lhe tudo o que fez por mim.

MARIANA - Eu não fiz nada!

SIMÃO - Fez muito!

MARIANA - Muito mais podia eu ter feito; mas Deus não me deu essa oportunidade.

ROSA - A princípio, nem me parecia ele!

TABERNEIRO- Disfarçou-se para não ser reconhecido.

ROSA - Se a menina Teresa não tivesse dito nada!

TABERNEIRO- Aquilo saiu-lhe sem ela querer!

ROSA - E foi o fim. Que desgraça!

BALTAZAR - Essa sua demora prima Teresa, quererá dizer que está a repensar?! TERESA - Repensar?!

BALTAZAR - Sim ... na minha proposta : lembre-se que se aceitar o meu amor, ainda pode evitar esta viagem tão enfadonha até ao Porto.

TERESA - Não conheço o Porto, primo; e não vou perder esta oportunidade.

BALTAZAR - Ainda se há-de arrepender.

MARIANA - Ainda vai se arrepender, senhor Simão.

SIMÃO - Porquê?

MARIANA - Não vão deixá-lo aproximar-se da menina Teresa.

SIMÃO - Ninguém me pode impedir.

MARIANA - Vista esta roupa. Assim, vão confundi-lo com um pobre.

SIMÃO - E posso aproximar-me dela ....

MARIANA - Pensaram que vai pedir-Ihe uma esmola ... 
SIMÃO - .... um beijo ..... ( oh! desculpe Mariana, foi sem intenção .... desculpe.) MARIANA - Eu sei .... foi um ensaio .... para quando chegar lá .... correr tudo bem

TERESA - Estou pronta !

SIMÃO - Adeus!

BALTAZAR - Vamos!

FREIRAS - Vamos!

TERESA - Vamos!

MARIANA - Ele beijou-me ...

BALTAZAR - Ela rejeitou-me ....

MARIANA - Foi sem querer!

BALTAZAR - Foi de propósito!

TABERNEIRO E ROSA - Uma desgraça!

NAQUELE DIA A PORTA DO CONVENTO

QUEM LÁ PASSOU POR CERTO NÃO ESQUECEU

UM SÓ SEGUNDO E NAQUELE MOMENTO

CRUEL DESTINO TUDO SE PERDEU

SIMÃO MATOU A LIBERDADE

PERDEU A VIDA O PRIMO BALTAZAR

TERESA PERDEU A OPORTUNIDADE

DE ALGUM DIA SIMÃO CASAR

MARIANA! CHORA! SABE QUE A VERDADE

VAI SER UM TRISTE FIM TRISTE ACABAR!

SIMÃO - Uma esmolinha pelo amor de Deus.

BALTAZAR - Não incomodes a menina.

FREIRAS - Estamos cheias de pressa.

BALTAZAR - Vamos para o Porto. 
TERESA - Não te posso dar nada porque o meu pai tirou-me tudo!

SIMÃO - Decerto não the tirou a esmola que eu the peço.

AS 3 MULHERES - Simão!

MÚSICA SEGUE

TERESA - Simão!

SIMÃO - Sou eu

(e música segue)

20ํTEMA - "SIMÃO"

BALTAZAR - Afaste-se daqui seu espantalho! dançam

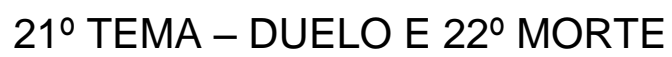

FREIRAS - Vá-se embora, seu porco!

BALTAZAR - Fora do nosso caminho.

SIMÃO - Qual caminho?

FREIRAS - Vamos para o Porto!

TERESA - Ele está armado, Simão! Eu...

SIMÃO - Teresa vai para o Porto mas tu vais p'ro inferno!

Tiro e grito (pára)

SINOS

SIMÃO - Perdoa-me Teresa; apesar de tudo,sempre era da tua família. 
Sinos (12)

23ํTEMA - SINOS

aqui segue música $24^{\circ}$

FREIRAS- Somos agentes da polícia disfarçados de freiras:

Considere-se preso.

Como é que se chama?

SIMÃO - O meu nome é Botelho! Simão Botelho!

MARIANA DESMAIA

MÚSICA DE SAÍDA

24ํTEMA - "AMOR DE PERDIÇÃO"

e segue caixa de música

25 TEMA - REALEJO - (mais baixa com texto do padre)

ROSA - O Sr. doutor Simão Botelho... condenado à morte!

Tenho de fazer qualquer coisa!

Vou falar com o juiz.

Irmã.... sempre fui uma mulher séria, mas para salvar um homem da forca ... eu sou capaz de tudo!

Música baixa quando ela está na direita baixa e diz:

ROSA - E é que eu vou a tribunal (sobe)

(Rosa sai para o tribunal) (música para a caminhada)

26은 TEMA - FILME MUDO JUIZ 
ROSA - Sr. doutor juiz, clemência!

JUIZ - Sim, sim, sim.

ROSA - O nome é Rosa, para o servir

JUIZ - Sim, sim, sim.

ROSA - Venho pedir a V. Exa. clemência!

JUIZ - Ofendeste a moral pública?

ROSA - Não.

JUIZ - Cometeste homicídio!

ROSA - Não

JUIZ - Matricídio!

ROSA - Não

JUIZ - Parricídio!

ROSA - Não

JUIZ - Suicídio!

ROSA - Não

JUIZ - Adultério

ROSA - Ainda não.

JUIZ - Mais afinal, o que tu fizeste?

ROSA - Eu não fiz nada, Sr. doutor Juiz!

JUIZ - Vem pedir clemência para uma falta que ainda não cometeste? Não deixa ser original, fora do vulgar.

ROSA - Venho implorar clemência para o senhor doutor.

JUIZ - Para mim? Mais isso é contra os regulamentos!

ROSA - Para o senhor doutor Simão Botelho!

JUIZ - Simão Botelho? Não sei quem é!

ROSA - Mandou-o para a forca!

JUIZ - Ah! Esse!

ROSA - Sr. Doutor juiz ... Dê o dito por não dito e vai ver que não se arrepende.

JUIZ - Dar o dito por não dito?! Não posso! O carrasco ia ficar chateadíssimo comigo; há mais de uma semana que não mando ninguém p'ra forca! 
ROSA - Arranja-te outro! Não falta por aí quem mereça esse destino!

JUIZ - Mas não há provas ... E o que a senhor me está a pedir é duma crueldade sem limites!

ROSA - É cruel pedir que poupe a vida a um homem?!

JUIZ - E o carcereiro ?O carcereiro já está a contar com esse trabalho! O que é que eu ia dizer ao pobre do carcereiro? Não posso agora desiludi-lo!

ROSA - O Sr. é juiz? Pode inventar uma desculpa qualquer que ninguém duvida! JUIZ - Sim, sim, sim ... mas não ! Não posso!

ROSA - Pode dizer que pensava que tinha ... mas afinal não tem a prova do crime.

JUIZ - Mas tenho e ainda ali está! Quer ver?

ROSA - A pistola?!Pode fazê-la desaparecer.

JUIZ - E o morto? Acha que também posso fazer desaparecer o morto?!

ROSA - Tive uma idéia, Sr. Doutor juiz! Podíamos fazer uma troca.

JUIZ - Uma troca?

ROSA - Simão ia para o lugar do morto ... e mandava-se o morto para a forca!

JUIZ - A senhora ainda é pior que a justiça! Quer enterrar um vivo e mandar para a forca um inocente!

ROSA - O morto não ia dar por nada; o carrasco ficava contente; enchíamos o caixão com pedras, Simão desapareceria sem deixar rasto... não acha que isto é uma boa idéia?!

JUIZ - Peça-me outra coisa qualquer, mas isso não!

ROSA - Senhor doutor juiz... reconsidere, peço-lhe.

JUIZ - Eu já Ihe disse ...

ROSA - Se não lhe agrada a idéia da troca, mude a sentença ... não fuja ... venha cá ... vai ver que não se arrepende ...

Entra música 8

(Juiz e Rosa vão-se embora )

(Mesma situação do princípio desta cena )

27ํTEMA - FILME MUDO JUIZ - 
- O que é que aconteceu á outra pequena, à Mariana?!

- Ao saber que o amante foi condenado e vai p'ra forca, enlouqueceu!

- Então ele era amante dela ou da outra?!

- Das duas!

- Xiça! Há gajos cá com uma sorte!

- Uns com tudo e outros sem nada!

- Então a Mariana enlouqueceu!

- Completamente ! Está, que nem parece a mesma!

Música

- Bandamerda!

(Vira-se entra música da Febre)

28은 TEMA - FEBRE

MARIANA - Eu já não sei bem quem sou

CORO - Nunca soube bem quem é

MARIANA - Eu só sei que estou diferente

Sinto-me boa, à toa, neste cabaret

CORO - Ela está com febre!

MARIANA - Desde o dia em que te vi

Logo te perdi Simão

CORO - A pobre não se conforma

Foi um amor

CORO - Amor e de perdição

MARIANA - Devo estar com febre!

CORO - Febre! 
MARIANA - Quero cobrir-te de beijos

Sentir o teu corpo nu

Saciar os meus desejos

CORO - Quer entregar-se toda, toda a Belzebu

Deve ser da febre!

CORO - Febre!

MARIANA - Não sei o que faço aqui

Donde venho ou para onde vou

Só sei que ao olhar p'ra ti

CORO - É evidente que Mariana desmaiou

Por causa da febre!

CORO - Por causa da febre!

Febre! Febre!

(Entra música mas não há!)

$30^{\circ}$ TEMA - FILME MUDO JUIZ

№. 26 - cassete

ROSA - Venha cá! Não fuja ... não se esconda ... Sr. Doutor juiz ... reconsidere ... peço-lhe ...

JUIZ - Eu já disse ...

ROSA - Dê o dito por não dito ... o senhor pode ... se quiser ... um rapaz tão novo $\cdots$

JUIZ- Eu?!

ROSA - E com uma corda ao pescoço ...

JUIZ - Ninguém o mandou carregar no gatilho!

ROSA - Foi um crime de amor! 
JUIZ - Não tem perdão!

ROSA - O Sr. doutor nunca amou?

JUIZ - Já não me lembro ...

ROSA - Eu podia fazê-lo recordar ...

JUIZ - Esteja quieta!

Rosa - A toga fica-Ihe tão bem ...

JUIZ - Esteja quietinha!

ROSA - Mas por baixo dessa toga eu sei que existe ...

JUIZ - Está a fazer-me cócegas

ROSA - Existe um homem com bom coração! ! Deixe-me ver o seu coração e eu mostro-lhe o que é o amor ... e depois o senhor doutor vai concordar que é possível matar por amor...

JUIZ - Quem é que quer que eu mate?! Eu mato! Eu mato!

ROSA - Mas eu não quero que mate ninguém! Só quero que lhe tire a corda do pescoço.

JUIZ - Oh! D. Roooosa!

ROSA - O Sr. Doutor juiz é um croissant!

JUIZ - Meu pãozinho de leite!

ROSA - Se não fosse juiz, aposto que era bombeiro voluntário.

JUIZ - E se isto fosse ficção científica e D. Rosa era um micro-ondas!

JUIZ - A justiça esteve a reflectir ... e acabou de verificar que se baralhou um bocadito!

(exclamações de desagrado da parte de todos)

JUIZ - Silêncio!

Decidi portanto ...que Simão Botelho não vai p'ra forca

(Simão exclama com alegria "não vou p'ra forca! Não vou p'ra forca" e todos os restantes mostram desagrado). 
JUIZ - Silêncio ou mando evacuar a sala!

BALTAZAR - Sr. doutor juiz desculpe mas ...

ROSA - Você cale-se que já morreu!

JUIZ - O réu tem alguma coisa a dizer?!

SIMÃO - Sr. Doutor juiz ... se eu não vou para a forca ... então, para onde é que eu vou?!

(exclamações:"p'ra câmara de gás!" "é matá-lo à pedrada!" "Afogá-lo, como os gatos"!) "(guilhotina!)".

JUIZ - Silêncio! Lembro aos presentes, que não estamos na Idade Média! Neste momento e devido ao adiantado da hora o que é preciso é um fim feliz, um fim que agrade a todos!

Simão Botelho, vou mandá-lo para o degredo!

TODOS - Onde?! Para onde?!

JUIZ - Ilha da Madeira!

(exclamações de desagrado "Oh!")

SIMÃO - (feliz) Obrigado Sr., doutor juiz. Nunca fui à llha da Madeira!

ROSA - É um autêntico jardim!

PADRE - Não pode ser! Ele é deportado para a Índia, mas morre antes de lá chegar!

ROSA - O senhor não tem vergonha?! Então o senhor é padre e quer que ele morra?

JUIZ - O Sr. Quer saber mais do que eu que sou juiz?

Está decidido, vai para a Madeira!

BALTAZAR - Então e eu?!

JUIZ - Tem de compreender que eu sou juiz, não sou Deus!

Posso deixá-lo falar de vez em quando, mas não posso ressuscitá-lo por completo!

ROSA - A Madeira é um jardim!

JUIZ - E a D. Rosa uma flor!

PADRE - Um fim feliz! Quem diria?!

SIMÃO - Mais uma vez ... obrigado! 
JUIZ - Agradeça à D. Rosa! Foi ela que abriu os olhos à justiça! Música M7

30ํTEMA - OPERA DITO POR NÃO DITO

ROSA - Senhor doutor juiz acabou de alterar a

A sentença vai de novo proclamar

POLÍCIAS - Não é justo Deus do Céu

Houve um homem que morreu

BALTAZAR - Quem me matou, ele vai ter de castigar

JUIZ - Reuni com D. Rosa

E alterei toda prosa

Vou mandá-lo para a Índia degredado

POLÍCIAS - ROSA - MARIANA - JUIZ

Senhor Simão saia daí, vai viajar

SIMÃO - Já só via a minha hora de morrer

TODOS menos JUIZ

Cuidado que vai p'ro mar

Entre o ir e o voltar

Muita coisa pode ainda acontecer

JUIZ - Eu não quero discussões

Já basta de opiniões

Dei a sentença já não há nada a fazer

Já disse tudo aquilo que teria p'ra dizer

Não dou o dito por não dito

Já cumpri o meu dever

JUIZ REPETE UMA VEZ 
Todos - Já disse tudo aquilo que teria p'ra dizer

Não dá o dito por não dito

Já cumpri o meu dever

TODOS MAIS UMA VEZ

JUIZ - Não dou o dito por não dito já cumpri o meu dever

TODOS - Não dá o dito por não dito

JUIZ - Já cumpri o meu dever

TODOS - Dever

LISBOA ANTIGA - Um fim feliz! Quem diria?!

E no entanto, também eu queria!

Mas um fim feliz assim

É claro, não pode ser,

Que eu aprecio um bom drama

E Simão, Teresa e Mariana

Todos têm de morrer.

Faça-se luto pesado,

E nem mais uma cantiga!

LISBOA MODERNA - Mas quem és tu, mulher de negro?

LISBOA ANTIGA - Eu sou a Lisboa antiga!

LISBOA MODERNA - Pois eu prefiro um fim feliz

Divertido e brejeiro

Que p'ra ver grandes desgraças

O povo não dá dinheiro

Um guarda roupa cuidado

Um final bem arejado

Música, p'ra dar à perna. 
LISBOA ANTIGA - Quem és tu, que odeias drama?

LISBOA MODERNA - Sou a Lisboa Moderna!

LISBOA ANTIGA - Se eu sou a Lisboa antiga

E tu Lisboa Moderna

Há algo aqui que está errado.

LISBOA MODERNA - Por isto não ser revista?!

Ó Antiga, qual é a tua?

Isto está tudo trocado

LISBOA ANTIGA - Estamos num quadro de rua

AS DUAS - Que faz ligação ao fado!

Música (Desgarrada)

31 TEMA - DESGARRADA

Só o fado é a verdade

Nesta mentira que é a vida

No teatro há falsidade

Toda a verdade é fingida

E quem já riu do amor

vai passar um mau bocado

Deus inventou p'ra castigo

A dor sentida do fado

Que o destino de Simão 
Foi um destino danado

Tanta dor não cabe não

$\mathrm{Na}$ letra triste de um fado

Ele não foi para a forca

É verdade sim senhor

Mas não partiu p'ra Madeira

esse jardinzinho em flor

A Índia foi o seu destino

Para lá foi degredado

Mariana foi com ele

Não largou o seu amado

Ao ver partir o barquinho

Teresinha estremeceu

e à janela do convento

a pobre desfaleceu

Os três amantes tiveram

Destino triste e igual

Com grande mágoa vos digo

Morrem todos no final

Com grande tristeza nossa

o final é p'ra chorar

Contém mensagem singela

vão para casa pensar

Que este amor sincero e puro 
Também é de perdição

Por isso lá vamos juntos

Nesta nossa procissão

E à luz das velas partimos

para a grande catedral

do fado! Fado chorado

sofrido e sentimental

Também ele o expoente

Da perdição nacional.

\section{Segue}

$32^{\circ}$ TEMA - SINOS 


\section{O Sangue}

Os actores/personagens assistem ao final de um dos actos de "O Fantasma da Ópera". No camarote da família Barros preparam-se para "comer o farnel", mas a própria cena leva-os a guardarem o petisco para mais tarde. Nicolau não tira os olhos de Tomasinha.

É intervalo.

AMIGO

Fiz mal em ter-te convidado! Durante todo o acto não paraste de olhar para aquele camarote!

NICOLAU

Não! Fizeste bem! Nem imaginas o quanto!

AMIGO

Imagino que não deves estar a perceber nada do que se está a passar no palco!

NICOLAU

Enganas-te novamente! Já vi "O Fantasma da Ópera" umas quatro ou cinco vezes!

AMIGO

É um privilégio de quem tem dinheiro para correr mundo!

NICOLAU

Começo até a pensar que há qualquer coisa que me liga a esta ópera!

AMIGO

Só falta dizeres que de certa forma te identificas com o protagonista!

NICOLAU

Desta vez acertaste!

AMIGO

Por amor de Deus! Não me vais agora tentar convencer que a tua cara não é a tua cara, mas sim uma máscara com a qual escondes as cicatrizes provocadas por um incêndio ou mordeduras de ratos ou qualquer outra catástrofe! 
NICOLAU

Este rosto é o meu... mesmo assim... tenho atravessado a vida como um fantasma!...

AMIGO

Já percebi que te agrada o papel de mártir!

NICOLAU

Não podes entender!!! Não nos víamos há cinco anos!...

AMIGO

Aviso-te que estás tal e qual como sempre te conheci: um dramático! Um grande amigo, um homem bom, mas acima de tudo: um dramático!

NICOLAU

Não nego que sempre fui um romântico!

AMIGO

Negar não te valia de nada! Mas gostava que me explicasses... com mais clareza... o que é que a tua vida tem a ver com "O Fantasma da Ópera"!

NICOLAU

Ele ama Cristina desde o primeiro momento em que a viu... mas sabe que o seu coração pertence a outro. Sofre em silêncio... mas não desiste de conquistar o seu amor. Ele sabe que é capaz de tudo por aquela mulher. Decide raptá-la e leva-a consigo para o seu esconderijo, nos subterrâneos do teatro. Tudo o que ele pretende é fazer dela uma diva... a sua diva... E Cristina descobre aos poucos que no interior daquele que todos consideram um monstro se esconde uma alma boa, um coração puro... está a um passo de se apaixonar por ele... mas a sociedade que os rodeia nunca permitiria esse final. Levam-no à loucura... e ao suicídio... Cristina foi a sua doce fatalidade.

AMIGO

Esqueceste-te da célebre cena em que o fantasma faz cair o candelabro, matando uma série de pessoas!

NICOLAU

A cena do candelabro não passa dum “pormenor cénico sem importância”...

AMIGO

Para ti, talvez, mas não para o autor e muito menos para o público de ópera que adora ouvir uma ária enquanto o sangue escorre e os mortos não morrem! Seja como for, continuo sem perceber o que é que te liga a esta ópera!

NICOLAU

Vi-a pela primeira vez em Caminha... 
AMIGO

Não sabia que em Caminha já há teatro de ópera!!!

NICOLAU

Aquela mulher... vi-a pela primeira vez em Caminha... e desde esse dia que não me sai do pensamento... desde esse dia que outra imagem não mais pude ver em meus sonhos... Ela... é a minha inevitável fatalidade! Que julgas tu que sou capaz de fazer por aquela mulher?

AMIGO

Asneiras superiores ao meu cálculo.

NICOLAU

Amo-a desde o primeiro momento... se me perseguirem e eu me vir em risco de a perder... sou capaz de tudo!

AMIGO

Nicolau de Almeida: sempre foste um romântico, mas o destino continua a fazer de ti um homem com pouca sorte! A D. Tomasinha casou há pouco mais de dois meses.

NICOLAU

Como é que sabes o seu nome?!

AMIGO

Frequentei a mesma escola do marido.

NICOLAU

És amigo desse homem?!

AMIGO

Apenas colegas de carteira; fui a casa dele duas ou três vezes. Sabes portanto que ela é casada?!

NICOLAU

$\mathrm{E}$ isso que importa? Se o destino quis que eu hoje a tornasse a encontrar!

AMIGO

Não foi o destino! Fui eu que te arranquei de casa para virmos ao teatro!

NICOLAU

Tens de ajudar-me! Conheces a família, podes arranjar forma de eu me encontrar com ela... tenho de Ihe falar!

AMIGO

Estás doido?! 
NICOLAU

Se não me ajudares é isso que me espera: a loucura... talvez o suicídio...

AMIGO

És um romântico doentio! O que tu queres é ficar imortalizado numa ópera!!! Mas em Portugal não há autores de grandes óperas! Verdi! Wagner! Etc. Etc... esses sim; mas nenhum deles é português!!!

NICOLAU

Queres dizer com isso que não me ajudas?

AMIGO

A ajuda que tu pedes, não!

NICOLAU

Haverá outra?!

AMIGO

Conheces Camilo?

NICOLAU

Qual Camilo?!

AMIGO

Camilo Castelo Branco! Escreve romances de fazer chorar as pedras da calçada! Posso falar-lhe de ti; talvez se interesse pelo teu melodrama, ainda que na sua vida não lhe faltem temas para desenvolver!

NICOLAU

Se outra ajuda não me queres dar... conta-me tudo o que sabes dela... da Tomasinha...

AMIGO

Sei que a mãe morreu de parto, e alguns meses depois morreu-lhe o pai...

NICOLAU

É órfã!...

AMIGO

Foi recolhida pelos padrinhos, judeus e muito ricos, que nessa altura já tinham um filho de 3 anos, o Inocêncio.

NICOLAU

Foram então os padrinhos que arranjaram o casamento?! 
AMIGO

Consta que sim; mas a ama de Tomasinha - penso que se chamava Custódia da Porciúncula - fez tudo para impedir que eles se casassem! Era uma velhota muito crente a São Gonçalo de Amarante e foi a principal responsável por uma troca de cartas de namoro entre a Tomasinha e aquele que foi o seu primeiro amor...

\section{TOMASINHA}

«Suspiro por vós como o rolo que geme na árvore solitária pela rolinha amada.»...

CUSTÓDIA

"O rolo geme pela rolinha amada"...

TOMASINHA

Mas que bem que ele escreve, Custódinha!

\section{CUSTÓDIA}

Foi São Gonçalo d'Amarante quem mo enviou, menina!!! Olhe que quando ele se achegou a mim com a primeira cartinha... lembro-me tão bem!... tinha acabado de pedir a São Gonçalo que arranjasse à menina um noivo como deve ser! Que o seu padrinho bem quer casá-la com o filho, esse narizinho de judeu! Mas a menina merece melhor!!! O Inocêncio é um safado dum mulherengo! Um tirano! Um malcriadão! Judeuzinho rico, mimado! Sempre a zombar de tudo e de todos! Aquele velhaco, ainda era menino já me fazia a vida negra; pinchava-me às cavaleiras, dava-me aqui com os calcanhares nas ilhargas, aqui onde tenho uma obstrução de cada lado. Outras vezes fazia-me aqui por detrás pontaria às ilhargas, com a bengala do pai, Jesus, até se me repuxavam os refegos do nariz...! Mas o que é que ele diz mais?! Leia! Leia, menina!

TOMASINHA

Diz que gosta muito de mim... e, olha!..

\section{CUSTÓDIA}

Vejam vocês!!! Que graça têm estes bonecos! E este menino, tão gordo! Isto não pode ser o menino Jesus, porque tem aqui uma cestinha à bandoleira. Será São Joãozinho?

TOMASINHA

Não é! Isto é o Amor!!..

CUSTÓDIA

O amor?! Este rapazinho assim em pêlo é o amor?...

TOMASINHA

É pois! Chama-se Cupido. 


\section{CUSTÓDIA}

Ah! isso pode ser; que eu, lá em Serpa, quando era moça, bem me lembra de ouvir cantar o boticário, umas modinhas à guitarra, onde dizia lá o verso:

\section{Maldito seja o Cupido}

Que cravou no peito meu

A «setra» que não penetra,

Marília no peito teu.

Já hoje se não cantam destas modinhas! Agora o que se ouve por aí é umas senhoras a dar uns guinchos que parece que estão com as dores de parto. Pelos modos cantam à moda italiana... Mas continue lá, menina, que eu ainda não ouvi aquilo que quero ouvir!

TOMASINHA

Que queres tu ouvir mais, Custódinha?

\section{CUSTÓDIA}

Não se faça de novas!... Ele parece sincero, sim senhora, e lá letrado é ele, mas eu já lhe disse, menina, se ele demora muito a falar em casamento, acaba-se 0 namoro e pronto!

TOMASINHA

Ele diz que "o rolo quer a rolinha"...

CUSTÓDIA

Isso do rolo e da rolinha já eu sei!

TOMASINHA

Que suspira por mim como o rolo...

CUSTÓDIA

Suspira pela menina como o rolo... e que mais?

TOMASINHA

Diz que o rolo que geme pela rolinha...

\section{CUSTÓDIA}

Também já ouvi! "O rolo que geme pela rolinha"... mas casar?!... Se não fala aí em casar acabam-se hoje mesmo as cartinhas!

TOMASINHA

Fala! Fala!... Aqui está... "o rolo... ...quer casar...!"... CUSTÓDIA

Quer casar? 
TOMASINHA

Com a rolinha!!!

CUSTÓDIA

Quer casar! Então é um homem honrado! Eu sabia que São Gonçalo d'Amarante Ihe havia de arranjar um noivo como deve ser! Vá lá escrever-Ihe, enquanto me apronto! O boticário de Serpa também cantava esse verso à guitarra!

TOMASINHA

Qual verso?!

CUSTÓDIA

Deixa cá ver se me lembra......já sei!

"O rolo quer a rolinha

E a gemer chama por ela;

O pombo quer a pombinha;

Só tu me desprezas, bela!"

TOMASINHA

Sempre que o vejo na rua

ao rosto me sobe a cor, ...Mesmo que eu queira, não posso...

Mesmo que eu queira, não posso,

negar que lhe tenho amor.

SEBASTIANA

Não sei porquê, mas de há uns tempos para cá, que a Tomasinha me parece diferente... as manas não notaram?!

FLORÊNCIA

Está agora diferente!

SEBASTIANA

Está diferente!

FLORÊNCIA

Lá crescer, cresceu ela! Está tão linda, mana Sebastiana!

TOMÁSIA

Já tem 16 aninhos e hoje em dia as crianças desenvolvem mais depressa do que no nosso tempo.

SEBASTIANA

Acho-a muito diferente! 
GUIMARÃES

$$
\begin{aligned}
& \text { Vai-te carta aventurada, } \\
& \text { ver um bem que Deus me deu, } \\
& \text { Tu vais para lá ficar, } \\
& \text { em teu lugar... fora eu! }
\end{aligned}
$$

TOMASINHA

Meu amor, eu disse ao Sol, que não tornasse a nascer.

Eu tenho o Sol dos teus olhos;

que vem o Sol cá fazer?

\title{
SEBASTIANA
}

Acho-a muito diferente!

FLORÊNCIA

Eu com 16 aninhos já era muito alta, mas nunca tive o seio tão desenvolvido como o da Tomasinha!

\section{SEBASTIANA}

Com certeza foi por isso que não casou! Não é o seio mana Florência! Eu noto-a diferente mas não tem a ver com o seio!...Parece-me... parece-me... mas só a mim é que me parece!...

TOMASINHA e GUIMARÃES

Há uma semana que te amo,

Há duas te quero bem, Há três te trago no peito, Sem o dizer a ninguém.

\author{
SEBASTIANA \\ Parece-me... eu cá tenho as minhas razões... \\ TOMÁSIA e FLORÊNCIA \\ Parece-Ihe o quê, mana Sebastiana?! \\ SEBASTIANA \\ Parece-me... muito feliz! Pronto!
}


TOMÁSIA

Por amor de Deus Sebastiana! A Tomasinha é uma menina que só tem motivos para se sentir feliz!!!

FLORÊNCIA

Eu concordo com a mana Tomásia!

SEBASTIANA

Mas de há um mês para cá que ela anda mais feliz do que o costume! Acho muito estranho, muito estranho!!!

TOMÁSIA

A mana desculpe, mas eu não vejo o que é que isso tem de estranho!!!

SEBASTIANA

Se houvesse um motivo... não seria estranho! E cá para mim há!!! Há, porque ela está diferente!!!

FLORÊNCIA

E a mana a dar-Ihe!!!

SEBASTIANA

Pois! Eu a dar-lhe e a burra a querer fugir!

FLORÊNCIA

Ó mana Sebastiana!!!

TOMASINHA

Eu gosto tanto de ti, eu quero-te tanto tanto...

Parece ser o Diabo, ou o milagre de algum Santo.

GUIMARÃES

Eu quero-te tanto tanto, que não sei onde te meta... dentro do meu coração, ou dentro duma gaveta!

\section{TOMÁSIA}

Eu não queria dizer-Ihes, porque ainda me parece muito cedo... mas talvez haja um motivo! Há muito tempo que o Gervásio alimenta o desejo de casar o Inocêncinho com a Tomasinha! Não é para já, que eles ainda não estão na 
idade... mas a seu tempo, se eles gostarem um do outro, é claro! Há oito ou dez dias... perguntei à Tomasinha o que é que ela pensava, se gostaria, de um dia mais tarde... vir a casar com o meu Inocêncio.

\section{FLORÊNCIA}

E ela?!

\section{TOMÁSIA}

A Tomasinha ainda é uma menina muito inocente... ruborizou... ia para dizer qualquer coisa mas não the saiu nada; eu disse-lhe que não precisava de me responder naquele preciso momento, mas a nossa Tomasinha ainda balbuciou: "Sim, madrinha! Sim madrinha!".

\section{SEBASTIANA}

E o Inocêncinho! Qual foi a reacção do Inocêncinho?!

\section{TOMÁSIA}

O pai ainda não falou com ele... mas penso que vai falar... em breve!

\section{GERVÁSIO}

Ainda bem que... ainda bem... ainda bem que estamos todos... a família Barros!... e o Inocêncio... onde está o Inocêncio?...

\section{FLORÊNCIA}

Deve estar no quarto.

GERVÁSIO

Ainda bem.

SEBASTIANA

Quer que o chame?

GERVÁSIO

Ainda não!

FLORÊNCIA

Deve estar no quarto.

GERVÁSIO

Ainda bem.

SEBASTIANA

Quer que o chame?

GERVÁSIO

Ainda não! 
TOMÁSIA

Não se chama!

GERVÁSIO

A Tomasinha também cá está, é claro!

TOMÁSIA

É claro!

GERVÁSIO

Ainda bem!

FLORÊNCIA

Passa-se alguma coisa?!

GERVÁSIO

Ainda não!

SEBASTIANA

Mas passa-se alguma coisa?

GERVÁSIO

Ainda não!

TOMÁSIA

Ainda bem

TOMÁSIA

Eu conheço-te Gervásio! Passa-se alguma coisa!!!

GERVÁSIO

Não se passa nada!

TODAS

Ai, não se passa nada; graças a Deus!

GERVÁSIO

O que se passa é que... sentem-se, sentem-se. A Custódia... não está?!

SEBASTIANA

A esta hora deve estar com S. Gonçalo de Amarante!

GERVÁSIO

Ainda bem! $O$ assunto... é um assunto que só diz respeito à família. $O$ que se passa é que... nós pensávamos que ainda era cedo... mas depois do que me foi dado saber... receio... receio que se continuarmos a pensar que ainda é cedo... é muito capaz... de... quando chegar a altura... já ser tarde demais!!! 
TOMÁSIA

Assustas-me, Gervásio!

GERVÁSIO

Temos de os casar... e o mais depressa possível! A Tomasinha com o Inocêncio!

\section{TOMÁSIA}

O Inocêncio ainda só tem dezanove anos!

\section{GERVÁSIO}

Os tempos são outros! Eu tinha vinte e oito e alguns meses, quando pensei em procurar companheira. Isto agora é outra coisa. Voltou-se o mundo. As mulheres estão desaustinadas; e os mancebos, assim que Ihes pinta o buço, ninguém tem mão neles...

\section{TOMÁSIA}

O nosso filho é bem comportado!

\section{GERVÁSIO}

O nosso filho é como o filho dos outros. O que me foi dado saber é que Inocêncio... o nosso filho... namora!

\section{FLORÊNCIA}

Virgem Santíssima!

\section{SEBASTIANA}

O cunhado tem a certeza?!

\section{TOMÁSIA}

Santa Maria Goretti! O meu filho namora! O meu menino tem uma namorada! Vamos ficar sem o nosso menino!

\section{GERVÁSIO}

Temos de casá-lo com a Tomasinha... e já!!!

\section{TOMÁSIA}

Mas se ele já tem uma namorada!...

GERVÁSIO

Aí é que está, antes tivesse! Aquele pedaço de asno não tem uma! Tem seis!!!

ELAS

Seis?!!! 


\section{GERVÁSIO}

Pois que cuidam? Vocês não sabem que ele é rico? O Inocêncio vem a ser o homem mais rico do Porto! Vocês também não sabem, mas há por aí muita moça que pensa que há-de casar-se rica, porque tem um palmo de cara ajeitada!

\section{TOMÁSIA}

Seis?...

\section{GERVÁSIO}

De seis, vim eu a saber que andam na peugada do Inocêncio, mas podem muito bem ser mais! E não há uma que tenha dez reis de seu!

\section{TOMÁSIA}

Mas elas não vêem, essas mulheres desaustinadas, que o nosso Inocêncinho ainda é uma criança?!

\section{GERVÁSIO}

Elas vêem o que querem ver... e o que elas querem ver, D. Tomásia, é o dinheiro dos Barros!!! O nosso dinheiro!!! Que me dizem agora vocês? É tempo de o casarmos ou não?

TIAS

E quanto antes!

GERVÁSIO

E tu que dizes, Tomásia?

\section{TOMÁSIA}

Que hei de eu dizer?... Afigura-se-me que a Tomasinha gosta dele... mas ele?! E se o nosso menino não gosta da nossa afilhada? Tínhamos combinado que eles a casar, tinha de ser como nós... por amor; achas que o nosso filho, se quisesse casar com Tomasinha, andaria lá com esses namoros que dizes?... 
GERVÁSIO

Valha-te Deus, mulher! Valha-te Deus! É claro que gosta! Mas um homem é um homem. A culpa não na têm eles; são elas. Elas... e as famílias! Não têm dez reis de seu, Tomásia!!! Para nos apanharem o dinheiro são capazes de tudo e o que eu tenho medo é que alguma mais espertalhona enfeitice o rapaz!!!

\section{FLORÊNCIA}

Tem de falar com ele, cunhado!

GERVÁSIO

E quanto antes!

\section{TOMÁSIA}

Eu ainda nem quero acreditar! Apenas com 19 anos... e já com seis mulheres!

\section{SEBASTIANA}

Há-de ouvir os seus conselhos; sempre foi tão respeitador, tão bem educado...

"E o até então tão falado Inocêncio, faz a sua entrada em cena!"

INOCÊNCIO

Bom dia paizinho! Bom dia mãezinha! Bom dia tia Florência! Bom dia tia Sebastiana!

\section{ELAS}

(Chorosas) Bom dia... Inocêncinho!...

GERVÁSIO

Bom dia meu filho.

INOCÊNCIO

Aconteceu alguma desgraça?!

ELAS

Ainda não!

INOCÊNCIO

Alguma coisa aconteceu para estarem assim!... Podem dizer-me!... Já sou um homem!

ELAS

O nosso menino! 
INOCÊNCIO

Foi o tio Luís que morreu?!

GERVÁSIO

Inocêncio, precisamos de ter uma conversa, de homem para homem! Quero ficar a sós com o meu filho. Não!... O teu tio ainda não morreu!

INOCÊNCIO

Mas então... está para breve?

GERVÁSIO

Há cinco anos que o teu tio Luís está para morrer, Inocêncio...

INOCÊNCIO

Coitado do tio Luís! Lá longe, no Brasil, cheio de dinheiro... e às portas da morte!

GERVÁSIO

Sim, mas agora não é dele que eu te quero falar. É uma conversa de homens... sobre... sobre mulheres!

INOCÊNCIO

Eu sabia que Ihes tinha acontecido qualquer coisa! O que é que aconteceu à mãezinha, à tia Florência e à tia Sebastiana?!

ELAS

Nada!!!

GERVÁSIO

Nada! Não Ihes aconteceu nada! Não é dessas mulheres que eu te quero falar! É das outras!

INOCÊNCIO

Da Custódia e da Tomasinha?!... Estão doentes?!

GERVÁSIO

Nesta casa ninguém está doente, Inocêncio!

INOCÊNCIO

Graças a Deus! Mas então?...

GERVÁSIO

Então... cala-te um bocadinho e... escuta: A minha afilhada... a Tomasinha...

INOCÊNCIO

Eu conheço! 
GERVÁSIO

...tu sabes como eu gosto dela... como se fosse uma filha... e tu... com certeza que também gostas dela!?

INOCÊNCIO

Pois não havia de gostar?! É a minha maninha!

GERVÁSIO

Sim... mas na verdade... sabes que não é!

INOCÊNCIO

Não é... mas é como se fosse!

\section{GERVÁSIO}

Claro, claro! Mas agora que já são ambos crescidos - e aqui está uma parte da tal conversa "de homem para homem" - ...eu tenho motivos para pensar que ela vê em ti... mais do que um irmão!... E gostava também de ter motivos para pensar que tu... embora inconscientemente, porque ainda és muito novo... gostavas de casar com a Tomasinha.

INOCÊNCIO

Casar com a mana?!!!

GERVÁSIO

$\mathrm{Ai}$, ai, ai, ai, ai! Vocês não são irmãos de sangue!

INOCÊNCIO

É verdade que não somos irmãos... e somos muito amigos... mas, casar com a Tomasinha?! Ela ainda é uma miúda!... Ela nem tem... quero dizer... ela só tem... 12 ou 13 anos!...

ELAS

$16 !$

GERVÁSIO

A Tomasinha já tem 16 anos!

INOCÊNCIO

Já?!... mas sempre me pareceu mais nova!...

GERVÁSIO

E sempre foi mais nova do que tu três anos, mas já tem $16 \ldots$ e se olhares bem, vais reparar que já não é nenhuma criança... está até... bastante desenvolvida 
para a idade... e está numa boa idade para casar!... contigo! Aqui para nós, é o meu sonho! E o da tua mãe também!... Então?! O que é que dizes? Pára de desenhar narizes, que me enervas!!!! Vou dar-te um conselho; tu tem-me lume nesse olho: pensa bem! Não faças cavalada. Eu ouvi uns zunzuns...

INOCÊNCIO

Uns zunzuns?!

GERVÁSIO

Sim, uns zunzuns!... Mulheres!...

INOCÊNCIO

Mulheres?!

GERVÁSIO

Não tens que ter vergonha Inocêncio, eu sou teu pai, eu compreendo isso tudo e sei que a culpa não é tua! Elas agora andam desaustinadas! Mas olha que as moças que te fazem festas, o que querem é o teu dinheiro; mas vão erradas; que elas podem levar-me o filho e tu podes querer ir... mas o dinheiro é que não me levam... Elas não sabem... mas tu sabes... que o dinheiro dos Barros tem de continuar na família dos Barros! A Tomasinha é minha afilhada... é como se fosse da família...

INOCÊNCIO

Mas eu tenho a certeza que ela não gosta de mim...

GERVÁSIO

Como é que podes dizer uma coisa dessas?!

INOCÊNCIO

Para casar! Ela não gosta de mim para casar, nem eu dela!

(D. Tomásia tem o terceiro desmaio da noite)

GERVÁSIO

Outra vez?!!!

(Vão para outro "espaço" e Tomasinha é surpreendida a escrever)

TOMASINHA

Ai, que susto, carago! Padrinho!!!

GERVÁSIO

Que é isso?! Que medo tiveste, rapariga?!

TOMASINHA 
Eu estava aqui... Estava... a escrevinhar...

GERVÁSIO

Deixa cá ver! Vês como ela está adiantada...

TOMASINHA

Ora...

INOCÊNCIO

"Meu caro amor do meu coração, e único bem da minha paixão..."

\section{GERVÁSIO}

Ai! A menina faz versos?

TOMASINHA

Ora...

GERVÁSIO

Ou isso não é da tua cabeça?...

INOCÊNCIO

"Não tenho palavras com que possa explicar-vos..." O paizinho não sabe o que é isto?... Não sabe? É uma carta de namoro.

GERVÁSIO

Escrevias esta carta a alguém, Tomásia?!

\section{TOMASINHA}

Escrevia, sim senhor... mas não a mandava... Eu bem sei que me não ama a pessoa a quem eu escrevia...

GERVÁSIO

Querem vocês ver... que maravilha... querem vocês ver... Tu ainda não percebeste, Inocêncio?!

INOCÊNCIO 
Eu, não, senhor.

\section{GERVÁSIO}

Pois não percebeste, pedaço de asno?... A carta era para... Diz tu, menina... Diz tu para quem era a carta...

TOMASINHA

O Inocêncinho bem sabe... mas não the faz mossa contar.

GERVÁSIO

Entendeste agora, rapaz?

INOCÊNCIO

Ora, meu pai... eu não engulo maranhões... Esta carta não era para mim...

\section{GERVÁSIO}

Pois para quem havia de ser, pedaço de asno?! Eu bem sei que és boazinha. Pena é que este rapaz não tenha o coração de teu padrinho... Ó alma de cântaro! Pois tu acharás debaixo da rosa do sol rapariga mais galante e que mais te encha as medidas?!

INOCÊNCIO

Esta carta não era para mim... "Não tenho palavras com que possa explicar-vos..." Pois ela que me queria explicar?! Sim; que me queria explicar ela a mim?

\section{GERVÁSIO}

Eu te desengano e já!... Pateta! Tomasinha: diz ao padrinho como é que estavas a pensar continuar esta carta.

TOMASINHA

Ora, já me não lembro como tinha começado.

GERVÁSIO

Eu leio-te: "Não tenho palavras com que possa explicar-vos..."

TOMASINHA

"...a satisfação que recebi quando sua mãe me disse que nos queria ligar pelos sagrados laços do..." não me lembra do que ela disse... é uma coisa muito falada nas comédias... os sagrados laços do... laços do...

\section{TOMÁSIA}

Do himeneu! 
TOMASINHA

É isso: os laços do himeneu. Escrevia-lhe, porque me envergonhava de tho dizer de cara a cara. Ai que vergonha!

\section{GERVÁSIO}

Percebes agora, pedaço de asno?! Que estás aí malucando? A apostar que tens alma de não amar este serafim!! Esta criaturinha tão linda que foi criada contigo! Inocêncio de Barros, queres receber por legítima esposa a minha afilhada Tomasinha? (deteve o rapaz a resposta, roendo a unha do dedo polegar) Então? Comes os dedos ou respondes?

INOCÊNCIO

Ela que diga...

D. TOMÁSIA

Tomasinha, queres receber por legítimo esposo o meu filho Inocêncio de Barros?

TOMASINHA

A madrinha bem sabe a minha vontade... mas eu sou órfã... e venho doutra classe social... não me corre nas veias sangue judeu... e sou pobre...

\section{GERVÁSIO}

Qual quê?! Fica sabendo que mesmo que ele não te queira, metade do que eu tenho há-de ser teu; essa fortuna, já nem a justiça nem o Bersabu ta tiram! Quanto ao nosso sangue, ainda não te corre nas veias... mas há-de correr! E agora, responde lá rapaz: Queres receber por legítima esposa a minha afilhada Tomasinha?

INOCÊNCIO

Ela ainda não respondeu...

D. TOMÁSIA

Responde tu a teu pai, menino! Ou sim, ou não. Contra vontade não quero que te cases...

CUSTÓDIA

Peço desculpa! Peço desculpa por vir interromper... mas eu tenho de dizer isto: a senhora D. Tomásia tem razão. Casar, se o coração não puxa, é mau arranjo.

"Menina casar sem gosto, por fazer vontade alheia; é cair no inferno em vida, remar contra a maré cheia!" 
Não venha com sentenças, que o negócio há-de arranjar-se sem o seu voto, se Deus quiser...

CUSTÓDIA

Pois; se Deus quiser sim... mas se Deus não quiser...

SEBASTIANA

Deixe-a falar cunhado, deixa-a falar, que é mulher experimentada.

GERVÁSIO

Fale! Mas depressa!

\section{CUSTÓDIA}

Estes meninos, afiançou-me S. Gonçalo de Amarante, não estão talhados para se casarem. O senhor Inocêncinho não gosta da senhora D. Tomasinha; se gostasse, já Iho tinha dito. Queira perdoar o meu atrevimento, mas S. Gonçalo de Amarante aconselha-o que os deixe ficar solteiros. Ao seu filho não hão-de faltar noivas... e olhe bem p'ráquela carinha! Isto que digo é p'ra seu bem, menino; está-lhe estampado que não gosta da menina! Prometo-lhe que intercedo por si a S. Gonçalo, que Ihe há-de arranjar noiva de seu agrado... e rica... muito rica!

GERVÁSIO

Um momento... conhecem esse tal S. Gonçalo de Amarante?

D. TOMÁSIA

É um santo de confiança e com muito prestígio!

FLORÊNCIA

Muito amigo das velhas... a quem gosta de fazer milagres!

D. TOMÁSIA

Dizem que esse poder está no bastão!

SEBASTIANA

É! As velhas agarram-se-lhe ao bastão enquanto fazem os pedidos. Recorri a ele três dias antes do meu falecido dar o último suspiro!

GERVÁSIO

Mas então não the valeu de nada; se ele morreu! 
SEBASTIANA

Foi isso mesmo que eu the fui pedir, cunhado!... Estava num grande sofrimento... Ainda demorou três dias, porque a grande especialidade do santo são os casamentos!

GERVÁSIO

Ah! Sim?...

D. TOMÁSIA

Diz que sim... e eles a casar... tem de ser por amor, como nós!

GERVÁSIO

Estou esclarecido. Inocêncio! Gostas da rapariga ou não gostas? Diz lá o que quiseres, que eu não to levo a mal. Se vês que te não agrada o casamento, di-lo à boca cheia. Cá às costas não quero culpas. Queres a moça ou não queres?...

INOCÊNCIO

Meu pai... eu então... peço quinze dias para pensar.

GERVÁSIO

Para pensar o quê?! Deixemo-nos de histórias. Se o coração to não pede, acabouse. Arrumou-se a pendência. ( $D$. Tomásia desmaia) Preparem as malas do rapaz! Hoje mesmo vai pisar uvas p'ró Douro!

FLORÊNCIA

Vai mandar o Inocêncinho p'ró Douro?!

GERVÁSIO

Pois se quer "pensar", que vá pensar p'ra longe!!!

SEBASTIANA

Sábia decisão, cunhado! Longe dessas mulheres desaustinadas o nosso menino talvez consiga raciocinar com mais clareza!

\section{GERVÁSIO}

Talvez!... e ouve lá, que isto é a valer: Se a não quiseres para tua companheira, quero-a eu para minha filha. Para ela ter que comer à farta não precisa de casar contigo. Olha se me entendes, Inocêncio! Se deixas a minha afilhada lá por alguma farroupilha que te botou o anzol... não és só um pedaço de asno!... És um asno completo!!! Boas noites.

\section{TODOS}

Boas noites.

SEBASTIANA

Aqui para nós...eu também já tinha reparado que de há uns tempos para cá o Inocêncinho andava diferente! Muito Estranho!!! A mana não notou?! 


\section{FLORÊNCIA}

Para lhe responder francamente...

\section{SEBASTIANA}

Não notou, é claro! Nem sei porque lhe fiz esta pergunta! Nunca nota nada!!!

\section{FLORÊNCIA}

Estou preocupada é com a mana Tomásia! Continua desmaiada.

\section{SEBASTIANA}

Pois! Mas olhe que isso é que não tem nada de estranho! Só nos últimos dez minutos a mana Tomásia já desmaiou quatro vezes!

\section{FLORÊNCIA}

Mas desta vez está a durar mais tempo que o costume!

\section{SEBASTIANA}

Pois!... Deixe lá... sempre é menos uma a debitar texto!

\section{FLORÊNCIA}

Não lhe ocorre que a mana... possa estar morta!

\section{SEBASTIANA}

Eu já teria percebido! Desde o funeral do meu marido que sou alérgica a corpos mortos! Começo a espilrar e nunca mais paro!... Deve ter adormecido...

\section{TOMÁSIA}

Gervásio... onde está o Gervásio?!...

\section{SEBASTIANA}

Eu não dizia?!... Acabou de acordar!

\section{TOMÁSIA}

O Gervásio acabou de acordar?!

\section{SEBASTIANA}

Não, mana! Acabou de sair!

\section{TOMÁSIA}

Onde é que ele foi?!

\section{SEBASTIANA}

Como é que quer que eu saiba?! Nunca fui mulher de andar atrás de homens casados! 
FLORÊNCIA

Quem acabou de acordar foi a mana!

TOMÁSIA

Devo ter adormecido!

\section{SEBASTIANA}

A mana não adormeceu, teve mais um chelique!

TOMÁSIA

Ah!... Já me lembro! Desmaiei... porque o Inocêncio não ama a Tomasinha!

SEBASTIANA

Mana! Onde essa cena já vai!

TOMÁSIA

Não percebo o que quer dizer!

SEBASTIANA

Exactamente o que ouviu, mas eu repito: Onde essa cena já vai! Há uma semana que o Inocêncinho foi p'ró Douro! Trabalhos forçados nas vindimas!

\section{FLORÊNCIA}

Esteve desmaiada uma semana inteirinha.

\section{SEBASTIANA}

Cá para mim esteve uma semana em estado de coma! Para a mana... foi um tempo morto! Mas não se preocupe... que nós encarregamo-nos de o preencher!

\section{TOMÁSIA}

Manas! Manas! Como é que o destino pode ser tão cruel?! Acabo de sair dum estado de coma e sou informada que o meu filho está no Douro, descalço, com as calças arregaçadas, sabe Deus até onde... e a pisar uvas! Um Barros! Pergunto a mim própria: Que teria acontecido e que mais ainda estará para acontecer?! O meu coração de mãe pressente... tragédia!

TOMASINHA

Eu Quero amar, amar, perdidamente... amar por carta é uma espécie de vaivém!

E ao apalpá-las sinto um desejo ardente... de te apalpar, amor, a ti também!

\section{CUSTÓDIA}

Ai menina, menina! Nem sei como lhe dê a notícia! Mas trago notícia ruim! 
TOMASINHA

Que aconteceu, Custodinha?!... Já sei! Faleceu o tio Luís?!

CUSTÓDIA

Antes tivesse falecido, menina!

TOMASINHA

Credo, Custódia, isso nem parece teu!

CUSTÓDIA

Pois se há tanto tempo ninguém está à espera doutra coisa, antes isso do que a desgraça que trago no peito, que até se me embarga a voz, que eu quero falar e nem me saem as palavras!

TOMASINHA

Poderá haver coisa mais terrível que a morte?!

CUSTÓDIA

Há sim, menina! A vida! Quando ela não corre à nossa feição!

TOMASINHA

Mas o que é que não corre à tua feição?!

CUSTÓDIA

Não corre à minha nem vai correr à sua, quando souber; que eu só quero o seu bem menina, mas eu ia lá agora duvidar de S. Gonçalo de Amarante; é que levoume à certa! Ele, o bastão e o outro!

\section{TOMASINHA}

Qual outro?!

CUSTÓDIA

O Guimarães, menina! Esse Guimarães! O tanto que eu rezei!... mas não há-de ser ele... que a vai levar à igreja!

TOMASINHA

Estás a dizer-me que o Guimarães não me quer levar à igreja... o Guimarães não gosta de mim?!... não... não pode ser... deves estar enganada Custódia...

CUSTÓDIA

Antes estivesse, minha rica filha!...

TOMASINHA

...se ele não gostasse de mim, para que me havia ele de escrever tantas cartas... 


\section{CUSTÓDIA}

Para a iludir... e para a menina the responder com outras tantas, que ele lê aos amigos... e todos se riem com os dizeres da menina!!!

\section{TOMASINHA}

Ele lê as minhas cartas aos amigos?!

\section{CUSTÓDIA}

Vi eu com este olhos, quando vinha a sair da igreja. Reparei num ajuntamento duns quatro ou cinco basbaques, todos a olhar para o Guimarães, que estava empoleirado num palanque a ler um papel, que eu ainda não sabia o que era. $E$ então pensei: "Querem ver que o homem anda metido em coisas da política?!" e aproximei-me sem eles dar conta! Pois eram as cartas da menina! E todos, numa galhofa pegada! As lágrimas saltaram-me como punhos!

TOMASINHA

Que diziam eles?

CUSTÓDIA

Chamavam-Ihe seresma... que queriam conhecer essa seresma da rua das Cangostas!!! Não chore, meu anjinho, não chore, que me parte de meio a meio o coração.

\section{TOMASINHA}

Disseste-me que ele era um enviado de S. Gonçalo de Amarante!

\section{CUSTÓDIA}

Tem razão, tem razão: mas que quer, menina? A gente engana-se. E o santo também!

\section{TOMASINHA}

O Guimarães!...

\section{CUSTÓDIA}

Que leve a breca o homem e má peste o tolha! Tantos diabos o apanhem como bagadas me caíram por esta cara!... Ora diga-me cá, menina... que lhe parece... 0 Inocêncio?

TOMASINHA

O Inocêncio?!

\section{CUSTÓDIA}

É que está-me a parecer que o rapaz lhe quer bem, e lá como casamento não era desarranjo! Eu tomara ver a menina casada com outro!... mas se ele fosse bom marido... e rico é ele! A menina tem de casar quanto antes! 
TOMASINHA

Quanto antes porquê?!

CUSTÓDIA

Por causa das cartas, menina! Antes que chegue aos ouvidos do Inocêncio que andou a mandar cartas ao Guimarães e que ele as lê na praça pública!

TOMASINHA

Casar com o Inocêncio?! Mas... eu gosto dele, mas não o amo Custódia!

CUSTÓDIA

Ora! O amor vem depois, vai ver! Pense no dinheiro. A menina sabe lá quanto esta gente tem de seu!

TOMASINHA

E se ele não gosta de mim?...

CUSTÓDIA

Não há-de agora gostar! A menina deixe-me manobrar, e lá pela sua parte não faça nada! Isto é, quando o Inocêncio olhar para a senhora D. Tomasinha, olhe também; se ele Ihe falar, fale-lhe; se ele não falar, não fale. E deixe-o andar; que o rapaz há-de ganhar-lhe paixão.

\section{TOMASINHA}

Mas ele está no Douro...

CUSTÓDIA

Há-de voltar!... Há-de voltar!!!

Inocêncio de Barros. Eu te salgo e te ressalgo e te torno a ressalgar

P'ra que não possas comer, nem dormir, nem sossegar!

Pensa só na Tomasinha, sempre ela no teu pensar!

Hás-de amá-la sem sossego, hás-de querê-la p'ra casar!

Eu te salgo e te ressalgo e te torno a ressalgar!...

TOMASINHA

Inocêncio!!!

INOCÊNCIO

Shuu! Os meus pais ainda não sabem que já cheguei! Tenho de falar contigo... tinha de ver-te... desde que parti que não tenho sossego.

TOMASINHA

Estás com um ar cansado...

INOCÊNCIO

Tenho pensado muito... 
TOMASINHA

Eu também...

INOCÊNCIO

...crescemos juntos Tomasinha e eu sempre olhei para ti como uma irmã...

TOMASINHA

E eu também...

INOCÊNCIO

Depois, comecei a olhar para outras raparigas... e às vezes, até pensava que gostava duma... ou doutra... mas nunca tinha a certeza... porque não sentia...

TOMASINHA

Não sentias o quê?...

INOCÊNCIO

...não sentia o que agora sinto... E só agora é que eu sei o que realmente se sente... quando se gosta de alguém.

TOMASINHA

Sabes?...

INOCÊNCIO

Sei: É de ti que eu gosto Tomasinha.

TOMASINHA

Não acreditaste em mim...

INOCÊNCIO

Perdoa-me ter duvidado do teu amor... e não duvides tu do meu.

TOMASINHA

Como posso acreditar... que o que dizes é verdade?

INOCÊNCIO

E eu vinha de tão longe para te mentir?! Trouxe-te uma lembrança. Não consigo comer, não consigo dormir... desde que olhei para ti com outros olhos que não tenho um minuto de sossego... sempre a pensar em ti...

TOMASINHA

Também tenho pensado muito em ti Inocêncio... Cheguei a escrever-te... mas depois guardei a carta...

INOCÊNCIO

Porquê?! 
TOMASINHA

Tive receio de que não acreditasses nas minhas palavras...

INOCÊNCIO

E que palavras eram essas! Quero ouvi-las agora!

TOMASINHA

$$
\begin{gathered}
\text { "Eu gosto tanto de ti, } \\
\text { eu quero-te tanto, tanto... } \\
\text { Parece ser o diabo, } \\
\text { ou milagre de algum santo." }
\end{gathered}
$$

INOCÊNCIO

Tomasinha!...

CUSTÓDIA

$$
\begin{gathered}
\text { Tomasinha é nome doce, } \\
\text { marmelada derretida }
\end{gathered}
$$

GERVÁSIO

TODOS

$$
\text { Vai casar com a Tomasinha! }
$$

Vai comer doce toda a vida!

\section{GERVÁSIO}

Eu vos agradeço meu Deus! Sou um homem feliz!... Não posso ser mais feliz!... O meu filho vai dar o sagrado nó com a minha afilhada... que já era minha filha adoptiva... e que muito em breve vai também passar a ser... a minha nora... a futura mãe dos meus futuros netos... herdeiros absolutos da fortuna que os Barros acumularam ao longo dos anos! Eu sei que sou judeu, e vós sabeis que eu sou e que me orgulho do meu sangue de judeu... mas não tenho vergonha de me ajoelhar perante vós... porque agora... eu já posso morrer com a consciência tranquila... já posso morrer e descansar em paz... porque o dinheiro dos Barros... vai continuar na família dos Barros!!!

\section{TOMÁSIA}

Não sei o que se passa comigo, mas desde que eles partiram, tenho andado numa preocupação constante... tenho tanto receio que lhes possa acontecer alguma coisa...

\section{SEBASTIANA}

Foram em Lua de Mel, mana Tomásia! Mal fora que não lhes acontecesse... alguma coisa! 
FLORÊNCIA

E correu tudo tão bem! O noivado, o casamento, o copo de água... e fiquei tão contente por ter sido eu a apanhar o ramo da noiva, quando a Tomasinha o atirou!

TOMÁSIA

Teve muita sorte, mana.

FLORÊNCIA

Muita!... Ainda nem sei que pensar!

SEBASTIANA

Se não sabe, eu digo-lhe: Pense que o mais difícil não é apanhar um ramo mana Florência! É apanhar um homem!

\section{TOMÁSIA}

Não leve a peito o que ela diz; ambas sabemos que a mana Sebastiana fala assim... porque nunca foi feliz; o marido gastou tudo o que tinha ao jogo... e com outras mulheres; quando morreu não lhe deixou nada... nem um filho... nada...

\section{FLORÊNCIA}

Eu sei... mas não precisava de se ter tornado tão amarga... tão agressiva; fala connosco duma maneira... - que Deus me perdoe, porque nós somos manas mas às vezes, a mana Sebastiana... parece mais um homem do que uma mulher!

\section{SEBASTIANA}

Eu só nunca lhe disse para não a ferir, mas quantas vezes também pensei: "Há qualquer coisa de errado na mana Florência, porque se não olharmos para as saias... coitadinha, tem tão pouco de feminino!".

\section{TOMÁSIA}

A mana não quis ofendê-la... nunca diria que parece um homem, se soubesse que estava a ouvir!

\section{FLORÊNCIA}

A mana sabe como eu gosto de si... eu seria incapaz... desculpe...eu pensava que tinha saído!

\section{SEBASTIANA}

Foi uma saída por entrada! "Falsa saída"... "Entrada brilhante"!... ...Terei de voltar a sair para continuarem a falar?!...

\section{FLORÊNCIA}

O Inocêncio e a Tomasinha... fazem um bonito casal, não fazem? Fiquei tão emocionada quando o padre disse: "estão unidos para sempre!"... marejaram-seme os olhos de lágrimas! 


\section{SEBASTIANA}

Ah! Sim? Não reparei, mas deve ter sido uma imagem muito bonita!...

\section{TOMÁSIA}

E eu, que estou farta de pensar... e não me lembro de ter ouvido essa parte...!

SEBASTIANA

É natural que não se lembre; foi logo a seguir à mana ter tido o chelique!

TOMÁSIA

Eu tive um chelique?!

FLORÊNCIA

Dois!

\section{TOMÁSIA}

Dois cheliques?! Não me lembro de nada!

\section{FLORÊNCIA}

$\mathrm{O}$ primeiro foi logo à entrada na igreja. Deve ter ficado almariada da cabeça com o cheiro das velas e então teve o chelique, mesmo quando ia a dirigir a mão para a pia da sagrada água benta!

\section{SEBASTIANA}

Resultado: o que lá meteu não foi a mão, foi a cabeça!

TOMÁSIA

Enfiei a cabeça na pia de água benta?!

FLORÊNCIA

A cabeça e o chapéu!

\section{TOMÁSIA}

Podia ter morrido afogada!

SEBASTIANA

A mana salvou-se... o chapéu é que não.

\section{TOMÁSIA}

Não me lembro de nada!... mas que vergonha!

FLORÊNCIA

Ora! Vergonha é roubar!... E foi há uma semana, já ninguém se lembra, mana!

TOMÁSIA

Graças a Deus. 
SEBASTIANA

Pois eu garanto-Ihe que foi uma cena que quem viu... dificilmente esquecerá!

FLORÊNCIA

Mesmo assim... foi uma cerimónia muito bonita!

SEBASTIANA

Em toda a cidade não se fala noutra coisa!

TOMÁSIA

O meu marido é um homem muito rico! Faz gosto que este casamento seja falado em todo o lado!

\section{SEBASTIANA}

Eu sei que o seu marido é muito rico e este casamento, notícia de primeira página, mas quando eu disse que em toda a cidade não se fala noutra coisa, estava a referir-me ao chelique da mana, que continua a ser o pico das audiências!... porque foi muito ridículo!!!

(Tomásia desmaia)

\section{FLORÊNCIA}

Dou-Ihe razão, mana! Enfiar a cabeça na pia baptismal...

FLORÊNCIA E SEBASTIANA

Foi muito ridículo!!!

GERVÁSIO

Depressa D. Tomásia! Venha ver quem acabou de chegar!

\section{SEBASTIANA}

Ela agora não pode sair daqui cunhado!

\section{FLORÊNCIA}

Teve mais um chelique!

\section{TOMÁSIA}

Gervásio... onde está o Gervásio?!...

SEBASTIANA e FLORÊNCIA

Está aqui, mana!

GERVÁSIO

O Inocêncio e a Tomasinha acabaram de chegar!

\section{TOMÁSIA}

Mas eles... não iam ficar lá por fora 15 dias?! 
GERVÁSIO

E ficaram!

TOMÁSIA

Então... isso quer dizer que...

SEBASTIANA

Quer dizer que a mana esteve outra vez desmaiada...

TODOS

Uma semana!!!

CUSTÓDIA

E então, menina?! Que cara é essa?! Conte lá como é que foi!

TOMASINHA

Ora!...

CUSTÓDIA

Não me diga que já não tem confiança em mim!...

TOMASINHA

É claro que tenho Custódinha!

CUSTÓDIA

E então?!... O que é que o rolo disse à rolinha?!... O que é que o Pombo fez à Pombinha?! Vá lá, desembuche!...

TOMASINHA

Lua de mel, lua de mel!!! Não foi nada como eu imaginei!

CUSTÓDIA

Pois como é que a minha menina imaginou que havia de ser?!

TOMASINHA

Quando entramos no comboio eu perguntei logo para onde é que íamos, mas ele fez um grande mistério e só respondeu: "É surpresa!" Ora, eu pus-me logo a pensar que íamos para Itália, ou França! Agora vê tu bem como é que eu não fiquei quando saímos na estação em Caminha e ele diz: "É aqui que vamos passar a lua de mel!".

CUSTÓDIA

Eu nunca lá fui, mas dizem que Caminha é uma terra muito bonita! 
TOMASINHA

Será, mas com tanto dinheiro que a gente tem, eu até sinto vergonha de dizer a alguém que fui passar a lua de mel em Caminha! Eu pôs-se-me um nó que nem Ihe respondi, mas fiquei tão desiludida!!! É que não estava nada a contar! Pois temos nós tanto dinheiro para quê?!!!

\section{CUSTÓDIA}

Deixe lá! A menina tem de compreender que eles não são como nós, são judeus! Sempre foram muito agarrados ao dinheiro, mas não é por mal! E se não o gastaram agora, pense que vai poder gastá-lo à sua feição quando eles morrerem, que o dinheirinho há-de ser todo seu!!!... Mas aparte isso... conte lá... o que é que o rolo mostrou à rolinha?!...

INOCÊNCIO

A senhora Custódia não se importa de sair?! Eu preciso de...

\section{CUSTÓDIA}

Mas com certeza senhor Inocêncio!... Não querem lá ver que vão tomar banho juntos!... Com licença...

\section{INOCÊNCIO}

Agora, que estamos em casa, eu espero que tenha a delicadeza de disfarçar, pelo menos à frente dos outros!

TOMASINHA

Está a pedir-me para mentir?!

INOCÊNCIO

Peço-Ihe apenas para mostrar um pouco de consideração pelo paizinho e pela mãezinha, já que por mim não mostrou nenhuma!

TOMASINHA

Já lhe disse mil vezes que não tive culpa do que aconteceu... e não aconteceu nada de que me possa envergonhar!

INOCÊNCIO

Eu estou coberto de vergonha! Vergonha! E a senhora tem o desplante de dizer na minha cara que não aconteceu nada?!!!

TOMASINHA

Eu não podia impedir que as pessoas olhassem para mim!!!

INOCÊNCIO

As pessoas que olhavam para si eram homens!!! 
TOMASINHA

E que culpa tenho eu?! Já pensou o que vai ser a nossa vida se continuar a sentir esses ciúmes doentios, de cada vez que alguém olhar para mim?!

INOCÊNCIO

Não é "alguém", são os homens! Os homens!!!

TOMASINHA

Pois sejam homens! E depois?! Que pensa fazer?! Cegá-los a todos?!!! Ou mandar sair uma lei para proibi-los de olharem para as mulheres?!!! Não tem tanto poder assim senhor Inocêncio de Barros!!! Nem eu casei para isto!

INOCÊNCIO

Então casou para quê?! Para me desfeitear?! Para me faltar ao respeito?!

TOMASINHA

Como é que pode dizer que eu the faltei ao respeito?!

INOCÊNCIO

Sabe muito bem ao que eu me refiro! Não se faça de lorpa! Um homem pode olhar uma vez para uma mulher que passa! Mas quando ele olha pela segunda vez e pára para olhar uma terceira, com a cobiça estampada nos olhos e a baba a escorrer-Ihe pelos queixos, é porque há qualquer coisa nessa mulher que... que Ihe dá coragem!!!

TOMASINHA

Eu não encorajei ninguém!!!

INOCÊNCIO

Ah, não?! Então como é que explica que no restaurante, no miradouro, no jardim público, junto ao coreto, onde quer que fôssemos, eu desse de caras com o mesmo indivíduo, que não tirava os olhos de si! Esse inegrúmeno perseguiu-nos para todo o lado desde o primeiro dia! A senhora foi a cobiça de todos... mas esse homem foi longe demais!!! E só pode ter ido longe demais porque a senhora o encorajou!

\section{TOMASINHA}

Não vi ninguém a olhar para mim com a cobiça estampada nos olhos senhor Inocêncio!!!

INOCÊNCIO

Não me desminta! Olhava! Olhava!!!

TOMASINHA

Com admiração... talvez!... E uma mulher gosta de ser admirada!!!

INOCÊNCIO

Finalmente confessa que também viu!? 
TOMASINHA

E também confesso que apenas vi um a espumar-se de raiva, mas foi o senhor!!!

INOCÊNCIO

Acabou-se a conversa!!!

TOMASINHA

Foi o senhor quem a começou! Mas pode ficar descansado que não voltarei a dirigir-Ihe a palavra... nem hoje, nem nunca mais!

INOCÊNCIO

Tomasinha... acabemos com "o senhor e a senhora"... vamos começar tudo do princípio, está bem?... vamos fazer de conta que não se passou nada...

TOMASINHA

Não precisamos de fazer de conta Inocêncio... não se passou nada!...

INOCÊNCIO

Está combinado: não se passou nada... e não te esqueças... eles iam ficar muito tristes se soubessem que a nossa lua de mel foi... foi o que foi!

TOMASINHA

Foi de fel e vinagre!

INOCÊNCIO

Amo-te muito Tomasinha... deixaste de ser apenas a minha mana... e a verdade é que eu nunca pensei gostar assim tanto de ti... eu amo-te muito... é por isso que eu... eu amo-te muito... Vou agora até ao café... cumprimentar os amigos... dizer que já chegamos...

CUSTÓDIA

Ele gosta muito da menina! É natural que sinta ciúmes!

TOMASINHA

Pois fez-me desesperar e arrepender mais de cem vezes de ter casado com ele!

CUSTÓDIA

Não diga isso! Ele zela pela menina... porque o amor é assim! O amor é cego!...

INOCÊNCIO

Calem-se todos! A minha mulher é uma mentirosa! O amor é cego, mas estas cartas não mentem!!! Tenho vergonha de ser seu marido! Tenho vergonha de ter casado com a senhora!!!

GERVÁSIO

Inocêncio! 


\section{TOMÁSIA}

Que tens tu meu filho?!

INOCÊNCIO

Afastem-se de mim! Deixem-me!!! E a senhora, diga-me agora na minha cara que estas cartas não existem! Vá! Diga que nunca existiram nem foram escritas por si! Vá lá! Minta! Minta à frente de todos! Diga quem é que escreveu estas cartas ao Guimarães e quem é que as levou!!! Não foi a senhora! É claro que não foi a senhora! Eu digo quem foi: Ninguém!!! Ninguém!!! Sou eu que estou doido!!! Vá lá!!! Convença a família Barros que Inocêncio de Barros está doido!!! Estas cartas não existem! Estas cartas não deviam existir... nem estes versos...

"Eu gosto tanto de ti, eu quero-te tanto, tanto..."

É verdade... "o amor é cego..." Tenho vergonha de ter casado com a senhora!!! Tenho vergonha de ser seu marido!

GERVÁSIO

Saiam. Eu falo com ele.

\section{INOCÊNCIO}

Tenho vergonha de sair à rua... a Tomasinha é uma mulher sem honra... escrevia cartas ao Guimarães... e todos sabem... só não sei porque casou comigo...

\section{GERVÁSIO}

Casou contigo porque gosta de ti Inocêncio. Fez uma acção muito má em escrever a esse Guimarães; mas olha que na idade dela... também não é crime que te envergonhe! Todas namoram, todas escrevem e a gente não pode pedir-lhes contas do que fizeram antes de serem nossas mulheres. Tua mãe, quando me escreveu a mim, já tinha escrito a outro; e há muitas senhoras honradas que escreveram a uma dúzia deles ao mesmo tempo. Mau é terem elas quem lhes leve as cartinhas...

\section{INOCÊNCIO}

Era a Custódia quem as levava.

\section{GERVÁSIO}

Isso é que foi muito feio da parte dela, um mau exemplo! Não se portou nada bem a senhora Custódia!!! Foi ela a verdadeira responsável... mas esse assunto eu resolvo, e já.

\section{GERVÁSIO}

Custódia, não podes estar mais tempo em minha casa. Escuso de te dizer as razões que tenho para te despedir. Não me serves...

CUSTÓDIA

Então... Assim se põe na rua uma velhinha... 


\section{GERVÁSIO}

Não vais p'rá rua. Vais para o convento de Santa Clara, onde te mandarei dar todos os meses o necessário.

\section{INOCÊNCIO}

No convento podes rezar e ouvir muitas missas à tua vontade.

\section{GERVÁSIO}

Cá em casa é que me não serves.

\section{CUSTÓDIA}

E a minha menina! A minha filhinha do meu coração... hei-de deixá-la?!... eu morro! Não me faça uma coisas dessas senhor Gervásio! Se me afasta da minha menina... que eu embalei nos meus braços... que eu ajudei a criar... a quem eu quero como se filha fosse... eu morro, não me afaste da minha menina...

\section{GERVÁSIO}

A tua menina ia por bom caminho, se tu continuasses a levar e trazer cartinhas de sujeitos que tu lá sabes...

\section{CUSTÓDIA}

Mas eu só queria o bem dela senhor Gervásio... eu sei que fiz mal e fui a primeira a sofrer, Deus sabe quantas lágrimas eu derramei por causa desse homem que não a merecia e Deus é testemunha que mil vezes me arrependi e ele mil vezes me perdoou! Perdoe-me também o senhor Gervásio, que eu sei que tem bom coração e perdoe-me o menino a quem eu sempre quis muito... e se nem sempre o mostrei não foi porque não o sentisse... a menina também gosta muito de si... fazem um par tão bonito e hão-de ser muito felizes...

\section{GERVÁSIO}

Basta!!! Não quero polémicas! Sou um homem de palavra e já te disse que cá em casa não me serves! Prepara as tuas coisas, que daqui a uma hora vais para o convento!

\section{CUSTÓDIA}

...Eu quero dizer-lhe tudo o que me vai na alma... mas não tenho palavras menina... sei que vou morrer antes de partir... porque jurei à sua mãezinha que nunca havia de a abandonar... até que a morte me levasse... Deus entendeu por bem que aquele homem nos quisesse afastar... mas Deus também não há-de querer que eu falte ao prometido... perdoe-me menina... perdoe-me...

TOMASINHA

Eu é que te peço perdão Custódinha... 


\section{CUSTÓDIA}

$\mathrm{E}$ eu à minha menina, à filhinha do meu coração... perdoe-me... porque vou ter de Ihe morrer nos braços... Morro nos braços da menina... que em meus braços embalei!!!...

SEBASTIANA

O cunhado desculpe a intromissão, mas acaba de chegar um mensageiro!

TOMÁSIA

Eu bem lhe disse que a altura não era própria, mas ela insistiu!

SEBASTIANA

Insisti devido à insistência do mensageiro! Veio do Pará!

TODOS

Do Pará?!!!!

INOCÊNCIO

Deve trazer notícias do tio Luís!

FLORÊNCIA

Posso mandá-lo entrar cunhado?!

GERVÁSIO

Que entre o mensageiro!

MENSAGEIRO

Minhas senhoras e meus senhores, sou portador de uma notícia que por certo vai agradar a todos!

GERVÁSIO

Neste momento nada me podia dar mais prazer do que ouvir uma notícia agradável! Sente-se, sente-se!

INOCÊNCIO

Quer dizer-nos o seu nome?

MENSAGEIRO

O meu nome não importa! Importante é a mensagem que lhes trago! Podem pois chamar-me apenas "Mensageiro".

TODOS

É o mensageiro! 
MENSAGEIRO

Relações públicas da agência de Viagens "Mensageiro"! "O Prazer de viajar por pouco dinheiro". Venho da parte do senhor Luís de Pinhel!

MANAS

O nosso mano Luís!

MENSAGEIRO

As senhoras são portanto todas "de Pinhel"?

TOMÁSIA

Eu agora sou "de Barros" pelo meu Gervásio!

SEBASTIANA

Eu fiquei "de Freitas" pelo meu defunto!

FLORÊNCIA

Eu sou a única que ainda me mantenho "de Pinhel"!

MENSAGEIRO

Permita que lhe diga menina...

FLORÊNCIA

Florência.

MENSAGEIRO

Menina Florência de Pinhel! É a cara chapada do mano!

SEBASTIANA

Não é só a cara que é chapada!!!

GERVÁSIO

Não se importa de continuar! É que temos ali um problema que ficou em suspenso! Se pudesse ir direito ao tal assunto agradável, eu agradecia!

\section{MENSAGEIRO}

Nada me dá mais prazer! Como sabem, o senhor Luís de Pinhel esteve durante cerca de cinco anos a lutar entre a vida e a morte! Ele queria morrer no seu país... mas o destino prega partidas e ele chegou a falar comigo para saber se no caso de vir a falecer antes de poder concretizar esse sonho eu arranjava maneira de mesmo assim o transportar para a sua terra natal, dentro do respectivo caixão, é claro! Mas o que ele mais desejava, antes de partir para a última viagem era poder voltar a Portugal para conhecer o sobrinho... rever as manas... enfim, matar saudades... - disse-mo de viva voz, quando ainda articulava sem grande dificuldade. Prestem atenção. 
LUÍs

Chamo-me Luís de Pinhel e nasci no Porto, mas vim para o Pará há mais de quarenta anos para encontrar uma vida melhor; comecei a trabalhar na apanha da banana e foi aí que conheci um amigo com quem fiz sociedade e os dois montamos um negócio de bananas por conta própria. Ele depois montou-se noutro ramo mas eu continuei no ramo das bananas... e assim consegui amealhar bom dinheiro... De há cinco anos para cá não tenho andado muito bem porque fizeramme uma macumba e todos os dias me aparecem frangos sem cabeça à porta de casa... e eu tenho andado estes anos todos a matutar onde estarão escondidas as cabeças... porque em algum sítio elas hão-de estar! E é assim que eu agora passo o meu tempo, à procura das cabeças... Tenho três irmãs, de nomes Sebastiana, Tomásia e Florência... que eu nunca mais vi e de quem sinto muitas saudades. A Tomásia casou com um judeu muito rico, de quem tem um filho, que eu nunca vi e que gostava muito de poder abraçar antes de morrer.

INOCÊNCIO

Diga-nos, depressa!

MANAS

Onde está o mano Luís?!!!

LUÍs

Estou muito contente por saber que andam todos à minha procura e espero em breve, poder abraçar-vos.

TOMÁSIA

O mano Luís ainda está vivo?!

\section{MENSAGEIRO}

Eu não quero dar-Ihes falsas esperanças; passados uns tempos de ele ter tido comigo este monólogo... ele deixou de falar tão articuladamente... metade do que ele diz não se percebe...

SEBASTIANA

Mas talvez se consiga tirar o sentido pela outra metade!...

MENSAGEIRO

Bem... eu não quero fazê-los sofrer mais tempo...

FLORÊNCIA

Ora essa, demore o tempo que entender...

MENSAGEIRO

Vá lá... olhem todos para ali... pode entrar senhor Luís de Pinhel!

(Vem "entubado" e com aqueles aparelhos na garganta para poder falar, mas ainda se percebe pior o que ele tenta dizer). 
LUís

Estou muito feliz por conhecer-te Inocêncio! (Nada se percebe)

MENSAGEIRO

Diz que está feliz por ter conhecido o sobrinho!

INOCÊNCIO

Sou eu, tio Luís!!! E estas são as suas irmãs!

LUís

Isso agora não interessa nada!!! É muito tarde!

MENSAGEIRO

Disse que isso agora não interessa porque é muito tarde!

LUís

Quando eu morrer a fortuna que eu fiz com as bananas é toda para ti... só tens de ir buscá-la ao Pará...

MENSAGEIRO

Quando morrer a fortuna dele é toda para si, só tem de ir buscá-la ao Pará!

\section{GERVÁSIO}

Mas porque é que ele não a trouxe?! Já cá ficava e pronto!

MENSAGEIRO

Informei-o desse pormenor, mas ele não gosta de viajar com dinheiro, tem medo dos assaltos...

FLORÊNCIA

E cada vez estão mais barcos a ir ao fundo! $E$ homens!

LUís

Está-se-me a acabar o oxigénio, vou morrer não tarda nada!

MENSAGEIRO

Sabe que vai morrer, porque o oxigénio está a chegar ao fim!

MANAS

Mano! Ó mano!!!!

LUís

Então... já chamaram as carpideiras?! 


\section{MENSAGEIRO}

Pensa que são carpideiras!

INOCÊNCIO

Assim que ele morrer, parto imediatamente para o Pará!

GERVÁSIO

Levas a Tomasinha contigo?

INOCÊNCIO

Faz-me tanta falta a sua companhia como uma viola num enterro! O Mensageiro não está aqui por acaso! É Deus que através dele, me indica um caminho a seguir! A luz ao fundo do túnel está no Pará!... Talvez aí eu consiga esquecer a afronta... Consente que eu parta?

GERVÁSIO

Talvez seja melhor para ti... mas espera ao menos que o teu tio morra!

TOMASINHA

A Custódinha... morreu... e o meu sogro foi o causador da sua morte!

TOMÁSIA

Não Ihe chames sogro Tomasinha!

SEBASTIANA

Isto é muito estranho!... Não deve estar morta... ou então eu já tinha começado a espilrar!

\section{FLORÊNCIA}

A mana é alérgica a corpos mortos!

LUís

Está quase...

MENSAGEIRO

O seu tio está a dizer que está quase...

TOMASINHA

A Custódinha... morreu atormentada e sem os sacramentos...

CUSTÓDIA

Ai minha rica filha, minha rica menina...

SEBASTIANA

Eu não dizia?! 
LUís

Está quase... (vai repetindo nos intervalos da morte de Custódia)

CUSTÓDIA

Adeus filhinha do meu coração... até ao dia do juízo final... saibam que não vou descansar em paz... hei-de amaldiçoar-te a cada minuto, porco! Judeu!... o dinheiro não te há-de valer para nada!... separaste-me da minha menina... eu te amaldiçoo para que durante o tempo que te resta de vida sejas roído e corroído pelo remorso e quando morreres hás-de arder nas chamas do inferno!...

(Silêncio total e absoluto e depois... Sebastiana começa a espilrar)

FLORÊNCIA

Agora é que já morreu!!!

MENSAGEIRO

O tio também já cá não está!

TOMÁSIA

É estranho...

GERVÁSIO

É a vida.

TOMÁSIA

... tenho estado este tempo todo à espera de ter mais um chelique!

GERVÁSIO

Se não tiveste é porque Deus achou que não era oportuno mais um corpo morto!

INOCÊNCIO

Posso agora ir à procura da minha luz ao fundo do túnel?

GERVÁSIO

Já podes partir filho! Vai! E que Deus te traga com mais juízo do que levas. Eu cá fico a proteger a tua mulher, que eu desgracei, pensando que a fazia feliz!

TOMASINHA

Bem me dizias tu: Pobres órfãos, vós não chorais em meninos, porque a vossa vez de chorar vem depois!

GERVÁSIO

D. Tomásia: parece-me que temos de repensar muito bem a nossa vida! A partir de hoje temos de poupar, poupar, poupar...

TOMÁSIA

Mas nós sempre fomos muito poupados! 


\section{GERVÁSIO}

Sim, mas vejo as despesas a aumentar e de que maneira! Só este ano... já vamos em um casamento e dois funerais!!!

\section{SEBASTIANA}

Aaaaaaatchim!!!!

TODOS (incluindo os "mortos")

Santinha!

... e finalmente...

... é o FIM do Primeiro ACTO!

E aqui temos o princípio do

SEGUNDO ACTO,

que tal como o primeiro, tem lugar no Teatro $S$. João do Porto, onde se representa mais um final de acto de "O FANTASMA DA ÓPERA".

É a célebre cena do candelabro que o Fantasma faz cair sobre o público que assiste à representação do "Fausto".

No seu camarote a família Barros come o farnel. Quando o candelabro começa a tremer ficam boquiabertos! O Sr. Gervásio segura na mão uma coxa de carneiro; quando a vai levar à boca ouve-se um grito de mulher e ele deixa-a cair!!!

E é mais um intervalo!

AMIGO

Querias aproximar-te da tua Mulher Fatal! Aí tens uma oportunidade! O patriarca da família deixou cair uma perna de carneiro!

\section{FLORÊNCIA}

Esta cena do candelabro a cair foi muito impressionante, não foi?

SEBASTIANA

Podia ser mais!!! Só matou dois figurantes!

GERVÁSIO

Para onde raio teria caído a perna de carneiro?! 
TOMÁSIA

Nem sei como é que a mana não desatou a espilrar!

SEBASTIANA

Se ainda não percebeu, isto é tudo a fazer de conta! Só espilro com mortos verdadeiros!

GERVÁSIO

Eu só gostava de saber...

NICOLAU

É disto que V. Excelência anda à procura?!

TOMÁSIA

Que graça! Também se lembrou de trazer carneiro?!!!

AMIGO

É a perna do seu marido!

GERVÁSIO

É a minha perna, Tomásia! Muitíssimo obrigado!

FLORÊNCIA

Tenho a impressão de já o ter visto!

AMIGO

É natural, sou um colega do Inocêncio!

SEBASTIANA

Pelos vistos, a mana só é cega para algumas coisas!!!

TOMASINHA

Ficou com as mãos todas besuntadas de gordura.

NICOLAU

Não tem importância!

FLORÊNCIA

Dizem que gordura... é formosura!

TOMÁSIA

Eu tenho de ir aos lavabos e trago-Ihe um cleanex! Não querem aproveitar?...

GERVÁSIO

Eu também tenho de ir, estou aflitinho, este acto era enorme!!! 
AMIGO

Como tem passado o Inocêncio?

GERVÁSIO

Está no Pará há pouco mais de um mês... foi receber uma herança...

(Nicolau e Tomasinha ficam sós)

NICOLAU

Algo me diz que ainda se lembra de mim.

TOMASINHA

Mesmo que quisesse, nunca poderia esquecer o seu rosto. $O$ meu marido passou a lua de mel a falar em si; na forma como olhava para mim... (sorri)

NICOLAU

Porque ri?!...

TOMASINHA

Estava a lembrar-me... ele dizia que o senhor se babava.

NICOLAU

Isso é mentira!

TOMASINHA

Eu sei; eu só vi que havia muita tristeza no seu olhar!

NICOLAU

No seu também.

TOMASINHA

Pareceu-me uma pessoa infeliz.

NICOLAU

E sou... (ela ri de novo) De que ri agora?...

TOMASINHA

Não queria rir!... Penso que foi uma reacção nervosa!...

NICOLAU

Ficou impressionada?

TOMASINHA

Porquê?! Costuma impressionar as pessoas? 
NICOLAU

Não sei; é a primeira vez que faço esta pergunta a alguém.

TOMASINHA

O senhor aparecia em todo o lado para onde nós íamos... decerto por acaso! Essa coincidência impressionou-me um pouco...

NICOLAU

Não foi por acaso! Desde o primeiro momento em que a vi, mandou-me o coração que a perseguisse para todo o lado.

TOMASINHA

Mas se eu estava com o meu marido!

NICOLAU

Só tinha olhos para si. Amo-a desde o primeiro momento e cada vez mais.

TOMASINHA

Não diga isso por amor de Deus! Não diga mais nada!!!... Já sofri demais!

NICOLAU

Eu sei. Não ter pai nem mãe é a maior pobreza deste mundo. Também sou órfão. Tive por mãe uma ama e o meu pai adoptivo era o Padre Almeida, prior duma igreja... foi ele que me encontrou numa cesta de verga, aos pés do altar de $S$. Nicolau, recém-nascido... por isso me chamaram Nicolau. Até aos dezoito anos vivi no desespero por não saber quem eram os meus verdadeiros pais e qual 0 motivo porque me tinham abandonado!

\section{TOMASINHA}

Os pais verdadeiros fazem sempre muita falta.

\section{NICOLAU}

Mas eu amava aquela ama e o meu pai adoptivo!

TOMASINHA

Isso é natural... foi com eles que cresceu.

NICOLAU

Amava-os demais! Demais!!! Eu não devia amá-los tanto! Porque eles não eram os meus verdadeiros pais, que não me saíam do pensamento e tinham no meu coração um lugar cativo.

TOMASINHA

E nunca chegou a saber quem eles eram? 
NICOLAU

A minha ama morreu quando eu tinha 15 anos; no dia em que completei 18 anos, morreu o padre Almeida e deixou-me por herança toda a sua fortuna, e uma longa carta onde me pedia perdão e me revelava que a ama... era a minha verdadeira mãe... e ele o meu pai. No dia do meu aniversário fiquei a saber que era filho do pecado! E o desespero que me tinha acompanhado até então transformou-se em revolta!!! Uma vida inteira à procura de saber quem eram os meus pais... e eles, sempre tão perto de mim! E só então é que eu percebi que aquela força que fazia com que eu os amasse tanto... era a voz do sangue! Ninguém pode fugir à voz do sangue!

TOMASINHA

A sua história... é muito comovente...

NICOLAU

Agora... há outra força que me impele para os seus braços...

TOMASINHA

Isso não é possível!... Sabe bem que não é possível!...

NICOLAU

Ambos podemos pensar que isso não é possível... mas neste preciso momento... também sabemos que não podemos fugir ao destino! Desde que a vi, eu soube que a Tomasinha estava destinada a ser a minha doce fatalidade.

SEBASTIANA

Tens lágrimas nos olhos Tomasinha.

FLORÊNCIA

A cena do candelabro foi muito impressionante!

TOMASINHA

Pois foi! Esta ópera é... é muito pesada!...

GERVÁSIO

Fiz mal em trazê-la... com o marido fora há mais de um mês ela naturalmente sente saudades.

AMIGO

E ele também, com certeza!

GERVÁSIO

Sim! São um casal muito feliz!

TOMÁSIA

Estás tão branca! Preferes ir embora Tomasinha?! 


\section{FLORÊNCIA}

O último acto ainda deve ser mais impressionante!

AMIGO

O fantasma enlouquece e suicida-se!

\section{TOMASINHA}

Prefiro ficar. Quem aguentou até aqui... aguenta até ao fim... seja ele qual for.

E pronto! Tomasinha e Nicolau já estão completamente perdidos um pelo outro! E o público já só anseia vê-los...

na cena de sexo!

Vamos agora mudar de cena e surpreender o público com... CABARET!!!

Inocêncio está no quarto do hotel. Olha para o relógio. Está nervoso porque aguarda a chegada duma artista de cabaret. O público não sabe... Ouve-se a campainha da porta. Ele levanta-se para se mirar rapidamente num espelho. Poderá pôr um spray na boca, não vá estar com mau hálito! Vai finalmente para abrir a porta, mas ela entra, plena de salero! Vê-se à légua que é espanhola. Trás uma mala, de onde irá tirar os "adereços" necessários ao "número" que vai fazer em privado. Na mala poderá ou não ler-se "Sarita Star" - "Spanish Private Dancer". Fala em espanhol, Inocêncio fala em português, tentando fazer-se entender pela beldade do país vizinho.

INOCÊNCIO

Sarita Star!

SARITA

Como não abrias, o garçon do hotel abriu-me a porta!

INOCÊNCIO

Estava em lá casa de banho!

SARITA

Hoje não posso perder muito tempo; tenho consulta marcada no dentista! Porra! Acordei com uma dor de dentes que estava a ver que não vinha! Estás pronto?!

INOCÊNCIO

Estou! Puedes começar quando quiseres!

SARITA

Não queres fazer o jogo de luzes, querido?! Ou hoje não te apetece?! 
INOCÊNCIO

Quero! Tinha-me esquecido, desculpa!

SARITA

Vá lá... depressa!... que a sua queridinha tem dói-dói no dentinho!...

(Inocêncio prepara umas luzes "ridículas" de discoteca foleira. Ela põe-se em "pose" e a um sinal ou um "abrir de leque" por exemplo, entra a banda sonora, sobre a qual ela recita um poema. Depois, ainda sobre a música continua:)

SARITA

Confessa lá à tua Sarita Star: é mesmo verdade aquilo que me disseste ontem?!... Vais pedir o divórcio da tua mulher?...

INOCÊNCIO

Ela só casou comigo por causa do meu dinheiro... nunca gostou de mim...

\section{SARITA}

Mas agora tens quem goste de ti... não tens?... e tu também gostas muito de mim não gostas?!... Promete que nunca me abandonas... promete...

INOCÊNCIO

Nunca!...

SARITA

E também é verdade que vamos viajar pela Europa?... E Estados Unidos?... Só nós dois!...

INOCÊNCIO

Sim...

SARITA

Prometo-te que abandono a vida artística... e só danço para ti, meu amor!...

INOCÊNCIO

Sim! Só para mim, só para mim!...

SARITA

Agora tenho de ir, querido! Está na hora do dentista!... a tua Sarita vai tratar do dói-dói e já volta!

GERVÁSIO

Finalmente chegou uma carta do Inocêncio!!!

TOMÁSIA

Graças a Deus!... Tomasinha, vem cá depressa!!! Chegou uma carta do Inocêncinho! 
GERVÁSIO

Finalmente!

TOMASINHA

Para mim?!

GERVÁSIO

Não... só há uma... é para mim... mas com certeza que também te vai escrever...

TOMASINHA

Há dois meses que partiu... e nem uma palavra!

TOMÁSIA

Talvez já te tenha escrito! A carta pode ter-se extraviado...

TOMASINHA

Pois pode...

GERVÁSIO

Não queres saber o que ele diz?!...

TOMASINHA

O mais importante é que esteja bem de saúde...

GERVÁSIO

"Querido Pai, só agora the escrevo, porque não tenho andado muito bem de saúde..." Ó diabo!

\section{TOMÁSIA}

Com certeza anda lá por fora a comer coisas que não deve! Não há nada como a comidinha caseira e ele sempre sofreu muito do estômago! Continua, Gervásio!

GERVÁSIO

“...mas felizmente agora já me sinto bastante melhor!"

\section{TODOS}

Graças a Deus!

\section{GERVÁSIO}

"Fico por cá mais uns tempos para conhecer melhor esta terra. Quem vê o mundo aprende tudo quanto há sem ler livros e as viagens dão muita experiência aos homens; estou também a aprender dois dedos de idioma espanhol, pois estou a pensar ir visitar o México e é para não fazer má figura! Saudades para as titis e para a mãezinha. Um abraço do seu filho..."

TOMASINHA

E para mim, nem uma palavra! 
TOMÁSIA

É o que eu digo: escreveu-te e a carta perdeu-se, foi o que foi!

TOMASINHA

O que se perdeu foi o nosso casamento, a nossa felicidade... e para sempre!

GERVÁSIO

Escreve-Ihe tu Tomasinha; agora pelo menos já sabemos onde ele está... e que está bem... há-de gostar de receber uma carta tua... faz isso por mim e pela tua madrinha...

TOMASINHA

Está bem....mas eu sei que ele não me vai responder.

GERVÁSIO

Quando um homem gosta duma mulher, não leva a bem que andem por aí a dizer que ela gostou doutro;... fizeste mal com aquela história das cartas, mas o que lá vai, lá vai! Agora tens de ajudá-lo a esquecer o passado. Ficou como louco! Temos de ter paciência e esperar que a razão lhe volte!

TOMASINHA

Vou escrever-Ihe.

TOMÁSIA

Que te parece agora esta ideia dele ir para o México?!

GERVÁSIO

O que é que me havia de parecer? Uma grandessíssima asneira!!!

TOMÁSIA

Também acho. Dizem que a comida mexicana faz muito mal ao estômago!

GERVÁSIO

Eu quero lá saber do estômago do rapaz! Eu estou é preocupado com o dinheiro!!! Não vai descansar enquanto não gastar o dinheiro todo da herança!!!

\section{TOMÁSIA}

Se ao menos esse dinheiro o fizesse feliz!...

GERVÁSIO

Anda a esbanjá-lo em aulas de espanhol e sabe-se lá mais em quê!!! Só espero que quando se lembrar de regressar, não nos apareça no mesmo estado em que apareceu o teu irmão Luís de Pinhel! 


\section{TOMÁSIA}

Por amor de Deus, Gervásio! Se alguém te ouvisse falar assim, até havia de pensar que não gostas do nosso filho!

\section{GERVÁSIO}

Não digas isso Tomásia! Não digas isso que me magoas! O que me faz falar assim... é porque eu gosto muito do nosso filho, do nosso Inocêncio, o Inocêncinho! E custa-me sabê-lo lá longe... sem querer saber de nós... sem querer saber da desgraçada da mulher... que a Tomasinha sim, sente-se-lhe 0 desgosto... o arrependimento sincero... a angústia de ser esposa sem marido... a dor... só de pensar que o pode ter perdido para sempre!

Tomasinha entra no seu quarto. O público só percebe que lá está também Nicolau, no momento em que ele responde (Se fosse uma comédia de boulevard, ele surgiria do roupeiro, da varanda ou de baixo da cama; todo nu, é claro e segurando na mão a roupa com que taparia ou não as "partes baixas". Neste "melodrama"... ainda não sei de onde ele aparecerá! A ideia do "todo nu" mantémse... Tomasinha entra apreensiva. Estava muito bem, mas aquela chamada do Padrinho por causa da carta caiu-Ihe muito mal e veio fazer-lhe lembrar que é uma grandessíssima pecadora! Com este espírito de remorso a primeira parte do diálogo, após o que se entregam às mais lindas fantasias de amor!

TOMASINHA

Já se foram deitar.

NICOLAU

Desconfiam de alguma coisa?...

TOMASINHA

Não. Chegou uma carta... do meu marido.

NICOLAU

Não fales assim. Ele não é digno dessa palavra! Abandonou-te...

TOMASINHA

Um dia, há-de voltar.

NICOLAU

Escreveu-te a dizer que voltava?

TOMASINHA

Escreveu ao pai... não pronuncia sequer o meu nome... não vai voltar tão cedo...

NICOLAU

Então... está tudo bem... 
TOMASINHA

Até quando?!... Eu não aguento esta situação por muito mais tempo! Quando estou contigo, ao escutar as tuas palavras... consegues fazer-me acreditar que ainda posso ser feliz...

NICOLAU

Havemos de ser felizes...

TOMASINHA

Mas assim que te vais embora... e até voltares no dia seguinte... vivo carregada de medos, angústias, remorsos... ando pela casa toda como uma louca... sem saber que fazer... sempre a pensar em ti... e em mim... e que este nosso amor é impossível!

NICOLAU

Não digas isso!

TOMASINHA

Ele vai voltar! Um dia... mais tarde ou mais cedo;... Mas ele vai voltar!

NICOLAU

Podemos fugir para Espanha!

TOMASINHA

Fugir?!... Não posso dar mais esse desgosto aos meus padrinhos.

NICOLAU

Mas então... quando ele voltar, o que é que fazemos?!

TOMASINHA

Não sei! Não me obrigues a pensar nisso! Não sei responder-te! Havemos de encontrar uma solução; amanhã ou depois!

(E pronto! Ela tem aquela brasa à sua frente... e lá por dentro toda ela já é também um braseiro... está mais que disposta a continuar o que já tinham começado... está por tudo e o "tudo" é aquele momento; nem precisa de tirar muita roupa porque já pouca tem para tirar... mas a que tem pode tirá-la muito lentamente... com um tema musical por fundo... e ambos iluminados por um candeeiro de petróleo. Depois vão falando, brincando aos namorados...

TOMASINHA

Agora... eu só quero pensar que está tudo bem... porque tu estás aqui... e eu amote muito... És o meu Fantasma... 
NICOLAU

E tu a minha Diva... vou ter de raptar-te...

TOMASINHA

Sim... leva-me para o teu refúgio...

NICOLAU

Podes ter a certeza que te levo...

TOMASINHA

Não penso noutra coisa...

NICOLAU

Não tens medo de estar comigo?!...

TOMASINHA

Sim... mas é este medo que me faz desejar-te ainda mais!...

NICOLAU

És a minha doce fatalidade!

TOMASINHA

E tu, a minha doce fantasia...

A próxima cena passa-se no hotel onde está hospedado o Inocêncio. Em cena apenas se encontra "Sarita Star" (que afinal é uma falsa espanhola! Ou seja, é uma portuguesa que vive de expedientes no Brasil... e um dos expedientes dela é fazer-se passar por espanhola! Camilo havia de gostar desta ideia!). Como toda e qualquer pessoa, o amor é um factor importante na sua vida, que só parece fácil para quem está de fora! Há um homem na sua vida: José! Para não o perder ela é capaz de tudo e por isso se entrega aos "Inocêncios" que Ihe aparecem à frente. José é de descendência cigana e mais novo que ela, com quem forma parelha,

sob o disfarce de "recepcionista" do hotel. Sarita Star, vestida de "Bárbara Guimarães", aguarda no quarto a chegada de Inocêncio, mas quem entra em cena é o tal José.

JOSÉ (Fala-lhe em espanhol, apenas esta frase.)

Então Sarita Star?! Deixaste fugir o teu Inocêncio?

SARITA

Nunca! Está pelo beicinho, já não me foge!!! Teve de ir à farmácia; parece que sofre do fígado!!!

JOSÉ

O anjinho acreditou mesmo que eras espanhola!!! 


\section{SARITA}

Os homens acreditam sempre naquilo que eu quero que eles acreditem!

JOSÉ

Estou incluído nessa lista?!

(Aqui, Sarita vai ter de mostrar que está "sinceramente" louca por aquele miúdo; aquilo que lhe diz é verdade e é uma verdade sentida, em contraste com a falsidade profissional com que fala a Inocêncio; talvez possa falar-lhe com um pouco de amargura... mas com muito amor.)

\section{SARITA}

Tu és o meu homem! É por ti que eu vendo o meu corpo, que me entrego aos solitários, aos mal amados, aos maridos enganados e a todos aqueles que têm de comprar o que o destino sempre lhes negou! Mas tu és o meu homem! Não estás nessa lista! Estás no meu coração! É pelo amor que te tenho que eu me vendo!

(Ele não sente a mesma paixão, nem de perto nem de longe. Nem se preocupa com a forma como Ihe fala; a verdade é aquela e pronto! Ele está com ela porque ainda "rende")

JOSÉ

Sarita Star: antes de me teres conhecido... já trabalhavas neste ramo!

SARITA

Nesse tempo entregava-me só por dinheiro. Agora, entrego-me por amor!

(Sarita entrega-lhe umas notas, que ele conta e guarda, enquanto continuam o diálogo)

JOSÉ

Como é que te lembraste de ser "espanhola"?!

\section{SARITA}

Um ricaço que chega ao Pará não vem à procura duma portuguesa; e eu ainda não apanhei bem o sotaque brasileiro: fico sempre meio brasileira e meio palhaça! Mas um papalvo português até se vem, só de pensar que engatou uma estrangeira! Escolhi ser espanhola porque nasci em Elvas... tinha Badajoz à vista... domino a língua!

JOSÉ

E os homens! És uma mulher... fatal!

SARITA

Agora vai, ele pode aparecer! 
JOSÉ

Chegou mais uma carta do paizinho do papalvo... e outra da mulher.

\section{SARITA}

Depois leio; ele pode entrar de repente.

INOCÊNCIO

Demorei porque a farmácia estava à cunha! (acha estranho a presença do recepcionista) Aconteceu alguma coisa?!

SARITA (obviamente a partir de agora fala em espanhol)

Nada, querido! Está tudo bem!... O rapaz da recepção só subiu ao quarto para... para despejar os penicos! (Para José) Muitas gracias! (Para Inocêncio) Estava no ar um cheiro que não se aguentava!

INOCÊNCIO

Já que aqui está leve esta carta e ponha no correio. (Dá-Ihe a carta, uma gorjeta e José sai)

SARITA

Devias dar-Ihe uma gorjeta maior!

INOCÊNCIO

Só tem de meter a carta; o que Ihe dei até é muito! Quem costuma despejar os penicos não é aquela empregada mulata?!

SARITA

Sim, mas hoje faltou - deve estar com o período - e ele teve de substituí-la!

INOCÊNCIO

Não gosto nada da cara dele!

\section{SARITA}

Ele também não gosta da tua!... mas gosto eu... estava cheinha de saudades... anda cá... vamos já tratar desse fígado... E então... aquela carta era para quem?...

INOCÊNCIO

Para o paizinho... a dizer que te conheci... e que vou viver contigo...

\section{SARITA}

...e também lhe disseste para mandar a tua mulher dar uma volta... porque quem não volta para ela és tu...?

INOCÊNCIO

Nunca mais!... Eu agora só me volto para ti... sou todo para ti Sarita... sou todo para ti... e nada para ela!... 
(... e quando estiverem quase a chegar à "queca"... baixa a luz ou baixa o pano!)

Voltemos agora para as Manas, que ainda têm muito textinho para debitar! Estão em casa, entregues aos seus pensamentos e ocupações habituais.

SEBASTIANA

A Tomasinha não anda bem!... Ninguém me tira da ideia que ela não está bem!

TOMÁSIA

É claro que não está bem; já lá vão mais de quatro meses e o Inocêncinho nunca mais voltou a escrever! Tenho tanto medo que Ihe tenham feito alguma macumba!

SEBASTIANA

Já é um homem! Deve andar distraído no meio... das bananas! Se fizeram alguma macumba foi à Tomasinha, porque ela é que não está nada bem!

FLORÊNCIA

Com o marido tão longe como queria a mana que ela estivesse?!

SEBASTIANA

Branca de desgosto! Magra! Seca! Chorosa!

TOMÁSIA

Ela está com muitas olheiras...

\section{SEBASTIANA}

Sim, mas de há umas semanas para cá subiu-lhe um rosado às faces... e está mais gorda... ninguém me tira da ideia que ela está mais gorda...

\section{FLORÊNCIA}

Não digo que não tenha razão, mas olhe que eu não notei nada!

\section{SEBASTIANA}

Quando é que a mana assume que está quase cega?!!!

\section{TOMÁSIA}

Pensando bem, ela talvez esteja um bocadinho mais gorda de cintura...

\section{SEBASTIANA}

... e de peito!

\section{TOMÁSIA}

Tem razão... o peito também aumentou um bocadinho.

\section{FLORÊNCIA}

Eu sei que vejo mal, mas oiço muitíssimo bem!!! 
TOMÁSIA

Por amor de Deus! A mana não lhe chamou mouca!

\section{FLORÊNCIA}

Anteontem, acordei às quatro da manhã com vontade de ir à casa de banho - a dobradinha do jantar deve-me ter caído mal - ia pelo corredor e ao passar pela porta do quarto da Tomasinha... ouvi-a... ela estava aos vómitos!!!

\section{TOMÁSIA}

Agora já percebo donde é que veio aquele vomitado que apareceu à porta de casa!!! O passeio da rua estava um nojo!

\section{SEBASTIANA}

Está explicado o mistério!

\section{TOMÁSIA}

Cheguei a pensar que fosse de algum cão vadio, ou algum bruxedo... mas tem razão: está explicado o mistério do vomitado!

\section{SEBASTIANA}

O mistério deixou de ser mistério: A Tomasinha está grávida!!!

(D. Tomásia desmaia uma vez mais! Entra Gervásio)

GERVÁSIO

Porque será que sempre que eu entro a minha mulher está esvaída?!!!

\section{SEBASTIANA}

Ainda pergunta?

\section{FLORÊNCIA}

Tem a certeza que ela está grávida?!

\section{GERVÁSIO}

Mas que disparate mana Florência! Isso é impossível! Eu sei muito bem o que faço e o que não faço!

SEBASTIANA

Não é a mana Tomásia que está grávida!

TOMÁSIA

Gervásio... Gervásio... ela... ela está grávida!...

GERVÁSIO

A cunhada Sebastiana está grávida?!!! 
SEBASTIANA

O meu marido onde está, já não engravida ninguém!

FLORÊNCIA

A Tomasinha é que está grávida!

MANAS (perante a reacção de Gervásio)

Fez-se luz!

GERVÁSIO

Bendito seja Deus!... Vou ser avô! É preciso chamar um médico imediatamente, uma parteira, uma ama! Vou já escrever ao meu filho a dar-Ihe a notícia! Bendito seja Deus, porque o meu filho partiu, mas deixou dentro dela a semente! Quando o Inocêncio souber que a sementinha germinou, ele vai perdoar-lhe... e vai voltar! Comprem um berço, façam uma limpeza geral a esta casa! Abram as portas e as janelas para que todos saibam que o meu filho vai voltar! $O$ nosso filho $D$. Tomásia, vai voltar! A honra voltou a instalar-se na família dos Barros!!!

Tomasinha está no quarto, aguardando a chegada de Nicolau! Pela primeira vez está visivelmente grávida. Nicolau entra com os sapatos na mão.

TOMASINHA (Está de costas, para o público só ver a barriga depois; sente que ele chegou)

Já descobriram!

NICOLAU

Mas eu nunca fiz barulho!... Descalço-me sempre!...

TOMASINHA

Já descobriram que eu estou de esperanças! (E pelo tamanho da barriga, era preciso ser-se mesmo cego para não descobrir!) O Padrinho já escreveu ao Inocêncio! Ele vai voltar!... Mas mesmo que não volte, eu estou perdida!

NICOLAU

Mas então, eles pensam que o meu filho... é filho do Inocêncio?!

TOMASINHA

Pois de quem querias tu que eles pensassem que era a criança?!

NICOLAU

Mas ele está longe! Como é que é possível que eles pensem...

TOMASINHA

Não é possível nas nossas contas... mas é nas deles!!! 
NICOLAU

São mesmo judeus! Só sabem fazer contas ao dinheiro!

TOMASINHA

Conhecemo-nos um mês depois dele partir; para quem não sabe, tanto posso estar grávida de quatro, como de cinco ou seis meses!!!

NICOLAU

E o Inocêncio, quando souber, achas que também vai acreditar que o filho é dele?!

TOMASINHA

Não, isso não!

NICOLAU

Também pode ser fraco em contas!

TOMASINHA

É impossível que ele acredite que o filho lhe pertence! Não houve nada entre nós!...

NICOLAU

Então... não tens que te preocupar! Se ele sabe que o filho não é dele... não volta com certeza!

TOMASINHA

Pode voltar, sim!

NICOLAU

Para se cobrir de vergonha?!

TOMASINHA

Para dar cabo de mim! Para me matar!... Se não tiver coragem, escreve ao pai a contar tudo! Seja como for, estou perdida!

NICOLAU

Só há uma coisa a fazer: temos de fugir.

TOMASINHA

Fugir?!... E o nosso filho?!

NICOLAU

Está contigo... vai connosco...

(Tomasinha tem medo de tomar uma resolução... e dá a volta ao texto, vira o bico ao prego!)

TOMASINHA 
E daí... talvez Inocêncio não the conte... nunca respondeu às cartas do pai... talvez não queira mais saber de mim, nem da família... talvez não volte...

\section{NICOLAU}

Talvez...

TOMASINHA

E depois, os meus padrinhos e as titis... estão tão felizes... faz-me pena dar-Ihes assim de repente mais uma desilusão;... a vida nesta casa tem sido um inferno para todos... está nas nossas mãos prolongar-lhes este momento de felicidade...

NICOLAU

Mais tarde ou mais cedo vão ter de saber a verdade...

TOMASINHA

Mas não é preciso que seja já!... Peço-te Nicolau: deixa o bebé nascer primeiro, para que eles o possam ao menos conhecer... deixa-o nascer primeiro, e fugimos depois. Prometo.

NICOLAU

Prometes?

TOMASINHA

Prometo.

No quarto de hotel, no Pará. José está a ler a carta de Gervásio. Entra Sarita Star

JOSÉ

O anjinho mentiu-te! Disse-te que nada o ligava à mulher, que ela não the interessava.

SARITA

E não lhe interessa, já deu provas disso!

JOSÉ

Ela talvez não Ihe interesse, mas está à espera dum filho!

SARITA

A mulher está à espera duma criança?!

JOSÉ

Deixou-a de esperanças! A criança deve nascer daqui a dois meses, lá p'ra Dezembro!

\section{SARITA} Isso não é possível! Não é dele! Ele jurou-me que... não! Não pode ser dele! JOSÉ 
O velhote está convencido que vai ser avô! E o dinheiro há-de ir todo p'rá criança!

\section{SARITA}

Se lhe mostrarmos a carta, ele vê que a mulher o atraiçoou... e isso pode ser mais um trunfo a nosso favor! Vai desprezá-la ainda mais... vai querer desmascará-la perante a família!!!

JOSÉ

Estás a esquecer-te do reverso da medalha! Ele pode ter-te mentido... e o filho ser mesmo dele! Uma amante como tu pode ganhar a batalha... contra uma esposa... mas nunca contra um filho. A voz do sangue! dificilmente alguém the pode resistir!

SARITA

Eu só não quero é perder-te!

JOSÉ

Não o percas a ele também!... Saca-lhe o resto da herança... e depois já podes enfiar-lhe a carta pelas goelas!

SARITA

Hão-de aparecer mais papalvos como ele!

JOSÉ

Papalvos sim... mas com tanto dinheiro não.

(Inocêncio entra; Sarita imediatamente tenta justificar a presença de José; pega numa toalha de rosto e entrega-a ao chulo)

SARITA (em espanhol)

Pode levar! Muitas grácias!

(Ele sai com a toalha. Inocêncio ficou desconfiado)

INOCÊNCIO

Não gosto nada da cara deste tipo!

SARITA

Já me tinhas dito, querido.

INOCÊNCIO

Mas não valeu de nada, pois não?! Que veio ele cá fazer?!

SARITA

Não viste?! Só veio buscar a toalha!

INOCÊNCIO

Veio buscar a toalha p'ra quê?! 
SARITA

Para substituir por outra!

INOCÊNCIO

E aposto que vai esperar que eu saia para trazer a outra... é isso?!

SARITA

Não te entendo!...

INOCÊNCIO

Mas eu é que já estou a entender! Ele entra quando eu saio e sai assim que eu entro! Eu já fui enganado uma vez Sarita! À primeira quem quer cai, mas à segunda só cai quem quer, ouviste?!

SARITA

Já te disse que não te entendo!

INOCÊNCIO

Se me andas a pôr os cornos com o rapaz da recepção eu dou cabo de ti!

SARITA

Ah, sim?! Matas-me?! É isso?! Matas-me!!! Não tens coragem, senão também tinhas morto a outra!!! (Ele prega-Ihe uma violenta bofetada, com que ela não contava! Cai. Quando se levanta, tem sangue a escorrer-Ihe da boca, ou do nariz). Se queres dar murros, vai dá-los à tua mulher! Não há-de ser um porco como tu que me levanta mais a mão!

INOCÊNCIO

Sarita! Tem piedade de mim! Tu não vês que eu estou doido de ciúmes! Eu amote! Perdoa-me! Ouve Sarita... não me deixes! Se não voltas eu mato-te!... e matome depois a mim!... ... Não volta... já vi que não volta... gostava dela... ainda gosto dela... mas estraguei tudo... não posso matá-la!... E de nada vale matar-me a mim... ninguém ia querer saber... o meu pai nunca respondeu às minhas cartas... a minha mulher escrevia cartas a outro... e com esta... nem sequer cheguei a aprender espanhol como deve ser!... Não me dou bem com este clima... tenho saudades da minha casa... tenho saudades dos meus pais... das titis... e até tenho saudades da Tomasinha... de quando éramos irmãos e brincávamos às escondidas... o destino nunca quis que gostássemos um do outro doutra forma... Tenho tantas saudades!... Já sei!... Vou escrever à minha mãe a dizer que vou voltar e para ela interceder junto do paizinho... ele acha que eu fui injusto com a Tomasinha... mas não há-de fechar-me a porta na cara! "Querida mãezinha... eu sei que não me portei lá muito bem , mas morro de saudades..."

(O fim da carta ouvir-se-á na próxima cena.) 
Em casa dos Barros, estão todos com os olhos postos na carta. Ouve-se a voz de Inocêncio

INOCÊNCIO

“...já falei com aquele senhor da Agência Mensageiro, o mesmo que aí esteve com o tio Luís, que me tratou da viagem; diz ele que o barco deve chegar ao cais de Leixões no dia 24 de Dezembro..."

FLORÊNCIA

Já só falta uma semana!

TOMÁSIA

Se Deus quiser faz a consoada connosco!

INOCÊNCIO

"...e se Deus quiser ainda faço a consoada convosco".

SEBASTIANA

$A$ mana às vezes parece bruxa!

GERVÁSIO

O nosso filho vai voltar! Tomasinha, o teu marido vai voltar!!!!

TOMÁSIA

Diz que morre de saudades, ouviste?!!

TOMASINHA

Ouvi sim... morre de saudades.

SEBASTIANA

É estranho!

TOMÁSIA

Pronto! Lá está a mana com as suas estranhezas!

\section{SEBASTIANA}

Não me digam que não é estranho ele não falar da criança que vai nascer!!!

GERVÁSIO

O Inocêncio nunca foi de falar muito... mesmo quando a gente lhe fazia perguntas... punha-se a desenhar narizes e primeiro que the arrancássemos qualquer coisa!

\section{FLORÊNCIA}

O cunhado tem razão, ele nunca foi de exteriorizar sentimentos... 
GERVÁSIO

Mas de certeza que se sente feliz por ir ser pai , doutra forma não vinha a correr assim que recebeu a minha carta!

(Tomasinha começa a ficar com as dores de parto)

\section{SEBASTIANA}

Ele não respondeu à sua carta, ele escreveu à mãe!

GERVÁSIO

Lá está! Porque não gosta de exteriorizar comigo!

TOMÁSIA

E toda a gente sabe que "Mãe" sempre é "Mãe"!

\section{SEBASTIANA}

E algumas não são mesmo mais nada! São mães!

(Percebem que Tomasinha não está bem)

\section{GERVÁSIO}

O que é que tens, filha?!

(Tomasinha está cada vez com mais dores)

TOMASINHA

Não sei... parece que vai ser... não quero... quero morrer... matai-me Senhor!... Etc...

(Frases a distribuir pela gritaria que se vai gerar)

SEBASTIANA

A criança vai nascer!

TOMÁSIA

E a parteira que não foi avisada!

GERVÁSIO

Alguém que traga toalhas! Água a ferver!

FLORÊNCIA

Toalhas! Água a ferver!

\section{TOMÁSIA}

É melhor ires chamar a parteira, Gervásio! 
SEBASTIANA

Deixe lá agora a parteira! Segure-lhe nas pernas cunhado!

FLORÊNCIA

Eu também quero ajudar, mas não sei como!

TOMÁSIA

Reze, que já é uma grande ajuda!

SEBASTIANA

Segurem-lhe nos braços, que ela não pára quieta!!!!...

SEBASTIANA

Pronto, já está!!!! É um menino!

(Gervásio ergue-se e D. Tomásia também. Tomam cena frente ao evento)

TOMÁSIA

Nasceu de oito meses. Está vingado e perfeitinho!

GERVÁSIO

Não me lembro de nada!...

(Gervásio desmaia)

É o dia 24 de Dezembro. Num dos espaços estará uma árvore de natal e a família Barros. No outro, é o quarto de Tomasinha.

FLORÊNCIA

Está tudo tão bonito mana Sebastiana: a árvore de natal, os enfeites, o presépio!...

SEBASTIANA

Fiz o melhor que sei.

TOMÁSIA

Dou-lhe os meus parabéns!

SEBASTIANA

Mas olhe que a mana Florência também se esmerou a embrulhar as prendas!

FLORÊNCIA

E já viu a travessa de aletria que fez a mana Tomásia?! 
TOMÁSIA

Sempre tive mão para a aletria, mas o mais bonito é o que a mana Florência escreveu com a canela em pó: "Benvindo Inocêncinho!".

SEBASTIANA

Como é que conseguiu, mana?!

FLORÊNCIA

Não sei se é por ser Natal, mas estou a ver muito melhor!

GERVÁSIO (Trás um barrete de Pai Natal)

Feliz Natal!

MANAS

Feliz Natal!!

NICOLAU

Feliz Natal!

TOMASINHA

Feliz Natal!...

NICOLAU

Está tudo pronto?

TOMASINHA

Está tudo pronto.

NICOLAU

O nosso filho?

TOMASINHA

Está ali... está a nanar...

NICOLAU

Trouxe-Ihe uma prenda... um ursinho de peluche...

TOMASINHA

Nicolau... tenho tanto medo...

NICOLAU

Vai correr tudo bem...

TOMASINHA

Não é por mim... é por ele!... 
NICOLAU

Está tudo preparado, não lhe vai faltar nada; vamos daqui direitos a Vila Nova de Famalicão e lá encontramo-nos com a ama que hoje mesmo segue connosco para Caminha. Amanhã de manhã partimos para Espanha.

TOMASINHA

Quando eles descobrirem... nem quero pensar no que pode acontecer!

NICOLAU

Pensa que está em jogo a nossa felicidade e a do nosso filho!

TOMASINHA

Eu sei.

NICOLAU

Agora não podemos voltar atrás. O meu amigo deve estar a chegar com a carruagem.

(As manas e Gervásio cantam uma canção de natal.)

GERVÁSIO

Daqui a uma hora ou duas chega o nosso Inocêncio! Não quero desmaios!!! É Natal!

SEBASTIANA

Que horas são cunhado?!

GERVÁSIO

São... quatro e meia!

SEBASTIANA

Que estranho! Está na hora da ama dar de mamar ao Pedrinho e lá nisso a Tomasinha costuma ser pontual!

TOMÁSIA

É capaz de ter adormecido ao lado do bebé, o parto cansou-a muito!

SEBASTIANA

É capaz...o melhor então é eu ir acordá-la...

Tomasinha!...

TOMASINHA

Vem aí alguém! Esconde-te, depressa!... Sim?...

SEBASTIANA

Afinal estás acordada! Está na hora do Pedrinho ir mamar! Esqueceste-te?! 
TOMASINHA

Não... mas agora... talvez seja melhor não... mais tarde...

\section{SEBASTIANA}

Os bebés têm de mamar a horas certas!...

\section{TOMASINHA}

Eu sei... mas ele está a dormir tão bem... parece um anjinho...

\section{SEBASTIANA}

Acorda-se o anjinho... olha, nem é preciso. Já acordou! Vá lá, venha ao colo da titi que está na hora da papa do bebé... olha que gracinha!... não larga o ursinho... quem deu o ursinho ao bebé, quem foi?, quem foi?... foi a mamã?!... (enquanto fala chega ao "espaço" dos outros") Quem estava a dormir era o bebé, mas já acordou!

\section{GERVÁSIO}

Venha ao colo do avô!... sou o avô!... dê um beijinho ao avô!... olha, não me deu um beijo, mas deu-me um ursinho!...

\section{TOMÁSIA}

É muito bonito! Foi a mana Florência que lho ofereceu?!

\section{FLORÊNCIA}

Não; Deve ter sido a mana Sebastiana!...

\section{NICOLAU}

A carruagem acabou de chegar à porta! Temos de ir!

TOMASINHA

Agora não podemos! A tia Sebastiana levou o menino!

NICOLAU

Levou o menino para onde?!

TOMASINHA

Estava na hora dele mamar!

NICOLAU

Tens de ir buscá-lo, depressa!

\section{TOMASINHA}

Como é que eu posso ir buscá-lo?! O que é que eu digo à ama?! 
NICOLAU

Não tens que lhe dizer nada! Ela sabe que és a mãe dele! (Ouve-se um assobio lá fora) Estão à nossa espera!!!

\section{TOMASINHA}

Os outros hão-de querer saber porque é que eu vou buscar a criança! Temos de esperar...

NICOLAU

Não podemos!...

TOMASINHA

É só meia hora, ou menos! E depois vou buscá-lo!...

NICOLAU

Não queria dizer-te... mas soube antes de vir para aqui que o barco já atracou no cais há muito! O Inocêncio está aí não tarda nada!!! Temos de fugir quanto antes! Não quero que esse homem te torne a ver Tomasinha!

TOMASINHA

Mas o nosso filho!...

(Ouvem-se dois assobios)

NICOLAU

Só há uma solução: fugimos agora os dois e eu venho buscá-lo mais tarde!

TOMASINHA

Eles não te dão a criança!!!

NICOLAU

Assim que o Inocêncio chegar eles vão saber que o filho não é dele! Não vão querer ficar com o menino, sabendo que ele é filho doutro homem!!! São demasiado orgulhosos para o aceitarem na família! Não tem o sangue dos Barros!!!

TOMASINHA

Vão amaldiçoar-me para sempre!

NICOLAU

Vamos.

(Todos cantam o "Noite de paz, Noite de amor...", a dada altura, ouve-se a campainha da porta. Florência vai à porta!)

FLORÊNCIA

Eu vou abrir! 
GERVÁSIO

Deve ser o Inocêncio!

TOMÁSIA

Mas onde se meteu a Tomasinha?!

SEBASTIANA

Então, é ele?!

FLORÊNCIA

Ainda não! Mas é o Mensageiro outra vez! Reconheci-o logo assim que abri a porta!

\section{GERVÁSIO}

Mas então porque é que não o mandou entrar?!

FLORÊNCIA

Já mandei! Mas ele vem com uma muleta!

SEBASTIANA

Se vem do Pará, deve trazer é uma mulata!

MENSAGEIRO

Minhas senhoras e meus senhores, hoje sou portador duma muleta!

FLORÊNCIA

Eu não dizia?!

GERVÁSIO

Venha como vier, será sempre bem recebido neste lar! Só espero que desta vez não demore tanto tempo a mostrar-nos quem trouxe para nos mostrar, porque já fez esse número com o tio Luís, deve lembrar-se!

MANAS

O nosso falecido mano!

MENSAGEIRO

Vejo que estão muito esperançados... mas eu não lhes quero dar falsas esperanças...

GERVÁSIO

Por amor de Deus, já sabemos que faz esse "suspense" muito bem feito, mas é Natal! Mande-nos a todos olhar para ali... e mande-o entrar!

\section{SEBASTIANA}

Espere cunhado! Falta aqui a Tomasinha! 
TOMÁSIA

Mas onde se teria metido a pequena!

FLORÊNCIA

Eu vou chamá-la!

MENSAGEIRO

Não vale a pena menina Florência! Verifico que ainda não sabem... embora já conste... mas o barco em que viajava o Sr. Inocêncio de Barros... foi... a pique... e ele lá ficou!

\section{(Silêncio)}

\section{TOMÁSIA}

Mas a ilha de Pique não é nos Açores?! Que ficou ele a fazer nos Açores?!

\section{SEBASTIANA}

Nos Açores é "Pico!"... a pique... é ao fundo!

TODOS (Só agora perceberam)

O barco foi ao fundo?!!!

\section{MENSAGEIRO}

O barco e toda a tripulação! Fui o único que escapou à tragédia! Agarrei-me à muleta e fiquei a boiar, até ser salvo por um barco de carga, que por feliz coincidência também vinha para Leixões!

\section{TOMÁSIA}

A Tomasinha... está viúva!...

SEBASTIANA

E ainda não sabe!

\section{FLORÊNCIA}

Eu vou chamá-la!

MENSAGEIRO

Não vale a pena, menina Florência!

SEBASTIANA

Já é a segunda vez que diz isso! O senhor repete-se!!!

TOMÁSIA

Não vale a pena porquê?! 


\section{MENSAGEIRO}

Porque não está cá em casa! Quando eu estava a chegar aqui à rua, estava ela a descer por uma escada de corda, duma janela do primeiro andar! Depois um vulto, que me pareceu dum homem com uma capa negra, amparou-a até uma carruagem... e partiram!!!

TOMÁSIA

A minha afilhada foi raptada!

\section{SEBASTIANA}

O senhor viu isso tudo e não estranhou?!

\section{MENSAGEIRO}

Quem tem uma profissão como a minha, vê tanta coisa que já não estranha nada!

\section{GERVÁSIO}

Tragam-me a criança que nunca há-de conhecer seu pai! (Com a criança nos braços) Meu anjinho... o que é que eu te hei-de dizer?!!!... É noite de Natal... o teu paizinho morreu afogado... a tua mãezinha foi raptada pelo homem da capa negra... e por agora... meu anjinho... não me ocorre dizer-te mais nada... que mais é que eu te posso dizer?!... Seja como for... é Natal!... cantemos!... cantemos para não chorar!!!

E cantam: "Noite de paz... noite de amor, etc."

(No dia seguinte, ou dias depois!)

\section{GERVÁSIO}

A Tomasinha não foi raptada! A Tomasinha tinha um amante, com quem fugiu! O cocheiro que os transportou bateu com a língua nos dentes! Em toda a cidade não se fala de outra coisa!!! Que vergonha! O marido no fundo do mar e ela nos braços dum miserável!!!

\section{TOMÁSIA}

Meus Deus! Abandonar o filho para se entregar a uma vida de luxúria e de pecado!

\section{SEBASTIANA}

Esse homem tem de ter qualquer coisa!...

\section{FLORÊNCIA}

Tem a nossa Tomasinha!

\section{GERVÁSIO}

Miserável! 
FLORÊNCIA

Esta noite de Natal vai ficar inesquecível!!!

GERVÁSIO

Nunca mais vamos poder festejar o Natal sem nos lembrarmos desta vergonha e desta tragédia!

\section{TOMÁSIA}

Meu querido marido! Está a cair-te em cima a maldição da Custódia!!!

SEBASTIANA

Era uma mulher muito experimentada cunhado!

GERVÁSIO

Não posso fazer o funeral ao meu filho, mas posso fazer-Ihe o enterro a ela!!! E a esse miserável que veio emporcalhar a honra dos Barros!!!

TOMÁSIA

Estás a pensar em matá-los Gervásio?!

FLORÊNCIA

Sabe quem ele é, cunhado?!

GERVÁSIO

Um aventureiro! Um vagabundo! Um miserável! Um oportunista!

\section{TOMÁSIA}

Como é que sabes tantas coisas sobre esse homem?!

\section{GERVÁSIO}

Seduziu a Tomasinha para apanhar o nosso dinheiro! Mas está muito enganado que não vai apanhar-me nem uma moeda!!! Tomasinha é uma mulher, foi uma presa fácil, mas de mim não vai ele conseguir nada!

\section{TOMÁSIA}

Ele pode roubar-nos?!

\section{GERVÁSIO}

Qual é o homem que quer uma mulher que já é mãe, senão para roubar o dinheiro do sogro?!

\section{FLORÊNCIA}

Mas como?!

GERVÁSIO

Ele sabe que o meu dinheiro há-de ser todo para o meu neto! Ele é filho do meu filho, é sangue do meu sangue e juro por Deus que há-de ser o herdeiro de toda a 
minha fortuna!!! A Tomasinha é a mãe, figura no meu testamento, também tem direitos enquanto for viva e esse miserável vai obrigá-la a reclamar, a invocar a lei! Sabem que o meu filho morreu!

\section{SEBASTIANA}

Isso eles ainda não sabiam, quando fugiram!

\section{GERVÁSIO}

Essa gente sabe sempre tudo antes dos outros! Até o Mensageiro pensava que nós já sabíamos, mas só nós, os mais interessados, é que fomos os últimos a saber!!!

MANAS

Virgem Maria Santíssima!

Santa Maria Goretti!

Sagrado Coração de Jesus!

\section{GERVÁSIO}

Mas não está nada perdido! Temos o poder do dinheiro! Usêmo-lo!!! Mesmo nas grandes catástrofes, nas grandes derrocadas, quem tem poder nunca fica mal, mesmo que sejam obrigados a abandonar tudo! E é isso mesmo que nós vamos fazer!!!

\section{MANAS}

Vamos deixar o país?!

\section{GERVÁSIO}

Preparem as malas! Os ricos têm sempre um plano de emergência! Vou levantar todo o dinheiro, anular o testamento, espalhar aos sete ventos que fomos roubados e que estamos na miséria! Mantemos apenas esta casa... tal como está... um dia, talvez possamos voltar... quando todos esquecerem esta vergonha.

\section{TOMÁSIA}

E vamos, para onde?!... Para África?!!!

\section{GERVÁSIO}

Não vamos daqui deportados, D. Tomásia!!!! Ninguém sabe, mas continuamos ricos! Vamos para Londres!

\section{FLORÊNCIA e SEBASTIANA}

Londres!

\section{TOMÁSIA}

Mas eu nem falo francês! 
SEBASTIANA

Não Ihe vai fazer falta nenhuma, pode ter a certeza!

GERVÁSIO

Londres... vai ser muito bom para a educação do menino... o ensino em Portugal está cada vez pior!...

FLORÊNCIA

Vamos conhecer Londres!!! Piccadilly! O Covent Garden! O Hyde Park!!!

GERVÁSIO

E vamos poder ver...

TODOS

Os grandes Musicais!!!

AMIGO

Dona Tomasinha?...

TOMASINHA

Sim... sou eu...

AMIGO

Não sei se ainda se lembra de mim... sou amigo de Nicolau de Almeida... estava com ele no dia em que the falou pela primeira vez... no Teatro São João... não se lembra?!...

TOMASINHA

Já passou... tanto tempo!...

AMIGO

Dezassete... ou dezoito anos...

TOMASINHA

Uma vida!

AMIGO

Desde que saíram do Porto, nunca mais o voltei a ver... julgava-os em Espanha.

TOMASINHA

Soubemos da morte do Inocêncio... já não era preciso fugir... e ficávamos mais próximos do nosso filho...! Não... não me lembro do senhor...

AMIGO

O seu marido há-de lembrar-se de mim. 
TOMASINHA

Talvez... não sei... ele... está diferente...

AMIGO

Diferente?!... Como?!...

TOMASINHA

Tentámos tudo... e nunca soubemos do paradeiro do nosso filho... onde é que está... se ainda é vivo... e se sabe da nossa existência; o que pensa de nós... não sabemos nada!... Há dezoito anos que vivemos neste inferno!... Mil vezes a morte!

NICOLAU

Pedro!... Pedro!... .... Onde está o Pedrinho?!... ...Saiu de casa e ainda não voltou!... ...Quando ele chegar temos de falar com ele... um filho não pode estar tanto tempo longe dos pais... ...Não sabes onde ele está, pois não, Tomasinha?... ...Talvez seja melhor eu ir procurá-lo... pode ter-lhe acontecido alguma coisa......é isso!... ...eu vou procurá-lo... e quando o encontrar, eu vou falar-lhe ao coração... ele há-de ouvir-me... ...um filho nunca pode ficar indiferente à voz do sangue!...

TOMASINHA

A voz do sangue!... A voz do sangue!...

AMIGO

Vai deixá-lo partir?!!

TOMASINHA

Mil vezes partiu e mil vezes voltou...

AMIGO

Tenho de falar-Ihe! Ele não me reconheceu, mas mesmo assim...

TOMASINHA

Às vezes nem a mim reconhece!...

AMIGO

Lembre-se que a esperança é a última coisa a morrer!

TOMASINHA

A minha, já morreu há muito tempo... e a dele... morre aos poucos...

NICOLAU

...Perdoa-me Tomasinha, perdoa-me... prometi-te que o trazia de volta... ...mas não consigo encontrá-lo!... ....Não consigo... perdoa-me...!

TOMASINHA

Descansa, Nicolau... descansa um bocadinho...! Não penses agora nisso... não penses em nada... ...descansa... ...Vá-se embora, peço-lhe! 
AMIGO
O seu padrinho voltou ao Porto... e o seu filho também!

GERVÁSIO

Quis voltar a Portugal, porque quero acabar os meus dias na terra onde nasci e também queria que conhecesses a casa que te viu nascer... you were born here... this is all yours...

PEDRO

It's a very nice house, indeed...

GERVÁSIO

Filho do meu sempre chorado Inocêncio... é chegada a hora de te dizer o que não sabes... tua avó e tuas titis, que Deus tem... disseram-te que teu pai e tua mãe tinham morrido. Teu pai... your daddy... é certo que morreu... mas tua mãe... não! You understand?

PEDRO

My mother is alive?!

GERVÁSIO

Your mother is alive!

PEDRO

My mother is alive?!

GERVÁSIO

Yes! Yes! Yes! Morreu para nós, porque foi a vergonha da minha cara e a desonra do teu pai!

\section{PEDRO}

My mother is alive?!

\section{GERVÁSIO}

Yes!!! Só o teu pai é que morreu! Na noite em que o esperávamos, era noite de Natal... Christmas!... fugiu ela para a companhia de um homem, com quem ainda vive amantizada!!!

PEDRO

My mother is dead!

GERVÁSIO

No! She's amantizada with a man... you uderstand?

PEDRO

Yes! Then, for me, my mother is dead too!... compreende?! 


\section{GERVÁSIO}

Yes! Yes!... Trocou o teu pai... your daddy... e abandonou-te... por causa desse homem... you understand?

PEDRO

Yes!

\section{GERVÁSIO}

Foi ele que emporcalhou a nossa honra!!! Eu já não tenho forças para limpar a honra emporcalhada... mas tu, agora que és conhecedor da verdade, the truth and nothing but the truth... se algum dia te encontrares com esse homem... - chama-se Nicolau de Almeida... - podes fazer o que te ditar a voz do sangue... toda a minha fortuna é tua... e a vingança também! Eu já não vivo muito Peter... seis meses quando muito...

\section{PEDRO}

Don't go! Please don't go!

GERVÁSIO

Ainda não vou!... Mas quando for... vou feliz... porque o dinheiro dos Barros vai continuar na família dos B...!

PEDRO

My grand-pa... is dead!...

TOMASINHA

...Pedro?!...

PEDRO

No... Gervásio... Gervásio de Barros!... Compreende?...

TOMASINHA

Sim... é o meu padrinho... eu depois falo com ele...

PEDRO

Christmas... Heaven... compreende?

TOMASINHA

Sim... foi no Natal que te levaram!... Eu sou...

NICOLAU

Pedro!... Pedro!... Não encontro o nosso filho...

TOMASINHA

O nosso filho... talvez não consiga entender as nossas palavras... 
NICOLAU

Quem é aquele homem!?

TOMASINHA

...Não ouves... a voz do sangue?!...

NICOLAU

O meu filho!... O meu filho!... Saiu de casa e ainda não voltou! Quando ele chegar temos de falar com ele... um filho não pode ficar tanto tempo longe dos pais!... Quando ele voltar... eu vou falar-Ihe ao coração... um filho nunca pode ficar indiferente à voz do sangue!...

PEDRO

I don't understand... não compreende!...

TOMASINHA

Aquele ursinho... foi o teu pai que to deu... tinhas três ou quatro dias... o teu pai...

PEDRO

Pai?!... Daddy!?...

TOMASINHA

Sim... o teu pai e eu... procurámos-te por todo o lado! Há dezoito anos que a nossa vida é um inferno!!!...

PEDRO

My father is dead!... Meu pai morreu... compreende?

TOMASINHA

Não! O teu pai não morreu!... Meu Deus misericordioso fazei com que ele me entenda!!... Aquele homem... chama-se Nicolau de Almeida!...

PEDRO

Nicolau!?...

TOMASINHA

De Almeida!... E é ele o teu verdadei...

(Pedro saca de uma pistola e dispara sobre Nicolau)

NICOLAU

Tomasinha... parece que vou morrer... sem ter conseguido encontrar o nosso filho... promete-me que não vais desistir... e quando o encontrares fala-lhe de mim... leva-o junto ao meu túmulo... fico à espera desse dia... ainda tenho esperança de ouvir da sua boca a palavra "pai"... fala-lhe ao coração... ele há-de ouvir-te... um filho nunca pode ficar indiferente à voz do sangue... 
TOMASINHA

Perdoa-me, perdoa-me... ter-te amado tanto... e ter-te dado tão pouco...

NICOLAU

Não tens que me pedir perdão!... Desde aquele dia em que te vi... em Caminha... eu sabia que tu havias de ser a minha doce fatalidade. 
A Vida Trágica de

CARLOTA

A Filha da Engomadeira

A partir do romance de Camilo C. Branco Coisas Espantosas

COISAS ESPANTOSAS

O enredo deste belo romance de Camilo Castelo Branco gravita em torno do trinómio Crime - Expiação - Felicidade, três elementos essenciais, e omnipresentes, no universo romanesco de Camilo.

"Coisas Espantosas", o $16^{\circ}$ romance do autor, saiu em primeira edição em 1862, mas os primeiros capítulos foram publicados em 1859, com o título "A Natureza das Coisas".

Quando, em 1861, um editor Ihe pediu para escrever a sua autobiografia romanesca, Camilo retomou o enredo de 1859

e pensou dar-Ihe um novo título: "Os Miseráveis de Cá", procurando assim atingir um duplo objectivo: aproveitar em benefício do livro a publicidade feita na época em Portugal aos "Miseráveis" de Victor Hugo e desafrontar-se pela pena - como costumava de resto fazer dos miseráveis que o perseguiram no processo de adultério.

A dinâmica da intriga impôs um desfecho incomum e o romance sairia com o título definitivo de "Coisas Espantosas".

CARLOTA

Carlota é uma das personagens que está no centro deste romance e é a sua história que vamos contar, uma história comovente até às lágrimas, já que o autor é considerado por consenso universal um mestre do romance passional português. 
KlássiKus

associação cultural

Apresenta

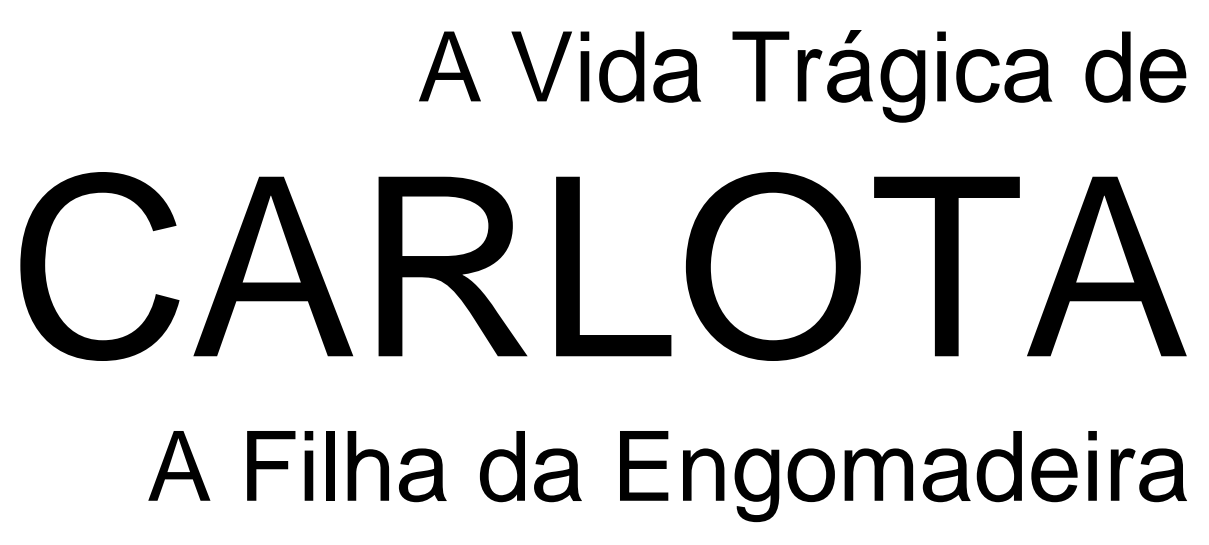

A partir do romance de Camilo C. Branco Coisas Espantosas

Texto e Encenação Fernando Gomes

Coreografia Victor Linhares

Cenografia e Grafismo Jorge Galvão

Figurinos Lucilia Telmo

Direcção Vocal Fernando Luis

Fotografias Pedro Lemon Garcia

Desenho de Luz Luis Balola

Estreia: 11 Julho 2002 - Teatro Há-de Ver Produção Manuela Jorge 


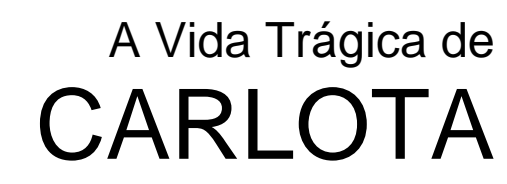

A Filha da Engomadeira

A partir do romance de Camilo C. Branco Coisas Espantosas

Personagens e Intérpretes

Mendigo, Inácio Botelho, Menino Augusto Carlos Macedo Mendiga, Carlota dos Reis Elsa Galvão Mendigo, Gregório Redondela Fernando Gomes Mendiga, Carolina, Anita, D. Rosa, Madre Isabel Ribas Mendigo, Manuel, Calmeirona Luis Pacheco Mendiga, D. Leonor, Betinha, Françoise Paula Fonseca Mendigo, Dr. Januário, Chulo, Adido Cultural, Freira Pedro Fernandes Mendigo, Anão dos Assobios, Fininha, Garçon, Freira Rui Raposo 


\section{A Vida Trágica de CARLOTA A Filha da Engomadeira}

\section{Melodrama Passional}

Carolina dos Reis era uma engomadeira competente e assim ganhava dinheiro para o seu sustento e da filha ...até que um dia começou a ver mal, e já quase cega de todo, viu-se obrigada a abandonar a profissão!

Carlota, a filha da engomadeira, na sua inocência de menina, brincava com bonecas e sonhava que ainda havia de conhecer o pai ... até que um dia, apenas com 15 anitos,

teve de substituir a mãe e abraçar a profissão de engomadeira!

E Carlota começou a engomar as camisas do sr. Inácio, um viúvo endinheirado e pai dum menino com 4 anos, que ela ajudou a criar como se de um filho se tratasse ...até que um dia o viúvo não conseguiu resistir aos seus encantos e Carlota deixa-se arrastar para o leito do patrão!

Carlota já não era virgem, mas ainda não sabia o que era o amor ... até que um dia conheceu Manel, um rapaz com problemas económicos e também com uma grande necessidade de afecto! E Carlota, a filha da engomadeira passou a ter dois amantes!

Ter dois amantes não é nenhuma tragédia ... e a vida de Carlota, a filha da engomadeira, nem estava a correr assim tão mal ....até que um dia ...cinco anos depois, a "Morte" bate à porta da casa de Inácio Botelho ...e o viúvo, que até então era o "mealheiro" do filho, da Carlota, da mãe e do amante ... é levado para descansar em paz!

A grande tragédia ... vai começar! E ainda vai durar mais dez anos! 
A Vida Trágica de CARLOTA a Filha da Engomadeira

Dez Anos Depois ...

Dez anos depois - estamos no século XIX - continuava a ser impressionante o número e condição dos mendigos de Lisboa.

Mendigavam cegos, aleijados, velhos, doentes, anormais, desempregados.

Alguns mendigos, em troca duma esmola, cantavam e contavam, pelas ruas e pelas feiras, histórias comoventes que relatavam amores não correspondidos ou crimes recentes. Também para eles, a vida era madrasta, injusta, ingrata!

Até que um dia ... ao saberem duma engomadeira que ficou cega, duma tal Carlota que esteve anos internada num manicómio, dum criminoso que teve de abandonar o país e acabou por regressar riquíssimo,

dum tal Gregório que milagrosamente escapou à morte

quando já ia a caminho do cemitério e muitos outros espantosos

acontecimentos ... nesse tal dia, os mendigos juntaram-se

e passaram a noite inteira a falar destas Coisas Espantosas ...

E chegaram à conclusão de que tinham ali uma boa história, coisa comovente que eles haviam de gostar de contar e que o povo havia de gostar de ver!!! Durante algumas semanas não pensaram noutra coisa ... até que um dia ... acharam que já estavam preparados para cantar e contar, para quem os quisesse ver e ouvir,

\section{A vida Trágica de CARLOTA A Filha da Engomadeira}




\section{PRÓLOGO.}

A Klássikus orgulha-se de apresentar em estreia absoluta:

“A Vida Trágica de Carlota, a Filha da Engomadeira”.

Trata-se de um Melodrama Passional, escrito a partir do enredo do $16^{\circ}$ romance de Camilo Castelo Branco: "Coisas Espantosas”, que saiu em primeira edição em 1862.

Carlota é uma das personagens que está no centro deste romance e é a sua

história que vamos contar, uma história comovente até às lágrimas, já que o

autor é considerado por consenso universal um mestre do romance passional

português.

A acção decorre em Lisboa, na segunda metade do século XIX.

Grande parte do povo vivia de esmolas.

Era impressionante o número e condição dos mendigos de Lisboa.

Mendigavam cegos, aleijados, velhos, doentes, anormais, desempregados.

Alguns mendigos, em troca duma esmola, cantavam e contavam, pelas ruas e pelas feiras, histórias comoventes que relatavam amores não correspondidos ou crimes recentes.

Hoje, sem dúvida que teriam preferido um palco ... e seria assim ... 


\section{MENDIGOS}

Nas "Coisas Espantosas"

Que Camilo escreveu

Neste Romance passional a Carlota nasceu

É um melodrama

Com enredo até mais não!

Dava um grande programa

P'rá tele-visão!

No palco este romance

Tem de ser encortado

É uma bela chance de fazer um reciclado!

Teatralidade

Tem para dar e vender

A grande dificuldade

Está no es-colher

Há sangue! Há crime! Há morte!

Cenas de amor também

E mulheres de mau porte, tudo isto a peça tem!

É um melodrama!

Cheio de cenas reais

E assim se enreda a trama

Mas ainda há mais!

Há o Inácio Botelho

Amante da Carlota

O homem não é velho, mas bem cedo bate a bota!

Porque alastra a peste

Mata sem escolher qual

Cena pungente e agreste

A deste fu-neral!

Gregório o seu criado

Noutra cena cruel

Vai ser assassinado e por causa dum papel! 
O tal papelinho

Causa do acto em questão

Rende bom dinheirinho a

Quem lhe deite a mão!

A Carlota enlouquece

Que o remorso é fatal

Teias que o autor tece e a levam p'ró hospital

Pobre desgraçada

Que o destino maltratou

E ao sair curada

Vê que a mãe - cegou!

E é vê-las lado a lado

A cega e a pequena

Pedir esmola é o seu fado mas ninguém tem pena!

Quadros deste estilo

Continuam imortais

Assim escreveu Camilo

Mas ainda há mais!

Que às "Coisas Espantosas"

Não se lhes vê o fim

Tem cenas amorosas; é um grande folhetim!

É uma tragédia!

Cheia de cenas reais

Mas também tem Comédia!

Já vão ver! Que há mais!!!

É uma tragédia!

Cheia de cenas reais

Mas também tem Comédia!

Já vão ver! Que há mais!!! 


\section{CASA DE CAROLINA DOS REIS}

\section{MENDIGO}

A primeira cena passa-se numa pobre casa, situada no Beco das Gralhas.

Carolina dos Reis, assim se chamava a mãe da Carlota, era filha de família limpa, mas foi amaldiçoada pelo pai por ter casado contra sua vontade.

\section{CAROLINA}

Teu avô não quer saber de nós, Carlota ... e o teu paizinho, por môr de ter casado comigo contra a vontade de quem mais pode ... todas as portas se lhe fecharam e ficou sem trabalho ... e ele hoje, não está aqui ao nosso lado, porque teve de embarcar p'ró Brasil, a ver se ... (chora a seco) ... mas ele um dia vai voltar Carlota ... e assim que ajeitar emprego, há-de nos mandar algum p'ra nosso arremedeio ... e entretanto, arremedeia-se a gente como pode e com a benção do Senhor! Graças a Deus que aprendi a arte de engomadeira ...por enquanto só engomo para o $\mathrm{Sr}$. Inácio Botelho ...

\section{MENDIGO}

Ganhava pouco, mas era dinheirinho certo ...

\section{CAROLINA}

... é pouco, mas é dinheirinho certo... e a ti, filhinha,

\section{MENDIGO}

E a ti, filhinha, continuou a pobre mãe, "nem que eu tenha de tirar da boca, não te há-de faltar nada!"

\section{CAROLINA}

... Dorme ... dorme, meu anjinho ... pelo menos enquanto dormes não pedes papa! ...

\section{MENDIGO}

Carlota fingia dormir, para não atormentar ainda mais a pobre mãe ... e continuou a fingir ... a fingir ...

Até que um dia, ... dez anos depois ... 
CARLOTA (Off)

Quem era, mãezinha? ...

(Carolina entra a ler um papel)

CARLOTA

Carta do paizinho?!!!

CAROLINA

A conta da mercearia! ... A Ti Ingrássia diz que tem muita pena, que se lhe parte o coração, mas que não pode continuar a fiar-nos enquanto não pagar esta dívida! ...Virgem Maria Santíssima! Que vai ser de nós, minha filha?! ...

\section{CARLOTA}

O paizinho há-de voltar!!!

Não é o que a mãezinha me responde quando eu entristeço, por ter de brincar com uma pobre boneca de trapos?!

Que o paizinho há-de voltar e que vai traser-me muitas bonecas ... e que nenhuma delas há-de ser de trapos! Todas de porcelana! ...

O paizinho há-de voltar!!!

\section{CAROLINA}

Não sei, minha fillha, não sei! ... Eu agora já não sei! ... esgotaram-se-me as ilusões e já nem tenho forças para te mentir ...se há já dez anos que ele partiu e nem uma carta escreveu ... diz-me o coração que o teu paizinho, Carlota, já não vai voltar ... nunca mais! ...

\section{CARLOTA}

Nunca mais?! ...

O pai natal não existe $\ldots$ o paizinho não vai voltar ... as dívidas aumentam ... e Deus dorme...

\section{CAROLINA}

Não digas isso Carlota! Deus é Deus, é todo poderoso ... "Sabe-se lá ... se esta vida é boa ou má ... sabe-se lá, amanhã o que virá ...

\section{CARLOTA}

Não podemos ficar mais tempo à espera, a ver o que é que acontece amanhã, ou no outro dia, ou no outro ...

O sr. Inácio Botelho ... a mãezinha está sempre a dizer que ele é muito boa pessoa $\cdots$

\section{CAROLINA}

Pela vontade de Deus, é ele quem nos tem valido! ...

\section{CARLOTA}

Podia pedir-lhe um aumento de ordenado ... 


\section{CAROLINA}

Podia, mas ... eu estou a ver cada vez pior ... a tua mãe está quase a ficar cega, Carlota! ... eu já não engomo como dantes ... eu não te contei nada, mas outro dia, saltou uma fagulha do ferro, eu não reparei ... e peguei fogo à casa ...

\section{CARLOTA}

A mãezinha pegou fogo à casa?!

\section{CAROLINA}

Graças a Deus só ardeu metade da cozinha e a despensa ... o Sr. Inácio perdoou-me e foi quando me deu estes óculos ... mas ele agora tem mais despesas ... a Balbina, a cozinheira, vai ser mãe ...

\section{CARLOTA}

Não me disse que a Balbina tinha casado!

\section{CAROLINA}

Porque a desgraçada não casou! ... que Deus lhe perdoe ... o filho é do senhor Inácio Botelho ...

\section{CARLOTA}

Mas então ele ... não vai reparar o mal que lhe fez?! ...

CAROLINA

É um bom homem ... tenho a certeza que vai perfilhar a criança ...

\section{CARLOTA}

E a Balbina? ...

\section{CAROLINA}

Também há-de ter as suas regalias! ... desde que foi lá para casa, que ele obrigou logo toda a gente a chamar-lhe "Dona"! ... Dona Balbina.

\section{CARLOTA}

Se a Balbina é "Dona" e a criança vai ser perfilhada, isso quer dizer que o senhor Inácio ...

\section{CAROLINA}

É um homem como deve ser! ... Um bom homem!

\section{CARLOTA}

Pois então, peça-lhe um aumento, mãezinha! 


\section{CAROLINA}

Não sei ... tenho medo! ...

\section{MENDIGOS/CAROLINA}

O preciso é ser-se forte

Ser-se forte e não ter medo

Porque na verdade a sorte, como a morte,

Chega sempre, tarde ou cedo.

Ninguém foge ao seu destino

Nem para o que está guardado

Pois por um condão divino

Há quem nasça pequenino

P'ra cumprir um grande fado

Sabe-se lá, quando a sorte é boa ou má,

Sabe-se lá, amanhã o que virá

Breve desfaz-se, uma vida honrada e boa

Ninguém sabe quando nasce

P'ró que nasce uma pessoa.

\section{MENDIGO}

E até agora, tudo leva a crer que o senhor Inácio nasceu para ser uma boa pessoa.

Acedeu ao pedido de Carolina e deu-lhe um aumento, por interferência da Dona Balbina, a mãe solteira, que tinha tanto de sofrida como de bondosa ...

E assim passaram mais cinco anos!

\section{CAROLINA}

Carlota! Carlota! Onde estás Carlota?!

\section{CARLOTA}

Estou na retrete, mãezinha! Já vou!

\section{CAROLINA}

Que grande desgraça! Mas que grande desgraça, minha filha!!! Agora é que eu não sei mesmo o que é que vai ser de nós duas! ...

\section{CARLOTA}

Mas que aconteceu?! Tanto alarido?! Que grande desgraça é essa?! 
CAROLINA

A D. Balbina! ... A Dona Balbina morreu!

Não somos nada neste mundo Carlota! Nada!

CARLOTA

Morreu?! ... Mas como?!

\section{CAROLINA}

A desgraçada, que a esta hora é cadavre, desceu à adega p'ra buscar vinho para o senhor Inácio e caiu-lhe uma pipa em cima que a esborrachou logo ali! ... Não somos nada neste mundo Carlota! Nada!

\section{CARLOTA}

Coitadinha ... e o filhinho, o menino Augusto, já lhe disseram que ficou sem mãe?!

\section{CAROLINA}

Parece que não, mas o menino, que só tem quatro aninhos mas é uma criança muito inteligente, Carlota, percebeu logo que ali havia coisa! ... não parava de gritar pela mãe! ... e o cheiro a vinho era tanto e entranhava-se de tal maneira, que naquela casa até parecia que estava tudo bêbado! ...

\section{CARLOTA}

Coitado do senhor Inácio; deve estar desfeito! ...

\section{CAROLINA}

Ninguém estava à espera e ficou toda a gente desfeita, Carlota! O senhor Inácio, o menino Augusto, eu! ... Mas quem menos estava à espera e a que ficou mais desfeita foi a Dona Balbina!

\section{CARLOTA}

Quem diria que havia de morrer esmagada por uma pipa de vinho!

\section{CAROLINA}

Ficou toda desfeita! A pipa ... e a Dona Balbina! ...

O senhor Inácio já fala que vai ter de meter uma pessoa para tomar conta do menino! ...

\section{CARLOTA}

Tem lá em casa aquele criado, o Gregório, que é como se fosse da família!

\section{CAROLINA}

Já está muito velho ... e o que faz falta à criança não é um avô, é uma mãe! ...

\section{CARLOTA}

A mãezinha é que podia tomar conta dele e sempre ganhava mais algum ... 


\section{CAROLINA}

E bem falta nos fazia, mas ... eu ainda não te disse ... e nem sei como é que te heide dar esta notícia ..., uma meia hora antes de ter descido à adega, a Dona Balbina disse-me que o sr. Inácio estava a pensar em despedir-me ...

\section{CARLOTA}

Voltou a deitar fogo à casa?! ...

\section{CAROLINA}

Não ... mas esta semana já lhe queimei quatro camisas e dois pares de ceroulas ... eu então pedi à Dona Balbina para interceder por mim, que se ficasse sem engomar havíamos de morrer as duas à fome ... e ela teve pena e prometeu-me que havia de falar com o sr. Inácio, assim que voltasse da adega! ...

\section{CARLOTA}

E nunca mais voltou! ...

\section{CAROLINA}

Ele ainda não me disse nada ... mas eu já sei que vou ter de ser substituída! ...

\section{CARLOTA}

Meu Deus! ... não sei como é que a gente aguenta tanta desgraça! Elas são umas atrás das outras! ...

É a fome que aperta, o dinheiro que escasseia, o paizinho que está mais que visto que já não volta, as dívidas que aumentam, a mãezinha que está quase cega, e agora é uma pipa que cai e a outra que morre esmagada num banho de sangue e de vinho!!!

Já que a minha mãe está cega, chegou a altura de eu fazer alguma coisa que se veja!!!

\section{CAROLINA}

Eu ainda não estou cega!!!

Que vais fazer, minha filha! Carlota! Carlota!

\section{MENDIGO}

Que poderá ir fazer Carlota, com a inexperiência dos seus 15 anitos? ...

\section{CARLOTA}

Vou malhar no ferro enquanto ele ainda está quente A minha querida mãe não está cega, mas pouco falta! ... e eu juro-lhe, por alma do meu querido paizinho ... o pão não há-de faltar nesta casa! Vou ser a mãe do menino Augusto ... e vou passar a engomar as camisas do pai!!! Juro-lhe que o pão não há-de faltar nesta casa, não seja eu Carlota, a filha da engomadeira. 


\section{MENDIGO}

E a seguir a este monólogo, ainda acrescentou:

"Se Deus quer que seja este o meu fado ... pois que seja!"

Bem pensado, todos temos nosso fado

E quem nasce mal fadado

Melhor fado não terá

Fado é sorte

E do berço até à morte

Ninguém foge, por mais forte

Ao destino que deus dá

\section{MENDIGO}

E foi assim mesmo que tudo se passou! E que Deus castigue aquele que não acreditar nas minhas palavras!

Em cima da cena que acabaram de ver já passaram cinco anos ...

Carlota teve a sorte de logo agradar ao menino Augusto e a desgraça de também agradar ao pai ... que ela não queria ... o coração dizia-lhe que não, mas a razão soava-lhe lá dentro, cada vez mais forte ...

Bem pensado, todos temos nosso fado

E quem nasce mal fadado

Melhor fado não terá

Fado é sorte

E do berço até à morte

Ninguém foge, por mais forte

Ao destino que deus dá

\section{NA TAVERNA}

\section{TONINHO}

Cada um tem o seu fado ...

GREGÓRIO

Pois! ...

\section{TABERNEIRA}


Estava a ver que não chegavas ao fim Gimbrinhas!

Que isto da gente não poder falar enquanto vocês cantam, não é nada bom p'ró negócio!!!

\section{GREGÓRIO}

... mas olha que nem todos têm o fado que merecem! ...

\section{TABERNEIRA}

Vá lá! Toca a encher os copos ou então vai já tudo p'ró olho da rua, que isto aqui não é para alapar o cu sem fazer despesa! Isso é que era bom! ...

\section{TONINHO}

Fado é sorte! ...

\section{TABERNEIRA}

Pois! E a sorte de cada um está na letra dum fado, não é Gimbrinhas?!

\section{GIMBRINHAS}

E há fados para toda a espécie de má sorte! ...

\section{GREGÓRIO}

Pois olha que até parecia não haver letra de fado que encaixasse na vida do meu amo! ...

\section{ZÉZINHO}

Ao sr. Inácio Botelho nunca faltou dinheiro! ...

\section{GIMBRINHAS}

E que eu saiba continua a não faltar, senhor Gregório!

TABERNEIRA

O sr. Inácio é uma boa alma! Havia de haver mais como ele!

\section{ZÉZINHO}

Lá isso! E amigo de fazer bem! ...

\section{GREGÓRIO}

Um exemplo para o filhinho, o menino Augusto ...

\section{TABERNEIRA}

Pois! ... Um bom pai! ... Que idade é que já tem o miúdo?

\section{GREGÓRIO}

Nove, vai p'ra dez anitos ...

É como te digo Gimbrinhas! Se não fosse a peste ... até parecia que não havia letra de fado que encaixasse na vida do meu amo ...

\section{TONINHO}


E a guerra!!! A guerra, aí pelas ruas, que a gente nem sabe por onde é que há-de ir p'ra chegar vivo a casa! ...

\section{GIMBRINHAS}

A guerra e a peste! ...

\section{TABERNEIRA}

Que peçonha!

\section{GREGÓRIO}

A peste apanhou o meu amo desprevenido ...

\section{TABERNEIRA}

Pois! ... Há toque a finados a toda a hora! ...

\section{GREGÓRIO}

Olha!!! ... lá vai mais um! ....

Maldito troar dos canhões

E o dobre a finados

Na rua que se vê?! Caixões

Também homens fardados

Maldita seja esta guerra

Alastra em todo o lado

E que trás ela à nossa terra?!

Letra p'ra mais um fado!

E que fizemos nós de errado p'ra tanto tormento?!

Meu Deus, p'ra quê mais este fado!

Assim, eu não me aguento!

Que mal Vos fez o meu patrão

P'ra estar todo acamado!

Lá se me vai o ganha pão

Está aqui, está enterrado!

São os primeiros a partir

Os bons vão sempre à frente!

E nós ficamos a carpir

Com "ais" e água ardente!

Com a bebida a gente esquece a dor e o passado

$\mathrm{O}$ homem bebe e embrutece!

E que pariu o fado! 
Pois assim mesmo é que é falar

Vá lá! Mais um copinho!

Eu já 'stou quase a vomitar!

Já não aguenta o vinho!

Se mais ninguém quer emborcar

Só tu me pões em brasa!

Tira as mãozinhas! Vou fechar!

Andor p'ra vossa casa!!!

Com a bebida a gente esquece a dor e o passado

$\mathrm{O}$ homem bebe e embrutece!

E que pariu o fado!

\section{CASA DE INÁCIO BOTELHO}

\section{MENDIGO}

A guerra e a peste, devastavam Lisboa.

O troar da artilharia e o dobre a finados, estridor medonho com que falava o rancor humano, casavam-se em lúgubre toada.

Inácio Botelho agonizava nas derradeiras ânsias da cólera.

\section{INÁCIO}

Carlota! ... Carlota! ....

\section{CARLOTA}

Credo! Que embaciou o espelho todo! ... Graças a Deus! ... é bom sinal ...

\section{INÁCIO}


$\mathrm{Au} \ldots$.

CARLOTA

O quê?!

INÁCIO

Augusto .......

CARLOTA

... o menino Augusto está no quarto ... já está a dormir ... e o sr. Doutor Januário há-de estar a chegar ...

INÁCIO

Carlota ... Carlota ...

CARLOTA

... agora não senhor Inácio ... por amor de Deus ... agora não ... olhe qu'inda se

lhe apaga o bafo ... bateram à porta ... deve ser o Dr. Januário ... sossegue um bocadinho ...

\section{$\underline{\text { A CAMINHO DE CASA }}$}

TABERNEIRA

Vá lá! Que eu tenho mais que fazer! Ajuda aí! ...

GREGÓRIO

Parece que vou vomitar!

TABERNEIRA

Outra vez?!

FANHOSO

Já Vomitou três vezes!!!

GREGÓRIO

Não! Parece que não! ... E em continuação do que eu lhe estava a dizer ... eu não achei aquilo nada bem!... 


\section{TABERNEIRA}

Pois!

\section{FANHOSO}

O sr. Gregório não achou bem o quê?!

\section{GREGÓRIO}

O quê?!

\section{TABERNEIRA}

Ele está a perguntar o que é que não achou bem!

\section{GREGÓRIO}

Então ...entra uma galdéria em casa de gente honrada e temente a Deus ... e ter de lhe chamar "Dona" ... Dona Carlota!

... quando não passa duma espertalhona ... ela e a mãe! ...

\section{TABERNEIRA}

Pois! Já conheço a história! A engomadeira!

\section{GREGÓRIO}

Essa já Deus castigou, que está quase cega!...

\section{TABERNEIRA}

Ai está?! ... Isso é que eu ainda não sabia! ....

\section{FANHOSO}

A engomadeira está ceguinha, há que tempos!!!

\section{GREGÓRIO}

Porque é que eu nunca percebo o que ele diz?!

\section{TABERNEIRA}

A mãe era alcoólica e ele nasceu sem céu da boca!

\section{GREGÓRIO}

Ah! ... olhe! Não se esforce a falar porque não se percebe nada do que você diz! ... Você não tem céu na boca! ...

Você tem boca, tem dentes e tem língua ... mas não tem céu!

E então o meu amo teve pena da ceguinha e deu emprego à filha ...

Mas gente dessa laia não perde tempo! ...

Por compaixão o meu amo abriu-lhe as portas ... e logo ela lhe abriu as pernas!

\section{TABERNEIRA}

E ele não queria, é claro! ... 


\section{GREGÓRIO}

Pois não! .... Ele não queria, mas essa Carlota soube levá-lo à certa, instruída pela mãe, de certeza! ...

\section{TABERNEIRA}

Pois! ... de certeza! ... A mãe devia ter cá uma instrução! ...

\section{FANHOSO}

A mãe está ceguinha, há que tempos!

\section{TABERNEIRA}

Está bem! Ele já sabe! ... Olha a minha vida! ...

\section{GREGÓRIO}

E a minha! Que eu assim que vi entrar a filha da engomadeira, estava o caixão da Balbina a sair, eu disse logo cá comigo ... “esta mulher está aqui p'ra endrominar o meu amo! ... “. .. e meu dito, meu feito, eu até parecia que já estava a adivinhar ...

Primeiro ela ... e agora a cólera! .... O pobre do meu amo às portas da morte ... e a puta com uma saúde de ferro! ....

\section{CASA DE INÁCIO}

\section{JANUÁRIO}

Dona Carlota ... dona Carlota!

CARLOTA

Como é que ele está?

\section{JANUÁRIO}

Demorou o seu tempo a assinar o papel ...

\section{CARLOTA}

Qual papel?! ...

\section{JANUÁRIO}

O testamento ... mas agora já está tudo em ordem ... e ele sempre ficou mais descansado ...

\section{CARLOTA}

É ele que está a assobiar?! ...

\section{JANUÁRIO}

Não, não! É o meu assistente ... para ver se ele adormece mais depressa ... isto deixou-o um bocado excitado ... 
CARLOTA

Já há pouco, quando lhe fui dar os medicamentos ele me pareceu ...

JANUÁRIO

Pareceu-lhe?...

CARLOTA

Um bocado excitado ... com certeza por estar à espera que o doutor chegasse!

ANÃO

Deve estar a chegar!

CARLOTA

Quem?!

ANÃO

A morte! ...

JANUÁRIO

Ele não adormeceu?!

ANÃO

Sim, mas antes ... esteve a falar com ela!

CARLOTA

Com quem?!

ANÃO

Com a morte!

E depois com ele ... com o filho.

CARLOTA

Mas o menino Augusto está a dormir!

ANÃO

Falou comigo, mas a pensar que estava a falar com ele ... chamou-me Augusto

JANUÁRIO

Deve tê-lo confundido com a criança ...

ANÃO

E deu-me um bilhete, para quando ela chegasse entregar à Dona Carlota.

\section{CARLOTA}


Quando ela chegasse ... quem?!

\section{ANÃO}

A morte!

\section{JANUÁRIO}

Tem aí o bilhete?!

ANÃO

Não era para mim! Fui pô-lo no quarto do menino Augusto; na mesinha de cabeceira. Ele depois há-de dar-lho ... é por causa duns dinheiros ...

\section{JANUÁRIO}

Podia dar-lho já!

ANÃO

O velho recomendou bem que era só para ser entregue depois dela chegar ...

\section{CARLOTA}

A morte!...

ANÃO

$\mathrm{Ah}$ ! E antes de adormecer ainda falou consigo!

\section{JANUÁRIO}

Comigo?!

ANÃO

Comigo, mas a pensar que estava a falar consigo!

Pediu para chamar um padre!

E depois ... pediu-me um beijo!

JANUÁRIO

E pensava que estava a falar comigo?! ...

ANÃO

Não! Nessa altura já não!

\section{JANUÁRIO}

Deve tê-lo confundido com alguma rameira!

\section{ANÃO}

Talvez seja melhor irmos chamar um padre! ... Ele quer confessar-se ...

\section{MENDIGO}

E o doutor Januário e o assistente - o anão dos assobios, como era conhecido - 
partiram, na esperança de poderem regressar com um padre ... ainda antes dela ...

CARLOTA, ASSISTENTE, JANUÁRIO

Da morte! (a seco)

(Ouve-se um tiro e o MENDIGO é atingido)

MENDIGO

Maldita guerra! ... Já nem os artistas escapam! ...

E que fizemos nós de errado p'ra tanto tormento?!

Meu Deus, p'ra quê mais este fado!

Assim, eu não me aguento!

\section{CARLOTA}

Já podes sair.

\section{MANUEL}

O velho já morreu? ...

\section{CARLOTA}

Ainda não ... o dr. Januário e o Anão foram à procura dum padre ... o sr. Inácio quer confessar-se, antes dela chegar ...

\section{MANUEL}

Está à espera de mais alguém?!!!

\section{CARLOTA}

Está à espera da morte, Manuel!

\section{MANUEL}

Estes ricaços são todos iguais: passam a vida a encher o bandulho e a lixar o próximo; olham p'rá gente todos empertigados, como se tivessem o rei na barriga; põem-se nas criadas, e elas ... bico calado ou lá se vai o emprego; são mais miseráveis que aqueles desgraçados que têm de roubar p'ra comer, ou daquelas que para aguentar a vida têm de aguentar com eles! ....

E depois querem um padre! ...

\section{CARLOTA}

Não fales assim, Manuel!

\section{MANUEL}

... E sabes porquê?! ... porque sabem muito bem

o que fizeram ... e têm medo!!! Têm medo de não ir d'esta p'ra melhor!!!

E gajos deste calibre são tão gananciosos que nunca se contentam com 
a riqueza que tiveram em vida, percebes?! ... Eles mesmo depois de mortos estão-se nas tintas para quem fica ... e só querem é uma coisa: ir para melhor! Ele agora quer um padre porque tem medo de não ir d'esta p'ra melhor!!!

\section{CARLOTA}

Cala-te! ... Deus ainda nos castiga!

\section{MANUEL}

Mais?! Mais ainda? Então e o velho, não merece castigo, é?! ...

Vieste para aqui para tomar conta do filho que ele fez à outra amante e como é que ele te pagou?!

\section{CARLOTA}

Sempre foi meu amigo ... sempre me deu bons tratos ...

\section{MANUEL}

Pois! E quando se meteu na cama contigo, também te tratou bem? ... gostavas do que ele te fazia? ...

\section{CARLOTA}

Não! ... sabes bem que não! ...

\section{MANUEL}

Então porque é que vens agora com essa história dele te tratar bem?!

CARLOTA

Não era tratada como os outros criados ... até mandou que toda a gente me chamasse dona ... dona Carlota ...

\section{MANUEL}

Olha o esperto! Andou a comer-te de borla durante cinco anos e em troca deu-te um título!!! Tens ali um grande amigo, não há dúvida!

Julgas que é com o título de dona que vais fazer face à vida quando o velho bater as botas?!

\section{CARLOTA}

Tu hás-de arranjar um emprego Manuel, vais ver!

Deus há-de ajudar-nos! ... Foi ele que fez com que nos conhecêssemos, foi ele que te mandou para os meus dias serem menos cinzentos e as noites menos negras ... Deus é testemunha de que te amo mais que a tudo na vida ... se não fosses tu ... eu não sei se teria aguentado tanto tempo ...

Havemos de ser felizes, Manuel! Ainda havemos de ser muito felizes!

\section{MANUEL}


Mas mesmo que eu arranje trabalho ... daqui até lá, como é que a gente vive?! O velho está por um fio ... aqui em casa já não há mais nada que se possa gamar ... e tu, com o que é que ficas? ... podes ter a certeza que não se lembrou de ti no testamento!

\section{CARLOTA}

Manuel! Acabei de saber que ele deixou um bilhete ao filho ...

\section{MANUEL}

Um bilhete?! ...

\section{CARLOTA}

Parece que escreveu ... não sei bem o quê ... para me ser entregue ... está no quarto do menino.

\section{MANUEL}

Vai buscá-lo, depressa! Pode ser o testamento!

\section{CARLOTA}

Não! Quem tem o testamento é o doutor Januário; mas parece que o bilhete é por causa doutros dinheiros ...

\section{MANUEL}

O velho é bem capaz de ter mais graveto escondido, aqui em casa!

(Carlota vai ao quarto onde dorme Augusto, encontra o bilhete e entrega-o a Manuel, que o lê).

\section{CARLOTA}

Então ... o que é que diz?! ...

\section{MANUEL}

Tinhas razão, Carlota! Deus está do nosso lado! Vamos ficar ricos, Carlota, muito ricos! ...

\section{CARLOTA}

Então, ele não se esqueceu de mim! ... Eu não te dizia? ... Ele sempre me tratou bem, sempre me considerou ...

\section{MANUEL}

Nem fala em ti, Carlota! ...

\section{CARLOTA}

Mas então?! ....

\section{MANUEL}


Ouve ... " ... escrevo este bilhete para dar conhecimento duma quantia em dinheiro que tenho aqui em casa e que me esqueci de mencionar no testamento. Guardei-o no baú de latão" ... onde está um baú de latão?! ...

\section{CARLOTA}

Deve ser aquele ali ...

(Ele vai buscar o baú e Carlota continua a ler o bilhete)

"Nesse baú estão 300 peças de 7.500 reis e 200 moedas de prata em cruzados Novos, para serem entregues à minha irmã D. Leonor Botelho, que reside em Montalegre ... e tu, Carlota, és a pessoa indicada para lho fazeres chegar às mãos."

\section{MANUEL}

Somos ricos, Carlota, somos ricos!!!

E em tendo sorte ao jogo ... em menos dum ano teremos o dobro!

\section{CARLOTA}

Mas ... mas este dinheiro não nos pertence!

Eu trabalharei para te sustentar, Manuel! E não me dês nada! Não me dês nada que para mim eu arranjarei! Torno para o ofício de engomadeira ... e olha, quem sabe se ele me deixa alguma coisa no testamento?!|

\section{MANUEL}

Que te há-de ele deixar?! Alguma dúzia de moedas para comprares um capote!

Ainda és de bom tempo!

(GREGÓRIO presenciou parte desta cena. Pega num objecto para bater com ele em Manuel. Dá-se o confronto. MANUEL pega num garfo e dá garfadas no desgraçado, que acaba por tombar)

\section{CARLOTA}

Pára! Pára, Manuel! Já chega!!! Pára!!!

Que fizeste?! ... Que fizeste, Manuel?! ...

\section{CARLOTA}

Que fizeste, Manuel?! ... Que fizeste?!... 


\section{MANUEL}

Foi sem querer, Carlota! Eu não queria ... mas o cabrão do velho assustou-me ...

CARLOTA

E mataste-o! .. Mataste-o Manuel! ...

\section{MANUEL}

Viu-nos com o dinheiro ... havia de acusar-nos à polícia ...

\section{CARLOTA}

Se lhe déssemos algum ele talvez se calasse ...

\section{MANUEL}

Achas que sim?! ...

\section{CARLOTA}

Não sei! ... mas agora está morto! ...

\section{MANUEL}

Já era velho ...

\section{CARLOTA}

... mas ainda vendia saúde ... e agora ... quando descobrirem o corpo do homem, todo crivado de garfadas ... vão querer saber quem lhe fez aquilo ...

\section{MANUEL}

Mas também são muito capazes de pensar que foi ele que se matou ...

\section{CARLOTA}

Isso que estás a dizer não me tinha ocorrido! ... mas pode ser! ... Todos sabem que para o Gregório, o sr. Inácio era como se fosse um filho e podem muito bem pensar que ele $\cdots$

MANUEL 
Não aguentou com o desgosto do amo estar às portas da morte ... e resolveu ir primeiro $\cdots$

\section{CARLOTA}

... pediu perdão a Deus ... pegou num garfo e zás, zás, zás ...

\section{GREGÓRIO}

Bem pensado ... (arrastam o corpo de Gregório para a rua)

Bem pensado ... todos temos nosso fado ...

E quem nasce mal fadado ... melhor fado não terá

Fado é sorte ... e do berço até à morte ...

Ninguém foge por mais forte ... ao destino que Deus dá.

\section{CARLOTA}

Mas ninguém foge ao seu destino, Manuel! Por culpa minha mataste um desgraçado que ainda havia de viver, sabe Deus até quando! ... Ninguém foge ao seu destino! Entreguemo-nos nas mãos de Deus, antes que descubram o nosso crime e o nosso pecado! Deus perdoou a tanta gente! Há-de perdoar-nos a nós também, Manuel!

\section{MANUEL}

Entregarmo-nos nas mãos de Deus? ...

\section{CARLOTA}

Sim, Manuel! Peço-te!!! Eu não ia aguentar com os remorsos ... e tu também não, que eu sei que só o mataste porque o garfo estava ali ... e o demónio algures, para te atentar ... entreguemo-nos nas mãos de Deus! ...

\section{MANUEL}

Estás arrependida por teres gostado de mim ... é isso?

\section{CARLOTA}

Não, Manuel! Eu continuo amar-te e cada vez mais e mais, mas a culpa do que se passou foi só minha, não te devia ter falado no bilhete nem no baú ... eu havia de saber que se visses tanto dinheiro ... 


\section{MANUEL}

Sempre fomos uns miseráveis, Carlota ... e sabes porquê?! Porque há outros, ainda mais miseráveis que nós, que fazem sempre as contas à maneira deles, e à maneira deles gente como nós nunca tem direito a nada! ... Mas "cá se fazem, cá se pagam!” ... e agora ... podemos refazer a nossa vida ... não era isso que estavas sempre a dizer? ...

\section{CARLOTA}

Mas esse dinheiro não nos pertence ...

MANUEL

Não acreditas no destino?

\section{CARLOTA}

Acredito ... que ainda podemos ser felizes ...

\section{MANUEL}

Então, pensa que se o graveto está aqui é porque o destino assim o quiz! Para podermos ser felizes! ... Não tens que ter remorsos ...

\section{CARLOTA}

... mas por causa dele morreu um homem; somos uns criminosos, Manuel!

\section{MANUEL}

Pois bem; ... serei homicida, já que não posso deixar de o ser ... mas não te esqueças que foi para realizar a tua felicidade que eu me fiz assassino ... que eu tingi as minhas mãos de sangue ...

\section{CARLOTA}

Perdoa-me, desculpa o meu remorso, que eu sou fraca, e receio que Deus mude em Inferno a felicidade que esperas ... e eu já não posso esperar ...

\section{MANUEL}

Então deixa-me; deixa-me para sempre! ... Eu rejeito esse dinheiro ... não hás-de ir presa! ... eu direi que não te conheço, que entrei nesta casa p'ra roubar e por isso matei o velho ... não quero consolar-me de ter matado um homem, com a posse do teu amor ... se é assim que tu queres, assim será. Adeus Carlota. 


\section{CARLOTA}

Não, Manuel! Não me deixes, que me matas, e a consciência não se sossega com a morte.

Liga-me ao teu destino; aceito-o, seja ele qual for.

Eu já sei que de hoje em diante sou entre as mulheres perdidas a mais desgraçada de todas.

\section{MANUEL}

Com este dinheiro ... podemos fugir para Espanha ...

\section{CARLOTA}

Como tu quiseres ... desde que não me deixes ... preciso de ti para me defenderes deste remorso ...

\section{MENDIGO}

Por certo que devem ter estranhado que ao longo da cena violenta a que acabaram de assistir, nem o menino Augusto nem o pai tivessem acordado ...

Há uma explicação: de há uns tempos para cá que o menino Augusto sofria com terriveis pesadelos, e então, antes de se deitar bebia sempre um copinho de leite bem quente ... a qual Carlota tinha o cuidado de acrescentar um forte calmante, para a criança ter um sono descansado ...

Quanto ao senhor Inácio Botelho ... que cada um tire as suas conclusões ...

\section{CARLOTA}

Agora tens de te ir embora, Manuel; ninguém te pode ver aqui e o Dr. Januário há-de estar quase a chegar com o Padre e o Anão dos Assobios ...

\section{MENDIGO}

Ouvem-se passos a correr que se aproximam da casa!

Há cães que ladram! 
Carlota mal consegue balbuciar:

\section{CARLOTA e MENDIGOS}

Meu dito, meu feito! Devem ser eles! Esconde-te, depressa!!!

\section{MENDIGO}

Manuel tem esperança que não sejam eles!

\section{MANUEL}

Pode ser uma caravana!

\section{MENDIGO}

Se fosse uma caravana, o malandro fiava-se no ditado que diz:

\section{MANUEL \& MENDIGOS}

Os cães ladram e a caravana passa.

\section{CARLOTA}

Os cães pararam de ladrar!

\section{MENDIGOS}

Mas não era uma caravana!

\section{CARLOTA}

Eu bem me parecia! ... é o senhor doutor Januário! ... esconde-te, depressa!

CARLOTA ( $\mathrm{P}^{\mathrm{a}}$.Januário, que entrou)

... e o Padre? ...

\section{JANUÁRIO}

Eu vim à frente ... para preparar a D. Carlota para o que vem aí atrás! ... 


\section{CARLOTA}

Vem aí alguém ... atrás de alguém?! ....

\section{JANUÁRIO}

Quero dizer, eu entrei primeiro ... para não ser um choque muito grande quando perceber quem vai entrar a seguir ...

\section{CARLOTA}

A seguir?! ...

\section{JANUÁRIO}

Não conseguimos encontrar um padre! ...

\section{CARLOTA}

Mas havia tantos padres em Lisboa! ...

\section{JANUÁRIO}

E há! Mas estão todos ocupados! Com a maldita peste ... os que não fugiram e os que ainda não morreram, estão ocupadíssimos com as cerimónias fúnebres ... ela está em todo o lado ... a morte ...

\section{CARLOTA}

Mas o senhor Inácio Botelho mostrou tanta vontade de não morrer sem se confessar ...

\section{JANUÁRIO}

E havemos de satisfazer a sua última vontade ...

\section{CARLOTA}

Como?! Se não encontraram um padre ...

\section{JANUÁRIO}

Nesta altura, o mais importante é que ele parta em paz ... ora, ele já não diz coisa com coisa ... ele pensa que fala com a própria morte, ele confunde o anão com o filho ... 
Fàcilmente pensará que está a falar com um padre ... se lhe pusermos à frente uma sotaina preta ... ele estará acordado? ...

\section{CARLOTA}

Não sei ... talvez ...

\section{JANUÁRIO}

Vou falar alto, para criar melhor a ilusão de que ele vem aí ... Pode entrar senhor padre! ...

$A N \tilde{A} O$ (vestido de Padre)

Que a paz esteja convosco e comigo também! ...

\section{CARLOTA}

Deus todo misericordioso! Afinal, sempre conseguiu encontrar um padre!

\section{JANUÁRIO}

Eu não the dizia que a ilusão havia de ser perfeita?!

Dona Carlota: Foi o hábito que fez o monge!

\section{CARLOTA}

Ah! É então um monge?

\section{JANUÁRIO}

Nem monge, nem padre!

Repare: É o anão dos assobios ... e se a D. Carlota o confundiu com um padre, de certeza que com ele, este nosso plano também vai resultar!

\section{MENDIGO}

E mal o Anão dos Assobios e o Doutor Januário se dirigiram para o quarto do moribundo, Manuel escapulia-se do esconderijo e levava com ele o dinheiro roubado.

Começou então a ouvir-se o anão a assobiar, uma tentativa para acordar o moribundo. De repente, o assobio deu lugar ao silêncio! 
ANÃO

Dona Carlota: Estou desfeito! Acabei de perder a grande oportunidade de representar o papel de padre ... padre e anão! Podia ter sido o papel da minha vida!

\section{CARLOTA}

Mas, o que é que aconteceu?!

$A N \tilde{A} O$

... há pouco, consegui adormecê-lo tão bem... mas agora, por mais alto que assobie ... eu não consigo acordá-lo! ...

JANUÁRIO

Talvez seja melhor ... lermos o testamento.

$A N \tilde{O} O$

Eu queria proporcionar-lhe um final de acto feliz ... mas ela chegou primeiro ... e quando o pano caiu ... eu não estava lá! ... e foi a morte que recebeu os aplausos do público!!!

E a Morte atravessa o palco, levando consigo o corpo inerte de Inácio Botelho.

E caiem pétalas pretas, ou rôxas ... que se espalham por toda a cena.

Depois deste "final de quadro" Carlota lê o testamento ...

\section{CARLOTA}

Eu não posso acreditar ... eu não quero acreditar ...

\section{INÁCIO}

E deixo à minha criada Carlota dos Reis a quantia de dez mil cruzados ... 


\section{CARLOTA}

Dez mil cruzados! ...

\section{INÁCIO}

... pela boa companhia que me fez no espaço de cinco anos ...

\section{CARLOTA}

Dez mil cruzados ...

\section{INÁCIO}

E porque além disso, lhe devo reparar de algum modo os danos que causei à sua honestidade ...

\section{CARLOTA}

Pai do céu! ... Valei-me! Valei-me senhor! ....

\section{INÁCIO}

... gostava que o meu filho continuasse na companhia da dita Carlota dos Reis .... Porque sei que ela continuará a ser, como sempre foi ... uma segunda mãe para o Augusto ...

\section{CARLOTA}

... a gente devia ler os testamentos antes das pessoas partirem ... porque o coração dizia-me que sim ... perdoai-me senhor! ... perdoai-me por ter duvidado! ... E valei-me! Valei-me nesta agonia! ...

- Como é que podes pensar que Ele te vai valer se acabaste de ser cúmplice dum crime ... e dum roubo?! ... 
- E achas que isso vai ser o suficiente para que Ele, na sua infinita misericórdia te perdoe?! ...

Eu não quero nada do roubo nem da herança! Quero morrer penitente e contrita!|

Hei-de pedir que me deixem ser a mãe do menino Augusto nos poucos dias que me restam de vida!

Oh mеи Deus! O que eu estou sofrendo é maior castigo que o meu crime!

Morro! Morro se a graça de Deus me não acode!!! (E desmaia).

\section{MENDIGO}

Carlota dos Reis foi levada para o hospital e Inácio Botelho foi a enterrar no dia seguinte.

(Os Mendigos vão limpar o “palco” ...)

\section{LEONOR}

São os Almeidas aqui na zona?!

\section{MENDIGOS}

Não, não! ... mas há pouco trabalho ... e quando não temos carros para arrumar fazemos aquilo que vai aparecendo para fazer ...

\section{LEONOR}

E também dão informações ... suponho!

\section{MENDIGOS}

É só perguntar ...

\section{LEONOR}

Acabei de chegar a Lisboa! Sabem onde vive um tal 
Inácio Botelho?!

MENDIGO

Dois dias mais cedo e ainda o encontrava com vida ...

\section{LEONOR}

Isso, eu sei! Sou a irmã dele, Leonor Botelho, e não me dava ao trabalho de sair de Montalegre se fosse apenas para falar com ele!

\section{MENDIGO}

Está no cemitério dos Prazeres ...

\section{LEONOR}

Esteja onde estiver, que Deus o tenha em eterno descanso ...

\section{MENDIGO}

Que Deus o tenha no céu e em eterno descanso!

\section{LEONOR}

E deve ter ... porque não passava dum fraco! O meu irmão era um mulherengo e um fraco! E sempre ouvi dizer que os fracos e os pobres de espírito têm sempre um cantinho reservado no céu!

\section{MENDIGO}

Eu ainda cheguei a falar com o seu irmão! Um dia, ele até me disse que ...

\section{LEONOR}

Não me interessa saber o que ele lhe disse! ... Nunca disse nada que geito tivesse! Sempre foi um fraco, um mulherengo e um tolo!!!

Sabem então onde ele morava?! 


\section{MENDIGO}

Assim que a gente terminar isto ...

\section{LEONOR}

Eu espero.

Só um tolo é que se deixava enrolar por mulheres que de seu nada tinham, a não ser a esperteza suficiente para se aproveitarem da sua fraqueza!

Eu sempre o preveni mas ele nunca me deu ouvidos! Nunca! Saiu de Montalegre e veio para Lisboa com uma putéfia que conheceu em Lamego só para não ter que me ouvir!!!

"A mana só por ser mulher, meteu-se-lhe na cabeça que as conhece a todas!"

Repetia esta frase vezes sem conta ao meu primeiro marido!

\section{MENDIGO}

É então ... viúva?

\section{LEONOR}

Três vezes! Três casamentos, três funerais ... e três idiotas que também devem ter o seu cantinho no céu!

Ainda falta muito?!

\section{MENDIGO}

Não, está quase ... está quase ... é aqui!

\section{LEONOR}

Já não era sem tempo!

\section{JANUÁRIO}

V.Exa. é portanto a mana do falecido? O senhor Inácio Botelho era ... 


\section{LEONOR}

Eu sei o que ele era, não precisa de mo repetir!

Um fraco! Um mulherengo e um tolo!

Meteu-se-lhe na cabeça que era um bon-vivant, como dizem os franceses, e um homem irresistivel! Só podia ter acabado como acabou: com a peste!

Mas os homens são todos iguais e o meu irmão não fugia à regra! Nunca percebeu que o que essas mantilhonas viam nele era o dinheiro!

\section{$A N \tilde{A} O$}

Deseja tomar alguma coisa, enquanto espera?... um chá?!

\section{LEONOR}

O que eu espero é não ter de ficar muito tempo à espera!

Não vim a Lisboa para tomar chá ... mas para resolver o que tem de ser resolvido ... por aqueles que cá ficam, com a árdua tarefa de arcar com a irresponsabilidade dos que partem! Deixam as nódoas ... e os familiares que as limpem!

\section{JANUÁRIO}

Ele deixou em testamento uns dinheiros para a educação da criança ...

\section{LEONOR}

Levarei tudo o que me pertence por direito e por lei!

E por vontade de Deus, que eu amo e temo, levo também comigo esse filho de ninguém ... como é que ele se chama? ...

\section{ANÃO}

Augusto ...

\section{JANUÁRIO}

O menino Augusto é seu sobrinho ...

\section{LEONOR}

Sim, mas não é por isso que deixa de ser filho duma rameira! ... 


\section{ANÃO}

A mãe do menino Augusto não era rameira!!!

\section{LEONOR}

Não minta! !!! Ou quer que Deus o castigue ainda mais do que já castigou?!!!

\section{JANUÁRIO}

Ele não está a mentir! A dona Balbina não era uma rameira!

\section{LEONOR}

Está aqui, está a dizer-me que ele também não é anão!!!

E a filha da engomadeira, também não era rameira, é claro!

\section{$A N \tilde{O} O$}

A Dona Carlota estimava muito o senhor Inácio Botelho.

\section{LEONOR}

Se o estimava assim tanto, melhor fora que o tivesse acompanhado para debaixo da terra!!!

\section{JANUÁRIO}

A verdade é que o sr. Inácio mostrou vontade que a dona Carlota continuasse a tratar do menino Augusto ...

\section{LEONOR}

Mostrou vontade? ... mas então ... é uma pena ele agora estar morto e não poder confirmar essa sua pretenção ... porque eu não vou consentir que um sobrinho meu continue a ser educado por uma putéfia!

\section{$A N \tilde{A} O$}

Um chàzinho de cidreira talvez não lhe fizesse mal ...

\section{LEONOR}


Tragam-me o pequeno! ... E acabou-se a conversa!!!

Já tive três maridos - e Deus mos levou!

E todos eles - me deixaram - as mãos a abanar!

Sou viúva sem vintém - Agora sei e Deus também!

Hei-de vencer!

Enriquecer! - E que doa a quem doer!!!

Que eu sou mulher!

E não desisto fàcilmente

Mesmo em frente da desgraça

Eu estou atenta e vou p'rá frente!

E sei que sou uma ameaça

Sou viúva sem vintém

Deus bem sabe e agora vocês também!

Hei-de vencer!

Neste momento - o pensamento

Todo ele está voltado

Para aquele testamento - que em breve será queimado!

Hei-de vencer!

Enriquecer! - E que doa a quem doer!

Que ela é mulher!

E não desiste fàcilmente

Mesmo em frente da desgraça

Eu estou atenta e vou p'rá frente!

Esta mulher é uma ameaça!

Sou viúva sem vintém!

Deus bem sabe e agora vocês também! 
Agora o testamento - já desapareceu!

E o maninho! - Pobrezinho! - Esse está no céu!

Carlota enlouqueceu! - O dinheiro vai ser meu!

E vai vencer! Enriquecer! E que doa a quem doer!

Que eu sou mulher!

Mas o menino, o meu sobrinho

Um ano ou dois vai estudar ...

Só que depois o "coitadinho” - Eu hei-de pô-lo a trabalhar!

Vá com Deus que eu também vou!

Que vá comer o pão que o diabo amassou!

E Vai vencer!

Só porque Deus assim o quer

E no livro do destino - Ele escreveu que esta mulher

Escreveu que esta mulher

Há-de vencer!

Enriquecer! - Eque doa a quem doer! ....

\section{MENDIGO}

E o menino Augusto Botelho foi levado para Montalegre ... sem lhe ter sido pedida a sua opinião sobre o assunto ...

\section{CASA CAROLINA DOS REIS E HOSPITAL}




\section{CAROLINA}

És tu, filha? ... És tu, Carlota?! ...

HOMEM

D. Carolina?

\section{CAROLINA}

Sim ... quem é o senhor?! ... não lhe reconheço a voz ...

\section{HOMEM}

Não me conhece ... trabalho no hospital ... foi lá que conheci a sua filha ...

\section{CAROLINA}

A minha Carlota?! ...

\section{HOMEM}

Sim.

\section{CAROLINA}

Está então no hospital? ... Ainda bem ... Ela engoma muito bem ... aprendeu comigo ... eu também era muito boa engomadeira, antes de ficar cega ... mas trabalhei sempre para o mesmo patrão ... eram outros tempos ... havia pouca procura ... fico contente por saber que a minha Carlota agora também engoma no hospital ...

\section{HOMEM}

A sua filha Carlota ....

\section{CAROLINA}

É ela que me tem valido, é muito boa filha ... não me falta com nada ...

\section{HOMEM}

Ela não está no hospital como engomadeira! ...

\section{CAROLINA}


Desde que o meu marido partiu para o Brasil ... que só a tenho a ela ...

HOMEM

A Carlota foi levada para o hospital há dois dias ...

\section{CAROLINA}

E se ela um dia me falta ...

\section{HOMEM}

... não sabe quem é ... repete frases que não fazem sentido ...

CAROLINA

Desde esse dia ... que só peço a Deus que ela nunca me falte ....

\section{HOMEM}

D. Carolina, a sua filha teve de dar entrada na enfermaria dos doidos ...

\section{CAROLINA}

Não quero saber mais nada ... não diga mais nada ... peço-lhe ...

\section{CARLOTA}

Não me deixes ... não me deixes, que me matas ... e a consciência não se sossega com a morte.

Liga-me ao teu destino; aceito-o, seja ele qual for ...

Eu já sei que de hoje em diante sou entre as mulheres perdidas a mais desgraçada de todas.

\section{ENFERMEIRA}


Consta que estava amantizada com o patrão há já cinco anos ... e ao saber que ele tinha morrido ficou assim! ... Devia gostar muito dele ...

HOMEM

D. Carolina ... ainda há uma esperança ...

\section{CAROLINA}

Só Deus é que sabe ...

Sabe-se lá, quando a sorte é boa ou má,

Sabe-se lá, amanhã o que virá

Breve desfaz-se, uma vida honrada e boa

Ninguém sabe quando nasce

P'ró que nasce uma pessoa.

\section{$\underline{\text { SEGUNDA PARTE - Dez Anos Depois ... }}$}

\section{NO LARGO DAS ATAFONAS}

\section{MENDIGO}

Passaram dez anos ...

Lisboa continua na mesma ... é uma cidade suja, desordenada, mal cheirosa ... encanta os estrangeiros pela sua beleza e pitoresco mas também os decepciona pelo aspecto caótico das ruas e o atraso em que vive a população.

As ruas estão entregues ao povo ...

É de noite.

Um Chulo lê o Diário de Notícias, encostado a um candeeiro ... uma prostituta despacha um cliente, enquanto uma outra observa a cena ...

\section{ANITA}

Vá lá! ... despacha-te que eu não tenho a noite toda! ... 
Uma outra aproxima-se do Chulo e dá-lhe dinheiro.

\section{CHULO}

Ó Betinha!

\section{BETINHA}

Que é que foi?! Não está certo, ou aumentaste a "percentage”?!

\section{CHULO}

Não é isso! Tu ainda te lembras do criminoso do garfo?

\section{BETINHA}

O gajo que deu 17 garfadas no Gregório Redondela?! Atão não me lembro!

\section{CHULO}

Vem aqui no jornal!

\section{BETINHA}

Mas isso já foi há dez anos, ou mais!!!

\section{CHULO}

Vem nas "infemérides"; "Lisboa ... há uma década atrás: Acontecimentos de relevo: A cólera, a Guerra Civil e o Mistério do Criminoso das Garfadas”.

\section{BETINHA}

Deixa ver ... e até trás um desenho do Gregório com o garfo espetado nas costas! Ó Anita, tu já viste isto?!

\section{ANITA}

Eu agora não posso! ... Vá lá despacha-te!

\section{BETINHA}


... ela é que inda conheceu muito bem o Gregório ... e a irmã ...

\section{FININHA}

Ela agora não pode vir! Está a tentar despachar o guarda nocturno ... quem é que vem aí?!

\section{BETINHA}

Tu não te deves lembrar qu'inda eras um chiço! Foi o crime das garfadas!!!

\section{FININHA}

Atão não me lembro! A minha mãe não falava doutra coisa! Nem saía à rua com medo de ser apanhada pelo tarado do garfo!!!

\section{CHULO}

Se não consegues, pira-te e já, t'ás a ouvir?!

GUARDA-NOCTURNO

Éstá quase ... está quase ...

\section{ANITA}

Há uma hora que está quase!!! ...

\section{CHULO}

Já pagou?! ...

\section{ANITA}

Já! ...

CHULO

É pá! Pira-te e já! Andor! ...

\section{CALMEIRONA}

A quem é que vocês estão a tentar convencer que sabem ler?! ... 


\section{BETINHA}

Só cá faltava a calmeirona! A tua zona não é no Terreiro do Paço?!!!

\section{CALMEIRONA}

Pois é! Gosto de espaço e de ter o Tejo aos meus pés ... porquê?! ...

\section{FININHA}

Não me digas que também gostas de despachar dentro d'água?!

\section{CALMEIRONA}

E se gostar, qual é o problema, ó Fininha?!

\section{FININHA}

Nenhum, filha! ... E até ganhas tempo!!!

\section{BETINHA}

É! ... Fica logo lavadinha p'ra atender o senhor que se segue! ...

\section{FININHA}

Ou a senhora! ... O que consta p'rai é que não é esquisita!!!

\section{CALMEIRONA}

Isso é mesmo paleio de quem está com dor de cotovelo! ...

\section{CHULO}

Que é que estás aqui a fazer?

\section{CALMEIRONA}

Vim trazer-te o “cachet”! ... Não estás sempre a dizer p'ra não andarmos com muito dinheiro ... que podemos ser assaltadas!!! ... 
ANITA

Ou mortas! ...

\section{BETINHA}

Já lão vão 10 anos, mas ninguém nos diz que ele não volta a aparecer por aí!!!

\section{ANITA}

Quem?!

\section{BETINHA}

O que espetou 17 garfadas no Gregório! Tu conheceste-o!

\section{FININHA}

Um tarado!

\section{BETINHA}

Desconfiaram dum tipo que andava metido com a Carlota ...

\section{FININHA}

Aquela doida, que às vezes aparece por aqui?!

\section{ANITA}

Ela já num está doida!

\section{BETINHA}

... mas as autoridades nunca o encontraram!

\section{CHULO}

Está visto que se pirou p'ró estrangeiro! ...

\section{BETINHA}

Talvez ... mas logo a seguir ouve mais dois casos de garfadas!!! 
ANITA

Isso foi a Tininha Côxa e aquela galega que vendia rufadas!

\section{FININHA}

Da galega lembro-me eu! Mas quem lhe espetou um garfo na testa foi um tipo que não lhe quiz pagar as rufadas ...mas foi preso!!!

\section{BETINHA}

Ele disse que não foi ele e cá p'ra mim pode muito bem ter sido o outro!!!

\section{CALMEIRONA}

E a Tininha Côxa toda a gente sabe que quem lhe espetou c'um garfo nas mamas foi o chulo ...

\section{BETINHA}

Ele também negou! ...

\section{CHULO}

E achas que o gajo era burro p'ra confessar!?

E desatam a falar ...

Calou! ... e vamos mas é ao trabalhinho, está bem?!

\section{CALMEIRONA}

Olhem! Ai vem a alma penada! ...

\section{BETINHA}

Cheira-me que que quer entrar p'ró ramo! ...

\section{ANITA}

Está um farrapo ... coitada .... 


\section{FININHA}

Era mesmo o que fazia aqui falta ... p'ra afastar a clientela!!!

\section{CALMEIRONA}

Fazia falta, o quê?! P’ra eles darem de frosques já cá estás tu! ...

\section{FININHA}

Eu vou-lhe às trombas! ...

\section{CALMEIRONA}

Tenta! ... e levas um murro nessa cabeça que ficas anã!!!

\section{CHULO}

Isto não é lugar p'ra ti ...

\section{CARLOTA}

... Não tenho p'ra onde ir ...

\section{ANITA}

Não vivias no Beco das Gralhas, com a tua mãe? ...

\section{CARLOTA}

... A minha mãe estava cega ... já morreu ... enquanto foi viva ... andavamos por aí ... a pedir esmola ...

\section{BETINHA}

O povo sempre teve muita pena dos ceguinhos ...

\section{ANITA}

E então quando são ceguinhos e velhos ... chega a dar mais do que esta vida ...

\section{CARLOTA}


Ainda não era muito velha ... mas estava acabada ...

\section{FININHA}

Mas se era ceguinha ... deviam fazer uma boa semanada?! ...

\section{CALMEIRONA}

Melhor que a tua era de certeza! ...

\section{CARLOTA}

Ia dando p'rá renda da casa ... mas morreu vai p'ra seis meses ... continuei a pedir ... mas agora ... até os cães fogem de mim ... não faço pena a ninguém ...

\section{ANITA}

A gente tem pena de ti ... mas nesta vida também não se ganha tanto como as pessoas pensam ...

\section{FININHA}

Só algumas! ...

\section{BETINHA}

Também gostava de te ajudar, mas só na percentage vai metade do que a gente faz ...

\section{CALMEIRONA}

Toma ...

\section{CARLOTA}

Que o Senhor te favoreça ...

\section{FININHA}

Se eu fosse a ti, arranjava uma criança de colo e fazia de conta que era cega! 


\section{ANITA}

Se ela se arranjasse melhor ... podias tomar conta dela ...

\section{CHULO}

Não sei se vale a pena ...

\section{BETINHA}

Este mundo é uma miséria ... ninguém quer saber de ninguém ... e p'rá gente não morrer de fome ... somos condenadas a morrer de vergonha ...

\section{CALMEIRONA}

Eu não tenho vergonha.

\section{ANITA}

Não temos que ter vergonha.

\section{AUGUSTO}

Boa noite ...

\section{ELAS}

Boa noite! ...

\section{AUGUSTO}

A senhora é capaz de me dizer ...

\section{BETINHA}

Senhora!!! 


\section{FININHA}

Ai mulher, que foste promovida!!!

ANITA

Não lhes ligues filho! ... Qual é a graça?! Vá lá! Qual é a graça?!!!! ...

\section{CALMEIRONA}

Não queres vir até ao Terreiro do Paço? ...

\section{ANITA}

E tu, não te chega a tua zona?! Andor! ...

\section{CALMEIRONA}

Não te zangues! ... Só estava a fazer conversa! ...

\section{ANITA}

E não era comigo que ele estava a conversar? Não era?!!!

\section{CALMEIRONA}

Vocês são mesmo pobrezinhas!!!

Queres fazer-me companhia até ao rio? ...

\section{CARLOTA}

Eu?! ...

\section{CALMEIRONA}

Podes aproveitar p'ra tomar um banho! Cheiras mal que tresanda! ...

Podes comê-lo à vontade que eu já estou de barriguinha cheia!!!

\section{BETINHA}

Então tem cuidado! ... Não vá apanhares uma indigestão! ... 


\section{AUGUSTO}

Eu peço desculpa por ter ...

\section{CHULO}

Não peças! ... É a primeira vez que vens aqui, não é?

\section{AUGUSTO}

É. Eu cheguei ontem a Lisboa ... e ando à procura duma rapariga ...

\section{FININHA}

E vieste ao sítio certo, meu lindo ...

\section{ANITA}

Pois veio! Mas era comigo que ele estava a falar, num sei se reparaste, ó Fininha!

\section{CHULO}

Vá lá! Deixem-na trabalhar! ...

\section{ANITA}

Diz lá, filho! ... O que é que queres que eu te faça?! ...

\section{AUGUSTO}

Eu ando à procura duma rapariga que morou por estes sítios ... a senhora talvez a conheça ... eu já não a vejo há muitos anos, mas ela era ...

\section{ANITA}

Estás a dizer-me que não sirvo p’ró que tu queres, não é?! ... Puta de sorte! ...

\section{AUGUSTO}

Eu não quiz ofendê-la! ... eu não a conheço, mas ...

\section{ANITA}

Ninguém me conhece!!! ... Nem o guarda-nocturno ... 
Vá lá! ... Como é que se chama a tal rapariga?

\section{AUGUSTO}

Foi ela que me criou ... é como se fosse minha mãe.

Chama-se Carlota.

\section{ANITA}

Carlota?! ...

\section{AUGUSTO}

Carlota dos Reis! Eu cheguei ontem a Lisboa e fui à junta perguntar se sabiam dela; disseram-me que devia morar no Beco das Gralhas, eu fui lá, mas ...

\section{ANITA}

Já não mora no Beco das Gralhas.

\section{AUGUSTO}

Então conhece-a?!

\section{ANITA}

A mãe era engomadeira, não era?

\section{AUGUSTO}

Sim!

\section{ANITA}

Então estamos a falar da mesma.

\section{AUGUSTO}

E sabe dizer-me onde é que ela agora vive?! 


\section{ANITA}

Se é que se chama àquilo viver! ...

\section{AUGUSTO}

Ela está mal?! ...

\section{ANITA}

... então, tu és o filho do patrão da Carlota?

\section{AUGUSTO}

Sou.

\section{ANITA}

Está um farrapo humano! ...

\section{AUGUSTO}

Ajude-me a encontrá-la, peço-lhe!

\section{ANITA}

.. tu próprio, não a reconheceste ...!

\section{AUGUSTO}

$E u ? !$...

\section{ANITA}

Saiu daqui à bocado! ... Deve estar no Terreiro do Paço;

Se fores depressa, talvez ainda a encontres!

\section{AUGUSTO}

Muito obrigado, muito obrigado! ... 
ANITA

Ó Betinha!!! Betinha!!!

\section{BETINHA}

Agora não posso ir aí! ... Vá lá, despacha-te!!!!

ANITA

Nem vai acreditar quando eu lhe disser quem é o rapaz!!! 


\section{MENDIGO}

Foi muito comovente o encontro de Carlota com o menino Augusto.

Perceberam com certeza que aquele era o filho de Inácio Botelho, que a tia levou para Montalegre ... e que veio para Lisboa com saudades do passado ... da Carlota ...

\section{CARLOTA}

Então é mesmo verdade! ... o menino ... é o menino Augusto ...

\section{AUGUSTO}

E partir de hoje vai ser tudo diferente, Carlota ....

\section{CARLOTA}

Não é um sonho?! ...

\section{AUGUSTO}

Não é um sonho! Agora, vou ser eu a tomar conta de ti ...

\section{CARLOTA}

Deus castigou-me, mas foi um castigo merecido ...

\section{AUGUSTO}

Mesmo que tenhas pecado, Deus já te perdoou, Carlota! ...

\section{CARLOTA}

E o menino?

\section{AUGUSTO}

Eu não tenho nada a perdoar-te ...

\section{CARLOTA}


O meu menino! ...

$\cdots$

Por culpa minha ...... morreu um homem bom ...

\section{AUGUSTO}

Pensavas que a culpa tinha sido tua ... por isso é que estiveste internada ... mas a culpa não foi tua, Carlota! O meu paizinho morreu por causa da peste ... não foi por falta de cuidados teus! ...

\section{CARLOTA}

Mas o Gregório! ... também morreu.

\section{AUGUSTO}

O Gregório morreu?! ... paz à sua alma.

\section{CARLOTA}

A sua tia não lhe disse?!

\section{AUGUSTO}

A minha tia?! ... Nem do meu pai me falava ...

Está a arrefecer. Vamos?!

\section{CARLOTA}

O menino Augusto! ... Ainda me parece um sonho!

Nem quero acreditar

Que acabei de encontrar

Aquele que embalei, que tanto beijoquei

O meu menino que ajudei a criar 
E que o destino de mim quiz afastar

Foi grande o meu sofrer! Enorme o meu penar

Mas Deus assim o quiz! E agora sou feliz!

Dê à mãe um beijoca! - É o meu menino!

Está nos braços da Carlota!

Agora vamos ser

Bem felizes os dois

Vou voltar a viver! Renascer e depois ...

Basta esquecer tudo o que a gente passou!

Comi do pão qu'esse diabo amassou!

Do mesmo pão também! Eu tive de engolir!

Agora o sol nasceu! Já podemos sorrir!

Dê à mãezinha uma beijoca! - É o meu menino!

Está nos braços da Carlota!

Nem quero acreditar

Que acabou de encontrar

Aquele que embalou, que tanto beijocou!

O seu menino, que ajudou a criar

E que o destino dela quiz afastar! 
Foi grande o meu sofrer! Enorme o meu penar!

Mas Deus assim o quiz! E agora sou feliz!

Dê à mãezinha outra beijoca! - É o meu menino!!!

Voltou p'rá sua Carlota!

\section{CARLOTA}

Ainda me parece um sonho! ...

\section{BETINHA}

Eu ... estou tão comovida!

ANITA

Ela tinha direito ... a ser feliz! ...

\section{FININHA}

Foi uma cena muito bonita, não foi? ...

\section{CALMEIRONA}

Foi! Foi um momento musical de cinco estrelas!

\section{CHULO}

Foi tudo muito bonito ... mas a noite ainda não acabou!

Toca a trabalhar!!! 


\section{A CAMINHO DO CEMITÉRIO}

\section{CARLOTA}

... então a sua tia não o deixou continuar a estudar?! ...

\section{AUGUSTO}

Com o dinheiro da herança mandou rezar dez missas por alma do meu pai ...

depois, matriculou-me na escola, mas ao fim de sete meses ... decidiu que era melhor eu ir trabalhar...

\section{CARLOTA}

Era melhor, porquê?! ...

\section{AUGUSTO}

Eu era mau aluno ... e já que na escola não aprendia como deve ser, entendeu que era melhor eu aprender um ofício qualquer ...

\section{CARLOTA}

Parece impossível!

\section{AUGUSTO}

Mandou-me para Chaves porque era lá que morava um tio meu chamado João Torto - chamavam-lhe assim porque ele era vesgo! - , que tinha uma mercearia e uma quinta; primeiro eu era para ir atender a clientela, mas como era muito pequeno e não chegava ao balcão ele disse: "és muito baixo, rapaz! Para este trabalho não serves porque ninguém te vê!"’ "Baixote como és, o melhor é ires aprender a tirar leite às vacas!".

\section{CARLOTA}

E o menino aprendeu?!

\section{AUGUSTO}

Mais ou menos! ... Fazia-me muita impressão ter de me agarrar às tetas das vacas ... estava sempre com medo de as magoar ...

\section{CARLOTA}

E deve doer-lhes, coitadinhas! ...

\section{AUGUSTO}


Depois, com o desgosto comecei a definhar ...

CARLOTA

Há quem diga que com o desgosto, até se pode morrer! ...

AUGUSTO

Pois é! E com a falta de alimento também.

CARLOTA

O menino não comia?!

AUGUSTO

Comia o que me davam: caldo verde migado com pão de centeio ... mas não retinha no estômago! E então, como estava sempre a vomitar as couves e o unto do caldo, desisti de comer.

\section{CARLOTA}

E não o levaram ao médico?!

AUGUSTO

Não! O meu tio até achou bem que eu deixasse de comer, porque como eu deitava tudo cá p'ra fora aquilo era um desperdício e uma afronta a Deus!

\section{CARLOTA}

Uma afronta a Deus, porquê?!

AUGUSTO

Ele nisso tinha razão Carlota; Há por aí tanta gente a passar fome e eu a deitar fora as couves e o unto do caldo! ...

\section{CARLOTA}

É ali que está o senhor Inácio Botelho ...

AUGUSTO

Paizinho ...

Querido paizinho, que eu mal conheci ...

MENDIGOS

Está ali! Está ali! Está ali!

AUGUSTO

Estas flores silvestres que há pouco colhi

São P'ra si! São p'ra si! São p'ra si!

Eu morri de saudades! Mil vezes morri! 
MENDIGOS

Ele tinha ansiedades!

AUGUSTO

Papá o que eu sofri!

Meu anseio era vê-lo ...

MENDIGOS

E por isso está aqui ...

AUGUSTO

Estou aqui! Estou aqui!

MENDIGOS

Está aqui!

MENDIGOS

P'ra longe a tristeza, sofrimento e dor!

Tanta dor! Tanta dor! Tanta dor!

MENDIGOS e AUGUSTO

Carlota vai ter um futuro melhor!

Bem melhor! Bem melhor! Bem melhor!

MENDIGOS

Vai poder esquecer para sempre o passado

Com a graça de Deus tem Augusto a seu lado!

Seu mal fadado fado acabou e ela diz:

CARLOTA

Sou feliz! Sou Feliz!

MENDIGOS

É feliz!

TODOS

Se pensam que a história está a chegar ao fim

Que é o fim! Que é o fim! Que é o fim!

Estão bem enganados porque ainda não!

Ainda não! Ainda não! Ainda não!

MENDIGOS

Que Camilo entendeu o enredo esticar!

Com saber e com arte vai fazer voltar,

Alguém que há muito tempo desapareceu!

Pensáveis vós! Pensava eu!! 
Estar no céu!!!

E entra Gregório Redondela e D. Rosa, casados de fresco!

MENDIGOS

Para espanto de todos, Gregório Redondela não morreu!

Chegaram a passar-lhe uma certidão de óbito, mas quando ia a enterrar,

Um barulho estranho que vinha do interior da urna, obrigou a que suspendessem a cerimónia!

E logo alguém jurou reconhecer a vós do próprio Gregório!

\section{GREGÓRIO}

Mas não era eu! Depois de me meterem no caixão, sem que ninguém se apercebesse, entrou lá para dentro um ratinho, e quando colocaram a tampa ele ficou a fazer-me companhia!

Como todos sabem o ratinho, não sendo uma toupeira, é um animal que gosta de esgravatar! E foi esse ruído que ouviram e que levou o padre a ordenar que abrissem a urna!

\section{MENDIGOS}

O ratinho saiu de imediato, e quando iam a repôr a tampa no seu devido lugar, uma velha gritou:

D.ROSA

Párem, que ele está a mexer-se!!!

\section{GREGÓRIO}

$\mathrm{Eu}$ estou crente de que foi o contacto físico com o meu companheiro de cativeiro que me fez voltar à vida!

\section{MENDIGO}

Chegaram a dizer que Deus tinha feito o Milagre do Rato!

\section{D.ROSA}

Levaram-no para o hospital, mas ainda esteve em estado de côma três anos. mas depois, aos poucos, começou a recuperar e ao fim de sete anos ... conhecemo-nos $\cdots$

\section{GREGÓRIO}

O casamento foi hoje mesmo e eu quiz vir aqui, com a minha mulher, para dizer ao meu amo que ainda estava vivo e Ele, em paga da minha bondade, faz-me encontrar o meu menino!!!

\section{MENDIGO}


Carlota, ainda bastante debilitada, recusa-se a acreditar no que os seus olhos vêem $\cdots$

\section{CARLOTA}

Não ... não é verdade! ....

Foi Deus ...que o mandou ... para me castigar ... daqui a nada vai desaparecer ... é um aviso de Deus para me lembrar que eu ainda não estou preparada para ser feliz ... Deus, com toda a sua misericórdia mostra-me a felicidade que ele podia ter alcançado ... se eu tivesse tido forças para impedir o acto cruel com que o meu amante lhe tirou a vida ...

Vou denunciar-me à justiça: quero ser castigada para salvar a minha alma!

D.ROSA

Quem é esta mulher?! ...

\section{GREGÓRIO}

É Carlota, a filha da Engomadeira!

D.ROSA

Aquela ... que foi amante do falecido?! ...

\section{AUGUSTO}

Ela ... foi amante do meu pai?! ...

\section{GREGÓRIO}

... já lá vão dez anos ... e estou agora a lembrar-me ... ela tinha outro ...

\section{AUGUSTO}

Pobre Carlota ...

D.ROSA

Pobre mulher! ...É uma mulher ... perdida!

\section{MENDIGOS}

Quem vir uma mulher perdida

Que nunca a trate com desdém.

Eu vos lembro que Deus castiga!

Sem dizer quando nem a quem!

Todos devemos ter compaixão

Da mulher desprezada, chorosa!

Antes de cair na perdição, 
ela também foi virtuosa!

EM CASA DE GREGÓRIO REDONDELA

\section{MENDIGOS}

Gregório Redondela era um bom homem e embora naquele dia, ao ter recuperado a memória, tivesse percebido que Carlota tinha sido a causadora do crime das garfadas, perdoou-lhe ... e levou-a para sua casa.

A ela e ao menino Augusto. D. Rosa não se importou por no dia do seu casamento ver assim alargada a família ...

Também era uma boa mulher, e muito temente a Deus ...

E assim passaram ... três meses.

D. ROSA

O jantarinho está quase pronto!

AUGUSTO

D. Rosa, aquilo ...que eu estive a desabafar consigo, ... não conte nada ao Gregório, nem à Carlota, promete?

D.ROSA

Esteja descansado, menino!

AUGUSTO

Obrigado; e então, o que é que temos hoje?!

\section{D.ROSA}

Iscas, arrozinho de grelos, saladinha de tomate, pescadinhas com o rabo na boca, sopinha de agriões e maçãzinha assada para a sobremesa.

AUGUSTO

Não será muito pesado, para a Carlota?!

D.ROSA

Para a Carlota grelhei um robalinho, com arroz branco a acompanhar e uma canjinha de galinha!

AUGUSTO

A D. Rosa é uma santa! ... Eu ainda não lhe disse, mas tenho a impressão de já a ter conhecido... 
D.ROSA

Augustinho .... Isto que não saia daqui; eu ainda não tive coragem de contar ao Gregório, mas eu ... muito antes de o ter conhecido ... eu era meretriz ...

\section{AUGUSTO \\ Meretriz?! ... \\ D.ROSA \\ Rameira ...}

AUGUSTO

Rameira?! ...

D.ROSA

... era puta ... no largo das Atafonas ...

\section{AUGUSTO}

Foi nesse largo que eu encontrei a Carlota! ... mas não a posso ter visto lá ... foi na véspera do seu casamento ...

\section{D.ROSA}

Deus deu-me forças para conseguir sair dessa vida ... mas ficou lá uma rapariga ... é esta ... (mostra foto) ...

\section{AUGUSTO}

É muito bonita! ...

D.ROSA

Era .... Chama-se Anita ... é minha irmã gémea!!!

Está-me sempre a dizer que um dia há-de casar com um guarda nocturno e que deixa a vida ... mas eu não sei! ...

\section{GREGÓRIO}

A nossa doentinha está cada vez melhor!

\section{D.ROSA}

Sim, tem recuperado bastante bem! ...

\section{GREGÓRIO}

E graças aos cuidados da D. Rosa, que é uma santa!!!

D.ROSA

Não me chames santa que Deus ainda me castiga!

\section{AUGUSTO}

Lembre-se que Deus, através de Jesus, perdoou a Madalena! 


\section{GREGÓRIO}

O menino Augusto às vezes sai-se com cada uma! O que é que D.Rosa tem a ver com a Madalena? Madalena era uma rameira e Rosinha é uma santa!

\section{D.ROSA}

Ora!

Há-de haver por aí quem diga que eu só casei contigo por causa do dinheiro!

\section{GREGÓRIO}

Pois deixa-os falar! ...

É bem verdade que Deus escreve direito por linhas tortas, menino Augusto!

... lá no hospital, quando eu já estava capaz de entender e me disseram que o seu paizinho me deixou aquele dinheiro todo em testamento, fiquei tão comovido, que os médicos até tiveram medo que entrasse outra vez em estado de coma! ... Quem não gostou nada foi a sua tia Leonor, porque se eu tivesse morrido aquele dinheiro havia de ser para ela!...

\section{AUGUSTO}

Nunca me disse que não tinhas morrido! ...

\section{GREGÓRIO}

Sabia que o menino me estimava e não quiz dar-lhe essa alegria! ...

\section{D.ROSA}

Desculpe que lhe diga, mas a sua tia é uma víbora!!!

\section{GREGÓRIO}

Rosinha, vai lá ver se a pequena já se aprontou ... é uma boa mulher! ...

Menino Augusto .... Isto que não saia daqui ... que eu não lhe disse, nem tenho coragem para lhe dizer ... ela não merece que eu a magoe ...

Mas a D. Rosa, antes de casarmos, era prostituta no Beco das Atafonas!

\section{AUGUSTO}

Tens a certeza, Gregório?!

\section{GREGÓRIO}

Mas ela não sabe que eu sei! ... Foi um sinal de Deus! Quando saí do estado de côma ... eu não me lembrava de nada, fiquei sem memória! ... pois a única imagem que eu recordava com todos os detalhes ... era o rosto da D. Rosa ...

Eu já tinha ido com a Rosinha, no Beco das Atafonas! ...

AUGUSTO

E mesmo assim, casaste com ela!

\section{GREGÓRIO}


Pois se Deus me mandou aquele sinal ... foi com certeza porque queria que eu a fizesse encontrar a felicidade ... eu fui o instrumento nas mãos do Senhor, para a D. Rosa ser feliz!

\section{AUGUSTO}

Deus escreve direito por linhas tortas ...

\section{GREGÓRIO}

Porque é que eu recebi as 17 garfadas?

Porque é que aquela desgraçada enlouqueceu?

Porque é que a D. Rosa foi uma mulher perdida?

Porque é que o menino teve de comer o pão que o diabo amassou?

E depois de tudo isto, porque é que um simples ratinho entra para dentro do meu caixão?!

Porque Deus escreve direito por linhas tortas.

\section{D.ROSA}

Vem aí a nossa menina!

\section{CARLOTA}

Eu agradeço-te do fundo do coração, Gregório! E à D. Rosa, e ao menino Augusto ... mas eu, eu não sou merecedora de tanta bondade ...

\section{TODOS}

Ora ..

\section{CARLOTA}

Com estas roupas tão finas ... eu não me sinto bem ... quero dizer ... eu olho para o espelho e eu ... eu não sou eu! ... Não pareço eu ...

\section{GREGÓRIO}

Foi isso que combinamos e é assim mesmo que vai ser ...

D.ROSA

A partir de agora és outra mulher, Carlota! ...

\section{AUGUSTO}

É a única forma de apagares o passado ... que volta e meia continua a apoquentarte! ...

\section{CARLOTA}

Mas tanta despesa por minha causa! ... eu ainda não sei se mereço ... 


\section{GREGÓRIO}

Prometi que havia de fazer de ti outra mulher ... e não te apoquentes com o dinheiro ... tenho o bastante para que todos possamos ser felizes!

\section{CARLOTA}

Mas, Gregório ... a felicidade não se compra ...

\section{GREGÓRIO}

Lá nisso tens razão; mas um título, isso sim, pode comprar-se!

D. ROSA

E olha que não vais ser a única a fazer-se passar por aquilo que não é!

\section{AUGUSTO}

A partir de agora passas a ser Dona Carlota dos Reis Redondela Pinto e Basto

\section{ROSA}

A Viscondessa dos Reis!

\section{GREGÓRIO}

E deixas de tratar o menino por Menino Augusto, que ele agora já é um homem!

D.ROSA

Já é um homem e tu ... uma bonita mulher ... e quem sabe?! ... Deus está sempre a escrever direito por linhas tortas ...

\section{AUGUSTO}

Aceitavas ser minha mulher, Carlota? ...

D.ROSA

Então?! ...

\section{CARLOTA}

Eu andei com ele ao colo! ...

\section{D.ROSA}

Isso faz parte do passado! ... e nem queiras saber com quantos eu andei ao colo antes de casar com o Gregório!

\section{GREGÓRIO}

Então a D. Rosa e a senhora viscondessa querem matar-nos à fome?!

\section{CARLOTA}

A Viscondessa dos Reis vai já para a mesa! 
D. Carlota dos Reis Redondela Pinto e Basto ...

D.ROSA

"Viscondessa dos Reis", eu gosto! Mas ... "Pinto e Basto", porquê?!!!

GREGÓRIO

Isso, Rosinha, vais ter de perguntar ao Camilo Castelo Branco!

D.ROSA

E tu, chegaste a perguntar ao pequeno se ele sabe o que foi feito da tia?!

\section{GREGÓRIO}

Perguntei; e só para satisfazer a tua curiosidade!

Pouco antes dele ter vindo para Lisboa casou pela quarta vez com um emigrante que apareceu em Montalegre cheio dele!!! O homem vinha de França disposto a gozar o resto da vida na terra ... mas ela convenceu-o a irem viver para Paris! ...

\section{PALACE HOTEL - PARIS}

\section{LEONOR}

Agora já sou rica, vivo no estrangeiro

Meu maridinho! É velhinho! E cheio de dinheiro!

Em Paris enriqueceu! E o argent agora é meu!

E já venci! Enriqueci! E a Deus digo merci!

Já sei falar! 
Qualquer coisinha em fraciú

$\mathrm{O}$ argent eu sei gastar!

E sei dizer merci beaucoup - ando a aprender p'ra melhorar!

Sei que devo o que hoje sou

Ao idiota que comigo se casou!

ASSIM VENCEU!

Porque sou boa e sou mulher!

ELA HAVIA DE SER RICA E DÊ LÁ POR ONDE DER

APOSTOU ESTA MULHER!

Hei-de vencer!

ENRIQUECER! - E QUE DOA A QUEM DOER!

\section{LEONOR}

Deixa cá ver como é que eu hoje me vou desenrascar com o garçon!

Bonjour!...

\section{GARÇON}

Bonjour Madame! Le Palace hotel vous remercie votre préferance!

\section{LEONOR}

Já sei que estou em Ferance! Diz-me isto todos os dias o "papagaio"!

GARÇON

Qu'est ce que vous désire, cette jolie matin!? ...

LEONOR

"Matin", é isso mesmo! .... Esta matin ...manhã ... mon mari .... Está trés fatigado ... comprenez?! ...

GARÇON

Bien sur! Votre mari est trés fatiguée!

Et pourtant ... il a besoin de rester à la chambre tout le jour!

\section{LEONOR}

Calma aí ó papagaio louro! Que eu falo franciú mas ainda não sou a Sara Bernard!!! MANUEL

Posso ajudá-la, madame?

\section{LEONOR}

Um homem que fala português! Foi Deus que o enviou!

MANUEL

Não, Madame! Venho encontrar-me com um amigo ... 


\section{LEONOR}

E que bem que desenvolve o português! ... Nem ponta de sotaque!

MANUEL

Se tivesse sotaque ... eu não seria digno da pátria que me viu nascer!

\section{LEONOR}

Agora é que não estou a perceber!

\section{MANUEL}

Eu sou português!

\section{LEONOR}

Mon Dieu! ... Pois olhe que não se nota nada! ... Os meus parabens!

Eu digo isto, porque todos os portugueses que conheci até hoje têm estampado no rosto que são completamente idiotas! Aqui p'ra nós, já enterrei três!

\section{MANUEL}

Os meus sentimentos.

\section{LEONOR}

Serão entregues.

\section{MANUEL}

Há já muitos anos que vivo em Paris ... se poder ser-lhe útil em alguma coisa.

\section{LEONOR}

$\mathrm{Eu}$ estava a tentar dizer àquele papagaio que o meu marido não quer ser incomodado; demos ontem um passeio nos "Campos Elisês" e ele ficou de rastos! $\ldots$

\section{MANUEL}

Penso que o papagaio já a entendeu ...

\section{LEONOR}

Tinhamos combinado para hoje um outro passeio com um amigo do meu marido ... deve estar a chegar ... ah!!! Falai no mal!!!!

\section{ADIDO}

Et voilà! Una belle portuguèse à Paris! 
Sou dado à cultura; como tudo-tudo o que é francês!

É língua que me agrada e em Paris fui colocado

Adoro opereta! O Moulin Rouge e um bom linguado!

E o Follies Bergère, Montparnasse e a Torre Eiffel

Pintores em todo o lado! Aguarela e também pastel!

Adoro mulher fina que a francesa é toda "queque"!

E até já me perdi pela divina Mistinguette!

Adora mulher fina e a francesa é muito queque!

Adora mulher fina e a francesa é muito queque!

A até já se perdeu pela divina Mistinguette, é do mais queque!

E este meu amigo é outro emigrante português!

Põe as mulheres malucas - eu já conheci duas ou três

Que ficaram de rastos só de verem o fulano

Ele é o supra-sumo do bom macho lusitano!

Elas ficam malucas só de verem o fulano

Ele é o supra-sumo do bom macho lusitano

Tenho muito prazer em conhecer Madame, é uma beleza

É rosto do mais fino e sangue azul, ai terá de certeza!

É linda e o recheio é um delicioso croissant

Um pãozinho francês que eu trinco logo p'la manhã!

É nossa obrigação dizer Madame seja bien-venus!

Por estar aqui, merci, merci, merci, merci, merci beaucoup

Em Roma sê romano! Aqui é tudo em francês!

As saudades que eu tinha de falar em português!!! 
Em Roma sê romano! Aqui é tudo em francês!

Em Roma sê romano! Aqui é tudo em francês!

As saudades que têm de falar em português!!! Em português!

De Portugal recebo as notícias com atraso tal

“O crime das garfadas”! Imagine! Já foi no Natal!!!

Queremos saber tudo aquilo que por lá se passa!

Quando saí de lá, Lisboa estava uma desgraça!

E querem saber tudo aquilo que por lá se passa

Ao sairem de lá Lisboa estava uma desgraça!!!

\section{LEONOR}

Mas isto quer dizer que estavamos os dois à espera da mesma pessoa!

\section{MANUEL}

Parece que sim!

ADIDO

Tomei a liberdade de convidar este meu amigo, que conhece Paris bastante melhor do que eu!

\section{LEONOR}

E fala um português que ninguém diria!

\section{MANUEL}

Ele é português!

\section{LEONOR}

Mesmo assim! Ali o papagaio é francês e não se percebe metade do que ele diz!

\section{ADIDO}


Então tu andaste a mentir à senhora?!

\section{GARÇON}

Pensei que estava a ajudar!

\section{$A D I D O$}

Ele veio da Madragoa, fui eu mesmo que lhe arranjei este emprego!

\section{LEONOR}

Palhaço! ... Está a ver?! Outro com cara de idiota!

\section{ADIDO}

E pensavas que estavas a ajudar, porquê?!

\section{GARÇON}

Ela pensa que já sabe falar francês, mas não dá uma p'rá caixa! Por isso, o velho, o marido, pediu-me para eu só falar com ela em francês, para ela praticar a língua e ao mesmo tempo convencer-se que está a falar muito bem, porque julga que eu a entendo!

\section{LEONOR}

O papagaio já se calou?!

\section{$A D I D O$}

Já. Foi tudo um mal entendido! ...

Ainda não lhe apresentei o meu amigo! É o conhecidíssimo Barão da Nóbrega!

\section{LEONOR}

Um Barão?! Oh! Mas quem me dera ser reposteiro!!! ... foi uma graça!

\section{GARÇON}

Estou aqui que não me aguento de tanto rir! ...

\section{ADIDO}


Podemos sair assim que o seu marido descer!

\section{LEONOR}

Felizmente ele não nos pode acompanhar! ... A caminhada de ontem já foi demais para quem tem tão pouca pedalada!

\section{$A D I D O$}

Podemos então tomar um chá ... aqui mesmo ... que lhes parece?!

\section{LEONOR}

Isso do chá fez-me lembrar um certo anão ... mas vindo da sua parte, parece-me bem! E o Barão?

\section{MANUEL}

Acho muitíssimo bem! Podemos aproveitar para nos falar de Lisboa.

\section{LEONOR}

Mas eu sou de Montalegre, Barão! ... Lisboa! ... não sei, mas deve continuar uma desgraça! ... A última vez que lá estive aquilo estava impossível, por causa da guerra e da peste!...

\section{ADIDO}

Qual guerra? A guerra civil?!

\section{LEONOR}

Não sei ao certo, já foi há dez anos, mas devia ser! Essa ou outra qualquer!

Passam a vida a guerrear-se e vá lá a gente saber porquê! ...

\section{GARÇON}

Tomam alguma coisa ou só vão fazer sala? 
MANUEL

Um chá ...

$A D I D O$

E dois bagaços!

\section{LEONOR}

Por amor de Deus! Dois, não! Que eu com um já fico tonta! ...

\section{GARÇON}

Percebi perfeitamente: saiam três bagaços!

MANUEL

Disse que tinha estado em Lisboa há dez anos?

\section{LEONOR}

Mais coisa, menos coisa ...

\section{MANUEL}

Eu tive um amigo ... que vivia exactamente em Lisboa nessa altura, mas foi obrigado a abandonar o país ...

ADIDO

Por causa da guerra?

\section{MANUEL}

Parece que sim ... divergências políticas! ...

\section{LEONOR}

Claro!

MANUEL 
Teve de fugir, primeiro para Espanha e depois para França ... também esteve uns tempos na Suiça ... teve sorte, ganhou muito dinheiro ao jogo e ficou riquíssimo!

\section{LEONOR}

Foi o que me aconteceu e nem sequer precisei de sair de Montelegre!

(Campaínha para chamar Garçon, que sai)

\section{MANUEL}

Esse tal meu amigo gostava de voltar a Portugal, mas tem medo de ser preso ...

\section{$A D I D O$}

Por causa da política?!

\section{MANUEL}

Parece que sim ...

\section{LEONOR}

Desculpe que lhe diga isto, Barão, mas esse seu amigo é um tolo! Um idiota!

Para que é que ele quer voltar para um país onde se vive tão mal se no estrangeiro ele está tão bem!? ... Olhe que eu, mal o dinheirinho foi ter comigo a Montalegre, só pensei numa coisa: pirar-me dali p'ra fora!

\section{GARÇON}

Posso interromper?!

\section{LEONOR}

É claro que não! ...

\section{MANUEL}

O que o leva a querer voltar são razões ... sentimentais ... e remorsos ...

\section{$A D I D O$}

Remorsos? 
MANUEL

Sim ... parece que sim.

\section{LEONOR}

Não diga mais, que eu já estou mesmo a ver a "opereta”!

Razões sentimentais: esse seu amigo tinha uma conversada a quem jurara amor eterno, $e$ eis senão quando, por causa das políticas, teve de a abandonar, porque ela - filha de boas famílias - nunca poderia acompanhá-lo para o exílio! Não foi assim?

\section{MANUEL}

Deve ter sido ... parece que sim.

\section{$A D I D O$}

E a razão para os remorsos?!

\section{LEONOR}

Muito simples! A conversada não the disse naquela altura, mas mais tarde ele veio a saber que a deixou de esperanças! Ele sabe que ela vai ter de aguentar sòzinha, com o desprezo da família, com a maldade do mundo e com a criança que ele nunca chegou a conhecer. Naturalmente ... sente remorsos!

Não teria sido assim?!

\section{MANUEL}

Assim ... tal e qual ... parece que não!

\section{GARÇON}

Já posso interromper?

\section{LEONOR}

Traga mas é o que lhe pediram e não se meta onde não é chamado!

MANUEL 
Penso que se ela tivesse ficado de esperanças ... os remorsos haviam de ser muito maiores.

Não estou a maçá-los?!

\section{LEONOR}

De forma alguma! É uma história interessantíssima! ... Pelo menos, da forma como eu a estou a imaginar!

GARÇON (enquanto põe na mesa os copos)

O seu marido chamou-me e ...

\section{LEONOR}

E então o que é que está aqui a fazer?!

Vá lá ver o que ele quer e cale-se! (Bebe)

$A D I D O$

Eu juro-te que tenho estado a tentar perceber onde é que queres chegar ... e não consigo!

\section{MANUEL}

Eu sei que esse meu amigo, na impossibilidade de voltar, havia de gostar de saber o que aconteceu à conversada ...

\section{$A D I D O$}

Pode ser que esteja bem! ...

\section{MANUEL}

Se assim fosse, ele ia sentir-se melhor, tenho a certeza! ... 
Como tudo isto aconteceu quando a senhora estava em Lisboa ... o destino tem coisas inexplicáveis, pode ter ouvido falar no caso! ... Foi na mesma altura do "criminoso das garfadas", talvez ainda se lembre!

\section{LEONOR}

Disso lembro-me perfeitamente e até lhe digo mais: foram 17 garfadas, mas se fosse comigo haviam de ser $34 ! ! !$

\section{MANUEL}

Então, talvez também se recorde duma rapariga que era filha duma engomadeira ... e que foi dada como louca.

\section{LEONOR}

Carlota?! ...

MANUEL

Parece que sim ... Carlota.

LEONOR (Bebe mais um copo - o do Adido)

Como é que eu não havia de me lembrar! Se os mendigos e até os cómicos de terceira categoria andaram de terra em terra a ganhar dinheiro à custa dessa miserável!!! Chamavam à representação: "A Tragédia da Carlota!".

Essa Carlota! ... Uma putéfia, armada em heroína num romance de cordel!

(Bebe mais um copo - o do Manuel))

\section{$A D I D O$}

Porque é que não vais ver o que é que o homem quer?!

\section{GARÇON}

Não vale a pena. (Continua a falar-lhe, mas não se ouve)

\section{MANUEL}

E ainda se lembra como é que acabava ... essa representação?! 


\section{LEONOR}

Mal! É claro que só podia acabar mal! A mãe completamente cega, a que fazia de Carlota magra que nem um cão, e as duas miseráveis a pedinchar na rua, à frente dum cenário também muito pobre, uma pintura que dava ares de ser o cais do Sodré, com um arco iris muito lá ao fundo! ...

\section{MANUEL}

Um arco-iris?! ...

\section{LEONOR}

Sim! ... Mas era tudo tão pobre, tão pobre ... que até o arco iris era a preto e branco!!!

$A D I D O$

Talvez seja melhor beber outro bagaço ...

\section{LEONOR}

Já estava a sentir-lhe a falta ...

ADIDO

O seu marido chamou o garçon ...

\section{LEONOR}

Esse idiota é um chato! ...

\section{ADIDO}

Mas quando entrou no quarto ... deu com ele morto.

\section{LEONOR}

Está então morto! Felizmente quando eu dei com ele ... ainda estava vivo!

\section{GARÇON}

Há já dez minutos que é viuva. 


\section{LEONOR}

Já estou habituada! ... e isto só vem confirmar o que eu sempre disse: Deus escreve direito por linhas tortas! ...

\section{EM CASA DE GREGÓRIO REDONDELA}

\section{D.ROSA}

Pareces-me muito pensativa, Carlota! ...

\section{CARLOTA}

Eu?! ... estava a pensar nas voltas que a vida dá ... no passado.

\section{D.ROSA}

Esquece o passado! ... Tens de pensar é no futuro ...

\section{CARLOTA}

Qual futuro?! ...

\section{D.ROSA}

O futuro está nas tuas mãos, Carlota!

\section{CARLOTA}

O futuro só a Deus pertence!

\section{D.ROSA}

E Ele não está a querer ajudar-te?! Eu até me parece que o ouço: "P'rá frente Carlota! P'rá frente Carlota!", mas tu, filha, sempre a puxar p'ra trás, sempre a lembrares o que já lá vai! ... Assim, como é que queres encontrar a felicidade? 


\section{CARLOTA}

Eu não mereço ser feliz, D. Rosa!

\section{D.ROSA}

Lá estás tu com essa mania que não te sai da cabeça! Toda a gente merece ser feliz, Carlota.

\section{CARLOTA}

O que eu fiz não tem perdão ...

\section{D.ROSA}

Não tem é remédio! Mas o que não tem remédio, remediado está!

E já toda a gente te perdoou, tens um lar, és Viscondessa, já engordaste três quilos, o que é que tu queres mais?!

\section{CARLOTA}

Tem razão! Tem toda a razão D. Rosa!

Mas, está a ver?! Fazem-me bem e eu ... até parece que não sei retribuir ... sou mesmo "pobre e mal agradecida!".

Prometo que nunca mais volto a falar do passado!

\section{D.ROSA}

Nem mais uma palavra! ... E quanto ao futuro ... já pensaste o que vais responder ao menino Augusto?

\section{CARLOTA}

Responder? ... a quêe?

\section{D.ROSA}

Ora!...Não te faças de novas! 


\section{CARLOTA}

Ele estava a brincar D. Rosa! ...

\section{D.ROSA}

Os olhinhos dele não enganam! ... ele gosta de ti, Carlota.

\section{CARLOTA}

Sempre foi um bom menino ... e graças a Deus transformou-se num bom homem ... e se não estava a brincar ... só pode ter dito aquilo porque tem pena de mim ... quer ver-me feliz.

\section{D.ROSA}

O que ele sente por ti é amor, não é pena. Ter pena é um sentimento tão ... tão mesquinho!

\section{CARLOTA}

Eu não posso casar com ele, não posso! Ele é mais novo do que eu dez anos!

\section{D.ROSA}

E o que são dez anos, quando é a felicidade que está em jogo?

\section{CARLOTA}

Era como se casasse com o meu próprio filho ...

\section{D.ROSA}

Felizmente ele não é teu filho ... e ama-te muito.

\section{CARLOTA}

Como é que pode estar tão certa do que diz?!

\section{D.ROSA}

Porque ele próprio mo confessou!!!

\section{CARLOTA}


Casar com o menino Augusto?! ...

\section{D.ROSA}

Não foste a única que no passado teve de comer o pão que o diabo amassou.

Ele também sofreu muito ...

\section{CARLOTA}

Eu sei ...

\section{D.ROSA}

Todos nós sofremos; mas ele ainda era uma criança, deve ter sido pior, muito pior ... Mas agora ele encontrou uma razão para viver, encontrou uma pessoa de quem gosta muito e acredita no amor.

Depois de tudo o que ele passou ... e depois de tudo o que ele fez por ti ... peço-te Carlota, não o faças sofrer, não lhe dês mais um desgosto. 


\section{PALACE HOTEL - PARIS}

\section{GARCON}

Senhor Barão!

MANUEL

Sim?!

\section{GARÇON}

A viúva mentiu-lhe!

MANUEL

Mentiu-me?! ... em quê?!

\section{GARÇON}

Não lhe mentiu ... mas não lhe contou toda a verdade!

A Carlota passou um mau bocado, mas agora está bem!

Está até bastante bem!

MANUEL

Como é que sabes?!

\section{GARÇON}

Só estou aqui a trabalhar há dois meses ... e algum tempo antes de vir p'ra Paris, conheci a Carlota; ... até lhe chamavamos "a alma penada!" ... ela passou um mau bocado! ... 
MANUEL

Então, tu conheceste a Carlota ...?!

\section{GARÇON}

No Largo das Atafonas, que era onde eu trabalhava; ela aparecia muito por ali - cá p'ra mim era p'ra ver se entrava pr'ó negócio!

\section{MANUEL}

Qual negócio?

\section{GARÇON}

O mesmo que há aqui em Pigalle! ... Putedo, senhor Barão! Putedo! Mas nem p'ra isso ela servia ... Eu era ... "transformista” ... e olhe que era das que tinha mais saída! ...

\section{MANUEL}

Que aconteceu à Carlota?

\section{GARÇON}

Teve uma sorte do caraças!

Encontrou o filho do antigo patrão e foram os dois viver para casa do Gregório Redondela!

\section{MANUEL}

Isso não pode ser!!! ... O Gregório Redondela morreu!!!

\section{GARÇON}

Morreu nada! Esteve não sei quantos anos no hospital mas escapou!

A minha mãe estava sempre a falar-me no milagre do rato e no tarado das garfadas!!! Esse é que nunca foi apanhado!

\section{MANUEL}

O Gregório não o denunciou às autoridades? ...

\section{GARÇON}


Ele não morreu, mas parece que perdeu a memória ...

\section{MANUEL}

Portanto, a Carlota está bem ... e o Gregório perdeu a memória!

\section{GARÇON}

Está riquíssimo! Abriu um restaurante ...

\section{GREGÓRIO}

Agora sou rico!

Dinheirinho não me falta nem sei que lhe hei-de fazer!

Estava escrito, mas eu não sabia!

Havia de enriquecer!

Sou um Novo Rico!

Nem sabia como era ter dinheiro p'ra gastar!

De repente enchi o pé da meia!

E já posso descansar!

Logo montei um restaurante no Bairro Alto e aquilo cresceu!

Vai lá gente importante gastar o "seu”!

É o mais chique e o mais famoso, tem duas salas, sempre esgotadas!

E eu chamei-lhe por gozo ... "O Rei das Garfadas!”

\section{MENDIGO, MANUEL, GARÇON, D.ROSA}

Logo montou um restaurante no Bairro Alto e aquilo cresceu!

Vai lá gente importante gastar o "seu”!

\section{D.ROSA e GREGÓRIO}

É o mais chique e o mais famoso, tem duas salas, sempre esgotadas!

\section{MENDIGO}

E chamou-lhe por gozo ... "O Rei das Garfadas”! 
TODOS

É tão bom ser rico!

Ter dinheiro na carteira, não precisar de pensar:

Está na hora de pagar a renda; o que tenho irá chegar?!

GREGÓRIO e ROSA

Somos Novos Ricos!

OS OUTROS

Nem sabiam como era ter dinheiro p'ra gastar!

\section{GREGÓRIO}

De repente enchi o pé da meia!

E já posso descansar! (senta-se a dormitar; D.Rosa sai)

MANUEL

Tudo está bem ... quando tudo acaba bem! ...

Porque é que eu não vim ao Palace Hotel há mais tempo?

\section{GARÇON}

Isto aqui é cinco estrelas, senhor Barão!

MANUEL

Toma; bem o mereces!

\section{GARÇON}

Merci Monsieur!

\section{MANUEL}

...Agora, já posso voltar! 


\section{GARÇON}

E será sempre ... "Bien Venu!”.

"Tudo está bem ... quando tudo acaba bem!"

Que quereria ele dizer com isto?!!!

\section{EM CASA DE GREGÓRIO REDONDELA}

\section{D.ROSA}

Gregório! Gregório! Acorda Gregório!!!

\section{GREGÓRIO}

Mas, o que é que aconteceu, Rosinha?!

\section{D.ROSA}

É a Carlota! Ela não tem andado bem! Às vezes, lá conseguia disfarçar, e eu bem tentei convencê-la que estava tudo bem ... mas ela está sempre a matutar no mesmo! Sempre a culpar-se de tudo, e agora isto! ...

\section{GREGÓRIO}

Mas “agora isto”, o quê, Rosinha!

\section{D.ROSA}

Disto é que eu não estava à espera!

\section{GREGÓRIO}

Não estavas à espera de quê? Ó filha explica-te! ...

\section{D.ROSA}

Valha-me Deus!

\section{GREGÓRIO}


Acalma-te! Estás a deixar-me ansioso! ...

\section{D.ROSA}

A Carlota foi-se embora! Eu bem tentei impedi-la, mas não consegui!

Pediu-me para te entregar esta carta ...

\section{GREGÓRIO}

“Meu bom Gregório” ...

\section{AUGUSTO}

Boas noites!

\section{D.ROSA}

Boa noite, filho! ... Espere um bocadinho ... ele está a ler ... uma carta ...

\section{AUGUSTO}

Não são más notícias, espero!

\section{D.ROSA}

Quando se recebe uma carta e ninguém faz anos ... a gente nunca sabe bem o que é que pode vir lá dentro ...

\section{GREGÓRIO}

A letra está muito tremida ... e a tinta esborratada ... percebe-se que enquanto escrevia ... um vale de lágrimas deslizava-lhe pelo rosto e caía em cima do papel de carta ... Metade do que escreveu não se consegue ler ...

mas a outra metade diz tudo. ... é da Carlota!

\section{D.ROSA}

A Carlota deixou-nos! ...

\section{AUGUSTO}

A Carlota foi-se embora?! ... 


\section{D.ROSA}

Foi para um convento! Diz que quer ser freira! Que só assim poderá pagar pelos seus pecados ....

\section{GREGÓRIO}

Pede-nos perdão não sei quantas vezes ... e diz que aqui nunca iria conseguir encontrar

... nem sei bem o quê ... a seguir está tudo muito esborratado, por causa das lágrimas $\cdots$

\section{D.ROSA}

Mas ela gosta muito do menino Augusto! Disso eu tenho a certeza! ... Disse-me que também lhe havia de escrever uma carta, assim que chegasse ao convento

\section{AUGUSTO}

Pobre Carlota ...

\section{GREGÓRIO}

“ ... não consigo encontrar ...” pois! Está a ver menino Augusto?! Não se percebe o resto ...

\section{AUGUSTO}

Deve ser ... a Felicidade.

\section{D.ROSA}

Mas ela aqui, estava bem, não lhe faltava nada ...

\section{GREGÓRIO}

De que vale ser rico ;Quando a dor que a gente sente não se acalma com vintém! $O$ dinheiro ajuda a viver ... Mas não faz feliz ninguém!!!!

\section{NO CONVENTO}

GAMA

Carlota! ... Carlota! ... mas onde é que ela se teria metido, irmãs! ... 
Receio ter sido um erro tremendo tê-la deixado entrar para o convento!

\section{BORBULHA}

Ali está ela!

\section{GAMA}

Onde, irmã?!

\section{BORBULHA}

Na sala das torturas! ...

\section{GAMA}

Mas que está ela ali a fazer, se ainda nem sabemos qual foi o pecado que a trouxe até nós!!!

\section{CARLOTA (Voz OFF)}

É este o castigo que eu mereço ... ou então aquele! ... depois ... Deus vai perdoar-me todos os meus pecados! ...

\section{GAMA}

Estou bastante preocupada, irmãs!

Há já duas semanas que Carlota entrou para o nosso convento, mas não lhe sinto vocação para ser freira!!!

\section{LUFADINHA}

Não diz uma palavra!

\section{GAMA}

Senta aqui Carlota ... senta.

\section{LUFADINHA}

Para te integrares, tens de falar connosco Carlota ... tens de nos contar os teus pecados ... 


\section{BORBULHA}

Todas nós temos telhados de vidro ...

\section{GAMA}

Vais sentir-te como peixe dentro de água! ... Eu sou a irmã Gama; desde criança que comecei a roubar nas igrejas as esmolas que os fieis lá deixavam ... era fácil, porque os fieis estavam sempre de cabeça baixa e não viam ... os santinhos perdoaram-me e Deus também! ... És ladra?!

CARLOTA acena que sim.

\section{LUFADINHA}

Está visto que roubou! ...

\section{BORBULHA}

Temos de ter cuidado com a caixa das esmolas! ...

\section{GAMA}

Receio que não esteja aqui só por isso! ...

\section{LUFADINHA}

Eu sou a irmã Lufadinha ... porque passei metade da minha vida numa lufa-lufa à procura dum marido ... nessa lufa-lufa eu conheci muitos, mas nenhum me quiz ...

\section{GAMA}

Acontececeu-te assim ... alguma coisa idêntica?! ... Homens!

CARLOTA acena que sim.

\section{GAMA}

Não restam dúvidas: temos aqui uma ladra que também pode muito bem ser ... que Deus me perdoe! ... outra tarada sexual!

\section{BORBULHA}


Talvez seja melhor avisarmos o jardineiro! Já está muito velho! ...

Eu sou a irmã Borbulha! ... Naturalmente porque sou achacada às borbulhas!

As borbulhas, por sua vez, alteram-me o sistema nervoso ... também deves ser muito nervosa ...

CARLOTA acena que sim

\section{BORBULHA}

Fui cozinheira em casa de gente rica e um dia pediram-me para matar um porco ... levei-o para a cozinha, mas o animal fugia-me por tudo quanto era sítio!

Finalmente consegui apanhá-lo e prendi-o bem no meio das minhas pernas! Mas ele guinchava que nem um porco! Aquilo começou a mexer-me com os nervos e então espetei-lhe na cabeça com a primeira coisa que me apareceu à mão! Um garfo!!!

CARLOTA reage à palavra "Garfo"

\section{LUFADINHA}

... "Garfo!"

GAMA

Isto é muito estranho, irmãs! ... Tem reacção à palavra .... "Garfo!”.

\section{LUFADINHA}

Está visto que no seu passado há uma história qualquer relacionada com ...

\section{AS TRÊS}

"Garfo!"

Batem à porta do Convento. As irmãs saiem. Carlota dirige-se para o camarim e começa a escrever a carta. Irmã Gama volta a entrar. 
Carlota ... acabou de chegar uma pessoa ... que quer falar-te ...

\section{CARLOTA}

Irmã Gama, ... diga ao menino Augusto que eu ... que eu aqui dentro não o posso receber ... diga-lhe que não é permitido ...

\section{GAMA}

Mas, Carlota ...

\section{CARLOTA}

Se ele quiser esperar ... eu estou a terminar uma carta que lhe é dirigida, a irmã pode entregar-lha, não pode?! ...

\section{GAMA}

Com certeza que sim, que lha entrego;

mas só o poderei fazer quando esse tal menino Augusto vier ao convento.

\section{CARLOTA}

Mas a irmã não disse?! ...

\section{GAMA}

Quem te procura é um cavalheiro, o ... Barão da Nóbrega.

\section{CARLOTA}

Não conheço ninguém com esse nome!

\section{GAMA}

Chegou há dois dias de França e ele próprio receia que não te lembres dele; Por isso recomendou-me para te dizer que o seu primeiro nome é Manuel.

\section{CARLOTA}

Manuel?! ... Não é possível! ... 
É isso que queres que lhe diga? ... Que "não é possivel”!

\section{CARLOTA}

Não, irmã! Se é ele ... se é possivel que seja ele ... se me é permitido ...

\section{GAMA}

Se Deus o enviou de tão longe ... certamente é porque quer que se encontrem ... vou mandá-lo entrar.

\section{CARLOTA}

Bendito seja Deus! ... Perdoai-me Senhor! Perdoai-me por não ter acreditado que ainda podia ser feliz! ...

(Vai ao camarim e está para rasgar a carta, quando a Madre regressa com Manuel)

GAMA

Irmã Carlota!

Sem palavras, mas com música, caiem nos braços um do outro.

\section{MANUEL}

Perdoa-me, Carlota!

\section{CARLOTA}

Sou eu que tenho de te pedir perdão!

MANUEL

A culpa não foi tua ...

\section{CARLOTA}

Foi o destino ... mas também estava escrito que tu havias de voltar, Manel ... 
MANUEL

Para te ouvir dizer ... "perdoo-te”; ... só assim poderei encontrar a felicidade.

\section{CARLOTA}

Se tu dizes que só assim poderemos ser felizes, então eu ... eu perdoo-te.

Seremos felizes ... para sempre!

MANUEL

És ... realmente feliz, Carlota?!

\section{CARLOTA}

Não posso ser mais feliz!

MANUEL

Fico muito contente ... por ti ... e por mim.

\section{CARLOTA}

Temos muito que agradecer a Deus, Manel.

GAMA

A senhora pergunta se já pode entrar.

\section{MANUEL}

Sim; agora já pode entrar.

\section{FRANÇOISE}

Bonjour Carlota.

\section{MANUEL}

Chama-se Françoise ... 
CARLOTA

Françoise?! ...

FRANÇOISE (Em francês)

O Manuel tem-me falado muito de si;

GAMA

Está a dizer que este senhor lhe tem falado muito de ti;

FRANÇOISE

Queria saber se estava bem ...

GAMA traduz ..

FRANÇOISE

e vezes sem conta repetia que enquanto não soubesse o que lhe tinha acontecido ...

GAMA traduz

FRANÇOISE

não poderia nunca ter paz e ser feliz ...

GAMA traduz

FRANÇOISE

Acabei por compreender e aceitar, mas a princípio, confesso que senti ciumes!

GAMA traduz

MANUEL

Tudo está bem ... quando tudo acaba bem.

A Françoise é minha noiva ... e tu, noiva do Senhor. 


\section{CARLOTA}

Sim ... está tudo bem ...Temos de Lhe agradecer ... tanta felicidade ...

Manuel e Noiva saiem. Carlota entrega a carta à Irmã Gama e também sai.

Entra Augusto.

\section{AUGUSTO}

Peço desculpa por vir interromper.

GAMA

Se me interrompeu ... foi porque Deus assim o quiz ...

\section{AUGUSTO}

Deus escreve direito por linhas tortas.

GAMA

E eu também já não canto como cantava!

\section{AUGUSTO}

Ainda tem uma voz muito bonita ...

\section{GAMA}

... Mas com pouca projecção! ... Quando era jovem, sempre que cantava na igreja do Mosteiro dos Jerónimos, ouvia-se na Basílica da Estrela!

Deve ser ... o tal menino Augusto ... e está aqui para visitar a irmã Carlota.

\section{AUGUSTO}

Como é que adivinhou?! ... 
GAMA

Porque Deus, através da Carlota, confiou-me a missão de entregar esta carta a um tal ... menino Augusto; e naturalmente, ao encarregar-me desta tarefa, eu sabia que o menino haveria de chegar, mais tarde ou mais cedo ...

\section{AUGUSTO}

Não vim mais cedo porque ... quiz dar-lhe tempo para pensar ...

\section{GAMA}

Se Deus o levou a proceder assim ... posso garantir-lhe que chegou na altura certa!

Ouve-se um grito e um corpo a cair na água.

Irmã Gama sai.

MANUEL lê a carta de Carlota ...

“Menino Augusto, ... eu só podia ser sua esposa no céu, onde a alma está pura das nódoas do corpo ... lá o espero, filho da minha alma; ... enquanto viver, creio que verá a minha imagem sem o estigma fatal ... a terra no sepulcro é um crisol de purificação ... Agora lhe digo que o amei até morrer ... e morri porque Deus não quis que os meus olhos se afastassem do negro quadro do meu passado ... as maiores desgraçadas são aquelas que a si próprias não podem perdoar ...

Adeus! ... chore-me, não pelo que eu sou, mas pelo que fui ...

Fui uma mulher perdida, mas Deus, deu-me o mais que podem ter mulheres como eu ... o amor do menino que eu ajudei a criar ...

O seu retrato vai na minha mortalha ... Adeus ... Carlota.” ...

Sabe-se lá, quando a sorte é boa ou má,

Sabe-se lá, amanhã o que virá

Breve desfaz-se, uma vida honrada e boa

Ninguém sabe quando nasce

P'ró que nasce uma pessoa.

FIM. 
